





\section{BUTTERFLIES OF NORTH AMERICA. \\ VOLUME II.}



THE

\title{
BUTTERFLIES OF NORTH AMERICA
}

\author{
BY \\ WILLIAM H. EDWARDS
}

SECOND SERIES
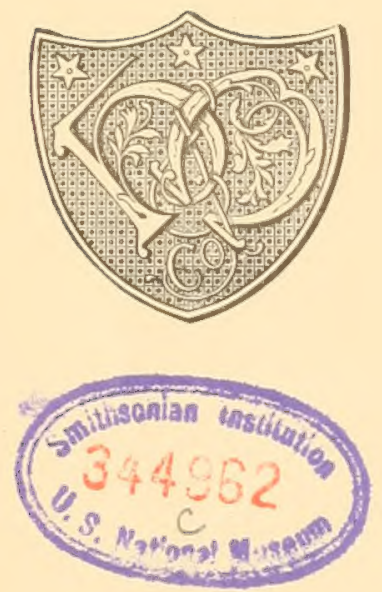

BOSTON

HOUGHTON, MIFFLIN AND COMPANY

New York: 11 East Seventeenth Street

Tbe Ribersioe jreos, Cambrioge 1884 
What a do was there made in London at a certein man becaufe he fayd, and in dede at that time on a iuft caufe. Burgeffes quod he, na butterflies. Lorde what a do there was for yat worde. And yet would God they were no worfe then butterflies. Butterflyes do but theyre nature, the butterflye is not couetoufe, is not gredye of other mens goodes, is not ful of enuy and hatered, is not malicious, is not cruel, is not mercileffe. - Latimer. 


\section{PREFACE.}

Is the present Volume will be found much original matter on the early stages of the species treated of, and in consequence of this the labor of preparing and coloring the Plates has been very much greater than it was in the first Volume. IIence the delay in the issue of the several Parts. I have been seconded to the utmost by Mrs. Mary Peart, who has not only drawn the early stages on the stone, but previously on paper, making in each case colored fignures; and in order to do this has had to aid in rearing the larva, and to take a vast amount of trouble upon herself. Of the one hundred and one Plates in the two Volumes, ninety-eight have been done by Mrs. Peart, with a fidelity to nature that camnot be surpassed; and of the total number one hundred have been colored by Mrs. Lydia Bowen and her sister, Mrs. Leslie, to whom I am under great obligations for the interest they have constantly taken in all that concerned their department. Their skill and patient care every Plate bears witness to.

I have received valuable aid in obtaining eggs or larva from many correspondents, whose names will be found mentioned.

In the Advertisement to the first Volume, 1868 , regret was expressed that in so few instances anything could be said of the larva: "Even among our old and common species, the larre are but little more known than in the days of Abbot, seventy years ago." $\Lambda$ ll that is changed, and to-day it can be said that the preparatory stages of North American butterflies as a whole are better known than are those of Europe; and so many zealous workers are now busy in the field that mother perior of sixteen years may leave comparatively little to be done in these investigations.

I hope, after an interval of a few months, to proceed with a third Volume, for which I have in hand abundant materials.

WILLIAM H. EDWARDS.

Coalburgh, W. VA., 1 November, 1884. 



\section{ERRATA.}

Colias Eurstmene. (Colias IV.) 3d page of, for brealth of chrysalis, ".09 and .11 inch," read .18 and .22 inch.

Linenitis Arthemis. (Limen. I.) 5th page of, Tth line from bottom, for 5th read 4th. In explanations of same Plate: for "young larva (not on Plate)," read not lettered on Plate,

Grapta III., in Note, 4th line of, for "nettle," read yooseberm.

Papilio India (Papo IX.), Ist page, bottom line, for "abdomen white," read abdomen wholly, ete. 



\section{SUPPLEMEN'TARY NOTES.}

PAPILio Zolichor. - In 1883, I raised many larva from eggs sent me by Mr. W. G. Wright, of Sin Bernudino, California, and obtained descriptions, as well as a series of drawings, of all the larval stages. It was my intention to give an additional Plate illustrating these stages and the corresponding ones of Asterias and Machaon; but circumstances have compelled me to postpone the Plate. If I go on with a third Volune this species will receive early attention.

In the text to Zolicaon I said: "Zolicaon belongs to the Muchaon group." Further examination of the imago shows that the two species are not members of the same group, and this is sustained by the comparison of the larval stages. Zolicaon is nearer Astericts. So far as concerns the butterflies I have treated of these species and their relationship at length in "Papilio," vol. iii., p. 45, et seq, 1883.

Papilio Oregonis. - In the descriptive text I said: "The anal spot small, . . with " rounded black spot in the middle, and which is connected with the narrow black edge of the margin." It should properly have read, "with a stripe or chub-shaped spot in the middle," etc. In the paper above referred to, in "Papilio," vol. iii., the peculiarities of the anal spots in Oregonia, Machaon, Zolicaon, and Asterias are illustrated by figures, and in the text the relationship of all these and other allied species is considered. As regards Oreyonin, I come to this conclusion: "Oregonia belongs to the Machaon group, and (perhaps with some other species) forms a sub-group of equal rank at least with the sub-group to which the species Machaon belongs. It certainly cannot have been derived from the species Machaon." I have a colored drawing of the mature larva of Oregonia, made by Mr. R. H. Stretch, and there is very little resemblance between it and the mature larva of Machaon.

Papilio Daunus. - Mr. B. Neumoegen received, in 1881, two blown skins of the mature larva of this species and three living chrysalids. One of the latter was given me, and after a drawing was made of it I put it in alcohol. The 
other two MIr. Nemmoegen retainch. One of them, on Tth September, 1882, save inagro, the other passed the second winter and then grave imago. So protracted a chrysilis period is remarkable and extremely unusual in butterflies. The caterpillar is very like that of Iiutulus, green, with a pair of club-shaped spots on fourth segment, after the pattern of liutulus, and therefore unlike Turnus. MIr. E. MI. Dotlge observed Dames ovipositing at Boulder, Colorado, 1852. By confining a female in bag over a branch of wild plum-tree he obtained many egres, and forwarded them to me. Unfortmately they were lost in the mail.

Colis Pmilonice. - The larval measurements in the text are given in the last part of the stages 3 to $\tilde{5}$. Taken at twenty-four hours from the several moults, the length would be -

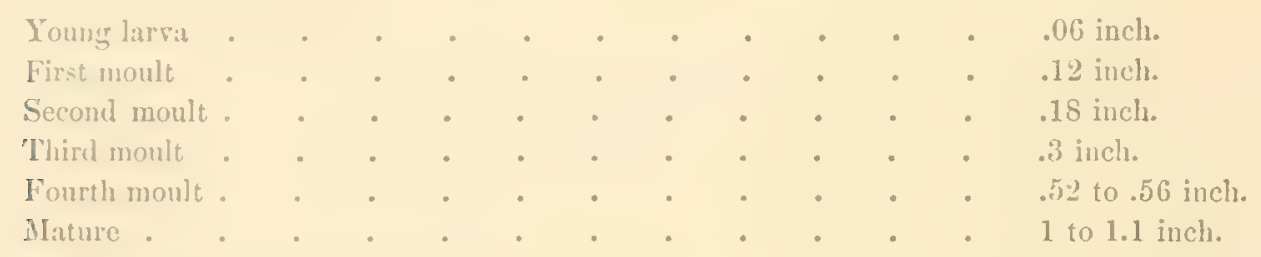

In general, the larval measurements in this Tolume have been taken at from twelve to twenty-four hours after the moult.

Argrisis Mesdr. - The extensive collections made in Nevada by Mr. Morrison render it highly probable that Meadii is an extreme variety of $\mathbf{A}$. Nevaalensis. On the Plate of Nevadensis, in vol. i., two species are figured, the male being Novadensis, the lemale Coronis, Behr, a species widely dispersed, flying from southern Cialifornia to Nontana and British America, and subject to a good deal of variation.

Melitan linetox. - In addition to the plants named in the text, the larva of this species is now known to feed on Mimulus ringens and Gerardia pedicu. latil.

Apaturi Leilis. - The male only is figured, and at the time the Plate issued the other sex was unknown. Subsequent collecting by Messrs. Doll and Morrison, in Arizonit, have made us familial with the species in both sexes.

Aratura Flora. - Under Clyton I described Flora as a possible variety of that species. In 1880, I received young larvie of Flora from Dr. Wittfeld, Indian River, Fla., who obtained eggs by confining females over branches of Celtis. Where I reared to imago. Since then I have several times had the species. It is undoubtedly distinct from Clyton. The preparatory stages are described by me in the "Cimadian Entomolorist," vol. xiii., p. \$2, 1881.

Apatura Alicis. - Figured and described in vol. $i$. This species also I liave 


\section{SUPPLEMENTARY NOTES.}

repentedly bred from the egg, and the preparatory stages were described by me in "Psyche," rol. iii., p. 123, 1880.

Satrrus Pegild, Fab. - Under S. Alope I had occasion to speak of Pegala, a species mostly confined to the southern part of the Gulf States. "Pegala is restricted to the vicinity of the Gulf of Mexico and a strip along the Atlantic const, at least as far to the north as Charleston, S. C. I camot learn that Pegula and Alope fly in the same localities or even in the same districts." Within the last two years, Mr. E. M. Aaron has discovered a few examples of Pegala in southem New Jersey, and I have seen some of them which were taken by him. 'They are like examples from Georgia, except that they are smaller. Mr. Aaron writes me that at the same time he took many Alope, but saw no evidence of any intergrading between the two species. Each was persistent to its own type. There is no reason as yet to doubt that Pegala and Alope are distinct species.

Chiofobas Califorvica. - The figures were made from a pair, two of four collected by Mr. Lorquin, and in Dr. Boisduval's collection. Since the. Plate was published Mr. Morrison has foumd the species abundant on Mt. Hood, Oregon (1S80). A series shows it to be constantly distinct from Iduna, which has also of recent years been taken in considerable numbers by Messis. Baron and Behrens, in northern California.

Lintmea Bacmuani. - The complete larval history was not known when the Plate issued, in 1874. I give it as follows:-

Young Lirva. - Length just from egg, .04 inch; cylindrical ; the segments a little rounded, and four times creased transversely; covered with a fue short down; color green, semi-translucent; head twice as broad as 2; obovoid, a little depressed at suture, the vertices rounded; sparsely pilose; color yellow-brorn. To first moult about 2 days, in July.

After first moult: Length at 12 hours, .0S and .09 inch; color brownish-green, the segments curved; head a little broader than 2, shape as before; color yellow-green. To next moult 2 days.

After second moult: Length at 12 hours, .12 inch; same shape; upper side dark green; a faint shade of yellow over and along basal ridge, rather macular; under side, legs, and feet lighter green; the seginents much specked with faint white on the ridges caused by the creases; on 3, high up, a black dot on either side; head as before; color light green. To next moult 2 days.

After third moult: Length at 12 hours, 26 to .28 inch; color dull green, yellowish along and over basal ridge; specked with pale white, or yellow-white, as before; the black dots as before; head green. To next moult about 2 days.

After fourth moult: Length at 12 hours, 4 inch. Four days later the larva reached maturity. 


\section{SUPPLEMENTARY NOTES.}

Mature LuRTA. - .7 to .9 inch; cylindrical; thickened at 3 and 4 , the dorsum of last segment abruptly curved down to the end; color dark green, the lower side, and also feet and legrs, pale green; each segment four times creased transversely, and on the flat ridges so caused are rows, one to each, of small tubercular flattened points, pale or whitish yellow; from 2 to 13 a white stripe along base just over the spiracles, and above this the ground is yellowish for a little way; a medio-dorsal yellow line and sometimes a fine line on middle of side; yellow tuberculated points over the legs, in ares of from 3 to 6 ; on foremost ridge of 3 d segment, high on the side, a dead-black tubercle, a little raised and rounded, in yellow ring; spiracles in brown ovals; surface covered with a fine short down; head obovoid, green, smooth, sparsely pilose; the ocelli brown.

Occasionally the larve in later stages are differently colored. Some have the dorsum dark green, edged on either side by a gray line, and successively by a band of yellow, a gray line, and a black band; 3 wholly, and 5 partly, black. Others are green, with a black band along base of body, and black patches on 3 and 11 ; and there is much variation in this way.

THecla Lista. - Figured in vol. i. Until 1882 this beautiful species was one of the rarest of its genus. Single examples only were recorded as taken in Quebec, Ontario, Maine, New York, West Virginia. I doubt if in all a dozen examples could have been found in the collections of butterflies in the United States. Therefore I was much surprised at learning that Mr. Morrison found it in some abundance at Mt. Graham, Arizoua. Its metropolis is in the Southwest, and hence its scarcity elsewhere. 


\section{DA'TES OF ISSUE OF PARTS $1-13$.}

Part 1. - July, 1874. - Containing Papilio Eurymedon, Anthocharis Olympia, A. Ausonoides, Argynnis Bremnerii, Libythea Bachmani, Chionobas Ictura, C. Gigas \&.

PArt 2. - March, 1875. - Containing Papilio Daume, Colias Nastes, C. Pelidne, Argymis Rhodope, Grapta Silenus, Chrysophams Rubidus, C. Cupreus, C. Sirius.

Part 3.- June, 1875. - Containing Papilio Zolicaon, Argynnis Meadii, Apatura Celtis, A. Leilia, Chionobas Gigas z, C. Califomica, Lycana Regia, L. Heteronea.

P.tiT 4. - December, 1875. - Containing Papitio Brevicanda, Argynnis Eury: nome, A. Bischoffii, A. Opis, Grapta Hylas, G. Marsyas, Melitca Phaton.

Part 5. - September, 1S76. - Containing Colias Philodice, Argymis Inomata, A. Rupestris, A. Diuna (preparatory stages of), Apatura Clyton.

PART 6. - December, 1877. - Containing Satymus Wheeleri, Papilio Asterias, var. Calverleyi, Asterias bi-formed, P. T'umus.

Part 7. - December, 1878. - Containing Papilio Indra, Anthocharis Genutia, A. Julia, Colias Eurytheme, Phyciodes Tharos, P. Phaon, P. Vesta.

PART S. - December, 1879. - Containing Limenitis Arthemis, Chionobas Ivallda, Grapta Rusticus, G. Marsyas, G. Zephymes (preparatory stages of).

Part 9. - October, 1850. - Containing Papitio Oregonia, P. Brevicanda (preparatory stages of), P. Bairdii.

Part 10. - June, 1852. - Containing Satymes Alope, Heliconia Charitonia.

PART 11. - April, 1883. - Containing Pieris Sisymbri, P. Beckeri (preparatory stages of), P. Nelsoni, Limenitis Eros, Lemonias Nais, L. Palmeri.

Part 12. - June, 1884. - Containing Lycana Pseudargiolus, Papilio Rutulus.

Part 13. - November, 18st. - Containing Papilio Rulutus, var. Arizonensis, Rutulus (preparatory stages of), $P$. Turmus (preparatory stages of). 
. 


\section{SYSTEMATIC INDEX.}

\begin{tabular}{|c|c|c|c|c|c|c|c|c|c|c|c|}
\hline Itealing of Plates. & & & & & $\begin{array}{c}\text { Numcrical } \\
\text { Order of } \\
\text { Plates. }\end{array}$ & Heading of Plates. & & & & & $\begin{array}{l}\text { Nitmerical } \\
\text { Orrler of } \\
\text { Plates. }\end{array}$ \\
\hline Papilio I. . & & • & & • & . 1 & Argynnis $V$. & & . & & . & .27 \\
\hline Papilio II. & & . & . & . & 2 & Argynnis VI. & . & & . & & 28 \\
\hline Papilio III. & & . & & . & 3 & Argynnis VIr. . & & . & & & . $\quad 2 ! !$ \\
\hline Papilio IV. . & & . & . & . & 4 & Melitien I. & & & . & & $: 31)$ \\
\hline Papilio V. & & & & . & 5 & Phyciodes I. & & $\therefore$ & & & $: 31$ \\
\hline Papilio VI. . & & . & - & 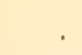 & 6 & Phyciodes II. & . & & . & & $\because: 2$ \\
\hline Papilio VII. & & . & & . & 7 & Grapta I. . & & . & & & $\because: ;$ \\
\hline Papilio VIII. . & & . & . & $\cdot$ & 8 & Grapta II. . & . & & . & & $\because 4$ \\
\hline Papilio VIII. B. & & $\cdot$ & & . & 9 & Grapta III. & & . & & & 35 \\
\hline Papilio IX. . & & . & . & . & 10 & Limenitis I. . & . & & . & & $\because i i$ \\
\hline Papilio X. & & 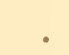 & & . & . 11 & Limenitis II. & & . & & . & 37 \\
\hline Papilio XI. . & & 。 & . & . & 12 & Apatura I. . & . & & . & & $3 S$ \\
\hline Papilio XII. & & • & & . & . 13 & Apatura II. . & & . & & . & $: \because ! 9$ \\
\hline Papilio XIII. & & • & . & • & 14 & Satyrus I. & . & & . & & 411 \\
\hline Pieris I. . & & • & & . & . 15 & Satyrus II. & & . & & . & +1 \\
\hline Anthocharis I. & & • & . & . & 16 & Satyrus III. . & . & & . & & 43 \\
\hline Anthocharis II. . & & . & & . & .17 & Chionobas I. & & . & & . & $4: ;$ \\
\hline Colias I. & & . & . & • & 18 & Chionobas II. & . & & . & & 11 \\
\hline Colias II. . & & . & & . & 19 & Chionobas III. . & & . & & & 45 \\
\hline Colias III. & & & . & . & 20 & Liby thea I. & 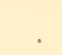 & & . & & $4 i$ \\
\hline Colins IV. & & . & & . & .21 & Lemonias I. & & . & & & 17 \\
\hline Heliconia I. & & . & . & - & 22 & Chrysophanus I. & 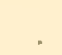 & & . & & 45 \\
\hline Argymis I. & & . & & . & . 23 & Lyсгепа I. . & & . & & . & $4 ! ?$ \\
\hline Argynnis II. . & & . & . & . & 24 & Lycæen II. & . & & . & & in \\
\hline Argynnis III. & & $\cdot$ & & . & . 25 & Lycena III. & & . & & & i) 1 \\
\hline Argynnis IV. & & & & & 26 & & & & & & \\
\hline
\end{tabular}

Note. - This Index will enable the Binder to arrange the Plates. 


\section{ALPHABETICAL INDEX.}

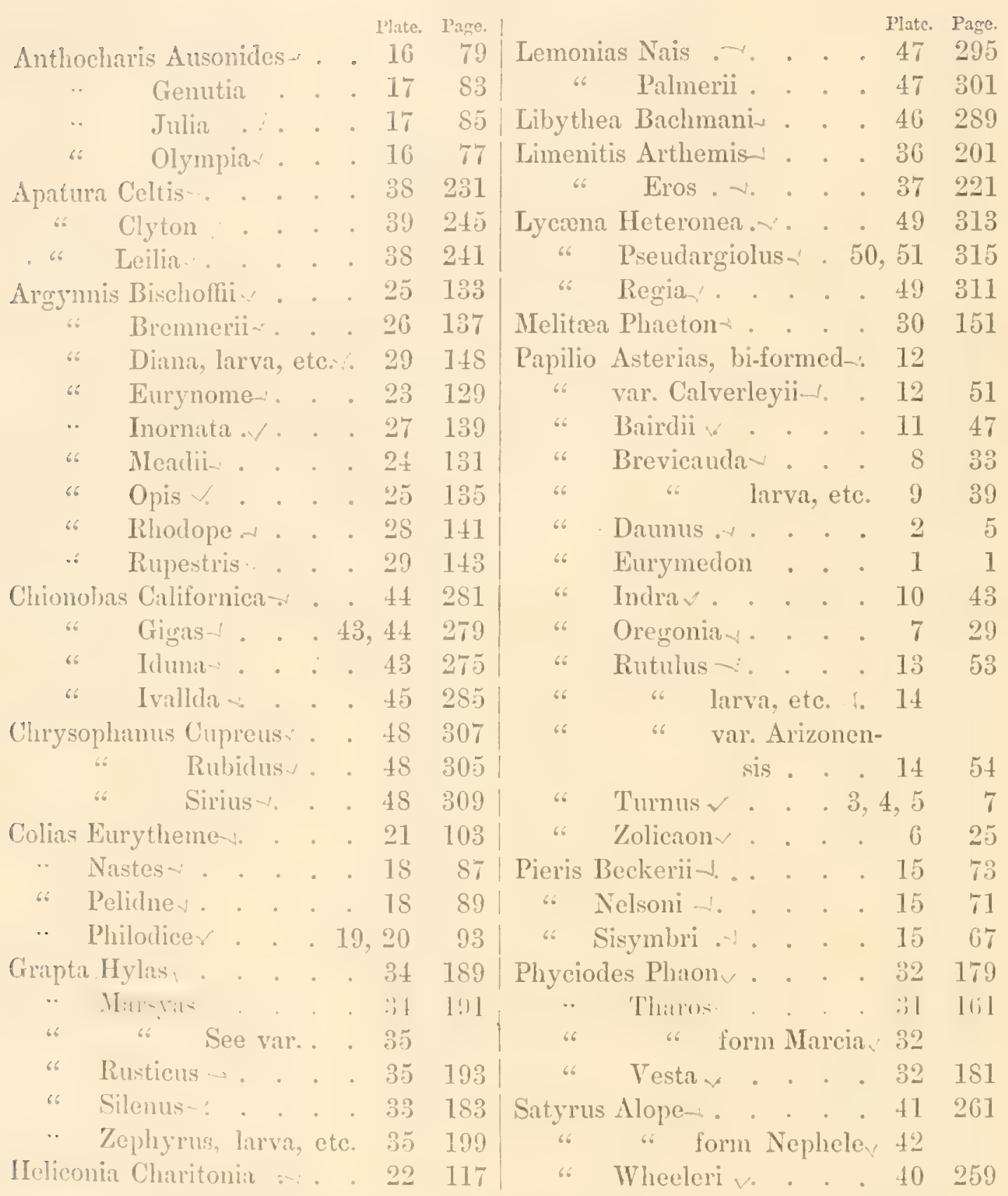

Nore. - The Plates and Pages of the hound Volume may be numbered in pencil according to this Alphabetical Index. 


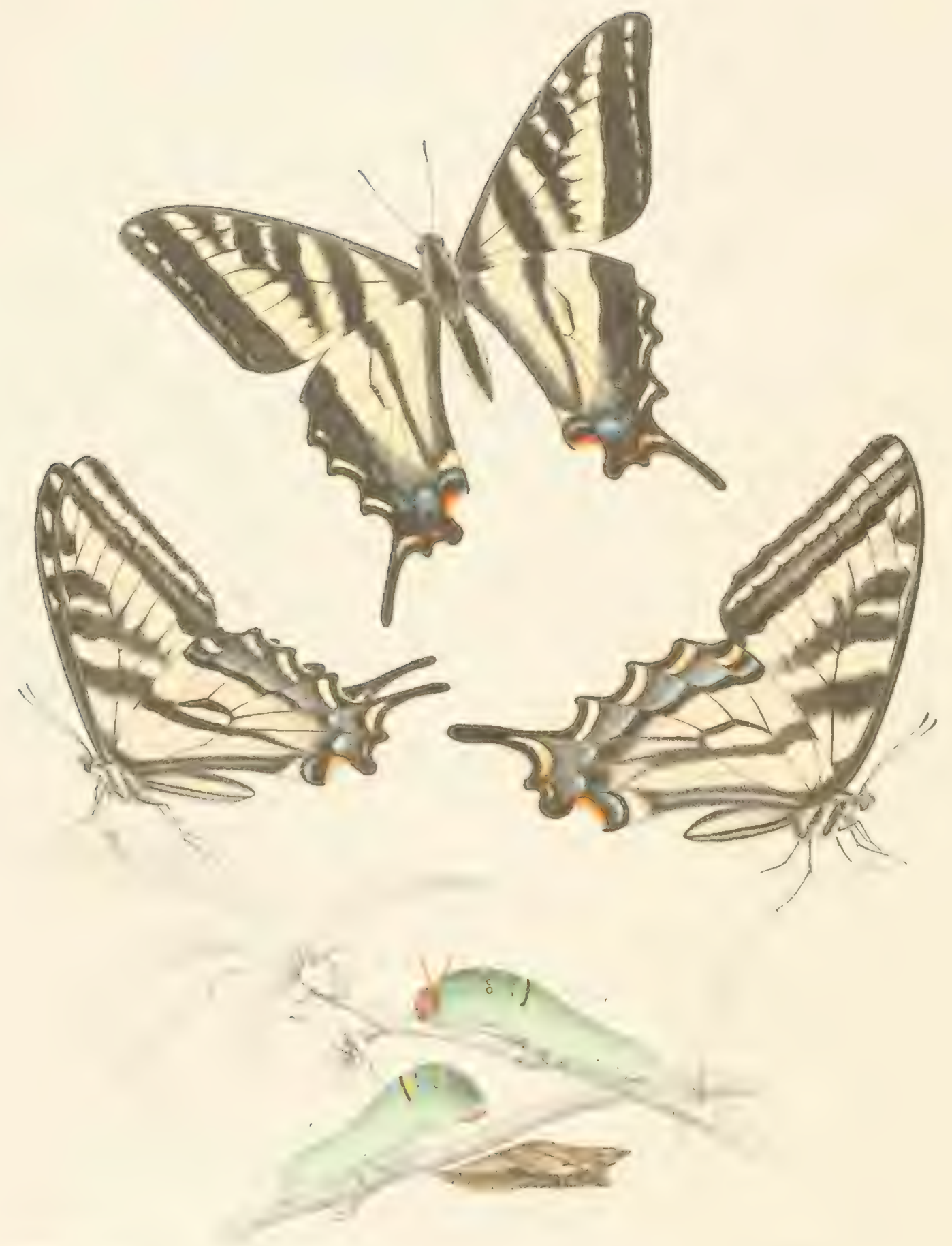




\section{PAPILIO I.}

\section{PAPILIO EURTMEDON, 1-3.}

Papilio Eurymedon (En-rym-exlon), Boisduval, Ann. Soc. Ent. de France, 18.52.

Var. Albanu, Felder, Zoöl. Novara Exped., pl. 71.

MALE. - Expands about 3.5 inches.

Upper side pale ochraceous-yellow, or often white with a buff tint, banded with black; costa of primaries black, sprinkled near base with yellow scales; a narrow band covers the bases of wings and abdominal margin; a second, proceeding from costa agrainst micldle of cell, crosses both wings and intersects the abdominal and marginal bands at lower median nervule, broad anteriorly, tapering gradually towards its other extremity; a third, nearly parallel to second, crosses primaries to sub-median; a fourth lies outside the disco-cellular nervules, stopping at median; and the fifth, abbreviated, triangular, reaches only the second discoidal nervule; the disco-central nervules of secondaries edged within by a black stripe, varying in individuals from a line to a heavy band; hind margins bordered by a wide band, within which, on primaries, is a sub-marginal series of separated, long, yellow spots, widest apically, gradually narrowing towards imner angle, and sometimes obsolete below middle of the wing; on secondaries, anterior to the tail are three narrow bars, yellow, usually more or less tinted with orange, a lunate spot at base of tail, and another near angle, small, often wanting; these two deep orange; the margin, above the angle, excised, and on the upper part of the curve an orange lumule; above this on the black ground, a lunate spot composed of blue scales, and still higher a small yellow spot; on the lower median interspace, in the middle of the black band, is a large patch of blue seales, and small clusters of similar scales are found on the two preceding interspaces, but are often wanting; that portion of the marginal band which lies within the median interspaces, next the yellow ground, sprinkled with yellow scales; tail long, slightly spatulate, edged posteriorly by yellow; fringe of primaries black, of secontlaries black at ends of nervules, yellow in the emarginations.

Under side paler, the black markings repeated; the sub-marginal spots of primaries enlarged, forming a continuous stripe, interrupted only by the black nervules; anterior to this stripe a wavy line of yellow scales; a similar line 


\section{PAPILIO I.}

within the marginal band of secontaries, edging posteriorly a line of blue lunations; the yellow gromul beyond cell tinted with orange; the sub-marginal spots enlarged, and all more or less orange.

Borly above black; a yellow line passes along the tholax from head to insertion of seconflaries; heneath, thorax yellow in front, alternately yellow and black at sides in oblique bands; abdomen yellow with one lateral and two ventral black lines; legs black; palpi yellow; frontal hairs short, black; antennæ and club black.

FEMALE. - Expands about 4 inches.

Color ochraceous-yellow, in markings similar to the male.

Mature LARTA. - Length 1.7 inch. Cylindrical, thickest at fifth segment, tapering rapidly to the last; head small, ob-ovate, pinkish-brown; body applegreen above, greenish-white beneath, as are the legs and pro-legs; on the fourth segment are six small, yellow spots, two dorsal in advance of the others, which last are near together, one pair on either side, and ringerl with black; the fifth segment edged posteriorly by a broad yellow band, which joins a black band in front of sixth, the two terminating evenly half way down the sides; fronting them is a dorsal row of four small, angular, black spots; on the eighth to eleventh segments inclusive, is a lateral row of black dots parallel to the spiracles, which also are black; retractile horns bright orange.

The figures of larva from which the drawings on the Plate were taken, I owe to the kindness of Mr. R. II. Stretch, of San Francisco.

Cimysamis. - Length 1.3 inch. Cylindrical, greatest diameter at seventh segment, tapering slightly towards head, and rapidly towards last segment; surface rough, the abdominal segments tuberculated dorsally; head case long; corrugated, the palpi cases prominent, pyramidal; mesonotal process similar to palpi cases, but little smaller, and the ocellar projections of same general form; color pale fawn, streaked irregrularly with black and brown over entire surface; on either side a dark brown band along the wing cases and down the abdomen to last segment; tubercles and spiracles black. Mr. Ienry Edwards, of San Francisco, states (Proc. Cal. Acarl. Sci., 1873) that in some individuals the gromel color of the chrysalis is pale green. In this respect this chrysalis resembles that of Pupilio Thmus, which is occasionally green, though the usual shade is brown. Mr. Edwards grives Frangula Californica as the food-plant of the caterpillar. D1. Behr informs me that the chrysalis is often found by gardeners among their plants: and it is probable that the species feeds upon many plants, as dloes Tumes, which is to be found upon apple, thom, cherry, ash, tulip, birch, and others.

Individuals of this species vary inuch in the breadth of the black bands and in 


\section{PAIILIO I.}

the shade of the ground color. Those from elevated regions are undersized, and the bands are broaler in proportion. At the same time the ground color is paler. It is this upland form that has been named Albanus.

Eurymedon is found over the Pacific slope from Mexico to the borders of Aliaska. Also in Vancouver's Island, and inland throughout all the Territories as far as Colorado, where it has crossed the "divide" and made itself a home in the valleys of the Platte and Arkansas. Mr. 'T. I. Mead, who collected in Colorado, in 1871, considers this a rare species in that State. He writes: "A few Eurymedon were seen near Turkey Creek during the first week in June, resorting with Rutulus to the open woods and hill-sides where flowers were abundant."

Mr. Henry Edwards says of this species: "It is especially common in all the eanions of the Const Range and in the valleys of the Sierra Nevada. In California it is double-brooded, the first appearing from February to April, and the second from August to the last of September. In the warm days of March, it may be seen flying quietly along the margins of the streams which. flow from the mountains. It is rather a shy insect, but occasionally a clond of them may be seen settled on the edge of a mud-pool, their wings erect and swayed about by the wind like a fleet of boats with their sails set. In this condition, it is easily approached and captured, but once alarmed, it makes a bold dash for the tops of the trees, and is soon out of danger. I am led to believe that this butterfly is extremely rare east of this range of mountains."

Eurymedon in all respects, save in color, is wonderfully like Tumns. The shape is the same, and the arrangement of the bands and the form and disposition of the spots. The caterpillars are however distinct. 'The two species are part of a sub-group related to each other, as are the several species of Grapta that are allied to $C$. album. 


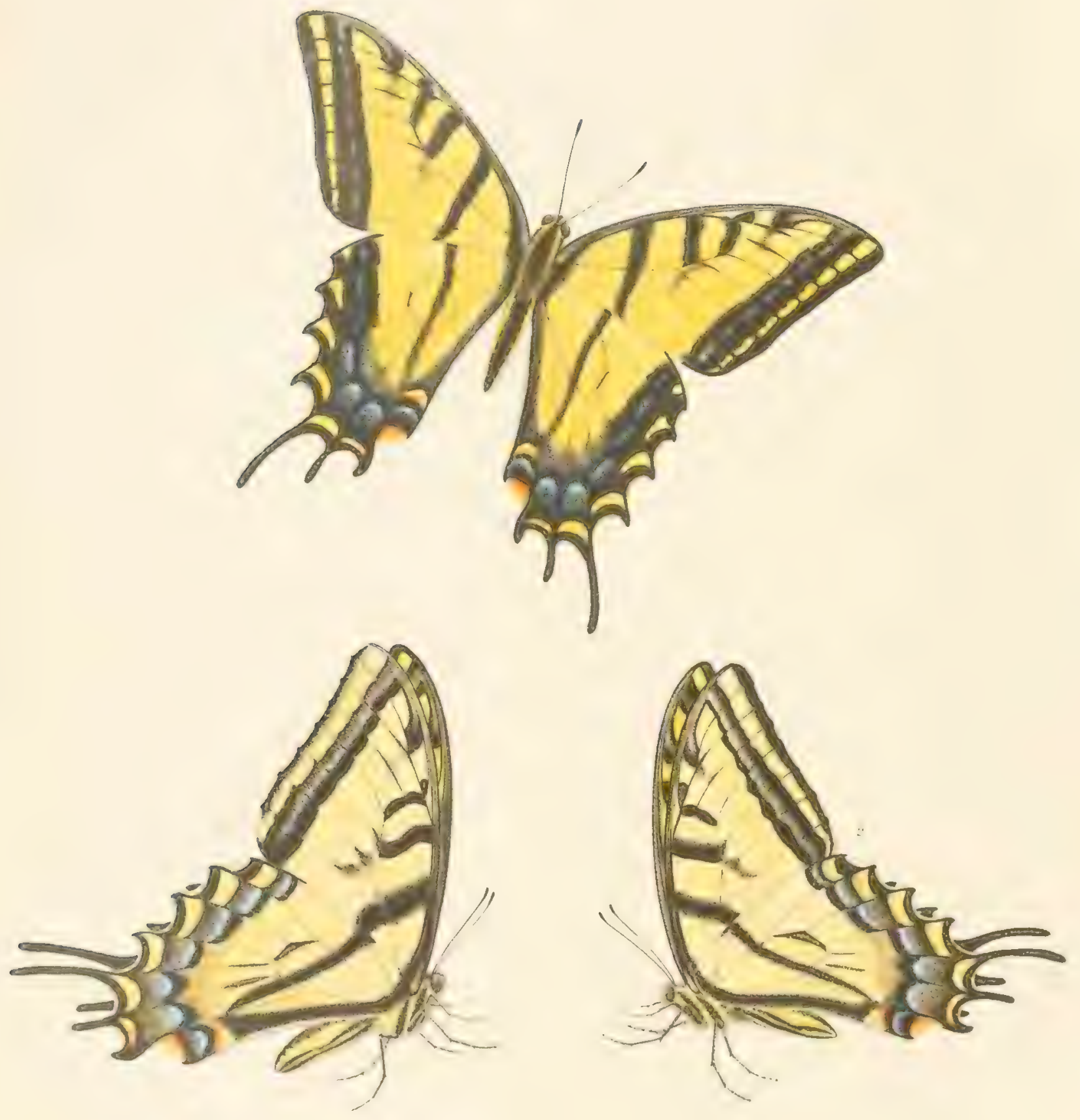




\section{PAPILIO II.}

\section{PAPILIO DAUNUS, 1-3.}

Papilio Daunus, Boisdural, Spec. Gén. des Lépid. I. p. 342, 1836. Ridings, Proc. Ent. Soc. Phill. 1562, p. 278.

Size and general form of Thrme; primaries more produced, more falcated; secondaries deeply dentated, many-tailed.

MiLE. - Expands about 4 inches.

Upper side bright yellow, banded with black after the same pattern as Tumus and Eurymedon; the costal and discal bands more delicate than in those species; costa of primaries black, sprinkled with yellow; a narrow band covers the bases of wings and the abdominal margin; a second, proceeding from costa at about two fifths the length of cell, crosses both wings and joins the first at lower branch of median nervure, broad anteriorly, tapering gradually, sometimes restricted to a narrow stripe or a line on secondaries; a third crosses the cell to sub-median nervure, but often is more or less obsolete below the cell, or represented by a few scales only; a fourth covers the are; in the costal interspace a club-shaped spot, inclosing a yellow stripe, and lying along the costal nervure, ending at the marginal border; sometimes black patches on the discoidal nervules; hind margins bordered by a broad common band, within which, on primaries, is a narrow yellow band, tapering from costa to inner angle, divided into spots by the black mervules; anterior to this a line of grayish-green scales, sometimes wanting; on secondaries are four wedge-shaped or lunate, sub-marginal, yellow spots, the one at outer angle small, sometimes a point only; a fifth spot on second median interspace, lunate, somewhat washed with fulvous; and a sixth, also lumate, wholly fulvous, near angle; above the angle the margin is excised and edged with fulvous; above this, on the black ground, a small cluster of blue scales, and an orange spot; in the median interspaces, within the marginal band, are patches of blue scales, and sometimes smaller clusters are found in each interspace to costal edge; the disco-cellular nervules more or less edged on the imer side by black; the exterior tail is long, narrow, convex outwardly; the second is two fifths the length of the first, straight, narrow; the third, at the angle, is half the length of the second; fringe of primaries black, of secondaries black at ends of nervules, yellow in the emarginations. 


\section{PAPILIO II.}

Under side paler, the black markings repeated; the sub-marginal yellow band minterrupted, dilated; the line of gray scales distinct; the sub-1marginal spots on secondaries much enlarged and the black ground next anterior to these densely corered with olive-green scales, on the imner edge of which are blue stripes and lumations; the rellow gromd in the median interspaces and near the marginal hand washed with fulvous; the two upper branches of median edged with black next the cell.

Body above black, a yellow stripe passing along thorax from head to insertion of recondaries; beneath, thorax yellow in front, alternately yellow and black at sides in oblique bands; abdomen yellow with two ventral and one lateral black line, the former coalescing at last segment, the lateral curving downward and touching the ventral at middle of the abdomen; legs black; palpi yellow; frontal hairs short, black, next the eyes yellow; antemna and club black.

Feyne. - Expands 4.5 inches.

Color deeper yellow than in the male; the black markings heavier; the line of greenish scales dilated to a broad stripe; otherwise very much as in the male.

LARVA unknown.

Mr. Henry Edwards says of this species: "It is found in rather high regions. I have seen it most abundant at Virginia City, where it flies in the mountain cañons, as Rutulus does in those of the valley. I have also taken it on the const range in Napi Comty, and near Mt. Diable, and have some beautiful specimens which I found at the Dalles, Oregon. I did not see it in Vancouver. It may be regarded as one of our rarities."

Daums has been brought from Southern Utah and Arizona by Lieutenant Wheeler's expeditions, and from Montana by those of Dr. Hayclen. According to Mr. Ridings, the specimen deseribed by him was taken in Kansas. 



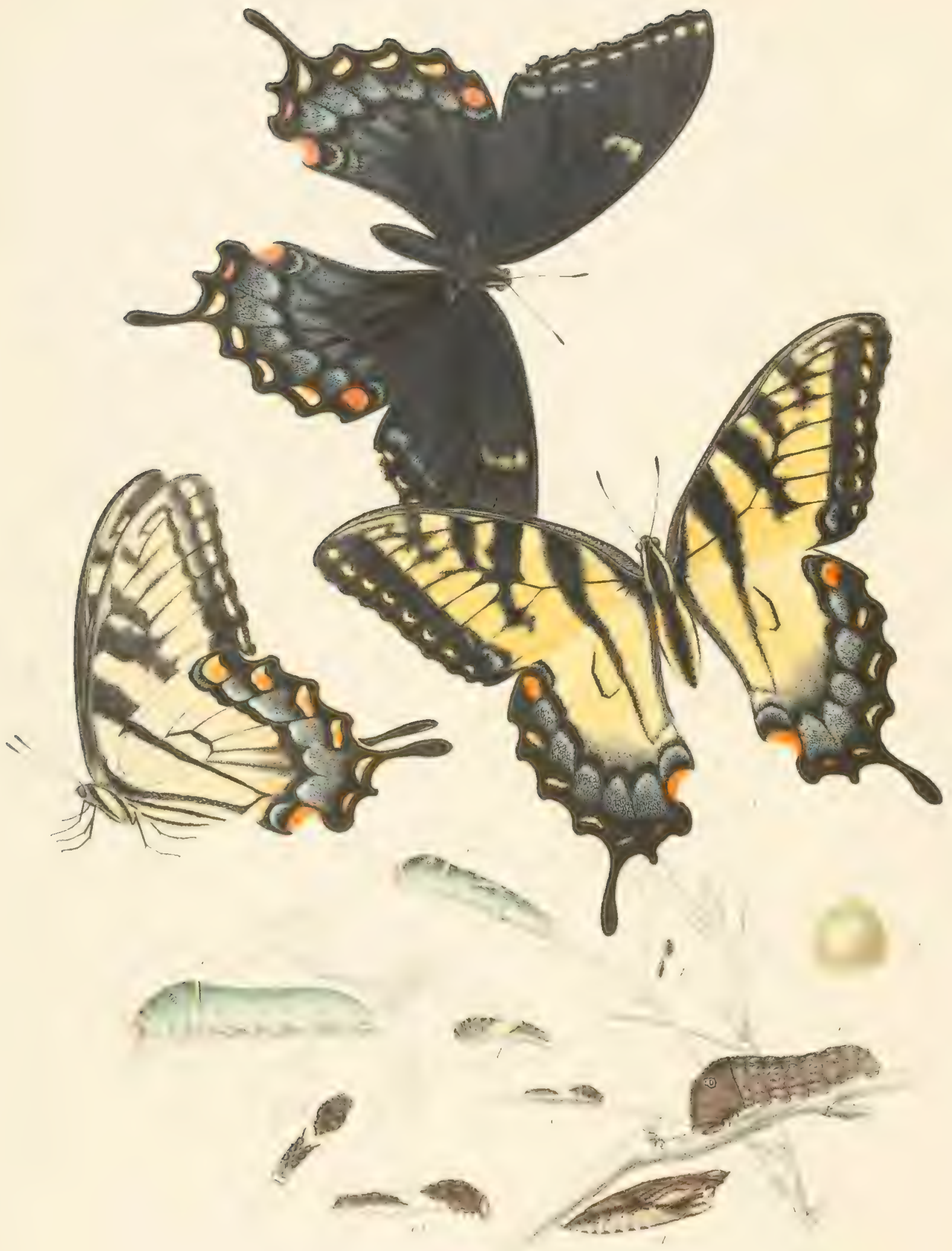




\title{
PAPILIO III., IV., V.
}

\author{
PAPILIO 'TURNUS.
}

Papilio Turnus, Lian., Mant., I., p. 536, 1771. Fub. Syst. Ent., p. 452, 1775. Ibid., Sp. Ins., II., p. $16,1781$. Godart, Enc. Meth., IX., p. 5j, 1819. Say, Am. Ent., Ill., pl.40, \&, 1825. Bois. and Lec., p. 19, pl. 6, 7, \$, 1833. Boisduval, Snec. Ge1., I., p. 338, 1836. Harris, Ins. Mlass., 2d ed. p. 268, 1862 . Saunders, Can. Ent., VI., T. 2, 1874.

Alcilamas, Cramer, Ins., I., yl. 38, 1779.

GLAUCUS, dimorphic form \&, Linn., Mus. Uhl, p. 190, 1764; Ibirl., Syst. Nat., Ir., p. 746, 1767. Fab. Syst. Ent., p. 445, 1775. Cramer, Ins., II., pl. 139, 1779. Godart, Enc. Meth., IX., p. 60, 1819. Bois. and Lec., p. 22, pl. 8, 9, 1833. Boisduval, Spec. Gen., I., p. 335, 1836.

MALE. - Expands 3.5 to 4.5 inches.

Upper side usually bright yellow, but often pale, banded with black; costa of primaries black, dusted more or less throughout, and densely next base, with yellow; a narrow band crosses the bases of both wings, and the abdominal margin, and near the outer edge of the yellow discal area bends inward at an obtuse angle and meets the second band; this rises on costa of primaries against the middle of the cell, and crosses both wings, is broad on primaries, but narrows gradually as it approaches the inner margin, and on secondaries becomes a slender stripe tapering to a line on the disk; the third band crosses the outer part of the cell of primaries and terminates either at median nervule, perhaps projecting beyond this a cluster of scales, or passes on to the lower branch of median; is often narrow, sinuous, but sometimes is a diffuse patch rather than a band; the fourth lies mostly on the outer side of the are, and varies in breadth and shape; the fifth is sometimes marrow and reaches from costil to second sub-costal nervule; but most often it forms a rounded knob to a club-like band which connects it with the hind margin and underlies the sub-costal nervure, and both knob and band are dusted with yellow; the hind margins bordered by a common band, which varies much in width, and as a rule is much broarter in examples from the south, though there are many exceptions; on primaries the inner edge of this band is either even, or it is slightly excavated in each interspace; and through it runs a sub-marginal series of small yellow spots; 
I'A PILIO III., IV., V.

these vary much, sometimes being rounded, sometimes lunular, or occnsionally double-convex, or mostly mere streaks; in some cases quite obsolete on the posterior half of the wing; on secondaries the margin is about one half broader, and often in very melanic individuals extends high up the disk on the posterior half of the wing, and is there much dusted with yellow; there is a sub-marginal series of six large spots, usually lumular, of which the four inner are yellow, the other's, one at ench angle of the wing, deep orange, and smallest; the abdominal margin above the angle excised, and there edged by an orange lunule, over which is a metallic-blue lunular cluster of scales on the black ground; loose clusters of blue scales also on the two lower median interspaces; sometimes these are obsolete, and the sub-marginal lunules are reduced to streaks; primaries usually have all the nervules black, and the sub-costal, especially; is heavily edged, but on secondaries the nervules are yellow, except the discocellular, which are covered by a black stripe; tail long, narrow, convex outwardly, on the imner side spatulate; at the end of second branch of median is a prominent dentation and there is another at anal angle, and in some cases these are so developed as to show a considerable approximation to the tails of Dumus; fringes of primaries yellow in the emarginations, black at the ends of the nervules, about equally divided; on secondaries yellow predominates.

Under side pale yellow; the nervules nearly all black; the sub-marginal spots of primaries enlarged, often confluent, and then forming a continuous stripe; anterior to this is a broad stripe of yellow scales which nearly covers the black ground; secondaries have a similar stripe and on its anterior edge is a line of blue lumatious; the yellow ground, next the margimal band, in the four or five posterior interspaces, more or less suffused with orange; the sub-marginal lumules all more or less orange, this color being sometimes limited to a patch on the milldle of ench lumule, but the one at anal angle is usually wholly covered, as is that at the excision.

Body above black; a yellow stripe passes along the thorax from the head to the insertion of secondaries; beneath, the thorax is yellow in front, alternately yellow and black on the sides in oblique stripes; abdomen yellow with a lateral black line from the wings to the last segment, and with two ventral lines posteriorly; legs black with a yellow stripe in front; palpi yellow; frontal hairs short, black; antenna and club black.

LiMaLE. - Same size.

Color rleeper, decidedly ochraceous on primaries and along the abdominal margin of secondaries, the remainder of secondaries usually colored as in the male, but sometimes also ochraceous; the markings as in the male, but the bands are heavier; blue patches on the inner half of the marginal border of 



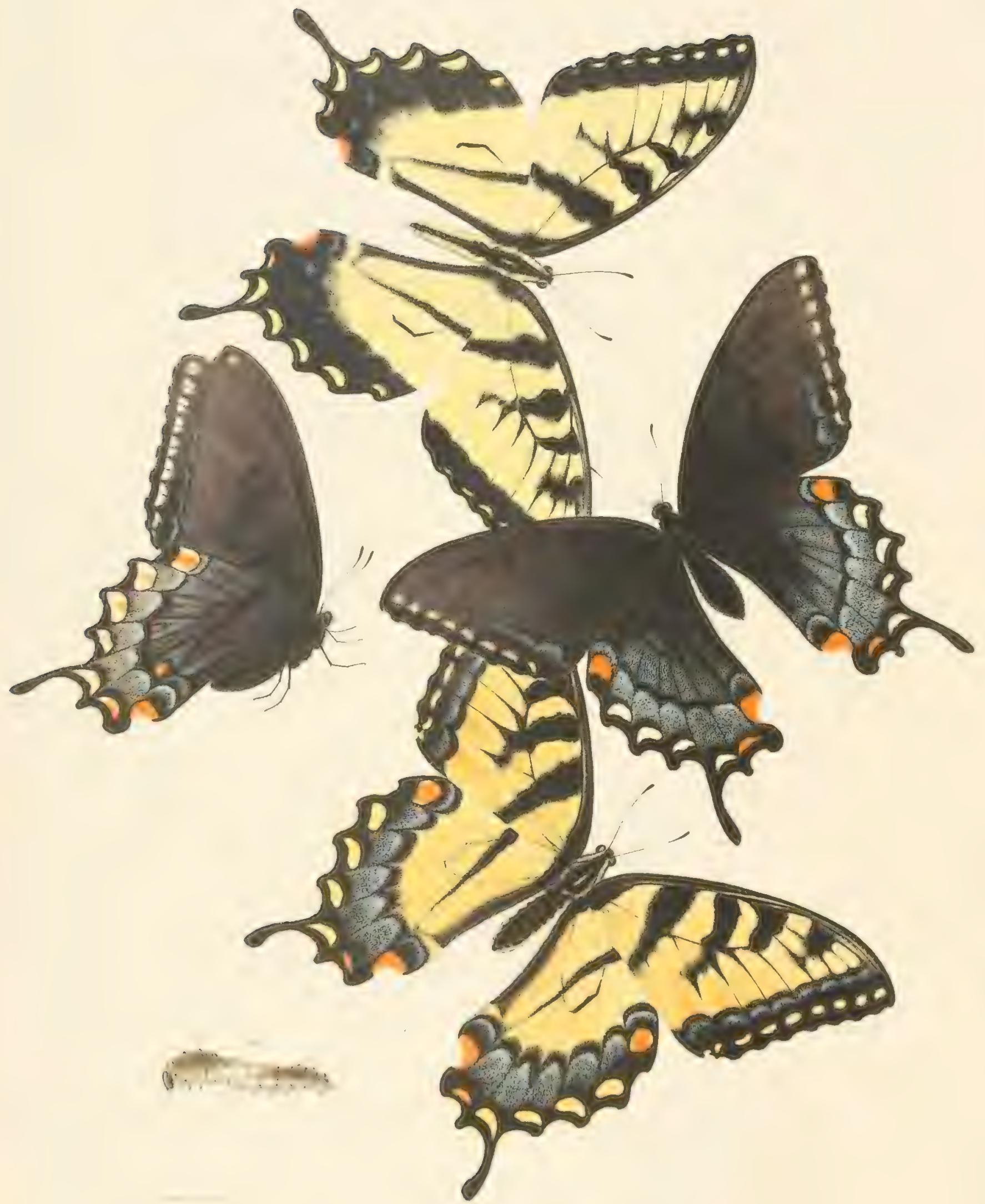




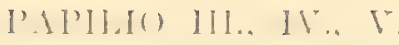

secondaries fill the interspaces across the whole wing, often taking a lanceolate shape; blue scales sometimes besprinkle the yellow ground quite up to the cell; the sub-marginal spots as in the male; in many individuals there appears a stripe of blue scales upon the inner side of the marginal border of primaries at inner angle. Under side as in the male.

GLAUCUS, dimorphic form; always fomale.

Upper side black; primaries without markings, except a sub-marginal series of yellow spots, which are similar to those of the yellow forn, but smaller and often minute; occasionally also there is a yellow lunate spot at the outer extremity of the cell, most often indistinct, but sometimes large and conspicuous; secondaries have the spots on both margins, and also the blue band, as in the yellow female; the disk nearly to base often thickly sprinkled with blue scales, and always in some degree. Under side black or bromnish-black; the black discal bands characteristic of the species are present in this form, distinct on secondaries, but faint on primaries, and in the blacker examples partly wanting, especially beyond the cell; the marginal black border sometimes distinct, but often only indicated by a deeper shade at immer angle, the inclosed spots as in the yellow female. (Plate III., Fig. 3, summer brood; Plate IV., Fig. 2, 3, winter brood.) 'The larger examples of the summer brood often have primaries strongly filleated.

Examples are occasionally seen of a chocolate-brown color, or of yellow suffused with brown, and in these cases all the bands are distinct; on the under side yellow or gray-brown, more or less suffused with black. (Plate V., Fig. 2.) Others occur mottled with patches of black and brownish or grayish-yellow. (Plate V., Fig. 3.)

The bi-formed female represented on Plate V., Fig. 4, was taken at Coalburgh, and, as will be seen, the right side is yellow, the left black, the dividing line passing down the middle of the body. 'This insect is distinguished as belouging equally to two of Huibner's coitus, by some esteemed genera, the yellow half being a Jasonides, the black Euphoeades.

EGG. - Sub-conoidal, the breadth and height equal, flattened at base, smooth, deep green, soon changing to greenish-yellow, and specked with reddish-brown. Duration of this stage eight to ten days. (Fig. $u$, magnified.)

YouxG Lirva. - Lengrth, .I inch; cylindrical, the anterior segnents thickened; color, black-bromn; on 7 and 8 is a white patch, saddle-shaped, reaching on dorsum to middle of 9 , and descending the sides on 7 and 6 to base ; at each end of a compressed chitinous cross-ridge on 2 is a large tubercle, rounded, 
sulb-ovoid, with one hair at top and six about the sides, these last rising from little spuns, cach lain ending in a knob; on dorsum of each segment, from 2 to 13 inclusive, are two points, with one short hair to each; and there are two subforsal rows of tuberclex, those on $3,4,11,12,13$, in shape as on 2 , but small and low, ench with a few clubbed hairs; from 5 to 10 , minute, without hairs; on cither side, a row of tubercles from 3 to 12 , with a point in same line on 2, bearingr a single hair; on 3 and 4 these are small, and show three and two hairs respectively, the remainder mere points without hairs; below the spiracles a row of points, on 2 one, on 3 and 4 three each in horizontal line, on 5 to 12 three ench in equilateral triangle, each point bearing one hair"; head ob-ovoid, brown. (Figs. $c, c^{2}, c^{3}$, XIII.; $b$, III. ; $a, I V$.; the last two representing the larva near the end of the stage.) To first moult about four days.

After first moult: length, at twelve hours, .25 inch; same shape; color, blackbrown; a black medio-dorsal line, expanding a little on 3 and $t$; the patch saddlo-shaped, very much as before, white; on front of 2 a compressed crossridge, with tubercles as before, more conical; 13 has a pair of similar tubercles, also on a ridge, 12 a smaller pair, and on 11 and 10 each two low cones; on 3, 4,5 , are two sub-dorsil rows of low, round, glossy, brown knobs; between these on 3 are two similar knobs, but minute, and the four are in line; in some exanples there is an additional small knob high on the side, the six being in line; on 4 the dorsals are in advance of the sub-dorsals, and there are always two outside, six in all; on this segment, the two outer knobs on either side ench have a lilac spot on the dorsal side; 5 has but four knobs, the dorsals much in advance, and these last have each a lilac spot on inner side; $6,7,8,9$ have no knobs or spots, but the points on 10 and 11 have each a lilac spot; head rounded, broadest below, the top depressed; color, dark brown. (Figs. e, $e^{2}$, XIII.) Later in the stage the surface is more or less mottled dark and light brown, with a greenish tint in some examples; the white of the patch changes to pale yellow. (Figs. $c, c^{2}$, III.) Duration of this stage about five days.

After second moult: length at twelve hours, .5 inch; much the same shape; color, black-brown, with shades of lighter; on back of $2,3,4$, a black patch to cach; the saddle yellow-white, and extending low down the sides; the last two segments mottled brown and yellowish; the ridge on 2 as before; at either end a small cone, the top of which shows several spurs, each with short hair; on 13 similar cones on ridge, on 12 a smaller pair; on 3 are six knobs in line, the dorsal pail small, the outer pair a little larger, the sub-dorsals large; on 4 are six, the dorsals large, the rest a little sumaller and equal, and on the inner side of each of these list is a lilac spot; also on the anterior outer side of each subdorsal a black bar; on 5 are two knobs in front, as large as the outer pair on 4 , 


\section{PAPILIO III., IV., V.}

and two sub-dorsals behind of same size, each of the last with lilac spot; on 9 to 12 are two sub-ilorsal lilac spots; head as at last previous stage. In a few lours the patch is tinted with red. (Lig. d, III.) Duration of this stage about four days.

After third moult: length at twelve hours.6 to .62 inch; anterior segments thickened; color in most cases dark brown, more or less mottled with lighter brown, the segments after $S$ darkest; other's have the anterior segments green, more or less soiled with brown, the posterior as first described; and others still are clear green anteriorly, the last segments brown mottled with green, especially on dorsum, the lower part of side whitish-green; the pateh salmon, and extending nearly to base, but in some eximples the red is overlaid, especially on dorsum, with pale green; "2 has the front ridge arched as before, the processes reduced; on 4 now appears a sub-oval greenish-yellow patch, the larger end outward, edged by a fine black line; inside, a henvy black ring, with an inner spot of lilac, and on dorsal side of the ring a black bar; next the pateh is a sub-dorsal lilac spot, rounded or quadrangular, often discomnected (as in lower Fig. $l i$, XIII.); at this period these patehes are separated across dorsum by a space varying from .12 to .15 inch (these are the extremes in 37 examples); on 5 are four equal lilac spots in line across posterior edge, two sub-clorsal, two lateral ; 9, 10, 11 have each four such spots; some larva have a pail of minute sub-dorsals on 12, others have four also on 7 , and none on dorsum of 8 ; from 6 to 12 a lilac spot on each segment, below spiracles; at either end of the ridge on 13 a low cone, and traces of a similar pair on 12, scarcely more than a slight elevation of the skin; head brown, pink tinted. (Fig. $t^{2}$, III., $h, h^{2}$, XIII.) As the starge progresses, the greener larve become uni-colored, and the darker become more green, but in the latter more or less brown remains to the and; in some cases the salmon patch hecomes wholly ehanged to green and is lost, in others its position is indicated by a paler shade of green, and often a little salmon at the edges on dorsum; the posterior edge of 5 becomes yellowish, and on the front of 6 is a black transierse band, concenled when the larva is at rest. (Fig. e, III.) Duration of this stage foul to seven days.

After fourth moult: at twelve hours from .9 to .95 inch; color invariably green, no matter what was the hue before the moult; the patch alnost always wholly suppressed, but occasionally traces of it can be seen in an indistinct salmon spot on either side of rlorsum. In five or six days is fully grown.

Miture TaArva. - Length, 1.5 to 1.5 inch; cylindrical; thickest at 4, 5, sloping on back and sides to 13 , and rapilly to 2 ; color, yellow-green, velvety, shading on the sides into whitish-green; under side white; leg's and pro-legs 


$$
\text { I'HUIJU III. IY.. Y. }
$$

yollowish; 2 has a narrow arched chitinous frontal ridge, the corners rounded; close to the back of this ridge is the orifice through which the scent organs are protruded at will, lone, slender, tapering to a blunt point, when fully extended, and bifureated at base, the color orange-red; (the larva at every stage from the egg las the use of these organs); on either side of 4 a sub-oval or pyriform greenish-yellow, or partly ochraceous patch, edged by a fine black line; on the outer part of this a heavy black ring, rounded or oval, enclosing a purple spot, and toward dorsum a black bar; the imner extremities of these patches are separated across dorsum by a space measuring .16 to .18 inch; 5 is edged on the posterior side by yellow, and the front of 6 has a black band restricted to dorsum; on 4 are two purple spots or dots, one on either side dorsum near the patcli; on 5 four spots in line near the posterior edge; on $8,9,10,11$, four to each, those on 8 small, sometimes partly or wholly obsolete; on 12 two subdorsal, small; on 6 to 12 one to each segment below the spiracles, small; head 'ather square, flattened in front, the top a little depressed, the vertices rounded; color brownish-pink. (Figs. $f$, III., $j, j$, XIII.) At about seven days before pupation the green becomes more yellow and a dull shade of it covers dorsum; and within twenty-four hours the whole boty changes to chocolate-brown, specked and mottled with grayish on segments after 5 and along base before 5 ; the purple spots retain their hue. (Fig. $f^{2}$, III.) Suspension takes place at one to two days from this change of color and pupation from one to two days later. From fourth moult to pupation about ten days. From laying of egg to pupation, in August and September, 32 to 38 days.

Cinrsalis. - Length of several 1.3, 1.4, 1.45, 1.48 inch, the larger being female; greatest breadth 1.3, 1.4, 1.44 inch; cylindrical, thickest at 5 and 6 , the abdomen tapering rapidly; head-case long, compressed at top transversely to an edge; the projections prominent, divergent, pyramidal, the edges raised into corrugated and thickened ridges, the tops rounded, the incision between them a right angle, with a small tooth on either side near the angle; the small projections at side of head pyraniclal, with thick, rough edges; the mesonotum prominent, but variable in length and thickness, directed forward, blunt and corrugated at end and on anterior side; two sub-dorsal rows of tubercles from 4 to 13 , largest on $8,9,10$, the rest small, on 6 and 7 nearly or quite wanting; below these another row on either side, small, from 4 to 13 ; whole surface corrugated; color variable, some examples being light or wood-brown, striped longitudinally on sides and dorsum with dark brown; others are very dark throughout, and some are green over wing-cases, sides and entire dorsal area, the abdomen light brown, or green only about the head and sides. (Fig. $g$, III.) 
PAPIIIO III., IV., V.

From a brood of larva, at Conlburgh, 1875, the first chrysalis formed July Ist, the last July Stlı; the first butterfly emerged July 23 ; others appeared at intervals till August 11th. Of fifty chrysalids twenty-seven gave butterflies that season, and the remainder not till the following spring. Duration of the chrysalis period in summer about twenty days. From a brood of larva, 1884, the first chrysalis formed 29th September, the last 4 th October, and all of them will hibernate. (I have re-written, in 1884, as this Volume is about to close, the deseription of Tumus larva which accompanied Plate III, issued 1STT, in order to make a direct comparison of each stage with a corresponding one of Putulus; and on Plate XIII. have figured several stages of these two species side by side.)

Turnus inhabits all sections of the United States from the $\Lambda$ thntic to the Rocky Mountains, and from Minine to Florida and Texas. A few intividuals were seen by Mr. Mead in Colorado, but the species there begins to be replaced by Rutulus, which occupies the remainder of the country to the Pacific. It inLabits also British America, and Newfoundland. I fomerly received several examples from Mrs. Christina Ross, taken at Fort Simpson, and others from the late Robert Kemicott, taken at Fort Youcon, both about lat. 65․ MIr. Seudder, "Proc. Bost. Soc. Nat. Hist." XII., p. 44, mentions the receipt of a large number from Lieut. W. H. Dall, "taken early in June, on the Upper Toucon, from Nulato to Fort Toucon, where the species is said to be common." There is a great difference in size between these indivichals from the fir north (Plate $T$., Figr. 1) and the usual type in the southern States, the former being small, with narrow border's and slight stripes rather than bands. Some from the White Mountains scarcely differ in both respects from those taken in Aliaska. In the Catskills the prevaling form is intermediate. Where the species is doublebrooded, as a rule, the butterflies emerging from over-wintering chrysalids are smaller and with narrower bands than are those of the summer broorl.

The larva feed on the leaves of a great rariety of trees, - apple, quince. thorn, plun, cherry, birch, basswood, ash, and, accorling to MIr. Seudder, on alder and oak; also, according to Mr. Akhurst, ou sassafias and catalpa. But in my neighborhood, its preference is decided for the tulip-tree, Liriodendron tulipifera, usually miscalled "poplar" at the south and west, and I have never found it here on any other tree. In Ontario, according to MIr. Saunder's, it chicfly fechls on apple, cherry, thorn, and basswood. 'The egg' is laid on the upper side of the leaf, and the young larvir takes up its abode on the same side, lying on a bed of 
silk which it spins for the purpose, and going to the edges to feed when disposed. $\Delta$ s it increases in size, the leaf is somewhat drawn together, so that on the large leaves of the tulip tree it is not difficult to discover one of these larva. It is sluggish in habit, usually moving only when impelled by hunger. When full grown it stops feeding, and in course of about thirty-six hours changes color completely from green to brown, and at this stage deserts its tree and often travels, and that with considerable rapidity, many yards or rods until it finds a suitable place for its protection while in chrysalis. 'The butterfly emerges, in the neighborhood of Coalburgh, early in April, or if the weather has been favorable, in March, sometimes as early as the fifteenth day of that month. In Maine, Mr. Scudder says, it appears about the first of June. In Ontario, its time is the last of May. At Coalburgh, the males are to be seen, on any warm day of spring, gathered in groups of from half a dozen to fifty, by the edge of the water, in company with Papilios Ajax, Philenor", and later', 'Troitus. 'The females are not found in such situations, but they frequent the fruit trees then in bloom (as do the males in some degree), peach, apple, and above all the wild plum. Later in the season, both seres abound on the red clover, then on the Asclepiades and thistles, and finally, at the close of the season, on the iron-weed, Vernonia. In the garden they delight in the lilacs, phloxes, and zimnias. Another plant, Catananche bicolor, with its tall mullein-like flower stalks, is also very attractive to Thurnes.

On the wing the males are swift, and when alarmed, soar high in air or among the trees; but when settled in groups by the water, or feeding on flowers, they are fearless, and may be captured with the utmost ease. Mr. Scudder mentions the fact of sixty-nine Thmus being caught between the hands at one grasp. In the "Canadian Entomoloyist," V. p. 19, Mr. Couper relates as follows: "I passed two months of the summer of 1871 on the Black River, about one hundred and forty miles north of Montreal, residing in a shanty on the road which follows the river through the mountains. Water in which pork had been parboiled was thrown out on the sandy lawn opposite the door, and I noticed that hundreds of Ihums frequented this spot during favorable weather, thrusting their tongues into the moistened siurd, when the fluid absorbed, for which they seemed to have such an extraordinary liking, rendered them semi-intoxicated. I have seen them flying from all quarters direct for the shanty. Nany of them, I believe, ame from a distance of two miles at least."

'l'he species of Papilio are subject to this sort of intoxication. There is a large patch of Asclepias purpurascens growing near my house, and all day long the flowers are thronged with butterflies, the Papilios especially abounding; and many may be seen hanging motionless and for a long time, with heads and 



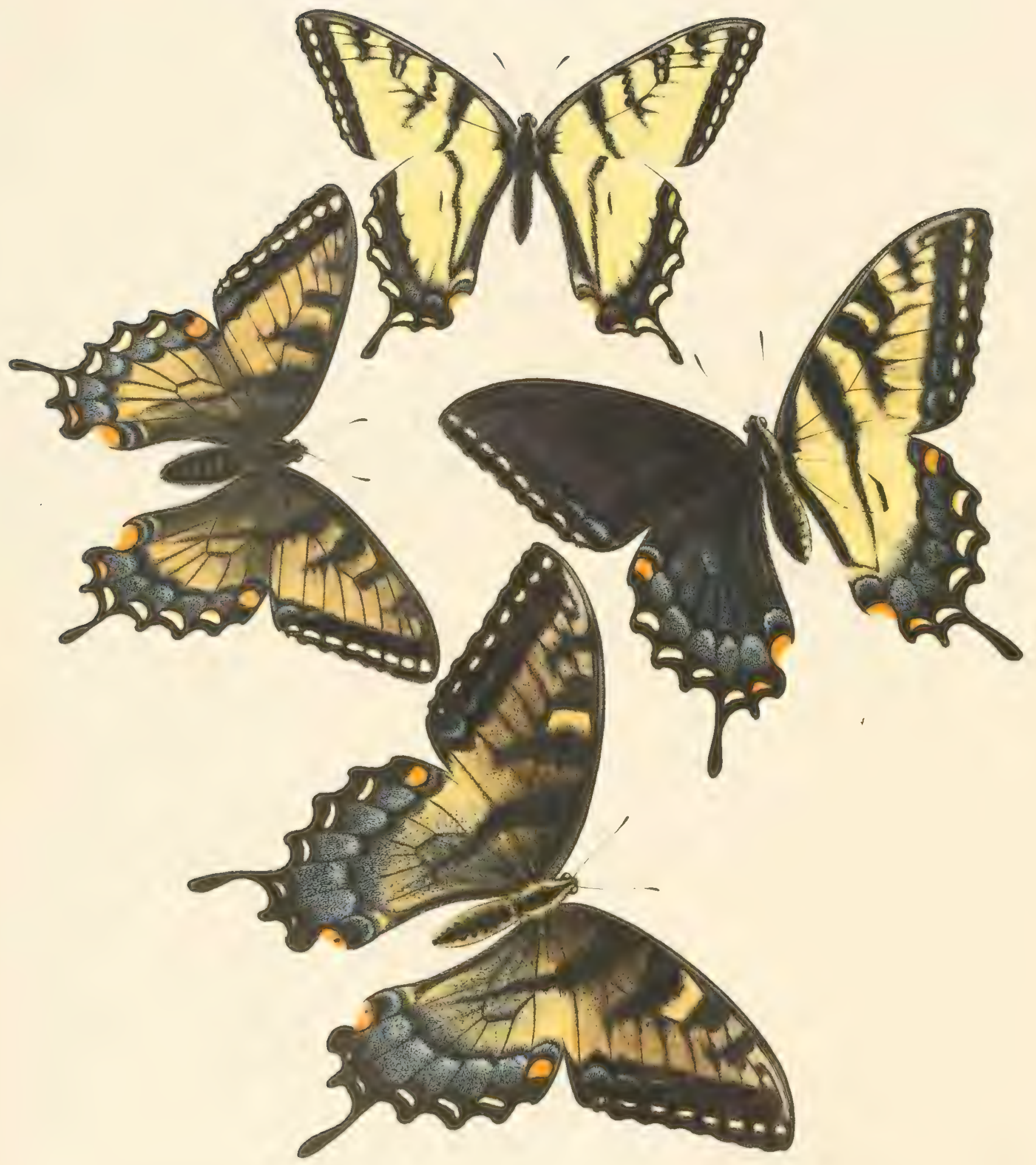




\section{PAPILIO III., IV., V.}

Longues buried in the sweet flowrets, so that one can pick them off with the fingers. More than once I have noticed them hanging late in the evening, and doubted not they would so pass the night.

Tirmus has many enemies, birds and dragon-flies by day, and probably small owls and others by night. In spite of their expanse of wing and power of flight, the larger Libelluda will pounce on them in mid-air, and carry them away. On several occasions I have known this to happen. I scarcely ever go into the garden of a midsummer morning that I do not see severed wings of Papilios and of some of the large bombycid moths upon the ground, and can only account for so much destruction at night by crediting it to the owls, which are not at all uncommon.

'The ecrgs are always liable to discovery by spiders and ants; and when the larva do emerge, some are destroyed by the same foes; others are stung by ichneumon flies, and either while larve or in chrysalis inevitibly perish. And when at last a chrysalis is formed, it is exposed to peril from new enemies, squirrels, mice, birds, and one would think few could possibly survive the long months of winter with such a risk of destruction. As each female Tumus litys about two hundred eggs, and there are in this region several broods in the season, the species would soon swarm were it not for these natural checlis. As it is, it barely holds its ground, and in some year's, as in 1876 , the early over-wintering brood seems almost lost.

Throughout the South and West there are three ammual broods of Thmus, and about fifty per cent. of the chrysalids of the first broot of the season pass the winter, so far as my experience shows, as do all the chrysalids of the last, or early fall brood, both giving butterflies at the same time the following spring. As to the intervening, or midsummer brood, although all chrysalids of this bred by me have passed the winter, yet as fresh butterflies are common the last of August and first of September, I infer that they come from the midsummer brood. In looking over my joumal for several years past, I find that eggs laid 3d June produced chrysalids 1-S July, and such of the butterflies as emerged the same year, did so between $23 d$ July and 11th August. This was the first brood from eggs of the season. Eggs laid 17th. July gave chrysalids 20 th and 25th August. This would be the second, or midsummer brood. Eggrs laid 22d August gave chrysalids 10th October and after. This, therefore, was the third brood of the season. But all the periods are apt to be irregular, and between the dates of these regular broods, I have bred several others. Thus eggs laid 6th July, gave chrysalids in the first days of September; eggs laid 3Ist July, gave the same in middle of September; and eggs laid 13th August, gave chrysalids early in October; these broods falling between the first and second, and sec- 
IPIIIIOI III., IV., V.

ond and third regular broods. And this shows how it may happen that Therme shall be on the wing from enrly spring till frosts destroy the species in the fall. In the Catskills, the egrgs are laid about the middle of June, and there is no second broot. Mr. Saunclers speaks of the larva, in Ontario, being full grown by 1.1 th July, and the egges therefore must have been laid early in Jume; and Mr. Scudder tolls us that throughout New England there is but a single brood.

Turves is remarkable for its peculiar dimorphism, which, so far as is yet known, is without a strict parallel among butterflies. We have in our fam several established examples of seasonal dimorphism, as in Papilio Ajax, Grapta Comma, the three Phyciodes, Tharos, Phaon, and Vesta; several Pierids, Colias Eurytheme, and no doubt future observations will discover many more. In Lycrma Pseudargiolus, the winter form is Violacea, and this last develops females of two colors, blue and black, in the south; and but one, the blue, at the north. Violacen in this respect resembles Tumus, but the dimorphism of the latter is not seasonal, the same characteristics being found in every brood of the year. In Grapta Interrogationis, also, the dimorphism is not seasonal, and the two forms appear in every brood. But they are represented in both sexes, the males of each being as distinct from each other as are the females. There is also a dimorphism confiner to the females of many species, as several of the Coliades, but it prevails wherever the species is found, and is not subject to geographical limitation. Now in Tumus, the males are always yellow, and to the north of a certain latitude, about $41^{\circ} 30^{\prime}$ on the Hudson River, and $42^{\circ} 30^{\prime}$ in Wisconsin, all the females are yellow. Below these lines, as one goes southwarl, the black females appear, at first but rarely, then increase gradually in proportion to the yellow, until an equilibrimm is somewhere reached, apparently between $39^{\circ}$ and $38^{\circ}$. But I cannot learn that, after that, the black everywhere continue to increase at the expense of the yellow, though they seem to do so in certain districts, or large sections of country. In this part of West Tirginia, lat. $35^{\circ}$, I have often taken yellow females in the garden and field, and while they seem to be never so common as the black, yet they camnot in most seasons be called at all uncommon. But I am certain that in some years, or rather in particular broods of some years, the black form does greatly outnumber the other. 'This was so in midsummer of 1876 . For some cause the species was excedingly scarce in the spring of that year, quite the reverse of what usually happens. During the month of July, however, when the new brood was flying, both males and females visited a field of clover within easy reach in swarms, and I made a special point of scarching for yellow females, as did Mr. Mead, who was with me, and we were both struck lyy their exceeding rarity. In fact, but one only was taken during the time the clover was in bloom, though we must have seen hundreds of the 
PAIIIIO III., IV., V.

black form. Mr. Walsh has stated that in Northern Illinois, both black and yellow fomales occur, though the black are five or six times more numerous than the yellow, judging from the careful observation of five years. But on visiting a clover ficld in southern Illinois he captured between seventy and eighty specimens, and every yellow one was a male. Professor Snow, in Kansas, tells me that there the black much outmumber the yellow. Mr. Aaron, at Maryville, eastern Tennessee, writes that the species is abundant, but the yellow females are very rare, while the black ones are as plenty as the yellow males. And Mess's. Boll and Belfrage, in northern 'Texas, and professional collectors of large experience, say that the black female is much more numerous than the yellow one. All these observers, however, allow that the yellow females are found in their several districts. On the seaboard, Mr. II. K. Morrison, also an experienced collector, who has spent much time in the southeastern States, says, "in Georgia half the females of Tums are black." And that he has a large nunber of specimens from Central and Northern Florida, "6 and about one half the females are yellow." But that among the momtains (Black. Mountains) of North Carolina, the females were yellow. "On my arrival at IIenry's, McDowell Co., N. C., I found the males and females, yellow form, July 15 th to 30 th, quite abundant and fresh. At the same place, August 25th to September 5th, I found the yellow form again abundant and fresh. I saw no black females. I caught one or two of these at Morganton, Burke Co., in July, but they were rare." Within the zone inhabited by the two forms of female, neither has been known to produce a black male, nor' is such an insect known to have ever been seen; the black females produce yellow males and mostly black females, only occasionally a yellow female appearing in the brood, so far as observed; and the yellow females in very rare instances produce black females. It is not possible to distinguish a yellow male or yellow female by a black mother, from the same by a yellow mother, or the black females from each other, whether the mother was yellow or black. And, as a rule, the separation of the two forms of female is complete. Intermediate examples do sometimes occur, but they are exceedingly rare. In the hundreds of this species which I have bred, there never appeared one such, anil in the field I have met but three or four, and these are chiefly represented on Plate V. The ochraceous female given on Plate IV. (Fig. 4), was bred by Mr. John Akhurst, at Brooklyn, N. Y., from eggs laid by a yellow female. Mr. Akhurst informs me that from this yellow female, inclosed in a box with a branch of sassafras, he obtained about eighty eggs, and raised from them a lirge number of butterflies. Two females were deep ochraceous, and two were black, all the rest being yellow. This is remarkable, considering that Brooklyn is near the extreme northern limit of the black form. It is very umusual, in a district in which the two forms 
PAPILIO III., IV., V.

are common, for a yellow female to produce a black, though the chances are that every yellow female in such district has had one or more black female ancestors. Therefore, where the black is an extremely rare form, with the chances largely ngainst any yellow female having inherited a tendency to melanism, that one should produce two black, and two deep ochraceous examples (for this latter coloration is of the same nature as the other), is almost as if this variation in the present case arose spontaneously. I have applied to several collectors in BrookIyn besides Mr. Akhurst, and all agree in the statement that Glaucus is an uncommon insect in that vicinity. Mr. Akhurst says also that he has occasionally taken such ochraceous individuals in the field. Here at Coalburgh there is observable in the yellow females a deeper coloring than in the males, especially of the fore wings (Plate 1II., Fig. 1), but I have seen no such example as that from Brooklyn. Formerly, in the collection of Mr. Wood, at Philadelphia, I saw a chocolinte colored Glaucus, and Mr. Aaron writes me that he has taken one similarly colored.

Many explanations of the phenomena of melanism in general have been suggested, such as meteorological conditions - excessive moisture, deficient sunshine, impure air; also vegetation defiled by soot from furnaces, and the like; none of which are satisfactory when applied to species on this continent, however it may be when they are restricted to limited areas, as in parts of Europe. In North America, the very reverse of these conditions obtains throughout the regions in which the melanic species are mostly found. And as a rule, melanism among butterflies is confined to one sex, and that the female. It is not always so, as appears by the melanic Philodice male figured in this volume, but nearly every known example belongs to the female. In case of the present species, the facts are, that in the warmer regions, where it is polygoneutic, or many-brooded, both yellow and black females exist, in some districts apparently in about equal numbers, in others with a more or less decided predominance of the black, but occasionally, as in the mountain district visited by Mr. MLrrison, the yellow predominating almost if not quite to the exclusion of the other; that at the north the black disappear at the line at which the species becomes monogonentic, and the yellow form in both sexes flourishes even to the aretic portiors of the continent. Dr. Weismann, speaking of Turnes, expresses the opinion that "the yellow is the ancient and original form, the black a much younger, or more recent form." During the glacial period, when the shortness and coolness of the season permitted but one brood in the year, just as in the boreal regions now, the species was yellow in both sexes. As the season becane longer and climate milder, from the receling of the ice which had covered the larger portion of the con- 


\section{I'IPILIO III., IY., V.}

tinent, there was at length time for a second brood to mature the same season, and the species gradually became digoneutic. Still later, for the same reasons, in the more southem districts, a third generation could mature. And with the summer generation, at some stage, came in the black form, which is restricted even now to the districts in which a summer generation is possible. The cause may have been in some way climatal, or this variety may at first have been accidental, and once in existence, fivored by circumstances, was able to perpetuate its type through its descendants till it has become common, sometimes almost to the exclusion of the yellow and original form.

"The origin of the black form we can only explain by supposing that, at one time, when 'Tumus already occupied a territory as extensive as it holds to-day, some umknown influence caused the black female form to appear as a distinct variety, and that, owing to some circumstance, it thereby gained an advantage over its rival, which caused it finally to supplant the other, and to spread over a large extent of country. This supplanting process must have begun with one individual, or a very few individuals. There is no case known where a whole species becane aberrant, and the supposition that the black form appeared simultaneously among hundreds or thousands of individuals may be rejected as untenable..... One or a few black females here stand opposed to myriats of yellow ones, and have finally proved victorious over them.... This victory can be explained in no other way than through the supposition of the usefulness of the black color." Dr. Weismamn inchines to consicler it a case of sexual selection, the superiority of the blacks having been gained by their attractiveness to the males. However this may be in general, it may be stated that the yellow females taken by me, at Coalburgh, have as surely been fertilized as the blacks, and have as readily laid eggs; and on the wing the males may be seen coquetting with the yellow as freely as with the blacks. There would seem to be no want of attractiveness in such individual instances.

I have experimented to see if it were possible that the butterflies emerging from chrysalis in midsummer might show a stronger tendency to melanism than those emerging in the spring, from over-wintering chrysalids, but have found no evidence that the heat of summer or cold of winter exert influence on the resulting forms of the female. In June, 1875, I obtained eggrs by confining several black females upon the limbs of a tulip tree, and there resulted therefrom, in August following, $90^{*}, 2$ black $\%$. Part of the clnysalids passed the winter, and in the spring there emerged 9 o", 5 black ?

In the spring of 1872 , there emerged from chrysalids of the previous year, the eggs having been laid by black females, 15 c $^{*} 7$ black $\%, 2$ yellow .

In the spring of 1877 , from eggs laid by black, 218,7 black 9 
PAPILIO III., IV., V.

So that the black form appears constantly in the spring as well as the summer irood. The difference between the summer and winter form of the black female in size and ormamentation is well shown in Plates III., IV., the first of these being the summer.

From eggs obtained in same way from yellow females, there resulted in the spring of $1872,88^{\circ}, 3^{\circ}$, all yellow. In August, 1875, $3^{\circ}, 12^{\circ}$ all yellow, and from part of the chrysalids of this lot which passed the winter, there appeared in the spring of $1876,4{ }^{\circ}, 12$ yellow ${ }^{8}, 1$ black $^{\circ}$. 'This is the only instance out of many broods raised, in which a black has come from a yellow mother, though on two occasions, besides the one above mentioned, a yellow female has come from black.

Mr. Darwin lays much stress upon the prepotence of transmission, in the case of peculiarities transmitted through one sex only of a species, and asserts that "characters may first appear in either sex and afterwards be transmitted to the offspring of the same sex." "Variation of Animals," etc., 1st Am. ed., II., p. 106.

That yellow females should rarely produce black is not surprising, but that the reverse should not often and constantly happen, inasmuch as the blacks are always crossing with the yellow males, does indicate an amazing energy in the black form, and implies a time when the yellow female will wholly succumb to the other throughout the regions now inhabited by the two, unless there be in certain districts some restraining influence, as climatal, or the existence of enemies. 'To the northward, and in elevated districts, there must probably be same restraining climatal influence on the black form. No black Papilio of any species is found in the sub-boreal regions, though on both continents, and at great elevation, the yellow Machaon flourishes, as does Tumus in North America.

Mr. WVallace, "Natural Selection," p. 154, speaking of Tumus and its dimorphism, considers it "highly probable that the existence of enemies and of competing forms of life, may be the influences which determine the relative proportions of each form;" and hopes that observations may ascertain "what are the adverse causes which are most efficient in keeping down the numbers of each of these contrasterl forms."

In looking for the causes of the decrease of the yellow female in the western and southwestern districts, and the manifest luxuriance of the black, it seems to me that it is not unlikely largely owing to the facility with which the yellow females are captured by birds and other enemies by day. They are slower of flight than the males, and when heavy with eggrs, are very sluggish, flying but little and at short distances, and their gay color renders them an easy prey. It is true, the black females are equally slow of flight, but they are less easily seen, and as other species of black Papilios, Troilus, Philenor, and Astcrias, are always 
P.MPI.IU III., IV., V.

in company with them, the black Tums is in a way protected. I think this sufficiently accounts for the scarcity at any time of the yellow females in this region (West Virginia). Papilio Philenor has a strong and disagreeable scent, and it has been suggested by Mr. Mead, that this rendering it distasteful to birds would serve to protect other black species flying with it.

IIow then does it happen that at the sontheast, in Georgia and Florida, the yellow females should strike so experienced an observer as Mr. Morrison as being quite as plenty as the black; the very opposite to the conclusion reached in Illinois and Kansas and Texas, by other experienced observers! That Mr. Morrison should consider the yellow fully as abundant as the black, leads me to believe that in reality they are much more so, and that in those districts they outnumber the black largely; for unless a collector is especially searching for them, their resemblance to the males would often cause them to be overlooked. Indeed, at a moderate distance one could not be distinguished from the other. 'The western region is largely prairie. It may well happen there that the constant elimination of the yellow form has in the course of time overcome any remaining tendency of the black to produce yellow females, for every black now flying must be supposed to be descended from many generations of black, with a yellow one in the line only at rare intervals, perhaps in not more than one generation out of a hundred. I can see how it is, that at the southeast, the repression of the yellow female by enemies may be greatly diminished, owing to the more wooded combry, the greater moisture of the climate, milder temperature, and the excessive luxuriance of all insect life, whereby there is no reason why one species only should be singled out as a special object of prey. The conditions are essentially different from those which prevail on the dry and exposed westem plains. Moreover, the peril caused by the bright color and slow flight of the yellow female Thmus, must be much lessened by it: constantly associating with other species of Papilio, similarly colored, such as Cresphontes and Palamedes, larger and gayer than itself. In fact it is the yellow female Tum which is here protected, and so it should not merely hold its own, but really be able to prevail against its sister form. It occurred to me whether it might not also be a fact that the insectivorous birds were more largely represented in the west than on the Atlantic seaboard, so that all species of butterfly might be more subject to destruction in the former regions, and I wrote Professor Baird for information on this point. In reply I have a statement from Mr. Robert Ridgway to the following effect: "A larger proportion perhaps of the birds belonging to the semi-prairie districts west of the Mississippi belong to the insectivorons series than is the case with those inhabiting the Atlantic seaboard. Thus, taking the Tyrannidre, for example, which are preëminently fly-catchers, 


\section{PAPILIO III., VI., V.}

and more prone to destroy Lepidoptera than any other birds, all the eastern species occun from Kansas to Texas, along with three additional species, Milvulus forficatus, Tyramus verticatis, and ' $\mathrm{T}$. vociferans, these latter being of large size, and, we may infer, correspondingly voracious. None of these species, however, oceur east of the Mississippi, so far as known, except perhaps casually. Upon the whole we may assume for the semi-prairie country a richer bird-life than is possessed by the South Atlantic States, with a corresponding larger number of insectivorous species." "That in the mountains of North Carolina there should be a district in which, though the species is abundant, there should be few or no black females, would lead to the belief that there may be similar areas of the most elevated portions in other southern States, where a like distribution prevails. It is evident, from the dates given by Mr. Morrison, that the species was not single-brooded, but that he collected from the midsummer and fall broods, and there must therefore have been at least three broods in the year.

For more than a century after both Tums and Glaucus were known to natmralists, they were not suspected of belonging to but one and the same species. Boisduval and Leconte, in 1833, figured both, and after describing the female Glaucus, say, "the male differs but in size, being a little smaller, and by the blue hand, which is less extended," and they figured and described the larve of the two as distinct. It appears that $\mathrm{Mr}$. James Ridings, of Philadelphia, an intelligent collector of butterflies, and now living at an advanced age, had taken a yellow male Turmes and a black female Glaucus in copulation, in 1832. And, in the same city, Mr. George Newman, a veteran and enthusiastic collector, - whom, in after years, it was iny pleasure to know, and whose delight, as he exhibited and expatiated upon the treasures of his cabinet, his many friends will recall, - had raised black and yellow females from the same laying of eggs. But to lepidopterists in general, nothing was known of these things till the late Mr. B. D. Walsh communicated a paper in the Proceedings of the Entomological Society, of Philadelphia, 19th January, 1862, which in part read thus: "That Turnus and Glaucus are identical seems to me to be proved by two facts, the one positive and the other negative. First, I am informed by Mr. Edwards that both Messis. Newman and Wood, of Philadelphia, say they have raised the black female, together with several shades of color between yellow and black, from the same laying of eggs. Seconi, nobody ever saw a male Glaucus. Now Glaucus is so common in suthern latitudes, that if it were a true species, not a mere sexual variation, someborly or other must have met with the male." And after reciting his own experience, Mr. Walsh expresses the opinion that south of lat. $38^{\circ}$ in the valley of the Mississippi, and perhaps of $36^{\circ}$ on the seaboard, the female Turme is black; that north of $41^{\circ}$ on the seaboard and $43^{\circ}$ in the valley, the female is 


\section{PAPILIO III., IV., V.}

yellow; and that in the intervening zone both colors are found. Mr. Walsh was nearly correct as to the northern limit. The most northern point on the seaboard at which I have known Glaucus to be seen or taken was at Newburgh, on the IIudson River, lat. $11^{\circ} 30^{\prime}$, 一 where I resided several years, - and then but a single eximple.

Dr. Hay, of Racine, Wisconsin, writes me that he once took Glancus in his garden, and on another occasion saw one near the month of the Wisconsin River, lat. 43․ And Mr. Brewer states (Can. Ent., 1X., p. 20), that in Nebraskil, as fur north as the Niobrara River, the black and yellow forms of lemale are about equal; lat. $42^{\circ} 30^{\prime}$.

Although Tumus has been so long known to naturalists and has been repeatedly figured, this, I believe, is the first attempt to bring the two sexes of the yellow form together.

There has recently been some effort on the part of the adherents of a rigid priority to change the name of this species to Glaucus, that mane having been given to the black fomale in 1767 , antedating by four yens the name Thmos applied to the yellow male and female. One would think a century long enough to confirm a name even if originally griven in error, especially in case of any species which had since been repeatedly figured and treated of in published works. and that nothing but confusion could result from a change after this lapse of time. But it happens in the present case that Gloucus is not the insect described as Tumus, being but a dimorphic form of one sex only, entitled as such form to its own special name. The species is Tumus, this form is Glaucus.

Note. - From what I have observed at Coalburol, the present seitson (1875), I think it probable that here, and to the sonthward, there may often he four annual broods of 'Lurnus, instead of three, as stated above; the existence of the fouth leing denentent on the weatler in April. This month was pleasant and warm, and different Papilios were exceelingly abundant; and, during the last week. the females of Tumus were frecly depositing eqgs. This would erive ample time for the maturing of the larve and emergence of the butterflies before the first of June, at which date the first of the three broods recorden had a heginning. I watched carefully for yellow females, and had a good opportunity as the butterdies gathered about the fruit trees and lilacs, but I saw only four; while there must have been scores of the black form, if not lundreds. 




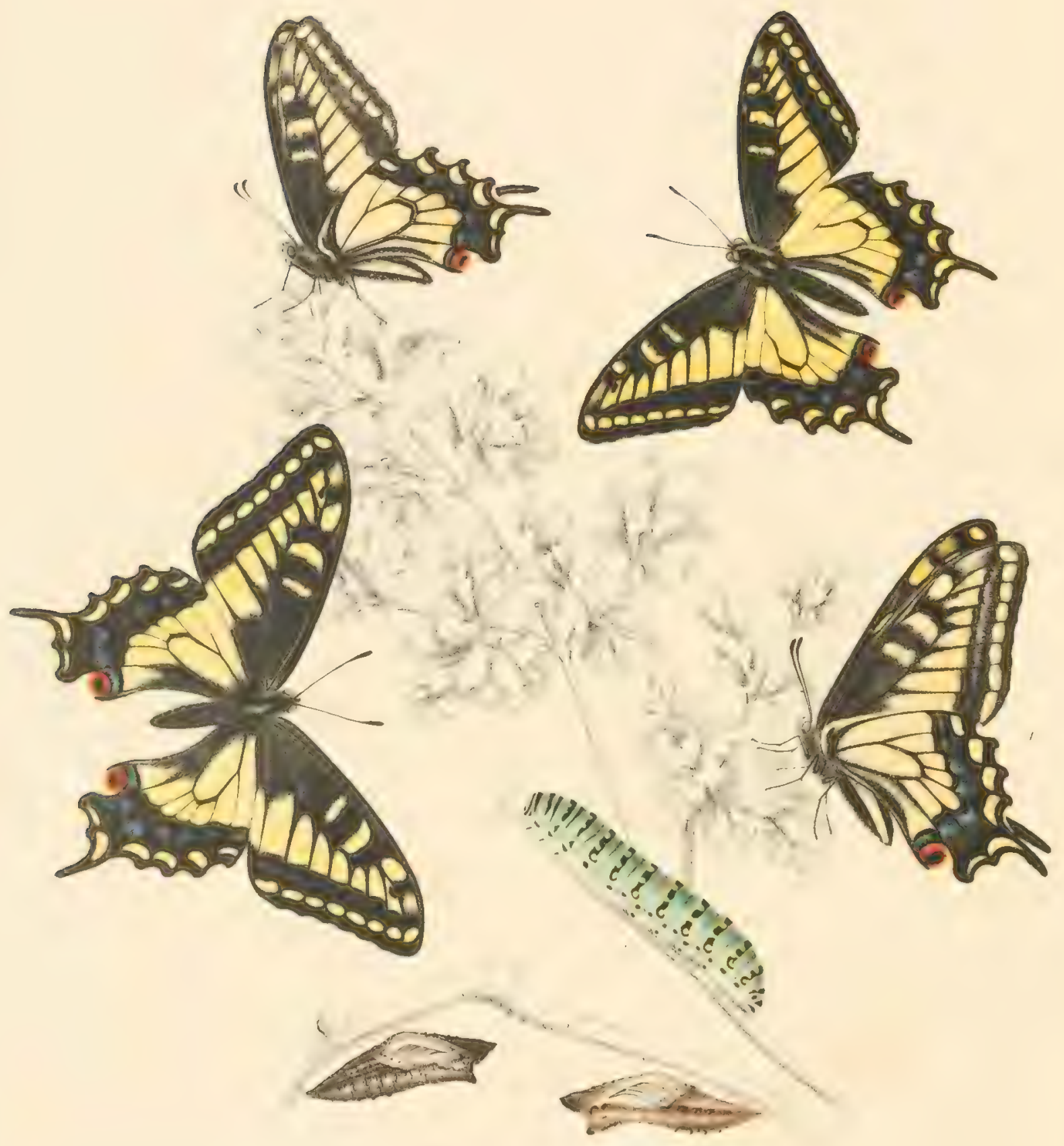




\title{
P A PILIO VI.
}

\author{
PAPILIO ZOLICAON, 1-1.
}

\begin{abstract}
Papilio Znlicaon, Boisduval, Ann. Soc. Eut. de France, 1532, p. 2\$1. H. Edwards, Proc. Cal. Acad. Sci, 1873, p. 3.
\end{abstract}
Primaries much produced, strongly arched, hind margin straight or convex; tails long, narrow; the sexes alike in color and markings.

MALE. - Expands about 3.25 inches.

Upper side of primaries black, marked and spotted with deep yellow; of secondaries yellow from base nearly two thirds the distance to margin, beyoud black: primaries have a sub-marchinal series of eight spots, equal, the anterior ones rounded, the rest either oval or lunular, and a discal series of eight forming a band across the entire wing; above these last, on the upper sub-costal interspace, a long patch of yellow scales, and a rounded or oval spot; the first discal spot deeply and romily excavated on the upper side, sometimes divided into two; the second shorter than the first, and the third than the second, after which the series gradually increases in length to the sixth, the breadth being nearly equal; the seventh is large, sub-rectangular, the eighth a narrow stripe on the inner margin; a narrow yellow bar crosses the cell inside the are, and near it is a second, also narrow, sometimes compressed in the middle and then expanding largely on sub-costal nervure; the basal area somerwat dusted with yellow scales. Secondaries have a broad black border which incloses a sub-marginal series of six yellow spots; the first, at outer angle, small, often wanting, the next three large and lunular, the fifth at base of tail lumular or sub-triangular, the last a streak near the angle; in the interspaces above these spots are clusters of light blue scales; the abdominal margin bordered with black to median nervure, leaving at the outer extremity of the submedian interspace only a small triangular patch of yellow; above the incision at the anal angle, over a yellow patch, is a ring, varying in color from orange to deep fulvous, which incloses a round or oval black spot, and is edged on the upper side by a blue crescent; occasionally the ring is wanting, being replaced by black which may have a very narrow edging of fulvous on the lower side; the rest of wing, which comprises the basal area and much of the disk, yellow, divided into eight spots, the cell being one, by the black nervures; fringes of 



\section{.}




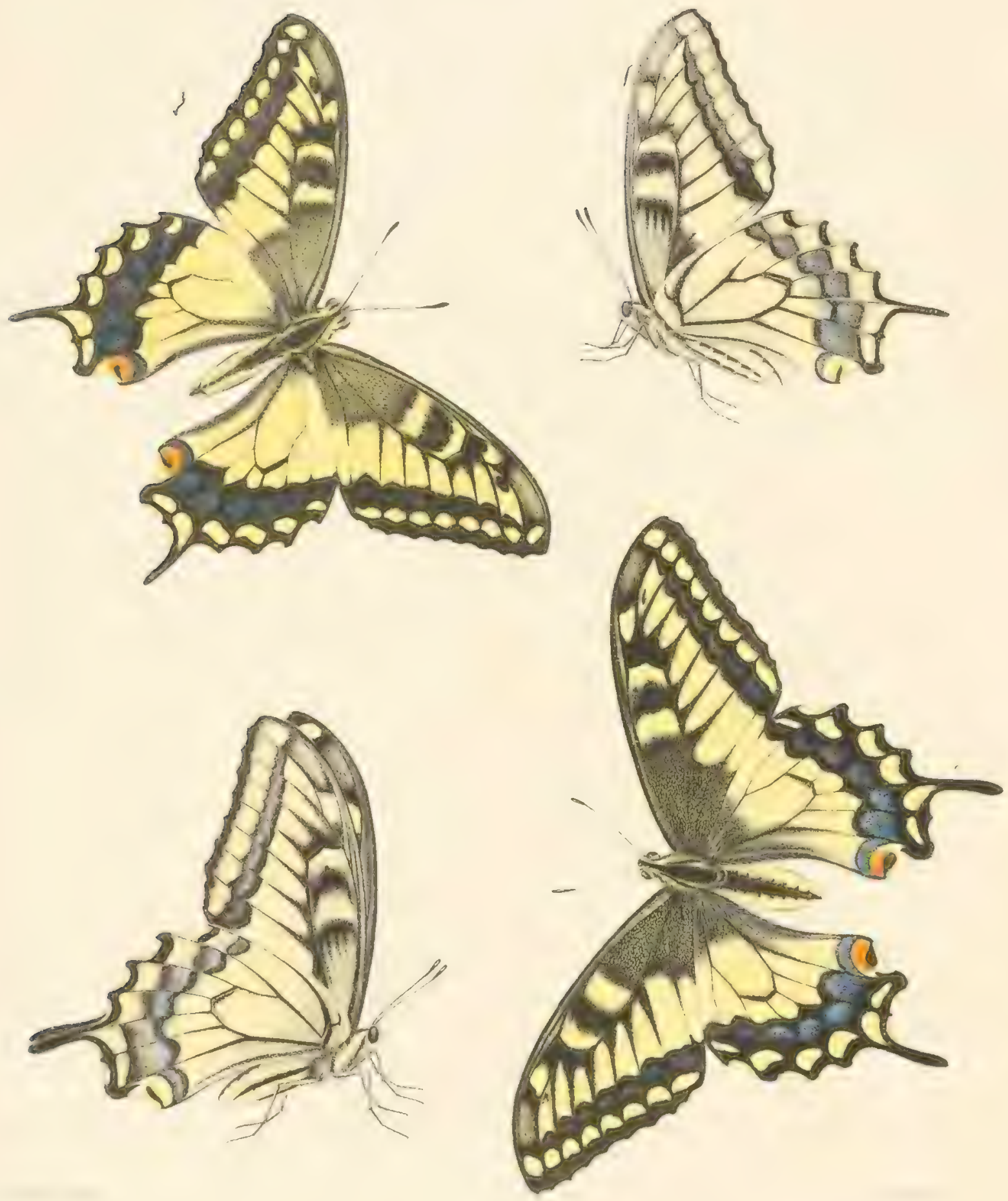




\title{
PAPILIO VII.
}

\author{
P'IPILIO OIRGONIA, 1-4.

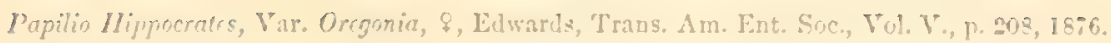

Purmsnes much produced, costal margin stronerly archerl, hiurl marenin straight or concave; tails long, narrow, and as in Zolicuon; the sexes alike in color and markings.

MALF. - Expands from 3.5 to 4 inches.

Upper side of primaries black, marked and spotterl with bright yellow; of secondaries, bright yellow from base to marginal border"; primaries have a submarginal row of eight spots, equal, mostly rounded, and a discal series of eight which form a transverse band; above them a long patch of yellow scales, and a little within this, towards base, a subovate spot, truncated on apical side; the first discal spot is deeply and roundly excavated on anterior side; the second is a little shorter than first, and third still shorter, after which there is a gradual increase in length, to the seventh, which is broad and sul)-rectangular; the eighth is narrow and marginal; at the extremity of cell within is a sub-lunate transverse yellow spot and a broader one in the middle, of irregular shape, the two being separated by a black space; the basal area thickly dusted with yellow scales.

Secondaries have a broad black marginal border, which incloses a series of six yollow lumular spots, the first, at outer angle, small; above these spots are clusters of blue scales, never distinct, sometimes nearly all wanting; the inner margin bordered with black, sometimes to median nervure, but in other cases very narrowly; the anal spot small, yellow below, fulvous above, with a rounded black spot in the middle and which is connected with the narow black edge of the margin; above the fulvous is a distinct blue crescent; tails of moderate length, narrow; fringes black, yellow in the interspaces.

On the under side, the Iarger part of the marginal border of primaries is occupied by a yellow band, and the remainder includes a nebulous stripe of dull 


\section{P.MPIITU VII.}

yellow on the black ground; in the cell the yellow spots are repeated and enlarged; the base of cell is dull or luteous yellow, and sends out four long rays which nearly reach the midnle; secondaries have all the nervures black, those about cell and the basal portion of the costal nervure being heavily edged with black; the lunules much enlarged and changed into subquadrate spots, occupying fully half the border, the black ground above them being hearily dusted with yellow and blue; the fulvous of anal spot is changed to orange-yellow, and the two yellow discal spots against cell sometimes have their outer ends yellowtinted.

Body black on upper side, elsewhere yellow, but about the thorax fulvoustinted; a black stripe from the head reaches the insertion of the wings; beneath abdomen two black stripes, and one on lower part of either side, from wings to last segment; legs black; palpi yellow, or with a fulvous tint; frontal hairs black, but next the eyes yellow: antenno and club black.

Feadue. - Expands 4.25 inch.

Similar to the male, the yellow paler; the blue clusters larger and more distinct.

I described this species as a variety of Hippocrates in 1876, from a female taken by Mr. Henry Edwards, at the Dalles, Columbia River. Mr. H. K. Morrison took several examples of both sexes in Washington 'Territory, near Olympia, in 1879, and from some of these the figures on the Plate are drawn. In all I have examined, $2 \approx 3$ \%. I am satisfied they are not Hippocrates, but a distinct species, of same sub-group, and near to Zoliccon. Felder, Verhand. Zoül. Bot., Geschied xiv. pp. 314, 362, 1861, describes Hippocrates as much larger than Machoon, the yellow area narrower, the wings narrower and more produced; the hind wings also shorter on the costa, more produced posteriorly; the tails longer, the anal spot more obscurely colored, and joined abruptly to the blue lumule; the black border of the hind wings on the under side much broader, the blue spots more distinct, and placed almost in the middle of the black ground, the outer ones accompanied by few yellow atoms, and the cells of both wings longer.

I'o this may be added that the black marginal border of lind wings on upper side is considerably broader than Machaon, if 1 may judge by 3 s of Lippocrutes, from Japau, before me. In all these this border is nearly straight-edged on the inner side, and almost touches the cell in two examples, and quite touches it in the other; and the tails, beside being longer, are not tapering as in Machuon, but are of nearly even width almost to the extremity, where they become broader, or sub-spatulate. On the under side of primaries the black cel- 


\section{PAPIITO VII.}

lular spots disappear almost entirely. The single female Ilippocrates cxamined has the yellow area very much restricted on upper side, all the discal spots on primaries being separated by wite black spaces, and the basal area is black to middle of cell; so is the space hetween cell and lower branch of median nervure to both margins, except a small yellow triangle at the extremity. There is the same absence of black in cell beneath primaries as in the male. All of both sexes have the black border of primaries scarcely, if at all, dusted yellow, and -all show the blue lumule meeting the fulvous anal spot with no intervening color; on secondaries beneath, the black portion of the borter to hind margin is very much less dusted than in Machaon, in which species the black area is usually hidden by the yellow scales, and the blue spots stand in the middle of the black, on each interspace.

Much of Felder's description will apply to Oregonic as contrasted with Mrachaon; but the former differs from Hippocrates in several particulars. In Oregonia the yellow discal spots of primaries are larger, the l)lack intervening spaces being natrower than in Llippocrates, and the yellow sjots in the cell are both much smaller; the yellow area is bronder on secondaries, and as in Heucheron and Zoliccon; on the under side there is much more black in the cells, which is about as in Alachaon; and the tails are shorter, narrow, and not sulb-spatulate. These are between . Kachaon and Hippocrates in lenesth and shape, and precisely as in Zolicaon. In both my z, the length of the tail measured on posterior side is .32 inch; the three Hippocrates show .44, 48 , and eft inch, respectively. In fact, Oregonia is nearer to Zoticaon than to either of the others. A large female of the last named species in my collection, expanding very nearly four inches, which is unusual, placed side by side with one of the female Oregonic, camnot be distinguisher from it by the appearance of the upper side, exeept hy the round and separated black spot in the fulvous anal spot, while in Oregoniu the corresponding black spot is a continuation of the black stripe which edges the imner margin, turned in and thickened so as to have an oval shape rather than round. On the under side I can see no difference, except that the same black spot is present in Zolicaon, and the cell of primaries is wholly black, with a terminal and central yellow spot. There is a marked difference, however, between the bodies in these two species, in Zolicaon the whole abdomen being black, with only a yellow side stripe, whereas in Oregonia the borly is yellow, with black on dorsum and with four narrow black stripes on sides and beneath, just as in Machaon. Oregonia bears much the same relation to Zolicum which Mippocrates hears to Machaon. In the same district with Oregonia, Machaon also flics, of the same type with the ILudson's Bay and Alaskan eximples, which are very like Var. Asiatious, Mènètriès. 




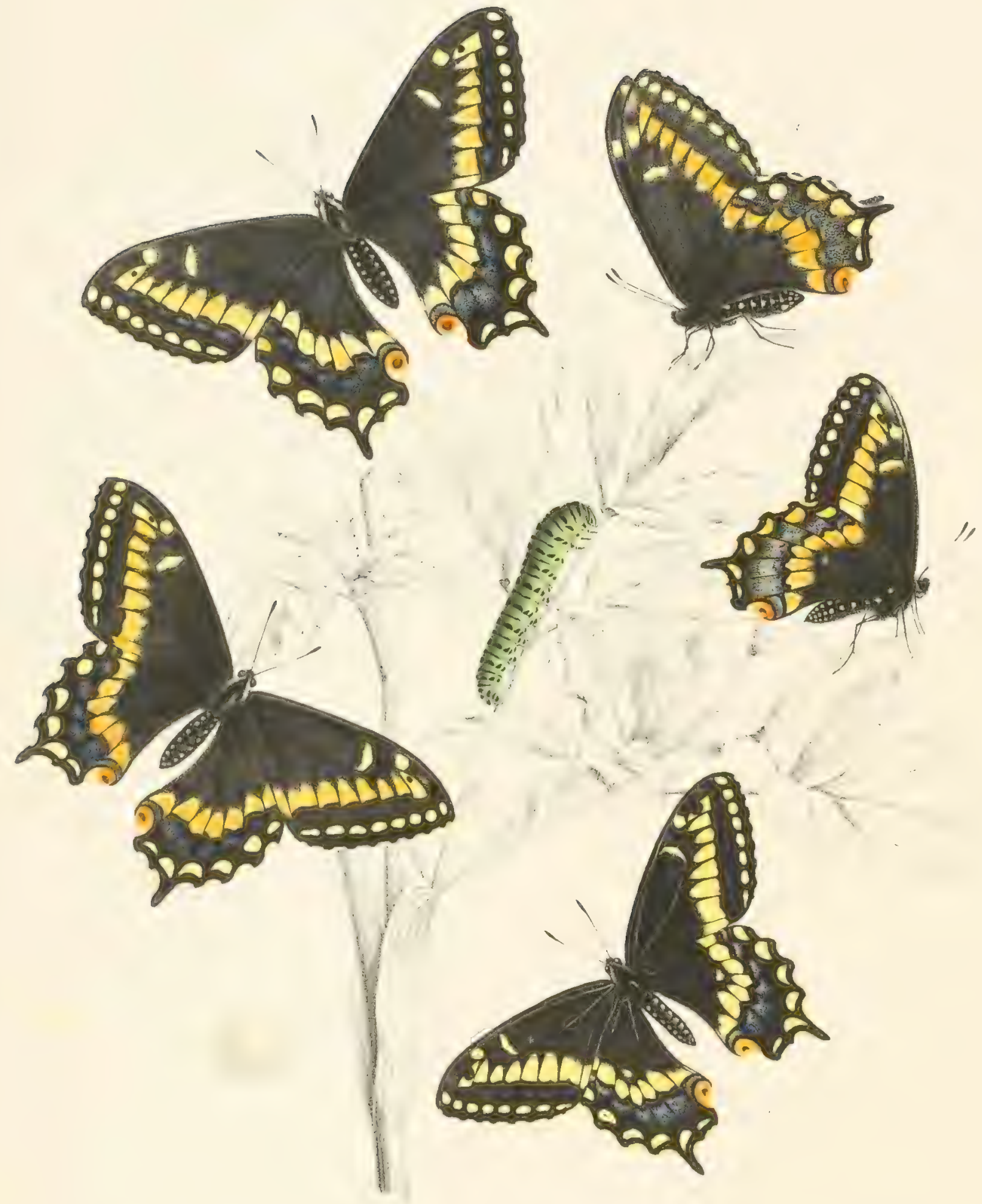




\section{PAPILIO VIII. \\ PAPILIO BREVICAUDA, $1-5$. \\ Papilio Brevicauda, Samders. Packard's Guide, p. 215. 1869.}

Priniaries moderately produced, costal margin much curved apically, hind margin much rounded; tails short, broad at base; the sexes alike in shape and markings.

MLALE. - Expands about 3 inches.

Upper side black; primaries have a sub-marginal series of eight small yellow spots, rounded or oval; secondaries have a similar series of six spots, large, mostly lunate; a common yellow band crosses the disks, composed on primaries of eight spots, the upper six sub-triangular, varying in size, the seventh subquadrate, the eighth a narrow stripe; the first of these spots has a circular incision on the costal side; a stripe or a rounded spot in the upper sub-costal interspace; the imer side of the are of cell bordered by a narrow stripe: on secondaries the band consists of seven spots separated only by the black nervures; occasionally the outer extremity of the cell is also yellow; beyond the band are clusters of blue scales in the interspaces; above the incision at inner angle is a fulvous ring on the upper side of a yellow patch, surmounted by a blue crescent, and inclosing a rounded black spot or point; fringes yellow, black at the ends of the nervules.

Under side blackish-brown; the spots repeated, and all but those of the submarginal row on primaries usually more or less suffused with fulvous, individnals varying greatly in this respect; in some there is an absence of fulvous on primaries, and but little on secondaries; on both wings the space between the row of spots and the band is dusted with yellow scales, most densely on secondaries, and on these last are patches of blue scales at the anterior edge of the yellow on each interspace; the ring at the angle as on upper side, but often the black spot is joined by a ligament to the black edge of the inner margin.

Body black, the wing covers slightly tinted with yellow; upon the abdomen is a row of yellow points on either side of the dorsum, and a lateral row from base 


\section{PAPILIO VIII.}

of wing to last segment; legs and palpi black; frontal hairs black, as are also the antenna.

Female. - Expands 3.25 inches.

Similar to the male in shape and markings, but more variable in color. In the typical specimen, which is a female (Figs. 3, 4), from Newfoundland, the band on upper side is wholly of deep fulvous, except the first spot, which is yellow; on secondaries the anterior edge and the two sides of each spot of the band are yellow, the posterior parts only being fulvous, and of a less intense shade than appears on primaries; all the other spots on both wings are yellow, except the one at outer angle of secondaries, which is partly fulvous; on the under side the sub-marginal spots of primaries are yellow, of secondaries partly fulvous; the band on primaries is fulvous throughout, and on secondaries nearly so, there being a very narrow edging of yellow to each spot, except on the posterior side of it.

In three other examples from Newfoundland, sent me by Mr. Saunders, and all of which are females, there is much variation in the extent of the fulvous coloration on the upper side. One of these (Fig. 5) has no trace of fulvous on secondaries, except a few scales on a single spot of the disk, while on primaries the four posterior spots of the band are fulvous, except a narrow edge of yellow on the basal side of each. 'The second has a slight wash of fulvous over each spot of the band and on both wings; and the third has all the spots of the band deep fulvous, except only those next the costa of each wing, which are yellow. The Newfoundland specimens show far more fulvous as a rule than those from Anticosti. These last most often have none of that color upon the upper side, but some are partly suffused with it.

EGG. - Spherical, flattened at base, smooth; pale yellow.

"The young larva are black when they issue from the egg, but the whitish patch on middle segments can be distinguished at this stage. At about a week old they are black, and the patch is pale yellow, mottled with black; surface covered with short tubercles. At the next stage, the length being $.25 \mathrm{in.}$, the color is dark brown, and the patch is replaced by a whitish band which encircles the body, and is mottled with black." (Mr. Wm. Couper in lit.)

MATURe LARTA. - Length 1-5 inch.

Cylindrical, slender, thickest at third and fourth segments, tapering slightly from fourth to the last, and rapidly from third to the head; when at rest the head is drawn partly within the second, and all the anterior segments are contracted, the dorsum being arched; the middle of each segment crossed transversely by a black stripe. which is complete on second to fifth, but from sixth to twelfth is broken into three spots, the central or dorsal being round, the others 


\section{PAPILIO VII.}

ares of circles, the curve in front; below these stripes and in same line, from third to last segment, is a spot on each, which on third and fourth is lunate, but from fifth to twelfth is a right-angled triangle, one of the short sides being in line with the posterior edge of the stripe, the other parallel with the line of the stigmata; there is also an infra-stigmatal row of spots, one on each segment after the first, and there is a single spot on each leg and pro-leg; the last segment has three spots on dorsal line, the central round, the others abbreviated stripes; one such stripe also on either side; at the intersection of the segments from second to last, a black stripe crosses the dorsum and ends midway down the side; color bright peagreen, changing to yellow-green on sides and beneath; the legs tipped with black; head ob-ovate, yellow-green, striperl vertically with black; retractile horns bright yellow. (From an eximple preserved in alcohol, and from Mr. Couper, in lit. Fig. 6.)

Brevicanda was first made known by Professor Packart, who prefaced Mr. Saunder's' description by these words: "Mr. Saunders has received from St. Johns, Newfoundland, several specimens of a butterfly, one of which I have before me, and which seems to be a very remarkable variety of Asterias." 'The next notice on record is from Mr. Couper, in Can. Ent., Vol. IV., p. 20'2, Nov. 1872, who, in a paper on the insects taken by him that year on the lsland of Anticosti, mentions having four specimens of this butterfly. In 1879, Mr. Comper again visited this island, and succeeding in taking many more, as well as in discovering the larva and egrg. In Can. Ent., Vol. VI., p. 33, for February, 1874, he says that he had formerly taken a single specimen of Brevicande on the coast of Labrador, and that he had made inquiries as to its existence in Newfoundland, and is satisfied that it is a rare species on that island; quoting from a correspondent, who states that he had seen but one specimen in three seasons, and further, that he had heard of this butterfly at Corl Roy, on the western coast, and at Notre Dame Bay, on the north of the island. Mr. Couper continues: "I am confident that it becomes rare as we proceed down the south coast of Labrador towards the Straits of Belle Isle. Its true habitat is the island of Anticosti, where it occurs more abundantly than in Labrador or Newfoumdland. It is met with occasionally at Mingan, but more especially at the mouths of rivers east of Seven Islands." Mr. Couper has kindly furnished me extracts from his note-book as follows: "Brevicauda was noticed and a specimen taken at Ellis Bay, 14th June. From the latter date, as the weather became warm, forty specimens were taken up to 26 th June. The female deposited eggs, 25th June, on Archangelica purpurea (see Plate), and I have also found eggs on Heracleum lanatum, but the former plant is its principal food, and occurs abundantly throughout the island. The egg is laid singly on the 


\section{PAPILIO. VIII.}

upper surfice of the leaf near the edge, where it is exposed to the full force of the sun's heat. On the 10th July, I found young laxva, about ten days old, fecring on the upper cuticle of the leaf. 'To procure the complete history of this Papilio, it would be necessary for an entomologist to remain on the island from May till August. I arrived at Ellis Bay on 14th June, and left at the end of July. Therefore I har no chance of obtaining a chrysalis, which could only be had in the first week in August. I took the largest caterpillars I could find before I left, and which had passed their last moult. By the time the adult larva are ready to go into chrysalis, the weather becomes cold, and the larva at the begimning of August are of various sizes. 'The undergrown ones hide in the leaves of their food-plants during the cold nights, and feed during the day, and by the middle of the month, probably, all have matured and changed to chrysalids." Mr. Couper writes again, April, 1875: "Brevicauda was sent me last season from Percé, in the district of Gaspé, on the south coast of the Gulf, opposite Anticosti, and about seventy miles sea distance from that island. It occurs to me that as the western portion of Newfoundland is only one hundred miles from the east end of Anticosti, the butterfly may occasionally cross over. But after all my correspondence with two intelligent gentlemen in Newfoundland, I camnot obtain a specimen taken there. Although long resident, these gentlemen have never seen Brevicauda. I believe Anticosti to be the true home of the species." And later, "Two specimens of Brevicanda have been taken this summer at Godbout River, on the north side of the St. Lawrence."

In the Ent. Mo. Mag. for April, 1875, p. 24t, Vol. XI., is a mention by Mr. H. W. Bates, of Brevicauda, as taken by Mr. Milne, at Betts Cove and 'Terra Nova River, Newfoundland.

It is surprising that a new species of Papilio should be discovered at this late day on the Atlantic coast, and great eredit is due Mr. Couper for the pains he has taken to elucidate its life-history. It stands midway between two groups, that of Mechaon, represented on this continent by its variety Aliaska and by Zolicaon on the one hand, and Asterias and its allies on the other. It resembles Aliaska in shape, the fore wings being less elongated than in Asterias, and their hind margins being convex instead of straight or concave. The hind wings are also less elongated, and the tails are shorter, and are like those of Aliaska. Horeover, the sexes are alike in color and markings, as is the rule with all the Irachaon group, but not with Asterias, in which the difference between the sexes in these respects is conspicuous. But the basal area of the hind wings is black, as in Asterias, whereas in the other group it is yellow; and the abdomen is marked by rows of yellow dots as in Asterias also, while in MLachecon and its allies the abdomen is striped longitudinally with black and yellow. The yellow bands of the wines are similarly disposed in both groups, but their suffision with fulvous 


\section{PAPIIO VHI.}

is a peculiarity which Brevicunda shares only with the dsterias group. The mature larva dillers from that of Asterias. Zolicaon, or Nachaon, in the absence of the yellow or orenge spots which ornament those species, and the black stripres are more broken. 'The caterpillar of Aliaska is unknown, but is probably closely like that of Machrom.

Mr. Bates, in the paper before quoted, considered Brevicauda as a local form of Asterias, but on my pointing out the differences between the two, he replies that Mr. Milne's specimens were so much damaged that a complete comparison could not he made, but that on my representation, "there camnot be any doubt of Brevicaula being a good species, quite as distinct from Asterias as the Corsican P. Hospiton is from Muchuon."

Aliaska flies over the northern portion of the continent from east of Hudson's Bay to the lacific, and the range of Lsterices is from Canata to Mexico and from ocen to ocean. It is therefore the more remarkable that Brevicande should be restricted to two islands on the coast, being also excessively rare on one of them, and to a limited district on the adjoining mainland. One may naturally ask, how happens it that a species midway between two others which divide between them the continent, should be found thus restricted. Its peculiarities preclude the iden that it can be a mere offishoot from either of the species named, for in such case, while it would agree in part with the parent stock, the points of divergence would not be just so many points of agreement with any other species, and most especially with the only other at all allied to it which is to be found in its district. The variation would take a new direction rather.

'There are two ways of accounting for this phenomenon; first, that Brevicandu has originated in hybridism between the two species named. A brood being hybridized, its members have proved fertile, have increased moderately, and have been prevented by segregation on the islands from subsequent intercrossing with either parent stock. By this means the individuals now existing have become essentially alike. Segregation again has originated and perpetuated certain minor diflerences between the inhabitants of the two islands, as in color, those on one being mostly yellow, on the other fulvous. And from the islands the main-land is now colonized.

Or, second, Brevicauda represents an ancient, dominating, now almost extinct species, from which Asterias and Machaon have naturally descended, and each of which, in process of time, has thrown off one and another variety, some of which, favored by circumstances, have become permanent, and now constitute the group which gathers about its intermediate stock.

This last seems to me a reasonable and probable statement of the relationship of these several species. 



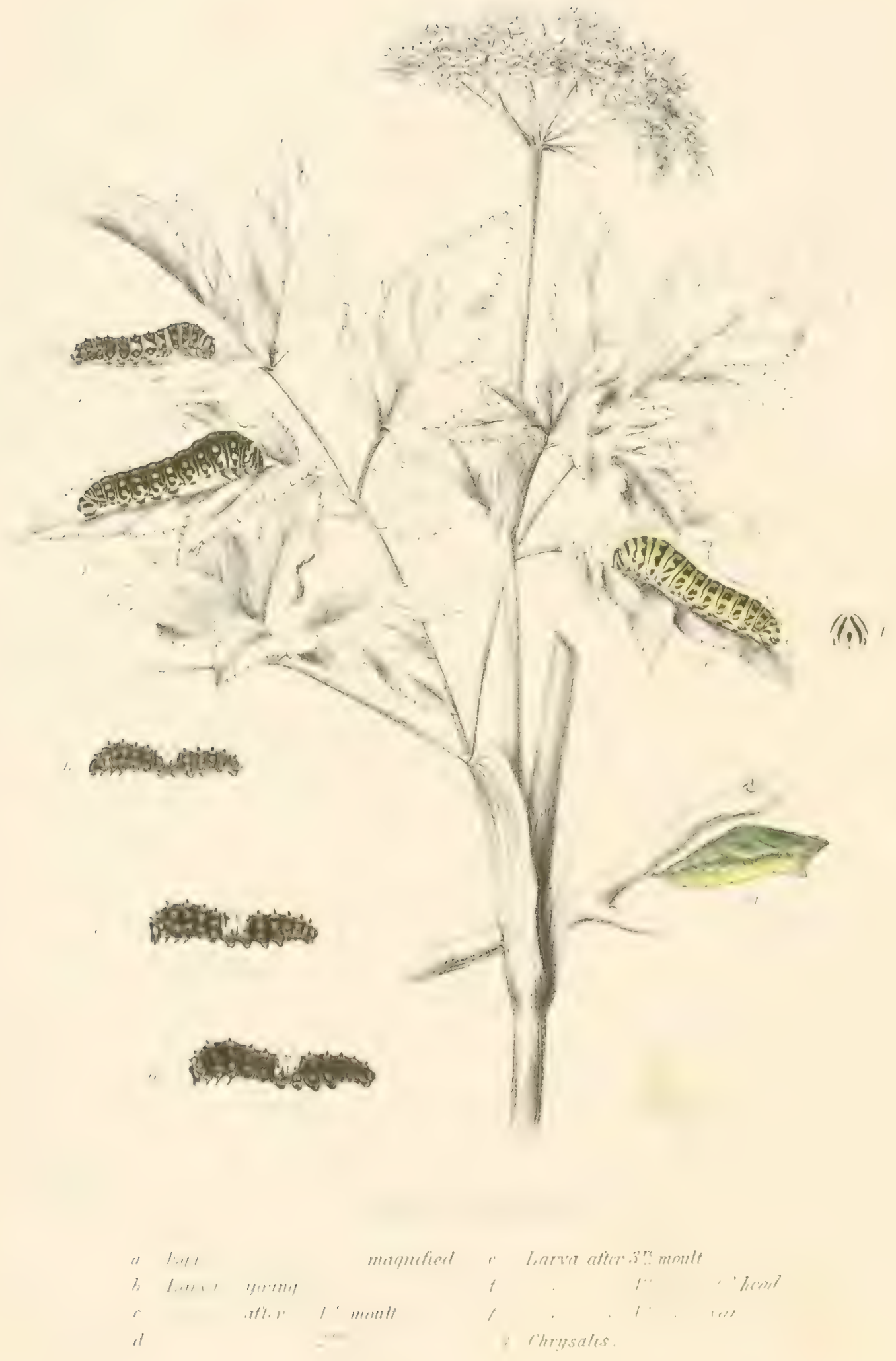




\section{P'APILIO VIII. B.}

\section{PAPILIO IBREVICAUDA.}

EGG. - Spherical, flattened at base; pale yellow. (Fig. a.)

Youxg Lirva. - Length .1 inch; cylindrical, the anterior segments thickest, and a little arched; color pale black; a white patch on dorsum, on segment $S$ and part of 7 ; the spines are in six rows, one sub-dorsal and two on either side; these are black and rise from pale yellow tubercles, each sending out a few black hairs; head black, pilose. (Fig. b.)

After first moult: length .25 inch; color black-brown, the patch white and extending well down either side; the spines as before, their bases pale yellow; head black, shining, with a white spot in front and one on either side. (Fig. c.)

After second moult: length .4 inch; color black, the patch as before; white marks over the feet; the bases of the spines chrome-yellow; head as at previous stage. (Fig. d.)

After third moult: length 8 inch; color black, with narrow white stripes at the junctions of the segments; white also on the sides of 7 and 8 , but not on dorsum ; white points on the last seginent and over feet; the yellow at bases of spines is brighter; head as before. (Fig. e.)

After fourth moult: length 1.1 inch, and reached 1.5 inch at maturity.

Mature Lurva. - Length 1.5 inch; cylindrical, slender, thickest at third and fourth segments, tapering slightly from four to last, and rapidly toward the head; the surface smooth, the tubercles of previous stages being suppressed, except those of the two dorsal rows which are reduced and scarcely elevated, and under the glass are seen to have a pencil of very short hairs each; when at rest the anterior segments are contracted and arched; the middle of each, from two to twelve, crossed by a black stripe or narrow band, broken on the middle of side after five; from four, divided a second time near its extremity, a triangular section being cut off on the posterior side; on thirteen the band is divided into three spots, the central or dorsal one being rounded; behind these are two sub- 
PAPILIO VIII. B.

dorsal round spots, and on either side a long oblique mark; the anal shield black; there is also a black stripe between each pair of segments, broadest on dorsum and diminishing to the middle of the side where it disappears; these are scarcely visible except when the larva is in motion; there is also a line of small black spots along base of body, one on each segment from 2 to 6 , and on 11 to 13 , two on 7 to 10 , and there is a spot over each foot and pro-leg; on each side are three rows of chrome-yellow spots, those of the two sub-dorsal rows being round and placed just within the tubercles, and on the firont edges of the bands; so the spots of the other rows on segments three to five are on the fronts of the bands; but after this they divide them, the middle row being round, the lower row straight and oblique, filling the space between the band and triangle; feet tipped black; color of body bright pea-green, changing to yellow-green on the sides; or a creamy-white tinted dorsally with delicate green, fading into white on the sides; head obovate, either yellow-green or pale green, marked in front by two oblique black stripes which nearly meet at top; two others on the sides, and between the front and side stripes at base is a short narrow stripe; on lower front face a rounded black spot; the retractile horns bright yellow. (Figs. $f, f^{2}$.)

Another larva at maturity was black, with white lines between the segments, and pale green between some of them, especially the anterior ones and the last two; much white along base of body. (Fig. $f^{3}$.)

Cimrsalis. - Length 1 inch; greatest breadth .3 inch; cylindrical, thickest in middle; the surface rough, corrugated; head-case produced, ending in two sub-triangular processes, the space between them concave; mesonotum prominent, pointed forward, sub-pyramidal; color green, on dorsum yellowish, on ventral side pale; the wing-cases dark; on abdomen two sub-dorsal rows of small rounded tubercles. (Fig. g.)

On Plate VIII. the mature larva of Brevicanda was figured, but incorrectly in one particular, as afterwards discovered, the yellow spots having been omitted. In 1878, Mr. Couper visited Godbout, on Lower St. Lawrence, north shore, and paid especial attention to this butterfly and its preparatory stages, taking notes of each. He also preserved each larval stage in alcohol, and on his return put the notes and material in my hands. Later in the season he sent me two living. chrysalids, from which the butterflies emerged at Coalburgh the following spring 'The chrysalis on the Plate is drawn from life; the larva from the alcoholic ex. amples. In these the markings are as distinct as when alive, but for the colora. tion, except when black, the notes of $\mathbf{M r}$. Couper have guided the colorist. The yellow spots had completely disappeared in the alcohol. Mr. Couper wrote as follows: "This butterfly was rare at Gorbout in summer" of 1878 , only about a 
l'.1PII,I1 YHI. H.

dozen being seen on a long range of coast. The first were noticen at the beginning of June. I think the rarity was produced by the want of the usual snowfall the previous winter. 'The depth of snow is usually nine feet, but was only about two feet on the north shore in the winter of $1577-78$. The food plants, namely, Angelica peregrina (not purpurea, as stated in the text to Plate VIII.), and the wild parsley were retarled by the cold weather. The first eggss were deposited 14th June, but a second bateh was laid about middle of July. I brought larve with me to Montreal in jelly glasses, and atter the Angelica was exhausted. I fed them on wild parkley; but they eat very little of it and all dwindled away and died. But my friend, Mr. Nipoleon Comean, of Godbout, had some of the larve, and has since written me that although his first trial with the caterpillars was not strecessul, he has now four which are progressing favorably." 'These caterpillin's reached chrysilis, and two of them were sent me by Mr. Couper, as I have mentioned.

I am pleaser at being able to represent the preparatory stages of Brevicundu in full, together with its food plant, Angelice peregrina, and to grive its history as worked ont so succesfiully by Mr. Couper.

Nore. Some delay in the issue of the present l'art gives me an opportunity to ald further information respecting lrevicumla and its history, kimlly rontributed by Mr. Mear.

New York, september $23,1880$.

DEar Mr. EDWArDs, - During my recent stay of three wecks in Newfoumdland, I was very successful in obtaining caterpillars of $P$. Brevicunda along the shores of both Conception and Placentia Bays, on the peninsula of Avalon, which was the only part of the island visited. In climbing a mountain at Iopsail, twelve miles from St. John's, I noticed one of these butterflies sailing about the rocky summit, very much as $P$. Inelre is always seen to do in the Sierra Nevada. Like that species, it made long tlights, rarely alighting, but apparently reconnoitering the whole mountain, as if in search of plants on which to lay its egrgs. Chase would have been useless, so stationing myself on what appeared to be an attractive grassy spot among the rocks, I waited for the insect and captured it on the wing. It proved to be a female; so confining it in a box mninjured, I made diligent search for plants on which it might lay eggs. But umbelliferous plants seemed very scarce throughout the country, and it was only by good fortune that I noticed an Angelica growing in a field as we drove back toward St. John's. The butterfly was confined with a stem of this plant, and laid nine eggs and then escaped. None of the eggs hatched, howevel. 'This failure I attribute to their having been kept from the sumlight, for the caterpillars afterwards 
PAPILIO VIII. B.

found seemed very susceptible to cold and prolonged darkness or close confinement of any kind.

The first caterpillars were found at Holyrood, at the head of Conception Bay, upon cultivated parsnips. 'This was on the 28th July, and though some of the caterpillars were in the last stage, the majority of them were young. In a drive of thirty miles across the peninsula to Placentia Bay I found no Brevicanda at points in the interior. Near Placentia, however, there were large patches of Angelicn, on which I found a few larve. In the kitchen gardens of the villagers one or two larve were on almost every parsnip plant, and in a small field overgrown with wild parsley I obtained nearly two hundred in the course of one afternoon. This was during the first week in August, and nearly all the larva were past the third or fourth moult. Not having expected such good fortune, I was obliged to nearly fill my butterfly collecting box with them, and carry it about a mile to my lodgings. Even this short confinement killed several of the larva and reduced many more to a state of insensibility. In their natural condition, they either rest upon the leaves in full sunlight, or bask upon the stones and coarse gravel among which their food plants grow. These stones are often heated by the sun during the day to a temperature of $90^{\circ}$ to $100^{\circ} \mathrm{F}$., and retain a part of the warmth overnight.

These caterpillars were large, measuring two inches in length when at rest. The colors in all were clear apple-green and black, with dots of orange-yellow disposed as figured on your Plate, and showing all intergrades between the varieties represented at $f$, and $f^{3}$. The larve did not seem to object to change of food, but eat wild parsley, Angelica, or parsnip almost indifferently.

From about three hundred caterpillars I obtained about one hundred chrysalids before leaving Newfoundland. They vary from 1.1 to 1.4 inches in length. Fifty-three are green and yellow, as shown on the Plate, fifty-nine are black or dark brown, marked with light woor-brown, and two are intermediate between green and brown. One chrysalis gave butterfly within a week of my return, thus not having been in chrysalis more than eighteen days. This was a fine female, expanding a little over three inches, and resembling Fig. 5, Plate VIII., in its color and markings. Four more have just emerged, all males; two of them show a little fulvous suffusion, while the others are like Fig. 1.

\section{Yours very truly,}

THEODORE L. MEAD.

It is evident from this communication of Mr. Mead that Brevicauda is a common species in southern Newfoundland, at least. Also that it might easily become double-brooded, if the length of the season permitted, or if it became acclimated in a more southern latitude. 



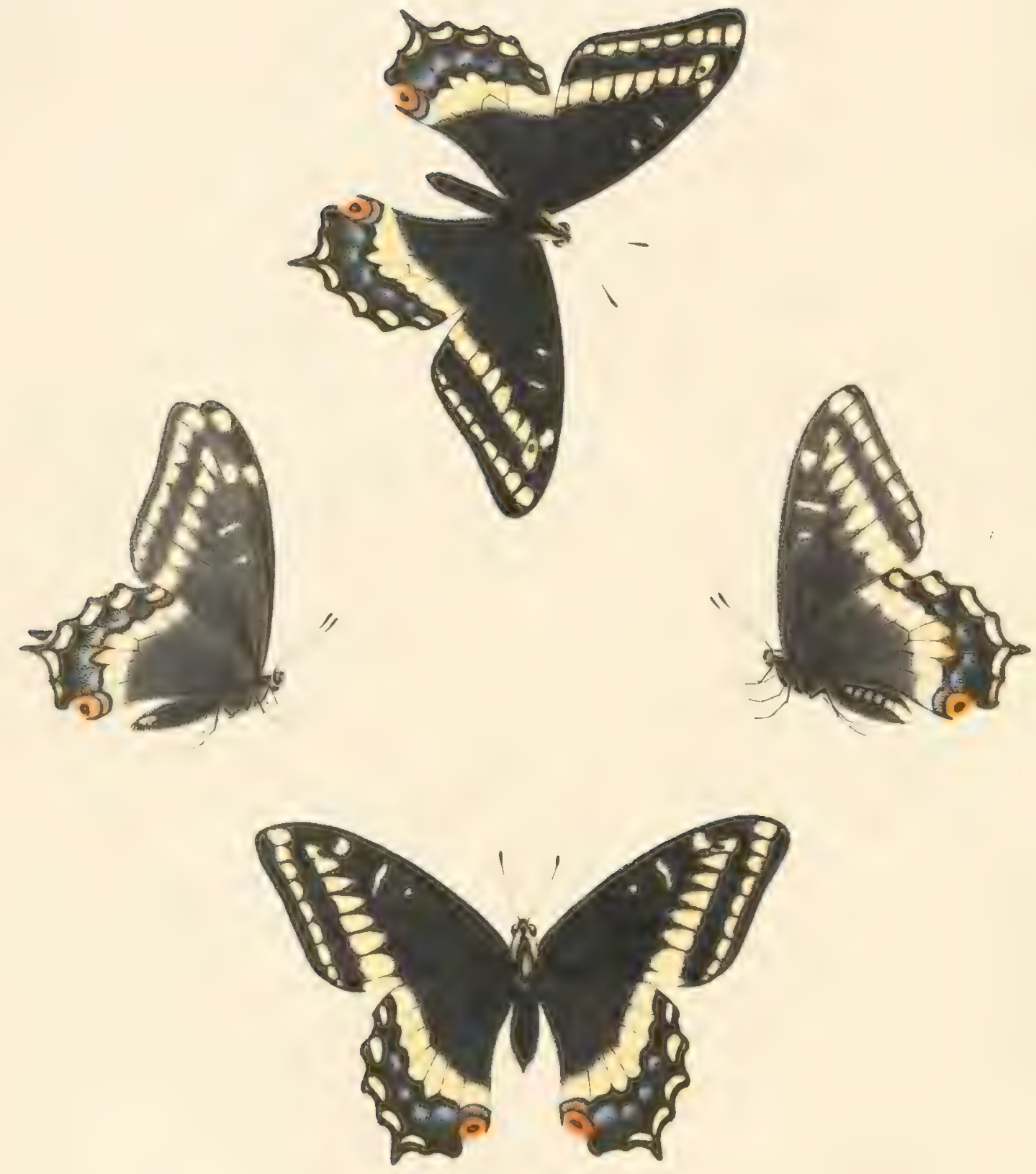




\section{PAPILIO IX.}

PAPILIO INDRA, $1-4$.

Papilio Indre, Reakirt, Proc. Ent. Soc. Phil., VI., p. 123, d", 1866. Putnam, Proc. Davenport Acad. Nat. Sci., I., pl. 35, \&, 1876 .

Priscines moderately produced; costal margin much curved near apex; hind margin in male either slightly excavated or sinuous, in female straight; tails short, broad at base; the sexes alike in color and markings; closely allied to Brevicaudo.

MaLE. - Expands 3 inches.

Upper side black; primaries lave a submarginal series of small yellow spots, largest anteriorly and regularly diminishing in size to inner angle; secondaries have a similar series of six spots, mostly lunate, the one at outer angle sometimes obsolete; a common yellow band crosses the disks, on primaries composed of eight spots, the upper six triangular, the seventh sub-quadrate, the eighth a narrow bar on imner margin; the first of these spots has a circular incision on the costal side, perhaps cutting quite across; on the upper subcostal interspace is a rounded spot; on the imner side of the are of cell a narrow bar or stripe, and a small patch within the cell; on secondaries the band is nearly straight on its inner side, or a little excavated, and consists of eight spots, the yellow extremity of the cell counting as one; beyond are clusters of blue scales; above the incision at inner angle is an orange-fulvous ring, edged on the side of the incision by yellow, surmounted by a blue crescent, and inclosing a rounded black spot; fringes of primaries black, of secondaries black, in the emarginations yellow.

Under side paler black, the spots repeated, paler colored, the submarginal spots enlarged; those at the angles on secondaries more or less covered with orange; also the spots on lower discoidal and upper median interspaces are tipped with orange; the black area between the spots and band, on primaries, immaculate, but on secondaries this area is dusted with blue or purple scales, and the middle of each interspace is of a deeper shade of black. than elsewhere.

Body black; the wing covers deep yellow; the abdomen white without yel- 


\section{PAPILIO IX.}

low excepting a lateral patch near the extremity; legs, palpi, and antennx hisk.

Female. - Expands 3 to 3.5 inches.

Similar to the male in color and markings ; the submarginal spots of secondaries below more or less orange-tinted; but in some examples the orange is confined to the two extreme spots, as in the male.

This species is as yet exceedingly rare in collections. Mr. James Ridings brought from Colorado, in 1864, two males, one of which came into my possession and is figured on the Plate, and the other was described by Mr. Reakirt, and is in the collection of the Entomological Society, at Philaclelphia. 'Tro females were taken by Mr. J. Duncan Putnam, in Clear Creek Cañon, above Golden City, Colorado, in 1S72, and one of these has been kindly loaned me for illustration. 'The other is figured in the proceedings of the Davenport Academy, and seems to have had no tail whatever, - merely a dentation a little more prominent than elsewhere. In the collection of Mr. Henry Edwards is a female taken in Tuolumne County, on the rim of the Yo Semite Valley, and a male found on Mount St. Helena, in Napa County. These were the only examples known to us at the begimning of 1877. Mr. Edwards wrote me in July, as follows: "I went up to the Sierras on 9th July and stopped at the Summit Station, 7,200 feet above the sea. The second day after my arrival I saw, close to the house, an Indra on the wing, and the next day I climbed to the top of one of the highest peals in the region, that is, to an altitude of 8,000 or 8,200 feet. Sporting about on the top of this peak, the plateau being about thirty yards by ten in area, were three grand Indra. But the wind was blowing fearfully, and they were constantly chased by Vanessas Curdui and Carye, and it was utterly impossible for me to catch one of them. They were very wild and over the edge of the eliff, which was quite precipitous, in a moment, forbidding the least approach. I had to go home the next day and had no chance to repeat my search."

After the plate of Indra was drawn, I received from Mr. Edwards a fine pair of this species, and as the female was larger than the example figured I regretted my inability to have given it also. Mr. Edwards writes: "Among some insects which were collected by a young friend of mine, Hermam Dwinelle, who died here a few weeks ago, and who desired that the whole of his collection should be sent to me, I find several specimens of Indra, taken by him in Shasta County, in July of the present year." Mr. Edwards adds: "There is no doubt that the Coast Range of Californin is the home of Indra, and that all examples 


\section{PAPILIO IX.}

taken in our Sierras and in Colorado, have strayed from their original birthplace. I have seen it now from Mentocino County; from Knight's Valley, in Sonoma County; and the examples taken by Mr. Dwinelle were taken near the fishing-station, McCloud River, Shasta Comnty. Now these localities are all in what is called the Coast Range of mountains, lying fur west of the Sierra Nerada, but comected with this range here and there by ridges of hills. Knight's Valley is only about 250 feet above the sea, MeCloud River abont 1,000, and the summit of the Sicrra, where 1 saw the eximples in July, about 8,000 , so that the species varies much as to its altitude."

Mr. Mead, who collected in northern Colorido for several months, in 1871, did not encounter this species there, nor did Lient. WT. L. Carpenter, U. S. A., who subsequently made extensive collections, both in northern and in southern Colorado; and Mr. H. K. Morrison, who brought, in 187T, an immense collection of butterties from southern Colorado, suw nothing of fuctra. Nor has it appeared from New Mexico, Arizona, or Montana. 'The metropolis of the species seems to be in western Californial, as stated by Mr. Henry Ehwards.

The principal difference between Intha and brevicundr, apant from the absence of orange in the former, and the presence of this color in a varied and often excessive degree in the latter, and which may be owing to climatal effect, consists in the markings of the abdomen and in the length of the tail. In Tudra the abdomen of the male is wholly black, excepting a yellow stripe on the side near extremity; in the female this is shown to be part of a stripe which extends the length of the aldomen, but which, except just at the extremity, is faint and nearly obsolete. 'This stripe on an otherwise black body is a characteristic of Zolicaon, and is there distinct. But in the Asterices group, while the body is black, insteal of a lateral stripe, there are lines of small yellow spots, and these are found in Brevicaula. At the opposite extreme from Asterias, Jachuon has the abdomen black above, but elsewhere yellow, with narrow lateral and vertical black lines. All these species, except Asterias, have the markings of the wing alike in both sexes, but in the latter species there is much difference in this respect. The series runs Machaon, Zolicaon, Initru, Brevicandu, Asterias.

The resemblance between Indra and Brevicauda, one at the extreme West, the other at the extreme East, and both restricted to very narrow limits, is suggestive of a period when both were represented by a single species which occupied the northen parts of the continent. This struck me when considering the peculiarities and the isolation of Brevicanda, and when I had only that species in view, and now the study of Indra seens to render the conclusion to which I then inclined more probable, - that, these two species represent most nearly the primitive form from which the Machaon and Asterias groups have descended. 




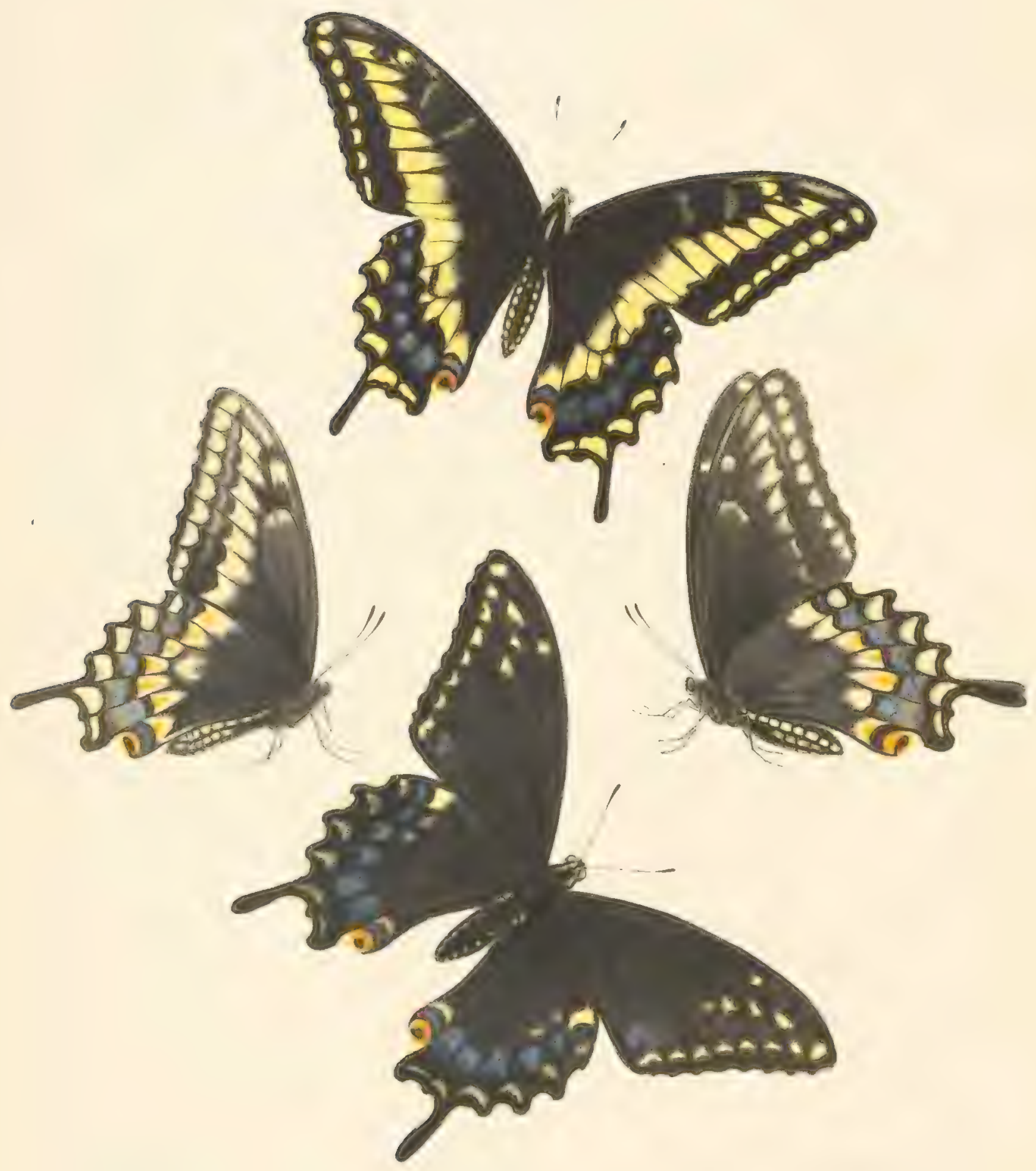




\section{PAPILIO X.}

PAPILIO BAIRDII, 1-4.

Papilio Bairdii, Elwards, o", Proc. Eut. Soc, Thil., Fol. VI., p. 200, 1866. \&, Edlw, Can. Tnt., Vol. XI., p. 83, 18.9.

Pimaries much produced, strongly arched, the hind margins concave; tails long, sub-spatulate; the sexes differ in omanentation.

Upper side black; primaries have a submarginal series of eight small yellow spots, those next apex rounded, the others lunate; secondaries have a similar series of six spots, the one at outer angle small, sometimes wanting, at immer angle narrow, the other's large, irregularly lunate; a common yellow band crosses the disks, composed on primaries of eight large spots, the first of which is long and pointed, but the basal half is nearly or quite wanting, owing to a circular sinus on costal side; the second to sixtl are sub-triangular, the seventh subquadrate, the eighth long and narrow; these spots, from second to eighth, are sometimes all truncated on the imer side; in other cases only the last three or four, and fade gradually into the black ground; most of them are also excavated on the outer side; in the upper sub-costal interspace a rounded spot; on the arc of cell sometimes an obsolescent yellow stripe, and another in the cell at about one third the distance from are to base; but in some examples no trace of these stripes is seen; the costal margin above the band is dusted yellow; on secondaries the band consists of seren spots, usually separated by the nervules only, but in some cases these spots are reduced and separated by considerable spaces; in some examples the breadth of the band is reduced from one half to two thirds; the space between the band and the marginal spots is broad, black, and occupied by clusters of blue scales, which increase in density towards imner margin; sometimes, however, these clusters are wanting; above the incision at anal angle is a fulvous ring on yellow ground, inclosing a rounded black spot; this ring is usually incomplete, the spot being joined to the black edge of the wing; above the ring is a blue crescent of densely laid scales; fringes yellow, alternating with black, yellow in the emarginations of secondaries. 


\section{PAPILIO X.}

Under side blackish brown; the spots repeated, the sub-marginal enlarged, especially on primaries; the sub-apical area on costa of primaries largely dusted with yellow; the middle of the black space between the band and the outer spots is also dusterl, so as to form a band or stripe of scales; secondaries have the outer ends of the discal spots more or less suffused with yellow-fulvous, usually only the two or three spots next the end of cell, but sometimes all are so colored; the black cxtra-discai space is nearly occupied by clusters of yellow scales, on the anterior edges of which are clusters of blue seales.

Body black; on either sirle of the thorax a deep ochre-yellow stripe to the insertion of the wings; on the abdomen a sub-dorsal row of small yellow spots on either side, and another row which is lateral; there is also a lower lateral row from middle of the abdomen to last segment, and a vertical row of about the same length; legs black, the outer side of the tibire and tarsi buff; palpi yellow and black; frontal hairs black, at the sides yellow; on either side, between the eyes and back of the antennx, is a yellow spot; antennx and club black.

Fearale. - Expands 4 inches.

Upper side black; the discal band represented by imperfect spots on both wings, corresponding to the outer portion of the spots of the male; there may be three or four of these on primaries, on the anterior part of the wing, or none at all; on secondaries, either a few small clusters of yellow scales, or nothing, except on costal margin, where there seems always to be a large and usually a distinct spot; all the yellow paler than in the males, rather buff; the clusters of blue scales sometimes large and conspicuous, sometimes obsolescent.

On the under side the spots are generally more distinct, and on secondaries, in all indivichals examined, form a complete series across the wing, but of single width, the spot in cell being obsolete in all cases; the spots are more suffused than in the male, either with dull fulvous or ochraceous, and the spots of submarginal row are often more or less fulvous; in some cases the extremity of the abdomen is yellow, and the central side largely so.

This species inhabits Arizona, and probably Southern Colorado and Utah. The example described by me in 1866 was a male, which I found in a badly damaged state at the Smithonian, and it was several years before other examples were received, taken in Arizona by the Wheeler Expedition. 'These were in bad condition and of little use for descriptions or figuring. Fortunately, Mr. B. Neumoegen receivert, in 1878 , several fresh examples of both sexes, and has kindly allowed me to use them. The males differ much in the discal bant, some having this of twice the brealth of others. In some the spots of this band are close together, in other's there are wide black spaces between them; all have 


\section{I'A PIILIO X.}

these spots fading out gradually on the basal side instead of being clear cut, and on the outer side, nearly all on the primaries are concave. On the under side there is an absence of the fulvous color which characterizes Asterias, there being at most a slight ochreous discoloration on the outer edges of the discal spots on secondaries, and sometimes this is wholly wanting, or is restricted to the two or three spots against cells. In fresh examples there is a belt of yellow scales iuside the sub-minginal spots.

'I'he female shows only traces of the band, sometimes limited to three or four obsolescent spots on the upper part of primaries, or perhaps entirely across. In one example these traces continue across sccondaries, but in all others examined they are absent. In all, however, there is a large spot of yellow, more or less dense, on costal margin of secondaries. The spots of the sub-marginal rows of same wings seem never to be distinct in the female, and often are represented by a few scales only. In both sexes there is much variation in the extent of the blue clusters on secontaries. On the under side in the female the band is always distinct on secondaries.

Asterias is also foum in Arizona, and I have received several examples of both sexes. They do not differ more from the northerm form of the species than individuals from one laying of eggs are found to differ in West Virginia. Invariably they are characterized by deep fulvous spots on under side. 




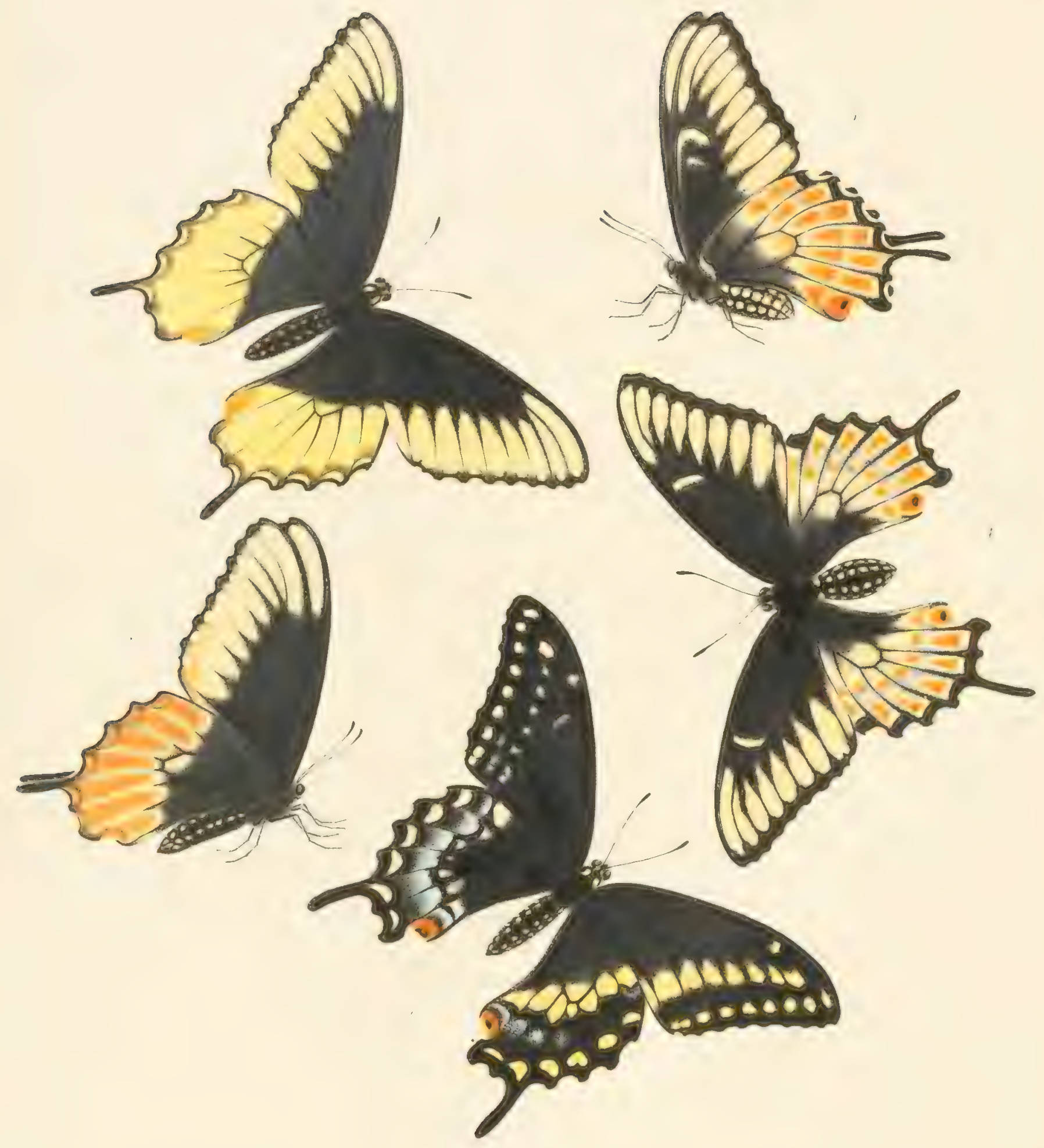




\title{
PAPILIO XI.
}

\author{
$+\cdots$ \\ ASTERIAS, VAT. CAIVVERLEYI, 2-5.
}

Papilio Calverleni, Grote, Proc. Ent. Soc. Plil., II., p. 4\$1, pl. 10, d". Mend, American Naturalist, III. p. $332,+$.

Tre male described by Mr. Grote was captured August, 1S63̈, by Mr. Louis Fischer, in the neighborhood of New Lots, (Dueens Co., Long Island, and is still in the collection of $\mathrm{ML}_{1}$. Stephen Calverley, now of Utien. N. Y., from whom I obfained it in order to figure it on the Plate. The female represented was taken by MIr. T. L. Mead, near Enarprise, Florida, April, 1869. I formerly thought it not impossible that we might have to do with a good species here, as both sexes harl heen taken, and one of them in a then little explored region. But very full exploration of Iilorida of late years has failed to produce another example, and I think this form must be regarded as a suffused Asterias. Such cases sure not of very uncommon occurrence in different species of butterflies. and I have several in my omn collection. Many are figured in Esper and other European author's. We have a goorl example of the phenomenon in Argynnis Ashtaroth, Fisher, which is a suffuserl Idatia. But when the suffusion is not restricted to one sex only, it would seem that under firvoring circumstances the peculiarities of color might be perpetuaterl, and give rise to a permanent variety, - that is, to a good species.

The causes of this suffusion in butterflies can only be sumised, but some experiments recently marle by me, in which the chrysalids of Phyciodes Tharos were subjected, immediately after forming, to a low temperature, $33^{\circ}$ Fahr.. for several days, indicate that continued severe cold, such as would ensue from an enveloping with ice or snow, for example, soon after the forming of the chrysalis, may be one cause of the blending of colors in the emerging butterfy. In the instance referred to, not only was there a decided change in the coloration of the butterflies brought about, but in many of them the colors of both surfaces har rum together, aftording as fine illustrations of suffision as in these P. Culverleyi. 




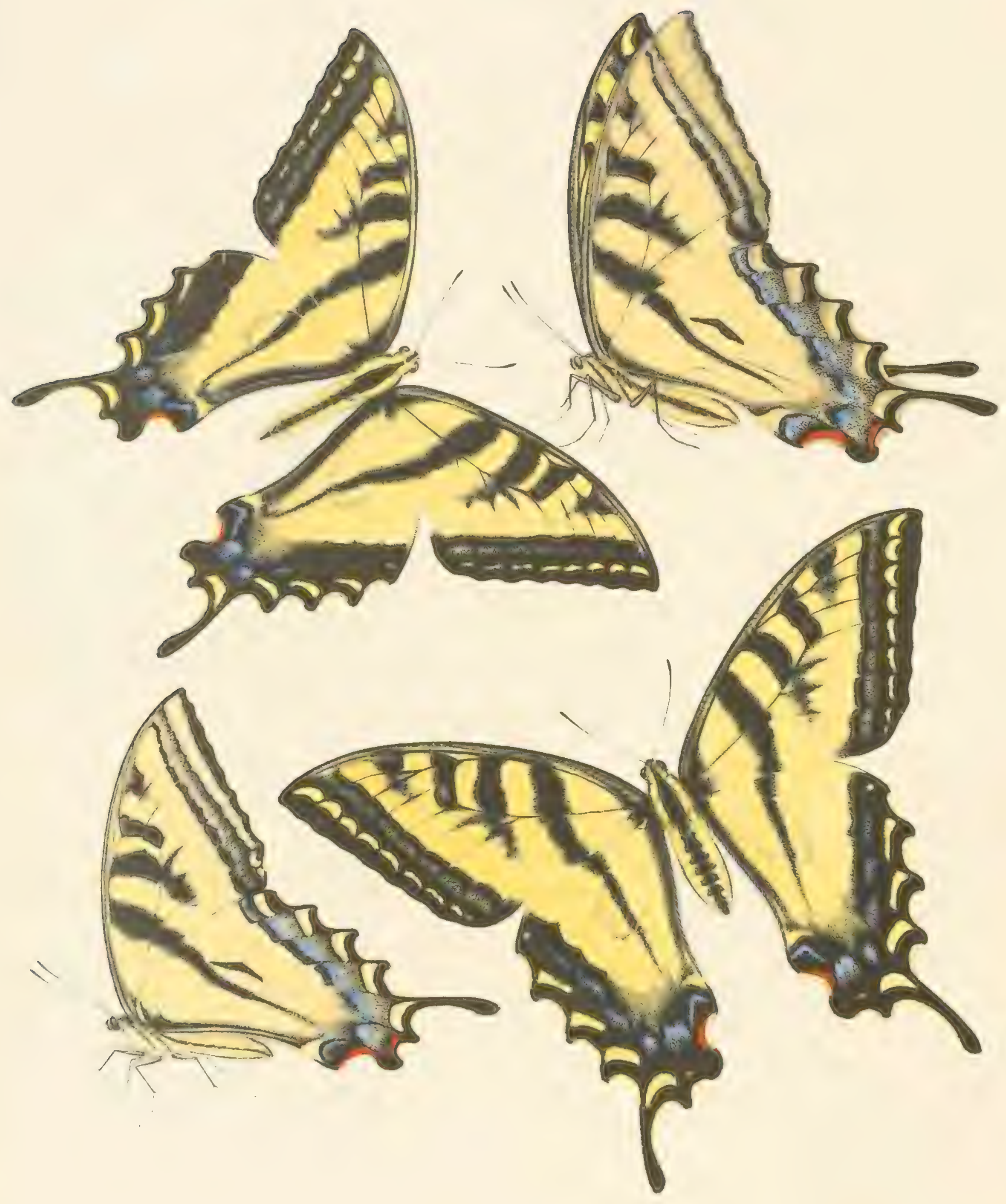




\title{
PAPILIO XII., XIII.
}

\author{
PAPILIO RUTULUS. 1-4.
}

Papilio Rutulue, Boisiluval, Ann. Soe. Ent. de France, 2we sor. r. X., p. 279, 1852.

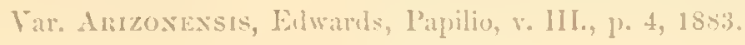

MALE. - Expands from 3.5) to 4.2.5 inches.

Upper side yellow, banded with black; costa of primaries black, more or less dusted throughout, and next base densely, with yellow; a narrow band crosses the bases of wings and follows the abdominal margin, bends inward at an obtuse angle and joins the extremity of the secont band; this last crosses both wings, is broad on primaries, but narrows gradually as it appronches the imer margin, and on secondaries is reduced to a slender, tapering stripe; the third bomd crosses outer part of cell of primaries, is loroad, usually curved, and is contimued by an irregular pateh to lower brunch of median nervure, with spurs alone the umper branches; the fourth band lies on the are of cell; the fifth is made up of a rounded spot in sub-costal interspace, and a patch which reaches the discoidal nervule; the marginal border is broat, even-edged within, and through it, on primaries, runs a series of small yellow spots, which form a tapering bant, the anterior spots oval or lumate, the others straight, and often mere streaks; on the basal side of these, on the black ground, is a stripe of yellow seales; on secondaries, the border widens posteriorly, and in the median interspaces is densely dusted with yellow on the inner side; along the margin are four yellow spots, the posterior one lunular, the remainder narrow bar's, curved ol straight; sometimes a fiftl spot appears at outer angle, but is always small, a streak, ol cluster of scales; next inner angle a small deep fulrous lunule, or a streak, often wanting; the incision at this angle edged fulvous; through the borter runs a series of loose clusters of blue scales, often wanting on anterior half of wing, but more compact on lower median interspace, there forming a large rounder patch; next inner margin a blue crescent; primaries usually have the sub-costal and discoidal nervules edged black; the are of cell on secondaries often covered by a black bar; tail long, narrow, bent, convex outwardly, somewhat spatulate on inner side, but often so little as to be scarcely perceptible; fringes of primaries black, 
a little yellow in the interspaces, of secondaries largely yellow, black at the ends of the nervules.

Under side pale yellow, the bands repeated, the submarginal yellow spots of primaries represented by a broad wedge-shaped band; the black ground anterior to this occupied by a band of loose yellow scales; on secondaries the corresponding black ground is densely covered with similar scales, having along the anterior edge a macular stripe of pale metallic blue; the submarginal spots repeated but cnlarged, and the one at outer angle is a broad rectangular bar; through the black discal bar sometimes runs a blue streak; in some examples there is a fint fulvous discoloration on the yellow ground of secondaries, in medim interspaces, but as a rule, there is no trace of this.

Body black above; a yellow stripe from the head to the insertion of secondaries; but often the black area is restricted to a narrow hand from head to end of abdomen; beneath, the thorax is yellow with two oblique black stripes; abdomen yellow with a lateral black stripe from insertion of secondaries to last segment, and two stripes rentral. (Figs. 1, 2.)

Feviale. - Expands from 4 to 4.8 inches.

Upper side as in the male; the blue scales in border of secondaries more dense, and continued across the wing, presenting the appearance of a macular band; the spot at outer angle as in the male. (Figs. 3, 4.)

The figures on Plate represent the summer brood, and examples of this brood from California and Washington Territory are nearly all ochrey-yellow, while those of the spring are clearer. All examples observed from the Rocky Mountains are less ochrnceous than those to the westwart.

Var. Arizonensis.

Wings less falcate, the black bands heavy, the tails bent in, very little or not at all spatulate on inner side. (Figs, 5, 6.)

EGG. - Sub-conoidal, hase rounded and flattened; surface smooth ; color deep green. (Fig. a.) Duration of this stage ten to thirteen days.

Young Lirva. - Length .1 inch; cylindrical, the anterior segments thickener? color dark brown, mottled black; on 8 a whitish patch, the width of the segment, rounded at the ends and taking in the sub-dorsal tubercles, but descending the sides no farther; this patch covers the posterior part of 7 also, and is there broken into spots; an obscure light line runs the length of the body just under the sub-dorsal tubereles; on dorsum of 2 are four minute tubercles, or mere points, in two cross-rows, the front pair twice as far apart as those on 3 , the other pair outside these; from 3 to 13 are two tubercles to each segment, close togrether, and ench of these points sends ont one short hair; the sub-rlorsals are large on $2,3,4,11$, and 12, conical, pointed, with one hair at apex and five about the sides, 



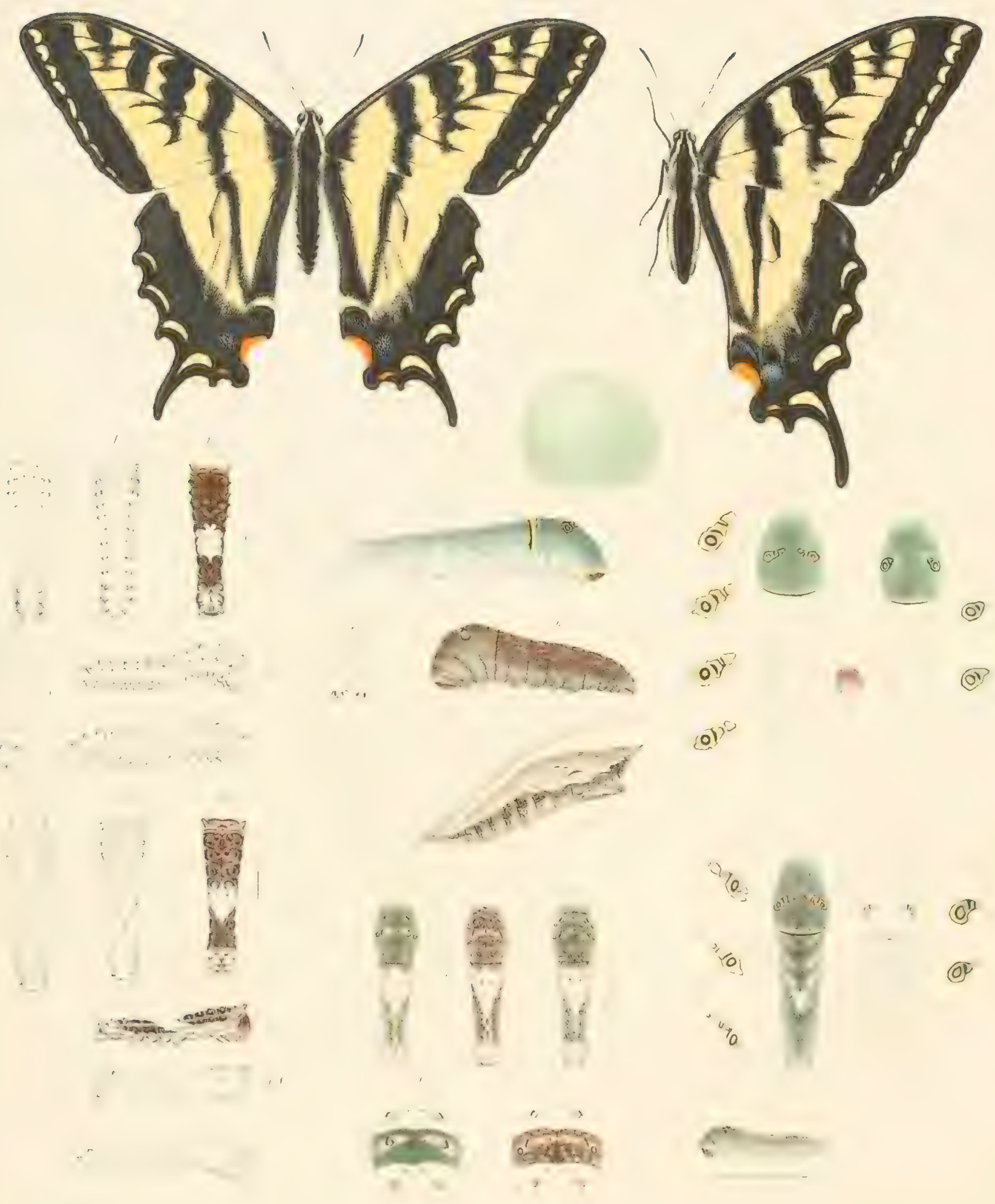




\section{PAPILIO XIL., XIIT.}

every hair straight and ending in a knob; on 13 is a similar tuberele, equal in size to that on 2, and armed in same way, these two being the largest of the row; the other tubercles of these rows are small, equal, each with three hairs; the upper lateral rows run from 2 to 12 , are small on 2, 3, 4, each with three hairs, the rest minute, with two hair's; below spiracles, from 2 to 13 , is another row, the three anterior ones small, with three hairs each, the others minute, with two; in all six rows, three on either side; head shining black, obovoid, bilobed. ( Figs. $b^{2}, b^{3}, b^{4}$.)

At two days from egg ; length .125 inch; color mottled light and dark brown; 12 and $1: 3$ are obscure whitey-brown; the lateral line distinet. (Fig. 6 represents this point in the stage.) 'To first moult about nine days.

After first monlt: at 6 hour's from moult, length .2t inch; shape as before; color yellow-brown, mottled with dark brown; on mid-dorsum on 3 is a black patch, and one on $4 \mathrm{im}$ shape of a cross; the patch on middle segments is formed of two narrow bands which meet on summit of 9 , and rui obliquely forward and down side to middle only; 8 is wholly white, but on 7 are two small brown dorsal spots; sometimes the posterior end of 6 is mottled with white; 11 and 12 are dull white and brown; along verge of dorsum a whitish stripe from 2 to 13 ; the lower part of sille is dull white mottled with pale brown; 2 has a narrow arcuate front ridge, at either end of which is a stont yellow-brown tubercle, conical, with short pointed spurs about it, and each of these as well as the top gives out a short hair; on 11 is a pair of sub-dorsal low brown cones; 12 and 13 each have a compressed cross ridge on dorsum, and at either end of this is a tubercle much like the one on 2, on 13 the size of that, on 12 smaller; on 3,4 , 5, are two rows, sub-dorsal, of round, glossy, light brown knobs, and on 3 and 4 each is one below these; on 3 are two minute knobs between the sub-dorsils, and a little in advance of them; on 4 are two of somewhat larger size, also in advance, and on 5 two minute ones more decidedly beyond the sub-itorsils; aiter 5 there are no knobs or tubereles to 9 inclusive; head obovoid, brown, the front greenish; the surface of head much covered with fine short hairs. (Figs. d to $\left.l^{t} \cdot\right)$

At two days after first moult: length .4 inch; the patch on dorsum has now a pink tint; the lower half of side of body is whitish-blue; on the other segments there is scarcely any change; on 3, 4, 5, outside of and at base of oach subdorsal knob, is a black dash, and on 7 is another in same line.

At three days after the moult: the color has become greenish, the light parts pink-white; a pair of light blue dots appear on dorsum of 9, 10, 11. Duration of this stage 4 to 5 days.

After second moult: length 4 inch; color either bright green and pale salmon, 
P’IPIIIO XII., XIII.

or olive-brown and salmon, or green mottled and specked with brown over dorsum (three distinct styles of coloring) (Figs. $f, f^{2}, f^{3}$ ); the side blue-white; the rlorsal patch triangular, one angle being on 9 , the others on sides of 7 , color silmon; 11 to 13 salmon mottled green; in the brown examples $2,3,4$ are green specked and mottled in shades from pale to olive-brown; in all is a salmon line, in part macular, along verge of dorsum, and along lower part of side is another, less distinct; from 5 to 11 , on the sides, are obscure oblique streaks of light specks, turned down and forward; front ridge of 2 yellow, slightly arched, at either end a yellow conical tuberele; on this segment are two minute sub-dorsal smooth green knobs; on 3 are two such knobs, mid-dorsal, and two of larger size, sub-dorsal, with a black bar on anterior outer side of each, the four in line (Figs. $f^{4}, f^{5}$ ); on 4 are six knobs in an arc, the dorsal pair small, the sub-dorsals largest; the two outer of these knobs on either side have each a pale blue or a purple round spot on the dorsal side, and the sub-dorsals have also each a black bar on the outer side; on 5 are $\iota$ wo small dorsal knobs near front and two large sub-dorsals on middle of the segment; on $6,8,9,10$ each is a pair of sub-dorsal blue or purple dots; on 12 and 13 each a pair of sub-dorsal yellow conical tubercles, that on 13 the larger, all these on the ends of narrow cross ridges; head shaped as before; color pale red-brown, lower part of face greenish (Figs. $f$ to $\left.f^{5}\right)$.

At twenty-four hours after second moult: length .5 inch, the green and salmon deeper colored, the lateral stripes more conspicuous, the lower one broad from 2 to 5 inclusive, the rest macular; on 4 the outer blue spot shows a brown ring.

At forty-eight hours: length .56 inch; the green now bluish with a gray tint, the salmon specks and small spots obliterated, the lateral stripes in part obsolete; the dorsal patch changed to pale green except at the angle on 9 , and a stripe on the side of 8 and 7 ; the patches on 4 , which are a marked feature at next stage, now begin to show faintly, and in a few hours become pretty distinct (as seen in Fig. $\left.f^{4}\right)$. Duration of this stage three days.

After third moult, at twelve hours: length .6 inch; color green specked with lighter or blue-green, least on anterior segments; the salmon patch has mostly disappeared, but has left some traces, varying in individuals; the lateral bands more or less distinct on two or three segments, the sides bluish or blue-green, varying; 2 has the front ridge as before, the processes at ends reduced; on 3 are sometimes two minute sub-dorsal green knobs, and two dorsals between them, but the last are often wanting even while the others are present; on 4 is an alongated ochre-yellow patch on either side, divided into two sections, the upper one being sub-rectangular, the other ob-oval, the broal part outward. both com- 
PAPILIO XII., XIII.

pletely edged by a fine black line, and separated by a narrow purple space; in the oval is a rounded purple spot in heavy black ring, and on the dorsal side of this is a black cross bar; within the patch are three red-brown knobs, placed as in the previous stage, two of them inside the oval, the third just at the mper edge of the smaller section (Fig. $g^{3}$ ); in one eximple these knobs were observerl to be suppressed inside the patch (as seen in the middle figure, $g^{3}$ ); in one, their position was indicated by a roughening of the surface with a brown discoloration; there is some variation in the shape of the patches, as shown in the figures; in nearly all cases they are separated across dorsum by a space measuling .04 inch, in one example the space was .045 , in one .05 inch, but no other was above .04 ; on 5 are four purple spots in cross line near the posterior edge; when the larva bends, the front of 6 is seen to be black across dorsum, and the posterior edge of 5 is often more or less yellow; on $9,10,11$ are two sub-dorsal spots to each; 12 has two yellow sub-dorsal points, scarcely raised above the surface, and on 13 is a slight cross ridge with a yellow point at each end; hear shaped as before, pink, the lower face pale colored (Figs. $g, g^{2}$ ). Duration of this stage six to seven days.

After fourth moult: length about one inch; in four to live days was fully grown.

Mature Lanva. - Length about two inches; cylindrical, thickest at 4 and 5 , sloping on back and sides to 13 ; color of dorsum and upper part of side dark green, the lower part of side pale or bluish-green; the whole side specked with lighter color than the ground in oblique streaks; 2 has a yellow front ridge, arched, the corners rounded; on either side of 4 is an irregular club-shaped ochre-yellow patch, usually divided near its upper end, but sometimes not fully, there being then a yellow ligament binding the two parts on the anterior side; the upper spot, so cut off, is either triangular or sub-rectangular, the other is obovate, sometimes double-convex; each spot edged by a fine black line; within the larger, and near its outer end, is a pale blue rounded spot in a heavy blats ring, and above this is a black cross-bar; these patches are separated across dorsum by a space which very constantly measures .06 inch; 5 is usually edged posteriorly with yellow, but slightly, and often there is no trace of this color; on front of 6 is a black band restricted to dorsum; on 5 are four purple dots in cross-line, and on 9, 10, 11 each are four similar ones, the interior pair always a little the larger; besides these is a row of purple dots below the spiracles from 5 to 10 , but obscure; 12 has a pair of sub-dorsal yellow points, 1 :s a largel pair; under side and prolegs whitish blue-green; legs yellow; head rounded, a little broadest across lower face, depressed at top, the vertices rounded; color pinkbrown (Figs. $i$ to $i^{4}$ ). 
At about four days before suspension, the color begins to change, at first a soiled surface showing on dorsum; this deepens and spreads during two days, and finally the borly becomes chocolate-brown, specked over dorsum with darker, and on sides with lighter brown; all the purple dots now appear distinctly. (Fir. $k$.) From fourth moult to suspension about ten days, to pupation eleven days; from hatching of egg to pupation about thirty-six days; from laying of egg forty$\therefore$ ix.

Chrisalis. - Length of several, 1.38, 1.44, 1.45, 1.56, 1.60 inch, the larger being female; greatest breadth .4 to .42 inch; cylindrical, the abdomen tapering; head case long, compressed transversely on both sides to an edge; the ocellar projections prominent, divergent, pyramidal, the edges raised into thin ridges on dorsal side, the tops rounded, the incision between the two a right angle, with a small tooth on either side near the angle; the mesonotum prominent, directed forwards, blunt and rough at tip, with a ridge passing down either edge; on back of abdomen two rows of romded corrugated tubercles from segments 5 to 13 , those on 8 to 10 large, on 11 a little less, the others small; the larger tubercles are green-topped for some days after pupation, but change to black; the others are yellow-brown; on 6 to 11 is a second row of small green-topped tubercles high on one side, and four same color and small in row across dorsum of 4 and 5 ; whole surface corrugated, the anterior part roughly, the ventral side finely; color of ventral side throughout either one shade of gray-brown, or the abdomen is lighter; or shades of wood-brown; of dorsal side brown or yellow-brown, often with a dull ochre tint on the middle segments; along the side from top of head case to 13 , with a branch along mesonotum, is a broad band of brown, or sometimes of black; just after pupation the club-shaped litrvil spots of fourth segment appear in nearly same shape in the chrysalis (Fig. m), yellow, each enclosing two tubercles; the color fades from these spots after a few days. Duration of this stage seventeen to tiwenty days. (Figs. $l, m$.)

Rutulus belongs to a small and well-defined sub-group, which comprises Eurymedon, Daumus, Pitumnus, and Tumus. 'The last named species occupies the continent east of the Rocky Mountains; Eurymedon and Rutulus the Pacific slope, and more or less of the mountain region to the eastern base; Danmus follows the Rocky Mountains pretty closely, and finds its metropolis in Mexico; and Pilumnes is a Mexican species, which on rare occasions has been seen in Arizona. The peculiarities of four of these species are shown on the plates of this Volume. Rututus and Eurymedon lie between Turnus and Daumes, and the latter leads up to Pilumms. All have the wings striped aftcr the same pattern, but with variations, which are most maked in Pilumms, the stripes in that species being reduced from five to four and considerably modified. Danmes has 
I'II'II.I" XII., XIII.

the posterior dentations lengthened into tails, and in Pitummes this peculiarity is carried still firther. In many respects Tumes is as aberant on the one sirio as is Pilummes on the other. Its form is compact, all the others having much produced wings, its tails are decidedly spatulate. It alone presents a large rounded fulvous spot at the outer angle of lind wings in the female; in all the others there is no spot there, or it is a minute one or a line, always yellow; in the same sex, the blue scales on Turnus form grent lunate clusters, while in Rutulus they lie in a nurrow macular stripe, and are often largely obsolete; in the remaining species they are still less definite. Tumus shows dimorphism in the female, and beyond a certain line as we go southward, the black females predominate, and fintly supplant the yellow females almost if not quite completely. No dimorphism appears in the other species. In the mature stage only is the larva of Eurymedon known, and the same is true of Dumms, while of Pitumms nothing is yet known. Of Tumus and Rutulus we have the full history. In the mature larval stage Rululus and Daumes are very much alike, both having the peculiar club-shinped yellow spots on fourth segment; Eurymedon, contrary to what might have been expected, as the butterfly is very close to Rutulus, differs much from these two; and Tumus and Rutuhes at each larval stage present marked differences. I compare T'umus with liutulus stage by stagre:-

\section{RUTULUS.}

VOUNG LAIRV.

Color dark brown; the white patch on 7 and 8 restricted to dorsum, just taking in the sub-rlorsil tubercles ou either verge.

$\Lambda$ light stripe runs the length of boly, ontside the sub-dorsal tubercles.

A double row of dorsal tubercles, minute, each with a lair.

'The tubercles on 2 at ends of the cross-ringe are regular cones, enling in a point $\left(b^{4}\right)$; the hairs long.

The sub-dorsal tubercles all prominent, those on middle segments with three hairs each; all hairs comparatively long $\left(b^{2}{ }^{3}\right)$.

The Iateral tubercles have three hairs each on $2,3,4$; on 5 to 12 , though small, are distinct, and each bears two hairs $\left(b^{3}\right)$.

The infra-sticrmatal tubercles are equal in size to those of lateral row on corresponding segments, three hairs ench on $2,3,4,13$, and tro exch on the rest $\left(b^{8}\right)$.

\section{I'URNUS.}

\author{
YOUNG LAltist.
}

Color dark brown; the white patch saddleshaped, descending the sides to or near to spiracles.

No stripe.

Dorsal tubercles in same position, but the merest points with scarcely the stump of a lair.

These tubercles rounded, sub-ovoid $\left(c^{8}\right)$; the hairs sliort.

These tubercles on 3 and 4 are small, low; on the widlle serments minute and without laxirs, on 11 to 13 small $\left(c^{2}\right)$.

From 5 to 12 are mere points without hairs; on 2 is a point with single hair; on 3 and 4 are small, size of that on 5 of Rumhes, and liave three and two hairs respectively $\left(c^{2}\right)$.

These tubercles are points, three in horizontal line on 3 and 4 each, on 5 to 12 three in equilateral triangle; on 2 one hail $\left(c^{2}\right)$. 
Aften Frnst Modrt (trelve hours). - Color sellow-brown, mottled darker, with black patch on top of 3 and a black cross on 4 ; patch on 7 and 8 triangular, stopping on mid-sides on $7\left(d^{24}\right)$.

The stripe below sub-dorsals distinct (as in first stage).

No lilac spots on dorsum in the early part of this stage; but at three days from moult appear a yair on 9, 10, 11 each.

Aftelz Second Moolt (twelve hours). Color either bright green (no brown); or green, mottled and specked over dorsum with olivebrown; or olive-brown, mottled in darker shades and no green.

The patch salmon-red, triangular.

A salmon stripe along edge of dorsum and another low on side, both the length of body.

The sides specked with light green, in the brown larve with brown, disposed in obscure oblique strines pointing forward and downward.

After Timro Mourt (twelve hours). - Color blue-green.

The patch mostly suppressed $\left(g, g^{2}\right)$.

The two lateral salmon bands more or less disinct.

On 4 is a long ochre-yellow spot, with a deep sinus on its posterior side, the sinus purple. (Figs. $g^{23}$.)

The distance between the inner extremities of the two spots across dorsum is $.04 \mathrm{inch}$, none over .05 inch.

Color green from the moult.

After Fourti Moult (twelve hours). - The spot on 4 variable iu slape, but always elongated; the inner extremities .06 inch apart. (Figrs. $i^{2}{ }^{3}$ )
After Finst Modct (trelve hours). - Color black-brown; a black medio-dorsal line, slightly expanded on 3 and 4 ; the patch not triangular but saddle-shaped, broad on each side and reaching nearly to the feet $\left(e^{2}\right)$.

No stripe.

Many lilac spots from the beginning, two on 4 insile the sub-dorsal tubercles, two on $5,10,11$. (Fig. e.)

After Second Moult (twelve hours). Color black-brown, mottled with lighter.

Patch yellow-white, saddle-shaped as before. No stripes.

No such markings.

Aften Thind Moult (twelve hours). - Color usually olive-brown; sometimes dull green on anterior segments; brown after S.

The patch distinct.

No bands.

On 4 is a sub-oval green-yellow spot, corresponding with so much of the spot on Rutulus as lies below the sinus; no purple. (Figs. $h, h^{2}$.)

The distance between the inner extremities is .12 to .15 inch.

At two days from the moult gradually loses the brown, but in many cases never wholly.

After liourth Modut (twelve hours). - The spot on 4 sub-oval or pyriform; the inner extremities .16 to .18 inch apart. (Figs. $j, j 2$.)

Rutulus inhabits the country west of the Rocky Mountains to the Pacific; is seen more or less in those mountains in Colorado and Arizona. How far to the north, in British Columbia, it flies, I am unable to say. In Ent. M. Mag., Lond. XIX. p. 276, is a mention of 'Turners, on Vancouver's Island, and it is stated that its egres are laid on willows. This was a mistake for Rutulus, of course; Tumus certainly not flying west of the main divide, and its larvæe not feeding on willow. 'I'hroughout California, Rutulus is common, and Mr. W. G. Wright, of San Ber- 
nartino, has paid close attention to its habits and larval history during the past year, 1SS3, from early spring to November, taking a vast deal of trouble expressly that he might aid me in making known this history by plates and text. Mr. Wright repeatedly obtained egrs from females tied in bags over branches of willow, which were sent me through the mail, and from these came larve which reached chrysalis and imago at Coalburgh. He has written notes on the species in substance as follows: "The first brood of Rutulus butterfly appears in the interior valleys of southern California early in March, the earliest examples flying in the cañons of the momtain side, in the equable thermal belt, at an elevation of a few hundred feet above the low-lying plain, and yet below the colder altitules. In a week or two, they are seen in all the willow thickets of the valley, and along the tree-lined roadsides. The males are out a week before any females appear. 'I'his first brood lasts but a short time, having wholly disappeared by the last of April. The second brood comes in May, and thenceforward the broods doubtless overlap, as there are alway's plenty of -butterflies throughout the summer, and into November. In July and August the females are more plenty and more prolific than carlier. 'The food plant of the caterpillar is willow of several species, chiefly Salix lasiolepis, and S. lasimdra, or what are locally known as white willow, from the smooth white bark. 'The butterflies never go near S. nigra, nor the narrow, silvery leaved Argyrophylla, or IIendsiana. I know of several copses of these black willows, and have not during all this season seen any Rutulus near them. 'Their habit, in laying egres, is to hover in rapid flight about the lower branches of the willows, and drop one egg on the upper side of a leaf, then fly rapidly to another plant. The color of the egg being exactly that of the leaf, it is not easy to find one, even when the laying is observed.

"Having agreed to do what I could to get eggs for Mr. Edwards, the chase began before any females were abroad, and was kept up almost daily for three months or more. 'The females of the first brood were all small-bodied, and could lay but few egrgs. They also proved very unruly and almost always refused to lay when in confinement. As at first it was thought that apple or cherry was the food-plant, females were unsuccessfully confined over these and allied plants; but at length one was detected in the act of laying on willow, so that fartlier mistake was avoided. But even on willow they so steadily refused to lay, that from several dozen butterflies of the first brood I only grot ten ergess, all of which were sent to Coalburgh.

"The males of the first brood were foud of feeding on blossoms of the ruming blackberry, and occasionally were seen on compositer, but I did not see a female of that brood feeding on any flower. By the time the first brood had grone, their 


\section{PAPILTO XII., XIII.}

habits and run-ways had been so well learned that I felt sure of vitimate success.

"About 10th May, the fresh, bright colored males of the second brood suddenly appeared in considerable numbers, and in a week females were also flying. One day, I took two fine females, and the next discovered several feeding on alfalfa blossoms. That dny eight were put in three bags and tied to willow boughs in the thickets, and the next afternoon quite a number of ergos had been laid and were sent forward.

"These females were all notably larger than those of the first brood, and generally laid several eggs in confinement. From one I got twenty-eight. When the butterflies were taken far from iny house, or in places difficult of access, they were put in tin boxes, and there confined with cut twigs of willow. But willow speedily wilts in a warm, dry place, so that in two hours the plant would be worthless, as the insects have sense enough not to lay on wilted leaves. 'To remedy this difficulty, I thought of the expedient of inverting over the plant, lenving off the bag, a wide-mouthed glass jar, of as large size as could be got. Jars of a gallon capacity gave excellent results. 'These not only kept the leaves from wilting, but also rendered the air moist and quiet, and evidently in a favorable condition for the object in view. But wherever possible, the butterflies were put in the gauze bags and left in the thicket where they had been found. In such cases three enemies are to be guarded against, boys, birds, and ants. The curious boys cannot possibly let the odd apparatus alone if they find it, and the sharp little Indian boys are quick at spying out such things. The birds are about as bad, for they eat the butterflies, prying open the meshes of the bag with their bills. 'T'o circumvent them, it is well to use a double bag, or to cover the bagr with a cloth on the upper side. As to the ants, I have, whenever possible, waded into a stream, or better, a wet bog, and so found places safe from both ants and boys. 'Then the bags must be placed low down near the ground and on thrifty fast-growing twigs. High-hung bags are never successful. Considerable shade must be had or the butterflies will die. All these things, easy enough when known, cost me days and weeks of experiment, and many disheartening failures occurred. From one cause or other it has sometimes been necessary to keep the captured females for several days. In such cases I fed them on sweetened water. They are easily tamed and soon leam to feed.

"It is probable there are more than three broods here when the season is so long. The butterflies will be flying in November, and if we allow two months for a brood, the fourth would appear about first of September, and their caterpillars would have time to pupate before cold weather, for with us October is very warn." 


\section{PAPILIO XII., XIII.}

Later Mr. Wright wrote me that on 15th September he found a half grown larva of Rutulus near his house.

Mr. Baron, some years ago, reported that in north California he saw Ratulus laying on willow, and he got the egg. 'This was mentioned in Papilio III., p. 65, 1883. Mr. R. H. Stretch, who has had great experience in collecting and breeding butterflies in California, and is a careful observer of their habits, wrote me, 30th April, 1883: "I see a note of yours about the eger of Rutulus on willow. Now Rutulus is always found hawking up and down willow thickets in preference to any other locality, and I have always supposed it to be a willow feeder, though I never succeeded in finding the larva." Unquestionably, willow is the usual food of this species, but other plints must also be eaten, though they may not be preferred.

Mr. T. L. Mead, in Psyche II., p. 180, 1878, says that one female of several confined by him when in Califormia over a branch of wild cherry laid twenty eggs, but the others refused. He found the young larve more difficult to raise than those of Turnus, and in fact they all died when past the first moult. He says, "Mr. Henry Edwards informs me that he has repeatedly found larva of this species, but usually lost them before they changed to chrysalis." As to this statement, Mr. Edwards tells me that he probably spoke of Eurymedon, which he formerly mixed up with Rututus, and that he never had larva of Rututus but once, and then from three eggs which he saw a female lay on alder, Alnu viridis, as mentioned in Papilio II., p. 113. These larva died from neglect after third moult. So that, as far as known, willow and alder are the only food plants of this species, for the eggs obtained by Mr. Mead were laid in confinement, and the larva died not long after hatching.

The first lot of eggrs sent me by Mr. Wright suffered from mould on the journey, and but one hatched. I offered the larva leaves of cherry, apple, and tulip tree (this last the favorite food of P. Turnus), but it died, having eaten nothing. The next lot arrived 31st May, ten days en route, and all apparently healthy. One larva came out 1st Jume and eight the next day. I gave these tulip leaves only. On the 5th five larva died suddenly, after vomiting a purple fluid, and by the 6 th all were dead. They seemed to have been poisoned by the food, which they had eaten of very sparingly, nibbling a little here and there. Evidently the food was distasteful to them.

On 5th June more eggss arrived, and to the larve from them I offered tulip, cherry, apple, and willow. Next day all were found on the willow and feeding. Two other lots of eggs came, to 11 th June, and only willow was given the larvæ. Henceforth there was no more trouble and no loss. The larva are as easy to raise as are those of Tumus. Some examples at each stage were preserved in 


\section{PAPILIO XII., XIII.}

alcohol, but fifteen were allored to go to pupation. The first chrysalis formed 5 th July and this gave butterfly 25 th July, or at nineteen days. The second formed Sth July and the butterfly came out 28th, or at twenty days; both female. On 25th August came a male at seventeen days, on 28th a female at nineteen; and others appeared at intervals to 5th September. Later some chrysalids which I supposed were hibernating gave buttertlies irregularly, the last on 18th November. One large male came 26th April, and two chrysalids died during the winter. This male was fully as large as any of the fall brood and in appearance like those.

The larva of Rutulus is in habits similar to Turmus. It is sluggish, scarcely moving at all. It weaves a web across part of the upper surface of the leaf it rests on, whereby the leaf is somewhat drawn together, enough to leave an open space between the web and leaf. 'The web serves as a bridge on which the larva lies in comfort when a flood pours down the leaf. I measured one of these webs on which a full-grown Tumus rested, and found it two and a half by one and a half inches in extent, and four tenths inch above the bend of the leaf. It was so firm that I observed no depression from the weight of the larva. On sprinkling water vertically upon the leaf, it passed through the web readily.

I ferl both weeping and golden willow, and they were equally relished. Although Tumus is known to feed on many species of plints, and of widely different groups, no one has observed willow to be one of them, and when 1 have attempted to force the larvie to eat willow, it was without effect. In California are many plants allied to those on which Turmus feeds, and that Rutulus should be nearly restricted to willow shows a difference quite as significant as anything seen in the larva or imago. During part of the summer I was rearing a lot of Tumus larve from the egg, and so was able to compare the two species stage by stage, with the results before set forth and shown on the Plate.

Note. While this paper was passing through the press, Mr. James Behrens wrote me from Mt. Shasta, Cal., that he had recently found larva of Rutulus on a species of balsam-poplar, and fed them with the leaves of this tree in confinement. 


\section{PAPILIO XIII.}

\section{EXPLANATION OF THE PLATE.}

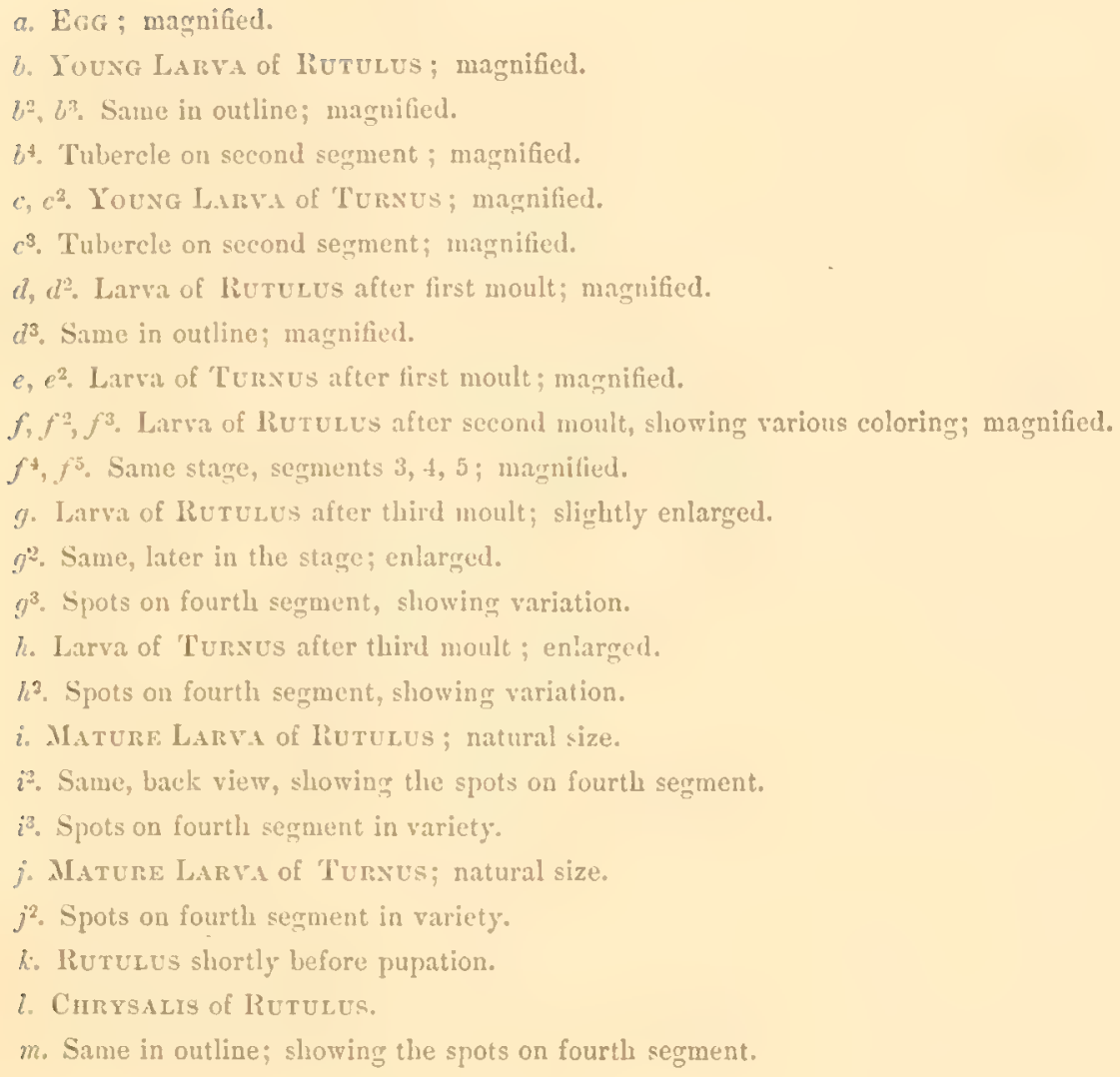





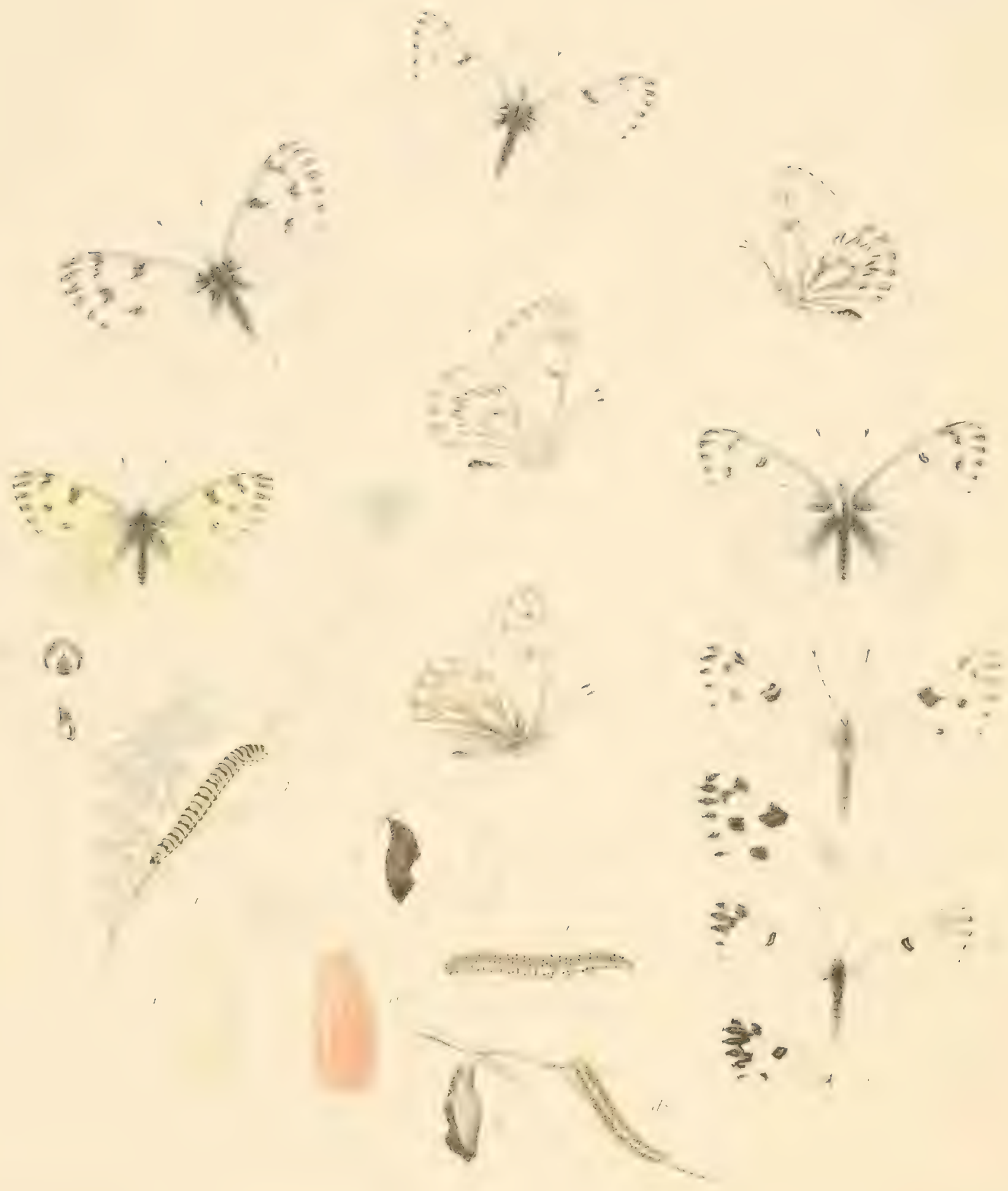

\begin{tabular}{|c|c|c|c|c|c|c|}
\hline 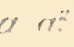 & Eipl & y+m!nlmy & ml1urllillie, & al al: & lorerter & Berkerii \\
\hline 1 & I. IIII"I) & , & $(m+r / m e r)$ & , & rlerysulis & ., \\
\hline 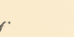 & ringeseles. & , & & & & \\
\hline
\end{tabular}




\section{PIERIS I.}

PILRIS SISYMIBRI, 1-5.

Picris Stisymbri, Boistuval, Ann. Suc. Lint. de France, 18j2, p. 284.

MiLE. - Expands 1.3 to 1.6 inch.

Upper side white with a faint yellow tint; bases of wings dusted with black; primaries have the costal margin gray for three fifth the length from base; the ends of the nervules from apex to second branch of median corered by black bar, which diminish eradually in length down the margin; midway between margin and cell is a transverse black band, intermpted opposite cell, and rumning from costa to upper median interspace; on the are a black bar, indented on outer side; secondinries immaculate; fringes of both wings white; black at the ends of the nervules.

Under side sane color; the markings repeated, but paler or gray, the bars along margin of primaries greenish-gray.

Secondaries have all the nervures and branches broadly edged on both sides with greenish-gray, somewhat interupted on the extra-discal area, and across this is a series of black serrations lying on the nervules, pointing towads and parallel to the margin.

Body gray above, thorax white below, ablomen yellowish; legs white; palpi white with black hairs in front; antenne black above, whitish beneath; club black, the tip orange. (Figs. 1, 2.)

Fexdle. - Expands from 1.6 to 2 inches.

Upper side like the male, but usually the extra-discal band is extended to submedian interspace, the second median interspace being immaculate; on under side the markings are as in the male, sometimes slight and pale, but of ten heavy, greenish-black; the nervures and branches of secondaries in many examples buff. (Figs. 3, 4.)

VAR. Fust. Female. - Both surfuces pale yellow. (Fig. 5.) 


\section{PIERIS 1 .}

EGG.-Long, narror, conical, the base and top flattened, depressed; ribbed longitudinally, the interspaces excavated, and crossed by numerous strix; of two examples under view, one has the ribs rather prominent, the other flattened, as are also the intervening spaces, and the middle is much swollen, after the manner of an egg of Colias; both have 14 ribs; color when first laid yellow, shortly before the end of the stage red (Figs. $a a^{2}, a^{3}$ micropyle).

MATure LARTA. - Length .9 inch; cylindrical, tapering slightly from middle segment to extremity; color light yellow crossed with stripes of black; each segment several times creased, and on the ridges so caused are small yellow tubercles of irregular sizes, each giving out a short, fine black hair; on all segments after 2 and including 12, are two stripes to the segment; on 3 and 4 these have nearly even edges; but from 5 to 12 the anterior one has the front edge either sinnous or escalloped, so that an arch falls on middle of dorsum, and sometimes it is produced quite to the anterior edge of the segment, and another falls on either edge of clorsal area; usually this stripe is broken on lower part of side; the stripe on posterior part of the segment is narrow and is prolonged to the basal ridge; along this ridge is a macular black band; under side yellow-white; feet black, pro-legs yellow; head sub-globose, granulated; the upper front face broadly blick; a black triangle over mandibles, and the ocelli are black on a black bar. (Figs. $6^{1}, 6^{2}, b^{3}$.) From egg to chrysalis 33 days in April and May; in May and June 30 days.

Cinissuls. - Length .5 to .53 inch; cylindrical; the head case narrow, excavated on either side; a short, stout projection between the eyes; mesonotum prominent, rounded, a little carinated, followed by an excavation about as deep as the mesonotum is high, but not evenly rounded, rather angular; on either side of dorsum, on anterior abdominal segments, are thin and angular elevations, all slight, the foremost one most prominent; color dark brown; whole surfice, except the wing covers, covered with irregular granulations. (Fig. c.)

This species is found both in North and South California, in Nevada, in Southern Colorado, and in Arizona. Mr. O. T. Baron, in his excursions through Northern California, found Sisymbri abundant, and twice succeeded in bringing the larvie to maturity, and imago. Egrgs latid 11th April hatched 25th. The furst moult took place 7 th Min, the second on 13th, the third 20th, and pupation took place 2Sth May. These egress were obtained by confining the female in bag over the food-plant.

Another lot of eggs which were found, hatched 5th May. The first moult took place 14 th, the second on 19 th, the third on 25 th, and pupation 4 th June. By Mr. Baron's observations there were but three monlts. Mr. 'T. L. Mead, in 1578 , found the buttertly as well as caterpillars in Southern California, and 


\section{PIERIS $I$.}

made the dratring which I have used. I was able to compare it with several larra in alcohol sent me by Mr. Baron. The chrysalis is drawn from an alcoholic example, also from Mr. Baron. The outline is correct, but the color may not be so accurately given as if I had had the living chrysalis at hand. Mr. Baron says the color is "dark brown," and the appearance of these examples would indicate that the natural color is of one shade. There are no black dots, as is common in chrysalids of species of Pieris. 



\section{PIERIS I.}

\section{PIEIRS NELSONI. 6,7.}

l'iris Nelsoni.

Mrize - Expands 2 inches.

Upper side white; costal margin of primaries and bases of hoth wings dusterl black; at apex of primaries and to second branch of median, serrated black patehes on ends of the nervules; and beyond, an extra-discal transverse row of small spots, of which two are deep black; namely, one in lower sub-costal, the other in upper median interspace; another spot in sub-median interspace is represented by a cluster of scales; on the costal margin, the upper spot is joinerl to the black marginal edging by a stripe of black; on are, a sub-oval black spot, through which rums a whitish streak; fringes white.

Under side of primaries white, with a faint greenish-yellow tint over apical aren; the markings repented, those about apex diffused, gray-brown; the inner row gray-brown, the lower spot, on sub-median interspace, as clistinct as the rest.

Secondaries white, faintly tinted greenish-yellow; all the nervures and hranches broadly bordered with gray-brown, especially those which include the cell, and the branches of median and the sub-median; indeed the interspaces are nearly closed up below the cell; beyond the disk these border's are joined by serrations in the interspaces, most conspicuous from outer angle to upper branch of mechin, but continued across the median interspaces.

Body alove covered with long gray hairs, abdomen black on both dorsum and sides; under side of thorax yellow-rray, abdomen white; palpi white with many black hairs; antenne black; club black, tip green.

From 1 of taken by MIr. J. IV. Nelwon, at St. Michatel's, Alaska, June, 1881.

Unfortunately no $q$ was taken. The species is near Callidice, Exper, but differs in the coloration of the under side, which is gray-brown instead of green, and on upper side in the shape of the cellular spot, which is a short oval, in stead of a long curved bar, as in 2 of 2 European Callidice before me (also in 


\section{PIERIS I.}

Esper's figure, Plate 115, Fig. 2), and in the presence of a spot in sub-median interspace. I submitted this example to Mr. A. G. Butler, British Museum, for comparison with Callidice, and he observed that it differed therefrom in the points indicated, and says: "We have a similar specimen marked North America, and which I had separated by a label as probably distinct."

Kirby, Catalogue, attributes Calliclice to Europe and Asia, with no special localities named. Staudinger, Catalogue, says: "Summits of the Alps, and Pontus and Asia Minor, Alpine." So that it would not appear to fly in Eastern Asia. 


\section{PIERIS I.}

PIERIS BECKERII. 8,9.

Pieris Becherii, Edwards, But. N. A. I, p. 28, pl. 8, 1871.

By the kinthess of Mr. Mead, I am able to give figures of the mature larva and chrysalis of Beckerii. The larva was drawn and colored by him from nature, and the outlines of the chrysalis were dramn, but not colored. The coloring given on the Plate is from Mr. Mead's description.

Mature LarTa. - "Length 1.25 inch; color greenish-white, thickly marbled or sprinkled with gray, and with a very distinct orange belt between the segments; each segment also has 16 or 18 jet black tubercles which taper into black bristles; the head is tinged with yellow." (Figs. $l, d^{2}$ ) T. L. MEdD.

Cirrsalis. - "Is of much the same general shape as that of Pieris Protodice, Bois., but less angulated; the front is terminated by a blunt point; the cephalic portion is rounded, with uneven surface, and with the dorsal surface of the thomax, is dark-grayish brown; the ridge above the wing cases, which is quite conspicuous in Protodice, is absent in Bectierii; the remainder is gray, nearly white upon the wing cases, and on the ridges of the first two abdominal segments; a pale stigmatal streak extends from the margin of the wing cases to the tail; in line across dorsum are four black dots at the boundary between thorax and abdomen. Duration of this stage about 15 days." (Fig. e.) T. L. MEAD.

Mr. Mead says: "In the Mohave Desert, 21th May, 1878, I found numbers of these larva on various cruciferous plants."

Since this species was figured, it has been alleged by several authors to be identical with P. Chloridice, a species creclited in Dr. Staudinger's Catalogne to Southem Russia, Persia, and Siberia. I have examples of Chlorictice from Dr. Staudinger, and I apprehend that while there is a certain resemblance, such as would connect the two forms in a sulb-group, there is by no mens identity. One cannot properly be called a variety of the other, or a local race of the other. Beckerii in both sexes is well represented on my Plate. Dr. H. A. Hagen, in 18S1, took 27 or more examples in Oregon and Washington 'Terr., and says: 


\section{PIERIS I.}

" MI specimens agree exactly with the excellent figures" of Tol. T., But. N. A. It is not necessary therefore to re-figure Beckerii on account of variation, but to make the distinction between it and Chloridice patent, I give figures of the upper and under side of Bectierii o (S); of upper side of the $q(9)$; both from Vol. I.; and the corresponding wings of Chloridice o (10), \& (11), from the examples in my collection. Chloridice is a much smaller species, and looks more like an Anthocaris than a Pieris. My examples of Beckerii measure of 2; 2.1 inches; 9 ? $2 ; 2.2$ inches. Of the of Chloridice, one is $1.6 \mathrm{in}$. the other $1.8 \mathrm{in}$; the 91.6 inch. The males Chloridice have a cluster of confluent black spots at apex of fore wing and on upper part of hind margin, and these are also confluent with the spots of the inner row, so that nearly the whole apical area is black and triangular, much as in certain species of Anthocharis, as A. Ausonides, for example, only the black is intense in the Pieris and pale in the other. The discal spot is jarticularly characteristic of an Anthocharis, being: a narrow, curved bar, with a fue white line ruming through it lengthwise, along the are of cell. In all respects this bar is very close to that of Anth. Hyantis.

In Beckerii, the apieal spots are smaller and shorter in proportion, do not touch each other, and are entirely separated from the spots of the inmer row. The spots of the two rows are parallel, and there is nothing of the triangle. And the discal spot is a large, nearly square patch, of quite another shape from that of Chloridice, with the white streak considerably thickened in the middle, not a uniform line. Beckerii 8 , on the upper side, looks in all respects more like o Pieris Occidentalis than it looks like Chloridice. Comparing the females: Chloridice has the spots at apex so run together that merely along the hind margin in middle of each interspace, is any white seen; the imner row of spots are lost altogether in the black area. This area ends below squarely at the second median interspace. The discal spot is of same shape as in the male, but twice as broact.

In Beckerii q there is a marginal series of comparatively small lanceolate separated spots, six in number, and there is an inner, or extra-discal row of four nearly equal large black spots in line across the wing, nowhere touching the marginal spots; and the disul spot is very large and rhomboidal. On the under sicle of primaries of Bectierii, in both sexes, are two black spots belonging to the inner row, one in the upper median, the other in sub-median interspace. (Figr. 8.) In the females these are linge, in the males they vary, and in one of $m y$ examples the lower" spot is wanting. "Dr. IIngen writes of his examples of Beckerii, that in the females the two spots are very marked and black, but the males never have these spots so large, sometimes faint, sometimes wanting. Dr. Hagen has examined figures of Chloridice in Fischer, Esper, Herbst, Hübner, and Bois- 


\section{PIERIS I.}

duval, and states that in all the figures only the black spot near the imner angle is represented, there being no sure indication of the other. In my examples of Chloridice, the femile has both black spots, the males have a few black scales in upper median interspace (Fig. 10), but none in the sub-median. This surface of the fore wing is that of an Anthocharis.

On the muler side of seconcluries, the general pattern is same in both forms, the spots heing bright yellow-green in Chtoriclice, more gray in Beckerii. (See Figs. 4, 7, in the Plate in Vol. I. 'The contrast is same as shown in Figs. 8, 10 , on the present Plate, of the apical aren of under side of primaries.) The patterns of under side should count for little in Pieris and Anthocharis, inasmuch as in both genera similar patterns in markings and color rum through a whole subgrroup in repeated instances. It is to the upper side we must look fol decided diliterences.

All we have to consider is, does Beckerii breed true to its type? 'Undoubtedly it does. No eximple has yet been seen differing in any degree from those figured in Tol. I. 'There is no evidence whatever that Beckerii and Chtoridice ever had any closer comnection with each other than any two species of any sub)group of butterfies may have. To assert that one is a variety of the other, therefore, is to assert what no one can prove, and no one can possibly know. All we do know is that Beckerii is a permanent form, separated by important characters from any other. That is to say, it is a species. We have to accept the facts as we find them.

Beckerii inhabits more or less of the Pacific slope from Oregon to Sonthern California; also Nevada, Colorado, and Arizona. Dr. Hagen's examples were taken June 2tth, 25th, and July 20th, and he regards them as of the summer brood. Mr. H. Edwards took those which are figured in Vol. I., in Nevada, in April, and they were therefore of the carliest brood of the year. Mr. Mead obtained several of the buttertlies in Southem Califomia in May, 1878, from chrysalids, some of which are in my collection, and these would be the second brood of the yenr. Mr. Baron took the summer brood in Northern California. I see no difference between the two broods. 



\section{ANTHOCARIS I.}

\section{ANTHOCARIS OLYMPIA, 1-4.}

Anthocaris Olympia, Edwards, Trans. Am. Ent. Soc., 1871.

MALE. - Expands 1.6 inch.

Upper side pure white, gray at bases of wings; primaries lave at the apex a pale gray sub-triangular patch terminating on either margin in a small spot of darker color; on the are a straight black bar, reaching the sub-costal nervure; costal margin slightly specked with black.

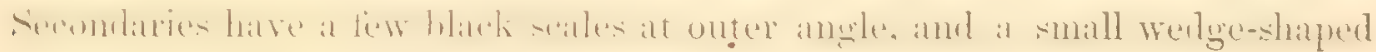
black spot preceding these scales on costa; fringes white.

Under side white; primaries have a small gray sub-apical spot on costa, nearly covered with green scales, and a faint greenish patch on hind margin partly covering the discoidal interspaces; discal spot narrow, lunate, inclosing a white streak. Secondaries crossed by three bands of yellow-rreen on a gray ground, the intermediate spaces being white; the first band, near base, forms the segment of a circle; the second, just anterior to the middle of the wing, of irregular width, projects a short, truncated branch on sub-median nervure that conneets with the third band, and ends in a sharp spur a little inside abdominal margin; the third band, commencing on abdominal margin, is at first broad, and after comnecting with the second, narrows to half its previous width, then enlarges greatly and curves towards hind margin, which it strikes in three branches, besides sending a fourth to outer angle; sometimes this last branch is disconnected and forms a marginal spot; these bands all marked more or less by small white spots and point.s. Body black, covered with gray hairs; benenth greenish white; palpi white with many gray hairs; antennx gray above, yellowish below; club brown above, bright yellow below and at tip.

FeMale. - Expands 1.7 inch.

Similar to male; the apical patch inclosing a single, distinct, white spot; discal mark broader, sinuous, sending a short spur along sub-costal nervure; costa] edge more irrorated; under side as in male.

The specimens of Olympia originally described, and till then the only ones known to me, were taken at Coalburgh, West Va., in April, 1871, by a young collector whom I had enjoined to take "everything that was white," and were 


\section{ANTHOCARIS I.}

brought in company with a number of Anthocaris Genutia and Pieris Tirginien. sis. Not long after, a collection of butterflies, made by Mr. Boll, in Texas, and belonging to the Museum of Comparative Zoölogy, at Cambridge, were sent me by Dr. IIagen for examination, and among them was a male of Olympia. Since that time I have been informed by Dr. L. K. Hayhurst, that he has once taken the same species in Missouri. Mr. G. M. Dodge also has taken a pair at his former residence in Bureau County, Illinois; thus showing a wide distribution for so extremely rare a species. In April, 1873, another fine male was taken in my garden at Coalburgh.

Olympia is more delicate and less strong of wing than Ausonides, and of a low, uncertain, and tremulous flight. In West Virginia it accompanies Genutia, and might ensily be mistaken for the female of that species, frequenting, with it, cultivated grounds - gardens and meadows. 


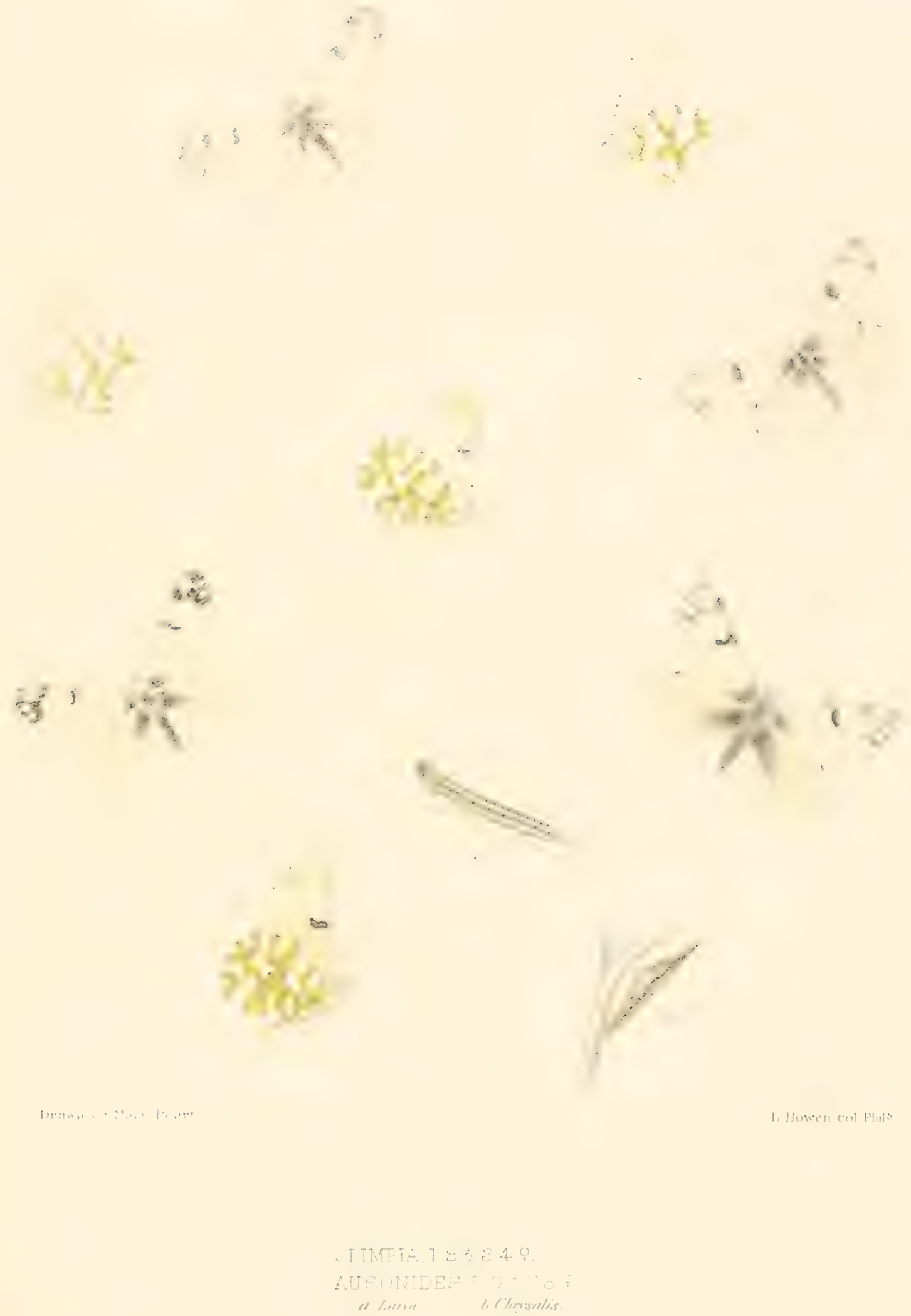




\section{.}




\section{ANTHOCARIS H. 'I.}

ANTHOCARIS AUSONIDES, 5-8.

Anthocaris Ausonides (Au-son'-ides), Boisduval, Ann. Soc. Ent. de France, 1852. Lep. de la Cal., 1869.

MALE. - Expands 1.5 to 1.9 inch.

Upper side white, sometimes pure, but most often yellow-tinted, much sprinkled with black scales at bases of wings; primaries have the apex gray or black, inclosing a white patch on costal margin, and white marginal rays in the discoidal and upper median interspaces; these rays sometimes expanding into oval or rounded spots, just within the margin, in which case, including the costal patch, there are three or four spots crossing the apex; costal cdge slightly specked with black; a black spot on arc, reniform or lunate, or sometimes a sinuous bar, usually reaching the sub-costal nervure.

Secondaries have a mottled appearance owing to their transparency; fringe of primaries altermately black and white, of secondaries white, black at tips of nervules.

Under side of primaries as above, except that the dark apex is wanting, or is represented only by small clusters of dull green scales, which are suffused with yellow, as is also all that portion which is dark on upper side, the white patch usually retaining its color; a white line on the are within the discal spot.

Secondaries mottled with dull green disposed in three ragged, transverse bands, and a demi-band on the inner side between the marginal and central; the marginal band deeply scolloped; all these usually suffised with yellow, and diversified with points and patches where the absence of the green scales discloses the white ground; the nervures of the disk yellow. Body above gray-black, beneath yellow-white; legs same; palpi white with many gray hairs; antenne and club gray specked with black above, ochraceous beneath.

Finale. - Same size, and closely resembles the male; frequently secondaries on upper side are suftused with a buff or ochraceous tint.

Mature Larva. - Length 1 inch. Cylindrical, slender; head small, round, green specked with black; body entirely covered with black granules, from each of which springs a short hair; marked longitudinally by three lead-colored stripes, one dorsal, two lateral, the intervening spaces being yellow; the lateral stripes edged below with white that shades into yellow; legs black, pro-legs greenishyellow. 


\section{ANTHOCARIS II.}

Crirsalis. - Length .9 inch. Slender, cylindrical, thickest in the middle, tapering therefrom pretty evenly, the extremities being of nearly equal size, the anterior a little flattened; viewed laterally, the figure is that of a highly obtuseangled triangle, the sides equal, the base nearly straight, there being only a slight wave at thorax; color gray-brown, covered with fine longitudinal darker streaks.

This species is common in California and Colorado. It is also brought from Utah, Arizona, and Nontana, and from Vancouver's Island. The late Robert Kennicott sent me, some years ago, a specimen taken by himself on the Yukon River, a very high latitude for a species of so delicate a genus. In the AtIantic States, the allied A. Gemetia is very rarely found north of latitude $40^{\circ}$, twenty degrees south of the Yukon River. Of the habits of this species Mr. Henry Edwards writes: "It is one of the very first to appear in spring, and as early as the end of February, if the weather be moderately warm, may be seen sporting orer the flowers of Brassica, Radix, and other cruciferous plants. It is local, but where found, occurs in some abundance. Through the whole of the San Joaquin, Alameda, and Napa valleys it is common, though only in the carly season, for it is single-brooded, and its existence seems to terminate about the end of April."

'The larva was discovered by Mr. Mead, in Colorado, in 1871, and from one sent by him the drawing on the Plate was made. Mr. Mead wrote, 28th June, as follows: "At 'Turkey Creek Junction there were many eggs and some larva of Ausonides to be found, the latter feeding on the flowers and seed-vessels of a cruciferous plant. The eggs were long, ribbed longitudinally, and in color light yellow. The larva are solitary, and are seen stretched at length on the stem or seed-pods of the plant."

From a chrysalis also sent by Mr. Mead, the butterfly emerged at Coalburgh, in the spring of 1872 .

There is a striking resemblance between the larva of Ausonides and that of Pieris Protodice, a buttertly very common in the Southern and Western States. Their larve are more alike in color, form, and markings than often happens between species of the same genus. The chrysalicls, on the contrary, may be said to have no resemblance whatever.

Ausonides, as remarked by Dr. Boisduval, is scarcely distinguishable from Ausonia, Hubner, a species found in the regions bordering the Mediterranean, and subject to much variation, especially in the degree of mottling of the under side of secondaries. 'The alpine var. Simplonia, Freyer', seems nearest the usual American type, though we have also individuals in which the markings approach Betia, Esper, considered to be another variety of Ausonia. A comparison of 


\section{ANTHOCARIS II.}

the larve and chrysalids would best determine the relationship, but 1 have been unable to find a description of these stages in Ausonia. It is to be noticed that. where a species becomes widely dispersed and sections are separated by impassable barriers, the larva are often first to differ, and may become quite distinct before any wide difference is observed in the imago. As in the case of the $P a$ pilios, Turmus, and Eurymedon, where the butterflies differ but in color, while the larva are strikingly umlike. So with several of the Graptas figured in Vol. I. of this work. And in determining the identity or otherwise of two forms from opposite sides of the globe, especially if they inhabit the regions below the Boreal, so that the segregation may be presumed to have been complete for a long period, the preparatory stages are a most important element in the comparison. If the separation is marked in these, even though not clear enough in the butterflies to be fixed by description - as, for instance, in the present case of Ausonia and Ausonides - it is safe to conclude that on one or both sides there has been a departure from the original type, and that henceforward between these two there will be nothing but divergence. They have reached a point at which they may properly be treated as distinct species. 



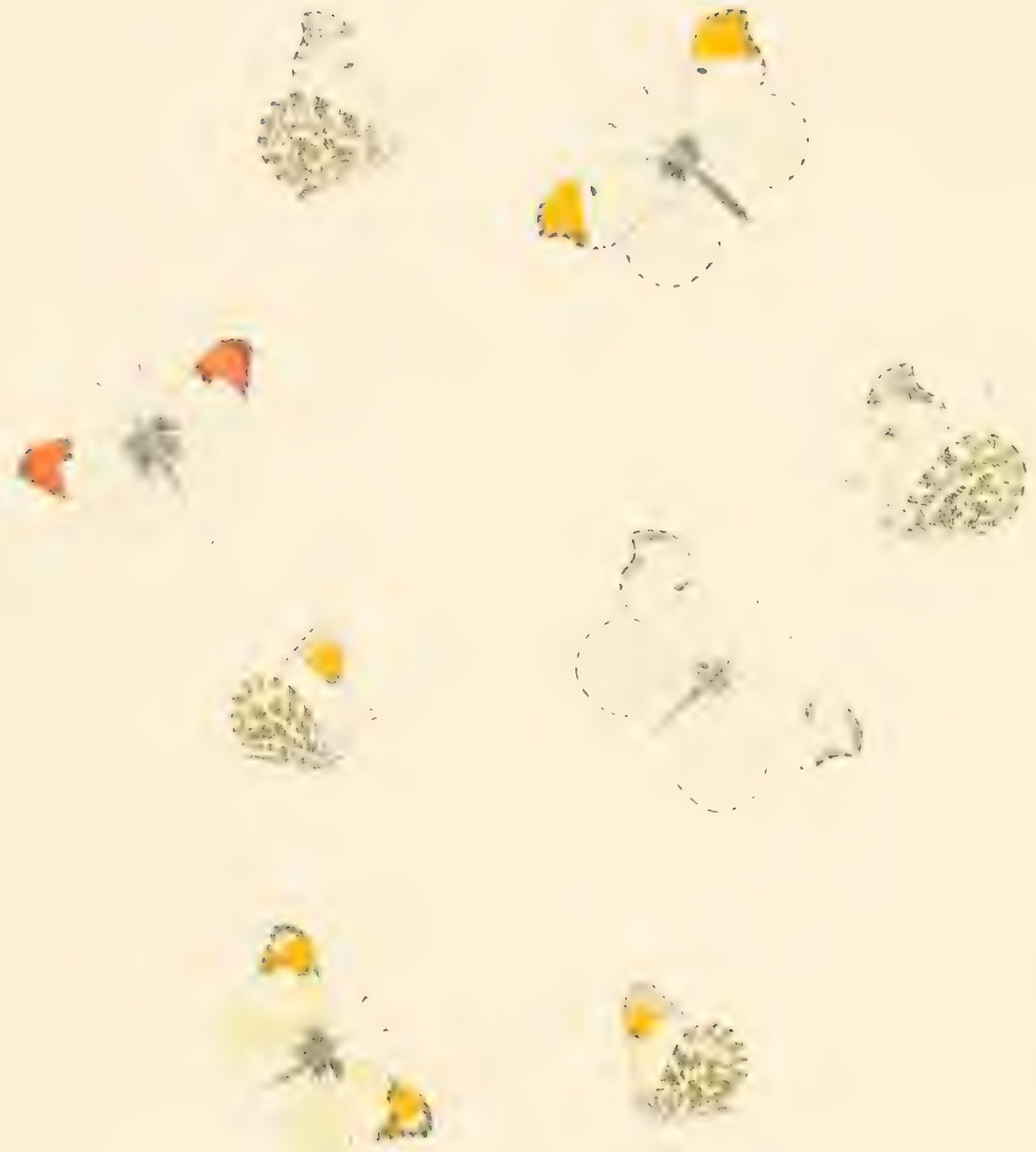


\title{
ANTHOCHARIS II.
}

\author{
ANTHOCHARIS GENUTIA, $1-4$.
}

Anthocharis Genutia, Fabricius, Ent. Syst, III., p. 193, 1893. Godart, Enc. MIeth., IX., p. 168, 8, 1519. Boisluval, Spec. Gen., I., p. 565, 1836. Butler, Cat. of Fab. Diurnal Lep. in Brit. Mus., 1869. Midea, Hübuer, Exot. Simml., 1816. L'herminicri, Godart, 1. C., 1. 167, \&.

MALE. - Expands from 1.5 to 1.5 inch.

Upper side white, often slightly tinted with yellow, the bases of wings dusted with black; a few black specks on costal margin of primaries; on the apex of primaries a large bright orange patch covering the area nearly to cell, edged on both margins with small patches of black scales: on the are a small rounder or oval black spot; secondaries delicate, immaculate; fringes white, black at tips of the nervules.

Under side of both wings white, slightly yellow along the margins; the orange shade shows faintly through the wing, and the apical area and costal margin of primaries are slightly specked and marked with greenish-yellow; the discal spot repeated; secondaries wholly mottled with patches of green scales.

Body blackish above, beneath, the thorax gray, abdomen yellowish; legss yellow; palpi gray; antenna blackish above, white beneath; club orange beneath and at tip.

Fexale. - Expands from 1.5 to 1.9 inch.

Similarly marked, but wanting the orange patch.

This pretty species is regarded by Dr. Boistuval and Mr. Butler as the one described by Fabricius under the name Genutiu, though the habitat is given as India, and the description is a brief one and applicable to other species as well. It is still rare in collections, and nothing is known of its preparatory stages, except that Mr. Boll has seen the female laying eggs upon a species of Cardimine. The larva and chrysalis will be found to resemble in shape and general appearance Arsonides, figured on the preceding Plate. Genutia flies in the spring, is single-brooded, and appears to be restricted to certain localities. I camnot learn by correspondence, or by reference to several local lists of butter- 


\section{ANTHOCHARIS II.}

flies, that it has been taken in the Mississippi Valley, outside of West Virginia, though it certainly must inhabit Ohio and the adjoining States. Mr. Butler credits the example in the British Museum to Illinois. Dr. Boisduval erroneously gives the habitat as Boston and vicinity. At Dallas, Texas, Genutia has been taken by Mr. Boll in low and open-timbered land along the larger creek and liver bottoms, in the months of February and March. It is found in certain spots in New Jersey, near Philadelphia, and in Maryland, near Baltimore, and I have taken it myself at Newburgh, N. Y., which is the most northeru limit of its flight recorded. Here, at Coalburgh, I used formerly to see it, in April, flying about my garden, but of late years it seems to have disappeared. It flies low, swiftly, with a peculiar, tremulous motion, and is readily distinguished from other Pierids by this flight, as well as by the conspicuous coloring of the male. 


\title{
ANTHOCHARIS II.
}

\author{
ANTIIOCIAARIS JULIA, $5-8$. \\ Anthocheris Julia, Edwards, 'Trans. Am. Ent. Soc., IV., p. 61, 1872.
}

MALE. Expands 1.3 inch.

Upper side clear white, the bases of wings dusted with black; the costal margin of primaries yellowish, specked and crossed by black; on the apical area a bright and deep colored orimge pateh, edged outwardly by a shiarply serrated black band, which is broadest at apex, and narrow as it deseends the margin, but is not broken into spots; on the are a sinuous black bar nearly protracted to costal edge, and at its upper extremity expanded in direction of base, filling the space between costal and subcostal nervules; from the lower third of hind margin proceeds a stripe of scattered black scales which borders the immer side of the orange patch, and sometimes ends a little below the lower outer comer of the discal bar, but more often curves round the bar, and is separated from it, reaching to the subcostal nervure; in no case observed does this stripe form a continuous line with the bar, as is often seen in $S$ (b) ally immaculate, but sometimes showing small marginal black spots, or clusters of scales on the nervules; fringes of primaries alternately black and white, of secondaries white, black at the tips of the nervules.

Under side white, the apex and hind margin bordered with yellow; between this and the orange patch a pinkish space; the nervules on both margins bordered with greenish-brown, dusted with yellow; the patch reduced, paler colored; costal margin pinkish specked and crossed by brown; the bar on the arc reduced and nearly bisected, ending at subcostal nervure; secondaries have the nervures on basal area orange, elsewhere yellow; the surface covered with irregular greenish-brown patches armenged along the nervules and branches, and on the marginal area forming a pretty contimuous broad band, all dusted thickly with yellow scales.

Body gray-black above; beneath, the thorax white, abdomen yellowish, legs white, the femora orange; palpi mixed white and black; antenne orange at base, gray-brown above, gray below; club black tipped with yellow. 


\section{ANTHOCHARIS II.}

Fexale. - Expands from 1.1 to 1.5 inch.

Upper side bright lemon-yellow, the orange patch as large as in the male, but paler, replaced by yellow next the serrated apical border; on the inner side of this yellow ground a line of black scales; the discal bar as in the male; fringes yellow; under side yellow, and marked as in the male.

This species was first made known by Mr. Mead, who took twenty-two examples, 108, 12\%, 10th to 12th June, 1871, in Colorado, at high elevations, in the pine woods near Fairplay, South Park, and on Beaver Creek. I have received a few others from parts of Colorado and New Mexico, and a single male from Montana. 


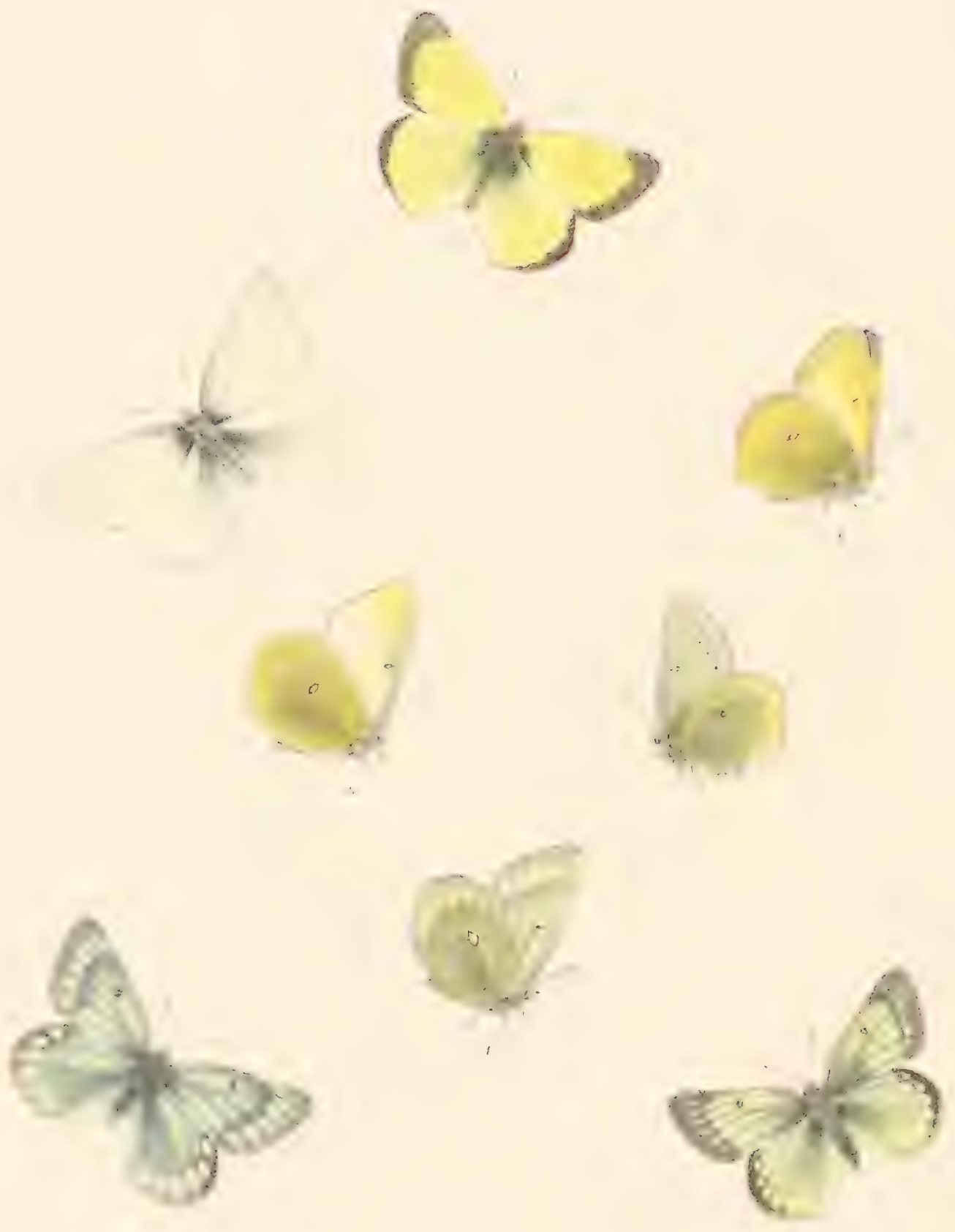

NASTES, 1? t, 3.4

PEIJINE \&6 5,78 


\section{COLIAS I.}

\section{COLIS NASTES, 1-4.}

Colins Lastes, Boisduval, Icones, pi. 8, 1832. Ibid., spec. Gén. I. p. 6t8, 1836. Herrick-Schäffer, Schmett. pl. 7, f. 41, 42, ant s5, f. 103, 401, 1813. Müschler, Wien. Ent. Monat. iv, p. 351, pl. 9, 1860.

MLLE. - Expands 1.5 inch.

Upper side greenish-yellow or greenish-white, usunlly much and miformly ilrorated with gray-brown over entire surface; sometimes but little however on the disks, though densely on the hind margins, in which case there is formed thereby a broar marginal border; hoth wings lave a sub-marginal series of oval spots, the color of the groumd, not very well detined, heing nore or less dusted with brown; those of secondaries often incomplete, and some of them, especially next imner angle, often lost in the prevailing brown shade; diseal spot of primaries small, black, of secondaries small, pale yellow, often indistinct; costal edges and fringes roseate. Under side of primaries either greenish-yellow or white, the apical region washed with yellow, and surfice more or less densely dusted with gray-brown; the discal spot black inclosing either a pure white space, on which are a few roseate scales, or the space is of the ground color, without roseate; beyond the disk a transverse row of brown points, obsolete except two or three next imer margin; secondaries dark green, or often greenish-yellow, the hind margin paler, and the whole surface densely covered with brown scales; discal spot white with a few roseate seales, and a clull red narrow border, a spur of same red often projecting posteriorly; or sometimes there is a rosente point outside the discal spot in direction of outer angle; a small red patch at base of wing.

Body gray above, thorax grayish-green beneath, the collar dull red; abdomen yellow; legs roseate; palpi greenish-yellow, with interspersed red hairs; antemme brown above, yellow beneath; club yellow at tip and beneath.

Eevale. - Expands 1.6 inch.

Upper side greenish-white, dusted as in the male, with wide, brown, margiual borders; the oval spots as in male, but well defined on both wings; underside of primaries densely covered with gray-brown, the ground being scarcely visible except along imner margin; aper slightly yellow; secondaries of nearly

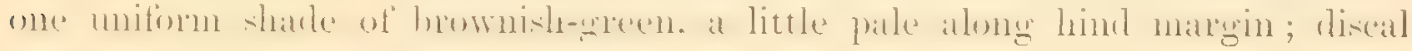
spots on both surfaces as in the male. 


\section{COLIAS I.}

always reaching immer angle, inclosing more or less completely four or five spots of the groumd colol"; sometimes the border is restricted to a narrow edging both at apex and on margin; secondaries usually immaculate, but occasionally a small cluster of dark scales is found at outer angle; discal spot of primaries, when present, a narrow, black oval, with white streak; of secondaries, small, pale orange; under side of primaries delicate greenish-white, apically yellow, either pale or dark, and this portion of the wing as well as the costal margin, more or less dusted with gray; secondaries yellow densely covered with gray; discal spot as in male.

LALVA unknown.

Pelidne is found abundantly in parts of Labrador, from far north to the extreme south, flying in July and in company with $N$ astes, occasionally with $P$ (ilano. All these species were taken by Dr. A. S. Packard, in July and August, 1866, on Caribou Island, Straits of Belle Isle, and at Strawberry Harbor, on the main land. I have received from $\mathrm{Mr}_{\mathrm{r}}$. Möschler a series of both Pelidne and Nertes, collected at Okkak, about six degrees to the north of the Straits, and the specimens from the two localities agree in all respects, so far as I can discover. I camnot learn that Pelidne has been taken on Newfoundland or Anticosti, but Mr. Scudder informs me that a single specimen has been taken at Waterville, Maine. Mr. Seudder described Labradorensis from Dr. Packard's specimens, under the impression that these represented a distinct species from Pelidne, Bois, a determination justified by the figures given in Boisduval and Leconte. In the accompanying text Pelidne is described as larger than Palceno, the reverse being the rule, according to $\mathrm{Mr}$. Möschler, and the figures, which are of a male only, represent a monstrous example, nearly twice the size of any received by me from Mr. Mïschler, and so out of drawing as to suggest that the original must have been an entirely different species from Pelidne, and that it never came from Labrador. In the "Icones" both sexes are given, and more correctly portray the Labrador Pelidne, and in H.-Schäffer, the figures are admirable both as to form and coloring.

Much has been written on the question as to whether Pelidne is only a form of Palceno or a distinct species. Mr. Möschler, in the paper eited, has compared the Labrador Pelidne with the European Palceno, and concludes that there are $n$ substantial reasons for regarding them as varieties of one species. On the other hand Mr. J. G. Schilde, in Stett. Ent. Zeit. 1873, argues that the European I'aleno, the Finland Lapponica, the Alpine Werdandi, and the Labrador P'elidne, are all one and the same thing, and the Labrator Palceno, which he allows presents constant differences from the European Palceno, forms the commecting link between the latter and the Labrador Pelidne. Some of the Lapponica also 


\section{COLJAS I.}

agree with the Labrador Pelidne, and some with the European Palceno, forming another connecting link. He attributes the differences between all these varieties to locality and climate. A careful reading of Mr. Schilde's paper leads me to the following conclusion: that occasionally a variety of Pelidne appears that resembles a variety of Paleno or the average type of that species; and the converse also is true. But the average type of each species is distinct, and the connection between the two is no more than might be expected between any two nearly relater species that at some time have come from a common ancestor. Both P'aleno and Pelidne are stated to be very variable, and among the multitude of rariations some of either species must approach the other. Even Mr. Schilde says that the name of Pelidne should be retained for the Labrador branch of the species, and really nothing more need be said, for if the two formis, supposing them to have at some time been one, are now so distinct that each breeds true to itself, each is to-rlay a good species. 'There can be no better test of a species. When eggs laid by a female Pelidne produce that type and also Palcuro, or eggs by a female Palcuo produce the two forms, then undoubtedly the two are shown to be one species, and dimorphic. And it is surprising that so little has been done in Europe, where Lepidopterists have worked for a century, towards settling such questions as this, whether any two or more given forms are species, or rarieties only. Certainly the relationship of Palceno and Lapponica, or Paleno and P'elidne, could be determined in one season by the rery simple process of shutting up one or more females of either with a plant of growing clover, on which the egg's will be deposited abundantly. This alone will test the relationship, and no amount of argument as to climatic influences ever cin. 


C(O) IIIS

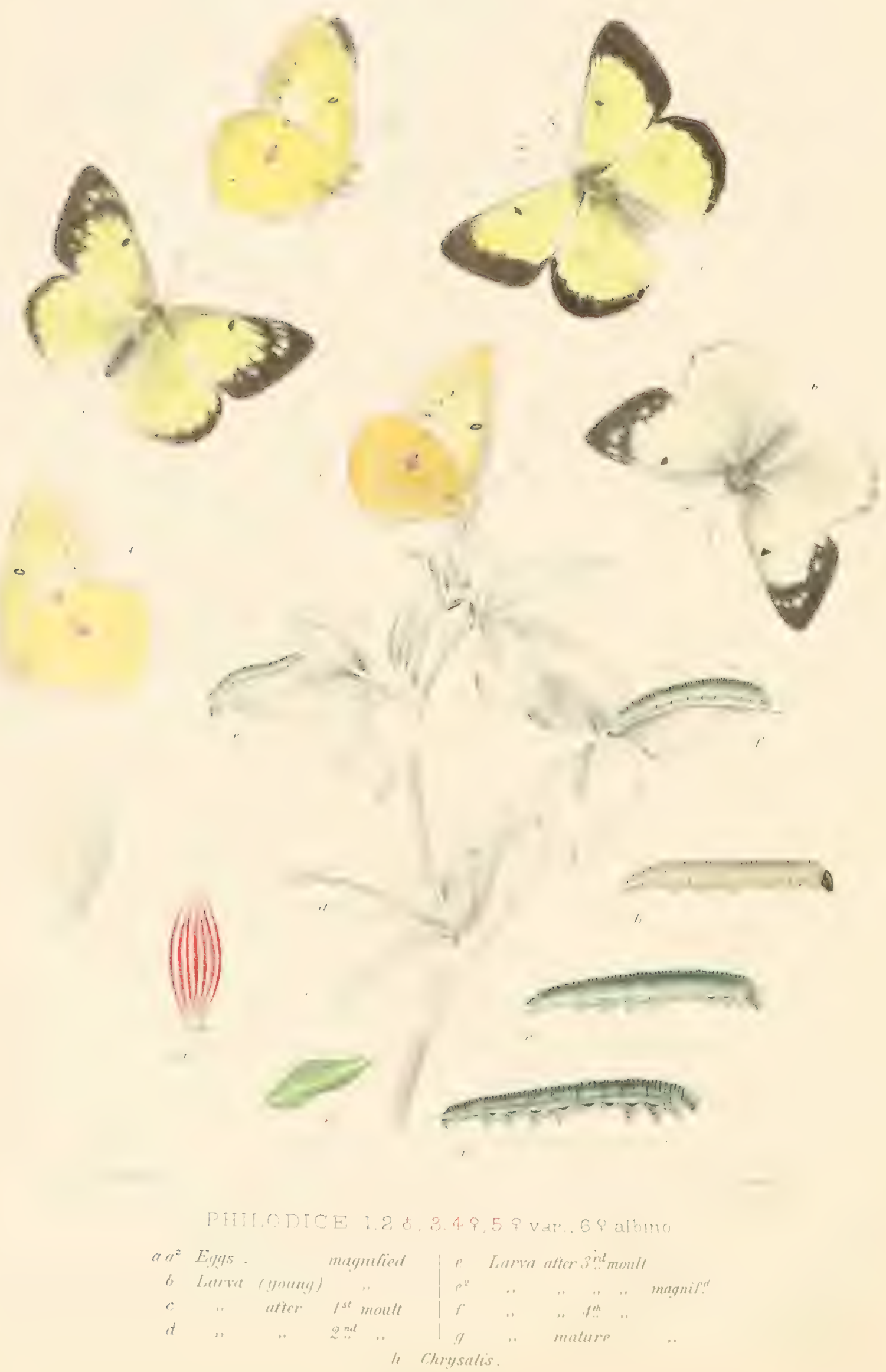




\title{
COLIAS II., III.
}

\author{
COLIAS PIILODICl:
}

Colins Phitulice (I'hi-Lorl-i-ce), Gorlart, Enc. Mcth. IX゙., 1. 100, 1819. Swainson, Zoül. Illust., 2d ser., II.. pl. 60, 1831. Bois. and Lece, p. 64, pl. 21, 1833. Buis, sprec. Gen., I., p. 647, 1836.

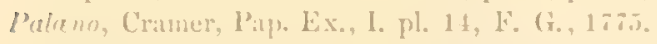

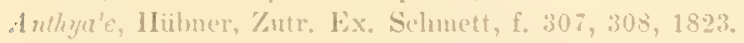

Buropomene, Stephems, Illust. lir. Ent. IIanst., I., p. 10, pl. 1, 1828. Swainson, Zoül. Illust., ahore cited, pl. 70,1831 . Humphreys and Westwood, 13rit. 13ut., p. 17, pl. :3, 1815.

MALE. - WXpands 2.25 inches.

Upper side sulphur-yellow, often lemon-yellow, usually but little ohscured at base; costal margin of primaries dusted with black; the border of hind margin broakl, black, more or less dusted with yellow, at the apex often partly erossed by the yellow nervules, sometimes irregularly dentated on the immer side, but usually even edged or slightly erose, curving romolly at the apex, generally much advaneed on the costal margin, and projecting a short spur on the inner margin; discal spot large, sub-ovate, black; costal edge pink.

Secondaries have also a broid marginal horder, usually somewhat excavated on each intersace, commencing above the upper branch of sub-costal nervure and ending a little before the imer angle; discal spot round, often duplex, pale orange; fringes pink and yellow.

Under side of primaries either of same shate as above, or deeper, the apical area sometimes orange-tinted; the costal margin dusted with brown; the discal spot black with yellow central point or streak, but occasionally this streak is pink or is silver white; both wings have an extra discal series of smill ferruginous or brown patches, or clusters of scales, which lies parallel with the hind margins, and on primaries curves at the apex, so that the upper two clusters fill on the elge of the costal margin, but often the series is partly, and sometimes almost wholly, wanting.

Secondaries usually either pale yellow or reddish-orange, and more or less dusted with brown; at the outer angle a ferruginous or brown patch, and a small 


\section{COLIAS II., III.}

pink patch at base of wing; the discal spot usually duplex, there being one large round silvered spot, and a small one, either with or without silver, in the direction of the outer angle, each edged narrowly with dark ferruginons, outside which is a broat ring either of pale ferruginous; or of deep yellow dusted with ferruginous; these rings usually confluent; the silver seales partially replaced by pink; costal edge of primaries and fringes of both wings pink.

Body above covered with greenish-yellow hairs, the collar dull red; under side yellow; lege pink; palpi yellow, redilish above and at tip; antemne brownishred above, pink below; elub brown, ferruginous at tip.

Fexnde. - Expands 2.5 inches.

Upper side usually of a brighter yellow than the male, but often green-tinted; the maremal borter of primaries broad, inclosing a series of yellow patehes, the one on the upper median interspace usually wanting; secondaries lare the borrer sometimes nearly as broul as primaries, and in that case it partially incloses rellow patches; but most often it is narrow, and sometimes is reduced to a slight blackening of the upper half of the margin, or even to small clusters of scales at the ends of the nervules; discal spots as in the male; under side as in the male, rarying in sime mammer both as to shades of color and degree of irroration.

Albixo, always female. Color greenish-white, marked as in the type. Indivichals are occasionally met, the upper sides of which are of a shade between greenish-white and yellow, the muler side fintly blue-tinted. (Figs. 5, 6, Pl. 3.)

Metwric var. Occasional and sulpect to much variation. So fin as known to me, confined to the male. (Figs. S, 9, Pl. 3.)

EGG. - Length .06 inch; narrow, fusiform, tapering evenly from the middle to either extremity, ribbed longitudinally and crossed by numerous strice; the extremities blunt, the base rather broader than the summit; color pale yellow (Fig. a.) when first deposited, which changes a few hours after to pale and then to dark crimson (Fig. $\left(i^{2}\right)$. Deposited on cultivated clover, especially 'Trifolium pratense, on the upper side of the leaf; also on the garden pea and on lupines. Mr. G. MI. Dorlge has found the eggs on the buftalo pea, Astralagus caryocarpus, in Nebraskal. 'The duration of this stage varies with the climate or the season. At Coalburyh, the larve emerged in July and August in four days, in Oetober in ten days. In the Catskill Mountains, New York, Mr. Mead found the period in July to be five and six days. Mr. Saunders gives seren days, in Ontario.

Iotixg Lami. - Length .06 inch, cylindrical, of uniform size from second to eleventh segments, thence tapering to the list; color bromish-green; each segment creased four or five times transversely, the foremost ridge thus caused on each marked by three black tuberculous dots on either side; similar dots in line below the spiracles; from each dot rises a short, whitish, clubbed process; 


\section{COLIAS II., III.}

the remainder of the upper surface irregularly specked with brown points, from each of which springs a white hair; head ob-ovate, granulated, dark-bromn. (Fig. b, magnified.) 'lo first moult three days.

After first monlt; length .12 inch; shape as before; the segrments creaved; the whole upper surfice covered with mimute whitish tubercles, which are black at their summits, and are disposed on the ridges so as to form both longitudinal and transverse rows; each tubercle giving a short hair; color dull green; under side and leys pale green; head black, shape as before. (Hig. c.) To second moult three days.

After sceond moult; length.$: 3$ inch; the body much as at last stage, but now blue-green, and showing a faint whitish lateral stripe; head pale green. (Fig.d.) To third moult four days.

After thind moult; length .7 inch; the principal change consists in the lateral stripe, which is now white and distinct, and usually shows a red, or orange, or yellow discolonation on the anterior secrments; sometimes black lunate spots appear beneath the stripe, on some of the segments, especially the second and third. (Fig. c., nat. size, e magnified). 'T'o fourth moult four days.

After fouth moult; length 1 inch; the stripe now incloses a crimson streak, sometimes broken into patches; there is most often an absence of black spots beneath the stripe, but many eximples direver more or less of them up to a complete series, largest on the anterior segments. (Hig. $f^{*}$ ) In about three days after this moult the larva is full-grown, and prepares to change to chrysalis. (These observations were made at Coalburgh, W. Vir.)

Mature LARPA. - Iength 1.2 inch; hody eylindrical, tapering slightly from serenth to last segment, and from the fifth towards the head; each segment creased four ol five times transversoly; the surface between the creases rising in rounded ridges, on which are arranged in rows fine whitish tubercles tipped with black, forming both longitudinal and transverse regular lines; each tubercle throwing out a short white hair; color dark green, pale green on under side; in line with the spiracles is a white or cream-white stripe from the front of recond to the end of the twelfth segment, through the middle of which rums a streak of crimson, broken at the junction of the segments; frequently on the lower edge of this stripe is a row of lunate, black spots, large anteriorly and diminishing to a point on twelfth segment, the posterior half of the row often obsolete, even when the other spots are distinct; head smaller than second segment, ob-ovate. pale green, finely tuberculated, pilose, the mandibles and ocelli black. (Fig. $g$ slightly magnified.)

Froni fourth moult to chrysalis there is an interval of four or five days. 'Total from the egg to chrysalis about eighteen days in midsummer. 


\section{COLIAS II., III.}

CHrisilis. - Length 1 inch; cylindrical, thickest in middle, tapering to either extrenity; head-case pointed, the eyes prominent; thoracic process slight, rounded; color yellow-green; a yellow lateral line from wing-case to last segment; and below this a row of red points, one on each segment. (Fig. h.)

Duration of this stage eight days. From the laying of the egg to the emergence of the butterfly, thirty days, in West Virginia, in July and August. In the Catskill Mountains, thirty-nine days. Larve which hatched 21st September, at Coalburgh, hybernated when about half grown.

Philodice is the commonest of butterflies throughout the Northem and Eastern States and Camada. Mr. Couper found it in the island of Anticosti. And it also inhabits Newfoundland. It is less abundant in Virginia, and still less southward, but its lange is limited only by the Gulf of Mexico. In the Mississippi valley the orange species predominate, but year by year Philoclice encroaches on their territory. Professor Snow states that it is becoming well known about Lawrence, Kansals, though as yet by no means equaling Eurytheme in numbers. Mr. Dodge writes to same eflect from enstern Nebraska. Mr. J. A. Allen foum it in Iowa, though nowhere abundant. I have also examples from Dakota and Texas. The rapid advance of the species is probably owing to the fact that the foodplant of its larva is the common red clover, which everywhere keeps step with the pioneer. The Coliades are not at all forest species, and it is reasonable to suppose that, on the first settlement of the country, the range of Philodice was restricted to the savimmahs along the seaboard, or to open spots where the native species of trifolium or of lupinus grew; but that with the introduction of a more palatable or les's precurious food-plant, it his increased and dispersed till it now occupies half' the continent. 'The orange species have nevel' mate their way east of the prairies, except as occasionally a few imdividuals have wandered. 'Their larvie naturally feed on such plants as grow on the prairies, and over the western territories, but are known to betake themselves to the red clover in some degree, and upon this ciremmstances may hereafter compel them to depend as the comtry becomes populated. All the other American species of Colias are comparatively local in their habits.

Where Philodice is found no one can have failed to notice it, either in garden or field, as it gently flits from flower to flower, or comses along the road or across the meadow, with sustained and wavy flight. It is sociable and inquisitive, and may often be seen to stop in mid-career as it overtakes or meets its fellow, the two fluttering about each other for a moment, then speeding on their ways; or they mount in air, approaching, retreating, with a slow, vertical and tremulous ascent, till the eye ceases to follow them. When the clover is in blossom the meatows are gay and amimated with these yellow butterlies, and wherever bright 


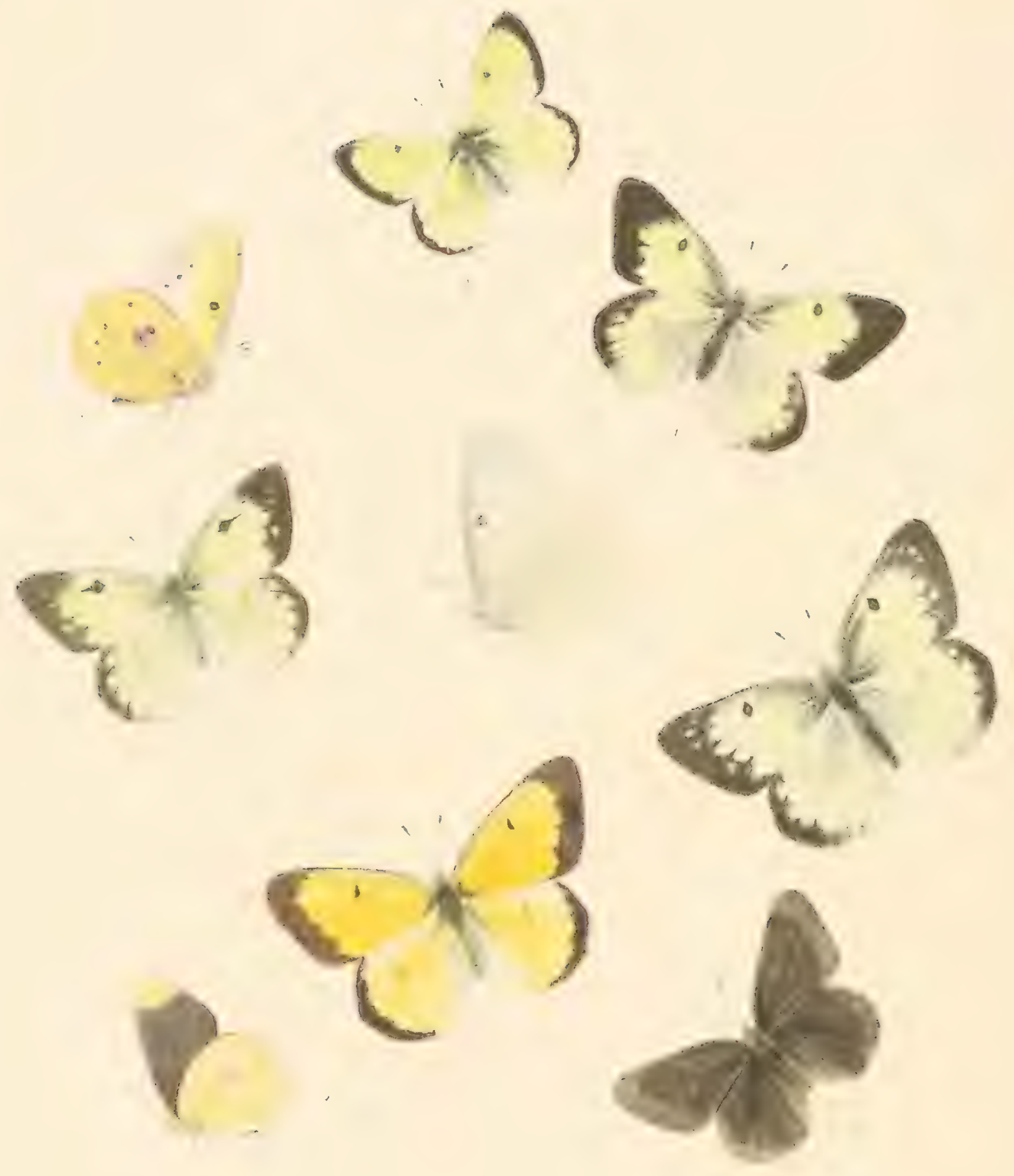


COLIAS II., III.

flowers are will surely he seen I'hitodice. On marigolds and brilliant single zinnias they delight to pasture, for they have a keen sense of color. I have known one of them to alight on an amethyst in a larly's ring, after hovering about its wearer so persistently als to attract attention, and it rested some seconds. Doulntess there were puzaled pereeptions on sounding that stony Hower.

It is the habit of Philodice to gather in dense masses by seores and hundreds: upon wet spots in the roarl, swaming when disturbed and settling again when the interuption ceases. In the Can. Ent. II., p. 8, 1869, the Rev. C. J. Bethme writes: *- On the third of August, a bright sumy morning, atter an excessively wet night. I drove about ten miles along country roads; every few yards there was a patch of mud, and at each there were from half a dozen to twenty Philorlice, at least one, I should think, fol every yard of distance travelerl. I must then have seen, at at rery moderate computation. ten thousand specimens of this butterfly." In Westwood's Arcana Entomologica, I., p. 14t, the late Edward Douhlerlaty sitys: . I have seen in Illinois, in the atutum, Colias Phitodice and Casoniu, 'l'erias Nicippe and Lise, and Callidryas Eubule, in groups literally of humdreds (the first-naned inseet generally making nineteen twentieths of the company), in as space not six leet squate."

As might be expected of so previling a species, Philodice is subject to great variation, and many of its varicties are extreme. It would be easy to indicate several of these which seem only to await favorable circumstances, as segregation for a period, to caluse them to become permanent; that is, to become distinct species. 'They viry in size, in color, in the extent and contonr of the marginal border, in the discal spots, in all the markings of the under side, and in the degree of dusting of hoth sides; in size, from an expanse of 1.9 to 2.6 inches; in color, from pale sulphur to lemon and bright yellow; in the breadth of the borders, from .1 to .3 inch; in its extent on costal margin; in the contour of its imner edge, from regular to erose and crenated, sometimes also crossed nearly to the margin by yellow nervules, sometimes only at the apex, and often not at all; in the size and shape of the discal spot of primaries, from a mere streak to a large romeded spot or an irregular patch, and with occasionally a long spur projecting from it, perhaps commecting it with the marginal horder; in the discal spot of secondaries from nil, or a shade scarcely differing from the gromel color, to orange, and either single or double; in the color of the under surface, from pale to bright yellow, or to ochraceous; in the discal spot of primaries, from yellowcentered to pink, or silver-white, or even wholly black; in the extra-cliscal spots. from a complete series across both wings to almost none at all, only a few dark scales here and there being present, (I have never seen an example in which there was absolutely no trace of these spots, and in color, from pink through 
ferruginous to black; in the spot at onter angle of secondaries, from nothing to a large brown patch; in the basal patch, from clear pink to rusty rect, and sometimes wholly absent; in the discal markings, from a single round silver spot in a slight ring, or without ring; to a double spot, or two separated spots, nearly equal, on a large ferruginous patch, which itself may be round or irregular; the silver scales often replaced by roseate; in the dusting of upper side, from a slight obscurity at base to so dense a covering as to give a gray shade to whole surface; of the under side, from a clear surface to one as thickly coated as in Peliche. 'The females vary in the same degree, and any peculiarity in one sex may be matched in the other. Occasionally a female is seen in which there is an absence of the usual sub-marginal yellow spots, the borders then being black, and so fir assimilated to those of the male. (Fig. 4, Pl. 3.) Sometimes also the males are orange-tinted, and two examples are known to me in collections. One of these is in the possession of Mr. Charles Wilt, of Philadelphia. The other was given me some years since by the late Benjamin D. Walsh, and was taken by him in Illinois, in coitu with a yellow female, which also I have. 'The orange hue of this male is decided, and especially upon the inner half of primaries. (Fig. 1, Pl. 3.) The yellow species ma sometimes acquire characteristics of the orange, without actual hybridism, according to the fact stated by Darwin (Orig. Spec., 5th ed. Am. p. 138), that "the varieties of one species when they range into the habitations of other species often acquire in a slight degree some of their characters." Or the present may be an example of hybridism, for that the orange species do sometimes mate with the yellow is not to be doubter. I have a pair taken in coitu by Mr. Dodge, in Nebraska, the male of which is an Eurytheme of the most pronounced type, the female the ordinary yellow Phitodice. Mr. Dorlge says: "Unfortumately I killed the male before separating them, and the female died without depositing eggs." It is stated by Möschler (Wien. Ent. IIonat., IV., p. 22), that the European Coliarles do occasionally liybridize, as Erate with Edusa and with Mymidone.

The melanic variety figured was taken by $\mathrm{Mr}$. Charles Worthington, of Chicago, "in an upland grass-field, near the village of Palmyra, N. Y. There were two, but only one was captured, and a third was seen about a mile away." Another example was taken by Mr. C. W. Pearson, of Montreal, in August, 1575, at Chateauguay Basin, the upper surface of which he describes as "deep brownish black, somewhat green-tinted if seen obliquely. On the under side the primaries are dark brown and secondaries almost olive-green."

The examples of Philodice taken in the district in which I live are of a larger average size than those from States farther north, but still many are diminutive. The small variety figured $3, \mathrm{Pl} .3$, and which seems to be identical with Hiib- 


\section{COLIAS II, III.}

ner's Anthyale, I have taken at Coalburgh, and have received both firom 'Texas and Nova Scotia. It is chameterized by very marrow borders, restricted on costa. and by the conspicuous makings of the under sile. A more diminutive pair, but less aberrant, I have in my collection, the male expanding 1.3 inch and the female but 1.2, captured in a meatlow at Newburgh, N. Y. The female (Fig. T, P1. 3.), in which the discal spot of primaries projects a spur towards the border. was bred by me at Coalbureh, as was the other, in which the borter is immaculate. Mr. Reakirt (Proe. Ent. Soc., IV., p. 219) mentions an example in which the comnection of the discal spot with the border was complete, as being in the collection of the Entomological Society; and Mr. Lintner (same work, vol. III. p. 55) describes a female with immaculate border. Mr. Reakirt also speaks of one in which the border takes the form of the "dog's head" characteristic of C. Cusonia, a variation which I myself have not observed in the present species, but which does sometimes appear in the female Eurytheme, and is indicative of the generic affinity of the two species.

By inclosing the females of Philodice, at the proper season, with a plant of growing clover, eggs are readily obtained, and in this way I have repeatedly raised the larve. In such cases the parent is carefully preserved for comparison with its progeny. Sometimes, out of a brood, the variation from the mother has been umoticeable, but in other cases very great, and this might well be owing to the difference between the parents. So a pale sulphur-colored female will produce some like itself and some of a deep yellow, etc. In the fer instances in which I have taken pairs in coitu, there wis a close revemblance between them in color and markings, but many observations are required to deduce any rule therefrom as to like seeking like. Albinism is confined to the female, and examples are not uncommon in the field. Of course, these unite with yellow males, and the product is partly albino and partly yellow, or it may be all yellow. In one instance I had five butterflies from eggs laid by an albino, and there resulted one male and four yellow females, no albino. In another case of four females one was an albino. Mr. Mead has met with similar results, and neither of us have known an albino to be produced from the eggs of a yellow female. The yellow females raised by me from albinos have all resembled one another in this, that the under surface of secondaries has been densely coated with gray scales, giving a peculiar and mealy appearance, and nearly all of both sexes have had conspicnous double discal spots on the under side of secondaries, as represented in Fig. 2, Pl. 3.

'The mature caterpillars differ in that some have a series of' black spots beneath the lateral band, while in others there is no trace of this; but the same brood will exhibit both varieties. The deepest colored examples of the butterfly which 
I have hred, a male and a female, were from larve which had these spots largely developed. Both are dark lemon-yellow above, and of a rich shade beneath, heavily dusted. In the male (Fig. 5, Pl. 1.) the discal spot on murer side of primaries is red-centred, and the fringes on upper side are roseate throughout, not mixed with yellow as is usual. The other butterflies of the brood were in no way singular.

Abont Coalburgh, Philodice appears enrly in May, and is on the wing in succcrive generations till about the first of November, by which time severe frosts destroy them. The eggs are deposited upon the clover leaves, a single one to a plant, and the females may often be seen flying about the lawn or meadow for this purpose. I have not attempted to obtain egg's in confinement upon other foodplants attributed to the species, but Mr. Dodge has succeeded with the buflalopea, Astralagus caryocarpus, which grows on the prairies, and is one of the plants on which the larve of Eurytheme feed. The young larve are at first rather difficult to manage, having a disposition to roll off' the leaves, and are apt to be lost in the breeding-cage. I have succeeded better when inclosing them in covered grliss versels, changing the leaves frequently. This tendency to drop at the least disturbance the larva retain till maturity, and it is naturally their sufficient protection against enemies or destruction. They lie exposed on the upper surfice of the clover leaf, and revemble its color closely. When first from the egrg, each makes for itself a hole in the leaf, and feeds at the edges of this for several days (Figs. c, $d$, ), but as it increases in size. it derours the leaf from the end or side. As the time approaches for the change to chrysalis, the larva seeks the protection of some stem, hit of bark, or fence rail, spins a button of pink silk and a light web over the surface of the object, fastens its amal feet in the one and its forefeet in the other, and hangs with its back curved downward or outward. Gradually the markings of the body become obliterated, lost in uniform green. In this condition the larva rests for some hours, then rousing itself, spins a loop of several threads from the base of the feet on one side to a like point on the other, instinctively knowing just how long to make the threads, and presently, seizing the loop in its jaws, manages to throw it partly over the head, and by a great effort works it entirely over and down the back to the fourth segment, and stops exhansted. Some hours pass without any motion, when suddenly the skin splits on the back of the anterior segments and is rapidly shuftled off, exposing the chrysalis, which rests secure on its girdle of silk.

The latest broods of larva, or those which are eaught by cold weather before they have matured, hybernate more or less, and further south this may be the habit. 'T'wice I have carried half-grown larve through the winter. Mr. Nead foumd hybernating larva inactive under boards, in the month of May, in Illinois. 


\section{COLIAS II., III.}

It is probable that in some clistriets, and especially in the more sonthern States. the butterly also sometimes hybernates, as Edusa and Iryale are said to do in Europe. On 12th December 1579, I saw a male Philodice on the wing at Coalhurwh. long alter we had suffered from severe frosts and cold weather, and when all butterflies seemed to have disippeared.

In the Cin. Ent. VI., p. 92, Mr. Comper notices some peculiarities in Philodice on Anticosti. He salys: "I took a few speemens last July. It is a rare butterty on the island, where its habits difler from those found at Quebee. It is diffieult to capture. Its flight is ripid and contimuous rluring the oceasional hours of its appeatrance, and it is only towards the end of July, when the weather becomes cold. that it can easily be approatchert. When it alights on a flower, instead of heing erect on its feet, it lies sidewatys, ats if to receive the warnth of the sum."

Mr. Reakirt. in his paper on Coloratan Butterllies, Proc. Ent. Soe. V1., p. 135, mentions Philodiee as having been taken in Colorato hy Mr. Ridings. 'This State was thoroughly explored by Mr. Meat, in 1871, and since that tine large collections of hutterfles have heen mate hy the mituralists of Lientenant. Wheeler's experlitions, and no eximples have been taken which can confidently be referred to Philodice, though a near related species is found, the same which Mr. Reakirt had before him. Mr. Mearlagrees with me as to the distinctness of this species from P'hilodice.

A very interesting Colice was bronght fiom Cape Breton island, in 1875 , by Mr. Roland 'Thaxter, and was described hy Mr. Scudder in the Proc. Bost. Soc. Nat. Ilist., Oct., 1875, als a variety of Philodice, under the name of lanerentina. It is allied to hoth P'eliche and Philodice, and, in my opinion, is nearer the former, and may have orignated in hybridism between the two. But it plainly breeds true to its present type, for besides the many individuals taken by Mr. 'Thaxter, it has occasionally been taken on the mainland. as stated by Mr. Scurlder. I regard it therefore as a true species, quite as much so as either of its presumed or possible parents.

Althongh Philotice is figured in Stephens, in Swainson, and in Inmphreys and Westwood, as having been taken in England, Mr. Westwood remarks that "its claim to be reginded as indigenous is still denied by several of our principal Entomologists." Stephens speaks of five specimens as having been seen by him in cabinets, and says that "till last stummer, it does not appear to have been captured in Fingland for upwards of forty years." It seems to me not improbable, in view of the trade, especially in timber, between Canada and England, that chrysalicts of this butterfly may occasionally be carried across the sea. In this way chrysalids of Cuban butterflies have been brought to New York on sugar or molasses hogshearls, as I have verified. 




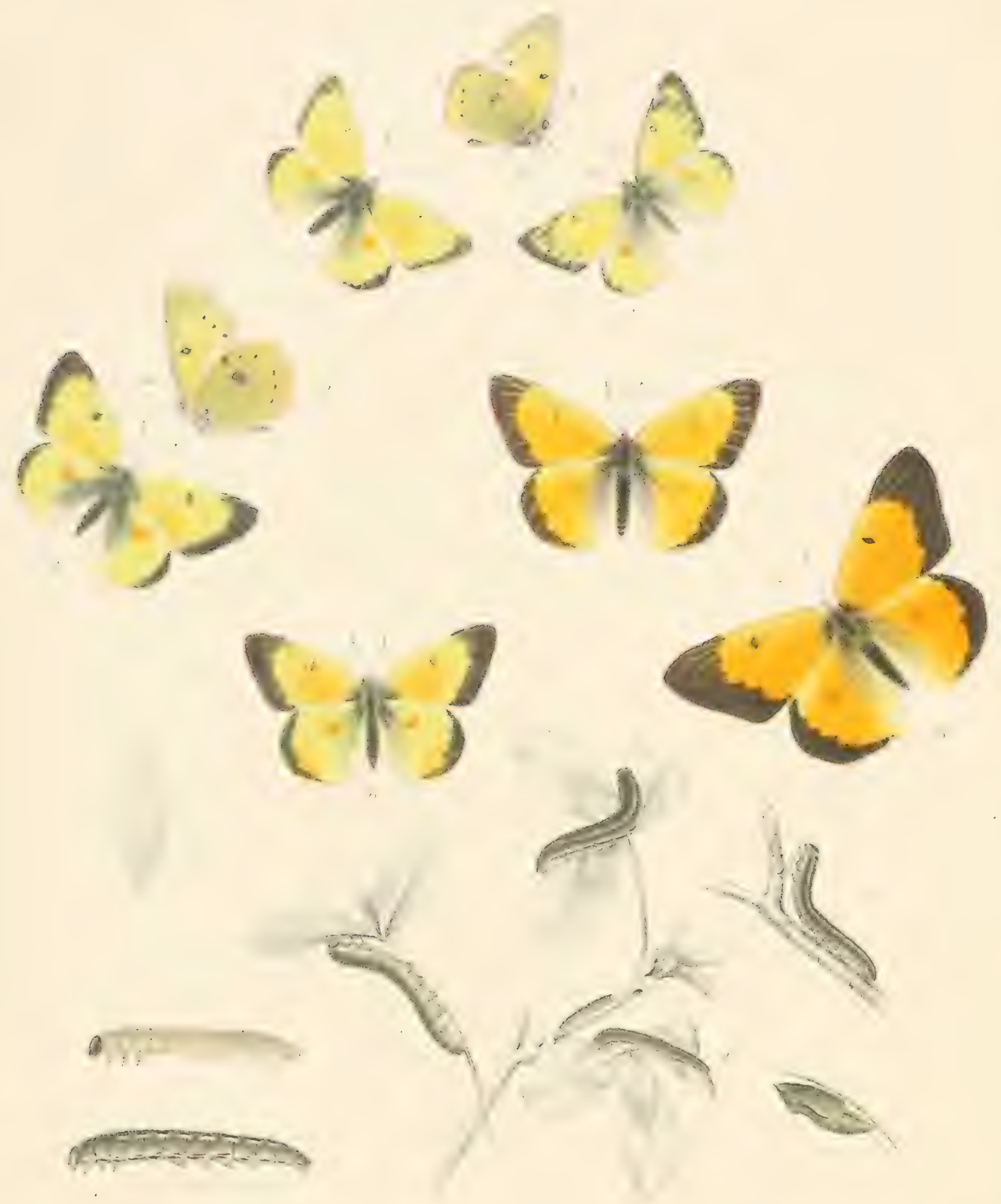

f.

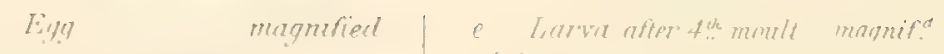

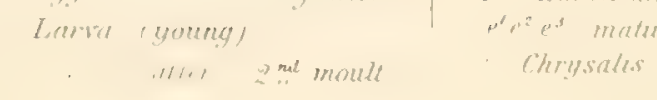




\section{COLIAS IV.}

\section{COLIS EURYTHEME, $1-8$.}

Colias Eurytheme, Boistural.

EURTTIEME: Bois., Ann. Soc. Fnt. Fr., Ser. 2, X., p. 236. Eilwards, But. N. A., I., p. 43, pl. 14.

Amplitilusa, Bois., l. c., p. 256.

Ëlusu, Bois. and Lec., p. 59. Eilusa, var. Californicn, Ménétriés, Enum. Corp. Anim. MIus. Petr., p. 80.

KEEW AYDIN, Elwards, But. N. ג., I., p. 47, pl. 15.

Chrysotheme, Bois. and Lec., f?. 62.

ARIADNE, Edwards, Trans. Am. Ent. Soc., III., p. 12.

EURYTHEME, FORI ARIADNE.

MaLE. - Expands from 1.3 to 1.6 inch.

Upper side bright lemon-yellow; on primaries an orange patch extends from unner margin to median nervure, or a little beyond, sometimes very pale and a mere tint on the jellow ground, but usually of decided color, and gradually passing into yellow beyond the middle of the disk; secondaries sometimes slightly tinted, but most often wholly yellow; the marginal borders very narrow, scarcely half as wide as in Kecroaydin.

Under side of secondaries greenish-yellow thickly dusted with brown scales; the discal spots duplex, a large and a small silver spot, each edged by ferruginous and placed on a large patch of pink-ferruginous.

Female. - Expands 1.6 to 1.8 inch.

The orange shade is restricted to a patch on primaries, as in the male; secondaries are greenish-yellow, much dusted, and often over the whole surfice; the marginal border of primaries narrow, and but partly inclosing the submarginal spots; sometimes it is restricted to a mere edging, and there is no trace of the spots, unless at apex, where they may be indistinctly outlined; under side of secondaries pale greenish-yellow, thickly dusted; the discal spot as in the male.

Ariadne is distinguished by its small size, restricted orange patch on primaries, and frequent absence of orange on secondaries; the narrowness of the border's; by the greenish hue of under side of secondaries and the heavy dusting, and by 


\section{COLIAS IV.}

the magnitude of the discal spot with its ferruginous rings and patch. This is the typical character, but there are intergrades comnecting this form with $\mathrm{Kee}$ wayclin.

EURYIIEME. EGG. - Length .06 inch; narrow, fusiform, tapering evenly from the middle to either extrenity, the base broad, the summit pointed; ribbed longitudinally and crossed by numerous strix; color buff-white when first deposited, after one or two days changing to crimson, and near the close of the stage to black. (Fig. a.) The larva emerged after six days in August, nime days in September.

Young LARta. - Length, .05 inch; cylindrical, of even diameter to eleventh segment, each segment several times creased, and on the ridges thus formed many black points, from which spring white hairs; color dark brown or chocolate; head obovoid, granulater, dark brown. (Fig. b.) Duration of this stage in August two days, in September five.

After first moult: length .125 inch; shape as before; body covered with minute black tubercles, disposed on the ridges so as to form both longitudinal and transverse rows, ench tubercle sending out a white hair; color dull green, head obovoid, dark brown. 'To next moult in August five day's, in September fourteen days.

After second moult: length .28 inch; color dark green; tuberculated as before; pilose; head as before. (Fig. c.) To next moult in August six days, in September seven days.

After fourth monlt: length .56 inch, color darker green, but varying, some examples having the sides only dark, the dorsum yellowish, the sub-torsal stripe sometimes wanting, but usually more or less defined; at the posterior end of each segment from 3 or 4 to 10 or 11, it becomes thickened, forming a distinct spot rather, while elsewhere it is faint; many examples show a red streak on each of these spots, and not unfrequently there is a black dot exactly under the feebly-flefined, fragmentary line of greenish-white; head obovoid, yellow-green. (Fig. d.) To next moult in August five days, in October ten dlays.

After third moult: length, .45 inch; cylindrical, long and slender ; color dark green; tuberculated and pilose as before; at base of hody now appears a white stripe through which rums a crimson line, and uncler this stripe are black semicircular or ovate spots, sometimes only seen on segments 3 to 6 , but usually from 3 to 11, diminishing in size posteriorly; in some examples these spots are wanting; at the beginning of this stage there is no indication of a sub-dorsal line, but presently appears a line paler than the ground, which gradually changes into a white spot on segments 5 to 10. (Fig.e.) To maturity in August seven days. 


\section{COLIAS IV.}

With the later brood of larva this period was greatly protracted by the cold weather, reaching twenty days and more.

Mature L.IRTA. - Length 1.1 to 1.2 inch; cylindrical, of even thickness, tapering on the last segments; each segment sevelal times creased, and on the ridges so formed are numerous fine papillw, mostly white but many black, and ench sending ont a fine, short, white hair ; color dark green; at base of body a band of pure white through which rums a bright crimson line fiom segments '? to 11 , almost continnous, seen fintly on 13 ; and beneath this band from 3 to 12 is a large semicircular or semi-orate black spot on each segment, the anterior ones largest, the rest diminishing gradually; on the edge of dorsal area is a faint whitish line, thickened at the posterior end of each segment so as to present well-defined white spots; next above the white line is one of crimson, broken on each segment, and usually well-defined only just above and near the white spots; beneath these last, on the last rilge of each segment from 5 to 10 is a black dot; under side, feet and legs pale green; head obovoid, pale or yellow green. There is much variation in the mature larva with respect to the subdorsal lines. I have secn no living eximnle in which they are wholly absent, but I have an alcoholic one received fiom Mr. Dodge in which there is no trace whatever of these lines, and the larva looks like that of Philoctice. So I have a carefilly drawn and colored figure from the late Dr. H. K. Mayhurst, which shows no trace of these lines. (Fig. e.) On the other hand, one in alcolool from Mr. Dodge shows a broat, contimous white stripe, like that at base, only a trifle marrower. Mr. Bean siy., "The grlass showed the upper line to be white, erlged with yellow only, there being no trice of red whatever, but the day after, the line was unmistakably margined with confused crimson and yellowish." I received a number of larvie in their last stages from Mr. Bean, and my notes read, "In some, the white, crimson, and black of upper band are distinct; some have no trace of the black, some neither of black or crimson; and in some the white line fades till nothing remains but the thickened end on each segment, and this may be represented by a dot or minute spot only." (Figs.e, $e^{1}, e^{2}$.)

Currsalis. - Length .S5, breadth .09, greatest depth .11 inch; compressed laterally, the thorax prominent, abdomen taperings, mesonotum rounded, head case pointed; color of anterior part and of wing cases dark green, of abclomen yellow-green; a light buff stripe on either side of abdomen from the end of wing cases to extremity, and on the ventral side of this stripe, a demi-band of dark brown; between the stripe and band three black dots, one on each segment; on the wing cases there is a submarginal row of black dots, one on each interspace, and on middle of the disk is a small black spot. (Fig. f.) Duration of this stage in September fifteen days. Of the later brood the periods varied, the 


\section{COLIAS IV.}

shortest renching twenty-five days. These as well as their larve were kept in a warm room.

The present species traverses a vast extent of territory, embracing all of the United States west of the Mississippi River, besides a considerable area to the east, and an undefined portion of British America as well as of Mexico. This region covers $40^{\circ}$ of longitude and upwards of $30^{\circ}$ of latitude, and presents every variety of surfice and climate. To the southward, the summer is prolonged and the winter short and mild; at the north the reverse of this is the fact, but on the plains of 'Texas or the prairies of Illinois, on the elevated plateaus of Colorado, or in the secluded valleys throughout the Rocky Mountains, and over the Sierras to the Pacific, the species is equally at home and is everywhere abundant. It occupies with Philodice the whole of the United States and much of British America, and like that species, which it resembles in every respect but in color, it is subject to great and extreme variation, there being no feature whether of size or ornamentation that is not unstable. In Vol. I., I gave such history of Eurytheme and Keevaydin as I was then able, but since those brief relations were printed, and indeed, within the past three years, by repented breeding from the egg, together with careful and extended olservations in the field, in many localities, it is rendered certain that we are dealing with a biformed and triformed species, and that Ariadne, Keewaydin, and Eurytheme are but so many seasonal manifestations of it. Also, that in some districts the species is not seasonally polymorphic, but is simply a variable one, like Philodice:

This Colias is not found in West Virginia, nor have I ever seen it alive, but I have been aided by several friends in the effort to learn its full history: by Mr. Dodge, of Glencoe, Nebraska, who has raised several lots of larva from summer females, and sent me the resulting butterflies; by Mr. Bean, of Galena, Illinois, from whom I received larve of the last brood of butterflies of the year, and so was enabled myself to follow the several changes. Mr. Bean has also given me full notes of all the stages of larve raised by him at same time, and of summer larve besides, and a tabulated statement showing the forms of this species taken by him in the field, with dates of capture. Mr. Worthington, at Chicago, has sent me a similar table. Mr. Mead has furnished notes from his experiences in Colorado and Califormia in 1871, and besides this, I had the opportunity of examining all the specimens collected by him. And Mr. Henry Edwards has sent many examples and records of his captures and observations in California and clsewhere on that coast. He has also published a valuable paper on the Coliades in the Proceedings of the Califomia Academy, Vol. VI., 1877, of which I have arailed myself. Finally, Mr. Boll, of Dallas, Texas, has sent a paper read by 


\section{COLIAS IV.}

him at Leipzig, upon Dimorphic species of Lepidoptera in America, in which C Eurytheme is discussed at length. Mr. Boll has, in addition, given me a series of examples of the several forms of the species to. illustrate his paper.

Keecuydtin was originally separated as a species from examples received principally from Texas and Mississippi. Large numbers from Texas were of this form, while from Mississippi all received were of the form Eurytheme. These last were taken late in the season, but the significance of that fact, $I$, of course, could not then apprehend. In California, Mr. Edwards and Dr. Behr were confident that two distinet species existed, Keewondin flying early and the other late in the season. 'This was long before anything wats known to us of seasonal dimorphism in buttertlies, and before any knowledge whatever bearing upon this phenomenon or even of simple dimorphism had been gained by breeding from the egg. At the time, the late MIr. B. D. Walsh, living at Rock Island, Illinois, in correspondence with me, strenuously combatted the idea of two species, asserting that it was a case of variation as in Philodice, and that all the varieties were flying at the same time, and must be from the same broorl. This he gave as the result of twelve year's' fimiliarity with the species. Mr. Walsh was undoubtedly right as regarded the district he had collected in.

I received from Mr. Dodge, 10th Jume, 1876 , several larva nearly mature, but they had suflered from want of food on the joumey and but one lived to make chrysalis. This gave butterfly 17 th June, Keewouglin of. In 1875, Mr. Dodge sent me three buttertlies, '2 8 18, all undoubted ficewaydin, which had emerged from chrysalis early in July, from egres laid by \& Keewaydin, 4th June. And he also sent eleven butterflies, 5869 , from eggs ${ }^{-}$laid by 9 Keewaydin, 18th July, 1877, and which emerged from chrywalis between 15th and 20th August, and of these butterflies, 483 are Eurytheme, 18 is are Keewaydin. In 1876, I received from Mr. Bean larve bred from eggs laid by Eurytheme 17th September. These larva would naturally have hybemated when about half grown, but being protected in a warm room, they proceeded slowly to chrysalis, and the butterflies emerged between 1st and 15th February, 1877, 48 39. Mr. Bean retained several of same lot of larva, and from them obtained nine butterties, $8 \delta 1$; , the first one emerging $23 \mathrm{~d}$ December. These sixteen butterflies are all of one type. They are as large as the average Keewaydin, and with as broad a border, but the coloration of the upper side is that of Ariadne, the orange being restricted to a patch on the inner margin of primaries. On the under side the color of secondaries is greenish, heavily dusted with gray scales; the discal spot is duplex, large, ferruginous, more or less suffused with pink; and the extra-discal points form a complete series on each wing. In these respects this variety is most like the typical Ariadne. It is an intergrade which I designate as Var. A. (Figs. 4, 5.) 


\section{COLLAS IV.}

Mr. Bean also bred from Keewaydin \&, which laid fire eggs 1st August, 1876. From these he obtained two butterlies, 15th and 19th September, one of them Eurytheme 8ै, the other Treewaychin of.

And he gives the following statement of his captures at Galena.

I. Eurytheme \&, typical form.

30th May, faded, evidently a hybernator; 29th June (1st brood); 6th, 10th August (2d brood); 21 st September ( $3 d$ brood).

Eurytheme \&; 11th July (1st brood); 27th August (2d brood); 24th September (3d brood).

II. Intermediate examples.

4 th, 18th July (1st brood); 6th August (2d brood); 15th, 24th September (3d brood); Sth, 10th October (belated 3d brood).

III. Keewcryctin 8 , typical form.

22d June to th July (1st brood); 20th September (3d brood).

Feeucaydin ?; 18th July to 3d August (2d brood).

The typical Ariadne Mr. Bean has not seen in Illinois.

Mr. Worthington states that he took Eurytheme, in 1876, 30th May (hybernator); 1st July (1st brood); in 187. 29th May (hybernator); 4th July (1st brood), and at intervals thereafter till frost. And Keewaydin 10th June, 1877, and at intervals thereafter till 10th September. But the form Ariudne he has never seen in Illinois, nor does he find it in several local collections examined. The nearest approach to it is the intergrade, designated above as $V$ ar. A.

Mr. Dortge, who lived several years in Illinois, and for several more has lived in Nebraska, giving his experience in both States, says: "As regards Ariadne" (which I had sent him), "I have never seen it before. I have never taken it. I have taken the other two forms both here and in Illinois, and am sure no such form as Ariadne exists at the North. I have seen the species flying here as early as the second week in May, some seasons not till last of May. 'There were in Illinois three distinct broods. In May, I used to find a few hybernated specimens, usually too much worn for identification. In Jume the first brood appeared. I had to look for these on the uncultivated prairie. This brood was never large in number. The second brood appeared in midsummer, and in September the third. 'The butterflies then became quite plenty on clover." Speaking of Nebraska, "I think the species hybemates both as imago and larva. I usually find fresh specimens in May that must have just emerged from chrysalis, but the worn and battered ones are the most abundant. 'The first brood ap. pears about the middle of June, the next, middle of July, and the third in September. If the weather is warm, the butterflies are abundant in October." The earliest butterflies spoken of by Mr. Dodge as fresh from chrysalis were evi-. 


\section{COIIAS IV.}

dently from hybernating larva. That hybernation takes place in larval stage in some districts is unquestionable. Mr. Boll writes me, Sth April, 1878: "When I caught the first specimen of Ariulne, in February of this year, in Archer County, Texas, on the same day I found a full grown caterpillar and a chrysalis, mater stones, both which produced slriadne."

The account Mr. Boll gives in his Leipzig paper is in substance as follows: The species begins its llight, in 'Texas, in November, and throughout the winter it is to be scen fresh from chrysalis, in warm days. It is common in March, rarer in May, and totally disappears in June. The larva feeds on Trifolium stoloniferum, rumning Bullilo Closer, which attains its greatest lusuriance and blossoms in April and May, and dies off' before the appearance of the last June butterflies. It does not spring up again till the advent of the October rains. As before stated, the buterflies apjear in November, and during the rest of the season larve and butterfies are taken at the same time. It is the opinion of Mr. Boll that the egres laid in June do not develop, owing to lack of food, till the summer is past. (I apprehend that if there is any retardation it must be with the larve.) 'There are four annul broods of this species and the first, or winter brood, appearing from November to end of February, is Ariadne. The prevailing form in Minch is Feevayctin, an example of Ariadne being then rarely seen. From April to June the form is what Mr. Boll in this paper calls Eurytheme, but his April and May examples of the series sent ne are what Mr. Bean calls the intermediate form, an intergrale leading to Eurytheme.

Mr. Boll says: "If we compare the specmens we find a steady increase in intensity of color from April to Jume; the orange-red becomes more fiery and extends in the male over the whole upper surface of secondaries, learing yellow only the costal margin of primaries, while the black marginal band becomes broader and broader. Through the influence of the sum the whole oramge upper side becomes iridescent, with a violet hue, as in the European species, C. Myrmidone. This is particularly noticeable during life, and is very brilliant, but gradually fades in dried specimens. The whole under side changes from grecnishyellow to deep yellow." "This is the typical Eumytheme. Mr. Boll adds: "The eflect of temperature is in perfect hurmony with the steaty increase in size and intensity of color." 'This is the result of field observation, and though breeding from the egrg might show that the members of the serics were not quite so sharply defined in all cases, it is clear that there is a regular succession of forms, and that there is 110 such intermixture as appears to the northward. The butterllies of the fourth, or late summer brood, and which are typical Eurytheme, do not hybernate. 'The length of the warm season admits of the laying of eggs by this brood, after which the butterflies die, as do all butterties shortly after 


\section{COLIAS IV.}

laying eggs. To make sure that I was stating the fact in this particular, I questioned Mr. Boll particularly as to the hybernation of both Eurytheme and Keewaydin, and he writes in reply, "I never saw specimens of the bright orange, or late summer type of this species later than the first days of November, and these were always much worn. I never saw Kecwaydin flying between November and IIay." In another letter Mr. Boll states that any worn individuals seen at the close of winter are Ariadne, and in March these are taken in copulation with Ariadne fresh from chrysalis. I received from Mr. Boll in April, 1878, 283 9, taken in Archer County, between the 24th and 2Sth February, all fresh from chrysalis. One of the females is an albino, one pair are typical Ariadne, and the other male and female are similar to the examples had from the lllinois larva mentioned, Var. A.

From Colorado, a very small percentage of the butterflies taken by Mr. Mead Ahow a mingling of the characters of Keewaydin and Ariadne, but nearest the former. (Var. B. Fig. 6.) The orange is limited on primaries to a patch on inner margin, and the under side of secondaries is much dusted. Mr. Mead, commenting on Mr. Boll's paper", writes, "I doubt if the form Ariadne occurs at all in northern Colorado, where the winters are severe. I met with Keewaydin and Eurytheme, in Colorado, in abont equal numbers, from first of June to last of August, when cold weather set in. The nights were cold most of the time, certainly often at the freezing point, during June and August, and by 10th September, the whole South Park was covered with snow. Keewaydin was as abundant at the last of the season as at the first. Ariadne I have only found in Yo Semite Valley, California, where it was rather abundant about the middle of October, in company with Keewaydin and a few Eurytheme. The temperature was then moderately cold, and it was at the close of the dry summer season." Examples of the form Eurytheme from northern Colorado have not the intensity of color and the iridescence of those from 'lexas, but among the butterflies col. lected in southem Colorado, in 1877, by Mr. Morrison, are some Eurytheme quite equaling anything seen from Texas in these respects.

Mr. Henry Edwards says of these forms, in the paper referred to: "Eurytheme is abundant in clover and alfalfa fields from July to September, the richest and most deeply colored individuals occurring latest in the season. It is rare in the mountains, while Keewaydin is abundant at even very considerable elevations. Keewaydin is the commonest buttertly of California, appearing in April or early May and continuing through the summer. I have taken it from San Diego in sontheru California to Vanconver's Island. Ariadne is a local and early species, of which there is a șecond brood. In the first warm days of February many specimens of Ariadne, entirely fresh, have been taken by me on the hills near 


\section{COILIAS IV.}

San Francisco, and in October some fine examples were hrought fiom Yo Semite by Mr. Mead. I have previously alluded to the tendency to hybrictization displayed by the species of this genus, and may here relate my experience therein. In July, 1874, while staying at the Big 'Tree Grove, Calaveras County, I took a \& and of Colias in coitu. 'The female was a small, pale-colored, narow-bortered Ariuthe, and the male a rich, deep orange, broad-bortered Hurytheme. Some few clays after, the exact opposite occurred to me. This time the female was a rich orange Eurytheme, and the male a small, pale yellow, faintly marked Ariadne. It can hardly be that the large, deep orange Eurylheme, and the pale yellow and fragile-looking Aviadne can be one and the same thing, linked together by Keewaydin and a series of intergrading forms; but it would be difficult to arrive at any other conclusion, unless, as I have stated, the abovementioned instances are regarded as eases of hybridism." Mr. Lidwards gives time and locality for Ariculne as follows: in Marin and other counties, February and Narch; Big 'lrees, July; Virginia City, Nevada, July; To Semite, July and October.

In reply to inquiries Mr. Elwards writes me thus, March, 1878: Early in the year, in the warm days of Mareh and April, I take many hybernated examples of Eurytheme and Ireevaydin, the former being most abundant. 'I'his refers to the immediate neighborhood of San Francisco, that is, to the lowlands. May is the first spring month of the mountains, at six or seven thousand feet elevation, and I have there taken hybernated Keewaydin, but have never seen Lurytheme in the mountains in the same condition. I find fresh examples of licerodydin, about San Francisco, in March, but none of Eurytheme, nor have I ever taken fresh eximples of the latter form before July, and in no quantities till August or September. I saw plenty of Kecuaydin on Vancouver's Island, but no Eurytheme, and even in Oregon the latter is very rare. Its home appear's to be within a couple of hundred miles north and south of this city. But Keevorydin is everywhere from San Diego to Vancouver's, where, as well as in Oregon, it is the commonest of species.

"Ariudne is rather abundant about Sancelito (near San Francisco), on some hills from seven to eight hundred feet above the sen, as early as February. As fur as I know, from my own experience, it is never found in the lowlands in fresh condition except in early spring. As we go further north, that is, to Oregon and Vancouver's Island, it is found in June and July, and in the Yo Semite Valley - four thousand feet - it flies as late as October. I have, therefore, always believed that this form was two-brooded, the June race in Oregon being equal to the February and March race here, and the June race of San Diegro being equal to the October one of Yo Semite." I may add here that my manuscript was 


\section{COLIAS IV.}

submitted to Mr. Edwards and he now concedes the polymorphism of this species.

The summing up of these histories in the several districts is as follows:-

I. In northern Colorado, where the summer is short, the species is but digonentic, the butterflies of the first brood appearing in June, and the second in July and August. Probably the species is here preserved by the survival of some of the last butterflies, which hybernate and deposit their egress in spring. It is doubtful if the climatic conditions will permit the growth of larva late in the season and their consequent hybernation. The species is restricted to Keewaydin and intergrades up to the paler variety of Eurytheme, but a few individuals are taken which show a tendency to vary in the direction of Ariadne. (Var. B. Fig. 6.) If there be any hybernating larve they would probably produce these individuals spoken of.

II. In Illinois and Nebraska the species is trigonentic, and many of the earliest brood are nearer Ariadne than Kreewaydin, but the typical Ariadne does not appear. Some individuals of the last brood of butterflies survive the winter, and thus appear in early spring in company with the buttertlies that have come from hyberuating larva, and consequently must breed with these. And intergrades between the forms are the result, and such are to be found throughout the year. So that in Illinois and Nebraska, as in Colorado and probably throughout the northern range of the species, it is rather a variable than a polymorphic species, and either form or any variety of either may appear from any one lnying of eggs.

III. In California, in the lowlands, the species is polygoneutic, either three or four brooded, the carliest brood, which tlies in February and March, being Ariadne. Keevaydin forms the second lrood, which Hies in April, and this form is on the wing during the remainder of the senson. Eumptheme appears in July, and is abmolant in August and September. And Ariadne appears in localities at different periods throughout the summer, and apparently in such localities must form part of every brood. Keewculdin is the usual form throughont the season in the mountains and also in Oregon and on Vancouver's Island, Eurytheme being rare. And Ariadne is taken occasionally also in those districts. By which it appears that in the lowlands of California there is a strong disposition towards polymorphism as distinguished from mere variableness, all the forms being present, and, moreover, that each in great degree is linited in its season. The surface of California is extremely varied, lofty mountains alternating with narrow valleys, with corresponding diflerenees of climate. Near San Francisco frost and snow are unknown, and there is every degree of climatic difference between this and a sub-boreal climate in one part or other of that 


\section{COIIAS IV.}

State. In the highlands this Colias is restrieted in the number of its annual broods, and the form Eimytheme is either unknown, or very rare, according to the locality, the species being mainly represented by Fecoroydin. And at certain levels throughout the State the upland races come in contact with the lowland, - the digonentic, practically linited to a single form, meeting the polygoneutic and polymorphic race; and by the consequent cross-breeding the thorough separition of the lowhanders into seasonally distinct forms is interrupted and can never become so definite as on the vast plains which occupy Texas, and the regions to the immediate north and south of it. (See Note.)

IV. In Texas and the regions adjoining there are no inequalities of surface sufficient to aflect the greneral result, and this species has for ages been subject to the most farorable climatic and geographic conditions for the development of polymorphism. 'There are four amual broods, the earliest, flying from November' to February, consisting of Ariudne, the next of leewerydin, the third of an intergrade, and the last of Eurytheme, the separation being marked. If either form appears in any degree out of its season, it is not in sufficient numbers to invalidate the rule. The species here is truly polymorphic and seasonally so.

Keewaydin, throughont the range of the species, is the most constant of the three forms, and I should consider it the winter form and therefore the primitive. But where the species is polygonentic, a second winter form, Arindne, has ariven, and in some districts where it is cli-or tri-conentic, an intermediate variety, strongly tending towards this second winter form, sometimes manifests itself. 'The case is much as in Papilio Ajax, which has one summer form Mlarcellus, hut two winter forms, T'elcmonides and Walshii, the first the prinary, the other secondary. Application of cold to chrysalids of any of the forms of sljax causes Telamonides to appear, and similar experiments made with chrywalids of this Colias will be apt to show which is the original winter form.

The resemblance between Eurytheme and Phitodice I have spoken of, and probably every variety and sub-tariety of ench form of the first of these species ean be paralleled in the other, color alone excepted. 'The rariety of Phitodice shown on Plate III., of Colias, Figs. 2, 3, corresponds with Ariadne; Figs. 1, 2, Plate II., correspond with the typical Eurytheme. Even the appearance of the dog's hear, characteristic of Colias Cosonia, and not unfrequently to be seen in the female of Eurytheme, occasionally appears in Phitodice. Albinic females appear in every brood as in Phitodice. In that species these females are as common in the early spring brood as in any of the later ones, although the contrary has been stated by authors; and judging from the number of albinos received by me from many quarter's, the same is true of Eurytheme.

The larve of Eurytheme and Phitodice are scarcely, if at all, distinguishable 


\section{COLIAS IV.}

in the earlier stages, and in the later are often just as much alike. But many larva of the former have developed a second lateral band, making the species at this stage polymorphic. The close resemblance extends also to eggs and chrysalids. In the notes to Philodice, I have recorded instances of hybridism between the two. The larval food plants are also the same. The larva of Eurytheme which I have received, and which were stated to have been fed on plants not found here at Coalburgh, fed as readily on red clover as do the larva of Philodice,

Philodice is nowhere a polymorphic species, but everywhere a variable one. Its varieties are not separable, but are so thoroughly intermingled that any female of any brood of the year may not unlikely discover in its progeny the extremes and all shades of variation.

And in the Rocky Mountains, and in the Mississippi Valley, where Eurytheme is but two and three brooded, the two principal forms of the species are intermingled as in Phitodice. In these districts it is a variable species. But in Texas, where the length of the warm season permits the species to become many brooded, it is seasonally polymorphic. The explanation of this difference I conceive to be this: at the north, more or less of the fall butterflies hybernate, as also do larva from eggs laid by some of the females of the fall brood, the latter producing butterflies in the spring and while the hybernators are still flying. The series begins, therefore, in the spring with all the forms or varieties of the butterfly which are found in the district, and cross-breeding occurs then and all the season through. But in Texas, the butterflies of September lay egrss, and the larva from these feed, and more or less of them mature aud reach the chrysalis stage, or even the imago, before cold weather comes; while others, though torpir during cold weather, are active upon the advent of every fine day, and so feed and mature at intervals throughout the winter months. The butterflies which have emerged in the early part of the winter are typical Ariadne, and a large proportion live in a state of semi-hybernation, according as the season permits, and are on the wing in February. 'Those which emerge late in the winter are mostly of the same type, with an occasional variety. (Var. A.) The series in the spring, therefore, begins with Ariadne alone and not with the three forms of the species, for two of them have been left far behind. They lived long enough in the autumn to perpetuate the species through the form Ariadne, and nature had no further use for them. Eggs laid in the spring by Ariadne produce Keewaydin, which in its turn is followed by Eurytheme, just as P. Telamonides is followed by Marcellus. It seems to me that if Marcellus hybermated in the imago and bred with Telamonicles or Walshii in the spring, the result would be a variable species, - at any rate, not one seasonally dimorphic. 


\section{COILAS IV.}

In the lowlands of Califomia, the species is apparently also four-brooted, and we are assured that hybernated examples of the two summer forms are seen flying in early spring. 'These may be supposed to be belated individuals of the last brood of the summer, for those of the same brood which earliest emerge must have laid their eggs, and the larva must have gone on to maturity, just as in Iexas, producing Ariadne. And the number of these hybernating butterlies must be too few to neutralize the influence of Ariadne in the succeeding brood, which Mr. Edwards tells us is made up of heewaydin. 'That this last mamed form appears in all subsequent broods, and Ariadne to some degree, may be attributed to the configuration of the country, compelling the hill races to intermingle with those of the valleys. In the lowlands there is eridently a strong tendency to seasonal polymorphism, but in the later broods of the year this is somewhere neutralized or interfered with.

Treewaytin is the form which has fiequently been assumed to be identical with Chrysotheme, and of which Dr. Boistuval, in the "Icones," says: "It is found in May in districts of temperate America. Individuals from this part of the world are as large as Eitusa." In the Lepid. de l'Am. Sept., Dr. Boiscluval says of Chrysotheme that it is found in the neighborhood of New York. Prof. P. C. Zeller, Ent. 'Zeit., 1874, p. 430, in a review of my Vol. I., says: "Certainly some of the species designated may be reduced to rell-known European ones. Thus I can assert heexcugdin to be nothing but our Chrysotheme, of which I myself have taken a male at Viema, with so little orange on the imer half of the wing borders that a North American could searcely distinguish it among a number of Ireecuydin. If Iicewaydin and Chrysolheme are really the same species, we may well say that species rary much more in North America than in Furope. Éurytheme of is sometimes no larger than our Myrmidone, to which it is besides very similar, though they camnot belong to the same species, as the latter possesses a glandular spot, which Eurytheme does not." I conclude from this that Profes:or'Zeller accepted Eurytheme as a good species, but believed Keewaydin to be the same as Chrysotheme, and was surprised at the degree of variation manifested by it. I express no opinion on the present identity of the two species through the form Keeucoydin, but if the latter was the primitive form on this continent, it may have peopled the old world before it became polymorphic in this, and the present representatives on both continents have come from one stock. As to whether they are distinct species now, much light would be gained if the life history of the European Chryscthene was followed out by lepidopterists in its territory. I have exerted myself in vain to obtain eggs, or larva, or drawings of its several larval stages, and I am not aware that either drawing, or proper description of these stages exists. 


\section{COLIAS IV.}

I have received a letter from Dr. James S. Bailey of Albany, N. Y., stating that in the autumm of 1876 he took what he supposed to be Keewaydin within five miles of Albany; and in Vol. VII., Canadian Entomologist, 1875, Mr. C. W. Pearson of Montreal, Canada, mentions taking an Eurytheme fresh from clirysalis.

The butterfly figured on Plate of Keewaydin, in Vol. I., as No. 7, supposed to be a variety of that species, is regarded by Mr. Henry Edwards as distinct, and has recently been described by him as C. Hrivfordii.

Note. - After the foregoing pages were in type, I received letters from Mr. Meal, in California, passages from which well illustrate the extreme differences in elimate in that State, and the effect upon insect life. "Yo SEMITE, June 10,1578. Up the watercourse behind the hotel, I found quite a smow-bank remaining, and near it the plants had hardly more than budded. One clump of a certain bush was in full blossom on the side towards the ravine, and was loaded with nearly ripe fruit on the other side. This state of things, of course, rauses a succession of fresly individuals among the butterflies, so that spring and summer broods cannot be well defined from each other where they exist." June 16. "The snow lies in large patches in the highlands still, and the willows are just putting forth their catkins. In ten days or two weeks there ought to be something to collect up there." At Glacier Point, in the same region, Mr. Mead notices tlat by a few flutterings of the wing, a butterfly may drop two thousand feet or more perpendicular, and arrive at a wholly different climate.

From Tallac Point, Lake 'Tahoe, on the eastern boundary line of California, Augrust 4 : "Tallac Peak, on the south sile of the lake, is exceedingly precipitous, and the snow lies in great banks in the ravines all sum. mer long. On the north side, however, the mountain slopes with a comparatively gentle inclination, and is overgrown with bunch grass, in many places even to within one or two luundred yards of the summit. Part way up the mountain I took Pyrameis Carye, a butterfy found abundantly throughont the lowlands and eveu in the tropics. This recion is said not to have very intensely cold winters, but the snow falls in enormous quantities - twenty feet deep on a level - so that the ranches, except some on the lake shore, are entirely deserted in winter, the farmers moving with their cattle to the lowlands, where pasturage is good." 


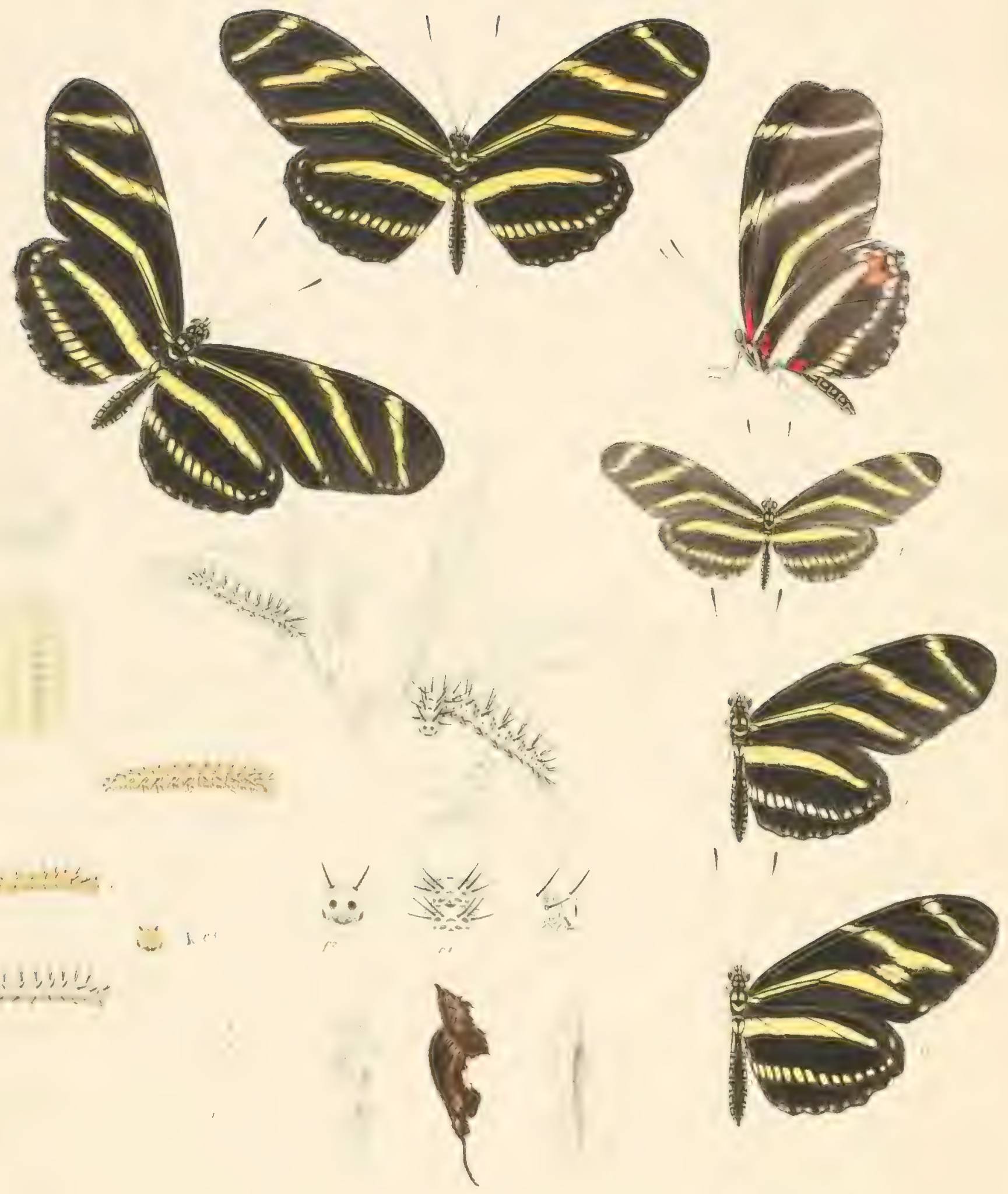




\title{
HELICONIA I.
}

\author{
IIEITCONTA CHARITONIA.
}

Heliconia Charitonic, Linn., Syst. Nat., II., p. 757. Cramer, II., pl. 191. Fab., Ent. Syrst., III., 1. 170. Bois. and Lec. p. 140, pl. 41.

MILE. - Expands from 2.5 to 4 inches.

Upper side black, banded with lemon-yellow; primixies have an oblique, transverse, narow apical band; a second from costa crosses the disk and ends on upper branch of median nervure, a little short of hind margin; a third, starting - from base, follows median, lying on both sides of it, makes an elbow at lower branch of same, and runs with this, along the anterior sirle, nearly to margin.

Secondaries have a broad band from inner margin near base across cell nearly to outer angle, and beyoud this a transverse row of yellow spots curving with the margin at outer angle, the anterior ones small, the others oblong or rectangrular, individuals differing; along the posterior half of hind margin yellow points, in pairs, on the interspaces; at base two bright red spots or points, the lower one sometimes wanting; fringes black, yellow in the interspaces of secondaries, and at inner angle of primaries; and somewhat, but irregularly, toward apex. The yellow bands are sometimes partly suffused or dusted with red.

Under side brown; costa of primaries next base bright red; the bands repeated, the mesial and lower one extended to hind margin, or very nearly, and next this margin suffused with salmon color; individuals vary in the color of the bands; some have the lower one as bright as on upper side, the others paler; some have all three of same shade, pale yellow; and not infrequently the two upper ones are washed at each extremity with dihuted salmon-red.

Secondaries have the band repeated, pale yellow; at the outer end of same two large salmon-colored patches, almost confluent; the row of spots repeated, but the outer half are whitish, the rest deep yellow; the marginal dots are enlarged to spots, and the pairs run from outer to inner angle and up immer margin; on this margin between the band and spots are two red spots, and two others at bases. 


\section{IIEISIONIA I.}

Body above black; benenth, the thorax black with an oblique yellow side stripe; a vellow matula stripe on side of abdomen and two yellow lines below; the ederes of the segments more or less rellow; under side pale satmon color; a red spot on either side of abdomen next the wings; four yellow spots across thorax and a har behind them; two rows of four small yellow spots back of the head; legs hack with dull vellow scales, the aborted pair bright yellow; palpi yellow with many long black hairs in front, the mpper sicle at tip black; antemae and club hlack.

Fracte. - Fxpands 4 to 5 inches ; similar in color and markings to the male.

The speries is subject to considerable variation: one eximple submitted to me has a patch of rellow on primaries between the two lower bands. (Fig. 6.) Another has the spots of hind wing pure white on both sides (Fig. 5): and there is much difterence in size, some being dwarfed. (Fig. t.)

Ear. - Cylindrical. one half higher than hroad, flat at base, tapering very slightly from base to about three fourths the length, athen conoidal, the top flattened and a little depressed; marked by fomrteen rertical ridges, straight, marrow, not very prominent, extending from bise to the micidle of the cone; below the cone are horizontal low ridges which, with the rertical ones, inclose long, rectangular spaces; there are nine ticrs of these, ench space being roundly excavated; next above the base of the cone is a tier of similar spaces, but higher, more nearly square, and more deeply excarated; next are seven cells, irregularly pentangonal. The flattened top is composed of three concentric rows of spaces, pentagonal, except the imermost, which are rhomboidal; color yellow. (Fig. $a, e^{2}$.) Duration of this stage three dats.

louxg Lanis. - Length os inch; exlindrical, segments 2 to 7 of about even thickness, then tapering, the dorsum sloping; marked by four principal rows of roumded and flattened tubereles, of which two are dorsil. and one is on either side: the former extend from 3 to 13 , the litter from 3 to 11 , each tubercle standing on the middle of the segment; there are also two rows of similar but minute tubercles, one lying between the dorsal and lateral, cach tuberele placed at the junction of the segments from 2-3 to 12-13, with another at the end of 13 ; and one over feet, two tubereles to each sexment in longitudinal line from 2 to 10 . and one from 11 to $13:$ : on 2 is a chitinous dorsal band with tubercles; a rounded tubercle on sile in line with the lateral body row, but small; and near the front of the sesment two others, one upper, one lower; each tubercle. wherever placed, sends forth a black tapering hair, those from the main rows long, and on dorsum, on the three anterior segments, bent forward, on the next three or four ereet, the rest recurved; of the side rows, hoth large and 


\section{IIEIICONIA I.}

small, the hairs to 6 inclusive are bent forwarl, the rest back, and all are depressed; color pale reddish-brown, like fresh cut cork; legs and feet same; head obovoid, a little paler in color than the body; a few scattered black hairs over surfice; ocelli blick. (Fig. b.) To first moult two to three days.

After first moult: length .22 inch; cylindrical, nearly even, the segments a little rouncled; color light brown, changing, as the stage proceeds, to greenishwhite, mottled with brown; armed with six rows of spines, one sub-dorsal, one midclle, and one infra-stigmatal (arranged as described under mature larva); these spines are short, slender, and tapering, black, with a few short black bristles on the sides; on second segment a chitinous dorsal pateh with hairs; feet and less brown; hear obovoid, truncated, a little depressed at the suture, the vertices low, rounded, and on each it short, talpering, blunt, black process, thinly beset with hristles. (Fig. $c$, $c^{2}$, head spine $c^{3}$.) 'To next moult two dirys.

After second moult: length .5 inch; color dull white, mottled or spotted with yellow-brown; moler side brown; the spines long, sharp; head as before the spines longer, direeted forward, at little recurved. (Fig. d.) To next moult two days.

After third moult: length .7 inch; slender, whiter than before, but greentinted; dorwal spines .1 inch long, upper laterals .0!) inch, lower .07 inch; hear grecnish-yellow, the processes like the body spines, os inch long. (Fig. e.) 'lo next moult three days.

Alter fourth moult: length 1 inch, and in three days reached maturity.

Blatere LARY. - Length 1.2.5 to 1.5 inch; eylindrical, slenter, nearly of even size from '2 to 12, the segments a little rounded; color dead white, with no glos, smooth, with no hails; spotted with black or black-brown, the spots disposed in cross rows, two of which are back of the spines and one on the extreme anterior end of the segment; mostly rounded or oval. but those on medio-dorsal line are half-oval except the spots on the posterior elges of the segments, which are triangular; these spots form one dorsal row and two on either sille; orer the basal ridge, on 4 to 11 , is a brown patch covering the adjacent edges of the segments; another patch cover's each spiracle; under side reddish-brown with a green tint; segment 2 has a dorsal chitimous bar divided in middle, and on either part are two black tubercles with hairs; the body furnished with six rows of spines, two sub-rlorial, one on middle of each side, and one infra-stigmatal; the dorsals rum from 3 to 13 ; the upper laterals from 5 to 13 , the lower from 5 to 12; and between 2 and 3,3 and 4 , in line with upper laterak, is a spine; the spines of the four mper rows are straight and erect, but those of the lower row are turned down and a little recurved; all are alike, shining black, small at base, tapering to a sharp point, and about each are from 5 to 7 short black bristles 


\section{HELICONIA I.}

irregularly placert; the dorsals measure .2 inch, the 1st laterals. 17 , the lower.14 inch, and there is little variation in the length of the spines of each row; legs brown, tipped black, pro-legs brown, with a black spot on the side of each; head obovoid, rounded in front, truncated, a little depressed at the suture, the vertices but little elevated, rounded; color greenish-white, vitreous; on either side the suture on mid-front a round black spot; the ocelli black on a small black patch; mandibles black; on each vertex a black spine nearly like those of the borly, but less tapering and more blunt, .12 inch long, directed forward at about $45^{\circ}$, and a little recurved. (Fig. $f, f^{2,3,4}$.)

As the larva approaches suspension the spots change to brown, and the white becomes dull and sordid. 'T'welve hours after' suspension, pupation takes place.

Chixsalis. - Length to top of head .95 inch, to end of processes on head 1.1 inch; slender, compressed laterally, the thoracic segments on ventral side highly arched and rounded abruptly down to abdomen; the sides of this elevation covered entirely by the wing cases, sloping, almost flat or a little convex, the two wing cases not quite meeting, but separated by a narrow depressed ridge, on either side of which is a row of small bead-like tubercles, each giving out at top a short sharp bristle or thorn; this ridge widens anteriorly so as to include the :ntenne cases, and the rows of beads pass along and around head case to its top on the dorsal side, but for a little distance at the base of the antenna lose their bristles; head case prominent, compressed transversely, nearly square at top; upon each vertex a narrow leaf-like process, lanceolate, flattened and thin, serrated on both edges, divergent, like horns; mesonotum prominent, compressed at top into a thin carina which rises on the anterior part in a double curve to a sharp point, but on the posterior side slopes at about $45^{\circ}$; followed by a rounded excavation considerably longer than the mesonotum itself; abdomen cylindrical; on the two upper segments a large sub-torsal, flaring, flattened process rounded irregularly on the edge and completely spanning both segments; on the next segment is a small sharp rounded process, and on the next another small and flattened; on the next a sharp tubercle, in some cases flattened; on the tops of all these processes are thorns, one on each of the smaller, and two on the largest; in row with these, on the depression and on the sides of mesonotum, are four low conical tubercles, each with a short thorn; segments $9,10,11$, in the ventral line, have the anterior edges turned up and produced into low divergent points; at the base of the head case on dorsal side a large burnished gold spot, and the tubercles behind the mesonotum gilded; general hue brown, in shades; the anterior parts, which includes head case, mesonotum, and half the wing cases, heing light or yellowish; the rest of wing cases dark, or streaked dark in the interspaces of the wings; the light part of these cases somewhat gray or whitish; the processes on head and 


\section{HELICONIA I.}

the antenne cases are dark; abdomen varied in longitudinal streaks, confined to each segment, dark and light brown, with some oblique whitish marks on the ventral side. (Figs. $y, y^{2,3,4}$.) Duration of this stage 6 to 7 days.

Charitonice is common in parts of Florida, as at Indian River, and is found along the Atlantic coast at least as fur northward as Port Royal, S. C. Many years ago, I received examples from Mr. James Postell, St. Simon's Island, Gar., and was informed that they were confmed to one particular locality, a dense thicket. It is, however, a sub-tropical species, and it abounds in the Antilles and Central America. I camnot len'n that any record exists of its preparatory stages prior to that given by me in the Canadian Entomologist, vol. xiii., p. 158, 1881. In 1875, 202 December, I received from D1: A. W. Chatpman, at Apalachicola, a chrysalis of Charitonia, of which he wrote: "In a flower-pot, with a Germimm, sprung up a Passiflora suberosa, a tropical plant, the seeds of which I brought from South Florida, in 1575, and have since eultivated in my gitrden. About the middle of November, I discovered two caterpillars on the plant, one about one and a half inch long, the other smaller, - white, beset on the segnents and head with slender black spines. Placing them in a glass jar, the larger one suspented in two days, the other a week later. (On December 14th, the last gave butterfly, II. Charitonia. The other, which I send you, I fear is dead. I suppose they feed on any species of Passiflora, of which we have two mative. Upon these the caterpillars of the few Charilonia seen here must have fed. 'The pupa is very singular, as you perceive, the projections from the hearl reminding one of the horns of some species of scmabus, ol the claws of a lobster. And then, the golden stripes over the abdominal segments, and the spreading plates behind them!"

I learned from Dr. Wm. Witteld that the butterfly was common at Indian River, and begged him to make observations on the caterpillars, and, if possible, obtain eggs. 'Thereupon, he set himself to examine carefully the leaves of Passiflora, but for some time discovered nothing. At last a female was seen ovipositing on the tender, terminal leaves, and thenceforth there was no difficulty in linding eggs. Females tied in bags over the ends of the stems laid abundantly, and several caterpillars were raised to chrysalis and butterfly. Attempts to get either enger oi caterpillars to me failed by reason of the leaves decaying in the mails. INowever, I received caterpillars 30th August, 1880. Eggs had been sent, which hatehed, and the caterpillars had passed their second moult when I received them. They throve on leaves of Passiflori coerulea, and the larval stages proceeded with rapidity, scarcely more than two days being required for each.

Dr. Witteld states that on touching the chrysalis he olserved that it gave out a creaking noise, wriggling about at the same time, and this is stated by Dr. Fritz 


\section{IIELICONIA I.}

Miiller, in a paper on Brazilian butterflies, to be characteristic of the genus Heliconia. Several butterflies came forth in my room, and one of them was set free in the garden, pliced gently on a flower of passion-vine. It rested some moments with wings fully opened and depressed a little below the horizontal, and then rose vertically some ten feet, circled two or three times, Hew slowly towards the woods, and was seen no more. I had a similar experience in $18 S 1$ with two others, both rising high and making for the nearest woods.

Dr. Witteld reports that these butterflies frequent paths in the forest, or are found feeding at a little distance from the forest, to which they at once betake themselves if alarmed, and then fly rapidly, though usually their flight is heavy. Also, that they have the lubit of gathering in flocks toward night, and roost, always with heads up, to the number of perhaps fifty or more, on Spanish moss, or on dry twiggs of trees, especially such as have dead leaves still hanging to them. In the morning, after the sum is well up, they come trooping forth in search of flowers.

'This habit was observed by Philip Henry Gosse, Esq., as is stated in a note in Doubleday's Genera, I., p. 97, and as this work is nearly inaccessible in this country, I repeat Mr. Gosse's remarks: "Passing along a rocky foot-path on a steep wooded mountain side, in the Parish of St. Elizabeth (Jamaica), about the end of August, $18 \pm 5$, my attention was attracted, just before sumset, by a swarm of these buttertlies in a sort of rocky recess, overhung by trees and creepers. They were about twenty in number, and were dancing to aud fro, exactly in the manner of gmats, or as Hepioli play at the side of a woor. After watching them awhile, I noticed that some of them were resting with closed wings at the extremities of one or two depending vines. One after mother fluttered from the group of dancers to the reposing squatron, and alighted close to the others, so that at length, when only about two or three of the fliers were left, the rest were collected in groups of half a dozen each, so close together that each group might have been grasped in the hand. When once one had alighted, it did not in general fly again, but a new-comer, fluttering at the group, seeking to find a place, sometimes disturbed one recently settled, when the wings were thrown open, and one or two flew up again. As there were no leaves on the hanging stalks, the appearance presented by these beautiful butterllies, so crowded together, their long, erect wings pointing in different directions, was not a little curious. I was told by persons residing near, that every evening they thus assembled, and that I had not seen a third part of the numbers often collected in that spot."

Mr. Wallace says of the Heliconide in general: "They all rest with their wings erect upon leaves and flowers, and at night I have observed them asleep, hanging at the extreme end of a slender twig, which bends beneath their weight and swings gently with the evening breeze." 


\section{HEIICONIA I.}

It is well known that species of an allied family, as Danais Archippus, wather in erreat flucks, but this seems to be only at certam seasons of the year, and then by day as well as night, and is apparently comnected with their migrations, which are believed to be periodical, at least in some districts. But Choritonia assembles for the night only. and for rest, dispersing during the day in seareh of food, after the fashion of our wild pigeons.

The family Ileliconicle embraces an immense number of species. Mr. II. W. Bates, in 1861 , stated that there were two hundred and eighty-four then known in tropical America. "l'hey ane most numerous in those parts of the country where the forests are most extensive and the climate most sultry and humid. They are peculiarly creatures of the forest, and like the Plattyrthine monkeys, the arboreal Gallinaces, and the other gromps of the same region, point to the grarlual adaptation of the fauni, during an inmense lapse of time, to a forestclad country."

It has been noticed by anthors who have treated of this family that the species, although exceedingly abmome in individuals, and of slow flight, and conspicuous colors, more ealsy to be canght by birds than almost any other insect, are not persecuted by birds, lizards, or other animals. Mlr. lielt, in "Naturalist in Nicaragua," relates that he hatd watched a pair of birds catching butterlies and AragonHies, which they brought to their nest to feed their young, and in no case did they catch one of the Heliconidae, which were in great numbers about, and could have been caught with less trouble than any others. Also, that a tame monkey, who was extrenely fond of insects, and would greedily munch up any beetle or butterfly given to him, never would eat a Ileliconia. There was no doubt, from his actions, that they were distasteful to him. And this immunity from attack is believed by Mr. Wallace to be owing to a "strong, pungent, semi-aromatic or medicinal odor which seems to pervarle all the juices of their system."

Dr. Witteld, in 1881, called my attention to a strange habit of these butterflies, as follows: "On May 28th, I observerl three Chrritonias on a chrysalis of same species in the woods. They were firmly attached, and on trying to drive them off they would not go. I tried repeatedly, and fimally used force, but after flying around a few times they took up their former position, heats down. 'The next day the same thing occurred, only I noticed that one butterfly at a time would leave to feed; force was again used, with the same result as before. The following day, shortly after dawn, only a trifle of empty shell remained.

"This observation prompted me to raise another chrysilis, which I suspended in a flowering shrub, which Charitonia frequented, June 27 th. Soon some butterflies came and touched the chrysalis, but its wrigghling seemed to canse them to move off. 'Two days before the imago was due, they attached themselves 


\section{HEIICONIA I.}

agrain, two or three at a time, and would only yield to force, always returning. On the third day, at daybreak, only a trifling bit of the empty shell was left, and the buttertlies were all grone."

I replied to this, asking how the buttertlies attached themselves. Did they actually rest on the chrysalis, holding on by the legs? Also, was I to understand by bits of empty shells remaining, that the imagos had come from the two chrysalids? I suggested, if this last was not what was meant, that perhaps the butterflies had discovered the chrysalids to be dead and decaying and came to them as to carrion.

On this Dr. Wittfeld again wrote: "In each case the buttertly emerged from the chrysalis. The chrysalis looked natural but was growing darker, and the day before the emerging, the coming live insect coukd, to some extent, be distiuguished. There was nothing deal or decayed or partly eaten about it. All the legs of the gruarding butterflies had firm hold of the chrysalis, and it required a little effort to remove them with the fingers. They sat firmly, not lightly upon it. To frighten them off did no grood, it required force to remove them. After having been picked oft they did not stay long away, but flying around a few times (I having removed to some distance), returned to the chrysalis and attached themselves to it just as they had done before."

I wrote Dr. Wittfeld, urging him to try again, and especially to ascertain whether the free butterties and the imago in the chrysalis were always of opposite sexes or not, and whether females were attricted to a chrysalis in any case. I received his further report, as follows: "With regard to the chrysalis found May 28th, of which I wrote you, I add, that there was found by me on the ground, on the morning the butterfly emerged, a female with wings but partly expanted, yet paired with a perfect male. Also, when I discovered that the butterfly had come from the second chrysalis, that of June 27 th, I found a similarly undeveloped female on the ground near by, paired with a free male. I lifted both and placed them on a twig. The male flew off in course of two hours, but the female remained, though a cripple and unable to move.

"After receiving your letter, for a long time I could obtain neither eggs nor" caterpillars of Chreritonia, but at last, near the end of September, I hung out a chrysalis. A heavy rain storm setting in, no butterflies were flying that evening, and next day, six A. I., I found the empty shell of the chrysalis and imago grone. On Octoher 1st, I suspended another chrysalis. Soon a number of butterflies appeared, flying around and touching it. Nono however attached themselves to it as in previous observations. I caught one after another of these butterflies, as they came, and put them in a bag. About eleven o'clock, the imago came from the chrysalis, and as it clung to the empty shell, an occasional free butterfly 


\section{HELICONIA I.}

would alight by it or fly about it. On examination this imago proved to be a male, and so dirl the captured butterflies.

"At the same time another chrysalis was suspended, and began to change color, October 4th, early in the aftemoon. Soon male butterflies appeared, took hold of the chrysalis, as before, but were easily frightened away. By six o'clock, same afternoon, the color had changed, and males came freely, attached themselves firmly, and would not let go, in fact, were utterly regarlless of their safety. When picked off they would fly around and return at once. T'wo males remainer all night. Before daybreak next morning, I was at my post, and there found the two males, opposite one another, head down, abdomen curved towards the abdominal end of the chrysalis, both apparently exercising a pressure. Lighted matches held near them would not drive them away, shaking the twig did not loosen their hold, only picking them off bodily separated then from the chrysalis. The latter was now almost black, and momentarily I expected the shell to burst. This happened, but the break was not at the usual place. Owing probably to the pressure or weight of the butterflies, the shell burst at the abdominal end, and instantly one of the males made comnection with the female inago, while the hear and thorax of the latter were still enclosed. After abont ten minutes, I determined to free the new insect, which was accomplished by a slight pressure on the shell, and I then removed the pair and suspended them to a leafstem. The wings of the female immediately began to expand, but they did not fully develop. Without my aid, the imago would not have been able to extricate itself from the shell, although copulation har been effected.

"I suspended another chrysalis, well discolored, under same conditions, October 7 th, in the moming. Males flocked, circled about a few times, approached closely and then flew off again, none having alighted or actually tonched the chrysalis. This went on for an hour, when a male emerged. 'The butterflies were mostly eaught and all proved to be males.

"October 17 th, another chrysalis was suspended under same conditions as the last mentioned. Males appeared, etc. Behavior just as before; none touching. The imago proved to be a male."

On November 1st, Dr. Wittfeld again wrote: "To-day I made another corroborative observation on Heliconia chrysalis. At eight A. M., two males attached themselves to a female chrysalis, and acted as before reported. Four more males had appeared by nine o'clock, took hold as best they could, and the six made quite a bunch. Soon after others came, but had to be content with flying in close proximity, as there was no more holding room. At ten o'clock. I freed the female from the crowd, and found the abdomen exposed, but head and thorax still in the shell. I carried her to the house, allowed her to suspend from a 


\section{HEIJICONIA I.}

branch, and being now out of the shell, the wings soon grew, and in another hour or so the insect flew off.

"November 11th, discovered two chrysalids of Charitonia on the same plant, about two inches apart, but as much as two feet from the nearest passion-vine. No. 1 was not discolored, No. 2 a little. 'To each chrysalis two males were attached. They would let go when tonched, those on No. 2 hesitating; however, all would return at once. On both chrysalids I noticed that the bodies of the males were bent up, that is, off from the chrysalis, and the pressure exercised in former observations was not yet applier by the males. Apparently they simply kept hold so as to be on hand when things developed.

"November 12 th; No. 1 was forsaken; to No. 2 four or five males clumg, heads down, bodies still bent up; they leave only to feed.

"November 13th; No. 1 still forsaken, but in course of the day males flocked to it, their bodies still bent up ; were frightened away rearlily.

"November 14th; No. 1 had all the attention of the males, while No. 2 remained forsaken, the bodies now touching the chrysalis, but almost midway of the abdomen of the pupa, not at the extremity.

"Later"; two males had taken firm hold, as in previous observations, touching at the end of abdomen of pupa; would not let go, but had to be picked off.

"Later; I found a pair in copulation on the ground. Now I examined No." and found the imago nearly developed, but dead, and this explains why the chrysalis was forsaken.

"During this observation I noticed that the males would alight on the chrystlis as they do on flowers, then wheel around quickly, head down, body up.

"November 14th; my attention was attracted by a flock of six ol eight Charitomia butterflies on the edge of woods, flying around an object which, on inspection, I found to be a chrysalis."

Dr. Witteld's olservations settle this: that in H. Charitonia the males are able, by some means, to distinguish the presence of a female in chrysalis, at least from the time when discoloration of the shell commences; that the attraction becomes stronger as the imago nears its emergence, that the females show no such attraction toward a male in chrysalis, and that males do not attract males. It is not unusual to find female butterflies of certain species, as Papilio Ajax, so lately out of chrysalis that the wings are at least limp, coupled with perfectly developed males, but I have not myself observed a case where the connection took place the instant the female broke from its shell, or even before the wings were expanded. Certainly I have never known of male buttertlies watching the advent of a female one moment, much more, for hours and days, nor have I read of such an occurrence. 


\section{HELICONIA I.}

I wrote MIr. Bates, whose experience of eleven years on the Amazon might have brought this habit in one or more species of Heliconidre to his notice. But. he informs me that he had observed nothing of the kind; and other naturalist travelers of whom I have made inquiry reply to the same elfect. It is to be supposed howerer that the hahit is generic, and that it will hereafter be observed in many species.

Although the cause of this assembling of the male buttertlies about the female chrysalids is sexual, yet incidentally the latter must be protected thereby from attacks of enemies. No one who has not risited the tropics can conceive the peril to which such objects are exposed, in the immumerable throng of spiders, ants, predacious insects of a thousand species, birck, and amimals of other sorts. Dr. Witteld has many times reported agrgravating losses which have befallen him; but I know of my own experience, for I formerly spent a year on the Amazon, that the active enemies of any chrysalis are thousands to one under the equator as compared even with Florida. 'The butterlies themselves mat be protected by their obnoxious smell or taste, and the chrysalis might prove just as obnoxious after it was seized. But the mischief would be done when that happened, and the female imago wounded or destroved. The color of the chrysalis is not sufficiently marked for its protection, as is the case with the butterfly. It may, in a measure, defend itself by wriggling about, and by the squeaking noise spoken of, but when the shell is softening and the imago is most sensitive to injury from any lough attack, it could protect itself by neither of these expedients. It is just then that the males gather about it, and effectively, if unwittingly, guard it till the danger is past, and the new butterty comes forth. In most of the instances observed by Dr. Witteld, the females emerging were crippled hy the premature assaults of the males, and if this were always the case, protection of the chrysalis would be purchased at a dear rate to the species. But we may assume that this does not generally happen, as the Heliconidx so abound.

In Churitonia we have a species interesting from its affiliations, its beauty, habits, and peculiarities, and all the more as it is the only representative of its kind in our fauma. 



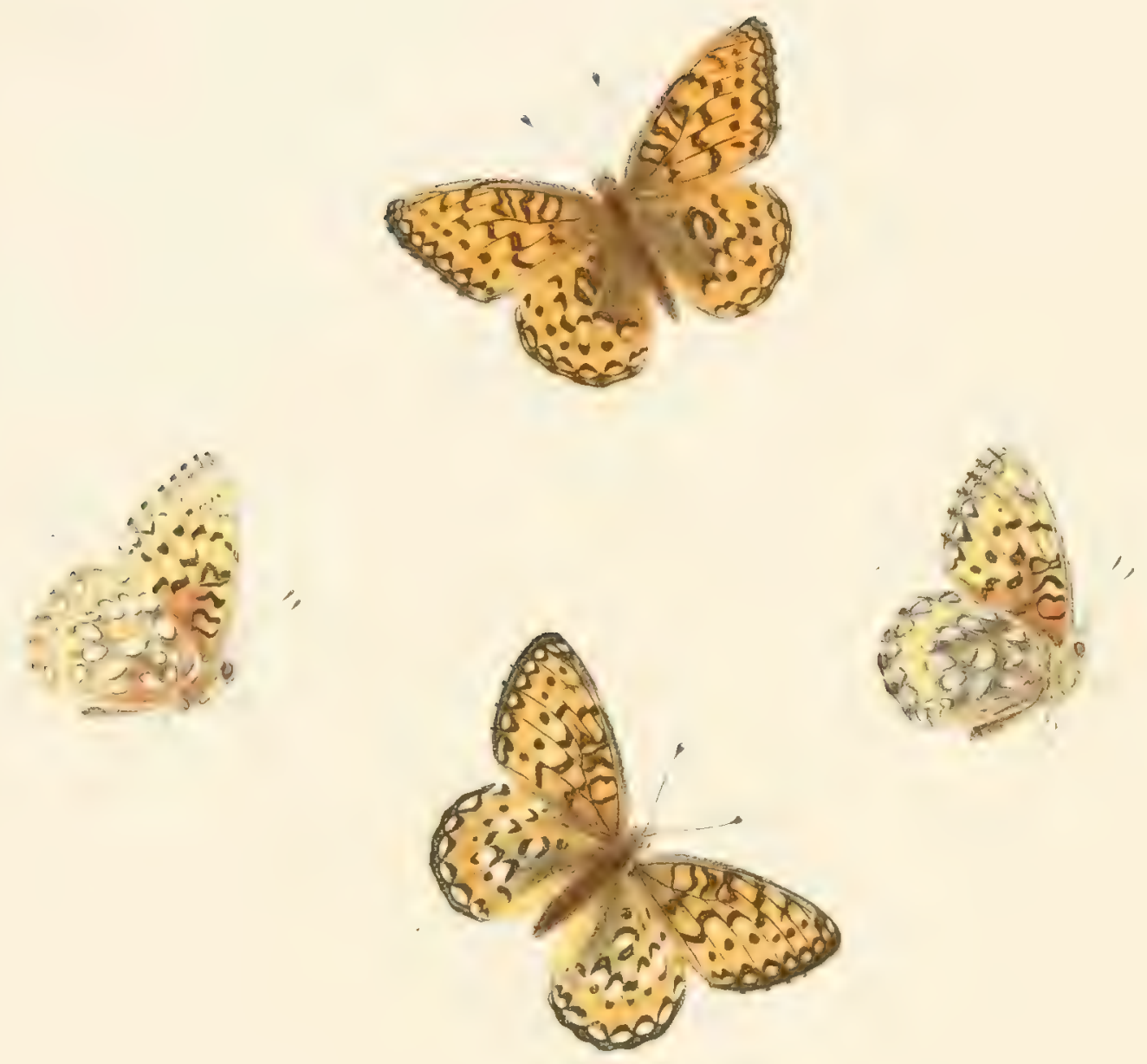


\section{A RGYNNIS I.}

ARGYNIS EURYNONE, 1-1.

Argynnis Eutrynome (Eu-ryn'-0-me), Eilwards, Trans. Am. Ent. Soc. Vol. IV., p. 66, 1872.

Pruturnes slightly arched, produced apically, the hind margins straight or convex.

Mate. - Expands 1.7 to 2 inclies.

Upper side bright yellow-fulvous, little obscured at base; the hind margins edged by two fine lines between which the fulvous space is very narrow; sometimes these lines broaden and are confluent; the sub-marginal spots lumular, confluent, and inclosing fulvous spaces of the ground color; the rounded spots small; across the disks a delicate zigrag band, rarely on secondaries broken into separate lumular spots; the cellular inscriptions on primaries include an angular inverted $P$, a wavy transverse central bar, and two similar bars which form the sides of a sub-quadrate spot; two small spots in the interspaces below the cell; the basal area of secondaries immaculate, the discal spot like the letter C; fringes luteous, largely black at the ends of the nervules on primaries, and slightly next inner angle of secondaries.

Under side of primaries pale buff, with a cimnamon-brown tint at base and along the nervules, especially the branches of median, the middle of each interspace showing a narrow strip of the ground color; the sub-marginal mostly silvered, and two or three silver spots anterior to these next costa.

Secondaries yellow-buff; the basal area and disk mottled with pale ferruginous, and often with more or less of olivaceous; the band between the two outer rows of spots broad, clear yellow-buff; the spots all well silvered; those of the submarginal row serrated, of the second mostly long oval; the first and fifth equal, the second, third, and sixth, narrower but equally long, the fourth minute, the seventh lunate, all slightly edged with black above, and all projecting olivaceous shadows on the band; in the third row are three spots, the first and third lunular, the second sub-quadrate; there is also a dash in this row, on inner margin; in the cell one or two rounded spots, below the cell a dong oval; all these lightly 


\section{ARGYNNIS I.}

edged with black; a dash at base of cell, and another at base of subcostal interspace; the shoulder and imner margin silvered.

Body above fulvous, benenth buff; legs buff; palpi buff, fulvous above and at tip ; antenna black, anmulated with grayish above, fulvous below; club black, tip ferruginous.

Femile. - Expands 2 inches.

Color paler, the spots in the sub-marginal lunules sordid white; the marginal bands broader and all the markings heavier; the second row of silvered spots indicated above by a shade lighter than the ground; the basal area of primaries beneath deep colored.

Occasionally an example of either sex is seen in which is no silvering, all the spots then being of nearly the same color as the ground.

EGG. - Conoidal, broad at base, truncated at summit; marked by numerous horizontal stria, and vertically by about twenty prominent ribs, some of which are intersected by shorter ribs which proceed from the base and connect at about two thirds the distance to the summit; color at first lemon-yellow, soon tuming to purple. Deposited upon Viola.

LARTA mknown.

From Colorado and the Rocky Mountains. Mr. T. L. Mear found this species common throughout the northern sections of the State, in 1871, "flying among the grasses and along the streams. It began to appear at Fairplay, 6th Jume, and was especially abumdant at 'Twin Lakes." I lave also received specimens from Dr. Hayden's Colorado expedition, and one or two from Montana. These last were erroneously mentioned by me in the Reports of the Geological Survey of Montana, 1871, as Montivaga, Behr, a species, so far as $1 \mathrm{know}$, confined to the Pacific const. I have seen Eurynome in no collection from Utah, nor from Arizona, or New Mexico. It would seem to be strictly a mountain species, most abundant in Colorado, and to be found more or less through the territories adjoining on the north. 


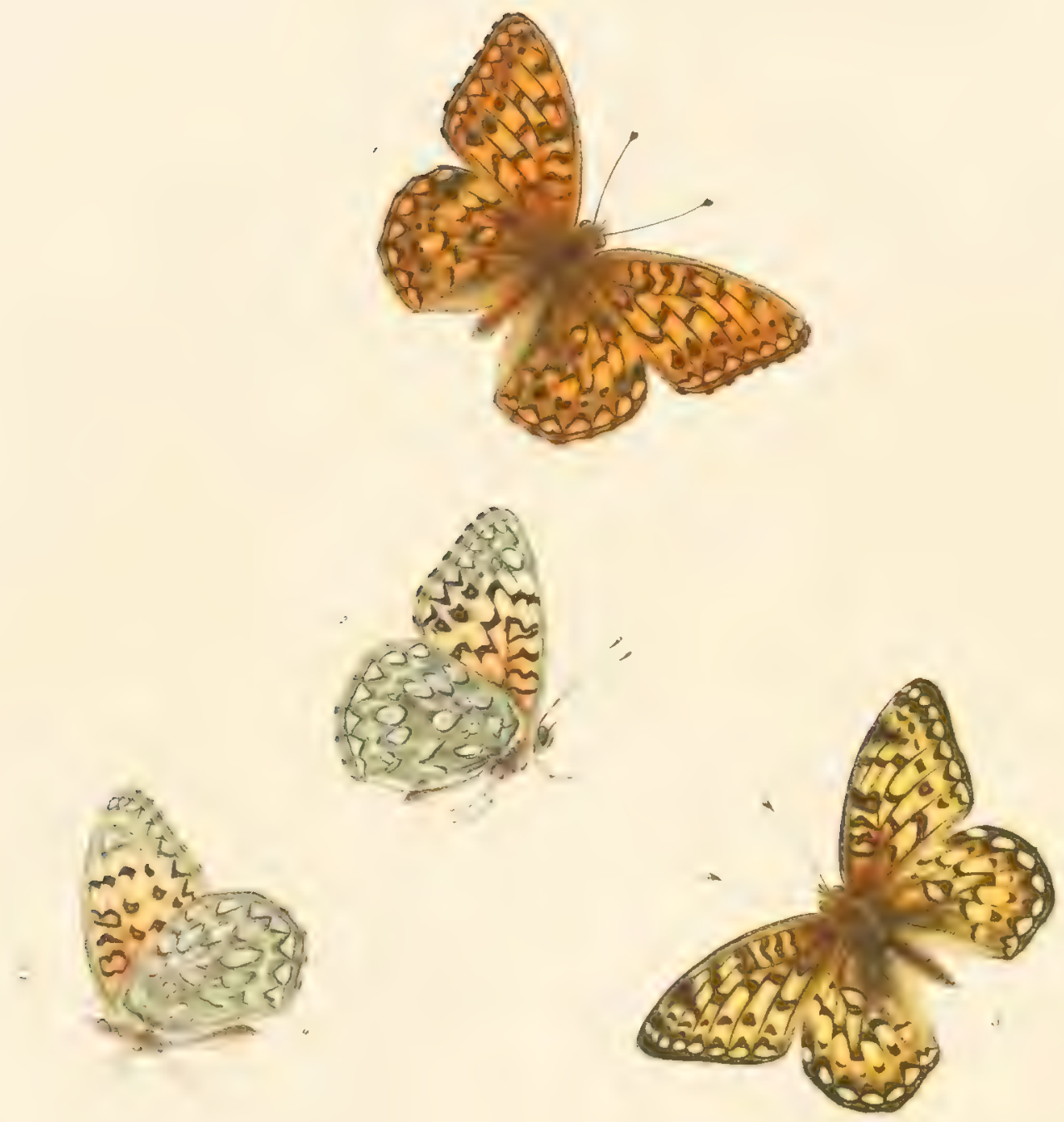


\title{
ARGYNNIS II.
}

\author{
ARGYNNIS MEADII, 1-4. \\ Argynnis Meadii, Edwards, Trans. Am. Ent. Soc, Vol. IV. p. 67, 1872.
}

Primaries slightly arched, but little produced, straight on hind margin.

MALE. - Expands 2.2 inches.

Upper side deep yellow-fulvous, but little obscured at base ; hind margins bordered by two fine parallel lines, inclosing throughout a narrow fulvous space; upon these rest a confluent series of black spots, those next. the apices lumate, the remainder serrate; the rounded extra-discal spots of medium size; the mesial band narrow, confluent on secondaries; in the cell of primaries, the usual inseriptions; at the origin of lower branch of median a black mark, and below, in next interspace, a sagittate spot; the discal spot on secondaries an inverted $\mathrm{C}$; the second row of silver spots indicated by a space slightly paler than the ground; fringes of primaries almost wholly fuscous, there being merely a little luteous in the middle of each interspace, of secondaries wholly luteous, except a few black hairs at the end of the posterior nervules.

Under side of primaries pale cinnamon-brown at base and along the nervures of the disk, the remainder light buft, except that the apical area and hind margin are yellow-green; the five upper sub-marginal spots well silvered, as also the three sub-apical spots. Secondaries wholly of a glossy golden-green, a buff subcolor showing along the middle of the band between the two outer rows of spots; all the spots well silvered; of the seven sub-marginal, the first is sub-ovate, the next two serrate, the three following broad and sharply serrate, and the last sublumate, all completely edged with black; those of second row are mostly long oval, the first, second, and sixth of equal breadth, the third narrower, the fifth broader than the first, the fourth a point, the seventh irregular, all heavily edger with black above and lightly elsewhere; of the third row, the first is nearly round, the second minute, the third trapezoidal, the other two dashes, all edged above with black; in the cell two rounded spots in black circles, a long oval in sub-median interspace, and a dash at base of sub-costal; shoulder and inner margin lightly silvered. 


\section{ARGYNNIS II.}

Body above fulvous; below, the thorax gray-buff, abdomen buff; legs fulvous; palpi white, furnished in front with long fulvous hairs which are black at tips; antenne fuscous above, fulvous below; club black, tip fulvous.

Feyale. - Same size.

Color pale; the sub-marginal spots in both wings lighter than the ground, as are also the spots on disk of secondaries corresponding to the second silver row; the marginal lines confluent and the connecting lunules heavy, especially on secondaries; in other respects like the male.

This species was discovered by Mr. T. L. Mead, who took a single male in perfect condition, at 'Turkey Creek Junction, Colorado, in June, 1873. Subsequently several specimens of both sexes were brought in by the Yellowstone expedition under Dr. Hayden, from Montana. In 1874, another male was sent me with a few buttertlies taken by Mr. W. R. Pywell, along the line of the Northern Pacific Railroad west of Bismarck.

Meadiihas been surmised to be a possible variety of Edwardsii, but it seems to me the differences between them are too considerable and persistent to admit such relationship. Meadii is of medium size, the primaries scarcely at all produced, the color deep. On the under side the basal area of primaries is pale cinnamon-brown, and the green on both wings is golden, with a gloss like satin, very difficult to represent sufficiently on the Plate. Edwardsii is one of our largest species, with long and tapering primaries, and its color is bright and clear beyond all others. The green of the under side is not of a lively shade, but is either brownish or olivaceous, and the basal area of primaries is fulvous to fieryred in the two sexes. 


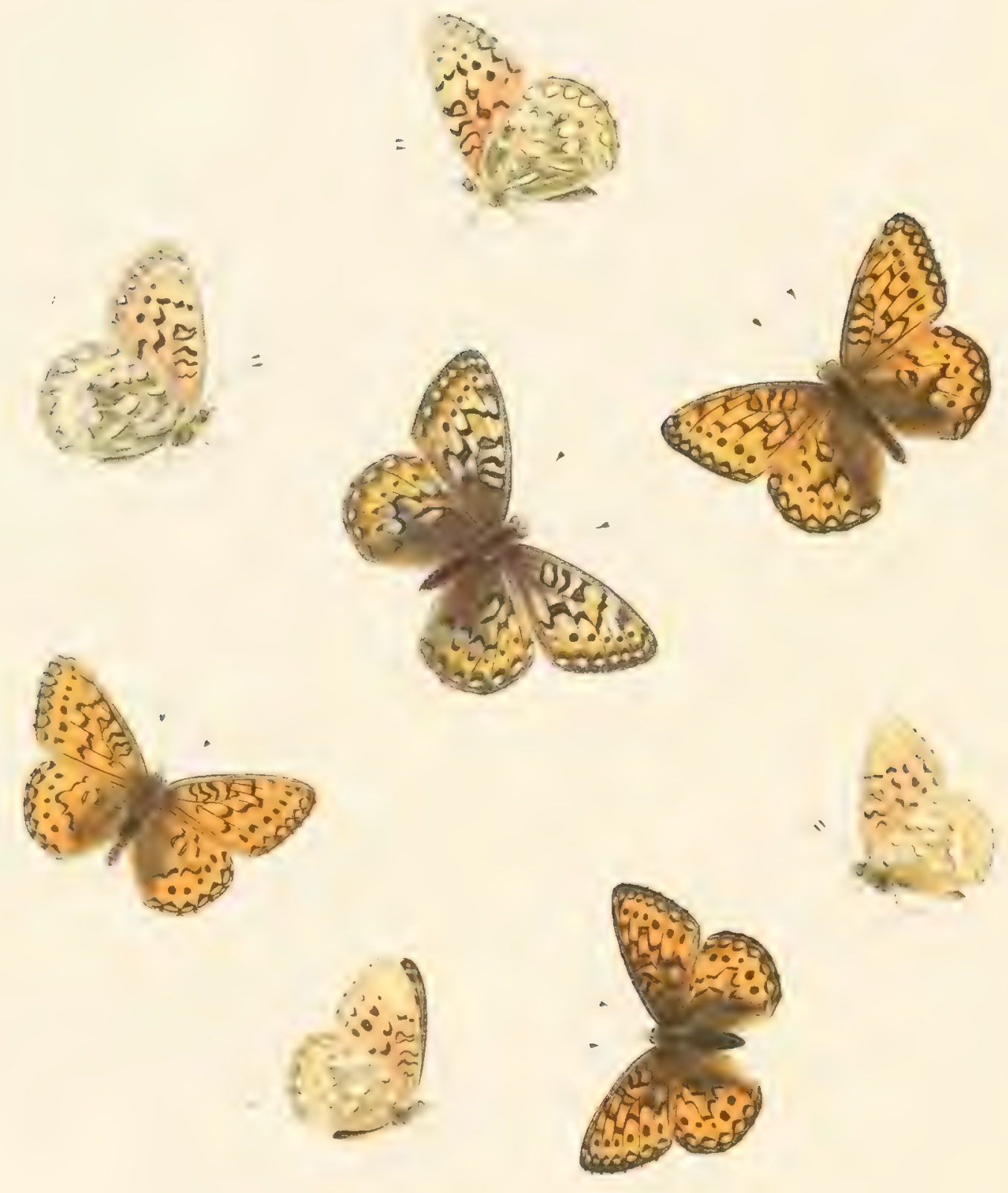




\title{
ARGYNNIS III.
}

\section{ARGYNNIS BISCHOFFII, 1-1.}

\author{
Argynnis Bischoffi, Edwards, Trans. An. Ent. Soc. Vol. III. p. 189, 1870.
}

PrIMARIEs short, slightly arched, the hind margins convex.

MLALE. - Expands 1.8 inch.

Upper side fulvous; the base of primaries and the inner half of secondaries densely obscured by purple-tinted black, so as to conceal the markings; both wings have broad black marginal borders, either crenated or erose on the inner side, and inclosing a series of small fulvous spots; often these are nearly or quite obsolete on the posterior half of primaries; the other markings much as in Eurynome; fringes luteous.

Under side of primaries with a faint fulvous tint at base and over the median interspaces; the apical area pale ochraceous, and often immaculate; often also the sub-marginal lumules are wanting or represented by a few brown scales only; but in some examples these lumules are distinct throughout.

Secondaries buff washed with ochraceous, mottled on the basal area with grayish-green, and sometimes with reddish-brown on the middle of the disk; the band between the outer rows of spots buff; the sub-marginal spots broad, serrated; of the second row, the first three are nearly equal, sub-ovate, the fourth minute, the fifth ovate, larger than the first, the sixth ovate, small, the seventh irregular; in the third row are three spots and in the cell two; also one in the interspace above cell. Individuals differ much in respect to silvering, the larger proportion of males examined being wholly without silver, the spots buff, while in the females silvered spots predominate; in many cases also where there is an absence of silver, the sub-marginal spots of secondaries, as well as of primaries, are nearly obsolete.

Body black, with fulvous hairs, beneath gray-fulvous; legs and palpi fulvous ; antemne brown above, fulvous below; club black, tip ferruginous.

Female. Expands 1.9 inch.

The basal half of primaries and almost the whole of secondaries obscured, to 


\section{ARGYNNIS III.}

such an extent often that the fulvous color is nearly limited to the extra-discal area of both wings; the disk and costal margin of primaries sordid white, as are portions of the interspaces on secondaries, especially those which correspond with the second row of spots on under side; the marginal borders broader than in the inale; the inclosed spots small, sordid white.

From Aliaska.

All the examples of the present species known to me in collections have been taken in one locality near Sitka, " upon some rising ground, covered with heathlike plants, two miles from the town, in the middle of July." Of these, $5^{+} 5$ \& were taken by the late M. Bischoff, and $1^{ \pm} 2 \&$ by Mr. Bendel, of San Francisco. Except one pair of M. Bischoff's collecting, I have seen, or Mr. Henry Edwards has examined and described to me, all these. Of the males, one only is silvered and four are not; of the females, four are silvered and two are not. In both sexes there is much difference in the unsilvered examples as to the distinctness of the marginal and apical markings, and all, of both sexes, are much obscured on the upper side.

Mr. Crotch did not meet this species in British Columbia, though he found several other Argynnides there in abundance. 


\title{
ARGYNNIS III.
}

\author{
ARGINNIS OPIS, 5-8. \\ Argynnis Opis, Edwarls, Trans. Am. Ent. Soc., Vol. V., p. 105, 187.
}

MALE。 - Expands 1.5 inch.

Primaries moderately arched, hind margins rounded; under side without silver.

Upper side uniform yellow-fulvous; primaries very little obscured at base, secondaries rather largely obscured both at hase and down the abdominal margin to the mesial band, that part of the wing being covered with a dense coating of dark brown bristling hairs; hind margins edged by two fine parallel lines, showing very narrow fulvous spaces between, and connected throughout with a series of small black lumules within which are fulvous spots; the extra-discal spots small; the mesial band delicate, and confluent on secondaries; in the cell of primaries a wavy stripe crosses the lower median intersace and part of submedian below cell; secondaries have on the disk an incomplete black ring; fringes luteous, fuscous at the ends of the nervules.

Under side of primaries buft; very slightly, if at all, red-tinted on basal area of primaries; the maxkings of the cell repeated, the mesial band represented by separated spots; the extra-discal spots obsolete except two or three next. inner margin; the usual sub-marginal spots obsolete, or near inner angle represented by a few scales only. Secondaries have the discal area pale ochraceous, somewhat mottled with faint red; the space beyond the second row of spots clear ochraceous; the sub-marginal spots faint, those of second row and those towards base scarcely more distinct; all these arranged as in Eumyome and allied species, but ochraceous, with no silver.

Body above fuscous with fulvous hairs; beneath, the thorax gray-fulvous, al)domen buff; legs buff; palpi gray-fulvous; antenna fuscous above, fulvous below; club black, the tip fulvous.

Femate. - Same size and shape. Color deeper fulvous; both wings olsscured from base nearly to mesial band; the marginal band with the connected lumules 


\section{ARGYNNIS III.}

and indeed all the markings, heavier than in the male. Under side of primaries red-tinted except at apex, which is ochraceous; secondaries as in the male.

The only locality at present known for this species is Bald Mountain, Cariboo, British Columbia, at which several specimens were taken in 1873 , by the late Mr. G. R. Crotch.

The virgins OPIS and ARGE first brought offerings from the Hyperboreans to Apollo at Delos; and dying there, "they receive honor from the Delians, the women calling on their names in a hymn; and ashes from the altar are thrown upon their sepulchre, which is behind the temple. of Diana, facing the east, very near the banqueting room of the Ceians." So the old historian; and later by three milleniums it pleased me also in naming this hyperborean butterfly to honor the heroic virgins. 


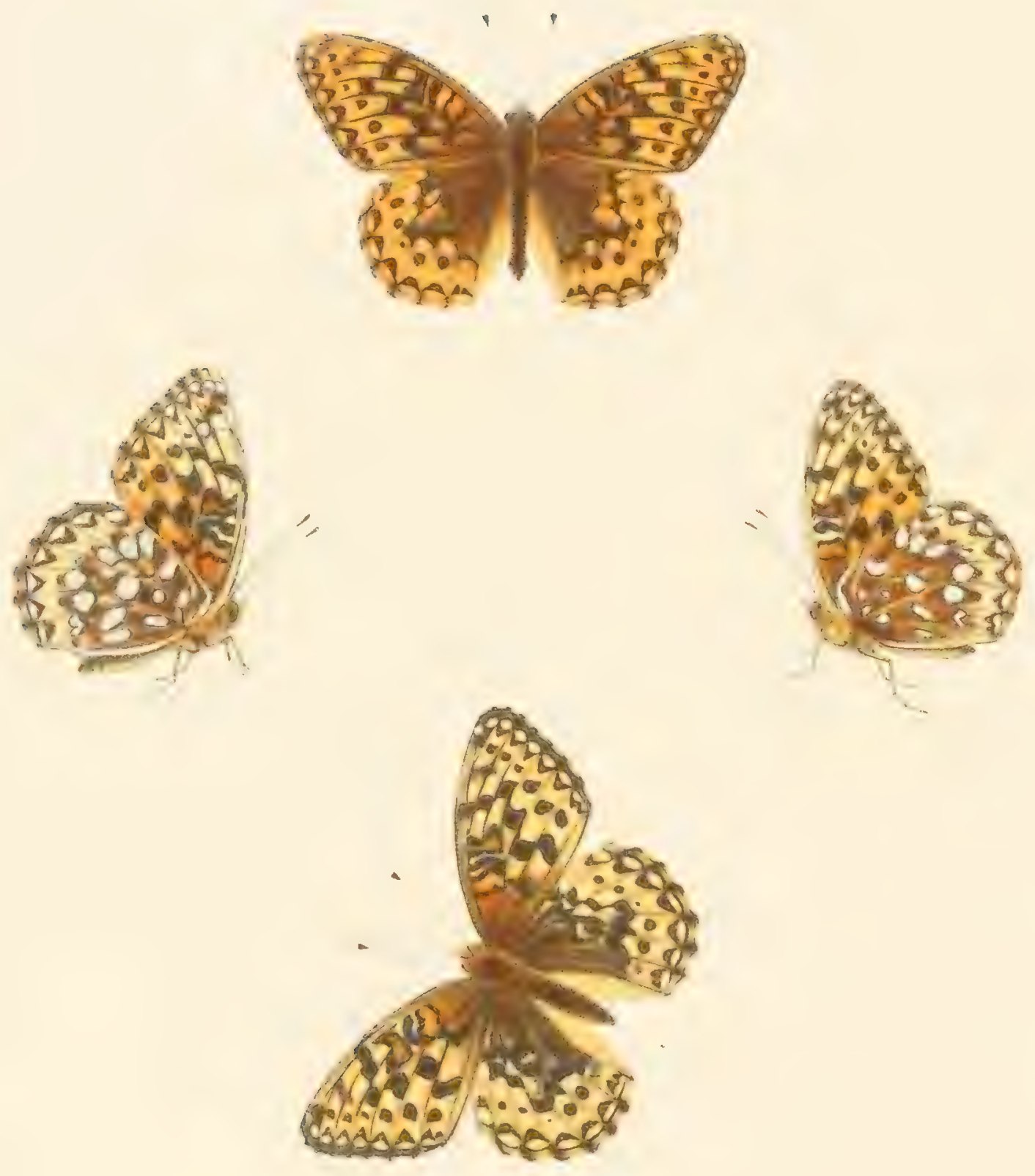


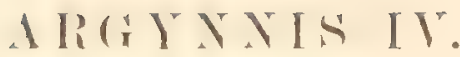

ARGYNNIS BREMNERII, 1-t.

Ammnis Lremnerii, Elwards, 'l'mus. Am. Ent. Soco, 1872.

Prunaries long, narrow, produced apically; hind margin more or less convex.

M.M.E. - Expands "2 to to.t inches.

Upper side deep fulrous, occasionally yellow-fulvous, dark brown at base and nearly up to mesial band; hind margins bordered by two parallel black lines, the intervening fintrons space divided by the hack nervules; resting on these lines a common series of black erescents, enclosing fulvous spots, small, mostly double-convex; other markings as in allied species, very heavy, as in Cybele; the mesial ham confluent on secondaries, and connecterl with the spot on the are by a black bar, that crosses the lower sub-costal interspace; this spot is shaped like an inverted $\mathrm{C}$; fringes luteous, black at tips of nervules.

Under side of primalies red-fulvous, sometimes cimmamon-red, next base and over immer margin up to median, huff along costa, in upper and posterior part of cell and in the discoidal interspaces; the hind margin from apex to median ferruginous, and a large ferruginous sub-apical patch, on which are two, rarely three, spots, sometimes well silvered, sometimes buff with merely a few seales of silver; the sub-marginal spots to the number of five or six from apex, either well silvered or slightly, like the sub-apical.

Secondaries deep ferruginous, somewhat mottled with buff; or greenish-buff; the space between the two outer rows of silver spots, usually buff, sometimes yellow, and not encroached on by the dark ground color, as in Cybele; but in other cases this space is nenly covered by ferruginous, as in Aphrodite; the seven sub-mitrinal silver spots narrow, sub-triangular, edged above with ferruginous; the seven of second row each narrowly edged with black anteriorly, the first three nearly equal, the fourth minute, the fifth largest, sub-rotund, the sisth sub-rectangular, the seventh lumate; in the third row are five spots, similarly edged with black, the first, third, and fourth equal, lunate, the second minute, often obsolete, the fourth a dash on the margin; a small round spot in cell and three spots at origin of nervures; making twenty-two silver spots in all; shoulder well silverer, abdominal margin lightly. Body fulvous above, 


\section{ARGTNNIS IV.}

beneath buff; with gray and fulvous hairs, abdomen buft; legrs fulvous; palpi fulvous, with buft hairs in front; antemne fuscous above, fulvous below; club black, fulvous at tip.

Fearate. Expands from 2.3 to 2.7 inches.

Upper side paler; the marginal lines and crescents confluent, forming a broad black band, the enclosed fulvous spots paler than the ground color; the other markings as in the male.

Under side of primaries deep red, ochraceous apically; the silver spots distinct, three on the ferruginous patch, and five or six along the margin; secondaries as in the male, but rather more mottled with greenish-ochraceous; spots larger, well silvered.

'This fine species was first marle known by Dr. Bremner, of H. M. Ship Zealous, who obtained a few individuals on San Juan Island, in 1871, and presented them to Mr. Henry Edwards. In 1873, Mr. Edwards himself visited Vanconver's Island, and writes as follows: "Bremnerii is remarkably common in the vicinity of Victoria. I observer it in great numbers at Esquimalt, and on a patch of clover, which was in full flower at the time of my arrival, I captured over sixty specimens. 'The great majority of these were males, and from my own experience, and that of other observers, with the larger Argmmides, I believe that the females of Bremerii would not appear in any number before the end of August, while the male is abundant in June. It seems to be the only large species of Argymis inhabiting this Island. Its flight is somewhat slow and henvy, and being a fearless insect, its capture is a matter of no difficulty." In August, 1873 , also, Mr. G. R. Crotch was collecting in British Columbia, and found Bremmerii abundant at Fraser's River and at Lake Labache. With it was flying A. Apleradite, scarcely differing from its type of the Eastern States. This alone of the large Atlantic species of Aryymnis is found on the Pacific coast, and so far as now known, is confined to British Colunbia. Both Atlantis and Aphrodite belong to the Coloradan fituma, and the males of the latter species have there undergone some modification, having assumed somewhat of the intense coloration of the female, while the fore-wings are more produced and more arched than in the Eastern type. 


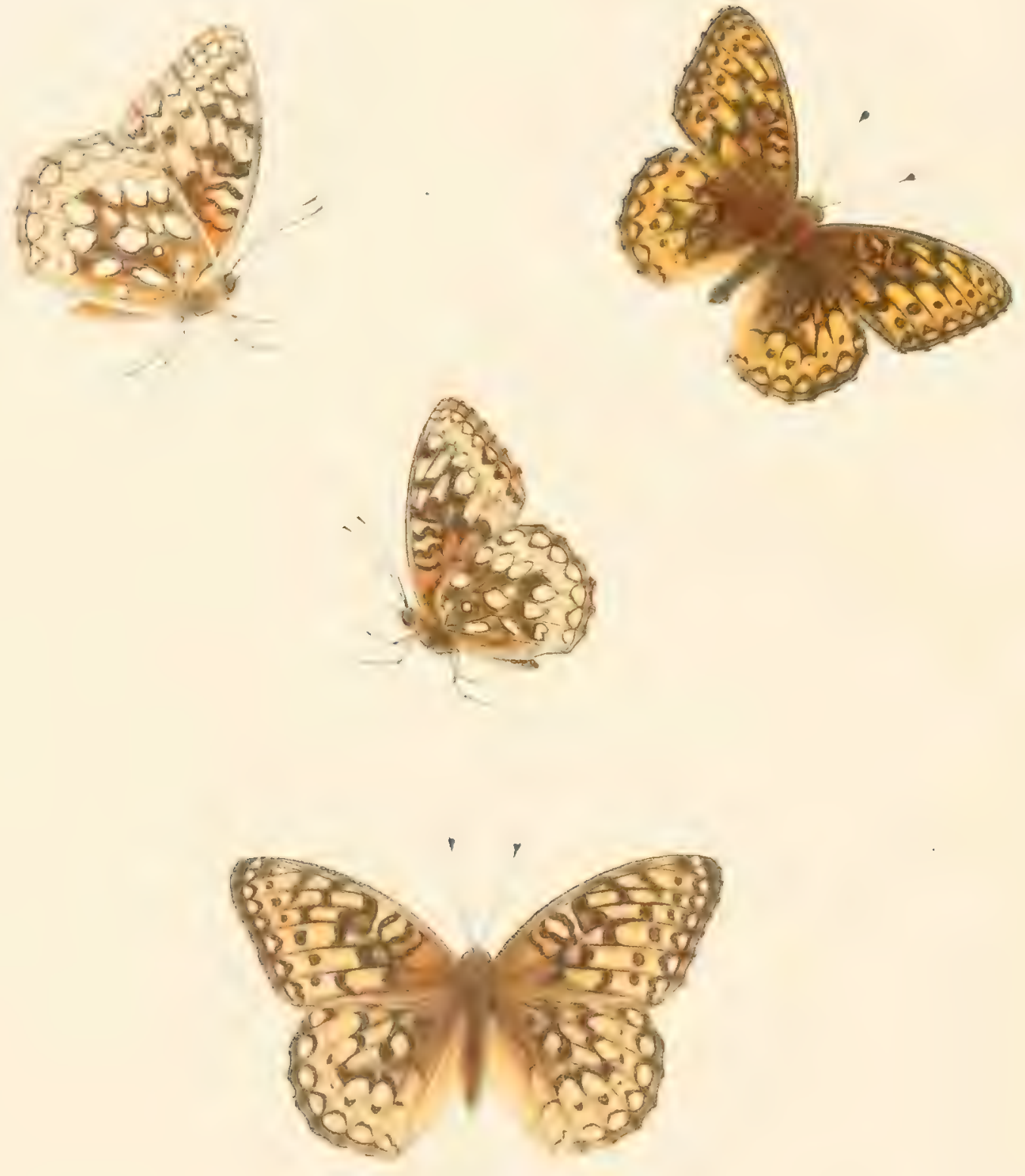


\section{A RGINNIS V.}

\section{ARGYNNIS INORNATA.}

Argynnis inomate, Eidwards, 'Trans. Am. Ent. Soc., Vol. IV., J. 64, 1872.

Primanes strongly arched, produced apically, straight on hind margin in the male, slightly concave in the female.

MLLE. - Expands 2.5 inches.

Upper sirle red-fulvous, much obseured from the mesial band to base, so as to render the blackish marking's indistinct as compared with Hesperis, the nearest allied species; margins bordered by two parallel lines that are confluent on primaties and on upper half of secondaries, forming a black band through which faintly appears a tint of fulvous in the interspaces; on the band rests a connected series of black lumules inclosing pale fulvous spots; the other black makings ns in Hesperis, but heavier; on disks of secondaries paler spots comesponding to the second row on mlerside; the black markings in cell of primaries next anterior to the spot on are strongly bent so as to inclose a sub-quadrate space which is paler than the ground color; fringes luteous, black at tips of the nervules. Under side of primaries cimmamon-brown at base, and up to the mesial black band and within the P like spot on the are; but the sub-quadrate space and that portion in cell next posterior is bufl; rest of wing buff, including the sub-marginal and sub-apical spots.

Secondaries reddish-brown from base to outside of second row of spots, the band between this and outer row buff and immaculate; the marginal spots large, broad, sub-triangular, very slightly edged above by brown; those of second row mostly large, broad-oval; of the third row, the first on costa is nearly round, the second trapezoidal, the third a dash only; the spots of the second and third rows lightly edged above with black; two round spots in black rings in cell, a long oval at base of sub-median and a dash at base of sub-costal; all these buff; scarcely diflering from parts of the ground color, and without silver.

Body covered with fulvous hair', gray-buff beneath, abdomen buft; legs buff; palpi same, fulvous in front and at tip; antemne black above, fulvous below; club black, tip fulvous. 


\section{A RGY NIS $V$.}

Fevite. - Expands 2.7 inches.

Upper side paler, the general appearance more that of an Euptoieta, the whole outer portion of the wings, including the sub-marginal spots and the discal spots of secondaries, futled to a whitish-ochraceous; in cell of primaries, the space within the $P$, and that between the two black lines next base deep orange-fulvous, rest of cell of same shade as the disk, the sub-quadrate space conspicuous; under side of primaries orange-fulvous instead of cimmamon-brown; secondaries next. hase pale brown mottled with buff, the spots shaped as in male but greatly enlarged; on the sub-marginal spots of secondaries may be seen a few scales of silver.

Tnomata was originally described from a single pair in the collection of Mr. Tames Behrens, and which had been taken at Downieville, Cal. Since 1872, the species has been found to range over a large territory, even to Virginia City, Nevada, where it was observer by Mr. Henry Edwards. Me writes: "It is a remarkably wild flyer, and never rests more than a second or two, in this respect differing very much from A. Zerene and Monticola. It alights on leaves of trees or on the road, but I never saw it settle on flowers." 



$$
a^{4}
$$




\title{
ARGYNNIS VI.
}

\author{
$\longrightarrow$ \\ ARGYNNIS RHODOPE, $1-4$. \\ Argynis Rholope (Rhodto-pe), Edwards, Trans. Am. Lint. Soc. 1874, p. 13.
}

Prinaries of medium width, moderately arched, straight on hind margin.

MLLe. - Expands 2.2 inches.

Upper side deep red-fulvous, the basal area of each wing up to the mesial band dark brown; hind margins edged by two heary, parallel, black lines, sometimes contluent, on which rest a series of lunules which inclose narrow, sub-ovate, fulvous spots; the preceding rounded spots small; other markings as in the allied species, but heary throughout; the mesial band on secondaries confluent; the discal spot on same wing oval, with a narrow, fulvous simus; beyond this spot to base, the ground in the cell, and for some distance on either side of the cell, is black, partially covered by brown scales; along the inner edge of the mesial band above median nervure are fulvous spots in the interspaces; fringes alternately luteous and black, the latter prevailing on primaries.

Under side of primaries dark ferruginous along the entire hind margin and apex quite up to the line of rounded spots; sometimes the basal area and inner margin are of same hue, but in other cases are paler; the sub-costal and discoidal interspaces yellow, as is also much of cell; the spots inclosed in the sub-margimal lunations small, and the upper five or six either yellow with a lew silver scales, or well silvered; on costal margin three sub-apical spots on a patch of reddish-brown, also either yellow or silvered, differing in individuals.

Secondaries uniform deep red-ferruginous from base to margin, except that sometimes there is a narrow pale space between the two onter rows of spots, as of a yellow sub-color washed with red; also in some cases the middle of wing, next anterior to the second row, is much covered with black; the marginal spots well silvered, narrow, elongated, lumular; those of second row nearly equal in size, excepting the fourth, which is minute; the first three, fifth, and sixth sub-quadrate, the seventh long and narrow, the eighth, on inmer margim, nearly obsolete; all these heavily edged above with black; the spots of third row small, edged above with black; in the cell a rounded spot, and at the base of 
median nervure, an oval, both ringed with black; all these spots, from second row to base, either well silvered, or pale yellow sprinkled with silver scales differing in individuals; silver patches at base of cell, at origin of sub-costal nervure and on shoulder; the abdominal margin lightly silvered.

Body above brown-fulvous, beneath light, the abdomen buff; legs fulvous; palpi buff at base, fulvous above; antemne fuscous, beneath ferruginous; club black, ferruginous at tip.

Feurate. - Expands 2.4 inches.

Upper side paler, the basal area nearly as much obscured as in male, the submarginal fulvous spots lighter than the ground; under side as in the male, the marginal row of spots in secondaries silvered, all the others yellow.

This beautiful and distinct species was discovered in 1873, by Mr. G. R. Crotch, in the Fraser's River country, British Columbia. Three males and one female only were taken, "in the forest on the way from Bates' (commonly called the 100-mile house) to Beaver Lake." 


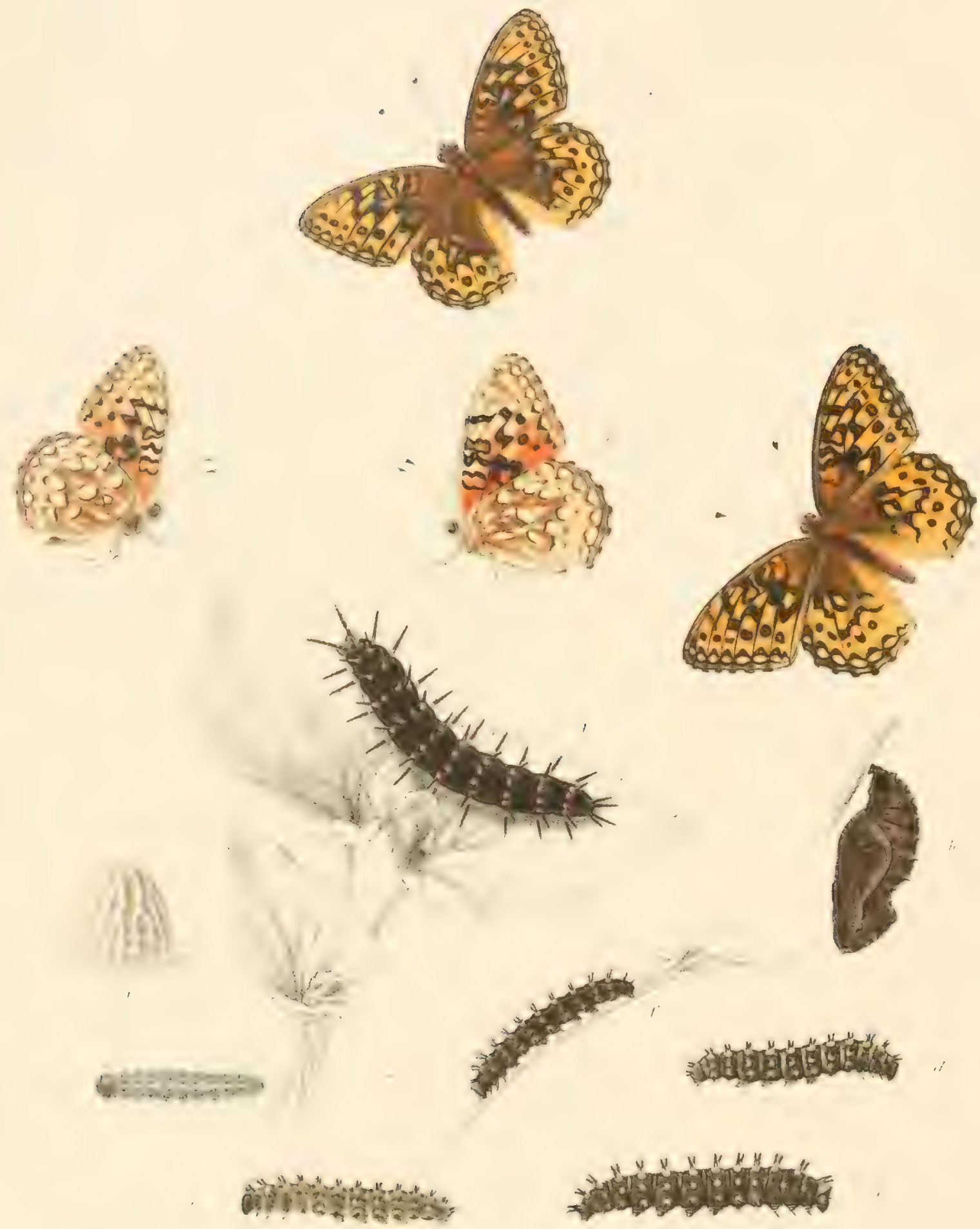


\title{
ARGYNNIS VII.
}

\author{
ARGYNNA RUPETTRIS, $1-1$.
}

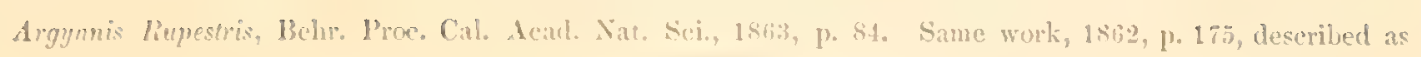

Mate - Expands two inches.

Priminies strongly archer, moderately produced, rounded apically; hind margin nearly straight.

Upper side deep red-fulvous, somewhat obscured at hase of primaries, and largely on secondaries, the dark portion nearly reaching the mesial band; hind margins hordered by two tine parallel lines, on which rest a series of lunules which inclose spots of the ground color; the extra-discal spots roundert, large. especially those on the posterior half of primaries, and all on secondaries except the one on upper median interspace, which is minute; the mesial band heavy. and confluent throughout; the usual inscriptions in cell of primaries, and a sagrittate spot in sub-median interspace; in the cell of secontaries a spot like an inverted $\mathrm{C}$; all these marks heavy; fringes luteous, black at tips of nervules.

Under side of primaries brick-red at base, bufl over outer part of cell and the apical area; the median interspaces tinted with red on buff ground; the markings repeated; near the apex a slight ferruginous patch; the sub-marginal lunules brown, darkest posteriorily, inclosing buff spots without silver; serondaries cimnamon-red on buff ground, the latter appenring in patehes on the disk and in the cell; the band between the outer rows of spots narrow, buff, enrroached on by the basil color; the sub-marginal spots light buft; very slightly silvered, long, narrow, edged above by red; the remaining spots yellow-buft, with no silver, each of those of second and third rows edged narrowly above by black; the second row consists of seven spots, of which the first three and the fifth and sixth are sub-ovate and erqual, the fourth minute, the seventh subImnate; the third row of three spots; in the cell two, and an oval at base of lower median interspace, these edged with black; a patch of buff at bise of subcostal interspace. 


\section{ARGYNNIS YII.}

Body deep fulvons above, beneath, the thomx buff, abdomen yellowish; legs buff. reil on the anterior sicle; palpi yellow at the sicle, fulvous in front and at tip ; antenne fuscous above, fulvous below; club black, the tip ferruginous.

Fenale. - Expands 2.2 inches.

Upper side less intensely colored, tending to yellow-fulvous on disk; the borders and lumules heavy; the spots inclosed on the lunules paler than the ground; all the markings heavy; under side of primaries light-red, and of nearly uniform shade over the basal area and all the outer limb below the upper branch of median; the discoidal nervules edged with red; remainder of the wing buff; the anteriol sub-marginal spots very lightly silvered, the rest buff as are alwo those on sub-apical patch; secondaries have the basal red of brighter tint than in the male; the sub-marginal spots partially silvered, the others clear yellow-buff.

This fine species, although described so long ago as 1862, by Dr. Behr, from a single male which had been received by him from some member of the State Geological Survey, had remained otherwise unknown until 1874, no other specimen having been taken, and no knowledge existing of its locality. During the past season Mr. James Behrens re-discovered the species at Soda Springs, in northern California, and from him I have received the pair figured on the Plate. 


\title{
IRIINXIS VII.
}

\author{
ARGYNAIS DINA. \\ Argynis Diana, Cramer, II., nI. 98. Edwards But. N. A., Vol. I. plate 20. \\ DESCIIPTION OF PIEPARATORT STAGES.
}

EGG. - Height, .086 inch, brealth at base, .09, at summit, .034; conoidal. truncated, depressed at summit, marked vertically by about eighteen prominent. slightly wavy, ribs, eight of which extend from base to summit, and form around the latter a serrated rim or crown; the remainder lie between these and end irregularly at one half to three quarters distance from base, sometimes squarely at one of the transverse strix, but often curve towarls and unite with the long ribs; between each pair of ribs are equi-distant transverse stria, about twelve in all, each one depressed in the middle and not often in line with the corresponding strix of the adjoining sections; the spaces between the ribs and strix excavated roundly. (Fig. $a_{0}$ ) Duration of this stage fifteen days.

Young LARVA. - Length, .08 inch; cylindrical, thickest at fifth and sixth segments, tapering slightly towards either extrenity; color dull green, translucent; each segment from third to twelfth marked by a transverse row of eight elongated, mostly ob-ovate, tubercular, dark spots, the second on either side the dorsal line lying back of the rest; on the thirteenth a straight row of lour spots. and behind this another of two spots; the second segment is marrow and is occupied dorsally by a blackish, oblong patch, on the front of which are four small, rounded tubercles, and immediately behind each of the two outer ones a similar tubercle; in addition to these, on either side of this segment are two spots like those upon the other segments; from each of the tubercular spots throughout spring one or two long black hairs, curved forward; head rounded in front and at the vertices, depressed in midlle at top ; color blackish brown, sparsely pilose. (Fig. b.) At this stage this larva camot be distinguished from that of Cybele or Aphrodite. The first moult occurred in eighteen days after the larva awaked from hybernation. 


\section{AIRTINIS VII.}

After first moult: length .15 inch; same shape as before; color olivaceous, mottled over the whole surface with brown; armed with six longitudinal rows of long, fleshy, black spines, each of which springs from a yellowish tubercle; these spines are somewhat tinted with fulvous at base, and from the sides and end of each proceed short, curved black hairs; legs and pro-legs dull green; head black. (Fig. c.) Duration of this stage sixteen days.

After second moult: length .3 inch; the segments firom fourth to eleventh enlarged, from fourth to second tapering more rapidly than before; color miform obscure greenish-brown; the spines as in the list stage, a dull yellow tubercle forming the base of each; legs black, pro-legs dull green; front of head blackish brown, bristling with hairs; back of head, at the junction with second segment, dull yellow. (Fig. d.) Duration of this stage fourteen days.

After third moult: lenerth .7; color as in last stagre, the upper surface with a silky gloss; the spines longer and more tapering, the basal third of each and the tubercle also orange; the bristles shorter; legs and pro-legs black; head sub-conic, truncated, with a prominent vertex on either side, between which and the apex is a rounded depression, the front flattened, the lower angles rounded; color brown in front, dull yellow behind; the ocelli black. (Fig e.)

Time to next moult seventeen days.

After fourth moult: length .1 inch; color miform deep chocolate-brown; the spines as before, except those of the two dorsal rows on second and last four segments, all of which are black; the bristles shorter; between the dorsal rows on each segment are two whitish dots; head black. (Fig. f.) Duration of this stage twelve days.

After fifth moult: length 1.5 inch. The liuva continued without change in coloration till maturity.

Mature Larva. - Jength 2.5 inches; cylindrical, Heshy, tapering at either extremity, each segment rounded; wholly velvety-black; armed with six rows of long, tapering, sharp, glossy-black spines, from each of which proceeds several short black bristles on the silles and one at the top; length of most of these spines .2 inch; on the second segment the two dorsal spines measure.3 inch, and are projected forward over the head; on each side of same segment is one other spine, starting from the posterior edge of the segment and back of the line of the dorsals, and these also are porrected; the remaining spines of the six rows radiate as if from a central axis, those of the stigmatal row being depressed so that their ends are on a level with the feet; the base of each spine deep orange or fulvous; between each pair of dorsals two whitish dots placed transversely; legs and pro-legs black; head small, but broader than the second segment, subconic, truncated and depressed at top, flattened in front, the lower corners rounded, 


\section{ARGYNNIS VII.}

the vertices prominent, the surface sparsely pilose; color brown, behind fulvous. ( Fig. g.)

'Thirty-six hours clapsed after suspension before the change to chrysalis took place, twenty-two days from the lifth moult.

Cinisulis. - Length 1.2 inch, greatest breadth .43 inch; cylindrical, with an angular excaration below the mesonotum; the whole surfince finely comugated: heal-ease scluare, tramversely romoled, with somewhat prominent vertices: mesonotum prominent, compressed, carinated, rounded at summit, and with a sharp tubercle at base on either side; two other tubercles just below and back of the head; wing-cases much elevated alove the surfice, the outer edges at base flaring; on the abdomen two dorsal rows of long, sharp tubereles, and smaller ones, corresponding to the first lateral spines on the larva, on the three or four middle segments; color of the anterior portions and of the wing-eases lightbrown, streaked with darker shates; of the abdomen dark brown, mottled on the sides with red. (Fig. h.) Duration of this stage nearly twenty-one days; making the time from the egrge to the imagro about nine montlus.

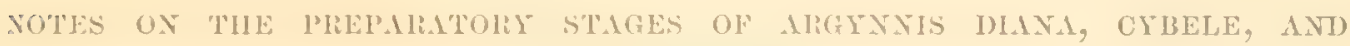
APIIIOITE:

After many discombing attempts at raising the larva of one or other of these species, I succeeded in bringing all from egges to chrysalids in $18730-4$. The females readily deposit their egrgs in confinement, and at different times I had had humdreds hatch, but lost the young larva alnost immediately. Cybele is a common species at Coalburgh, and in August and September multitudes of them may be taken on flowers, in the fields on Vernonia, in the garden on single zimnias. especially. Aphrodite is sometimes taken, but is rare, and as to Dieme, though ten years ago I was able to take many, of late it has become ahnost extinct hereabouts. But on last of August, 1573, Mr. 'I'. L. Mead brought from a locality fifty miles enst of Coalburgh, among the mountains, several living females of Aphroulite and some sixty of Dirma. These were placed in boxes and kegs, with fresh plants of violet, as were also females of Cybele, and a very larre number of egres were obtained of each species, laid upon the leaves and stems of the plants, and alo upon the sides of the boxes and the cloths which covered then. Dicna also deposited freely upon stems of Vermonia, but I was never able to discover that the young larve fed on that plint. Dr. II. K. Mayhurst, at Sedalia, Mo., to whom I had sent young larve of Dirne in 1869 , wrote me at the time that in some instances they dirl eat the surface of the leaves of Vemonia Novaboracensis. It is certain, however, that this larva thrives on violets of every 


\section{ARGYNYIS VII.}

variety, witc or cultivated, and upon pansies, as do the larve of Cybele and Aphrodile. The ergess of the three species are essentially alike, constructed on the same plan, and in about equal periods the larva hatched; namely, from twelve to fifteen dars. After emerging, an oceasional larva was noticed feeding, but only for a diny or two, and nearly all at once attached themselves to the muler sides of the leaves and upon the grooves of the stems, where row of half in dozen were to be seen ranged one behind the other, quite to the base, and became dormant. There is no perceptible difference between the larva of these three species at this or the next two or three stages. As it seemed necessary to keep the plants cool, I found great difficulty in carrying them through the enrly part of the winter, and as the leaves died off, and perhaps the whole plant as well, the larva had to be transferred to others, and a great many of them were lost in the process. Many also were destroyed by mould. Soon after the first of Janury, I placed the plants in the greenhouse, and a few days later discovered the larve of Cybele moving about and feeding. Two weeks later, on the twenty-first, those of Diana and Aphrodite were active. To prevent escape I confined them within glass globes set on the pots over the plants. But both plants and larvo suffered from the confinement, and there soon appeared a great mortality among the latter. But the most serious loss occurred from the smoking of the greenhouse with tobacco, one day in my absence, the gardener having forgotten to remove my pots. From this catastrophe emerged about a score of Cybele, half a dozen Aphrodite, and fewer Diana. The growth of all was slow, and it was the twenty-seventh of January before the first moult of Cybele took place, and individuals of this species were passing this moult irregularly for a fortnight afterwards. The other two passed their first moult about the middle of February. Each species moulted five times before maturing, and the intervals between the several corresponding moults varied much in individuals, no doubt owing to the state of the weather. On smmy days all were active, but when the sky was clouded or weather cold they meither fed nor moverl.

$\mathrm{U}_{\mathrm{p}}$ to the fifth moult the three species retained a close resemblance, Cybele and Diance being of equal size, Aphrodite smaller and slenderer. At the fifth, Dicua parted from the other two, increased rapidly in size, and the spines were longer in proportion, and radiated from a central axis like spokes from the hub of a wheel. 'The four spines of second segment were projected horizontally forward over the head, and the two midclle ones of these were longer than any others on the body. In these respects Diana differed from the other species. As they approached maturity the number of larva was reduced to four Cybele, two Aphrodite, and one Dicund, and how to preserve them to the end was a matter of much 


\section{ARGYNNIS VII.}

amxiety. I amanger a keg with a gauze bag high over the top, which was confined by the upper hoop of the keg, and planted fiesh violets, which had to be renewed almost daily, covering the earth partially with stones, and setting sticks which might serve as resting places for the larve. 'This appeared to answer the purpose well. 'I'he larve were fond of resting on the sticks, head downward, or upon the sides of the bag, coming down to feed when impelled by hunger. After remaining motionless for lours, they woukl suddenly arouse and start off in extreme haste, ruming all about the inclosmre, and on reaching the leaves would feed lavenously, and then return to their resting place. Not unfrequently they were extended on the stomes or the damp earth as if for coolness, the reather at this time having become warm.

It is meertain whether the lanve of butterflies see distinctly, or at all, although they are furnished with what are called ocelli, there being five of these organs on either side of the head. On one occasion I happened to be at hand when an Aphrodite suddenly started down the side of the bag, to disappenr below, and prevently emerge on one of the upright sticks. This it ran over and about, and from a point on the side of it towards the plant made great eftorts to reach one of the stems, which was at something more than an inch distant from the stick. Severil times the caterpillar stretched itself out till it was nearly twice its natural length, holding to the stick by its anal and last pair of ventral claspers, and moving its head and body from side to side to feel for the plant. But the attempts were in vain. 'l'hen it remounted the stick, and reached out in a similar manner from the top in directions where were no leaves, till at last it turned right again, and hy an eflort more violent than usual, seized a stem by its jaws and first pair of legs, and holding by them, dropped its body from the stick and climbed to the leaf. There was evidently a sense of direction in the first instance, from the descent of the bag to the reaching the stick, though not of sight, ats the stick was fixed at the base of the plant, and the latter was as casily reached as the former. And when on the stick, there was a sense that the leaves were near, without a certainty of the precise locality.

Only three Cybele reached chrysalis and one Aphrodite. They spun buttons of white silk and lung suspented, nearly straight, the anterior segments but little bent, and so continued for about two days and nights in the case of Cybele, thirty-six hours in Aphrodite. This last died in chrysalis; the others yielded the imago in twenty-two to twenty-four days. The Diona suspended in a similar manner: last of all, on seventeenth of May, and the change to chrysalis occurred on the nimeteenth, the interval having been fifty-four hours. It was so prolonged that I feared lest the larva had not vitality sufficient to enable it to change, and when on rising in the middle of the last night to see what the fate 


\section{ARGYNNIS VII.}

might be, I found the change passed, and the beautiful chrysalis formed, the sense of relief was great. It was the single outcome from at least three hundred ergrs, and I had watched over it in one stage or other almost daily for thirtyeight weeks.

From this chrysalis a female emerged twenty-four days later, nearly forty-one weeks from the laying of the egrg. As the several stages of these larva were reached, they were formarded to Miss Peart, in Philadelphia, for their portraits, which in every instance are drawn from life, and fortumately none were lost or injured on their travels.

In the fill of 1874 , I agrain obtained eggs of Cybele, and profiting by experi. ence, confined the young larva within cylinders of fine wire set over the plants and deep enough in the earth to prevent escapes. And 1 found no difficulty, after the larre began to feed, in rearing them, bringing seven to the imago. Fresh air and moisture is what these larve of Argymnis require, and I have no doubt now that I can successfully raise any species of this genus.

Three years ago, I received from Mr. Wm. Saunders, a few half-grown larve of Cybele, taken near London, Canada. They were found by him in the Spring, in swampy ground, hiding by day in holes made by the feet of cattle, and rere concealed also by dead leaves which more or less filled the holes. These larva matured in my possession. Mr. Situnders also found chrysalids of the same species suspended on the under side of pieces of bark near this swampy ground, and by scattering bark about, and frequently examining it, he obtained several chrysalids. In the same sort of hiding place, Mr. Nead found the chrysalis of $\mathrm{A}$. Atlentis, at Hunter, N. Y., in spring of 1873. 


$$
\text { , }
$$




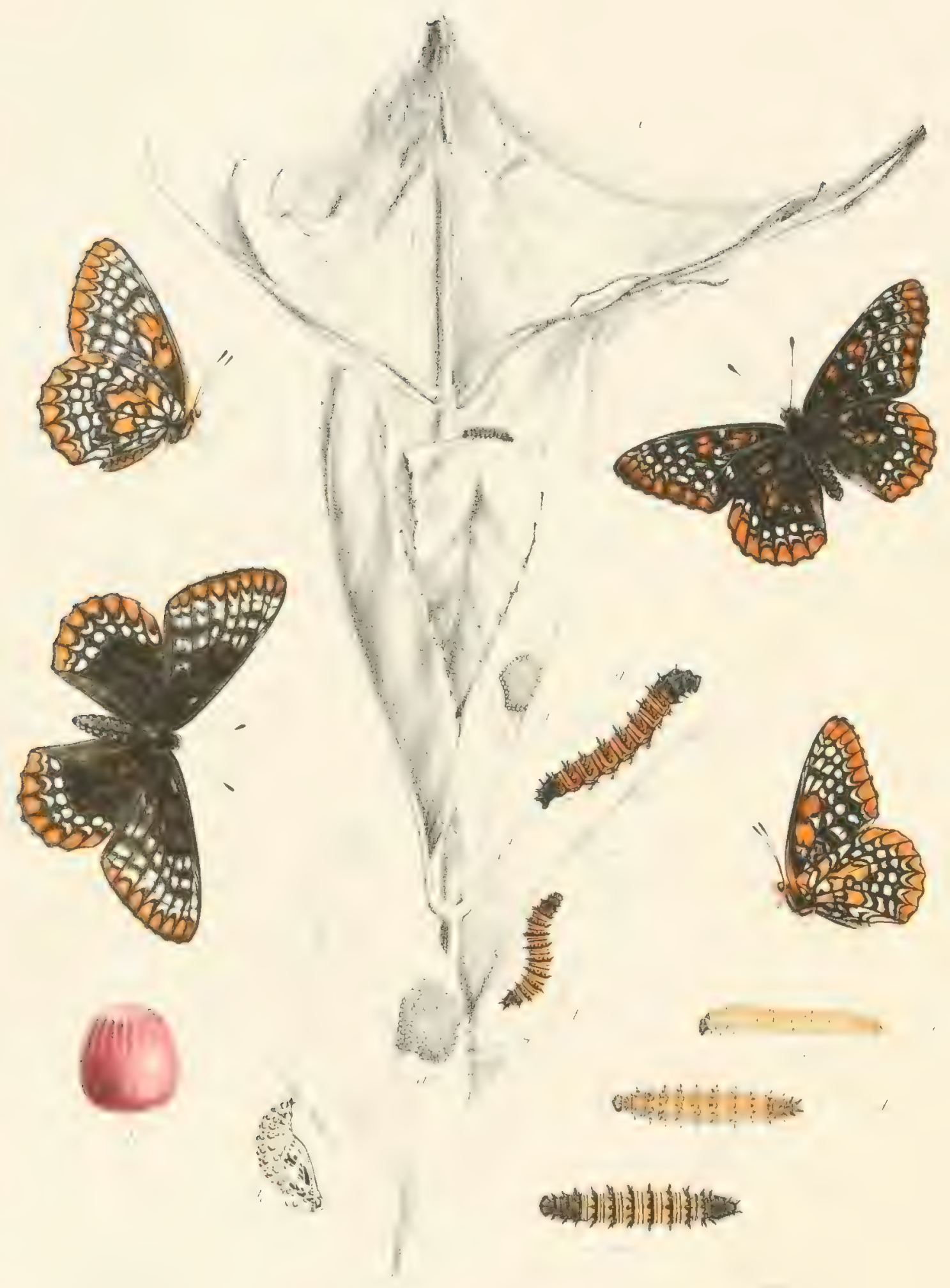




\section{MELITEA I.}

\section{MELTTEA PHAETON, 1-4.}

Mfelieg Phacton, Drury, Exot. Ins. 1. pl. 21, 1770. Cramer, Pap. Exot. pl. 183, 1782. Fabricins, Syst. Eat. p. 481, 1755. Ent. Syst. III. P. 16, 1793. Buis. and Lec., p. 167, pl. 47, 1833. Harris, Ins. Mass, p. $2 \times 8,1562$.

Phactontea, Gouart, Enc. Meth., 1X゙. p. 288, pl. 38, 1819.

MaLE. - Expands '2.2 inches.

Upper side black, spotted with fulvous and pale yellow; both wings have a marginal series of fulvous spots, those of secondaries large and bright colored, of primaries dull, often small, in which case they are rather sub-marginal; precerling these are two common transverse rows of small yellow spots, the first mostly narrow lumules, sometimes party wanting on primaries, or blended more or less with those of the second row, which are romuled; on primaries there is a third row, and a fourth which consists of three or four spots only against the extremity of the cell; within the are of eell a geminate fulvous spot, and another half way to base; between these atre two small round yellow spots, one being next either nervure; near base a patch of yellow scales; all the cellular spots vary in distinctuess and are often more or less obsolete.

Secondaries have a fulvous patch on costal margin, and two within the cell, these last often indistinct or wanting; fringes black, yellow in the middle of the interspaces.

Under side black, or brownish-black, the spots repeated and much enlarged; all the marginal spots large, equal on either wing, mostly crenate or serrate, and each is sumounted by a yellow lunule, which corresponds with a spot of the first yellow row of the upper side; the fulvous spots in the cell large, each pair confluent, and the two sometimes united by a ligament of same color. Secondaries, in addition to the onter row of yellow lumules, have three rows of yellow spots, rounded or irregular, and nearly equal; upon the basal area six fulvous patches, between which are several small yellow spots on the black ground; a fulvous stripe along the abdominal margin next above the angle. 


\section{MELITAAA I.}

Body above black, the abdomen with a dorsal and lateral row of yellow points; beneath, the thorax black; the abdomen black, with yellow at the junction of the segments, and with a fulvous stripe on either side; the extremity also fulvous; legs and palpi fulvous; antennæ black, slightly ringed with yellow on the upper side; club black, tipped either with fulvous or with black and fulvous.

Feyale. - Expands 2.2 inches.

Primaries less produced and broader than in the male; paler colored, similarly markerl.

EGG. - Ob-ovate, truncated, rounded at base, flat or slightly depresser at summit, smooth; the upper third marked by from twelve to eighteen vertical ridges which spring from the surface, increase in elevation as they proceed, and terminate at the edge of the Hattened summit; color lemon-yellow when first deposited, changing in a few days to dull crimson, and shortly before the disclosure of the larva to black. Duration of this stage nineteen or twenty days. (Fig. b, egg magnified.)

Young LAmi. - Length, .08 inch; cylindrical, translucent, luteons, ench segment showing a transverse row of brown tubercles, which indicate the position of the future spines, each giving a pencil of light hairs; legs brown, prolegs luteous; head broader than the body, obovate, bilobed, brown. 'Time to first moult six days. (Fig. c, larva magnified.)

After first moult: length, .16; shape as before; color dull luteous, the extremities dusky; from each tubercle arises a short black fleshy spine, which bristles with light hairs; head blackish-brown. 'I'o second moult six or seven days. (Fig. d. magnified.)

After second moult: length. .3 inch; the spines longer, the bristles larger and black; color either ochraceous or brown, the segments at either extremity black; head black, much covered with short black hairs. Duration of this stage nine to ten days. (Figure omitted accidentally.)

After third moult: length .35; the spines longer, black, shining, each springing from a glossyblack tubercle, the bristles radiating and interlacing; the extreme segments black, the others dark yellow-fulvous, with black stripes; head black. Immediately after this moult is completed, the larva cease feeding and become lethargic, in which state they remain till the following spring. (Fig. e, larva natural size; $e^{2}$, magnified.)

The fourth moult takes place a few days after animation is restored; length, .6 inch; scarcely changed in appearance from last stage; color dull yellow-fulvous. Time to next moult about ten days. (Fig. $f$, natural size.)

After fifth moult: length, 8 inch. The growth is now rapid, and in a few days the larva reaches maturity. (Fig. g.) 
MATUne LAita. - Length, from 1.1 to 1.3 inch; cylindrical, the extreme segments smallest, the others equal; the dorsum and sides amed with seven rows of long, tapering, fleshy, black spines, each of which springs from a round, shining, blue-black tubercle, the tubercles of ench segment nearly meeting; each spine bristling with stout black hairs; there is also another row of similar, but much smaller spines, below the spiracles; in this row the fourth segment has no spine, the fiftli to tenth two each, in line, the eleventh one, the twelfth a tubercle without spine; on the under side of the body, on fifth and sixth segments, in line with the legs, is a single small tubercle, with a short, branching spine, and hetween the pairs of legs on the same segments are several minute tubercles, with tufts of hair from each; the second, third, and part of fourth, and the last two or three segments black; the other's deep red-fulvous, striped transversely with black, one stripe ruming with the spines, one covering the junction of the segments, and another anterior to this last; under side orange, with a black ventral stripe; leggs black, pro-legs smoky-brown; head black, bilobed, tuberenlated and covered with short black hairs. The larva live in colonies, in webs of their own construction, until the hybernating period is over.

Cnrssulis. - Length, .8 inch; cylindrical, with a rounded dorsal excavation below the mesonotum; head case narrow, truncated, compressed transversely; mesonotum rounded, slightly prominent at summit; abdomen and thorax furnished with several rows of tubereles, those of the medio-dorsal and first lateral rows prominent, pointerl, the rest scarcely raised above the surface; color varying from pearl to pure white, marked and spotted with brownish-black; the tubercles orange, each marked anteriorly by a black crescent; a broad black band passes along the lower side from one extremity to the other, bifurcating at top of head; an irregular band more or less edged with orange crosses the wing cases, and the hind margins of the wings discover brown serrations; along the dorsum, at the posterior part of each segment, are four abbreviated black maxk, set obliquely as radiating from a common centre; between the medio-dorsal and first lateral tubercles, and between these last and the second laterals are two black dots, placer vertically on each segment, and there is also an oblique mark behind ench of the first laterals; other dots and marks on the head cases. (Fig. h.)

There is much variation in the extent of the black bands; some specimens also have the abdomen largely suffused with orange. Duration of this stage from fourteen to eighteen days.

This beantiful species is found as far northward as the Lake of the Woods, and in the States, from Maine to Wisconsin; also in Virginin, and the States 


\section{MELITEA I.}

bordering on the Ohio River, and in Kansas. It is the only Melitrea which inhabits the Atlantic slope, thongh from the Rocky Mountains to the Pacific the genus is numerously represented, and it is probably the only butterfly in its district whose larve construct and pass the winter within webs. It is always local, abundant where found at all, and is usually to be seen only in the vicinity of swamps. It is of slow and sluggish flight, and alights on the leaves of shrubs and on the ground rather than on flower's. The life-history of this species was long a mystery, and his only come to be understood within the last five years. In Norember, 1S68, Mr. Billings, Can. Ent. I., p. 28, writes that he has "accidentally discovered a locality for this rare buttertly within two miles of the city limits of Ottawa. It is in an open swamp, densely surrounded by coniferous trees which are almost impenetrable, and occupies a space of eight or ten acres. This season I watched fithfully for the appenrance of the imago, making occasional visits to the spot during the month of June. It was first observed on the $3 d$ of July, and between this and the 20th I made five or six excursions, capturing over two hundred specimens. I seldom met them on the wing, but generally resting on the alder's or ferns." And Mrr. Billings states that it is not improbable that the species is double-brooded, judging from the fact that two years before he had seen a female late in Aurust or early in September, which, as will appear, must have been an exceptional occurrence. The food-plant Mr. Billings had not discovered.

In a subsequent number of the same volume, page 59, I communicated some facts which I also had gathered. In May, 1868, a boy living in the neighborhood of Coalburgh had brought me several chrysalids of Placton, part of which he had found suspended on the under side of fence rails close to a small swamp near his father's house, and said that he had seen many caterpillars on the rails. Being umable to go to the spot, I sent him back with directions to bring me caterpillars and to search for the food-plant. A few days later he returned with about eighty chrysalids and but two caterpillars, which changed immediately after I received them. He reported that the caterpillars were running over the branches of the parpar bushes (Asimina triloba), though he could discover mone feeding thereon, and that such as he had taken had changed to the chrysalids brought in. The following year, 20 th May, I was passing this place when my young collector told me that he had found the plant we had been in search of, and would show it to me. We went to the border of the swamp and he led me to a clump of Chelone glabra, eaten nearly to the water, and said that this had been black with the caterpillars a few days before. There were several other clumps in view, all much eaten, and I succeeded in finding two caterpillars on one of them. This plant is common in swamps and in meadow brooks over the northern part of the continent, and from a large stool sends up many fleshy stems to the height of about three feet. 


\section{MELITAA I.}

On 221 April, 1874, I went again to the swamp, hardly expecting to find the Chelone out of the gromnd, as the weather had been cold and regetation backward. But the moment I reached the water my eye fell upon two or three of these caterpillan's on the lower leaves of an isolated stem which was not more than six inches high. Neal by. were other stems, each with one or more caterpillaus, and so it was as far as I could distinguish the plants over the water. These larvid were nealy mature. On the stem being jarred they instantly rolled up and dropped to the ground. Some I saw resting beneath the plants on ehips or leaves. Others were rumning over the hummocks which projected above the surfince of the rater, moving raphilly and throwing their hends to the right or left as if feeling theil way. 'Two days after I visited the swamp better prepared for exploring the water, and could have brought away hundreds of the caterpillars. 'They were to be found wherever a plant of' Chelone grew, not at all sereened, but in plain sight, and wherever there were fallen trees or dead branches there were to be seen many at rest.

At this larval stage this species must be subject to few enemies, and must be obmoxious to the birds which ahound in swamps. Otherwise none could reach maturity, for not the least eflort is made for concealment after the caterpillars have deserted the web, and the contrast of color with the green leaves makes them unusually conspicuous. The only shelter sought by them is in rainy weather or from the sun when the heat is extreme, and that is attained by shifting to the under sicles of the leaves.

At diflerent times up to september, 1875 , I visited the swamp, and so have become acpulinted with the complete history of the species. On 13th June, 1875, I foumd three clusters of eggr, and brought home two of them. These two were latid on leaves of the same stem, at some distance from the top, both upon the middle of the leaves, on under side, one close anginst the midrib, the other scarcely touching it. The former comprised about two hmolred eggs, densely packed in a somewhat irregular mis, two layers deep, each eggresting on its base. The other cluster was rounded, four layers deep, with a few eggs which represented a fifth, the bottom layers apparently regular, but many of the eggs of the upper ones inclined, and some lying on their sides. 'There seened to be about four hundred egges in this chuster. (See Figs. $a, a^{2}$.) 'The color was a peculiar shade of crimson, like that of wilted currants, having a tint of blue in it, but two or three of the eggs were lemon-yellow when first observed, and this I an informed by Mr. Seudder is the color when newly laid. From him also I learn that the duration of this stage is nimeteen to twenty days. The larve began to emerge 24 th June, thirteen days after I brought home the eggis, and about thirty-six hours before the disclosure the color of these had gradually changed from crimson to black. 


\section{MELIT'EA I.}

The larve were immediately placed upon a plant of Chelone, and in obtaining this I noticed many little webs already constructed. One colony which I encountered was in a state of great agitation, its members rumning about wildly and throwing their heads and two thirds the body in a jerking way from right to left, all in same manner and like so many automata. The cause of the alarm seemed to be a small crimson ichneumon fly which was hovering about, and which alighterl on one of the leaves which protruded from the web. My presence frightened it away, however, so that I failed to see its mode of attack.

Placing the young larve on the leaves, some at the top and some well down the stem, each lot began at once the construction of a web; in case of the terminal leaves, drawing them together. While part were busy at this, others were eatirg the pulp, and even gnawing the midrib, by which the leaves easily yielded and were soon folded over and incorporated in the web. Those on one of the lower leaves in same way contrived to double the leaf over, but. I noticed that in a few hours all those which began life low down the stem had climbed to the upper leaves and joined the colony there. As the larva grew, leaf after leaf was inclosed, a detachment working at the next pair of leaves below, which were taken possession of by the colony as soon as the upper ones were consumed. These first webs were slight, and quite transparent, the warp composed of long, regular and colorless threads, which ran from the stem to the middle of the next leaves below, and were bound together by innumerable cross-threads which took no regularity whatever. 'Two or more holes were left for egress, and the eating away of the leaf made other openings. The web at this stage does not resist rain very well, and in a long continued storm more or less destruction of the larve follows. But as soon as the skies clear, the survirors set themselves at repairing or rebuilding altogether.

Six days after leaving the egre, the larva began to pass the first moult, which process continued for two days before all the colony had changed, and forthwith they eat voraciously, stripping the leaves much faster than they could form a web to cover them. Many of the larva during this stage remained outside in small clusters, and fed on separate leaves, even on separate stems; but as the time for the second moult drew near, they came together and constructed a loose web, within which the moult took place.

About the middle of the next stage, on a bright day, I noticed that each of my colonies was suddenly active in spinning, and it at once occurred to me that they anticipated a storm and were providing against it. Before night much more substantial and larger webs than had been hitherto constructed were ready for occupation. During the night a steady rain set in and continued for twenty-four hours, but it found each colony safely housed. The next day was clear, and 


\section{MELITNAI.}

all hands were busy in repairing and strengthening, working both within the webs and without.

'The largest of these structures was long and narrow, tapering at either end, about three inches broad in the middle, and so thick and closely woven as to conceal the interior. For egress while at work, two somewhat tubular openings were left on the middle of one side, and the threats about these were doubled. To support this large web the upper part of a stem of swamp grass, which was growing in same tul), was bent down, and its broad and spreading leaves were bound over the surfice, and this with the stem of Chelone was stifl enough to resist the wind. After the linve had ceased work and finally retired within the web, a slight covering was spun across the outlets, sufficient evirtently to throw ofl' water and to keep out spider's. 'l'wo or three days later, about 20th July, the thim moult was paseed, and thenceforward the lanve did not leave the web, bit entered on their period of rest, which would endure till the following April. Watching the same stages in the swamp, the same peculiarities were to be noticed. In some cases very large welss were constructed, and the one represented on the Plite was $11 \times+$ inches at its extremes. In nearly all cases, assistance from other plants was sought to support the stem. And the completed webs were not confined to Chelone but were often built on other plants at some distance, one to three feet firm the food plant. I thought at first that such plants must also have been eaten of by the larva, but could find no evidence of it, and larve which I kept meanwhile confined in glasses would eat of no lealf but Chelone.

Six weeks later, the wehs were found to be bleached white, and were weatherworn and considerably shrunken; often distorted too by the growth of the plants. 'The effect of the shrinkage was to compress the larva into a hard, compact mass. On opening some of the webs, I invariably found a small percentage of larva which had not pasered the third monlt. The condition was not that of torpidity, nor even of lethargy, for there was an immediate and general movement on the disturbance being made, and many of the larva would attempt to escape. I brought home some of them and placed them upon a young plant of Chelone, but they showed $n$ disposition to feed, nor to construct another web. They ran over the leaves for a few hours till the whole plant had been thoroughly explored and then left it, betaking themselves to the grass.

I made an excursion to the swamp th April, 1875, to determine, if possible, how early the caterpillars left the web; but I found them already scattered, though the food-plant was as yet scarcely above the water. Several caterpillars which I brought home were placed on a clump of the plant in a vessel of water, to prevent escape, and sticks were set to give them opportunity to rest after 



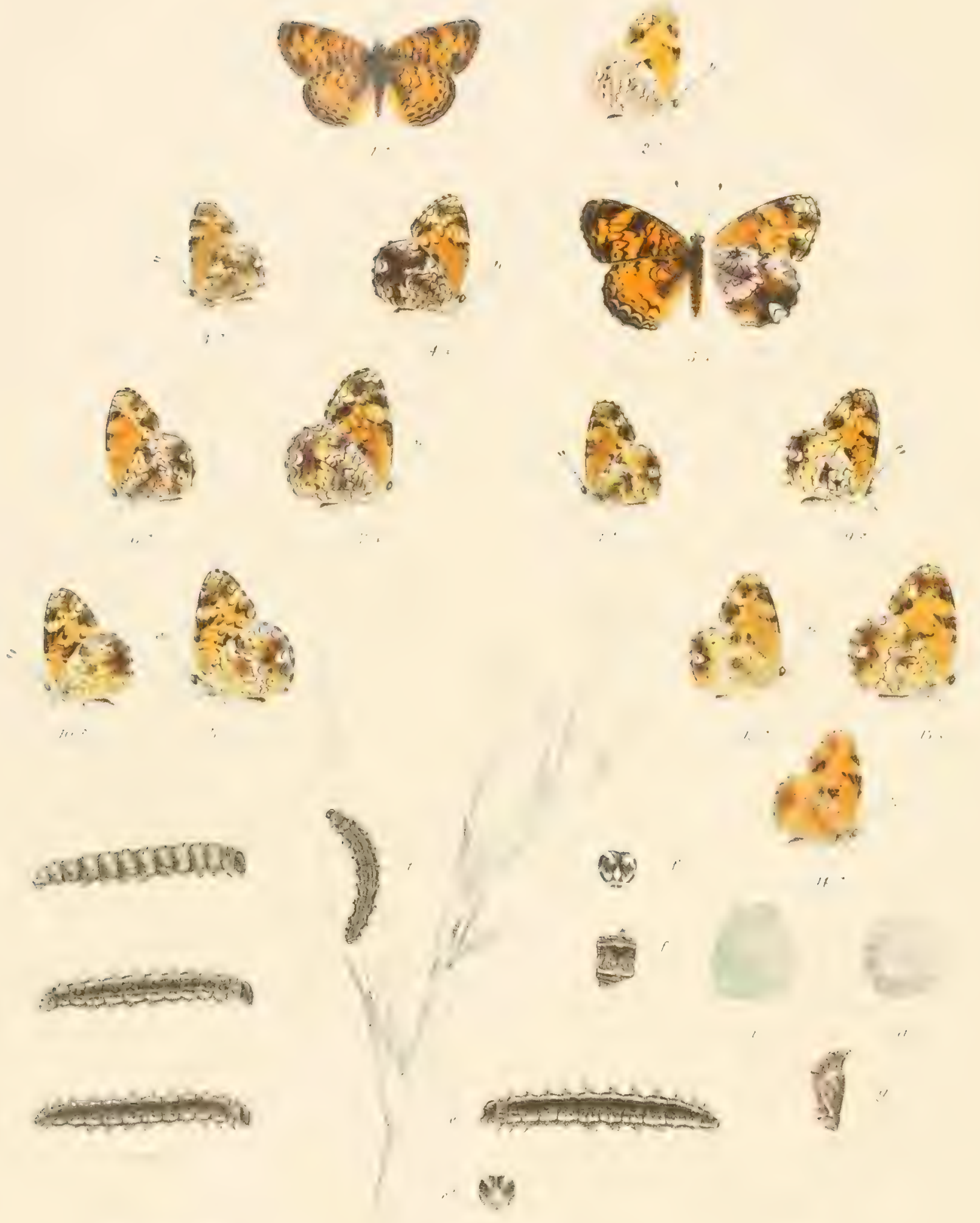


\title{
PHYCIODES I., II.
}

\author{
PIIYCIODES THAROS.
}

Phyciodes Tharos, Drury

MAliCI A, Edwards, 'Trans. Am. Ent. Soe, II., p. 207, 1868; Id., Can. Ent., IX., p. 1, 1877.

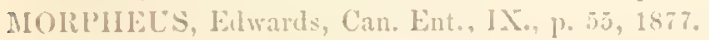

Morpheus, Fab. Syst. Ent., p. 550, 1745; IH., Lint. Syst., III., p. 155, 1793.

Thuros, Drury, 1., pl. 21 \&, 17. Bois. and Lec, p. 170, pl. 47 o" (not \&), 1833.

Cocyta, Cramer, Il., pl. 101., fiers. A., 13.

Pharos, Iharris, Ins, Mass, 24 ed., 1. 209, 1862.

Aberr. I'ackurdii, Saunders, in P'ackard's Guide, p. 256 .

\section{FOIM MARCIA.}

MLLE. - Expands 1.5 inch.

Upper side red-fulvous, banded and reticulated with black; the hind margin of primaries broadly bordered with black, throngh which rums a crenated line, or series of narrow crescents, either yellow- or red-fulvous, the one in upper median interspace large, the other's often obsolete; within the anterior edge of the border is a series of nearly equal and often contluent fulvous spots, extending from sub-costal to sub-median nervure, the lower spot sometimes pupillated with black; next beyond is a broad, sinuous, fulvous band, sometimes macular ; from the costa a subtriangular black patch covers the end of the cell, and is comected by an oblique line with a smaller patch on middle of imner margin; within the arc of cell is a black spot with interior fulvous spot or stripe; in the middle of cell a double ring, and another below cell; and at base of and below cell rounded black spots.

Secondaries have a black border of nearly even width, extending round outer angle, and inclosing near its anterior edge a yellowish crenated line, often macular, and sometimes quite obsolete; beyond is a series of seven large fulvous spots, each pripillated with black, the upper spot nearly or quite lost on the black ground at outer angle; these are edged by a black line, almost always interrupted on the discoidal and upper median interspaces; remainder of wing fulvous, the base black, and the outer portion of the basal area limited by black, irregularly chain-shaped spots, within which are similar spots crossing the middle 


\section{PHYCIODES I., II.}

of cell; there is great variation, however, in the extent of the black surface, the bands and lines often being so heavy as to render the surface of both wings largely black; in others the basal and extra-discal markings are small and attenuated, the reticulations distinct; fringes black mixed with cinereous, and sometimes with a little white at apex of primaries.

Under side of primaries pale fulvous, dull yellow on costa and at apex, bright yellow on middle of hind margin; often also a lilaceous tint suffuses the margin; the rest of the margin brown; a submarginal feruginous crenated line crosses the entire wing and at the apex is a second similar and anterior to the other; at the imner angle is a large black patch; the patches on costa and inner margin repeated, reduced; and a second one on costa half way from cell to apex; the outlines of the spots on basal area are seen indistinctly.

Under side of secondaries has the hind margin bordered by a double crenated line, making a complete series of long and narrow submarginal crescents, of which the middle one is most conspicuous; on the extra-discal area a series of small brown spots, corresponding to the pupils of the fulvous spots above; the basal area limited on the middle of the disk by two irregular lines, partly wavy, partly angular, and differing much in individuals, forming a transverse band more or less pronounced; anterior to these are several other wavy lines to base; all these usually ferruginous, sometimes brown; a brown clour corers more or less of the marginal area; on middle of costal margin a brown or ferruginous patch, and another on disk, both often nearly obsolete; the ground color of the wing varies much, being sometimes deep yellow, sometimes buff, or brown, or brown with much white over basal area, with more or less of a lilac tint; sometimes the whole wing is tinted with ferruginous.

Body above black; beneath, thorax and abdomen white, the latter yellowish at extremity; legs fulvous, the inner side of the femora white; palpi white at base, buff' above, black on upper side; anteunx black, gray beneath, and ringed with white; club black tipped with fulvous.

Female. - Expands from 1.5 to 1.7 inch.

Upper side very much as in the male, varying in similar manner, but never so denuded of black as is often seen in the male; in many examples the sinuous discal band of primaries is yellow-ochraceous instend of fulvous, and the spots of the outer series are partially pupillated. The under side shows similar variations to that of the male, but more extreme, the coloration being more intense, the band more distinct, and the dark areas more extended.

The ormamentation of the under side of secondaries indicates at least four principal varieties of this form of the species, distinct at the extremes in both sexes, and with many intergrades. The variation of primaries and of upper 


\section{I'HYCIODES I., II.}

surfice is less extreme and is not sufficiently distinctive, and therefore the secondarics alone may be used in characterization.

Yar. A. The marginal clour and costal patch wanting; the basal area silvered or white, perhaps a little discolored at extremity of cell; the crescents silvered or white; extri-cliscal area yellow-brown. (Figs. 1, 2 d.)

Var. B. 'The larger part of the wing dark brown, but usually the discal band is mobscured or nearly so, and is white and conspicuous, as is also the costal margin next hase and at outer angle; except at this angle the crescents obscured.

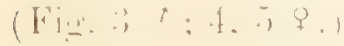

Var. C. In the male, the ground is either bright ochrey-yellow throughout, the band and basal area not differing from the area beyond the disk, with a marginal cloud, and a large brown spot on the disk (Fig. 9); or the ochre-yellow is slightly obseured over the disk and outer limb, and the spaces between the reticulated lines are partly yellow, partly faint white. (Fig. 6.) The discal spot varies much in shape, being sometimes a transverse bar, sometimes a longitudinal one limited to the cell (Figg. 6), or perhaps a triangular patch (Figg. 8). In the female, primaries have the hind margin largely covered with bright yellow; secondaries either bright or deep ochraceous, the band and spaces variegated with faint white and yellow, delicately tinted with brown on the disk, the crescents white or silvered where not covered by the cloud. (Fig. T.)

Var. D. 'This variety runs into the summer form of the species, the ground being either bright or deep yellow, or inclined to bufl, sometimes with a reddish tint; in the male, the retieulations are less distinct, the band always lost in the ground color, the cloud small, narrow, and dark colored, often concealing the crescents on middle of margin; on the disk a small brown patch and a slight one on costal margin; often one or both these are wanting. (Figs. 12, 14.) In the female the reticulations are strong, feruginous, the cloud and both discal and costal patches conspicuous. (Fig. 13.) This female resembles the female of Var. I of the summer form more than it does its own male. There are numerous intergrades between $B$ and $C, C$ and $D$, but want of space prevents my illustrating more than one of them, - C D. (Figs. 10, 11.)

\section{Fors MORPHEUS.}

Same size as Marcia in both sexes, and not distinguishable on the upper side, varying in same manner. On the under side of primaries, the male has the margin ornamented with dark brown and yellow, the black patches large and in. tense, the ground pale fulvous. Secondaries have the ground yellow-buff, but varying somewhat in individuals, the reticulations ferruginous, slight, often more or less obsolete, and no costal or discal patch, though sometimes there is a slight 


\section{PHYCIODES I., II.}

discoloration at the end of the cell; the marginal cloud narrow and dark, concealing the crescents; at the angles the crescents are of the color of the ground; in some examples the middle crescent on the cloud is silvered; in some also the cloud is reduced to a mere shade along the margin. There is little variation in the male, but much in the female. Some of these are like the male, the reticulated lines stronger, and a slight costal patch present; the cloud as in the male. I designate this variety as A. (Figs. 1, 2.) Var. B has the lines henvy, the costal patch conspicuous and dark, and a similar but larger one on middle of disk; the cloud diffuse. (Fig. 3.) This resembles Var. D, Marcia.

Nany examples of the summer brood of Morpheus are very melanic on upper side, especially those from the Catskill Mountains; the black being intense, while the discal band on primaries is pale yellow. (Fig. 4.)

A third variety, C, I have received from both Georgia and Texas, taken in May and August. On the upper side the fulvous is bright; the lines are fine and the meshes open; on the under side, secondaries are without patch or cloud, any dark shade being limited to the middle crescents on the edge of the margin; the submarginal lines on both wings dark and heavy, and the reticulations either faint or obsolete. (Fig. 5.) I have not observed this variety in more northern examples.

EGG. - Conoidal, truncated, depressed at summit, rounded at base, the lower half indented like a thimble, the excavations being shallow and arranged in close and regular rows; the upper half smooth, with about fifteen slightly raised vertical ribs, terminating at the rim above; color pale green. (Figs. $\alpha, \alpha^{2}$, magnified.) Duration of this stage four to seren days.

IOUxG LARVA. - Length .06 inch; cylindrical, largest anteriorly, the segments each well-rounded; sparsely pilose, the hairs black, and on the anterior segments directed forward; color yellow-green clouded with brown; head obovate, deeply cleft; pilose; color dark brown. (Fig. b, magnified.) Duration of this stage five to six days.

After first moult: length .1 inch; cylindrical, stoutest in the middle segments; armed with seven rows of short, fleshy, brown spines, each thickly set with short, concolored bristles; there is also at the base of body a row of small spines, similar to the others, one on each segment from the third, and over the pro-legs tro on each; on the second segment a dorsal collar, with minute spines; body striped longitudinally with light and dark brown and sordid white; the dorsum light brown edged with white, and on this brown area two interrupted white streaks; on the side a dark brown stripe on light ground, and in line with the lower lateral spines a white ridge; under side, feet and legs brown; head subcordate, the vertices rounded, and across each a gray band; another gray band 
PHYCIODES I., II.

on front lower face; color shining black. (Fig. c, magnified.) Duration of this stage five to six days.

After second moult: length .22 inch; same shape; the stripes almost the same, the white dull, the brown darker; a whitish line rums with the dorsal row of spines, which are light in color with brown tips; the first laterals are also light and stand on a whitish stripe; the second laterals on a broad, dark stripe, and are almost black; the lower laterals, on a white ridge, are white; the spines "thickly set with short, straight bristles, standing" at a high angle, and dark tipped; under side dark brown; head sub-cordate, dark brown and black, with a white spot on each vertex, and one on front lower face. (Fig. d, magnified.) To third moult in summer, three days. Where the larva passed the third moult in the fall the interval was from seven to fourteen days.

After third fill moult: length .3 inch; the dorsum light brown edged with faint white at the first lateral row of spines, the brown area showing two macular white streaks; below same spines a black stripe, after which the side is brown with a white stripe in line with lower laterals; head sub-cordate, shiming black, with a sray, illy-defined spot on each vertex, and another on side of face. (Figs $e, e^{2}$, magnified.) At this stage the larva becomes lethargic.

After fourth moult in spring: length .4t inch; color yellow-brown dotted with sordid white; the spines short, stout, yellowish at base, brown above; the bristles short, divergent, brown tipped with black; along the dorsal row a black stripe, a yellow one in line with first laterals, macular, irregular, and a yellow band with lower laterals; head small, cordate, shining black or bronze, with a few black hairs; across each vertex a narrow yellow bar, a yellow triangular spot on front lower face connecting at the lower angle with a curved bar which runs to the back of head. 'To next moult ten days.

After fifth and last moult in spring: length .6 inch; to maturity eight days.

Mature Larva in spring. Lenghth .85. inch; color blackish-brown, dotted, especially on dorsun, with yellow; the spines more tapering than at last stage; stout at base and there mostly yellowish; the bristles brown, black-tipped; on dorsum a black stripe, often wantiug; with first laterals a yellow stripe, and a band of same color next below third laterals; in some examples there is a black stripe between the two upper lateral rows; head cordate, shining bronze with black hairs; across each vertex a narrow whitish bar, thickened at the front and bluntly barbed on outer side; in front a triangular spot comecting at the lower angle with a sickle-shaped bar on the side.

After third moult in summer: length .45 inch; color olive-brewn, the dorsum much specked and dotted with dull white; a stripe of this color in line 


\section{PHYCIODES I., II.}

with first laterals, and a band below spiracles, above which is another band less distinct, whitish and macular ; the spines brown, light tipped, many with yellow or orange bases, the bristles black; head cordate, bronze; a straight, silvery bar across each vertex, a triangular white spot in front comnected with a curved white line at the side. To next monlt three to five days.

After fourth and last moult: length . 80 inch.

Mature Larva in summer. Length .95 inch; color dark brown, dotted with yellow and striped with yellow and black, the yellow always dull; armed with seven rows of spines, one dorsal and three on either side, besides smaller and similar spines at base of body, one on each segment from the third, and over the pro-legs two on each; the spines stout, tapering, dark brown, partly white-tipped, those of the upper and lower lateral rows more or less orange-tinted at base, each beset with many straight, black bristles; next below first laterals a blackish stripe edged on the dorsal side by yellow, and in line. with the lower laterals a yellow ridge; head cordate, either black or bronze, shining; on each vertex a cordate yellow spot, and on each side a sickle-shaped stripe. (Fig. $f$, nat. size; $f^{2}$, head masnified; $f^{3}$, section of side.) Duration of this stage four to six days.

Crimssulis. - Length .50 to .55 inch; cylindrical, thickest at ninth and tenth segments; head case narrow, excavated at the sides, nearly square at top, there being a slight depression in middle; the mesonotum moderately prominent, compressed at summit, followed by a deep excavation; the anterior edges of the last four segments of the abdomen prominent, especially that of the foremost, which is developed into a conspicuous ridge; on the abdomen several rows of fine tubercles, two of which are prolonged and terminate on the mesonotum; the color varies much, being light cinereous throughout, covered with fine abbreviated brown streaks; or cinereous on dorsum, the abdomen and wing cases tinted with yellow-brown; or dull white mottled on dorsum with brown and clouded with same color elsewhere; or wholly dark brown, specked with gray; often a row of light dots is seen at the ends of the nervules of the wings, and a similar row parallel, a short distance within. Many chrysalids of the summer broods are marked by black patches on abdomen and wing cases, the ground being brown, but in the spring the usual color is cinereous. (Fig. g.) Duration of this stage from six to thirteen days, umless retarded by cold. The earliest formed chrysalids of the hybernating larva gave imago 15th May, after thirteen days; later in the month, after eleven; chrysalids of July, in West Virginia, after seven days; of August, six; in Catskill Mountains, 1st September, after twelve, and in same district, chrysalids formed middle of September gave imago at twenty-nine on thirty days.

Tharos is one of our most widely distributed butterflies, ranging from $54^{\circ}$, in 


\section{PHYCIODES I., II.}

British Columbia, and $52^{\circ}$ in Labrador, at least as far south as Mexico and the Gulf States, and from the Atlantic to Montana and Colorado. I am not aware that it has been taken in the United States west of the Rocky Mountains, but Mr. Crotch found it in British Columbia, at Lake Lahache. From Labrador and Anticosti Mr. Couper brought many examples. Like the allied species, Tharos frequents meadows and open country, flying slowly, with tremulous inotion, for short distances and from flower to flower. In the early summer the males assemble by hundreds about wet places, keeping company, in West Virginia, with Nycteis, and in the Gulf States with Phaon and Vesta. It is one of the most variable of species, and besides the two distinct forms, winter and summer, under which it manifests itself, has a tendency to branch off into varieties and subvarieties, several of the first being well characterized. This peculiarity was noticed by Drury, more than a hundred year's ago, and he says, "In short, nature forms such a variety of this species that it is difficult to set bounds, or to know all that belongs to it." Both Phaon and Batesii appear to have formerly passed as varicties of Tharos. In 1868 , I described, as a distinct species, another of the hitherto supposed varieties, calling it Marcid. It seemed to be a wide-spread species, flying earlier in the season than the typical Tharos, and differed from it in many respects. But there were such resemblances also to Tharos that it was not possible to determine its specific value, unless the butterflies could be bred from the egg, and as yet the food-plant of the larva, and the larva themselves, of both 1Larcia and Tharos were unknown. But, in 1875, the food-plant was discovered by Mr. Mead. He states, in Can. Ent. VII., p. 161, that he planted in a large box specimens of all the common Compositw which he could bring together, covered the box with gauze, and introduced a number of females of this species. A few days later, on examining the leaves, he found eggs deposited on Aster Nova-Anglia, and on no other plant. Thereupon he transferred such females as were still living to a smaller box with fresh asters, and obtained several clusters of eggs. This happened in the month of July, near the last of the month, at Hunter, N. Y., among the Catskill Mountains, and as I reached the same place at that time, I saw the arrangement and received from Mr. Mead a cluster of the eggs. Others I obtained myself by confining the females in bags over the aster stems. The larva from these eggs were brought by me to Coalburgh, and as I was some days on the way, I found that they would eat the leaves of any species of aster, even German asters from the garden. And beyoud these plants I now know of none upon which they will feed. After passing two moults, and about 4th September, the larvw all became lethargic, and gathered in cluster on the cover of the glass in which I kept them. Two weeks later, part of them were again active and fed for a day or two, when these once 


\section{PHYCIODES I., II.}

more formed a cluster and presently passed their third moult, after which they became lethargic. I put them in the cellar, and there they remained till 7 th February, when such as were alive were placed on the leaves of an aster in the greenhouse. The same day some were feeding. They all passed two more moults before maturity. Probably those larva which had moulted twice only in the autumn died during the winter, as I found this to be the case in the winter of 1877-78. The first chrysalis was formed 5th May, and its butterfly emerged on 18th, or after thirteen days. Another emerged 30th, after eight days, this stage being shortened as the weather became warmer. There resulted eight butterflies, all Marcia, of the varieties designated B and C. This then settled the position of Marcia as a dimorphic form of the species.

The first individuals seen by me in the field at Coalburgh were three males Marcia, 18th May, and a week later both sexes were common. On 26th, I took seven females, all distinctly Marcia, and tied them up in separate bags, on stems of aster. The next day six of the seven had laid eggs, the clusters varying from about fifty to two hundred and twenty-five eggs each. They were always laid on the leaves, and usually on the uncler side of them, in rows nearly or quite straight, and touching each other. In the larger clusters the layers were three deep. These gave hundreds of caterpillars, and each brood was kept separate. The butterflies began to emerge 29th June, the several stages being thus: egg six days, larva twenty-two, chrysalis five. There were four moults and no more, but much irregularity in every larval stage, so that some of the butterflies did not emerge till 15th July. Just after these larva hatched I went to the Catskills, taking one brood with me, and they reached chrysalis there, and in that stage were mailed to Coalburgh whither I returned by the time the butterflies were emerging. There was no perceptible difference in the length of the several periods of this brood and the others which had been left at home, and nowe of either lot became lethargic. The butterflies from these eggs of May, with a single exception, were of the summer form, or the typical Tharos, which, for convenience, I designate as Morphens. This was the second generation of the season, counting the one which proceeded from the hybernating larvx as the first.

On 16th July, at Coalburgh, I again obtained eggs from several females, this time all Morpheus, as no other form was flying. The eggs hatched in four days, the larval stage was twenty-two, and chrysalis seven; but as before, many larvæ lingered." The first butterfly emerged 18th August. All were Morphens, and none of the larve had been lethargic. This was the third generation in succession, and from the second laying of egge.

On 15th August, at Coalburgh, I again obtained eggs from a single MForpheus 
PHYCIODES I., II.

and took them directly to the Catskills, where they hatched just as I arrived, 20th. This was the fourth generation of the season from the third laying of eggrs. The weather in Virginia had been excessively hot, and so I found it on the journey; but on reaching the mountains it was cool, and the nights decidedly cold. Two days after my arrival the mereury stood at sumrise at $40^{\circ}$ Far. September was a wet and cold month, and I protected the larva in a warm room at night, and much of the time by day, for they will not feed when the temperature is less than about $50^{\circ}$. The first chrysalis was formed 15 th September, twenty-six days from the hatching of the larva, and others at different dates up to the 26th September, or thirty-seven days from the egg. Forty per cent. of this brood, or fifty-two larva out of one hundred and twenty-seven, became lethargic after second moult. I entered in my journal as follows: "16th September, fifty-two larvæ have ceased feeding at second moult." "26th September, fully one half of the larve which had ceased feeding at second moult began to feed again, after resting a few days, and have now passed third moult." After which they became lethargic and so remained. I was surprised at finding in the summer that the broods then had but four moults, as I satisfied myself by repeated tests, in each brood, inasmuch as I had noted three fall moults in some cases, and two in the spring, in the larva of 1875. But later observations confrm the fact that both this species and $N$ ycteis pass five larval moults in the winter brood, and but four in any summer brood.

I returned to Coalburgh 15th October, and till I reached this place the weather on the way was cold, with several frosty nights. So that for a period of thirty days, the chrysalids had at no time been exposed to warmth. The day I arrived the butterflies began to emerge, and before the end of a week all that were living had come forth, namely, nime males, ten females. Of these nine males, four were changed to MIarcia, Var. C, three were D, and two were not changed at all. Of the ten females, eight were changed, five of them to Var. $B$, three to $C$. The other two females were not different from many examples of the summer brood, having large discal patteles on under site of hind wings, besides the markings common to that brood.

Ten of the chryealids I mailen from the Cittikills to Mr. Lintner', at Alhany, N. Y., asking him to keep them in a cool place until the butterflies should emerge. Between 21st October and 2d November, these gave six butterflies, all females and all Marcia, Var. B.

Eighteen of the chrysalids I had placed in an ice-house, at Hunter, 20th September, laying them in a tin box directly on the surface of the ice, the temperature being $40^{\circ}$, with little variation. Part were so placed within three hours after the forming of the chrysalis, and before they had hardened; others within 


\section{PHYCIODES I., II.}

six hours, and others within nine hours; and so all remained for seven days, that being the longest summer period of the chrysalis. On removing them from the ice they seemed to me dead. They were soft, and when they became hard had a shriveled surface. I brought them to Coalburgh, and discovered no sign of life till 21st October, when the weather suddenly became hot, the mercury rising to $87^{\circ}$, with a south wind. In two days fifteen butterflies emerged, every one IIarcia, not a doubtful form anong them in either sex. There wert ten males, five females; of the former, five were of Var. C, four of D, one of B. Of the five females, one was Var. C, four of B. The other three chrysalids were dead. All the butterflies of this brood were diminutive, starved by the cold; but those from the ice were sensibly smaller than the others. The examples of Var. B were intense in the coloring of the under surface, and the single male was as deeply colored as the females, which I have never seen in nature. The examples of the other varieties were extreme, but not so unusual.

So much for the Coalburgh broods, and I was able to compare their behavior with those of the same species in the Catskills. When I went thither in June, arriving on the 18th, I found a few male Marcia, Var. D, flying, no females. This was exactly one month later than the first males had been seen at Coalburgh. The first female was taken 26th. June, and on 27 th and 28 th I took one each day, all of them Marcia, C. No more were seen, and no Morpheus, though I was dxily in the fields. So that the first female was thirty-eight days later than the first at Coalburgh. These three females I set on aster, and two forthwith deposited eggs.

The eggs were mailed to Coalburgh, and, returning soon after, I found that they had hatched, 3d July. 'The first moult occurred on the 9th, the second on 12 th, the third on 15 th, the fourth on 18 th, and the first chrysalis was formed on 20th, its butterfly emerging 29th July. So that the periods were, egg six, larra seventeen, chrysalis nine days. Five per cent. of this brood became lethargic after second moult. This was the second generation of the butterfly of the season, from the first laying of eggs. All the emerging butterflies were Morpheus, no Marcia, and all were characterized by an intense blackness of the dark portions of the wings, as compared with any Coalburgh examples. Also nearly all the females showed the discal band on upper fore wings yellow instead of fulvous (Fig. 4). (This last peculiarity, the change in the band, appeared in some of the females of the third Coalburgh generation, but no other.) On the under side, the reticulated lines were unusually heavy, and the marginal cloud and brown patches largely extended and deep colored.

This second generation was just one month behind the second at Coalburgh. So far only could I trace the Catskill generation this year; but as, in 1875, Mr. 


\section{PHYCIODES I., II.}

Mead obtained egrgs on the 27th July and following days, the larva from which all hybernated, that would be the second laying of eggs of the season, and the resulting butterflies the first generation of the following year.

The foregoing Coalburgh observations were supplemented by others in August, 187\%. Between 14th and 20th, I obtained three lots of eggs, from which the larve in due time emerged. Those of the first all went on to maturity, giving butterflies after middle of September, the last emerging 26th. But of the other two lots all became lethargic. 'The reason for this difference I could not conjecture. It certainly was not owing to any change in the weather. In the field the species was abundant from 15 th to 25th August (this being the third brood of the year): But one month later, when the fourth brood should be flying, examples were remarkably scarce. In fact, I did not see more than a dozen. On 23d, I took one male, two females; one of the last was fresh from chrysalis and a fine Marcia, Var. C, snch as I take here in the spring. 'The other two were the summer form of the species. On 26 th, 1 took a female and set on aster. She laid about twenty-five egrgs and all proved infertile. It would seem, therefore, that in this district, part of the larva from egress laid by females of the third brood, middle of August, hybernate, and that the buttertlies of the next spring proceed from such larva only, no larve of any preceding brood having been known to hybermate. But a part of the larve of this third brood go on to maturity and produce butterflies last of September. Some of these may lay fertile eggs, but only in a very mild October could the larve from them mature, or their butterflies appear, and the generations could certainly go no further. But at the south, in the Gulf States, this fourth brood (there probably the fifth, owing to the interpolation of a brood in the spring) no doubt does mature, and its butterflies produce larva which hybermate; for fresh examples of the butterfly are taken in October and November', in Georgia and 'Texas. Of several received from Mr. Boll, taken in November, one was a female ILarcia, C, the others being of the summer form. There seems to be some tendency to a premature disclosure of the winter form in the last months of the year, such as is known in case of Colias Eurytheme. The same thing has been noticed in Phyciodes Phoon also.

At Coalburgh, therefore, there are three full generations, the first of which is Marcia, the second and third Morpheus, and the larva from the third in part hybermate. But those larva which go on to maturity produce the fourth generation of the butterfly, which is a partial one, and practically infertile. And in the Catskills, the species is digoneutic, there being two generations amulally, the first of which is Narcia and the other Mrorpheus, and a certain porportion of the larvæ proceeding from the first hybemate, so far as appears, and all those from 
the second. ${ }^{1}$ In a high latitude, or at a high altitude, we might then expect to find this species monogoneutic, and restricted probably to the winter form Marcia. And this is preciscly what does occur in the island of Anticosti, and on the southern coast of Labrador. Mr. Couper, who has collected on the island, informs me that he saw no examples Iater than 29th June, and expresses the opinion that no butterflies in Anticosti or Labrador produce a second brood. The summer is very short, and before the end of July the weather becomes cold. Of Tharos from Anticosti I received fourteen males, eight females. All the former were Marcia, Var. $D_{2}$ of the females, seven were $\mathrm{D}$, one $\mathrm{C}$. Of eleven males, two females, from Labrador, all were D. Of two examples from Lake Lahache, British Columbia, latitude $54^{\circ}$, the male is Marcia, D, the female C. Of four males from Colorado, all were MIarcia, D; of two females one was D, the other C.

On the other hand, I have received large numbers from southern Georgia, with the dates of capture; several from North Carolina, taken by Mr. Morrison; and many from middle Texas, from Mr. Boll. Those from Carolina were of the first two broods of the year, and the earliest were all Marcic, C. From Georgia the winter examples were Marcia, B and C. Mr. Boll sent examples of five successive broods, begimning with February and ending with November. The butterflies of the earliest brood were Marcia, B. All of the summer form were rery dark above, the black intense, the fulvous deep red, and some of the midsummer males had the upper side lightly reticulated and the under side of the hind wings alnost clear from markings of any sort. (Var. C, Fig. 5.) This variety appeared also in the examples from Georgia. A similar variety appears in the summer form of Phaon. The Texas Tharos are of small size, like those from the extreme north.

I have raised an immense number of Tharos larva from the egg to the butterfly. The eggs are obtained with the greatest.facility, and are laid almost immediately after the female leaves the chrysalis. The larva at all stages are hardy, and have not suffered from confinement. In their natural state they are at no period protected by a web, but are exposed and have no shelter beyond what the leaf over them affords. They are sluggish, differing greatly from the larva of Nycteis in this respect, and a pretty sharp jar is necessary to cause them to drop from the leaf. This they do in a coil, protected by their bristling spines from all harm. When about to moult they cease feeding, collect in groups,

I This habit of lethargy is serviceable in a two-brooled species, in a mountain region, and exposed to sharp changes of temperature. If the fate of the species depended on the last larval brood of the year, and especially if the larva must reach a certain stage of growth before they were fitted to enter on their hybernation, it might happen that an early frost or a tempestuous season would destroy all the larve of the brood. 
PHYCIODES I., II.

and rest nearly immovable for thirty-six hours. The body contracts, and as the time for the moult approaches, the skin becomes glassy, as it separates from the newly formed skin beneath. The new spines lie folded down and back, and as the old skin, after splitting behind the head, is shuffled past the successive segments, the spines and pencils of bristles suddenly spring up, and the latter instantly become divergent. For some moments the old mask adheres to the new face, but the larva presently proceeds to rub it off with its feet. When the larva prepares for chrysalis, it spins a button of white silk, and hangs suspended for about twenty-four hours, its position being nearly circular.

Dr. Aug. Weismann, in his essay, "Ueber den Saison-Dimorphismus der Schmetterlinge," Leipsic, 1875 , relates the history of experiments made by him with the view of determining the ficts concerning seasonal dimorphism; and experimenting on chrysalids of Pieris $N$ api, which presents itself under both a winter and summer form, and upon Vanessa Levana, which is the winter form, and Prorsa, the summer form of one and the same species, he found that by application of cold of the temperature $33^{\circ}$ Far., to the chrysalids of the summer brood, the resulting buttertlies could be changed more or less completely from the summer to the winter form, and yet emerge the same serison, but that it was not possible to constrain the winter into the summer form by the application of heat. And he concludes that this artificial change is based upon a reversion to the original form of the species, or atavism, which is most readily called out by cold; that is, by means of the same outside influence to which the original form was exposed through a long period of time, and the continuance of which has preserved in the winter form, to this day, the primitive markings and color. The arising of the summer form he believes to have occurred thus: During the so-called ice period, the summer was short and cool, and the existing butterflies could produce only one generation in a year. As the climate gradually became warmer, a period must have come on in which the summer lasted so long that a second generation could be interpolated. 'The chrysalids of Levana, which had hitherto slept through the long winter, could now, during the same summer in which they as larva had hatched, fly as buttertlies. There had come to be a state of things in which one generation grew up under very different climatic influences from the other, and gradually the difference which now exists between the two arose by the changing of the summer form. When the summer became longer, a third generation could be interpolated, so that two summer generations alternated with one winter.

Dr. Weismann further states that individuals of the Prorsa (summer) form sometimes emerge very late in the year (like those of the fourth brood of 
I'HYCIODES I., II.

Tharos which appear at Coalburgh, as I have stated), and that if the summer was lengthened by a month or two, these could lay the foundation of another summer generation.

The experiments related led me to try the effect of cold on chrysalids of the forms Walshii and Telamonides of Papilio Ajax, in 1875 and 1876. These are both winter forms, and from their chrysalids either the summer form Marcellus would have issued in a few days, or in case any chrysalis passed the winter, as happens to some extent in every brood of this species, either Walshii or Telamonides would have issued the next spring. The result was that a large proportion of the chrysalids subjected to cold yielded butterflies the same season, and nearly all these were changed to the winter form Telamonides. Where the cold was continuous (about $40^{\circ}$ ), the change was complete; where it was insufficient - and intermittent, the change was pairtial, individual butterflies blending peculinities of the summer and both the winter forms.

The experiments made on Tharos, in 1876, I have stated. 'The following year I brought to Coalburgh, from the Catskills, eggs obtained from Harcia. The chrysalids therefrom I placed in an ice-chest, at intervals of from ten minutes to some hours after they were formed. For twenty days they were subjected to a temperature of $33^{\circ}$ Far., when all were removed. They were divided into three lots, the first containing all which were exposed to cold at from one to nine hours after forming, the second at from thirty to sixty minutes, and the third at from ten to twenty minutes. But I afterwards discovered that in this last lot were three chrysalids which were two days old before exposure. The butterflies began to emerge on the seventh day, and by the ninth all had emerged that were alive. Of the first lot (exposure one to nine hours after forming), there emerged nime butterflies, 58 4․ The males were Marcia, D, and, though varying much on their under surfaces, were all like examples of Marcia taken in the Catskills. Of the females, two were good examples of Marcia, C, but the other two were suffused, the colors having run together, so that the definite markings of the species were lost; also the upper surfaces were more or less hoary. (Figs. 9, 10.) Of the second lot (exposure thirty to sixty minutes), emerged five females, no males. Three were very little if at all changed, but the other tro were suffused, though to a less degree than those before mentioned. (Figs. T, 8, 9.) Of the third lot (exposure ten to thirty minutes, but with three chrysalids at two days), there emerged two females only. One of these was not distinguishable from the summer form, but the other was a fine example of Marcia B, the under side of the hind wings being largely melanized.

Figs. 11, 12, represent the butterfly described by Mr. Saunders as Melitwa Packarclii; but it is evidently a suffused Tharos, of the same character as those 


\section{PHYCIODES I., II.}

produced artificially. It was taken at Grimsby, Ontario, and probably owes its peculiarities to its chrysalis having been frozen soon after it formed. That such examples are not frequently seen on the wing may be partly due to the fact that chrysalids of tender age subjected to severe cold are usually killed by it. Fig. 13 is the likeness of an aberration sent me by Professor Garman, and taken at Normal, Illinois.

Dorfineister, who experimented on the effect of cold upon the chrysalids of butterflies, as related by Dr. Weismamn, was led to believe that temperature exerts the greatest influence during the turning into chrysalis, but nearly as much shortly after that time. By my experiments it would appear unnecessary that cold should be applied before the chrysalis has fully hardened in order to effect a change of form, and this requires a longer or shorter time in different species, but never more than a fer hours. In 1876, the chrysalids of Tharos, which were exposed at from six to nine hours after forming, changed as completely as those at from three to six hours. In 1877 , all which were exposed at from one to nine hours changed, while some which were exposed at from thirty to sixty minutes were not changed at all, though others were. The turning-poinit is evidently not at or immediately after the forming of the chrysalis. 'The cold completely retards the development of the butterfly, and at least the full natural chrysalis period passes after removal from ice before the butterfly emerges. 'This has happened in every case under observation, even when from insufficient or intermittent cold no change of form has resulted.

The change of form seems to be almost wholly a matter of coloration, for the shape of the wings is not altered. The natural shape of Walshii is quite different from that of Marcellus, but when the latter by application of cold is forced to assume the markings of Walshii, it retains its own shape nevertheless. In the other species experimented on there is no difference in shape between the winter and summer forms. The coloring process in all chrysalids does not set in till just before the butterfly emerges, no matter how protracted the pupal period. It may be days or weeks, and in the case of over-wintering chrysalids, it is many months. On removing one of the wing cases, soon after the chrysalis is formed, the wing is seen to be a delicate, transparent, colorless membrane, crossed by white veins. Very gradually this membrane thickens, losing its transpareney, and becomes of a dull white. A few hours, or one or two days, before the close of the period, it grows darker, then a faint discoloration comes on, and the pattern begins to show itself, the colors becoming strong and the markings welldefined as the disclosure is about to take place. On removing the wing case from a chrysalis just off ice, the wing presents itself in its colorless and transparent stage; that is, the development has been arrested by the cold, and the 


\section{PIIYCIODES I., II.}

chrysalis apparently comes ont of, in precisely the same condition as it went into, its cold bath. Nevertheless, during the subjection to cold, some change has taken place, by which the coloration of one of two dimorphic forms of the butterfly has been made to appear rather than the other.

As to the degree of cold necessary to effect a change of form, it need not be extreme, or so low as the freezing point. The most successful changes, with little loss of life, have been effected when the temperature was about $40^{\circ}$. The steady coolness of the natural temperature on the last chrysalids at Hunter, in 1876, effected a complete change of form. A freezing temperature has resulted in the ruming of the colors to a considerable extent, and a few butterflies changed without suffusion, but the loss was very heavy. In 1878, I placed twenty-six chrysalids of Grapta Interrogationis on ice, keeping them at $32^{\circ}$; for an average period of fifteen days, and every one was destroyed. At the same time, however, chrysalids of $A j a x$ were in the box, and most of them survived the exposure, though up to the date of this writing, now forty-one days after they were removed from the ice, only three butterflies have emerged. One of these was exposed in chrysalis at full three days after forming, and is changed to Telamonides; and the other two, exposed at less than twelve hours after forming, are Walshii in markings, with the shape of Marcellets.

Of the four principal varieties of the winter form of Tharos, A appears to be an offset of $B$, in the direction most remote from the summer form, just as Walshii is on the further side of Telamonides, remote from the summer form ILarcellus. On the contrary, $\mathrm{C}$ leads from $\mathrm{B}$ through $\mathrm{D}$, directly to the summer form. Var. B may be nearest the primitive type of the species. Besides that this has appeared constantly in the buttertlies changed by cold, it predominates in this region over the other varieties. Moreover, its distinctive peculiarity of color is seen in the nearly allied species Phaon and Vesta, both which are seasonally dimorphic, and seem to be restricted in their winter forms to the single phase denoted by B in Marcia. And in their summer generations both these species have a close resemblance to the summer Tharos, even to the peculiar variety $\mathrm{C}$ of this form, which is found in all three. It is noticeable that these three species should be seasonally dimorphic, with the forms so resembling each other, while the other species of Phyciodes inhabiting the Atlantic slope show no especial difference between their winter and summer generations.

The significance of these phenomena I take to be this: when Phaon and Vesta and Tharos were as yet only varieties of one species, the sole coloration was similar to that now common to the three. As they gradually became permanent, or in other words, as these varieties became species, Tharos was giving rise to sev- 
PHYCIODES I., II.

eral sub-varieties, some of them in time to become distinct and well marked. while the other two, Phaon and Vesta, remained constant. As the climate moderated and the summer became longer, each species came to have a summer generation; and in these the resemblance of blood-relationship is still manifest. As the winter generations of each species had been much alike, so the summer generations sprung from them were much alike.

And if we consider the metropolis of the species Tharos, or perhaps the parent species back of that, at the time when it had but one annual generation, to have been somewhere between latitudes $37^{\circ}$ and $40^{\circ}$, on the $A$ tlantic slope, and within which limits all the varieties and sub-varieties of both winter and summer forms of 'Tharos are now found in luxuriance, we can see how it is possible, as the glacial cold receded, that only part of the varieties of the winter form might spread to the northward, and but one of them at last reach the sub-boreal regions, and hold possession to this day as the sole representative of the species. And at a very early period, the primary form, together with Plaon and Vesta, had made its way southward, where all three are found now, neither of them, so far as appears, having developed any marked varieties of the winter form.

It is the female of the summer form of Tharos, and that rariety of it which discovers the brown discal patch on the under side of the hind wings ( $V$ ar. B), which Drury figured under this name, in 1750. Cramer's Tharos is stated to have come from New York and reference is made in the text to Drury. But the figures are coarsely drawn and rudely colored, and there has been some difference of opinion as to the real species intended to be represented by them. Cocyta, Cramer, Figs. A, B, Plate 101, is Tharos male of the summer form (Var. A), and Fig. C is probably intended for female of same; but the text refers it to Surimam, and it is given with a doubt expressed as to whether it belongs to the male figured or not. Dr. Boiscluval considers this Cocyta to be synonymous with Morpleens, Fabricius, and locates it in southern California. Fabricius describes Norpheus as a North American insect, and in language applicable to the summer form of Tharos. "Parvus. Ala omnes integerrime, fulva, maculis margineque nigris. Postica punctis sex nigris in strigam dispositis rersus marginem posticum. Subtus antica fulva, nigro maculatw, postica pallascentes strigis undatis, margine punctisque sex fuscis." I therefore call the species Tharos, the summer form Morpheus, the winter form Marcia.

The figures of the male Tharos in Bois. and Lec. are not very exact, but maly be taken to represent the form Morpheus. But the female must have been drawn from Batesii, and evidently Dr. Boistuval had this insect before him when he wrote these words: "We possess individuals which we consider as varieties, of 
PHYCIODES I., II.

which the primaries are black, with some fulvous spots and a transverse macular band of the same color. The hind wings do not differ, except that the lines on the basal area run together. Beneath, the hind wings are wholly deprived of a brown border; the fore wings have likewise a part of the border effaced, but that which remains is blacker than in ordinary individuals." 

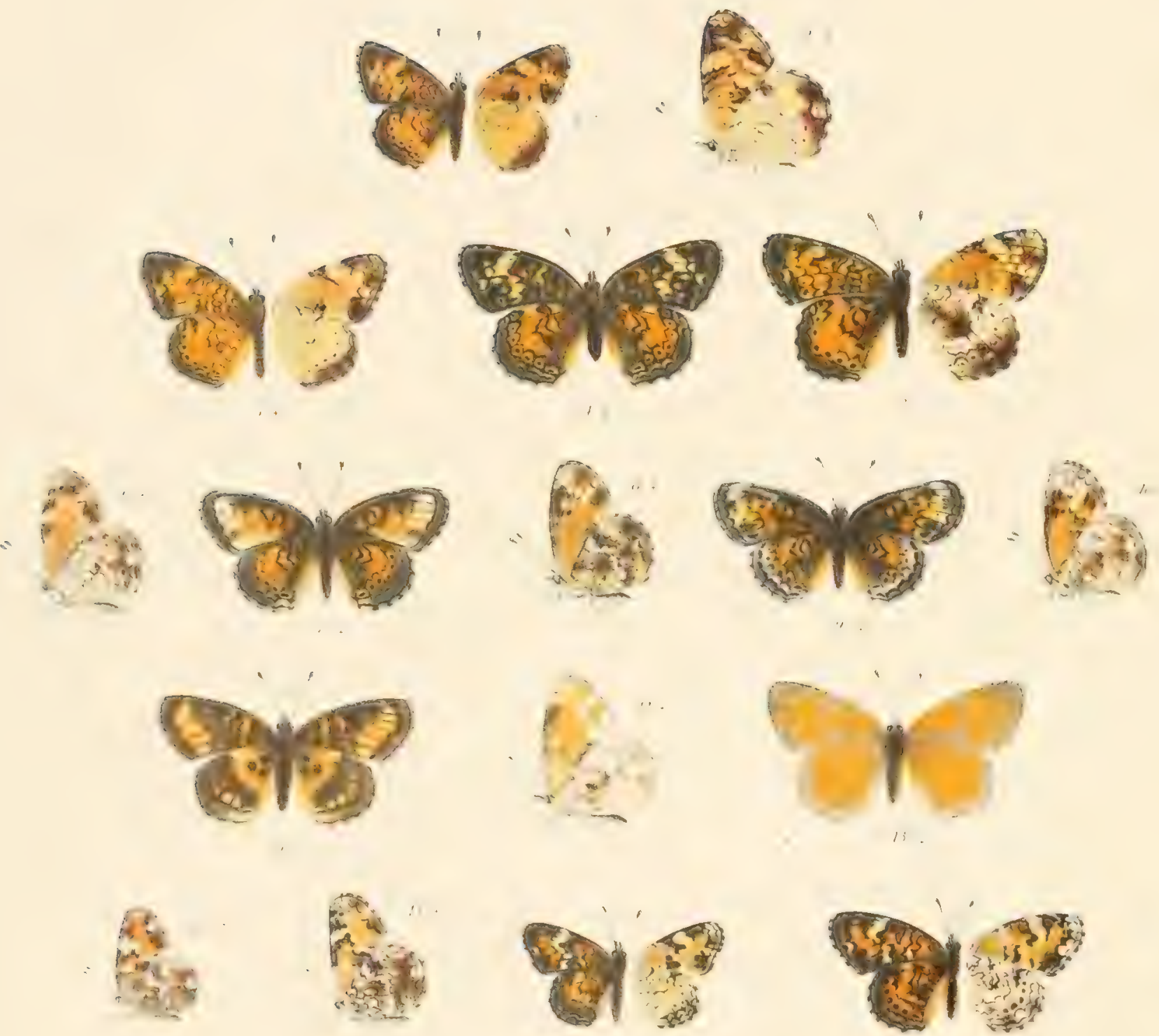

$$
1 ;
$$
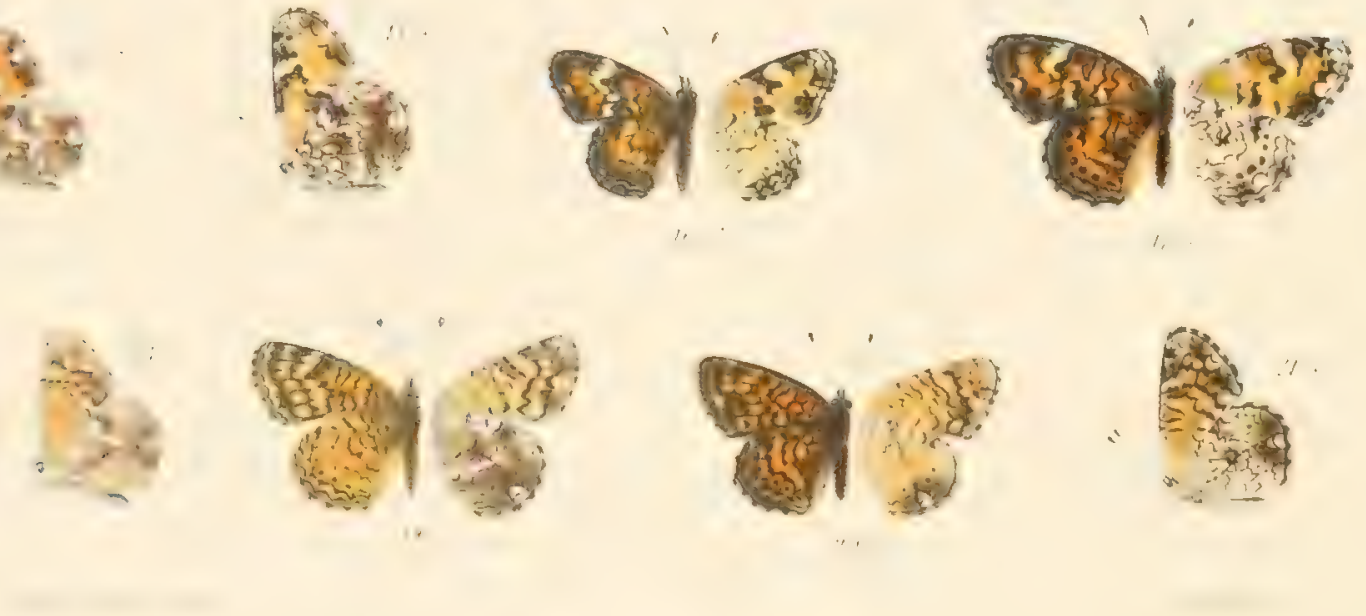


\title{
PHYCTODES II.
}

\author{
PHYCIODES PHAON, 14-17. \\ Phyciades Ihccon, Edwards, l'roc. Ent. Soc. Phil., II., p. 505.
}

Dimorphic form HIEMALIS. (Figs. 16, 17.)

MALE. - Expands from 1 to 1.4 inch.

Upper side black, bander and spotted with fulvons, the patterns being the same as in the melanic examples of the summer form of Tharos; the extradiscal band on primaries being lighter, more ormge-fulvous than in that species, and the simuous discal band rarying from yellow-ochraceous to sordid white; on secondaries the extra-discal series of pupillated spots is limited to six, and these are, in most examples, partly covered by the broarl black marginal borders; fringes of primaries black, yellow-white at the ends of the nervules, of specondaries yellow-white, black at ends of the nervules.

Under side of primaries orange-fulvous, the markings as in Tharos; the hind margins bordered with brown, deepening into black next inner angle; at the apex, and in the upper median interspace, yellow; the discal band repeated, diffuse, yellow; and next within this a conspicuous black band.

Secondaries pale buff, unevenly clouded with brown over the extra-discal area to margin, and on disk and toward base; the markings as in Var. B of the winter form of Tharos, the disk crossed by a clear band.

Body black, beneath white, the extremity of abdomen yellowish; legs fulvous, the imer sides of the femora white; palpi white at base, yellowish above, black on upper side; antennæ black, yellowish on under side, ringed with white; club black, fulvous at tip.

Female. - Expands 1.4 inch.

Similar to the male in color and markings.

Dimorphic form ESTIVA. (Figs. 14, 15.)

Same size as its co-form and not distinguishable on the upper side; on the 


\section{PHYCIODES II.}

Dimorphic form ESTIVA. (Figs. 18, 19.)

Same size as the winter form, and often not to be distinguished from it by the appearance of the upper sicle; but many examples are very black, the fulvous markings all reduced; on the other hand, some have the fulvous preponderating, as in the lighter examples of the summer form of Tharos, which they then greatly resemble; on the under side, primaries differ in no important respect from the winter form; secondaries uniform light ochraceous, the reticulations very fine, brown or ferruginous, and disposed as in the summer Phaon, the margimal cloud slight and narrow, the costal patch slight or wanting. In the female the ground is varied in pale and darker yellow, the band pale, as are several of the spots in the interstices near base; all the lines heavy, ferruginous; the marginal cloud extended toward the disk, the costal patch larger; there is also a distinct ferruginous patch on middle of the risk, as in one of the rarieties of summer Tharos.

Testa seems to be common in midille and southern 'Texas, and I have received a long series of examples from $\mathrm{Mr}$. Boll, showing all the variations observed by him. There is no marked difference between individuals of the winter form. The species flies in successive generations, from February to November, and there must be at least five amnual broods. The food-plant is at present unknown, as are also the preparatory stages. 


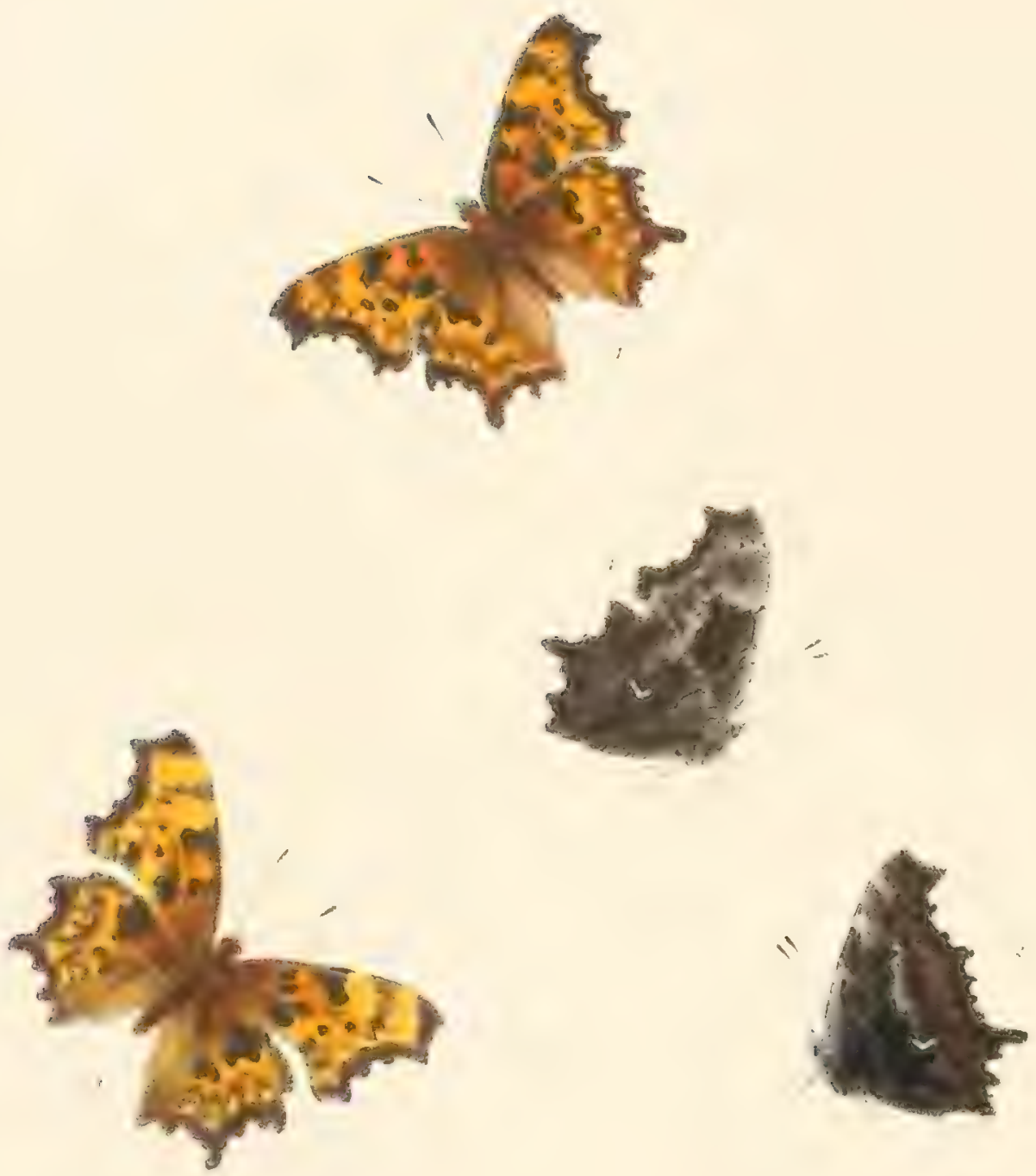


\title{
GRAPTA I.
}

\author{
GRAPTA SILENUS, $1-4$. \\ Grapea Silenus, Edwards, Trans. Am. Ent. Soc. 1870, p. 15.
}

MLiLE. - Expands 2.2 inches.

Primaries molerately incised; slightly dentated ; tail long, broad, and straight; a prominent dentation between tail and inner angle, which last is much produced.

Upper side deep red-fulvous, clouded with brown-ferruginous next base of each wing and on disks, and spotted with black; hind margins liave a broad common border of nearly miform width, black with a ferruginous tint; on the imner side a series of separate, pale fulvous spots, yellowish next apex of primaries, irregular in size, lanceolate; primaries have a large sub-apical ferruginous pateh on costal margin, another near inner angle, a lyoad black spot from costa covering the are, two oval spots in cell placed transversely and sometimes confluent, two others in first and second median interspaces, and a large sub-ovate spot on sub-median interspace extending partly over the one next above.

Secondaries have the entire costal margin brownish-black, a large irregular black patch on disk between upper branch of sub-costal and the median nervure; a brownish-fermginous patch at base of the upper median nervules; the whole extra-discal area suftused with ferruginous, passing imperceptibly into the marginal border; fringes fuscous, with a very little white in the emarginations.

Under side mostly in sharles of black or blackish-brown, the entire surfuce, except where deep black prevails, covered with fine, abbreviated streaks darker than the ground; apex of primaries fintly tinted with olivaceous; costal margin brown, with a few gray scales near apex, a whitish patch beyond extremity of cell and a smaller one nearer base; base of primaries brown, of secondaries brown next costa, black towards abdominal margin; the disks crossed by a common, broad, black band, very irregular in its exterior ontline, on lower part of secondaries merging into the black basal area, outside the band, on primaries and upper part of secondaries, grayish-white for a little space, densely streaked, and beyond to margin blackish-brown; the extra-discal points nearly or quite lost on the dark groumd; sub-marginal crescents black, obsolescent, often wanting altogether; in the cell of primaries three elongated, narrow, deep black spots, two of 


\section{GRAPTA I.}

which lie along the costal nervure, separated by a very small interval, and each edged by a velvety black line; the third, along median nervure, illy-defined with-

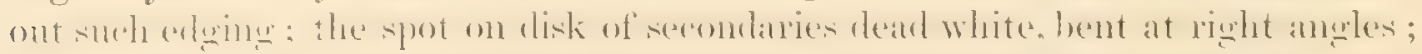

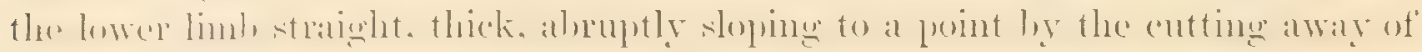
its upper side; the upper branch narrower, slightly curved, nearly as wide at top as elsewhere and ending bluntly; fringes with the white area more extended than on upper side.

Body above black, covered with ferruginous hairs, below black, sometimes with a gray sharle; legs gray-brown; palpi black at base and in front, with whitish hairs at sides, ferruginous at top; antemne black above, fulvous below; club black, fulvous at tip.

Feurale. - Expands from 2.1 to 2.3 inches.

In shiape very like the male; upper side dull yellow-fulvous, the spots large; under side more brown than black, the extra-discal area to margin pretty uniform in shade, the ground being dark gray, nearly lost in the denseness of the brown streaks; sub-marginal points and crescents obsolescent; silver mark of same shape as in the male, often quite as heavy.

LARVA unknown.

Sitemus is found in Western Oregon and in San Juan and Vancouver's Islands, where it flies in company with Satyrus. It may be readily distinguished by the general blackness of both surfaces, by the large size of the black spots on upper side, by the obsolescence of the usual sub-marginal crescents on under side, and by the character of the silver spots. In this last respect and in shape of wings it is near Gracilis; in the deep fulvous color, Fanms; in the sub-maxginal crescents of under side, Progne; but in important respects differs from each of these.

The genus Grapta is well represented on this continent, a greater number of species being already known than in the world beside. And as several are very local in their habit, it is highly probable that others remain still to be discovered. Our knowledge of the butterflies of the entire Rocky Mountain district-excepting Northern Colorado - and of the vast extent of territory to the Northwest and North, amounts as yet to a mere nothing, restricted literally to the scanty collections of the govermment surveying expeditions, and an occasionil specimen from some chance traveller. It is noticeable that the American Graptas show little tendency to rum into varieties. In a series of an hundred Comme, or as many $F^{7}$ cunus, all will be essentially alike, not differing between themselves to a greater degree than a number of Cardui or Atalanta. And in the case of those species that are dimorphic, I find the two forms of each nowhere convergent. 'This is remarkable, because there is a general similarity between so many of the species 


\section{GRAPTA I.}

that is very perplexing to lepidopterists who have but a limited acquaintance with them. And it is so contrary to the nature of the protean $C$ album, which branches into forms that imitate several of the American species (see notes on Comma and Satyms, Vol. I.), and into some that so far as known are not represented here, that it seems searcely credible to those who are fimiliar with that one species only. Fortunately the preparatory stages of most of the North American species allied to $C$ album, are known and deseribed; and the differences between the larva and chrysalids, sufficiently prove the distinctness of each such species, from the others and from $C$ album.

It is a peculiarity of this genus that so many of the species are dimorphic. In notes upon Interrogationis, Vol. I., I suggested that Comma and Dryas might also prove to be dimorphic forms of one species, but I doubted if the case would be found parallel with Interrogationis, in which the two forms seemed to be of equal value, either one producing both at all seasons. It seemed probable, that Comma and Dryas appeared in the early summer brood, and Comma only in the autumn, and this, because I had always met with Dryas in summer and not later, when Comma was exceedingly abundant, especially in West Virginia. 'The relationship was finally established in 1873 , by Mr. Mead and myself, at Coalburgh, and again by myself in 1874, and proves that the dimorphism has no seasonal peculiarity. In the first instance, we obtained eggss of Diyas, by inclosing two females in a muslin bag on a branch of hop-vine, of course, after examining carefully to see that no eggs had been already laid thereon. This was 30th July. In a few hours there were many eggs deposited on the leaves and on the muslin, and often in columns of four or five, as is the habit with Interrogationis. By 5 th August, the larva were hatched, and we carried them through their successive moults with little loss, so that by 21 st August, when the first changes to chrysalis commenced, there were more than sixty mature larva. 'There was not much variation in their appearance, most of them being of a black glound, with more or less yellow in short lines, and as represented on Plate of Comma, Vol. I. fig a. Only one of the lot was yellow-white, as shown on the Plate of Dryas, and eventually this one produced a Dryas buttertly. On 30th August, the buttertlies began to emerge, and all were Comma, excepting six, $2^{\ddagger}, 4^{\circ}$, which were Diyas. This last, therefore, has caterpillars of both the white and the black types, and appears in the autumnal brood, though perhaps not so numerously as Comme.

On the 10th May, 1874, I took a female Comma, true to its type, the upper side of hind-wings being red, and the under side of both wings plain brown, and inclosed in same way as before related, after examining the branch to which I fastened it. Within the next two days eggs were laid abundantly, and in due time I counted thirty-nine caterpillars. 
GRAPTA I.

At the last moult, nearly all these were light-colored, many being creamwhite, and scarcely half a dozen were black. On 4th June, they began to change, and by 6th, there were thirty-five chrysalids. On 10th June, the first imaso appeared, and by 13 th, there had emerged thirty-four butterties, $23^{\ddagger}, 11^{\circ}$, every one Diyas. One died in chrysalis. Dryas may be considered as the prevailing early summer form of the species, and Comma the autumnal.

A memorandum of the experiment made in 1873 was communicated to the "Canadian Entomologist" for October of that year, and I proposed that the name of the species should be Comma, and the two forms be designated as vars. Harrisii and Dryas, in the same way that Interrogationis is known in its two forms as Interrogationis vars. Umbrosa and Fabricii, this formula expressing clearly the relationship established.

A similar commection may exist between other Graptas. From the fact that the two forms of Interrogationis differ much in outline of wing, in color and markings, while the silver discal spot is identical, and that the same holds good of the two forms of Comma, I should not be disposed to look for relationship of this nature between two in which the discal spot is essentially different; as where one bore the $\mathrm{C}$ and the other the angular mark seen in Sileme. That is one reason why I do not believe Gracilis will be found dimorphic with Faumes as sugrgested by Mr. Scudder; the discal spot of the former species being a bent mirk something like Silems, but more like Progne, and of the latter a G, with barbed ends. The two species have been found inhabiting the same localities in the White Mountains, N. H., and on Anticosti Island by Mr. Couper. But in the Catskills, where Faums swarms in the month of August, the united collecting of Messrs. Mead and Meyer with myself, embracing at least six seasons, have never brought to light one Gracilis. Now wherever one form of Interrogationis, or one of Comma is found, both are found, and it is hardly allowable, unless proved, that Ficums could be dimorphic in one district and not in another. Progne and Comma both associate in the Catskills with Fannes, though in vastly less numbers. Mr. Couper wrote me on his return from Anticosti, in November, 1573, that while there, on 21st July, he found a Grapta caterpillar feeding on wild currant: in color "yellow, with long and short black marks on its sides;" and the spines were all "pink colored." The length of this was one inch, and therefore it was near maturity. As this is not the description of Proyne, nor 


\section{GRAP'TA I.}

Comma, nor Fanme, I presume it was Gracilis, as $\mathrm{Mr}$. Couper conjectured. It certainly was not Faumes, which is party-colored, in the general style of that of $C$ album and of Zephymes, but with differences. We owe this discovery of Foumes larvil to Mr. Seudder, who took mature specimens on willow in the White Mountains, in 1873, and who will publish a description and illustration of it in his fortheoming" work on the "Butterflies of New England." Willow is an musual food-plant for a Grapta, and not set down as one to which $C$ album is addicted.

It is desirable that the several American species of Gropta, where the larra are not already thoroughly known, should be experimented with, and lepidopterists having access to any of them, will do good service if they will take pains to obtain the eggs in the mamer I have indicated. 'This is always practicalble where the food-plant is known, and may be found so where the plant is only matter of conjecture, by testing the butterlly with any or all of the plants on which other Grapta larve feed. The larva are easily raised, being hardy and bearing confinement well, and as they mature rapidly there is very little trouble in breeding them even from the egg. It is easy to determine the female in this genus, apart from the plainer color and lesser degree of ornamentation that characterizes her as compared with the male. In the latter, the aborted forelegr: which may be seen folded down upon the thorax are thick and furry; in the female, thin and slightly clothed. 'This peculiarity was first pointed out to me by M.. J. A. Lintner, and I have often had occasion to test its value, especially in cases of abraded specimens, where the distinctive markings and colors were much obliterated. 



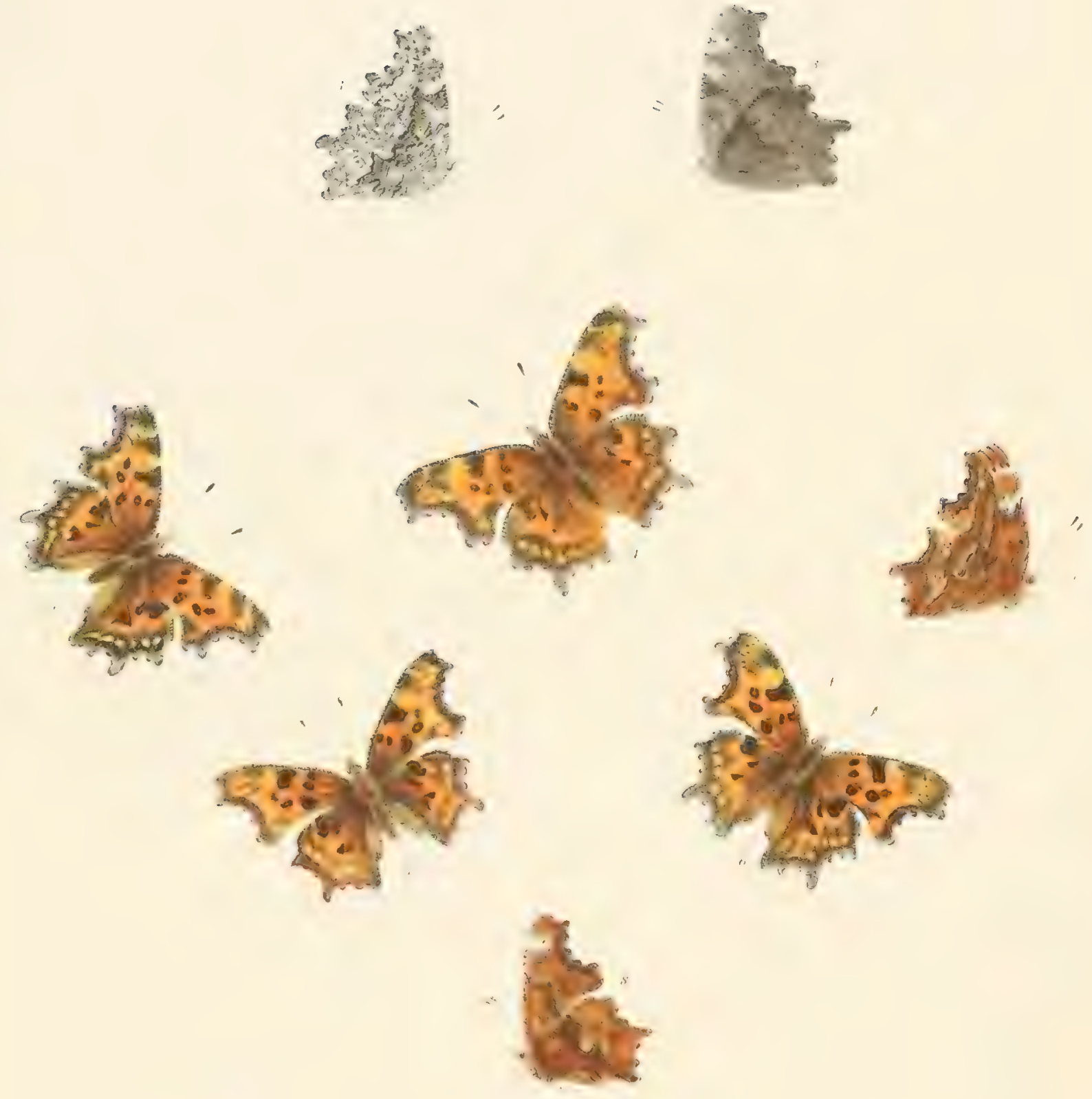


\title{
GRAPTA II.
}

\author{
GRAPTA HYLAS, 1-4. \\ Grapla IIylas, Edwards, Trans. Am. Ent. Soc., Vol. IV., p. 68, 1872.
}

MLLE. - Expands 1.7 inch.

Form neal Faums; primaries deeply incised, secondaries moderately; the two angles of secondaries somewhat and almost equally produced; tail broad, and a prominent dentation at the extremity of lower branch of median.

Upper side dull red-fulvous at bases of wings, fading into yellow-fulvous on the disks; the marginal border of primaries fuscous, edged within by a series of separated yellow spots, which are either serrate or dentate; the sub-apical patch and the patch near imer angle ferruginous on a black ground; the other spots black and as in F'cumus; secondaries have a broad fusco-ferruginous marginal border which covers one third of the wing, and includes a sub-marginal series of small rounded or lunate yellow spots; on costal margin a large black spot, a smaller one on the are, the two often confluent; inner margin much obscured by brown; the edges of both hind margins gray, dusted more or less with yellow; fringes white in the emarginations, fuscous elsewhere.

Under side marbled in shades of gray, tinted with brown over basal area, and densely covered throughout with fine abbreviated streaks of black or fuscous; the basal area limited by a dark, irregular, common band, which is erdged on its outer side by a black line; the space beyond to margin gray, of nearly an uniform shade, the usual sub-apical patch on primaries scarcely lighter than the rest; across the disks a common series of minute spots or points, complete on secondaries, sometimes wanting on upper half of primaries; under a glass these points resolve into dull green spots with black edging, or into patches of black and green scales; the incision of primaries bordered by dull green lunations edged on either side by black; similar lunations are found on secondaries entirely across the wing, but often they are partly wanting; discal mark a fine bent silvered streak, the upper limb curved, the lower straight, and the two equal in length. 
Body fuscous above, dark gray with a brown tint below; less and palpi gray; anteme fuscous above, anmulated with gray below; club black, tip yellow.

Fexale. - Expands 1.8 inch.

Upper side paler, the yellow spots larger; under side uniform brownish-gray; the markings nearly obsolete, the marginal lunations wanting; the discal mark scarcely distinguishable.

LARVA Unknown.

The only examples of Hylas thus far known to me have been taken in Colorado. Mr. T. L. Mead discovered the species in 1871, and since that time a few individuals have appeared among the butterflies collected by Dr. Hayden's expeditions. The information given of its habits is by Mr. Mead, which I repeat from the notes on G. Zephyrus, Vol. I. of this work.

"On the 28th August (1871), on the South Park road, in the mountains, and about twenty miles from the Park, I found a large smooth rock exposed to the sum, on which were several Graptas, Zephyyrus, and a species numbered 3 (Tylas). On this rock, and in the immediate vicinity, I captured twenty Zephyrus, and five of the other. I had previously, on the 16th August, found both species together in the vicinity of Berthoud's Pass, where fifteen of the smaller ones were taken with a few Zephyms, on a small patch of flowers high up the mountain. These were the only occasions on which the small Grapta was seen. Zephyrus was taken abundantly throughout the State wherever collections were made." 'To this I add that I have received Zephymes from various localities since 1871 . 'The expeditions under Lieutenant Wheeler have taken it both in Southern Utah and in Arizona; and, as stated by me in Vol. I., it has been received from Nevada, California, and even from Fort Simpson, Mackenzie's River.

Considering then that Zephyrus is so wide-spread a species and IIylas so local an one, and that the two agree neither in size, shape, color, or otherwise, except in group characters, there would not seem to. be much ground for a suggestion of relationship between them. Yet Mr. Scudder, in his lately published Synonymic List, treats the two as established dimorphic forms of one species, which he calls Zephyrus, and renames Zephyrus Edw. as Thiodamas var., giving the other as Hylas var. No evidence of dimorphism is alleged to have been discovered, nor does Mr. Sendder profess to know more of Hylas than what I have stated above. It is enough to say that such a relationship would be highly interesting if proven. That the two species were together in the few instances in which Hylas was seen is nothing, for that is the rule wherever any two or more species of Grapta are found. Faunus, Comma, and Prorne constantly associate. 


\title{
GRAPTA II.
}

\author{
GRAP'TA MARSYAS, \\ Grapte ITarsyas, Edwards, Trans. Am. Ent. Soc., Vol. III., p. 16, 1870.
}

MALE. - Expands 1.6 inch.

Primaries much incised, secondaries moderntely; outer angle of secondaries but little, "the inner angle largely, produced; tail long, broad and curved, followed by a deep and broad incision, and a narrow dentation at the extremity of the lower branch of median.

Upper side bright fulvous, obscured at base; primaries have a broad fuscous marginal border on which is a series of indistinct yellow spots, scarcely more than indicated by a yellow shade in the several interspaces, except near the apex, where they become distinct; the sub-apical patch large, fermuinous; the patch at imer angle small, rounded anteriorly, ferruginous; the other markings as in Commere.

Secondaries have a broad pale fuscous border, occupying one third of the wing, gradually passing into the fulvous shade of the disk, and completely inclosing a series of illy-defined small yellow spots; a large black spot on costal margin, a second, of small size, on the are, and a third at the origin of the upper median nervule; immer margin much obscured by brown; fringes alternately yellow and fuscous next the apex of primaries, white in the emarginations of the incision, fuscous elsewhere, and alternately white and fuscous on secondaries.

Under side varied in shades of brown, with a vinous tint over the basal area ; secondaries and the outer two thirds of primaries much streaked with darker brown or ferruginous; upon the disks a common band, irregular, and much as in Comma, the outer edge on secondaries only lined with dark brown; a dark stripe on secondaries near base; the space beyond the band gray across the median nervules of primaries and the discoidal nervules of sccondaries, this shade nearly hidden by the dense streaks; apex of primaries olivaceous, the color limited below by a fermginous stripe along the nervule; the sub-apical patch grayishgreen on a white ground; along the incision, and on entire margin of second- 


\section{GRAP'TA II.}

aries, a narrow broken stripe of light green, edged on the anterior side by black; the ustul extra-discal row of points distinct on primaries; the silver mark an are of a circle, thickened at the upper end, sharply barbed at the lower.

Bolly above fulvous, beneath vinous-gray; legs buff; palpi buff below, fulvous above and at tip; antennæ fuscous above, ochraceous below; club black, tip fulvous.

Fevile. - Same size.

Primaries less incised; tail short, narrow; the dentations less prominent; upper side as in the male, the yellow lunules obsolete; under side less variegated, the colors being brown in shades, and without white except along costal edge of primaries near apex; both wings densely streaked as in the male; the extra-discal points distinet, the green stripe indistinct on primaries, obsolete on secondaries; silver marks shaped as in the male, but larger, more delicate, pointed at the upper extremity, thickened, not barbed below.

This little species is only known at present by the pair delineated on the Plate. They were taken some years ago by the late M. Lorquin, and assigned to Mr. Reakirt, with no other locality than "Rocky Mountains."

Mr. Scudder (Syn. List, 1875), surmises that Marsyas may be dimorphic with Satymes. The two are different in size, in the ormmentation of both sides, and in the shape of the silver spots; and this holds in both sexes, as may readily be seen by comparing the figures of Satymes (Vol. I., Plate 40) with the figures now given of Marsyas. Satymus is not an uncommon species over large sections of the continent. It is found throughout the Rocky Nountains, and to Vancouver's Island. To the eastward its range is at least as far as Ontario, Mr. 'T. L. Mead having taken two examples a few miles north of Port Hope, in 1874 . It should be borne in mind when estimating the probabilities of dimorphism, that in the only species of Grapta in which this relation is established, viz., Interrogationis and Comma, both the dimorphic forms are found wherever one is foumd, and they agree in size, in the markings of the upper side, and in the form of the silver spots. In Comma there is an agreement also in shape. The differences in both species are found in the coloration of the two sides and in the markings of the under side only; and in Interrogationis there is a slight diflerence in shape, the primaries of one form being more decidedly falcated. If Marsyas, then, is really dimorphic with Satyrus, there should at least be some points of argreement, and the presumption is fair that it would fly with Satymes, and inhabit the same localities. 


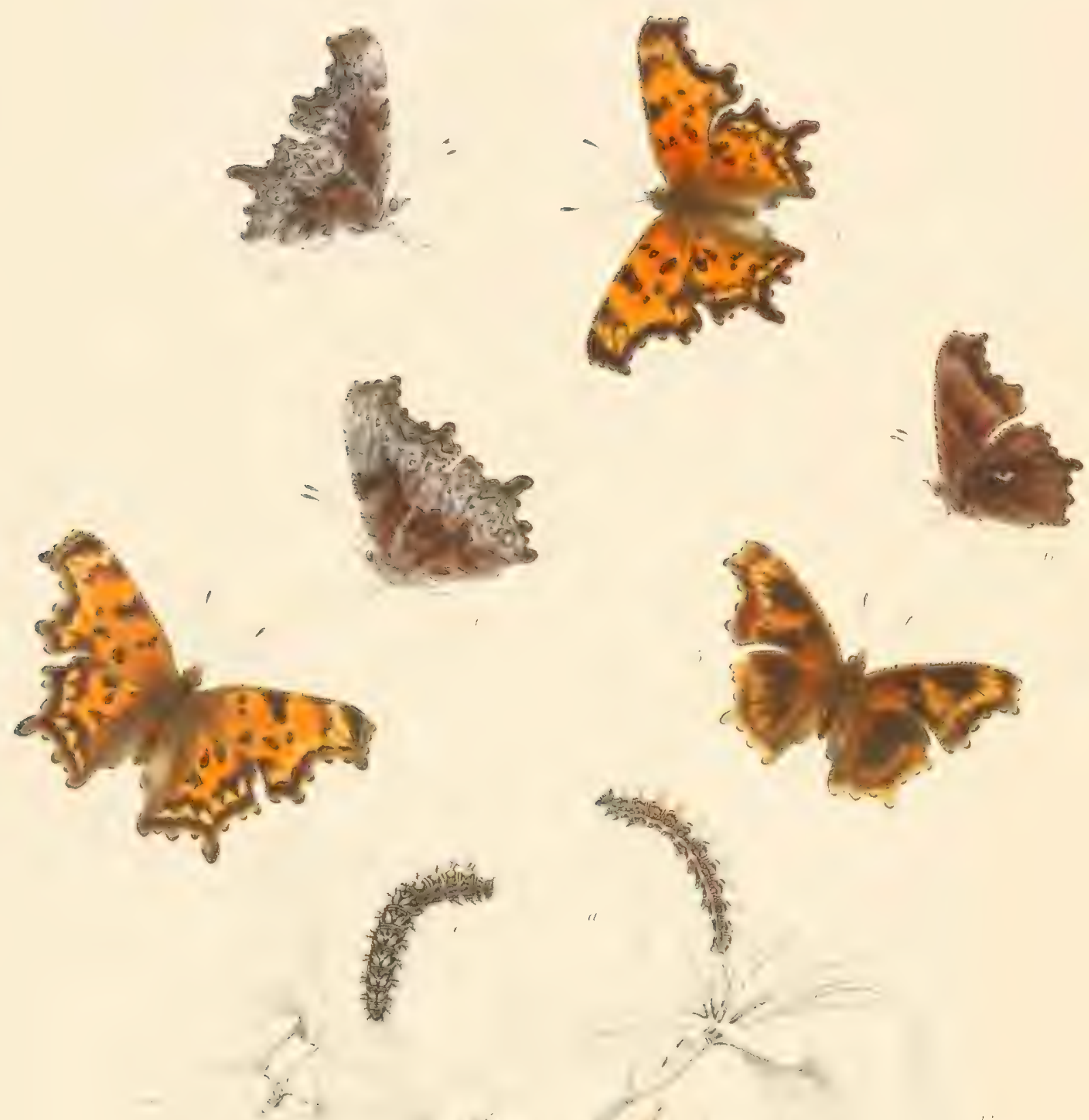

$i+$ int $\quad 4$.

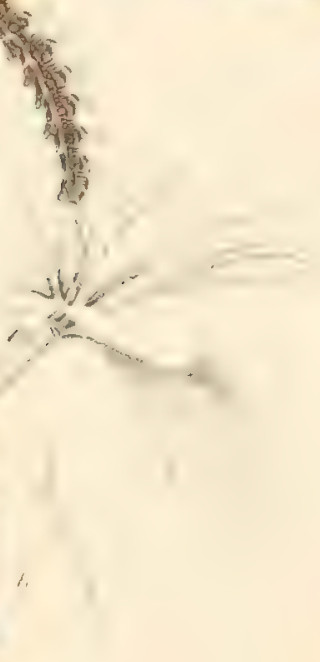




\title{
GRAPTA IIT.
}

\author{
GRAI'TA RL'SICUS, 1-4. \\ Grapta Tusticus, Edwards, 'Trans. Am. Ent. Soc, Tol. T., 1. 107, 1S74. Tar. Silvizs, \&, Edw., id., p. 108.
}

MALE. - Expands 2 inches.

Near Founus; primaries rather deeply incised; both angles of secondaries produced almost equally; tail long, broad, curved, followed by a deep incision, and at extremity of lower branch of median nervure a prominent tooth.

Upper sicle dull red-fulrous, pale on disk of primaries; marginal border of primaries broad, dark red-brown, in the incision mearly black; of secondaries wholly red-brown, occupving one third the wing, clearly defined on its inner edge, aud not shading gradually into the fulvous ground, as in Founus; the submarginal spots lunular, bright yellow, those of secondaries large; the other markings deep black, and disposed as in the allied species; hind margins edged with yellow seales, especially along the incision, and upon the anterior half of secondaries; fringes largely black, with a mixture of red-brown, and in most of the interspaces a little white.

Under side much less variegated than in Faums; the basal areas brown, darkest along their outer limits, and contrasting sharply with the pale olive-brown of the remainder of the wings; in cell of primaries two long concolored spots, edged with black, in that of secondaries a trausverse curved black stripe, and above this cell a few abbreviated fine black streaks; on costa of primaries a narrow erlging of white one third the distance from base to apex, and a sub-apical gray patch on white ground; the points on hind margin above the incision ferruginous; along the incision and to imner angle a submarginal band of green, formed of confluent crescents edged with black, and on basal side narrowly by gray; beyond this band is a transverse series of green spots, - the one on upper median interspace obsolete, - all edged on the outer side by black scales, and more or less by gray. Secondaries have a submarginal row of green, black-edged spots, separated, mostly crescent, crossing the entire wing, and an imner row larger than those on pri- 


\section{GRAP'TA III.}

maries, rounded, and both rows stand on gray ground; the silver mark an angular C, the upper limb stout and barbed.

Borly fulvous, coated with green hairs, beneath gray-vinous; the femora of middle and hind legs brown, the tibie buff or luteous; the aborted legs crayvinous, black in front; palpi buft, with many brown hairs, in front black; antenna black above, ferruginous below; club black, the tip ferruginous.

FEMALE. - Expands 2.1 inches.

Upper side closely resembles the male in color and markings; the yellow spots of secondaries still larger; both hind margins edged by yellow.

Under side as in the male, the shades of basal and outer areas contrasting in similar mamner; but the gray beyond disk is more extended, darker, and all that part of the wing is suffused with a delicate purple tint; the silver mark very slender, at most but a curved streak, representing the back of the C.

Var. A. - Female; the fulvous of upper side more fiery, the yellow spots small; beneath, both wings are of brown, of a nearly uniform shade, except that on the disks are darker patches; the green spots tolemably distinct; the silver mark obsolescent. ${ }^{1}$

Mature Lirvi. - Length 1.2 inches.

Cylindrical, the segments well rounded; color orange-fulvous, except the dorsal area of segments seven to twelve, which is white; the ends of the segments crossed by several stripes of black and fulvous, the latter very pale on seven to twelve, almost fading into white; the sides mottled with fulvous, black and bluish white, and marked by two irregular longitudinal fulvous lines, one below the spiracles, the other above, this last interupted and not always distinct; furnished with seven rows of long, slenter, tapering, many-branching spines (the branches numbering about ten of nearly equal size, besides a few others much smaller), each branch ending in a sharp bristle, and surrounded by several others; the spines of the dorsal and first lateral rows from segments three to six, buff; from seven to twelve, white; the second laterals smoky-brown, except on twelve and thirteen, where they are white; the lower laterals buff on three and four, the rest white; a black crescent, concave downward, over the base of each spine of second lateral row; and a black dash on the anterior part of each segment, in front of each of the spines of first lateral row, but nearly obsolete on the anterior segments; spiracles black in white rings; feet black; forelegs smoky-brown; head sub-ovate, deeply cleft, the vertices high, and on each a cylindrical, horn-col-

1 The female last described is that to which I formerly gave the name Silvius. I suspect it and the male are seasonally-dimorphic with Rusticus; but these two are the only examples I have met with, and this relationship is but conjectmal. The female was bred from the larva figured in Vol. I., Plate 40, Fig. 8, a drawing of which was sent me labeled Zephyrus, and so published. Unfortunately the male was afterwards destroyed in transit to Mr. H. Edwarts, and only the description remains. 


\section{GRAI'TA III.}

ored process, short, thick at base and top, the sides concave, ending in six equal spurs, one upright, the others surrounding it, each spur with a short bristle at its extrenity; whole face much tuberenlater, the sides especially being furnished with several long single conical light colored spun's, and many stout hairs (Fign. (1).

Cinysilis. - Length, .9 inch.; greatest breadth across alotomen, .26 inch.; across base of wings, .2s inch. Cylintrical, slenter; the heat-case high; compressed transversely, rounded; at each vertex a stout romded process, tapering to a blunt point, bent inward at two thirds its length, and at the bend on outer side projecting a very short conical branch; the space between these processes circular; mesonotmm larre, followed by a deep excavation, the sides somewhat flattened, the keel high, thin, rounded anteriorly, lut at posterior end sharp and truncated; the wing-eases much elevaterl, flaring at bise, the sides excavated; on the marginal borker on ventral sille a sharp conical protuberance; on the abclomen several rows of tubercles, most of which are small, but those of the two ventrall rows are large, and some quite prominent; those below the mesonotum grilded or silvered; color glossy light brown, or drab, the wingrasuses clouded (Fig. $\left.b, b_{2}\right)$.

Thusticus was described originally from eximples sent me hy Mr. Henry Fdwards, and the localities given were Big' 'L'rees, Cal., and Vanconver's Istand. In 1878, Mr. Mearl took the butterfly at Yo Somite, and, 16th June, found nine caterpillar's feeding on Azalea occirlentalis, some of which he ratised to the imago. From one of these larve and a chrysalis in alcohol, and a blown larval skin, assisted by Mr. Mead's written deseriptions, the fignres on the Plate have been drawn. The larva and chrysalis of this species, from drawings from life by Mr. Streteh, are figured in Vol. I., Plate 40, and are there enoneously attributed to Zephyms, as I learned long after publication. 'That larva was also taken at Yo Semite, on Azalea occidentalis, and it produced the aberrant female (posibly a dimorphic form) which I described in $187 t$ is Silvius. These mistakes I am happily able to rectify, by the kindness of Mr. Mead, than whom we have no more accurate observer or skillful collector among our lepidopterists.

Mr. Mead was also successul in finding and rearing many larve of both Zephymes and Satyme, and states that this last species shows great variation in the relative extent of the light and dark markings, after the manner of the larva of G. Comma, with the likeness to which he was struck, and that Figure 4, Plate 40. Vol. I., resembles one phase of it. As stated in the accompanying notes, Mr. Edwards found four of these larva on Urtica, and he wrote me that the colorition 
was the same in all. But I have alcoholic examples, one of which is dark, the other as white as the larva of G. Dryas figured in same Volume, Plate 37. In the description of larva of Satyrus, furnished by Mr. Edwards, it is said that there are six rows of spines. This should have been seven, as all the Vamessidie have seven rows, one dorsal and three on either side.

Since the Plate of Marsyas was published, in the present volume, Mr. O. 'T. Baron, of Navarro, Cal., has ascertained by breeding from the female Satyms in confinement, that Marsyas is seasonally-dimorphic with that species. He sent me the parent female and the resulting progeny, all which last were Marsyas, some as diminutive as the examples figured on the Plate, others larger, though noue equal in expanse of wing the parent Satymus. The suffused Marsyas on the present Plate (Fig. 5) represents one of these bred eximples.

Note. - We now know the full life-history, from egro to imaro, of several of the American species of this genus, namely: Interrogationis, Comna, Satyrus, and Progne; also the history of Zephyrus, Rusticus, and Founus, from the lalf-grown larva to imago. Mr. Scudder found Fumus feeding on willow, and sent me drawings of larva and chrysalis. Mr. Caulfield found the larva on nettle, and has described larva and ehrysalis in Can. Ent., Vol. VIJ. Professor Fernald writes that larva of Faunus have been found in Maine, feerling on currant, and Mr. Roberts, that he has taken them in Vermont on wild gooseberry. The larva is bicolored, of a pattern similar to that of liusticus and $C A l b u m$, and the chrysalis has a peculiarity found in both these species, the processes on the heal being bent in, and throwing out a little blunt spur at the bend, on outer side, as shown on the Plate. This peculiarity indicates the intimate relation of these species to one another, and it separates them from Comme and all the other American species, the chrysalids of which are known.

Of these species whose history we know, Interrogationis, Comma, and Satyrus are proven to be seasonally17imorphic. Some others may be, as possibly liusticus and Silcius, but as yet there is no reliable evidence of it. So much las been learned since I published the Plate of Faunus, in 1869, some ten years ago. As stated in the notes accompanying the I'late of Comma, two years later, I did not describe Faunus till I had sent an exanple to Mr. Stainton, asking lim to compare it with the Luropean $C$ Album. He replied that he lad done so, and that it was of a distinct, unnamed species, put down in the British Museum Catalogue as "Vanessa - from Iludson Bay." That it was eatalogned in this manner was proof that in the opinion of the entomolorists in charge at the Museum, it was something unknown, and therefore not the common and very well known $C$ Album. Nevertheless, after my Plate appeared, several lepidopterists on the continent declared that Foumus was nothing but $C$ Album, and to test the matter, I sent examples of Faunus, Satyrus, and Comma, to one of the most experienced, for his opinion. The reply came that all three were $C$ Album, but that Satyrus was more unmistakable, and apjroached the European form more closely than rliel the other two. (See Vol. I., note to G. Comma.) Looked at in the lioldt we have to-day, sained by breeding from the female Comma and Salyrus, that was a remarkable statement, that Satymus was more umnistakable and nearer than Finnus and Comma to CAllum. It meant at least that, in the opinion of Dr. Staudinger, Satyrus was close to, or ilentical with, the typical $C$ Allum. Now Faums certainly belongs to a distinet sub-group from that which comprises Satyrus and Comma, as is determined not only by peculiarities of the imago but of the larva and chrysalis as well.

So late as 1874, the venerable and learned Professor Zeller, in a review of my volume, in Ent. Zeit., Stettin, while allowing Comma to be a good species, because it and its dimorphic form Dryas had been proven so by breeding, and their larva were figured in the volume, concludes that Faunus is identical with one of the varieties of $C A$ Abum, found in certain parts of Europe, and which he specifies as $C A$ Hbum, variety $I 3$; and that Satyrus and $Z$ cphyrus are probably parcel of the same thing, or, in other words, sub-varieties of $F$ canus. He says: "That our Furopean $C$ Album appears with remarkable variation is often noticed by authors, but none lave faken the varicties for distinct species. Three of the varieties may be very sharply characterized. I can perceive in my example of Faunus only Var. B of $C$ Album." 


\section{GRAPTA III.}

He compares the ficures of Satyms and Zephyms with examples of $C$ Alnum in his cabinet, and finds resemblances thus: "I have now before me both sexes (of $C$ Allum), of which the male is indeed not quite so darkly spotted on the upper side as Zephyrus, but it is darker than Satyrus, and agrees with Zephlyrus in the presence of a dentation by the side of the chief one of the hind wing, while on the under side it might be taken for Satyrus, Fig. 2. The considerably larger female aqrees in the indentations and the eoloration of hind wing with Satyrus, Fig. 1. But why" then are the caterpillars (of Zeplyyrus and Satyrus) so different? Can the caterpillar (Fig. S, Zephyrus), which looks like the never otherwise drawn $C$ Album, in its variations come to resemble Fig. 4 (siatyrus), in Callifurnia? I believe not. But I an mindful of the fact that the anthor did not lave the eaterpillars before him alive, but only recwived the drawings from California. Therefore I suspeet that the caterpillar of Frunus has by mistake been given for Zephyrus. If this suspicion be correct, there can be no reason against declariner Fumus to be $C^{\prime}$ Allum, and uniting Zephyrus with Satyrus, at least as Turiety B." 'This last line seems to imply that Foumus is same as C Album type, and the other two are the Variety B; but as Faunus is before staterl to be only Variety B, I conclude that I'rofegsor Zeller regarls Salyrus and Zephyrus as probably sub-varieties of Fenenus or of Var. B.

Quite recently I have received from Mr. H. B3. Möshler a paper by himself on the menera of European butterties, in which he thus says: "It all events, C Alhum flies in North Amerien. It is impossible for me, at least, to discover any difference between this and the North American species separated by Edwards as Finnus."

It would he satisfactory to have the type $C$ Alhum pointed out and axpeed upon. Plainly in England it is something gute different from Founus, so different that Faumes is declined to he a distinet species. Dr. Staudinger says it is near Sitymus. Professor Zeller says that Fumus is Variety B, separated from the type, therefore, by another wariety, A. Mr. Mischler wa see no difference between $C$ Albam and Faunus. The truth is, no man knows. what is the typieal $C$ Allum. The descriptions of Linnens and of Fabricius read simply thus : "UPper side fulvous, with black spots; hind wings beneath marked by a white C." This determines nothing. 'The next species describer by Limneus is $C^{\prime}$ Aurenm, which was formerly supposed to be what we call Interrogation is, but is now understood to be another species, $G$. Angelica, Cramer, from Asia, and word for wort even to the white $\mathrm{C}$, the diagnosis is the same. So that we must look elsewhere for help in this matter. Kirby, syn. Cat. of Diur. Lepiel, after citing these two authors, next refers to Esper. Eur. Schmett. Pl.13, Fiw. 3, for a finure of $C A 16 u m$, apparently the first colored figure of the species after the time of Linnaus. 'Turning to this Plate I find set down as C'Album what I should consider a fair representation of the Ameriean species $G$. Comma. It is very unlike Faunus. Kirby cites as a synonym, Esper, Kl. 59, Fig. 3. But Esper says this is Tar. $C$. Alhum, and therefore it cannot be the twpe. The upper side of this figure resembles the fomale of Marsycts, as shown on my l'late. Making allowance for the coarseness of Esper's drawing, it is Marsygs if anything, and is a long way from Foumes. But the under side is unlike either sex of Mrasyus. The ground is colored in two shates of brown, nothing else. The marginal and extradiscal spots are conspicuous and green, and in this alone is there a suggestion of laumus, a species which has the under side marbled in half a lozen colors. I think it probable that this figure was meant to represent a form, or species, of which I have four examples sent me from Fingland as C Album, and with which Mr. Stainton, of course, was familiar. It is small as compared with Funtus, the tails longer in proportion and natrower, and the anal angle much more prolonged, the upper side more macular, nuch as in many Satyjus or Marsyas. The under side is brown, light and dark, over hasal area; the extra-discal area light brown with some gray; the spots are green, and the apical area of primaries is olivaceous. This is not Faumus, but if there is any European form of $C$ Album nearer $I$ Lave not seen it, though $I$ have bronght together all the varieties which I have been able to her or buy to illustrate $C$ Album. Several of these have an excess of yellow on under side, and one fumale would pass for Dryas, if taken here; that is, the under side is honeyyellow, densely streaked with ferruginous. I conclude, therefore, that the type of $C$ Album is uncertain. It means one thing to one collector, and something different to the next. It is like Crmma, like satyrus, like Ifarsyas, like Faunus, like Zephymus, and of course like Pusticus, as I slall soon hear. If Esper's Plate fixes the type, as I think it must, the true $C A 16 u m$ is like Comma.

Now, thanks to the zeal and skill of Messrs. Mead and Baron, Satyrus and Zephyrus are lifted out of the dust of this contest and stand in serene security alongside of Comm. That is, three goud species are alreaily established out of what export lepidopterists in Europe have asserted to be C Album or rarieties thereof. There 


\section{GRAPTA III.}

only remain Faunus and Iiusticus, Sitcius and ITylus, whose position can still be questioned. The larva and chrysalits of the first two of these are of the same general pattern with $C^{\gamma} A l$ lhm, but how close the resemblance between the three I eannot yet say. I lope before this volume closes to see the living larva of Fannus, as I know it only by description and drawing, and $C$ Allumionly by the very insullicient ficures and descriptions in books - insuffeient for any comparison. Mr. Scudeler wrote me at the time of his finding larva of Faunus, that while there was a close resemblance to $C A b u m$, which species he had learned to know well in Europe, there were important differences, and judging by the larva he believed Faumes to be a distinct species; and as to Rustirus, lretween the description drawn of the larva of Founus by Mr. Caulfield, which is quite minnte in its details, and the description of the other by Mr. Mead, there are consilerable differences, buth in color ant markings, thumgh the general pattern is the same. But the resemblance between the larva of any subgroup of butterlies is likely to be close, as becomes species lut one remove from a common ancestor. The larve of L'rogue and Zepleypus are very much alike, constructed on same plan; so of Commu and Satyrus.

It is beyond dispute that the identity of some of the many forms which lave passed under the name $C$ Album has been assumed from an inspection of the tried butterfles only. An example from Siberia or Japan like our Satyrus is brought in, and it is set down forthwith as $C$ Album. Another like Comma or Z Zepliyrus or Faunus, from Clina or Thibet appears, and behold! another varicty of $C$ Allum. I have never read that a $C$ Alloum female in Europe, of any one of the types in which it is supposed to manifest itself, has discovered in its progeny this miscellaneous assemblage of forms. I donbt indeed if much knowledge las ever or anvwhere been obtained of $C A l b u m$ by breeding it from the fenale. For a century collectors have amused themeelves in rearing saterpillars found on the food-plant, ol from exps gathered here and there on various plants; but who knew what type of butcerly lail those egros? It is not ten years sisce the fortunate discovery was male in this country that the female might be induced to lay her exgs readily in confinement, so that brecline could be conductel with certainty; and in these years I do not hesitate to say, more has been lened of the life-history of dmerican buttertlies than is to-tay known of European, though not a district of Europe, but has lual a long succession of active lepidopterists and diligent students of dried butterflies. Professor Zeller writes me: "It is certain that we Europens have been far from executing your methorl, which seems the only" correct one in order to olbtain cortanty and truth." Wre had no sooner begun to employ this method than the complieated relationship of L'apilio flax became clear, then that of Grapta Interrogationis; and from that day to this one species after another has revealed its true history, until there are few instances in the fauna east of the Rocky Mountains in which there is a doubt as to the position of any butterfly. A larese number of species are found to be polymorphic, seasonal or otlerwise, and some of these forms branch again in one or both sexes. Without breeding from the female, not one of these cases of polymorphism could possibly have been proverl, hovever much they might have been suspected. The knowledge thus obtained is available for other countries, esprecially where species of like grenera are concerned. And it is fair to assume, in the absence of positive proof to the contruy, that the species of Grapta, for example, will behave in the OH World as they do in the Xew. I can say as the result of my own large experience in hreeding butterflies, and that of others, that no Grapta on this contincnt is known to belave in the way that $C$ Album is supposed to do. Every one of them named as a species, whose history is known, breeds true to its true, or types if it is dimorphic, and of those whose history is not known, there hate not appeared marked varieties. To collector has repurted such, and there is no evidence that they exist. Commo lias never beun known to produce a Satyrus, though it belongs to the same sub-group, and though it has produced a dimorphic form Dryas, convilerably unlike itself; and each of these remains elistinct, though they may ap. pear in the same brood. So Sutyrus las never produced Comm or Dryes or Faunu, though it has developed a second form Mursyas. Founus ranges over the northern half of the continent, at least to the east of the Rocky Mountains, but an example from Newfomilland is not distinguishable from that taken in the Catskills of New York. The one I sent Mr. Stainton wiss from the Catskills, and he pronouncet it to be the same as the Museum example from Iludson's Bay. From localities thercfore separated by thousands of niles, across lakes, rivers, plains, and great mountain chains, comes the single type known is Funus, though in part of this tcrritory Comma abounds, and in part (Ontario) Sutymes is known to live. No one has ever reported a hyldrid between any two of our species of Grapta. Posibly butterflies resembling every one of the American species in this renus may be found in one part or other of Asia or Litrope; but I not only donbt, but do not believe that these are simply varieties of any one species. Knowing what $I$ do of our own Graptas, it is to me 


\section{GRAPTA III.}

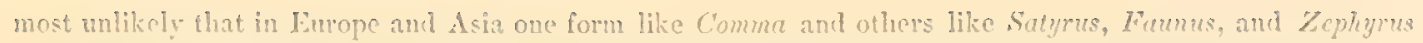
can be but one species and its varieties. In oller words, I believe that several good species have been confonnded unter the name $C^{\prime}$ Allum, am that it needs no long-continued lathor of a few intelligent workers to prove it so. But sitting in one's eleset and speenlating on dried butterfies will not do this, to the end of time. If the dily ever comes, when by hreeling from the female, the conjectures of our European friends are provert to be correct, and a dozen well-marked forms are proved to be mere varieties of but one specics, no one will be more pleased than myeclf, if I live to hear of it. It will be an met interesting, indeed a wonderful biological fact, comeiderine that in America what appear - that is, in the ophinion of some experts - to be identival forms have reached the standine of species. For this certainly is the standing of these Ameriean forms. 'Their differences are pemanent, and they breet true, showing no temdency to run into each other. What more conld be sait?? But, howerer unlikely it may seem that the forms are mere varieties in Europe, it will not do to decelare that stuch a thiner is impessible, for there wonld appear to be no reason in the nature of things why in one part of the worhl a certain assemblage of forms, he they animals or plants, might not he

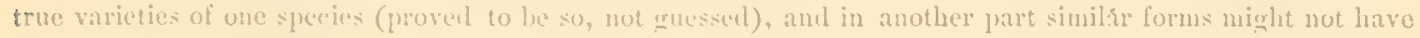
reached the rank of species. Every one who believes in the evolution of species must assent to that. Therefore let us lave the facts. And there is but one way to reach them, namely, to becin at flie founda-

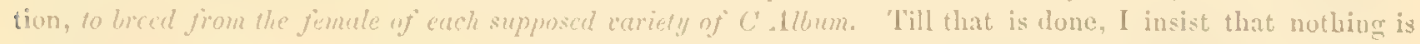
really known ahout $C$ ' Hllum. It has been well salul, "Indefinite knowlelge is definite ignorance."

JUIY, 1579 .

W. H. L.

\section{GRAP'TA YEPIITRUS.}

Gropta Zephyrus, Edwards, 13ut. N. Am., Vol. I., p. 123, I'. 40.

Matune Limita. - Length one inch.

Cylindrical, the segments well rounderl; general color black; at eithor end of segments three to fire on rlorsal surfice a pale yellow line, the remaining seuments similarly lined with white; a more or less distinct pale yellow medio-dorsal line extends over two, three, and sometimes four; armed with seven rows of spines, one dolsal and three lateral ; these spones are stout at hase, rather long, taper to a point, and give out from the end a sharp bristle; several similar bristles about each spine; those of clorsal and first lateral rows from three to six are reddish, and their hases and the spaces between them are of same hue; from seven to twelye the spines of these three rows have their bases white, and this color prestominates in the marbling of the dorsal surfice, so that what remains of the black sround resembles a series of arrow heads pointing backwarl, the doral spine arising at the base of the barls of the arrow; the white color extends some distance up the base of the dorsals and first laterals liom seven to twelve, and these, as well the others on anterior segments, are tipped with black; all other spines, inchding the second and third lateral rows and their branches, are black; on two is a clorsal collax of short, simple spines, each with pale bristle at top; at the sides of body are many small pale tubercles, each tipped with a pale hair; under side (lark brown; feet black, fore-legs brown; head small, sub-cordate, the vertices high, conical, each ending in a stout branching process, the branches near top being short and divergent; at base of these processes, in front and at 


\section{GRAPTA III.}

sides of face, several rather long black spurs, and numbers of others of irregular sizes on the face, some quite minute, part of them yellow, part black, each tipped with concolored hair. (Fig. c.)

CHrisulis. - Length .7 inch; greatest breadth .24 inch; shaped nearly as in G. Comma; cylindrical, slender; head-case high, compressed transversely; on its under side two protuberances, each ending in a short tubercle; at each vertex a short, stout, conical process, the space between square; mesonotum elerated, followed by a deep excavation; the carina rising to a high, thin, nose-like prominence; wing-cases much raised above the general surface, depressed laterally; on the marginal border of ventral side a sharp protuberance; on the abdomen several rows of tubercles, mostly small, but those corresponding to the first lateral spines of the larva large on the anterior segments; those in the excavation silvered; color marbled with shades of salmon and olive. (Fig. d.)

The larva fed on wild currant, and a number of examples were found by Mr. Mead at Yo Semite and bred to the imago. I am thus able to correct an error in Volume 1., in which the larva and chrysalis of $G$. Rusticus are attributed to Zephyrus.

As in the case of Rusticus, the present drawings have been made from alcoholic specimens and a blown skin of the larva, aided by Mr. Mead's carefully written descriptions.

Both larva and chrysalis closely resemble those of G. Progne, and these stages, as well as the imago, show that the two species belong to one sub-group. 



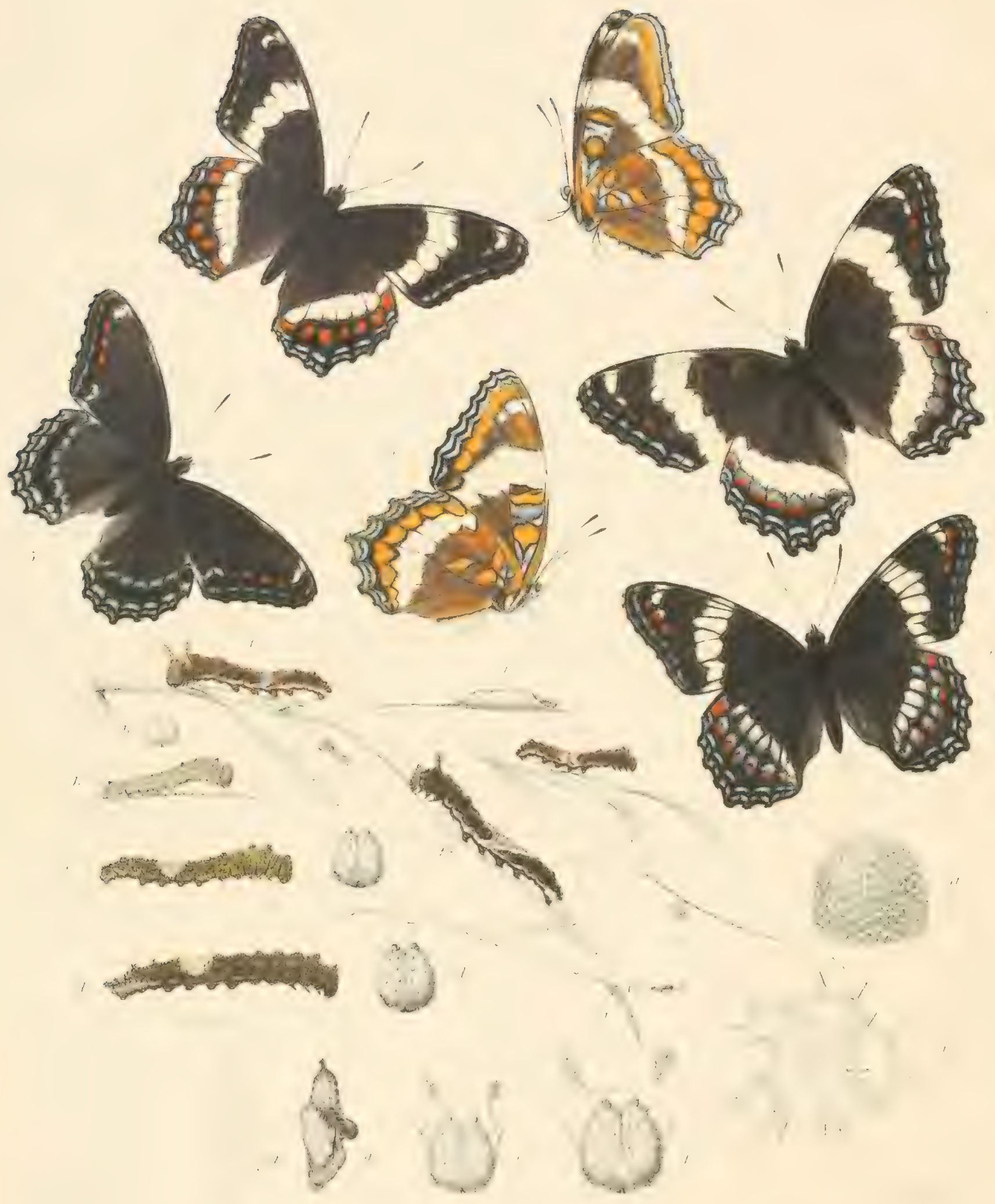




\section{LINENITIS T.}

\section{LIMENITIS ARTHEMIS, 1-6.}

Limentis Arthemis (Ar-the-mis), Drury.

IAIMINAC Fah.

Arthemis, Druyy, Illust. Exot. Ins., II., 11. 10, 1773 ; Say, Am. Lint., II., pl. 23, 1825; 13nis. and Lec.,

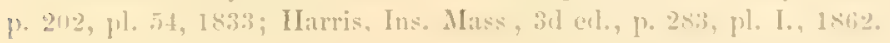

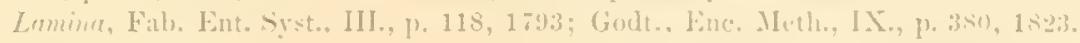

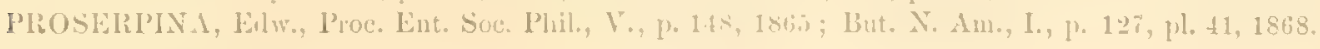

\section{Fiory LAIIINA.}

MaLE. - Expands from 2.2 to 2.6 inches.

Upper side hrownish-black; both wings crossed by an extra-discal white band which varies in breadth in individuals from three to four tenths inch; on secondaries this band is edged without by a series of blue patches, succeeded by rounded fulvous spots; the margins of same wings bordered by a double row of lunate blue spots; primaries have an abhreviated sub-apical white stripe, and a single sub-marginal row of blue lunules, before which is a short row of fulvons spots extending from sub-costal nervure to second branch of median; sometimes a fulvons stripe cover's more or less of the are of cell; fringes alternately white and pale black. But in the markings of the upper side there will be found much variation in a series of examples, there sometimes being no traces of fulvous, or it may be wanting on one wing only; the blue patches on secondaries maly be either broad and confluent, or narrow and faint, or altogether wanting, or may be replaced by green; in some examples the whole area between the band and the marginal lumules is black.

Under side brown, varying in shade in individuals; being of a pure umber, and without tint of fulvous over basal or apical areas, or may be wholly washed with ferruginous, and between these two extremes are several intermediate shades of color; the shoutler of each wing and the imner margin of secondaries ferruginous; the band, sub-apical spots, and blue marginal lumbles repeated, with the addition on primaries of a second and inner row of these last; in the cell of primaries a large rounded fulvous spot, and a bar of same color on the arc, both 


\section{LIMENITIS I.}

edged with black; on either side of this spot is a blue patch, and sometimes the whole space between spot and bar is blue; sccondaries have two similar spots in cell and arc, and a third at top of sub-costal interspace, the intervening area being more or less covered by blue; the extra-discal fulvous spots of upper side repeated and edged before and behind with black; these spots are often much enlarged, and sometimes are conthent, forming a band that reaches quite to the white one; primaries have the fulvous spots repented, but less distinetly, and they are always confluent.

Body brownish-black; on the back of head are two white dots, and behind the eye a white line; on under side blue-gray hairs cover the sides of the last two thoracic segments; on abdomen a white ventral and white lateral line; legs black, the posterior sirles of the femora gray-white, the anterior pair white in front; palpi white on outer and imner sides, black in front; antenna and club black.

Female. - Fxpands 2.8 inches.

Similar to male, and varying in same manner.

\section{FORM PROSERPINA.}

MALE. - Expands from 2.2 to 2.6 inches.

Size and shape of Lamina. Upper side black, secondaries sometimes having a bluish or a greenish tint; hind margins of both wings bordered by blue or green lunate spots, precisely as in the other form; so also are the ferruginous spots, being sometimes large and sometimes wanting; instead of the white band there is at most but a whitish, macular stripe across primaries, and rarely across secondaries, its position corresponding to the outer line of the band of Lamina; sometimes this stripe only appears on the posterior interspaces on primaries; often there is no trace of it whatever, unless on the costal edge where is sometimes a white dash; the subapical white line or spots always present; the under side varies in color from umber to ferruginous, and is in all respects similar to the other form, except in the absence of the band; this is often represented by a whitish stripe, of rather clear color along its imner edge but gradually fading into the gromd of the wing in the direction of the hind margin; occasionally this stripe becomes a band nearly as broad as in Lamina, especially on primaries, but is still only whitish, or gray white; in most examples it is broken and nearly obsolete, in some it is wanting altogether.

Intermediate examples connecting the two forms have occasionally been taken. One of these is figured on the Plate (Fig. 6), and is in the collection of Mr. Mead. In this the band on primaries is macular throughout, and on secondaries is macular', narrow, and blue-tinted: on the under side of secondaries it is nearly 


\section{LIMLNITIS I.}

wanting. 'This was captured in the Catskills. Another', from same district, has the band on upper side narrow and macular, and only pure white from inmer margin to cell, the remander being crocked and indistinct; on secondaries the band is vely narrow and ends at the first branch of sub-costal nervure, and nearly the whole area outside to margin is blue.

Egc. - Shape nearly spherical, flattened at base; the whole surface covered by hexagonal reticulations, forming cells which are roundly but shallowly excavated; from each angle of the cell arises a short, tapering, white, filamentous spine: color grayish-green. (Figs $a, a^{2}$ magnified.) Duration of this stage 7 to 9 days.

Iourg Lirva. - Length, .09 inch; cylindrical, thickest at segments 3 to 5 , tapering gradually and slightly to 13 ; color yellow-brown; covered with fine concolored tubercles, each giving out a short, white, clubbed hair; on segments $3,4,5,6$, and 12 , is one prominent conical tubercle of darker color on either side of dorsum, those on 3, 6, and 12 largest; under side, feet, and pro-legs, yellowbrown; head much broader than body, sub-globose, narrowing, a little towards top, bilobed, glossy brown. (Figs. $b b^{2}$, magnified.) The larva rests mostly on its ventral legrs, the anterior segments being raised and somewhat arched. To first moult eight days.

After first moult: length, .19 inch; color, blackish-brown; on $S$ is a lightbrown patch, covering the dorsum and part of sides; along base, over feet, a fleshy ridge; segment 2 is nurrow ; on segments after this there is one broad ridge, followed in most cases by two narrow ones, and these lisst are thickly set with small tubercles of irregular sizes, conical, each with short, whitish hair; on 3 the broad ridge is considerably elevated dorsally, and at each end is a tawny conical process, crowned by a cluster of little fleshy linobs, dark and light; between these are two small ones with little crowns; on t the elevation is less, and there are four small and equal crowned processes in line; on 6 , also elevated, are two large ones with crowns, and on 12 are two; on each of the intervening segments are two small similar ones, and on all the segments, from 4 to 11, are two small simple tubereles on the anterior part of the segment between the larger ones; these dorsal processes form two longitudinal rows, and are concolored with the ground they stand on; there is also a lateral row of small crowned processes, and others more irregular are placed on the basal ridge; feet and pro-legs, black; head obovate, truncated, and depressed at top, the vertices rather high, and each bearing a short, black, compound process; color black, the surface rough, and thickly covered vith conical tubercles, those at top, sides, and along the upper part of fice, being largest, and mostly yellowbrown; remainder black. (Figs. $c c^{2}$, magnified.) To next moult 6 days. 


\section{LIMIENITIS 1 .}

After second moult: Length, .21 inch; in shape and markings much as at the last stage, lout the principal ridges are more elevated and all the processes more prominent; those of 3,12 , and 13 now largest; on 13 are four, two at the extreme end and directed back so as to form a bifir tail, from the base of which rise two smaller similar ones at an angle of al,out forty-five degrees; the dorsal patch buff, and extended partly over 7 and 9 ; the basal rilge bufl on last three segunents; color of body, blackish-brown, the ends of the processes and tubercles generally lighter; the larger processes on 3 are not crowned as before, but the upper half is covered with knobs; head nearly as before, the face black, the upper part and side yellow-brown, with tubercles. (Fig. d, magnified.)

Five days after second moult (length 4 inch) each larva had begun to make its case or hybermaculum, and three days later all had entered into them.

The first larva left its case the 29th March following, at Coalburghl, fed a little, rested, and after tro days passed third moult.

After third moult: length . It inch; general color red-brown, somershat specked and mottled with black, especially at the junction of the segments, the processes ferruginous-red or partly castaneous; segments 2 to 4 yellowish, inclining to buff; on dorsum of 3 is a clear buff, smooth, elevated cross ridge, excavated on summit, and giving out at each corner an irregular, compound knobbed appendage, .05 inch long, and wholly red; between these, in line, two small crested tubercles; on 4 is a narrow and low ridge on which are four red tubercles, the two at the ends largest, and all crested with red knobs; 5 has a still smaller ridge with little red tubercles, and closely resembles 10 ; on 6 are two large mammilloid processes, which occupy the whole ridge, and are castaneous, with fine concolored crests; $S$ is immaculate, yellowish, except low lown the sides, where it is encroached on by the brown color; 7 and 9 have the torsal parts like S, but both are specked with red and a little black; on these three segments are fine concolored and crested tubercles dorsally; segments 10 to 13 are red-brown, the latter mottled with black; on 11 are two small processes, on 12 two larger, on 13 two quite prominent, directed backward; these list are black with red knobs, and at base of each rises a small upright process; in ardition to the tubercles on the dorsum, are small ones on sides of nearly all segments; the basal rilge is brown in the middle segments, hut after 10 gray-buff; making a distinct band of that color which widens posteriorly; hearl obovate, narew, high, the sides well rounded, the top deeply cleft with a broal suture down the fince; the vertices high and pointed, its whole surface covered with simple rombed or conical tubercles; those on the vertices rather more prominent than elsewhere, and those at back and sides long, conical, and separated; color of lower fice and of the sides of face up to the rertices blackish, the upper 


\section{IIMIENI'TIS I.}

parts suffused with red; the top, sides, and cleft, red; the tubercles mostly colored like the ground they stand on. As the larva approached fourth moult the red parts became dull and at length mostly brown. (Fig. e.) To next moult 6 days.

After fouth moult: length .6 inch: general color very much as immerliately after thirel moult; shape, same; segment 2 yellow-bufl, mottled with black, 3 dark buff, immaculate, the ridge as before, and the processes, which are .06 inch long; 4 is mottled buff, red and black, and on either side of the main ridge is a lower and narrower one; on the main ridge are no processes as before, but on all these rirlges are round, glassy, bead-like tubercles, thickly set, and red colored; on middle of clorsum of this segment, in firont of the anterior row of these beach, are two similar beads, but large and ovoid, and directly in front of the space between these two are small lound ones; on 6 the mammilloid processes are as before, and castaneous; between them are foir red beads, arranged in two pairs at anterior and posterior parts of the segment; there is also on this segment a posterior narrow ridge thickly set with beads; 6 is buff, largely red on dorsum, with a beaded ridge and scattered beads in front; the patch on $S$ is Hue-gray, and extends partly over 7 and $9 ; 10$ and 11 are alike, red with beads; on 10 are two small dorsal erested red tubercles, and on 11 two larger, these erests all yellowish; 12 and 13 are red, mottled with black; the procerses on 13 as at last stage; on the sides, on several segments, are beads and small tubercles; the ridge at base of body is gray-buft; distinct on last segments; feet and pro-legs red-brown; hend nearly same shape as at last stage, rather broader in proportion, the tubereles similar, exeept at the vertices, where they are longer and larger, the largest of all obliquely truncated; color of both head and tubercles anber, the ocelli black. (Fig. $f$.)

MATURE I ARTA. - Two days after fourth moult the red portion began to change to green, olive, and partly a light and deep green; individuals varied in this respect; the dorsal patch changer to sordirl-buff, in one case to dull red-buff, in another to whitish, the anterior segments to gray or whitish, in one case to dark buff, the side stripe to pink, and on last segment to pure white; the beats from red to blue; the head became a dark drab. The larva at maturity was 1.2 inches long. (Fig. $f^{2}$.) Nine days after fifth moult it began to spin a button of white silk on the under side of a willow branch, and thirty-six hours later became chrysalis.

Cintsuls. - Length.9 inch: sub-cylindrical, the abdomen somewhat com pressed laterally, and terminating rather abruptly; the edges of the wing-cases throughout very prominent and turned up, the midelle area incurved; hear-case long, narrow, and tapering, truncated, the vertices ending in two wary ridges, the 


\section{LIMENITIS I.}

shorter of which is perpendicular to the other; the mesonotum moderately prominent, with a slight, blunt carination at summit, and a small conieal tubercle on either side; on the middle of dorsum is a prominent, rounded, thin-edged appendage, corrugaterl, especially at base; color of wing-cases and anterior parts silverygray, the former tinged with brown, or pale black along their hind margins; there is some variation in the color of the wing-cases, from a lighter to darker shade, and the posterior part of the head-case is somewhat iriclescent; dorsal side of abdomen yellow-white, towards extremity gray; on the ventral side almost wholly gray and brown; the dorsal appendage dark smoky-brown; at base of this is a dark brown demi-band, crossing three segments; the surfice of the segment next before and next after the appendage, as well as between it and the wing-eases, silvery and corrugated. (Figs. $g, g^{2}$.) Duration of this stage nine to ten days.

This species, mostly in the form Lamina, inhabits the northern parts of the continent, east of the Rocky Mountains, and as far to the southward as the Hoosac Mountains of western Massachusetts, the Catskills of New York, southem Michigan and Wisconsin; to the eastward, as far at least as the St. Lawrence; also Nova Scotia and Newfoundland. 'The form Proserpina is limited to special localities or districts in the southern area of the species. In the Catskills the two are always found associating together, but the black is much less numerous than the other, the proportion apparently being about as one to ten. Mr. Mead, writing of his experience in these mountains, says: "When I collected every Proserpina I could find, I took 110. Of Arthemis I actually did take about 200, and could have taken a thousand without any difficulty." My own collecting there during several seasons shows substantially the same results. But in the Adirondacks of northern New York, where Arthemis abounds, Mr. W. IV. Hill, in four seasons collecting, has seen no exanple of Proserpina. So Mr. A. E. Graef states that he found Arthemis abundant in the Adirondacks, but saw no Proserpina.

Professor S. H. Peabody writes that he collected in the Hoosac Mountains the last week of June, 1873, and Arthemis was abundant. In 1875, was in Vermont the middle of July, and walkerl up the western slope of Mt. Mansfield, the highest of the Green Mountain range. Ile found Arthemis plenty, but neither there nor in Massachusetts has he seen Proserpina, and does not know of the latter having ever been taken in Vermont. Mr. C. H. Roberts, of Factory Point, southem Vermont, says "Arthemis is found abundantly in this region, and I have taken it in several counties of this State. I have collected for seven years, and have 


\section{LIMENTTIS I.}

not seen the Proscrpina form. I have twice bred Arthemis from the egg, with the result fifty-nine Arthemis, but no Proserpina."

Mr. Scudder, in Geological Report of New Hampshire, describes Arthemis as being exceedingly abundant in the White Mountains, as well as in northeru New Englund generally, and states that its southern limits nearly coincide with the northern limits of Ursula (Astyanax); also that it has not been taken south of Massachusetts, and but rarely in that State. Nothing is said of Proserpina in this report, showing that the presence of this form in the State was unknown to the author. Mr. Morrison, who collected butterflies in the White Mountains in 1875 , did not meet with Proserpina.

Mr. C. P. Whitney, of Milford, southern New IIampshire, says that Arthemis is rare in his district, and further: "What I have called Proserpina, that is, with a white band across the fore wings, or traces of it, is fully as abundant here as Ursula, which last varies much from examples of $U_{1}$ suld foumd further south. I am sure that my Proserpina are a variety of Ursuta - a northern form. A few weels ago I received a letter from a friend saying he hat seen an Arthemis raised from a brood of Ursula." With this letter Mr. Whitney sent me 881.8 taken at Milford. One of these males shows a broad white band across primaries below, and a macular stripe across same wings above; no white on either side of secondaries. Another shows a cluster of whitish scales in each interspace quite across primaries below, and a clear white spot at costal margin of secondaries; but beyond this there is no trace of a band on secondaries, or on upper side of either wing. 'The female also has a sight band on under side of primaries, and faint traces on upper side; but no white on secondaries. Three other males have very slight traces of the band on umler side of primaries, restricted to small clusters of scales in the two or three posterior interspaces. The remaining examples have nothing of this. The first three spoken of I lave no doubt are true Proserpina, and probably all the others are, though they cannot be distinguished from some examples of Ursula taken in certain districts where Arthemis is never known to fly. All these Milford examples, and all from the Catskills which I have ever examined, have this common peculiarity, that the general coloration of the under surface is similar to that of Arthemis, varying as this varies from cimmamon or ferruginous-red to chocolate-brown, exhibiting many shades of color. Now in Ursuta from the districts in which Arthemis is unknown there is almost always a flush of blue-black or of green over a dark brown ground, though occasionally an example is ferruginous or light brown, just as some Arthemis are. On the other hand, now and then an example of Proserpina from the Catskills has a flush of blne-black. I have in my cabinet such a Proserpinc placed side by side with an Ursuld taken at Coalburgh, W. Va., in 


\section{L.TMENITIS I.}

which last the blue fush is much less than usunl in examples here, and the two are scarcely if at all distinguishable from each other. Therefore I camnot say that all these Milford examples are not Proserpina; and indeed I do not know where Proserpina ends and Ursulu begins, though a typical example of each is distinct cnongh. Mr. Scudter, in the report before cited, speaking of Ursula (Astyanax), says: "It is tolerably abundint in the southem parts of New England, and occurs about as far north as the anuual isotherm of $15^{\circ}$, the northermmost points recorded beingr Dublin and Milford, N. H."

Arthemis must rarely cross the southern line of New Hampshire, or of Vermont except at the Hoosac Mountains, which are a continuation of the Green Mountains. Dr. Harris states that it is rare in Massachusetts; and Prof. H. W. Parker, of Amherst, writes that he has never seen it in his distriet, or on Mounts Tom and Ilolyoke, or on the hills about Chester.

Mr. Anson Allen, of Orono, central Maine, says, "Arthemis is common here, but I have never known of Proserpina being taken. Ursula is not found here."

Mr. II. II. Lyman, Can. Ent., VI., p. 38, speaks of Ursula (Ephestion) as having been taken at Portland, Me.; but I leam from him that he is now satisfied that the butterflies were Proserpina.

To the eastward, Proserpina is recorded by Rev. C. J. S. Bethune, Can. Ent., II., p. 55, as having been taken in Nova Scotia.

Mr. Robert Bunker, of Rochester, N. Y., says that Proserpina has not been taken in that part of the State, so far as he knows, but that Arthemis is taken about Rochester every summer. Also that Ursula is not common.

At Albany, N. Y., which is nearly in the latitude of the sonthern line of Vermont and New IIamplire, and is half a degree north of the Catskills, and not more than thirty miles from them, Arthemis is usually rare, but in some seasons has appeared in considerable numbers, according to Mr. Lintner. He has sent me two males of undoubted Proserpina, with traces of the band on both surfaces, and another like these, but with no trace. As these graded from Prosermina to what seemed to be Ursula, Mr. Lintner was led to the same conclusion that other observers had reached, that Ursuld orginated with Arthemis, through Proserpinu. This apparent Ursulu is precisely like the unbanded examples from Milford, with the coloration of under surface as in Proserpina.

Mr. Robert M. Grey, residing at Kenwood, near Albany, writes that he has taken examples of Proserpina three miles below Albany in company with Ursula. Anr of three males sent me by Mr. Grey, one was somewhat banded, while the other two showed no trace of the band, and were of same type as the supposed Ursule of Mr. Lintner. Mr. Grey states further that he has taken Proser- 


\section{LIMENITIS I.}

pind in the Heldeherg Mountains, fifteen miles back of Albany, in company with Arthemis. An eximple sent from that locality was Proserpina, slightly banded. A fifth male, taken live miles back of Albany, in "company with Arthemis and Ursuld," as Mr. Grey states, allo showed traces of the band. It is evident in all these cares that what has paksed as Ursuld is only distinguished from Proserpina by the absence of the band. Both these types in districts inhabited by drthemis probalbly come from the same brood of larve. With the examples sent by Mr. Grey was a very interesting one of Disimms, considerably melanized, so that there was sufticient approach to the black species to suggest hybridism between the two.

Mr. Arlolph Comradi, of Bethlehem, Penn., writes: "Arthemis is common in Monroe and Pike comnties, northeastern Pennsylvania, in the pine swamps. Proscrpinu I have never taken myself, but a friend took one in Monroe County last summer. 'This had the white band on primaries entirely wanting, whereas on secontiaries it was fully developed. I have been a collector of lepidoptera for the last eighteen year's and lave taken Ursula in at least twenty counties of this State, but I have never taken one which varies from the ordinary type."

Going westward, Dr. R. H. W. Gibbs, of Kulamazoo, Mich., writes that Arthemis is not a common species. 'That Proserpina has been taken in Wexford Comnty in the northwest (lat. 1t').

Prof. A. J. Cook, of Lamsing, says that Arthemis is found in the very north of the State, but is rare, so much so that no examples of it are in the cabinet of the Agricultural College. Proserpina is found in the middle counties, and Crsula in the south.

Mr. Charles E. Worthington, of Chicago, has collected extensively for several years in northern Indiana and Illinois, but has not met drthemis or Proserpina, though Ursula is firequently seen.

Dr. J. P. Hoy, of Racine, Wis., writes that Arthemis was formerly quite common in his neighlorhood, but of late years has becone very lane, and that Proserpina in certain localities wats numerous; and he sent me a well-marked example of the latter form, male.

Rev. J. D. IIulst collecterl in Mimesota, near St. Clourl, and at Duluth and Sault St. Inirie: found Arthemis everywhere, but saw no Proserpinu.

As to the northern limits of Proserpina: Mr. Wm. Brodie, of 'Toronto, writes that his experience is based on acpuantance of thirty years with Arthemis, mostly in the central parts of County of York, about thirty miles north of Toronto. Arthemis was very abundant, but he never saw a Canadian specimen of Proserpina.

On the other hand, Mr. W. Murray, of Hamilton, Ontario, says: "For" the 


\section{LIMENITIS I.}

last seven or eight years I have found Proserpina in company with Arthemis, but they are never plenty. Four years ago, 2d July, I tried sugaring in the day. time, and among the insects which came to the sugar were four Arthemis and one Proserpina. On the tree one of the Arthemis was trying to mate with the Proserpina, when I disturbed them." IIamilton is about fifty miles to the south of 'T'oronto, and nearly in line with the southern boundary of Termont. So in Can. Ent., IX., p. 140, Mr. Moffat states that Proserpina has been taken near IIamilton occasionally, and always in company with Arthemis.

In Can. Ent., VII., p. 208, is a list of butterflies taken at Godbout River, on the north side of the lower St. Lawrence, in the seasons 1873 and 1874 , in which Arthemis is included, and said to be common, but neither Proserpina nor Ursula are mentioned.

I formerly received a large invoice of butterflies collected by Mrs. Christina Ross, at Fort Simpson, Nackenzie's River, and among them were many Arthemis, but no Proserpina. But to the west of Fort Simpson, Mr. Dall did not find the species on the Yukon River. Nor did Mr. Croteh meet with it in British Columbia. I have never seen an example taken in the Rocky Mountains, and I think the statement of Mr. Reakirt, Proc. Ent. Soc., Phil., VI., p. 143, that Arthemis las becn taken in Colorado, must be erroncous.

'The western limit of the species seems to be to the east of the Rocky Moumtains, and the southern coincides nearly with latitude $43^{\circ}$, but where high momtains cross that line the limit lies a degree or two farther south. Proserpina appears in certain localities along. the southern area between latitude $44^{\circ}$ and $43^{\circ}$, and in the Catskills, $42^{\circ}$.

'The sonthem limit of Proserpina coincides with the northem limit of Ursula, and in some regions, as in Michigan, probalnly overlaps. And wherever Proscrpina appears there are found individuals banded almost as conspicuously as Arthemis, and from these there is a regrular gradation to what has been considered a northern form of Ursuld, showing no band or traces of one, and these last, as we go south, grade into the typical Ursula. Below the line of Arthemis there is a belt of several degrees of latitude in which many Ursula closely resemble Proserpina, with the exception of the band. In other works, the northern form of Ursula lives throughout this broad belt, side by side with the southern form. 'The former are blacker on upper sirle, the litter are suffused with blue or green, and the lustrous aren is not confined to the marrins of secondaries, but often rums quite to the base. The former have the under surface either dark or light brown, rumning into ferruginous, and the apex of primaries is of the same hue with secondaries. In the litter a blue or green sheen hides the gromd of secondaries, and the apex is of a light shade of brown, and often more or less suflused with a 


\section{LIMENITIS I.}

hoary white; and not unfiequently in this belt are taken individuals which have traces more or less distinct of a whitish band across one or both wings. I have occasionally taken such examples at Coalburgh, lat. 38 20'. Dr. Jolm ILamilton, of Allegheny, Penu., lat. $40^{\prime} 30^{\prime}$, writes: "During seven years I have never seen tothemis in this County, and I have never seen a specimen which was cap)tured in this State. Ursulu is common. Many of them, especially of the females, have the white band on both sides of the wing." Dr. Hamilton sent me a pair, both of which show this band, the female on both sides, the male on under side only.

I may mention here that the female figured as Proserpina in Volume I. of this work is undoubtedly a banded Uisule. It was taken in the mountains of l'emrsylvamia.

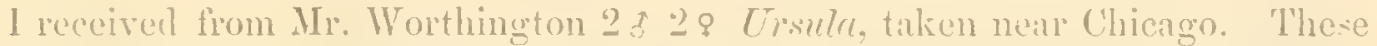
were of large size and of the southem trpe, hut one male and one female show the band rery plainly on the under side of primaries.

Examples of Ursuln from Arizona difter more from those of West Virginia than the latter from Proserpina of the Catskills. There is a constant departure from the northern type as we go to the sonth and sonthwest.

I believe, therefore, with Ilesws. Whitney, Lintner, Cirey, and other's, that of these forms, Arthemis is the original; that it first wave off Proserpinu in special localities and uncler some influence, perhips of climate, hnt not yet deternined, just as Papilio Lurmes gave oft Crlancus; and that liom Proserpina has come Crsuld, which, as it made its wiy south, became domble-brooded, and has more and more diverged firom its lirst type.

Unfortunately I have not yet been able to breed Lrsule, and know the larva only from figures. As given in Abluot, it is like the larva of Proserpina in color. It is quite unlike that given in Boishluval and Leconte, which resembles the larva of Disippus.

Arthemis is a forest species, and may be seen, in its senson, either singly or in groups, along the roaks and patlss, particularly wherever there is exerementitious or decaying animal matter. When alarmer, it darts swiftly away and conrses up and down the path, or flies into the trees, but will soon return to its first resting-place. It flies at some distance from the forest also, and visits orchards for the rotten apples, and firm-houses for the chance of what it may fiud to its liking. Mr. Scudder tells us that "the matrons of the louses in the valley of Peabody River, N. H., complain of these insects entering their kitchens in such number as to be a very nuisince. One of them relates how she has taken more than fifty on the inside of her winclows on a single morning. Mr. Hill saw, on one occasion in the Adirondacks, a log closely packed with Arthemis standing 


\section{LIMLNITIS I.}

side by side. The larra feed on the leaves of willow, aspen, bass-wood, and, it is said, on thom. In the Catskills, the eggrs are laid the last days of July or early in August, on young trees, and but one egg upon one leaf. This is placed near the tip (Fig. a), and the newly hatched larva eats away the leaf on both sides of the midrib. When at rest, it is to be fomd on the stripped portion of the rib, and is easily discovered by this habit. When two larve are hatched on one leaf, as happens when two eggs have been laid in confinement, Mr. Mead has noticed that one of them accupies the midrib, while the other rests on a pereh constructed by itself from the sile of the leaf. 'I'his perch, he snys, is nearly a quarter of an inch long and about one fifticth of an inch in diameter, irregularly cylindrical and composed of frass and small bits of the leaf, fastened together and covered with grayish silk.

Limenitis Disippus has in all respects larval hahits similar to Arthemis, and as I have often watched the construction of the perch in that species, one account will apply to both. The end of the rib is no sooner laid bare than it is coated and wound with silk, and to the extremity are fixed grains of larval excrement, at first but two or three, placed one alter the other in line. These are bound together and to the rib, and being small as grains of rifle powder, they form a continuation of about the same dimensions as the rest of the perch, and seem effectual to prevent curling as the rib dries (Fig. $b$ ). As the larva grows, the process is continued until this artificial portion will measure five or six tenths of an inch, and makes a stont, irregular cylinder, the entire perch reaching about one and a half inches (Fig. $h$ ). It is constantly strengthened by additions of silk, the larva ahmost invariably, as it goes back and forth from its feeding ground, adding threads and patching the weak places. On the perch the larva, in its younger stages, that is, before hybernation, always rests, groing to the leaf for food at short intervals. It occupies the middle of the pereh and its usual attitude is a twist, the ventral legs clasping; but the anterior half of the body is bent down by the side of and somewhat under the perch. If two larva are placed on the same leaf, one always takes possession of the extremity, often with something of a contest and knocking of heads together; but the other will presently be found on one edge, excavating on either sile of a narrow strip which is to con-

1 The habit of gathering in dense crowds is common to many species of butterflies, and, so far as I know, is confuned almost if not wholly to the males. I mentioned it in my history of Papilio Tumus; lut about the time that was printed, I saw a vastly larger cathering of P'apilios Turnus, Troilus, and Ajox, juincipally of the first of these, than I hal described. I was driving along a creek in this neighborhood, $24 \mathbf{J u n e}, 187 ;$, and passed a flat rock hy side of the water which seemerl to have been mointened by the drippings from a coal seam over it. A space not less than four feet square was crowded with these Parpilios. Allowing one inch for each butterfly, which seemed ample, there were upwards of 2,300 in that mass. In course of a fer miles ${ }^{2}$ drire I saw similar gatherings of from scores to hundreds of individuals. 


\section{LIMENITIS I.}

stitute the base of the perch. 'This is bound and lengthened with frass and serves every purpose.

Both these species of larve have a habit of accumulating little scraps of leaf at the base and under side of the perch till quite a packet is formed, and this is rolled back as the substance of the leaf is eaten so as to be close to the cut edge of the leaf.' 'I'his edge, in willow, is kept nearly square, a rection being eaten from one lobe and then a corresponding one from the other. In begimning on a firesh section, the larra lies diagonally across one comer, the anal legs clasping the base of the perch, and its head will strike the side of the leaf about two tenthis inch above the cormer. It eats a canal nearly perpendicular to the side and towarks the midrib; not all at once, by any means, for this is the result of several meals, in the intervals always retuming to the perch. When the rib is reached, the larva then begins to feed on the lower side of the canal next the rib, and to keep the slender and unsteady bit of leaf in position it spins guys from the end and edge to the solid leaf opposite and to the rib. As the feeding proceeds and a considerable triangle is held only by a narrow strip, which diminishes at each mouthful, more guys are put out, and, at last, when the triangle fills, it is held by the threats and swings to the base of the perch. If not, it is soon brought there by fixing one threal after another from it to the rib and leal till it is pulled to its place. Here it is bound loosely. As other bits are adderl, there comes to be an open packet, held together by simple threals, and of about one tenth inch cliameter. In the two younger stages this is moverl along as the larva feechs, and is always liept close to the leaf, partly by pushing, what is gained at each effort being secured by threads, or it is rolled by attaching successive threads from the forther side to the leaf and rils till the mass is turnerl over. After the second stage the packet is left behind, and no additions are made to it. (Fig. h). I was at first puzzled to accomt for this construction; but happening to see one of the caterpillars back down the perch and drop its excrement directly into the packet, it occured to me that really this was the magazine whence the larva drew its materials for lengthening the perch. On pulling some of the packets apart a few grains were always found in them. This I believe to be the use of the parcliets, and without some contrivance to catch the frass, it is difficult to see how the larva obtains the materials it uses. Apparently it drops just about enough into the packet for the object in view, for it is certain that the grains aro usually expelled wherever the larva happens to be, and fall to the ground. After the end of the perch is sufficiently strengthened and there is no further need of the grains, the packet is dropped behind and neglected.

The larva of Arthemis hatch in from seven to nine days, undergo two moults, and construct, each for itself, cases or hybernacula of leaves in which to pass the 


\section{IJMENITIS I.}

winter. As the weather in spring becomes settled and warm, they emerge from their cases, feed a few days sparingly, and pass the third moult, soon to be followed by the fourth and last, and must change to chrysalids from lst to 1 bth Tume.

The form Proserpina was by many lepidopterists considered to be a variation of Urata; by others as a probable hybrid between that species and Arthemis; and other's, asgain, suspected dimorphism with Arthemis. 'To settle the point, Mr. Mead marte efforts to breed from the eggs of both forms in 1575, and in Can. Ent., VII., p. 162, relates the history of the experiment as follows: "In obtaining egrgs of Arthemis, I have been very successful, partly, I think, on account of a method of keeping the parent in good health and spirits, devised some years agro, and which has griven very satisfactory results. $A$ motch is cut in the side of an empty wooden box, through which a branch of willow may be passed, care being taken to select a leafy spray so as to partially fill the lox with foliare. It is then covered with gauze tacked fast on one sicke and part way on the arljoining sides, that on the fourth being held down by a piece of rood firstened to the remaining flap of gauze. This renters easy the examination of the contents at any time. A sancer of raw dried apple, sugarerl, and partly filled with water, is put in, and the cage is complete. Butterflies like $A r$ themis will live in such a vivarium for two reeks and more after their capture. and appear to enjoy the food provided for them immensely, laying many more eugres than if inclosed in a bag and allowed to perish of hunger and thirst. My lifteen females of Arthemis have laid a very large number of eggs, probably orer five humdred. 'They at first observe the usual custom of depositing the eggs on the tips of the leaves, but become reckless after a while and lay them anywhere. I counted considerably over a hundred upon the cloth covering the bos. A female of Proserpina has also laid thirty-one eggr.." 'This was last of July, at IIunter, in the Catskills. The larve from these eggs in large numbers lived to make their cases, and part were brought by me to Coalburgh, while Mr. Mead retained part at Ithaca, $\mathrm{N}$. Y. All these were found to be dead in the spring, from our not understanding the conditions necessury for preserving them. But a few of the Arthemis larve had heen allowed to feed on the leaves of a small willow, in New York eity, and to make their cases on it, and three or four were alive These all produced Arthemis, and we therefore knew no more of the relationship of I'roserpina than before.

In August, 1876, I went to the Catskills too late by mearly a month for the season of these butterflies. But a few individuals, mostly females, were still fly. ing, and I took some of ench form and treated as directed by Mr. Mear. All re fured to lay except one Proserpina, which deposited eleven esgrs. The effect of 


\section{LIMENITIS I.}

the feeding on sugar water was to make the horlies enomously fit, so that they swelled out like the bodies of wasps and the insect could scatreely move about, and in a few disys died. Probably this exeess of fit hindered the laying of engs:

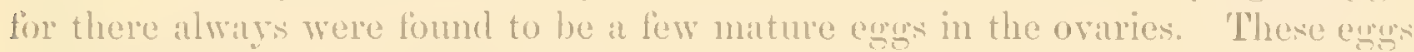
of Proserpince hatehed, begimning on the ninth dity, and the lanve fed well. But before they had reached the hybemating stage, I had to gruarl them in a wam roon, and to lieep branches of aspen and willow in water to supply them with food. Out of doors the leaves were filling, the frosts becoming severe, and it was certain that not one of these larva or of any larvie, then feeding naturally, conkl have reached the hybernating stage. The existence of the species is in fact due to the development of the egres laid in July and early in August. The larve hatched 10th to 1:-th September, hegan to pass their first moult, 18th, and second on 24 th. Nine lived through the second moult. On 27 th, the first one had completed and taken possession of its case. ${ }^{1}$ 'The eggrs had been laid on willow, but after second moult I transfered the litrve to aspen, which they readily took to. Tery soon alter the transfer some of them began to cut out the pattems of the eases. First eating a marow canal for one quarter inch, the width of the head, obliquely outwarl from the stem at base, $a$; next a canal of sime length on the sicle of the leal, about three fifths the distance to the apex, perpendicular" to the enge, $b$, then

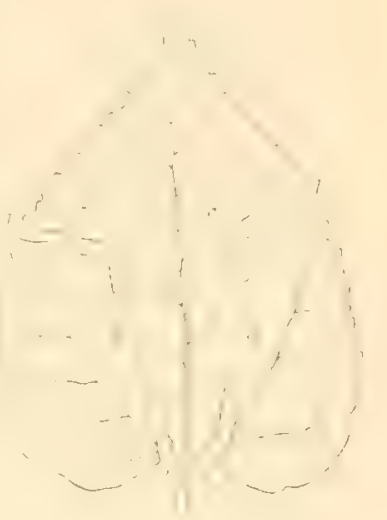
turning this at a right angle in the direction of the first canal and cutting for a little distance; then crossing to the other half of the leaf and cutting similan. canals; alter which the extremity of the leaf' was cut off' by an incision from the hend in the second camal directed obliquely forward to the midrib, first on one vide then on the other, $c$; next the first and second canals on one side were joinerl, ct, then on the other side, and there remained of the leaf' but a small fiddleshaped piece, lying almost exully on either side the rib. Before and during the time this work was progressing, the larva had taken intervals of rest fiom the cutting, and had occupied itself in weaving threads from the branch to the stem. and along the upper side of the leaf, thus conting with silk what was to be the inside of the case. Finally, beginning at the base, it drew the edgres partly together for a little distance, leaving an open space between of about one tenth inch, and held them in position by single threads; then proceeded to weave a

1 The larve of Disippus, at Cnalburnl, prass either two or three moults before hybernation, but I have Enown of only two moults in this species after hybernation. To the northward I think it possible that the fall moults are limiter to two, as with Arthemis. 


\section{IIMENITIS I.}

thick permanent covering to this gap; which done, it worked back, drawing the edges as before, and weaving, till at length the case was complete. (Fig. i.) As it spmm, the linra was in a constant state of anxiety about its work, as if it foresa the storms of ram and wind it must be subjected to for many long months, shut in this slender house. In closing, it lies along the midrib inside, its anterior segments extending over the top, and it moves its heal from side to side weaving a concave edge. But it often reached far over and added a thread here and there where the work seemed to be finished, and it would frequently leave the case to inspect the fastenings about the branch, and to weave additional threarls there as needed. The silk is passed entirely around the branch, and binds both sides of the leaf-stem. In weaving at the case the larva would soon become exhausted. I timed one actively at work for ten minutes, and there suceeded an interval about as long of rest, the larva lying motionless along the midrib. When at last the case is finisher, the larva enters, and rests awhile, but presently comes out, rums about examining the stem and the fastenings, then returnsand this scrutiny will be repeated perhaps three or four times. Two larve were kept in the sane glass, each of which had commenced a case and partly incloser it, when I removed one. The other soon began to amuse itself by shilting about, trying each case and working at it, and finally completed and occupied that which it had not begun. Some days after all had apparently retired for the season, one came out and wanlered uneasily about, but a few hours later was found to have returned to its case and was seen no more.

'There was some variation in the mode of cutting the pattern, as sometimes work was begrum on the side of the leaf instead of at the base. But it always resulted in the sume fiddle-shaped pice. 'The cutting was evidently fatiguing, from the inconvenient position of body reguired, the head and anterior segments having to be bent sideways, even to a right angle much of the time, and the larva firequently rested and shifted its place. It was never found on the wrong sicle of the ent, however, or in danger of falling with the rejected portion of the leaf. Occasionally after having begun a case the larva would desert it and construct another. The larva finally entered the cases head first, their bodies contracting in length and proportionately thickening so as to completely fill the upper end of the tube, and allow nothing to be visible from the aperture, while over this last the long flap of the leaf" soon curved sufticiently to keep out water.

Probably in natural state the case is constructed from the leaf on which the caterpillar began its existence, whether' willow or aspen. 'This is so with Disippus. The ends of the leaves have been eaten away and only the sides need shaping. But if the residue is insufficient, or for any reason does not answer the purpose, the caterpillar moves to another leaf and begins cutting. 


\section{LIMENITIS I.}

In relating the history of Melitar Phacton, I have shown how caterpillars worls in community for protection against the winter. In the present case we sce the individual taking care for itself, and with what forethought, mechanical skill, and patience the end is secured. Some caterpillars cover themselves in a web, or bind two leaves together loosely; more conceal themsclves under wood and stone, or in the sod; but here is one who has turned tailor, weaver, and house-builder. It knows just what sort of leaf to choose for its purpose, takes its own measurement, cuts out the pattern on a system peculiar but effective, sows it up, and inserts an elastic silk band which will be its security when the drying leaf contracts, upholsters the interior, binds the stem of the leaf firmly to the branch, and takes possession, even having provided against the ingress of water by a flap shaped when the pattern was cut out. One camnot but wonder how such a habit originated and how it is perpetuated. Young birds are supposed to make observations on the nest they were fledged in, and so prepare themselves to build a similar one when the proper time comes; but this caterpillar never saw anything like its winter house, and the butterfly which laid the egg from which the caterpillars came knew nothing of houses. In the event of there being a summer as well as a fill brood of one of these case-making species, as in the southern Disippus and Ursula, the larra of the early broorls need no shelter, as they take no rest, but proceed through all the larval stages to maturity and to chrysalis, and this habit of house-building manifests itself, therefore, only in the alternate generations. Nothing in the life-history of a butterly seems more wonderful than that the eggr should invariably be laid on the food plant proper to its caterpillar; for very few caterpillars are ommivorous, but nearly all will feed on two or three, and often on one species only of plant, and if they do not find the right plant they die of hunger. It would seem as if the butterfly has a remembrance of her former eaterpillar state. Now she is as different as possible, a creature of the sum and air, eating no solic food, for she has no month, but lives on liquids drawn up through a tube; then she was a crawling worm, and roraciously fed on leaves, cutting them with powerful jaws. And between these stages there has intervened another that would seem to have divided them completely, certainly to have extinguished all recollections in the butterfly. And yet she seeks the particular plant her caterpillar must feed on, and finds it.

1 At Coalburgh the larve of Disippus feed on willow, and no aspen grows in this part of the State. In the Catskills, both willows and aspens abound, and there this species prefers to feed on the latter. I have often found their cases on young aspens late in the fall, but never on willow, though willow would be used if there was no choice. In $1876, I$ brought several small aspens to Coalburgh and planted, and since that time I find many larve of Disippus feeding on the leaves; but on the willows near by, on which I had been accustomed to find them, I rarely hare met one. Here was a case where perhaps for hundreds of generations neither caterpillar nor butterfy could have seen an aspen, but the moment one was produced the butterfy knew what would stit the caterpillar best, and deserted the willow. 


\section{LIMENITIS I.}

The hyberuacula are liable to be robbed by birds and probably by some in. sects, for those of Disippus may often be found opened near the base, the larva missing.

I brought the cases of Proserpina to Coalburgh, and liept them out of doors during the fill and winter, exposed to the weather, but shaded from the sum, binding them to the twigs of a little tree, and covering the whole with a mushin bag to protect from birds or insects. This method succeeded well. On 10th Narch, I removed them to the greenhouse, having previously forced willow branches so that a provision of leaves was secured. On the 29th, two came out of their cases, and on the 31st passed the third moult.

One of the Proserpina larva came out of fourth moult with only one of the clubbed appendages on third segment, its place being supplied by a small tubercle similar to the two imner ones on same segment; but there was no deformity in the butterfly which came from this larva. They were voracious feeder's, liked best to be in the full glare of the sum, and moverl about very little. As they approached maturity, I arranged some arched twigs for them to suspend to, and was able to watch the process of spinning the button of silk and attaching the anal feet to it. 'This button was thick, rounded, made of white silk, and soon after it was finished the larva tumed round, and with some eflort got the himcler pair of its ventral legs upon it, moving back and forth till it reached that position, depending entirely upon its sense of feeling. 'Then it moved forward slowly till the anal legs touched the silk; after which it braced itself on all its thoracic and ventral legs and began, with much muscular action, especially apparent in the last three segments, to force the claws of the anal legs into the silk, pushing back, then pulling forward and pushing back again, with repetition for nearly five minutes, till the object was accomplished. 'Then the larva rested exhausted and perfectly quiet, its head and thoracic segments hanging so that the legrs on these segments did not touch the twig, the ventral legs all clasping it. Shortly after, it cast off and hung by the amal pair only, the body straight, the anterior segments nearly at right angles, the bend being on the fifth segment. 'I'wenty-four hours later, the body hung in a simuous curve, and the anterior segments were roundly bent up, the head resting on second segment. T'en hours after, I observed a muscular movement from tail to head, passing in waves beneath the skin, while the body was nearly straight and much clongated. After some minutes of these throes, the skin burst on the top of the hear and down the suture of the face as well as back to the third segment, and the mesonotum of the chrysalis forced its way through the rent, followed by the head case, and by the creeping movement of the body the skin was slowly shutlled back. The rent was oblique, the dorsal side of the chrysalis being exposed three segments 


\section{IIMENTTIS T.}

beyond the rentral, and the skin fitted tightly on the anterior parts, but at the last segments was loosening and packing in a mass. As the skin on the dorsal side was pushed back to the tenth segment, a violent and somewhat protracted chort hegan for the extrication of the tail of the chrysalis from the skin, and the abdominal segments were succeswively expanded and contrated to an extreme degree, while the chryalis rose steadily towatrls the button of silk and grasped it with the hooklets on the end of the amal pads, after an extramblimary and convulsive strugghe, in which it threw itself almost up to a line horizontal with the silk. Observations recently made on the pupation of the Symphalidat, by Dr. J. A. Osborne and others, show that the chrysalis at the crisis of pupation is smpported by a membrane or ligament formed of the imner coat of the lanval skin, which eatehes on two knobs or points developer about same time on the anterior edge of the last segment of the chrysalis, and so holds the chrysalis till the hooks are caught in the silk. It has hitherto been assumed that the support was found in the gratiping of the skin between the seginents of the chrysalis.

When the chrysalis of Proserpina rested, it was greatly stretched and quite different in shape from what it soon after became. At first it measured . 95 inch long, the head case wis very short, and the wing cases measured but. 3 inch in length, reaching just over the upper edge of seventh segrnent, and were scarcely mased aloove the surfice of the thomx. Ihe clorsil appendage was but little rounded, not very prominent, and its edge was blunt instead of sharp, the sicles swollen instead of excavated. Horeover", it was equally curved at both ends. In course of an hour the abdominal segments hat telescoped, the wing cases had crept to the top of eighth segment, lengthening one tenth inch, and were much elevated, giving the hunched form to the chrysalis which is characteristic of the genus; the head case had thrnst itself out, the mesonotum become rounded and very prominent, and the dorsal appendage was unevenly rounded at the ends, thin, sharp, excavated on its sides. 'The chrysalis finally measured .8 instead of .95 inch.

I had lost some of the lanve during the winter and brought but four to chryalis. From these chrysalids energed three Lamina and one Proserpina, which last is shown on the Plate (Fig. 5). As may be seen, this is very near Ursulu. In Tol. I. is figured a male with the white bands largely developed, and examples may be taken in the Catskills showing every grade between these extremes. 


\section{LINTENTTIS I.}

\section{EXPLANATION OF 'THE PLATE.}

\section{ARTHEMIS. Figs. 1, 2, FoRM LAMINA ơ., 3, 4, \&. \\ Frg. 5, FoRM PROSERPINA $\delta$. \\ VAR. OF SAME ơ.}

a. EGC; $a^{2}$, same magnified; $a^{3}$, micropyle of same.

b. Young Larva (not on Plate but near $\imath$ ); $b^{2}$, same maguified; $b^{3}$, head of same magnified.

$\therefore$ Larva after 1st moult; $c^{2}$, same; $c^{3}$, head, magnified.

d. Lurra after $2 d$ moult; $d^{2}$, head, magnified.

c. Larva after 3d moult, natural size; $e^{2}$, head, magnified.

f. Larva ter th moult, natural size; $f^{2}$, same stage, but mature.

$f^{3}$. Head after 4 th moult, magnified.

g. Curysalis ; $g^{2}$, dorsal view of same.

i. Hybernaculum or winter case, constructed and-occupied after second monlt.

$h$. Perch on which the larra rests after second moult, showing the rejected packet of bits of leaf. Two perches occupied by young larra are shown (without letter) and one of these represents the packet in its earliest stage. 



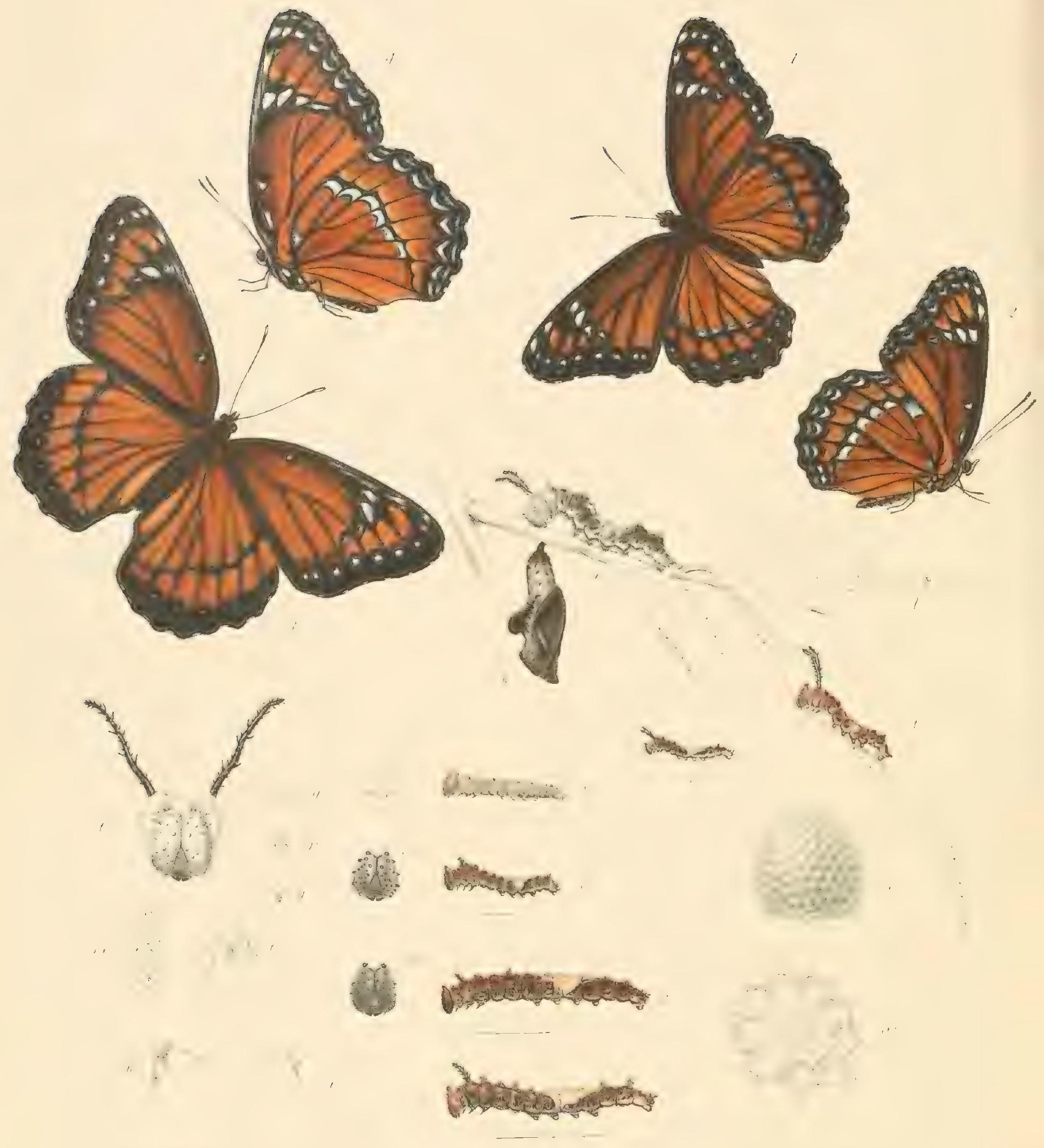




\section{LIMENITIS II.}

\section{LIMENITIS EROS. 1-4.}

Limenitis Eros, Eilwaris, Can. Ent., XII., p. 216, 1880.

MaLe. - Exprands 2.6 to 3 inches.

Upper side diuk red-brown, mahogany-color; hind margins bordered broadly with black, costal margins narrowly; imer margin of primaries black to the submediun nervure; all nervures and branches black, and narrowly edged with same color; against the end of cell, on primaries, a long subtriangular black patch, its short side resting on costa, its apex prolonged into a stripe which reaches the border of hind margin below second branch of median; beyond the disk, on secondaries, a transverse, curved, narrow, black stripe from margin to margin; within the borkters, and near their imer edges, a common series of white spots, which, on sccondaries, are small and more or less obsolete; on the black triangle, three white spots in line, the two nearest costa large, the third minute; a white spot at the origin of upper subcostal interspace, and a white streak on outer side of costal nervure, opposite the triangle, and a little way toward base; fringes black, white in the middle of each interspace.

Under side red-brown, nearly as dark as above, and of a miform shade over both wings; primaries have the spots on border repeated, enlarged and crescentshaped, white, with purple scales about the edges, and half way to margin is amother series of small purplish spots, one to each interspace; at apex these are round, the rest abbreviated streaks; the spots in the triangle repoated, as well as the markings next and on costa, all these pure white; in midlle of cell, next subcostal, a subtriangular white spot on black ground, and a white mark along same nervure nearer base.

Secondaries have the marginal spots repeated, much enlarged, crescent, and an obsolescent row of purplish crescents on middle of the border; the black transverse stripe repeated and on the imner side of same a crescent in each interspace, white, delicately tinted blue or purple; these vary in individuals, and sometimes are obsolete, or are represented by a few white scales. 


\section{LIMENITIS 11 .}

Borly black, the abdomimal segments beneath edged with white, and a white stripe along the side of ablomen; on thorax beneath are two oblique rows of three white spots cach; legs brown-black, the two lower joints of the front, or aborted, pair white; palpi black, white in front; antennæe black, the tips ferruginous. (Figss. 1, 2.)

Fevile. - Expands 3.2 to 3.4 inches.

Same color as male and similarly marked; the black triangle often shows a fourth spot; in some examples, the black cross stripe, on upper side of secondarjes, has white crescents on inner side, in the interspaces of anterior half the wing; there is also often a small white spot in cell of primaries next subcostal.

Under side like the male, the marginal spots greatly enlarged; the white crescents inside the stripe almost always conspicuous and sometimes very large, exceeding indeed those of the border. (Figs. 3, 4.)

Tar. Orsoletd, Edwards, Papilio, Vol. II., 22, 1882.

Color faded; very like Damais Strigosa, Bates; with the characteristic white spots of Eros, on the immer side of the discal band of secondaries, and on both surfaces. Taken, in both sexes, by Mr. Jacob Doll, in South Arizona, October, $18 S 1$.

$\mathrm{E}_{\mathrm{a}}$ G. - Shape as in Arthemis, but a little ligher in proportion; the surface -covered by reticulations which are mostly hexagonal, but some are 5 , others 7 sided, especially on the upper third; these form cells which are roundly but shallowly excavated, and from each angle rises a short, tapering, filamentous spine; the top a little depressed, and about the micropyle a rosette of four concentric rows of 4 and 5 -sided irregular spaces; color gray-green (Figs. $a$, $\iota^{2}$, egrg and micropyle magnified). Duration of this stage 4 and 5 days.

Youvg LARTA. - Length .1 inch; cylindrical, thickest at segments 3 and 4 , tapering slightly to 13 ; color light yellow-brown; covered with fine, but irregular, concolored tubercles, each giving out a short, white, clubbed hair; on 3 , $4,6,11$, and 12, is one pointed, conical, dark-brown tubercle on either side of dorsum, that on 3 largest, on 6 next in size, the others about equal; the segments from 4 to 10 have, in same rows, similar, but much smaller tubercles; these all stand on the ends of transverse ridges; under side, feet, and pro-legs yellow-brown; head sub-globose, narrowing towards top, bilobed; color glossy brown; a few scattered hairs over the surface. (Fig. b, $b^{2}$, magnified). Duration of this stage 3 and 4 days.

After first moult: length .2 inch; similar in shape and armature to Arthemis; cylindrical, thickest at 3 to 5 ; the dorsum red-brown, the sides and under parts 


\section{LIMENITIS II.}

back; on 9 is a patch across dorsum and down the sides, encroaching dorsally also somewhat on $S$ and 10 ; this is at first scarcely distinguishable from the general hue, but a few hours after the moult, it hecomes lighter, or red-huff; a fleshy ridge along the base, over lege, brondest on the last segments; on segments after 2 is one broad dorsal transwerse ridge, followed by one and two narrow and lower ridges, and these are thickly set with small, irregular, conical tubercles, each with short hitir; on dorsum, from 5 to 1 \% , are two rows of processes, placed at the encls of the brome ridges, each with a crest of little fleshy knohs, or grams; on 6 and 12, these are langer than elsewhere, more elongated and acute, on 11 next in size, the rest smatler; on the fronts of these segments, and on 4 , are two simple tubereles in alvance of and between the dorsil processes; on 5, 7, 8, 9 the processes are yellow; on the other"segments, red-brown; on 3 the broad ridge is considerably elevated and at each end is a prominent appendage, .03 inch long, stont at base, tapering to top, black, beset on sides with tawny spurs; between the bases of these are two small, vellow-eresterl tubereles; on 4 is a slight elevation, on which stand four equal yellow-erested tubereles; along- the basal ritge are others, similar; head obovate, narowing towark top, bilobert, the vertices lighl, mther conical, each hearing a short black knoh, the summit of which is rounderl, with a little cone in the mirdle, and a circlet of six others about it, springing from near the base, each with short bristle; color of face blackish recthrown; the surface rough, and on it many low, rounded and pointed tubereles, those at and near the top langest, and either red-brown, lighter than the face, or yellowish, — the rest black; along the back of the head, both at top and sides, at row of forked or branching spurs, one of which, standing back of each vertex, rises above the knob (as shom in Fig. $f^{s}$ ). The hear and its appendages scarcely rary from first moult to maturity, except in color. (Figrs. c, canagnified.)

As the stage progresses, the dorsal patch becomes distinct, whitish; and the general body-colon changes from recl-brown and yellow to sordid gray.

Duration of this stage 3 and 4 days.

After second moult: length. 26 inch; shape much as before; the appendages on 3 longer, reaching .05 inch, short at base, irregularly tapering, black, with irregular tawny knobs on sides; color of hody red-brown on dorsum, the processes and tubercles except those on 1 th and 13 (which are black), and those on the patch (which are concolored with it), red-brom; so are the tubercles on the basal ridge; sides black; the patch either yellow-butf or red-buff; 3 and the broad ridge of $t$ are red-buff; head as before, the face nearly all black, the edges at the sutures reddish (Fig. $d, d^{2}$ magnified). To next moult 1 days.

After third monlt: length, .t inch; general color, red; the anterior segments 


\section{LIMENITIS II.}

red-buff, 2 speckert dorsally with black; the patch red-buff; so also the basal ridge; the segnents from 4 to 11 , except 8 and 9 , much covered with round, glansy, bead-like proceswes, deep red in color; these are arranged just as in Arthemis; the appenclitges of 3 are now very long, measuring from .11 to .16 inch, slencler, tapering to the end, bent forward at about four fifths the distance from base to top; color blatck beset from base up with separated sharp spurs, large and small, black, with tiwny tips; hend as before; color red, across the lower front black-red. (Fig. e, nat. size, $e^{2}$ mag.)

At one day from third moult: length .45 inch; the beads now between red and blue; the patch yellow-buff, the basal stripe still more yellow.

At two days from the moult: length .55 inch; the beads now deep blue, the body lighter colored, but still red. Finally, as the fourth moult approaches, the dark portions change to olive-green. Duration of this stage 4 to 5 days.

After fourth moult: length six hours after the moult .7 inch; segments 2, 3, 4, cleal red-buff, very little specked with black at the junctions; $5,6,7,11,12$, 13 , red-ferruginous, with little or no black; the patch on 9 , and partly covering 8 and 10, on dorsum, red-buff, but a shade lighter than the anterior segments; the basal ridge still lighter; the appendages on 3 vary from .2 to .3 inch in length, slenter and tapering as before, also bent as before, and from base beset with irregulin and separated sharp spurs, the tips of which are tawny, but all else, as well as the stems, shining black; between these appendages are two fine crested tubereles, color of the ground; on 1 are two large crested tubercles at the ents of the ridge, and two small ones between them; there are also deep red, glassy beads on the ridges, as described at last previous stage; 5 has two small tubercles and three rows of beads; 6 has an elevated ridge, with a mamilloid process at each end, the top bearing a cluster of little fleshy grains (Fig. $h$ ), with no supporting tubercle; the succeding segments lave but two dorsal crested tubercles each, and to 11 they are small, those on the patch concolored with it; 7 is beaded like 5, and 11 and 12 are thickly bended; 12 has tapering processes, with crests of grains (Fig. i); 13 has two prominent pairs, one quite at the extremity, turned back, the others springing from bases of the first, at right angles to the dorsum; all crests are made up of little fleshy knobs, or grains, conical, forked, or elongated and acute, and all are red; crested tubercles in row on middle of side, small, and along basal ridge, larger; feet and proleges red ; head obovoid, nurrowing towards top, bilobed, the rertices high, rather conical, each bearing a short black knob, the summit rounded, a little cone in the middle thereof, and a circlet of six others about it, springing from near the base, each with short bristle (Fig. $f^{5}$ ); color wholly red, except across lower front, where it is reddish-black; the surface granulated and dotted with low 


\section{I.IMIENITIS II.}

rounded or pointed tubereles (Figs: $y^{2}, y^{3}$ ), those at and near the top lin rigent, nearly all red, but a few black both on front and side ficce; allound the top of head and flown the sides at back, a row of sharp spurs, some simple. some branching or forked (Fig. $g$ ), and one of these rises behind the process on vertex, and overtops it (Figr. $f^{3}$ ); color of the spurs red. (Figs. $f^{\circ}, f^{* 3}, f^{ \pm}$.)

At one day after fourth moult: length . 85 inch; all the dark parts paler, the red elanging to brown, and more or less mottled dark green; the basal stripe and the tubercles on it pure white; the patch lighter, with a yollow tint; the beads changed from red to blue.

At two days from fourth moult: length 1 inch; the red parts now olive-brown. The lanve reach maturity at about three days from fourth moult.

Mature Larr. - Length at rest 1.2 inch, greatest breadth, .26 inch; lenerth in motion 1.5 inch. As deseribed under fourth moult, but the dark parts are now olive-green, the beads blue; the dorsil patch either redhish-brown, or pinkwhite; the anterior segments pale red-brown; the stripe along the basal ridge broad, white, with a green tint; the head pile red. (Fig. $f^{2}$.) .

At from 4 to 5 days from fourth moult, pupation takes place.

Cinrsatis. - Length 1.1 inch; head case sub-pyramidal; the vertices have each a low elevation, triangular; mesonotum hichl, rounderl, with a thin low carina which rises to a blunt apex, sloping either way alout equally; wing cases much elevated above the surface on the dorsal and posterior sides, the middle being incurved; on middle of dorsum rises a process, broat at base but rapidly narrowing to a sharp elge, romeded at top, not quite circular, the anterior part having a more rapid curve than the other; the space between the base of this and the wing cases corrurated; abdomen sub-cylindrical, a little compressed latcrally, rising to a low medio-dorsal ridge; color of anterior parts, head and mesonotum brown; the dorsal side of heal case imperfectly silverert; wing cases deeper brown, the raised rilgres blackish ; the dorsal proecss same color as the wings; at base on either side is an oblique black bar which croses three segments, and the space between these and the wing cases is silvered on a whitish ground; abdomen buff, mottled with gray-green or olive-green, on ventral sirle quite uniformly, but on the rest the dirk shades are faint and do not much discolor the light; the list segments dark, like head. (Fig. $k$.) Duration of this stage $S$ days.

'The only examples which I have seen of this fine butterfly have been sent me by Dr. William Witteld, who hats taken it in considerable numbers, at Indian River, Florida, during 1880 and subsequent years. But I learn from Mr. 'T. L. Mead, now of Lake Eustis, Ormge Co., Florida, that he has seen Eros both there and in North Florida. At Indian River, it is the only red Limenitis flying. Dr. 


\section{IMIIENITIS II.}

Witteld has taken it as early as 25th March; also from 11th to 17th May, from 5 th to 30th Jume, on Sth July, and at several dates during the fall. He observer a female ovipositing in the early part of November, 1852. In October precerling, he had picked several eggs off willow, and from these, between 14th and 20th November, obtained eight hybernacula, constructed after second moult, while four of the caterpillar's went on to chrysalis. On December 11 th, a butterfly emerged, another 19th, and two others later in the month. On 18th Janury, 1853, one of these hybermating linva came from its case, and passed a moult on the 10th. Its period of hybernation, therefore, was about sixty days. The winter in that region is brief and mild, and probably the late buttertlies live through it, as Dr. Witteld has taken young caterpillars of Eros, not yet at their second stage, in January. These must have come from egrgs laid in that month. Limenitis Ursulc larvo bred by Mr. Uhlrich, of Tiffin, Ohio, discovered a habit similar to this; some late larve making cases, while part went on to chrysalis and butterfly. But, in Ohio, these late butterflies certainly would not survive the winter. On the other hand, I have never known late larva of Disippus to go on to chrysalis. Dr. Witteld is of the opinion that there are at least four broods of Eros larve during the year; and I can well believe this to be so, as Disippus has three annual broods here, at Coalburgh, and that between June and November.

In three instances, egrgs obtained by confining the females in bitgs over willow were sent me by mail; the first arriving in 1850, 20th July. They were nine days on the roarl, in tin box, but at six days, the box was opened at Macon, Georgia, by Prof. Jno. F. Willet, and fresh leaves supplied. The larva had emerged from the eggss before Professor Willet examined them, and when they reached me, the largest had passed second moult. In 1S81, 21th June, I received several larve from Dl. Wittfeld, this time by way of Cambridge, Mass., where Mr. Scudter had had consideration for them and fed them. Some of these were just past first moult, others in stage following, - ten in all. Finally, on th August, 1881, four liurva came direct to me, in five days from Indian River, and of these, two were lately out of egge. So that I have been able to cxamine every larval stage, and Mrs. Peart has made drawings of all.

In habits these larve are precisely like both Arthemis and Disippus, as related in this Tolume (under Arthenis). They make at once, after leaving the egrg, perches of the midribs of the leaves they feed on (Fig. b), lengthen and stiffen the perches by binding on with silk morsels of chewed leaf, so that their slender resting-places do not curl up, or bend; on these they live, except when they go to the near edges of the leaves to feed; they make little packets of bits of leat, which are held together, and fixed to the perch near its base by silk, and push and drag these packets back as the substance of the leaf is eaten. (The object 


\section{LIMENITIS II.}

of the mysterious packets much and patient watching has failed to discover, but their presence and the building up of the perches are very curious features in the history of these species.) Finally, part of the latest brood of the year make themselves cases in which to sleep away the short winter, while part go on to chrysalis and butterfly, as related above. So fir as Dr. Wittfeld has observed, these cases are made after the second moult. The larva of Disippus make cases both after second and third moults.

The egg and chrysalis of Lros are preciscly like those of Disippus; the egr is like that of Arthemis also, and the chrysalis scarcely differs from that of the last-named species, except in coloration. The caterpillars also at all stages are of same general form and armature as those of Disippes and Arthemis, but after the first stage they differ from both these in some very important points. 'The coloring is essentially different at all stages after first moult, from that of Disippus, until maturity is reached; that is, to the middle of the stage succeeding the fourth, and last, moult; and then, the two approach each other again, both changing color and becoming green. On the other hand, Eros is very like Arthemis, and still more, I apprehend, like Ursuld, in coloration, and these species also change to green at maturity. But Eros differs remarkably from the two first-named species ( Ursula I have never bred), in the length, shape, and color and armature of the appendages on third segment.

Mrs. Peart, who was making drawings of the larval stages of Eros and Disippus at same time, and had occasion to remark all the minor points, informs me that the grains on the dorsal tubercles and processes of Eros are both larger and in greater number than in Disippus.

I compare the differences between the larva in color; thus, -

Eros, after first moult.

Color red-brows; the appentages on 3 are .03 inch loug, taperiug to top, black.

After second moult.

Color red-brown; the appendages .05 inch long; tapering, black, with separated spurs on sides.

After third moult.

Color deep reil, or ferruginous, the anteriol segments and dorsul patch rel-buff; the appendages from .11 to .16 inch long, black, slender, tipering from base to top, bent forward near top, with scattered spurs over sides, which spurs are black, the tips tawny.
Disippus, after first moult.

Color mottled tawny and dark (not red) brown; the appendages on 3 are .01 inch long, merely tubercles, with cluster of grains (as in Arthemis Plate, Fig. $\left.c^{2}\right)$, some of these white, some black.

After seconl moult.

Color more black, less tawny; the appendages .03 inch long, thick, club-sliaper, covered closely with grains, mostly tawny, a few black (as in $\Delta r$ themis, Plate, fig. d.).

Aftel third summer moult.

Color black, the tops of all tubercles tamny; the appeudages .06 to .08 iuch loug, clubbed, as before, tawuy. 


\section{LIMENITIS II.}

After fourth moult.

Color red-ferruginous, the anterior segments and dorsal patch red-butt, the appendages from .13 to .3 inch long (almost always over .21 inch), glossy black, sleuder, tapering to top and bent forward near top, at an angle (even the shortest are bent), top thinly clothed with sharp spurs, which are blick, the tips tawny ; color of head red, the lower part of face red-black.
After fourth (the last) summer moult.

Color variable, either dark red-hrown (not ferruginous), the anterior segments brown-buff, the patch light-buff, pink-tinted, or, dark yellowbrown, the anterior segments yellow-white, the patch yellow, with buff tint; the appendages .12 to .22 inch loug (almost always uuder .18 inch), either clubbed and closely covered throughout with tawny grains, sometimes mixed with black; or tapering for three quarters their length, then clubbed, the club thickly covered with grains; (the shorter processes are clubhed, the longer tapering, but clubbed at top); head amber color. in some cases yellow-brown, the top and sides pinkish.

In general, at all stages after the first, the larva of Eros are red; those of Disippus tawny and black. The remarkable prolongation of the appendages on third segment in Eros, strikes the observer at first acquaintance forcibly, if familiar with the short clubbed ones of Disippus. Of 8 larva of Eros at third moult, the lengths of these in hundredths inch were 11, 11, 12, 12, 14, 14, 14, 16 ; averaging . 13 inch. Of Disippus at same stage, $6,6,7,7,7,8,9,10$ : averaging .76 inch. At fourth moult in Eros, 13, 14, 22, 24, 24, 26, 26, 26, 28, 30 ; averaging .233 inch. Of Disippus, 12, 14, 15, 18, 22, averaging .162 inch.

In the absence of a Plate of Disippus, this contrast in the appendages is well shown by comparing Fig. $f^{3}$ of Eros, Plate, with Figs $e^{2}$ and $f^{3}$ of Arthemis, as well as the figures of the larva in their several stages. 


\section{LIMENITIS II.}

\section{EXPLANATION OF THE PLATE.}

EROS. Figs. 1, 2, 3, 3, 4ฉ.

a. FGG; $a^{2}$, micropyle of same; magnified.

b. Young LarVa; $l^{2}$, head of same; magnified.

c. Larwa after first moult; $c^{2}$, head; magnified.

i. Larva after second moult; $d^{2}$, head; magnified.

e. Larva after third moult, natural size; $e^{2}$, same ; magnified.

f. Larva after fourth moult, natural size.

$f^{2}$. Mature Larva, natural size.

$f^{3}$. Face at fourth moult, slowing third segment, and appendages.

$f^{4}$. Face at fourth moult, side view.

$f^{5}$. Inob at vertex.

$g, g^{2}, g^{8}$. Tubercles on head, differing in shape.

$h$. Process on sixtl segment, and crest.

i. I'rocess on twelfth segment, and crest.

$k$. Curysalis.

b. Perch of larva in first stage. 



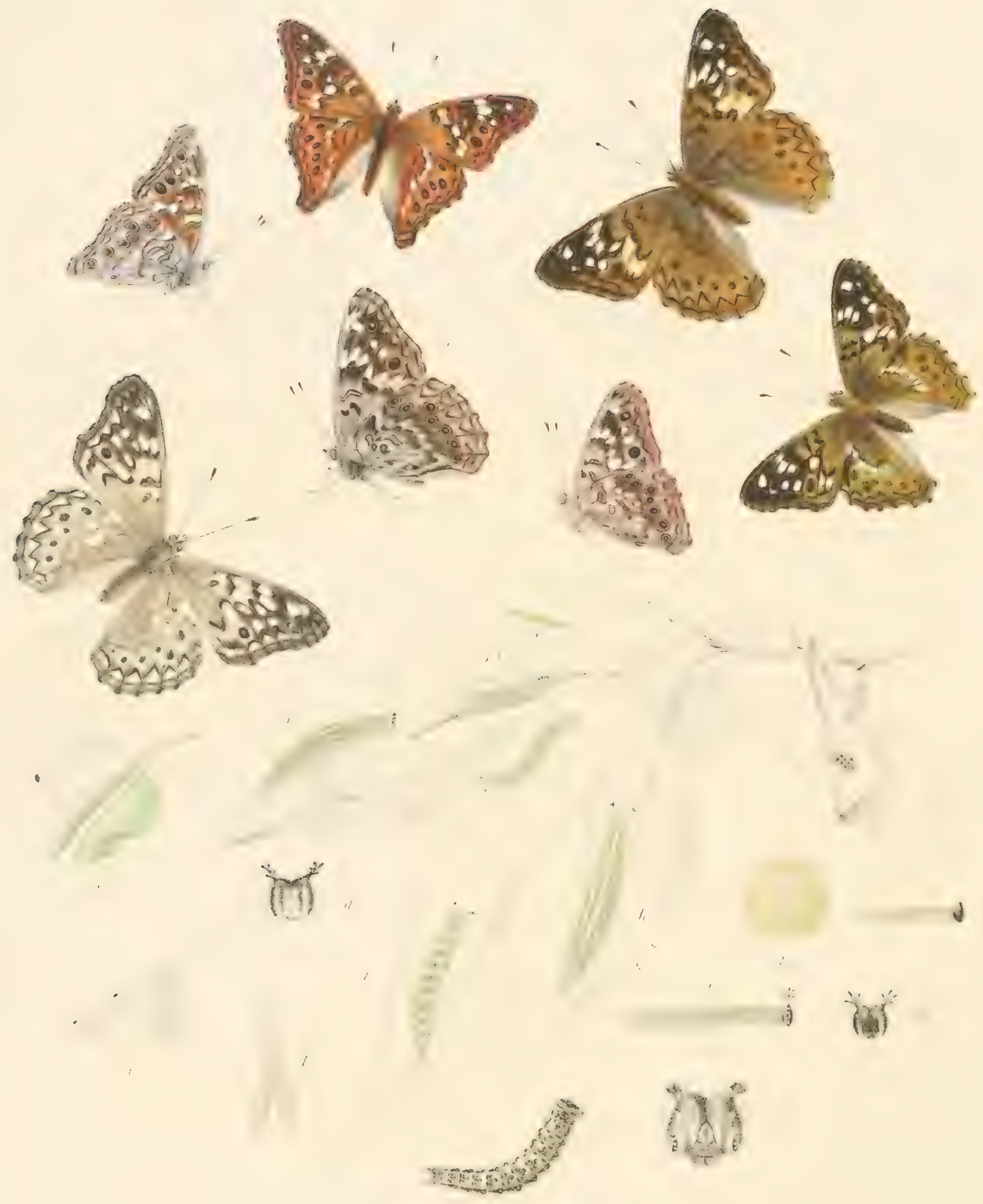




\title{
A P A T UR A I.
}

\author{
APATURA CELTIS, 1-5.
}

\author{
Apatura Cellis, Boisduval, Bois. and Lec., p. 210, pl. 57, 1833 \\ Lycaon, Riley, Trans. St. Louis Acut. Sci., III., p. 195, 1873. \\ Lbid., 6th Agr. Rep. Missouri, p. 137, 1874.
}

MALE. - Expands 1.8 inch.

Upper side of primaries next base and of secondaries thronghout either olivegray or olive-brown, the remainder of primaries being dark fuscous ; hind margin of same wing edged by a series of broad confluent lunules, sometimes not clearly defined, but often paler than the ground and distinct; these spots are bisected by a black line which runs parallel with the margin; on the extra-discal area two rows of white spots, the outer consisting of three, one of which is near costa, the second on the discoidal interspace, and the third on upper median; there is also a minute spot or point outside the line, next the margin on the lower sub-costal interspace; the second row crosses the wing in a double curve, and consists of seven spots, the first two nearly equal and smaller than the fifth, the third and fourth minute, the sisth and seventh about the size of the first; all these are sometimes clear white, or the imner row is more or less tinted with ochraceous; in the cell three black spots, two of them small, either sub-ovate or renate, one resting on the sub-costal nervure, the other on median opposite; a larger spot posterior to these, reaching across the cell, and in form a bent bar; on the second median interspace, in the outer line of spots, a black rounded ocellus with narrow brown iris and without pupil; in some cases there is a second ocellus on the upper median interspace, inclosing the lowest of the white spots, and rarely may be seen a third upon the discoidal interspace, also inclosing a white spot.

Secondaries sometimes fuscous for a narrow space along hind margin and at outer angle, sometimes of a uniform shade of color from base to margin; a sub-marginal black line as on primaries, preceded by a second line which is irregularly serrated, or sometimes wavy; upon the disk a series of six small blind ocelli crosses the wing, the second from costa being by its own breadth posterior to the general line; these are nearly equal in size, excepting 


\section{APATURA I.}

the last, which is minute and sometimes wanting; occasionally an additional ocellus, less distinct than the rest, maty be discovered on costal margin; on the middle of this margin a large sordid white spot, and five minute spots of similar color, form a band which passes around the extremity of cell; these last are not often distinct and frequently are in part or altogether obsolete, or are represented by a slightly paler shade of the ground color; in the cell are three faint spots, disposed much like the spots in cell of primaries; fringes white in the emarginations, fuscous at tips of nervules.

Under side of primaries either clear brown or grayish-brown, the outer limb pale fuscous; the marginal spots repeated, distinct; the white spots diffuse; in the discoidal interspace an ocellus inclosing the white spot; in the cases where there is more than one ocellus on the upper side there is a corresponding one below, and all but the lowest inclose white spots; next before the inner row of spots a sinuous fuscous stripe.

Secondaries either clear brown or grayish-brown, often with a pink tint; the ocelli repeated, seven in all, the one on costal margin being present, the seventh often duplex, each with blue or as often lilaceous pupil and yellowish iris, ontside of which is a narrow black ring; on the sub-median interspace is another ocellus, either rounded or long oval and without pupil; a pale fuscous band crosses the wing obliquely next anterior to the ocelli, and is preceded by an irresularly scalloped fuscous line, the space between the band and line being occupied by a row of small spots of the ground color, which extend quite across the wing and in part correspond to the discal row on upper side; the spots in the cell repeated; another above cell on the costal interspace, against the uppermost of the cellular spots and sometimes, seeming to be a continuation of it, but most often separated; each of these pale brown within and edged by fuscous; there is also sometimes a small spot at base of upper branch of sub-costal nervure, making on this area four or five spots; the sub-marginal lines repeated, distinct, brown or dull red; the imner margin also bordered by a line.

Body above olive-brown, beneath gray with an ochraceous tint on abdomen; legs light buff or cream color; palpi white, with brown hairs above and at tip; antenne fuscous, finely ringed on upper side with white, the under side being yellowish; club brown at base, clear white on upper half and at tip; sometimes the club is pale green.

Fexale. - Expands 2 inches. Similar in color, and varying as in the male; the markings similar.

The foregoing description is taken from the summer type of this species. The earliest brood, from. larvæ which have hybernated, are in general much paler colored, the gray shades predominating, and the fuscous portions being pale. 


\section{APATURA I.}

(Fig. $\left.5^{9}\right)$; occasionally, however, some of this brood are as dark colored as any of the later ones.

EGG. - Color pale green; in shape nearly spherical, lattened at base, and having eighteen slightly prominent vertical ribs and many fine, horizontal, equidistant stria.

The larva emerges from the egg in three days. Length .08 inch; whitishgreen; cylindrical, thickest at second segment, tapering gradually to the last, which is slightly forked; surface covered with minute tubercles from each of which springs a short hair; head roumd, bilobed, twice the diameter of the second segment, black, covered with tubercles. (Fig. c.)

The first moult takes place in three days from the egg. Length .2 inch; yellow-green, the dorsum covered by a band composed of yellow tubercles arranged in two longitudinal rows, with cross rows upon the anterior part of each segment, the remaining space on the posterior part of the segment green; along the side a crenated line, and below the spiracles a straight line, each formed of yellow tubercles; scattered tubercles over the whole upper surface; head either black, or purple, or green, the mandibles and ocelli brown in case green prevails; at the vertices large green stag-horn processes, with three fleshy prongs at top, smaller prongs below and at base, and three along the side of the head below the horns, the tips usually purple or black; tail forked and roughly tuberculated. (Figs. $d, d^{2}$, larva and head magnified.)

The second moult occurs in from three to four days. Length .25 inch; yellow-green above, blue-green at sides and beneath; the bands and lines as before; the tubercles much enlarged, prominent, irregular; tail more deeply forked; head brown, mottled in front with pale green, the homs enlarged. (Fig. e.)

The third moult follows in four days. Length .35 inch; not essentially different. (Figs. $f, f^{2}$.)

The fourth and last moult in four days. Length .65 inch; the body stouter on the anterior segments, the horms reduced in size, the prongs less prominent,

Before the fourth moult the larva covers the surface of the leaf about its resting place with silk, and after the moult remains quiet for nearly two days, when it becomes active and feeds ravenonsly; the body now grows rapidly, lengthening about one tenth inch daily, till it reaches maturity five days after the fourth moult.

Mature Larva. - Tength 1.2 to 1.3 inch; shape sub-cylindrical, being somewhat flattened dorsally, very thick in middle, tapering regularly either way, the second segment being of about the same width as the last; the tail deeply 


\section{APA'TURA I.}

forked; color yellow-green dorsally, blue-green on the sides; the whole surface granulated, owing to minute tubercles on the sides and larger and irregular ones on the back; these last arranged in transverse rows, separated by deep creases, there being four rows to each segment; on either side of the dorsum a clear yellow line fiom head to end of tail, and between these a less distinct pale stripe, on which is set an oval yellow spot on the anterior end of each segment; often this stripe is wanting, and the yellow spots only appear; on the side a pale yellow wavy line and an infra-stigmatal straight line; under side and legs blue-green; head sub-quadrate, longer than broad, punctate, covered with minute tubercles, green, with four pale vertical stripes upon the front; mandibles and ocelli brown; horns small, yellow-green, each furnished with two short terminal prongs, which are tipped with brown; other small prongs about the middle of the horns and at base, and along the top of the head, and three at sides of head. (Figs. $\mathscr{g}, g^{2}$.) Duration of the larval stage about twenty days.

The hybernating larve at maturity differ from those described above principally in that the yellow spots of the dorsum have disappeared, and given place to a longitudinal yellow line, making three similar lines on a dark green ground, the immer edges of the two exterior lines being whitish; the color of the whole body is greenish-yellow. (Fig.h.)

Curysulis. - Length . 85 inch; compressed laterally; the outline of the under side convex, regular; the abdomen prominent dorsally, much arched, sharply carinated, the anterior edge of each segment on the keel produced and clubbed (Fig. $j$ ) and marked on either side by a shining black dot; the last segment terminating in a long bifurcated pad of hooklets (Fig. k.) ; the thoracic segments depressed at an angle of forty-five degrees from the end of the keel, the sides excavated in the direction of base of wing; mesonotum angular, rounded somewhat at summit; the head case produced, sub-conic, the palpi cases prominent, pointed; color either delicate yellow-green or blue-green, finely specked with pale yellow over the whole surface; the neuration of the wings distinct; a yellow line passes along the keel and to the mesonotum, at which it forks to the palpi cases; another passes along the posterior edge of the wing case, and is joined by an undulating line upon the side of the abdomen. Duration of this stage, from seven to eight days. 'Total from egg to imago about thirty-one days.

Several of the larva of the first summer brood raised by me, in 1873 , stopped feeding after the sccond moult, and commenced their hybernation. Some composed themselves on the leaves in the glass in which they were kept, others directly on the sand at the bottom of the glass, in either case upon a coating of silk. The color of these larva soon changed to brown, in which was to be seen, 


\section{APATURA I.}

under the microscope, a mottling of vinous and green. (Fig. $e^{2}, e^{3}$.) The last fall brood all assume this color, and hybernate also after the second moult. And the earlier broods sometimes all hybernate, as I observed last season (1874).

Celtis is common in certain localities in West Virginia, usually, if not always, near streams, along the banks of which the food-plant of its larva grows. This is the Hackberry, Celtis occidentalis, a small tree much resembling the Elm in the shape and style of its leaves and the roughness of its bark; found, according to Gray, from New England to Wisconsin and southward. Probably the range of the butterfly is nearly coextensive with that of the tree, though the former must be rare in New England and eastern New York. Prof. H. W. Parker states that it is found in Massachusetts, along the banks of the Comnecticut River, but is not common. Throughout the Mississippi valley it is abundant, and I have received many specimens from Texas. It has not been taken, so fur as I know, in the Rocky Mountains, nor in New Mexico or Arizona, although Leilia inhabits the latter State. Celtis is exceedingly alert, restless, and inquisitive, active on the wing, but without sustained flight, and darts from one object to another so swiftly that the eye can scarcely follow it, alighting but for an instant on tree trunk or leaf, the dress of one passing, or the traveller's horse. More than once it has sprumg upon the net which I was carrying. Its usual attitude is expressive of its disposition, the wings erect, the head and antenne raised, suspicious of suprises. But it will haunt a favorite spot for days, and the collector has only to wait patiently a while and it may be captured. It is readily attracted also by a sugared bait, and a string of dried apples, saturated with syrup and suspended among the branches of the tree which it frequents, may be employed to advantage. Occasionally, I have seen it upon flowers, but a rotten apple or fallen grape is much more to its taste, and especially, if there is any decaying or fetid animal matter in the vicinity, it will greedily settle upon it, and then loses all sense of danger and may be covered by the net withont even attempting to rise.

Very early in the season a few fuded and broken females of Celtis are to be seen, the survivors of the last year's broods. 'The caterpillars also hybernate, probably hidden among the corky ridges of the bark of the tree, which in hue their winter coating closely resembles. It has been conjectured that they fall with the leaf, and attached by a web to its under surface, so pass the winter on the ground, and in the Northern States; under the snow, ready to discover the tree and ascend it on the first coming of spring. It is not unlikely that many of the hybernating caterpillars do fall with the leaves, which are detached by the first frosts, and carry with them also the newly hatched larve, or those of the 


\section{APATURA I.}

first moult and which not having reached the hybernating stage certainly perish. But I doubt if the species is perpetuated by the others. 'The leaves are blown far and wide, and in the district in which I live, the greater part of them find their way into the river. If any caterpillar should survive the winter in such encumstances, the chances would seem to be almost infinite against its reaching the food-plant. (See note.)

The first butterflies from these hybernating larva appear about the end of May, at Coalburgh, and by middle of June, those which have come from the eggs laid by hybernating females. Thenceforward, until October, an irregular succession of the butterflies are on the wing, and the larve are to be found at every stage of growth. It would appear by breeding from the egg, that occasionally part of a summer broorl stop feeding after the second moult, and commence hybernating, but this is not always the case.

I had known nothing of the preparatory stages of Celtis till 5th September, 1872, when a female was taken in my garden. I had planted there the previous spring several small trees of the Hackberry, in the hope of alluring this butterfly, and on one of the branches I tied the captive in a muslin bag. On the 7 th, it had laid a number of eggs, in clusters of six or more, upon the under sides of the leaves. One cluster of seventeen was arranged in close rows of five with an incomplete row of two, the eggs touching each other. (Fig. a.) On the 12th, the larvie began to emerge, eating away the shell below the crown until this was ready to break off and permit egress. I brought the limb to the house and placed it in a bottle of water. 'The little creatures seemed disinclined to feed, and ran about the leaves, one after another dropping by the thread which it spun, till it became certain that all would escape. 'This led me to break ofl' the leaves and inclose with the larve in a glass, and thereafter I had no trouble. Subsequent experience has satisfied me that this is one of the easiest species to rear, and I have rarely lost one of a brood. On the 26th, they were passing the second moult, and the stag-horn processes on the head were well developed. It is the custom of these larve from this stage to rest with the head bent forward and downward, so that the face is flat on the leaf and the horns project in the same plane, the back of the body being arched. (Fig. $f^{2}$.) They are disinclined to move, and will remain many hours in the same position or place. 'Their mandibles are strong, and the thickest leaves seem to be preferred in feeding. This is contrary to the habit of Libythea, which feeds on the same tree, but seeks the tender termimal leaves. Early in October, all these larva had changed color from green to brown, and sought the sides of the heavy midribs or depressions in the surfices of the leaves, remaining motionless. But then and at any time during their hybernation, it was not difficult to rouse one from its lethargy, 


\section{APATURA I.}

when it would slowly raise its head and perhaps move along a little, or would throw the head back drowsily as if to intimidate an enemy, an attitude which the larva when active would assume to drive away an ichneumon fly. These larva were alive on the 14th of Harch following, but shortly after were destroyed by an accident.

On 2Sth June, 1873, I again secured a female, and in same way as before obtained many eggrs, about seventy, laid singly and also in clusters. Two clusters were three layers deep. From these eggs I succeeded in raising about twenty butterflies before the end of July. All the larre which then matured retained their green color to the last, but the others, fully one half of the brood, after the second moult, stopped feeding and changed color. 'This change is not attendant upon a change of skin, but usually begins soon after the moult, and takes place gradually. In some cases it was complete within two or three days, but in others several weeks intervened. In the sime way the reverse change occurs in the spring before the third moult, but the process is then rapid.

Subsequently, September 7th, Mr. T. L. Mead, at Coalburgh, confined a dozen females in one large bag, and from these were obtained nearly or quite 1000 ergos, as we computed. More than 150 were laid on one leaf, and half of these in one great cluster. The caterpillars from these eggs were left on the tree under' confinement, and so remained till the cool nights made it advisable to give them protection. A few were then found to be still feeding, but most had changed color and were at rest. Of this large number that went into hybernation, about fifty only emerged alive. I had placed them in the cellar, where they were left till April, then removing to a moderately warm room, about the time the buds on the Hackberry were beginning to burst into leaf. Perhaps the result would have been more favorable had the larve been exposed to light and air during the winter. On 26th April, a few were observed in motion, and buds were introduced on which they readily began to feed. By 2d May, they were begimning to lose their brown coats, changing to pale green. After the third moult, which occurred on the 5th and succeeding days, they appeared in the beautiful emerald green that is natural to the summer brood. By the 21st May, the first change to chrysalis was made, and the butterflies began to appear on 30 th of same month.

The larva of the spring differ from those of the summer and fall so strikingly that had I met them at large I might well have supposed them to be of another species. Instead of the tessellated back, the ornamentation was restricted to longitudinal stripes. They were also unusually large. The differences may be seen by reference to the Plate. (Fig. h.)

The young larva of Celtis are not so intensely gregarious as those of Clyton, 


\section{APATURA I.}

but they remain upon the same leaf, scattered in small bodies over the surface, near together without being in close contact, as is the habit of Clyton. It is not usual to find more than one on a leaf in the natural state after they have become half grown, and they probably disperse at the third moult, that is, the few that survive the attacks of their many enemies.

When ready to change to chrysalis, the caterpillar covers the side of the leaf next about it with silk, and remains motionless for several hours. Its color now becomes of a uniform green, the yellow markings disappearing. The body shortens and contracts at either extremity, while retaining its full thickness in the middle segments. During this period, it does not hang suspended by its anal legs, as do the Graptas, but rests upon the leaf as usual, the tail more appressed to the leaf and the head bent under. Gradually the anterior segments contract, the seventh and next succeeding becoming at the same time compressed laterally and elevated, and the dorsal outline assumes the carinated shape of the chrysalis. At length it loses its foothold and hangs by the anal legs, the skin divides at back of the head and is speedily shuftled toward the tail, the pad of hooklets at the end is fastened into the silk by the same process as in Grapta, (see notes on Comma, Vol. I.), and with rapid whirls it divests itself of the cast off skin and the change is complete. The pad spoken of is filled with hooklets seemingly to the number of a hundred or more. (Fig. k.)

Although so many eggs are deposited by Celtis, few of its caterpillars can reach maturity, and probably few emerge from the eggen not so much because of the ordinary parasites that destroy most species, but of the spiders which infest the Hackberry to an unusual degree, so that it has seemed to me almost impossible that a solitary egg could escape them, much more clusters of eggs. I have not noticed any losses by ichneumon flies in this species, and $\mathrm{Mr}$. Riley has had a similar experience. This author has admirably described the life history of Celtis in the paper cited, and has elaborately and beautifully illustrated its phases by his pencil.

I do not know of any other food-plant for this species than the Hackberry.

Celtis is considered by some authors to be identical with Lycaon, Fab., and Alicia as only a variety of the same species. My reasons for differing from these conclusions are as follows:-

The description of Lycaon, Ent. Syst. IH., p. 228, No. 714, reads thus: "P. S. alis dentatis anticis fuscis tlavo alboque maculatis, posticis ferrugineis: ocellis sex coecis, subtus variegatis : ocellis octo."

Papilio Lycaon. Jon. fig. pict. 4, tab. 17, fig. 1.

Habitat. Mus. Dom. Drury.

"Corpus medium, fuscum abdominis lateribus fulvis. Alæ antice supra fusce, 


\section{APATURA I.}

flavo alboque maculatix ocelloque coeco, atro iride rufi, subtus basi flava, fusco maculatr, apice fusca maculis tribus albis ocellisque duobus atris iride flava, anteriori pupilla alba, posteriori coeco. Striga marginalis flava. Postica basi obscura striga e maculis quinque flavis, apice rufis, maculis sex ocellaribus, atris. Subtus Havo fuscoque variegato ocellis octo atris iride flava pupillaque coerulea."

"Fore coings fuscous, spotted with yellow and white; hind wings fermumous with six blind ocelli; under side variegated, with eight ocelli. Papilio Lyccom, of Jones's drawings, plate 17, fig. 1. Habitat unknown. Collection of Mr. Drury. Body of medium length, fuscous, the sides of the abdomen fulvous. Fore voings above fuscous, spotted with yellow and white, and with a blind ocellus, which is black with a reddish iris; under side yellow at base, spotted with fuscous, the apex fuscous, with three white spots and two black ocelli with yellow irides, the anterior one pupilled with white, the other blind; the marginal stripe yellow. Hind wings obscure at base, with a stripe and five yellow spots, mofous at apex, with six black ocelli. Under side variegated with yellow and fuscous, with eight black ocelli which have yellow irides and blue pupils."

This description cannot apply to Celtis, for in that species the upper side of the hind wing is not ferruginous, nor is the rpex rufous, and there is no yellow marginal stripe on either wing; the fore wing is also described as fuscous, which implies that it is wholly fuscous, whereas in Celtis the basal third is of quite another color. On the under side there is no yellow marginal stripe on the fore wing, nor is the base yellow, and the hind wing is not variegated with yellow and fuscous; nor are the sides of the abdomen fulvous. All the spots spoken of are characteristic of the entire group, and, color excepted, which is in every particular inapplicable to Celtis, there is not one specific character given. For the extra-discal rows of spots and the ocelli on the fore wings, and the discal spots and ocelli of the hind wings, are found in Celtis, Alicia, and Leilia, and with the single exception of the ocellus on the fore wings, are found in Clyton also, a species belonging to another group; and most of these markings, especially the ocelli of the hind wings and the apical spots of primaries are found in Idyja, Hiib., and its allies, which form still another group.

Fabricius is supposed to have made up his descriptions from the colored figures by Jones, but he refers to the insect as being in Drury's collection, and he must have seen it there, for that collection was one of the best known in Europe. These figures are still preserved at Oxford, and have been inspected by Mr. A. G. Butler. He is of the opinion that they were meant to represent Alicia, and says, in a letter to me, "It is certainly not Celtis, which I know well." Mr. Riley has received from Professor Westwood uncolored tracings, 


\section{APATURA I.}

copies of some formerly made from Jones's drawings, and has permitted me to see them. In the absence of coloring, these tracings may pass for Celtis, or Alicia, or Leilia. They merely exhibit the group characters, and are useless in determining the specific. Fabricius gave no habitat for Lycaon, and the chief reason urged for applying his description to any American species whatever, when it plainly fits none, is that no other is known to exist to which it would apply better, - truly a very insufficient reason. It is by no means impossible that a fourth or a fifth species belonging to this same group may yet be forthcoming, and it would be difficult to show that the Fabrician description, or Jones's figures, were not intended for one of these. And for aught that appears, the figures may have been taken from an Asiatic species. The same reason has been alleged for applying to Chyton Bois. the description of Herse Fab., founded also upon Jones's drawings. But after seeing tracings of these, I entertain not a doubt that they were meant to represent either Ilyja, or a species allied to that, and could not possibly have been meant for Clyton. Boisduval's names should be retained for both these species. They were figured and described by him now more than forty years ago, and as Celtis and Clyton have been known during all this periot.

The differences between Celtis and Alicia may be seen by comparing the figures on our Plates. (Alicia, Vol. I. pl.45.) They consist principally in size and color, the preparatory stages of Alicia not being known. It is a similar case to that of Turnus and Eurymedon, or Eurytheme and Philodice, which differ in color only, and with many species of many genera which might be mentioned. The description of Lycaon applies to Alicia, apart from the group characters, but in a single particular, the upper side of secondaries being ferruginous, and fails in every other point mentioned.

I have bred large numbers of Celtis from the egg, expressly to see if any variety like Alicia would result. But there has appeared nothing of the kind. Mr. Riley, nearly a thousand miles west of me, in Missouri, has had a like experience. And from Texas, as far south of Missouri, come numerous examples agreeing with those bred in West Virginia. 'The pair of Alicia from which the descriptions were drawn, were taken in Louisiana, but others have been received from Georgia, and the species may be common in the Gulf States. If it were a mere climatic variety of Celtis then it should take the place of that species in Texas, on the same parallel.

Note. - After the foregoing lines were in print, - 9 th May, 1875, - upon a half-opened leaf bud of Hackberry, on one of the upper branches of the tree, six feet from the ground, I found a caterpillar of Celtis, just out of hybernation, feeding. The ground had been swept by the winds all winter, and three weeks before the date mentioned had been ploughed. I must beliove that the caterpillar had hybernated on the tree. 


\section{A PATURA I.}

APA'TURA LEILIA, $7,8$.

A patura Leilia, Edwards, Trans. Am. Ent. Suc., Vol. V., p. 103, 1874.

MILE. - Expands 1.8 inch.

Upper side of primaries next base and partly in the median interspaces, and of secondaries throughout, ferruginous; the remainder of primaries, which comprises the apical area to median nervure and to cell, and the discal portion of the median interspaces, fuscous; hind margins bordered narrowly by fuscous; both wings have a sub-marginal black stripe, and a little anterior to this, a second, which, on secondaries, is either very slightly crenated, or is crenated next outer angle and serrated posteriorly; primaries have a transverse row of seven spots, either all white, or the upper three or four white and remainder yellow, arranged in a double curve, the first two and fifth nearly equal, the third and fourth minute, the sixth and seventh, near inner margin, equal, rather smaller than the fifth and sometimes confluent; nidway between this row and the margin is a second row of white spots and ocelli; the spots, two in number, being placed on the upper sub-costal and the discoidal interspaces; the three ocelli, on the lower sub-costal and the median interspaces, are black, rounded, the upper one small, with an indistinct pale iris, the others large, nearly equal, each with a few blue scales forming a minute eccentric spot and each surrounded by a pale brown nimbus; in the cell two transverse bars, the one at the outer extremity sub-reniform, the other near the middle straight, both obscure brown centrally, black at the edges, and separated by a space that is white irrorated with brown.

Secondaries have the costal margin fuscous; upon the extra-discal area a series of six black ocelli, arranged as in Celtis and Clyton, the second from costa largest and back of the line, the sixth minute, the others nearly equal and rather more than half the size of the second; each surrounded by a shade slightly paler than the ground color of the wing, and several containing small eccentric clusters of blue scales; on the middle of costal margin a white patch, in line with which five small white spots pass round the extremity of the cell; 


\section{APATURA I.}

two faint fuscous spots in the cell; fringes white in the emarginations, fuscous at the ends of the nervules.

Under side of primaries chestnut-red at base below the cell; also within the cell next base, but partly obscured by gray, especially along the sub-costal nervure; the remainder of the wing pearl-gray, showing a brown sub-color on the disk and in the middle of each interspace on the apical area, and at imner angle, the gray becoming suffused with pale blue as it approaches the hind margin; this margin narrowly edged with yellow-brown; the sub-marginal lines repeated, distinct, blackish-brown; the white spots repented, enlarged, and in addition, a white patch in the line with the outer series, on the costal margin; the lower spot of this row, on the discoidal interspace, nearly covers a small ocellus, a narrow black ring only being discernible on the anterior side; but the yellow iris is nearly complete; the other three ocelli reappear, enlarged, each with its cluster of blue scales and a well-defined yellow iris; the cellular spots as on upper side, the intervening space being clear white.

Secondaries pearl-gray, tinted with blue near hind margin; the gray shade least dense on the disk next before the cell, allowing a brown sub-color to appear; the inner margin also bordered by a brown line; the white discal patch and spots repented, and the line of spots extended across the wing to inner margin, following the course of a dark wavy line; the spots in the cell distinct, being two transverse bars, ench prolonged into the next upper interspace; the ocelli repeated, each containing a large blue patch and edged by a narrow yellow ring, which itself is edged indistinctly by fuscous; an additional ocellus is found on the inner margin, small, oval, and also with a blue spot.

Body above yellow-brown, beneath gray on thorax, yellowish on abromen; legs ochraceous, the tibia gray; palpi clear white, brown above and at tip; antennx uniform ferruginous throughout, very imperfectly annulated with white next the base; club fuscous at base, yellow at tip.

LATiva unknown.

The figures given represent one of three males, taken by Mr. Henshaw, of Lieutenant Wheeler's expedition, at Camp Lowell, and in Sonoto Valley, Arizona, August, 1874. Nothing is reported of the habits of the butterfly, or of the larva and its food-plant. But as Celtis reticulata, Torrey, is mentioned in the Botanical Report upon the plants of Arizona, Washington, 1574, it may be presumed that the larva of Leilic feed upon its leaves.

In the shape of the wings, this species is nearer Clyton than Celtis, the hind margins of primaries being more excavated, and of secondaries more sinuous, and the ant angle more produced than in Cellis. The three examples agree in shape, color, and markings. 


\section{APATIRAI.}

Leilia differs from the other nembers of its group, in that the black marks in the cell of primaries, which in Celtis and Alicia are three in number, two of them being in the middle of the cell, on the sub-costal and median nervures respectively, and placed obliquely to the nervures and parallel to each other, are here reduced to two, owing to the central marks being united in one straight bar, perpendicular to the nervures. These bars are also separated by a white space, which is not the case in the allied species. A similar arrangement of the bars is seen in Clyton, except that in this the imner bar is usually sinuons instead of straight, caused by the joining of the two oblique marks at their extremities. There are three ocelli on primaries of Leilia, as sometimes happens with Celtis, but in the former they contain eccentric patches of blue scales, as do also several of the ocelli on secondaries, a peculiarity observed in neither Celtis nor Alicid. On the under side the two lower ocelli on primaries contain similar blue patches, and the uppermost one a patch which is partly blue, partly white. The spots on the disk on upper side are white and distinct. The color of this side is nearly that of Aliciu, of the under side different from either that or Celtis, the basal part of primaries being castaneous, instead of light graybrown, and the remainder of both wings chiefly of a pearl-gray, suffused toward the hind margins with pale blue. In Cellis the prevailing hue is gray-brown, sometimes wholly pink-tinted, and of Alicia gray-white, tinted with purple. The antenna also are ferruginous above and below, with the slightest indications of ammulation near the base; these organs in Celtis are fuscous above, yellow beneath, and the fuscous portion is distinctly ammulated with white from base to club.

I regret having to figure this species without being able to give both sexes, as I aim to do in every case, but the difficulty of obtaining the butterflies of Arizona is so extreme that years might elapse before I should receive another example. 




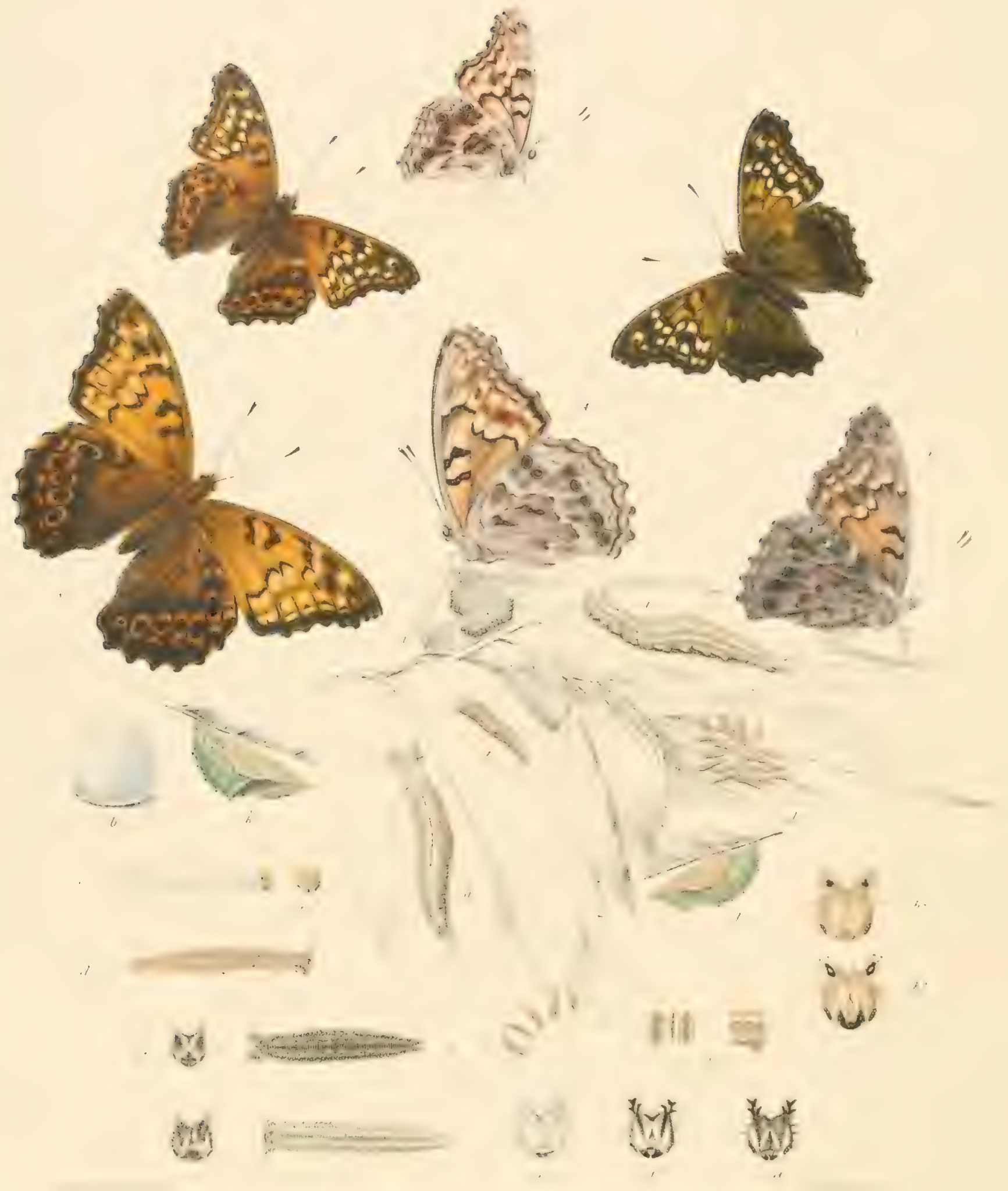




\title{
APATURAII.
}

\author{
Al'AULA CEMTON, 1-6. \\ Aparera Clymon, Boisduval, Bois. and Leec., p. 208, pl. 56, 1833. \\ Herse, Riley, Tmans. St. Isuis Aeal. Sci., III. p. 198, 1873. \\ Ibill. Gth Agrie. Kep. Mo., p. 140, 1874.
}

\section{VAT. OCELTATA.}

MiLE. - Expands 2.1 inches.

Upper side of primaries next base ferruginous, the remainder blackish-brown. the nervules sometimes fintly marked by ferruginous; secondaries blackishbrown, clothed at base and along the abdominal margin with long greenish-brown hairs; both wings have a black line, forming the imner part of the matrginal border, preceded by a series of small, pale ferruginous spots, wanting next the apex of primaries; on secondaries these spots are lunular and often concolored, but. the anterior side of each is edged with fuscous or brown, and together forms a distinct crenated tine which crosses the entire wing; on the disk of primaries a transverse simuous row of seven rounded yellow or yellow-fermginous spots, the sixth and seventh being in the sub-median interspace; beyond these a second row of five spots of same colvr as the others, occupying the median, discoidal and two lower subcostal interspaces, four of them arranged in a curve paratlel to the incised edge of the wing, and the fifth, on costal margin, forming a right angle with the two next succeding; in the cell two black, transverse, sinnous bars sometimes joined on the sub-costal nervure. Secondaries have an extra-discal series of six large, rounded black spots, disposed as in Celtis, each spot surrounded by a narrow fulvous ring, which is sometimes expanded on the basit side into a large fulvous patch, especially in the sub-costal interspaces; on the middle of the costal margin a pale, sordid-fulvous patch; fringes of both wings white in the emarginations, fuscous at the ends of the nervules.

Under side of primaries brom in several shades, grayish in the cell, with if yellow tint over the onter half of same, and grayish over the basal part of the sub-costal interspaces; somewhat red-tinted below the cell and in the median 
APATURA II.

interspaces; and clear brown with a faint purple tint along the hind margin; the discal spots repeated, luteous; the cellular bars repeated; next beyond the cell, a transverse, simuous black stripe; the sub-marginal line distinct and preceded by a complete series of blackish spots, which are lanceolate towards apex, elsewhere lumular.

Secondaries either light or dark brown next base, this area limited on the disk by a dark wavy line which begins on the middle of the costa and ends on the inner margin, at one-third the distance from base, after curving far down towards the angle, on the sub-median nervure; beyond this line there is a narrow space across the entire wing of gray-white with a pink tint, followed by a brown cloud on which are the ocelli; the margin as on primaries, purplish-brown; besides the sub-marginal line is a second composed of nearly confluent narrow lumules; in the cell a transverse fuscous spot, and another at the extremity; the ocelli seven in number, and the one next inner angle duplex; each ocellus black, pupilled with an abbreviated stripe of bright blue, and surrounded by a fine ferruginous ring. Individuals vary much in the shades of under side, and when these are light the purple tint is less perceptible.

Borly above greenish-brown, beneath pale vinous-brown; legs ochraceous, the front (or aborted) pair, yellow-white; malpi yellow-white, fuscous abore and at tip); antenua fuscous above, light brown beneath, imperfectly amulated with gray; club black, the tip greenish-yellow.

Fedrale. - Expands from 2.5 to 32 inches.

Upper side bright ferruginous nearly to the hind margin; in some cases the fuscous portion is confined to the midlle of the interspaces near the apex, in other's the interspaces on the disk are also fuscous; the spots more diffused and more yellowish than in the male; secondaries essentially as in the mate. On the under side the color's are lighter than in the male, and often the markings on outer half of the wing are much obscured.

\section{VAT. PROSERPINA,}

Seuduer, Trans. Acad. Nat. Sci. Chicago, I., p. 332, 1869.

This form differs from Ocellate in that secondaries are black throughout, the ocellar spots either wanting or scarcely perceptible; in some cases the sub-marginal ferruginous spots are faintly indicated; on the under side the difference is less marked, the ocelli reappearing. 'The female differs from Ocellata in same way, but on the under side there is a greater obscurity of color, the whole of secondaries and the apical area of primaries being of an uniform shade of brown, or fuscous, or fuscous with a purple tint; none of the markings distiuct, and the 


\section{APNTURA II.}

ocelli nearly obsolete, the rings especially being absent, and the blue pupils in a greater or less degree; and these last are often changed to a dull whitish-green.

\section{VIR. FIORA.}

I im uncertain as to the position of this form, whether it is to be considered ats a variety of Clyton, or as a grool species. After the Plate of Clyton was drawn, I observert in the collection of Mr. William Stadhmair, of Brooklyn, several males and a single female, lately $(\Lambda$ pril, 1876$)$ sent him by his son, who had taken them at Palitka, Florida, all of which differed from any variety of Clyton hitherto seen by me, whether from Georgia, Louisiana, Texas, or IVest Virginia. 'These males were, moreorer, alike in shape, color, and peculiarities of marking, except that on the under side there was a difference in the lightness or darkness of the colors, but just as I have seen in the same brood of Chyton in West Virginia. In these males both wings are more excised than is usual in Clyton, and secondaries are more prolonged and more pointed at the anal angle. The upper surface of both wings is of an uniform bright orange-ferruginous, except the extratiscal area of primaries, which is of a deep shade of ferruginous, blackenerl in the midclle of the several interspaces; primaries are scarcely at all obscured at base, and the two rows of spots are bright orange-feruginous, of same shate as the general surface, instead of being lighter, or yellowish, as in the nsual Clyton. Secondaries have the base and inner margin but slightly obscured, and a broad bright field extends from the middle of the wing to the marginal band. 'The ocelli lie on this field, and are large. 'The marginal band of each wing is remarkably broad, so that on secondaries it nearly reaches the ocelli; and except in the two interspaces next outer angle there is a total absence of the sub-marginal crenated line always seen in var. Ocellatu. Furthermore there is an absence of the light patch on costal margin. The peculiar shape of the wings, the uniform bright shade of ferruginous, extending even to the rows of extra-discal spots, the large ocelli, the broad marginal band, and the absence of the crenated line, and of the costal patch, strike the eye at once. On the under side the pattern is as in var. Ocellata, but the color's are all intense; the cell and nearly all the spots of primaries buff; the extra-discal area deep ferruginous; the basal area of secondaries deep gray-brown, tinted with fermginous next costa and towards anal angle; the sinuous discal stripe deep fermuginous, as is also the field on which are the ocelli, and between this stripe and field the space is lilaceous; the ocelli intense ferrugimous, with obsolete rings, and lilaceous pupils. And on both wings the broad marginal band is cut by a conspicuous blue-black stripe from anal angle to the second sub-costal nervule on primaries; this stripe 


\section{Al'A'TURA II.}

so expanded next inner angle of primaries as to occupy full half the width of the band. The female is duller colored, but as little obscured as the male. Primaries are crossed by a broad, smuous, deep black discal band, which in the usual Clyton is brown or ferruginous, and the bars in the cell are black and heavy. A broad, sub-marginal black stripe completely crosses both wings, the margin outside this stripe being ferruginous concolored with the disk. The erenated line is absent from secondaries, even at the outer angle.

I give this form, therefore, as a possible variety of Clyton, but my opinion is that it will be found to breed true to itselt, and, if so, it is a good species. Mr. Starlmair found these butterflies in one locality, resting on the leaves of trees, and evidently just out of chrysalis, and saw numbers of them, as he says in a letter to his father. With them were many A. Alicia, of which he took several, and these I also saw.

EGG. - Similar to that of Celtis; nearly spherical, flattened at base; marked by about eighteen slightly prominent vertical ribs, and by many fine horizontal expu-distant strix; color yellowish-ureen. Duration of this stage eight to nine days.

Youxg L.1rVA. - Length, .06 inch; cylindrical, somewhat tapering posteriorly, slightly pubescent; color pale green, translucent; head large, twice the diameter of the following segments, hemispherical, bi-lobed, brownish-yellow; the mandibles and ocelli brown. (Figs. $c$, $c^{2}$, larva and head magnified.)

The first moult takes platce in seven days. Length, .125 inch; borly tapering gradually either way from seventh segment; the second and last nearly equal in diameter, the latter terminating in a short, forked tail; the whole surface covered with fine whitish tubercles, from each of which springs a white hair; striped longitudinally and alternately with pale and dark green, the tubercles covering the pale stripes densely; in all there are six pale stripes, two broad, dorsal, one upper and one lower lateral, both narrow; of the intermediate dark stripes one is a narrow medio-dorsal, the others lateral; legs and pro-legs pale green, fringed at base with short white bristles; head large, broaler than the second segment, rounded, flattened, glossy, pale green, the forehead dusted with brown; the ocelli and mandibles brown; at the vertices fleshy stag-horn processes, with short, stout prongs; other prongs below at the sides of the face; all these, and the surface of the face, somewhat pilose. (Fig. d.)

'T'o the second moult thirteen days. Length, .2 inch; the pale stripes now changed to yellow-green; the surfice more roughly and unevenly tuberculated: the dorsal bands, before distinctly separated, now meet, but there are traces of a green medio-dorsal line; the second segment projects over the head a marrow sulb-triangular shield; the tails deeply forked; the horns shorter, pinkish, punctate; the forehead and sutures and the mandibles brown. 
Al'ATURA II.

Not long after this moult, having reached the leneth of .2.) inch, most of the larvie change color, the borly gradually becoming of a mixed red and graty, with dark green dorsal and lateral lines; the head and horns also change to brown. (Figs. $e, e^{2}$.) A tew may however proceed to their third moult, after which they will assume a winter coat, but of less decided color than that of the others, the green becoming brownish or vinous.

A fer days after resuming activity in the spring, the third mont is passed. Length now $t$ inch; the anterior segments have become much the largest, the shickl on second more pointed, the head larger in proportion, the vertices more prominent than at last stage, and the horms greatly developed; the horls green, striped longitudinally with white and yellow; color of head light green, with two pale vertical stripes in front. (Figs. $f, f^{2}$.)

Ahout ten per cent. of the lanve raised hy me varied at this stage in the markings of the face. One was wholly pale black except for four marks, two at the sides, and two in front above the mandibles; and the front of the antlers was black. 'This stage endured eight days.

After fourth monlt: length 8 inch. (Fig. g, nat. size; $j^{2}-g^{4}$ showing viniations in marking of head; $y^{5}$, sections of surface on dorsum and side.) 'The larve now grew rapidly and in from five to ten rlays had reached maturity, those which lingered, and changed to chrysalis the latest, invariably producing female hutterflies.

Mature Lami. - Length $1.4 \mathrm{in.}$ of $^{\circ}$ Fig. h) to $1.7 \mathrm{in.}{ }^{\circ}$ (Fig. i), greatent thickness of the latter, .24 in.; hody sub-cylindrical, somewhat Hattened dorsilly, the sides flattener, sloping, the base broad; thickest at sixth to eighth segments, tapering rather evenly either way; the last segment ending in a forked tail; the dorsum corered hy a broad yellow or buff band, which is edged on either side by white, and is bisected by an indigo-hlne line; the sides striped with dull green above, and below by two stripes of yellow, another of green being between them ; the under side and legs pale green; each segment creased five times so as to make four elevated ridges, the posterior two being broader than the others; the whole upjer surface covered with minute tubercles, white, translucent, sub-conic, irregularly placed on the ridges, some in each row being two or three times as large as others; some of these have at summit single short Heshy appendages. others a white hair; head pyriform, truncated at top, with an angular depression, the vertices sub-conic; on these last are stout many-pronged antler's, the prongs tleshy, round, and somewhat curved downward; on either side of the fice a vertical row of simple prongs; color of head pale green, the face marked by four vertical whitish stripes; the surfice both of head and antlers dotted with punctures which disclose a darker sub-color; the entire antler usually yellow- 


\section{APATURA II.}

green, but many examples have the front black, or merely a black dot at the base; ocelli and mandibles black. (Figs. $l^{2}$, $l^{3}$, hearls of mature larve.)

Cirrisalis. - Closely resembles that of Celtis in shape and color; the segrments of the abdomen are broader dorsally, making the keel one fourth longer, and the thoracic segments are proportionately shorter; the depression is less angular and the mesonotum is more rounded, while the head case is less prodincert.

Length, o .9 inch (Fig. $j$ ), 91.1 inch (Fig. $k$ ); compressed laterally; the ontline of the under side irregularly convex, the wing cases being nearly flat; the abdomen prominent dorsally, circular, sharply carinated, the anterior edge of each segment on the keel produced and imarked on either side by a shining black dot: the thoracic segments depressed from the end of the keel, the sides excavated towards the bases of the wings; the mesonotum rounded; the liead case moderately producer, sub-conic; the palpi cases sharp and prominent; color yellow-green, the wing cases and the whole under side pale bluish-green, nottled and inscribed with paile yellow; the neuration of the wings distinct; a yellow line passes along the dorsum ant forks to the palpi caces; another border's the posterior erge of the wing carses. Duration of this stage nine and ten rlays.

Clyton inhabits much the same districts as Cellis, feeling in its larval state on the same tree, the Hackberry, Celtis occidentatis. It is accasional in New Iork, and no doubt in New England, but the Valley of the Mississippi is its true home. Some years ago I took a single specimen, fresh from chrysalis, in a thicket near Newburgh, N. Y., and that is the only instance in which I have seen this butterfly on the wing, not having met with it eren in Wext Virginia. I was much surprised therefore at finding in my garden, at Coalburgh, th July. 187t, on a low Hackberry, a large cluster of freshly deposited eggs of Clyton. 'They formed a rounded mass one quarter inch across, were closely packed and five or six layers deep; in all about two hundred egress. (Fig.a.) Within the next-two days I found two similar but smaller clusters; in all these cases lipon the under side of the leal. On 12th of July the laxve began to hatch, and in course of a few hours had left the shells and gathered in a dense group near by. 'They are intensely gregarious in habit, and up to the time they separate, that is, till after. the third moult, they lie close together, completely concealing the leaf beneath, and it is one of their peculiarities, even to maturity, that they do not often lie straight, but take a sinuous position, and when in cluster as one curves so do those adjoining. Moreover they do not rest with heads all turned in the same direction and bodies in line or parallel, as is the habit of many species of gregarious larva, but they form an irregular mass, the heads mostly outside and fronting in every direction. This feature is correctly represented in the cluster of 


\section{Al'ATURA II.}

larva on the Plate, but the group in mature would be compact as I have hefore stated. I found that they fed principally at night, the leat in the moming having been eaten at one spot as if all had fed at the same time. When finally there remained nothing but the patch on which they rested, they were forced to shift to a fresh leaf. From the earliest stage, the surfice of the leat about and beneath these larvie was kept thoroughly clean, but just outside the gromp was a mass of exerement in a pretty redrular ridge and as if it had heen voided at that place. It was some days betore 1 diseovered the explanation of this, by happening to come upon the larvie one morning when they were engared in at general cleansing. The colony was comparatively active, many of its nembers moving about, some crawling over the backs of the rest. When a bit of frass was encountered by one of these last, who seemed especially deputed to act ats scavengers, it was seized by the mandibles, and if very small, the head and thoracic segments were jerkerl back, and by a snap the frass was thrown some distance, at least two lengths of the caterpillar. If this happened near the edge of the colony the frass probahly went over; if not, and it fell short, either one of the lanve on which it struck seized it, or it was met by one of the scavengers, and was again smapped oft; mil by repeating the process as often as was necessary, the obnoxious thing was gotten rid of. When a considerable mass was encountered, it was broken by jaws and feet, or two or three of the larva tugged at it till it was bronght near the edere and topzled over. In some cases, as one of the larve voided its frass, it turned and seized it, smapping it away. Presently the colony was cleansed and all its members resumed their usual attitude of rest. This sanitary work could only have been necessary when the larva were in confinement, as in nature they would have rested on the under side of the leaf.

Before the first moult took place, the larva remained immovable for about two days; the skin on the second segment became swollen and nearly covered the head. When the change occurred, this burst, disclosing the new hear and antlers, and the skin was speedily shuffled off' and devoured. 'This process of moulting was by no means simultaneous throughout the colony, but was going on for two or three days before all were changed. And the same may be said of each sincessive moult.

Soon after the second moult, which occurred lst August and days following; most of the larve began to change color, first to pink, then to brown. In other cases the change was very gradual, and the winter coat was not assumed before 1st September. All these at last rested on a common bed of silk web which covered the surfice of the leaf, each with head bent uniler so that the fice was in same plane with the lower side of the borly. the back arched, and the last segments appressed. But three of the larva behaved differently, and after having 


\section{APATURA II.}

censed to feed and partly changed color, again began to eat, though the leaves in their glass were thoroughly dry, and some time towards the last of September, passer the thirel moult. Not anticipating this I discovered the change accidentally, and was surprised at finding them active, and of a brilliant green color. I have since learned from Mr. Riley's paper, before cited, that he hat watched larva of Clyton when this third autumnal moult was taking place, though his experience agrees with mine that such instances are exceptional. 'These larve again changer color, but to mothing like the degree of the others, becoming greenish-brown or vinons-brown, and no shinkage of the body was perceptible. And at intervals through the winter, a few moments in a warn room would arouse them. Unfortunately two of these died before spring, and the third was accilentally killerl.

On gth May following, the shoots of the Hackberry beginning to put forth, I brought the larve from the cellar. Several were living and awaked soon after cxposure. Some began at once to move and eat, and of these part turned green within the next twenty-four hours. Others remained quiet, and changed gradually to pale vinous and then to green, taking three or four days to malie the complete change. Bit others still occupied several dinys more.

On the 15th those which had soonest become active showed the second segment swollen, and that day and the next they passed the third monlt, while the most tarly dicl not reach that stage till the first had begun to pass the fourth or last moult, which took place on 23d and 24th. By 30 th May these were in chrysalis, and the buttertlies appeared on the 10th June and days following. Meantime some of the larva continued to grow and reached a size which seemed enormous for this species. And it turned out that all these large larve produced female butterflies, and no female appeared until nearly all the males had emerged. I have not noticed this peculiarity, nor have I been able to distinguish the sexes by the size of the caterpillar, in any species but the present one.

After the fourth moult, each larva makes for itself a wel on the surface of the leaf, and draws the sides together until a sort of case is formed, within which it lives. From this it emerges to feed at night, as was evident by leaves at a distance being constantly ferl upon during the night. 'This is the habit in captivity, and is probably but a modification of its habit when free. Mr. Riley states that these larva scatter after the third moult, and thereafter hide within leaves drawn around them.

When preparing for the change to chrysalis, the body of the larva becomes contracted, broadened and rounded in the middle, the heal is bent under anr the last segrment pressed to the leaf; the color of the skin changes to a nearly uniform green, and the shape of the chrysalis gradually becomes apparent. Tine 


\section{API'URA II.}

final change is effected in the same mamner as in Cellis, and the chrysalis is also stupended by a pat of lrooklets.

Clyton is dimorphic in both sexes, but not seasonally-rlimorphic, as might be the calce were there two broods ammually. Of twenty-one butterflies raised by me firm the egg, eight were the form Ocellatu, numely: $4^{8}, 4^{\circ}$; of Proserpina thirteen, $88^{\circ}, 5^{-8}$.

In the fall of 1873,1 received a few larve of Clyton from Mr. Riley, in lethareic state. 'These heyan to move 2d May, 187t, but every stage was prolonged, and the first chryalis was not formed till th July, thinty-eight dars after the corresponcling change occurrerl with the larve found at Coalburgh. Is all the aftendant circunstances were apparently iclentical in the two cases, I can give no explanation of this singular phenomenon. The duration of the chrysalic stage was sime in both cases, about ten days.

The contrast between the two species Cettis and Clyton is striking as relates to their preparatory stages. 'The eggs and chryalids are nearly identical in form, and the caterpillats have a general resemblance. But the eggs of Clyton are laid in clusters of hundreds, those of Celtis either singly or in lots of from five to twenty. The larve of Cellis are gregrious, but are satisfed with nearness without contact; those of Clylon require actual contact and assemble in groups to which all scattered ones are attracted. I have frequentls separated a group, but in a few hours all its members were together agram. Cellis completes its history in one summer brood, though part of this may hybernate, and it has a recond. which always liybernates. Clyton, in West Virginia at least, has no second brood, but all the larve hybernate.

Of the habits of the butterfly I am mable to speak from my own knowledge, but I am informed by correspondents that it behaves much like Cellis. 'The larve of the two frequent the same tree, and Mr. Charles Dury, of Avondale, Ohio, tells me that he has taken as many as sixty larva of the two species at same time from a small IIackberry. II writes "I have often taken clyton, sometimes on trees from which there was an exudation of sap, and sometimes on rotten apples. But in most cases it is to be seen in the woods. Its movements are less lively than those of Celtis."

As is the case with Cellis, the larva of Clyton feed upon the thickest leaves. When winter approaches, they probably, to some extent, seek shelter on the rough, corky bark of the Iackberry, though many no doubt fill with the leaves and perish.

I know of no other food plint for this species than the Celtis occidentalis. Dl. Boiscluval gives Prunus as one of them, but I have been mable to verify the statement, even when the larve have been made to fast for hours. 
APATURA II.

Just as Celtis has been supposed to huve been covered by the description of Lyccom, Fab., so Merse Fab. has within the last two or three years been apportioned to Clyton, altogether wrongly. The description of Herse, Fab. Ent. Syst, III., p. 229, No. 718, is as follows:-

P. S. alis dentatis fusco ferrugineis: anticis albo punctatis, posticis utrinque ocellis septem coecis.

Papilio Herse, Jon. fig. pict. 4, tab. 7, fig. 2.

IIilbitat — - Dom. Drury.

Corpus fusco ferrugineum. Ala antica obscure ferruginex, pone medium fiscia e maculis sex punctirque quatuor apicis albis, subtus pallicliores. Posticie fusco ferruginer ocellis septem nigris iride ferruginea : secundo tertioque pupilla ferruginea, reliquis coecis. Subtus pallidiores ocellis septem coeruleis iride flara; ammulo nigro.

Wings dentated, marked with fuscous and ferruginous; the fore wings spotted with white, the hind wings also with seven black ocelli.

P. Herse, Jones' Icones.

Habitat unknown. Collection of M. Drury. Body fusco-ferrugineous; fore wings obscure fermginous, with an extra-median band of six spots and four apical spots, white; under side paler. IHind wings fusco-fermumous; with seven black ocelli with fermginous irides, the second and third pupilled with fermginous, the rest blind; under side yaler with seven blue ocelli, with yellow irides, in bluck rings.

This description cannot apply to Clyton, in which the fore wings are not obseure-fermginous, but ferruginous at base and blackish-brown towards hind margin; they are not spotted with white, but with yellow or yellow-ferruginous; the median band is composed of seven spots and the outer spots are five, instead of six and four, as in Herse. 'The hind wing's are blackish-brown in Clyton, not fusco-fermeninous; there are but six ocelli cund all are blind, with no fermennous pupils. In Herse there are seven, the second and thind mpilled with ferruginous. In Herse the under side of both wings is described as paler than the upper, with no variety of color or shade on the several areas; that is, the fore wings must be ferruginous, or less obseurely ferruginous, and the hind wings a pale fusco-ferruginous. In Clyfon the under sides are brown, gray, purplish with the least possible fuscous on primaries only, and in vars. Ocellate and Proserpina there is no ferruginous at all on either wing. In the form which I call flora there is ferruginous, but it is intense, and the whole surface is richly diversified in color. In Herse are seven blue ocelli in bluck rings, with yellow irides; in Clyton though the pupils are blue the ivides are fermginous. There is therefore no argeement between the description of ILerse and the insect Clyton except in the most general way. 


\section{APATURA II.}

'This description of Herse is also supposed to have been drawn from Jones' figures, though, as is the case of Lyecom, the insect is referred to as in Drury's collection, and undoubtedly was known to Fabricius, the chief lepidopterist of his day. I do not know on what authority such supposition is based, and there are certain discrepancies, to be hereafter spolien of, between Jones' figures and the description, which would seem to preclude the idea of the latter having been dram up firm the ligures. By the kindness of Prof.J. O. Westwood. I have in my poscession a colored copy marle by him of both Jones' figures of Herse, representing the two sides of the female. Also a peneil tracing of the upper side, and this I reproduce in orter to show more clearly the differences between the two species. But if it were practicable to wive the colored figures, there would be no doubt in the minds of my readers that they relate to quite amother insect from C'yton. In the figure of the upper side, the color of the basal half of primaries and of the whole of secondaries is of an uniform shade of ferxuginous, and the hind margin of primaries is also broadly bordered by ferruginons, a shate darker. between these two areas on primaries is at nebulous, extratliscal fuscous band cxtending quite across the wing; in Clyton vars. Ocellate and l'roserpina, while the base of primatries is ferruginous, the hind margin and disk, als well ats the whole of sccondaries, is blackish-brown or fuscons. In the ligure is a median band of six long, onel, equal spots, there beiny but one in the sub-median intersprece, armuged in a simple curee, concex ontwerdly; and five of these spots only are fulvous, the sixth on the costat margin. being pure white. Beyond are four white spots, two of them sub-aprical, and two are in the median interspaces, these last eary close to the brand and parallet with it. In the discoidal interspuce is no spot. In the insect this is totally different. The band is comprosed of seven spots, all of them rounded, arranged in a double curve like the letter $s$, and these spots are all yellow, or yellow with a tint of red. as are the outer spots (ears. Ocellata and Proserpiner), or: all are fermenimons (ver. Flora.) Of the onter spots there are five, two being sub-rpicot, the other three, occupying the discoidut and two mediun interspares. placed at some distance from the band and nearly parallet with the hind maryin. That is, their genemel course is exactly opposite that of the band in Herse. In the cell on the drawing is a concolored spot with a black ontline, and this is sheped like afigure 8 , made of two opposite double curves. In the insect, instead of this spot are two nearly parallel simuous bars. On the hind wings in the drawing are six spots, five of which are distinctly ocellated, having both pupils and irides, the spot next imner angle only being without pupil. In Clyton all the spots are without pupils. On the under side, the base of the hind wing, and all that part of primaries which lies back of the cell and the second median nervule, is pale ferruginous; the cell 
Al'ATUA II.

and remainder of primaries and the outer limb of secondaries, except a broad space along the hind margin, is pale fuscous, and between this fuscous area and the ferrumous of the base, on secondaries, is a whity-brown discal zone. All this is quite unlike the insect, as a glance at our Plate will show.

If Frabricius' description was taken from Jones' figures, why should all the spots on the forewings be called white, or why should the ocelli be describerl as blind, with the exception of the second and third! Or why should the description call for seven ocelli when the figure shows but six!

Now it happens that one of the gromps into which the American speeies of this gemus divide themselves is characterized by just such a simple curred discal band on primaries as appears in Jones' figures, made up of six oval spots, and outside these are four white spots, two of which are sub-apical, and two placed parallel to the band, just as in these figures also. Of this style of ornamentation are certain Central American species, and also the one called Ityja, Hübner, figured in the Samml. Exot. Schmett., a West Indian species; and that the resemblance to Herse may appear, I subjoin a cut of it also, copied for me by Mr. Scudder from IJïbner's figure. It must be allowed to approach Herse remarkably.

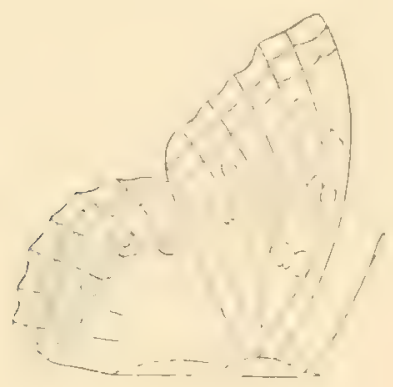

Herse $\$$.

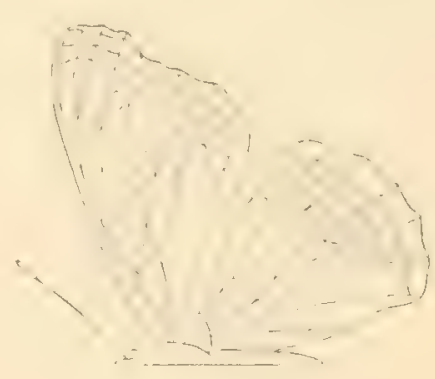

Idyja \&.

With the figures of Herse, Professor. Westwood also sent me colored figures of Lycaon, and they represent quite another insect than Celtis. On the upper side, prinuries are fuscous except the cell, and the larger part of this from the base outward is yellow. There is a yellow sumarginal stripe, and the discal band is composed of futvous spots The secontaries are fuscous over the basal area, and beyond to the hind margin the color is fulteous, as decided as in Argynnis Cybele. Upon the disk are five elongated, equal, white spots, arranged in a regular curve, and on the basal side of these is a conspimons yellow stripe which reaches half across the wing. On the under side, the basal third of primaries and the whole of the hind wing is yellow, the rest of primaries being fuscous, 
Al'ATURA II.

except the hind margin. which is yellow. In the sub-median interspace of secondaries are three broun stripes maliating from a common point near the base, and nearer the dist are three brown spols or palches. All which is in contrast to Celtis. In Fabricius' description of Lyecon the apex of the hind wings is called rufous (apice rufis), and the outer spots on the forewing are placed on the "apex." By modern anthors the apex of the wing is the upper outer angle. and not being aware of the Fabrician designation when I wrote my notes upon Celtis, I was mueh puzaled at the statement that the apex of the hind wing was. mous. I have since learned from Mr. A. (6. Butler, that Fabricius dividerl the wing into three sections, basal, diseal, and apical, the latter division comprising about one third of the surface, namely, the whole extra-discal and marginal areat. And so explained the description agrees with Jones' figure, the areal spoken of being rutous or fulvous.

In the text of Celtis, I stated that the species had been taken in the Valley of the Comnecticut River, erroneonsly quoting from a letter of Professor Parker. On the contrary it is not known that Celtis has been taken within the limits of New England. Nevertheless it probably dwells there, or at least comess as an occasional visitor.

By some late atuthors these American species of Apatura have been separated from the European, and placed in the gems Doxocopa, which is attributed to Hiibner. In the Verz. hek. Schnett., IHïhner has a coitus Doxocopa, thus defined, "The wings changeable blue on a dusky ground, marked with single ocellar spots," and moler it the European species Iris and Ilir stand, as is proper, being blue. But to place brown or red hutterflies in Doxocopa, which expressly calls for blue, is to do violence to Itiihner's arrangement, and is not to be thought of. For myself I rlo not regard the coitus as genera and arlmit no generic names whatever baserl upon them. 



$$
4
$$




\section{SATYRUS I.}

SATYRUS WHEELERI, $1-4$.

Satymus Wheeleri, Edwards, Trans. Am. Ent. Soc., IV., p. 313. Mead, Zool. lieport Wheeler Expedition, V., p. 773, pl. 39.

MLaLe. - Expands 2.1 to 2.3 inches.

Upper side light brown, clouded with dark brown, especially on the disks of each wing; the hind margins edged by two parallel lines, preceded by a common dark stripe, which on secondaries is somewhat macular; primaries have a light colored extra-discal area, on which are two large black ocelli, the upper one sub-pyriform, and as if two spots of mequal size had been compressed into one, and incloses two white pupils; the lower ocellus is larger, rounded, with white pupils; both ocelli inclosed in narrow yellow rings. Secondaries have one ocellus, of medium size, in the lower median interspace.

Under side light yellow-brown, covered with rather coarse, abbreviated, brown streaks, which are most dense from base to middle of disk on primaries, but pretty equally distributed over the whole of secondaries; both wings crosser by an irregular brown stripe, which stops at the sub-median nervure of secondaries and connects on that nervure with a similar stripe, nearly straight, which crosses the wing about half way between the first stripe and base; in some examples this basal stripe is continued faintly across primaries; the marginal lines and submarginal stripe repeated; the ocelli of primaries also repeated, but with much broader rings; secondaries have six ocelli, each with white pupil and in yellow ring; three of these are in the sub-costal and discoidal interspaces, the two outer ones small and rounded, the middle one long oval, or double-convex, and three on the posterior interspaces, all of them rounded, and the middle one largest.

Body yellow-brown; legs same; palpi darker brown; antemna brown with fine whitish annulations; club ferruginous.

Female. - Expands from 2.1 to 2.7 inches.

Upper side sometimes similar in color to the male, often lighter ; the dark hasal area, in the light examples, more sharply defined on middle of the disk; 


\section{SATYRUS I.}

the ocelli similar to male; there are also usually two black points, one on either side of the ocellus on secondaries, and in some examples the anterior one is enlarged to an ocellus with white pupil. The markings of the under side as in the male.

Several examples of both sexes of this fine species were taken, in 1871, by the naturalists comnected with the Wheeler Expedition in Southern California; and later by Mr. H. W. Henshaw, at Apache, Arizona. The figures given in the Koöl. Rep. Wheeler Expedition were copied by permission from my Plate. 



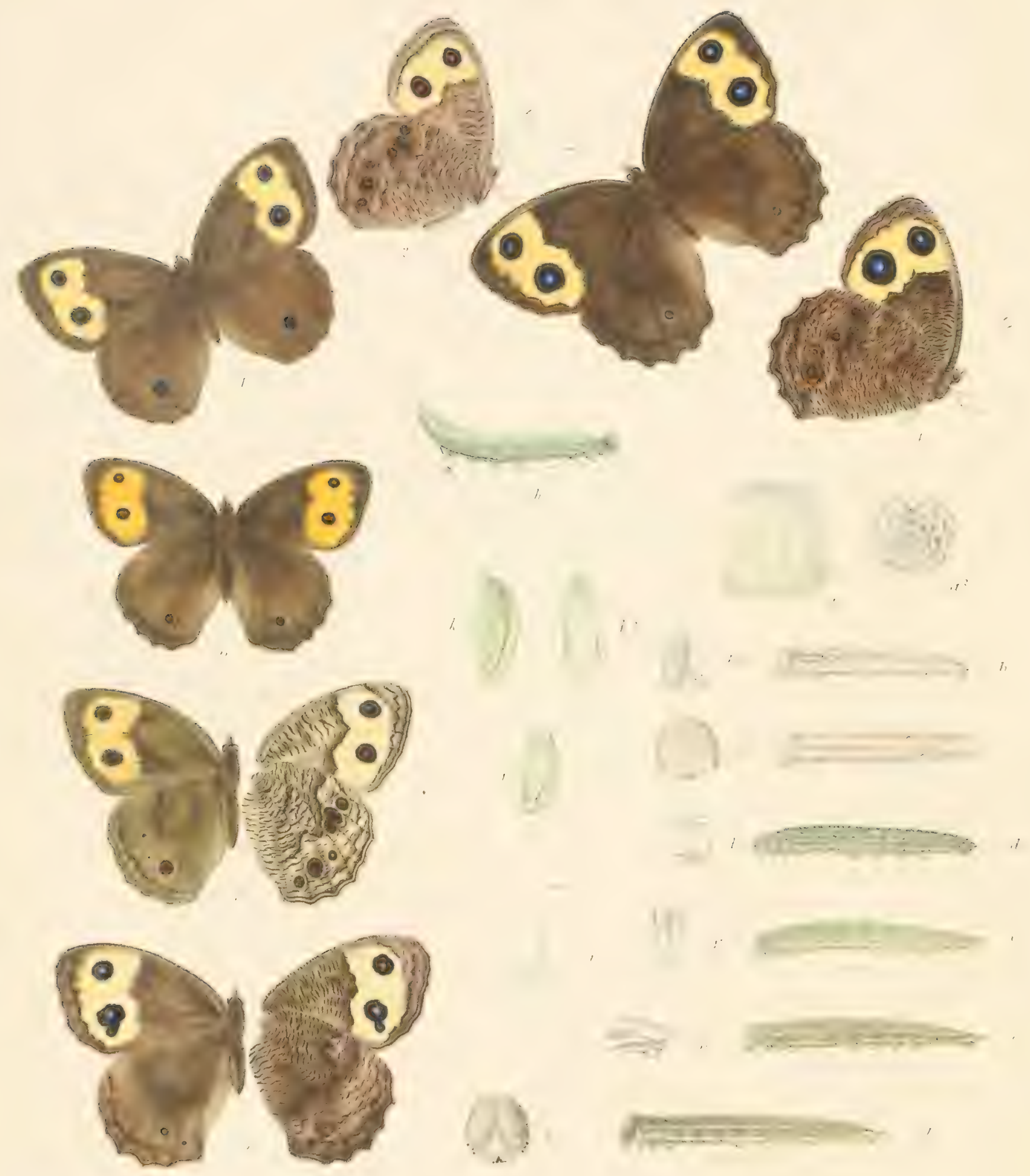




\title{
SA'TYYRUS II., III.
}

\author{
SATYRUS ALOPE.
}

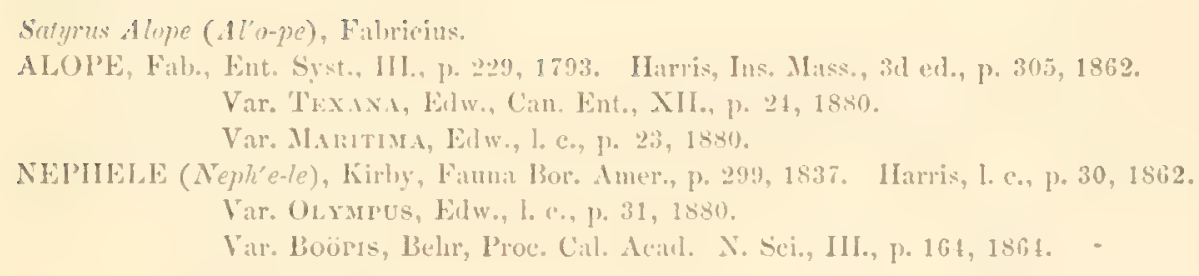

\section{ForM ALOPE.}

MALE. - Expands 2.25 inches.

Upper side hlackish-brown, datkest over basal areas; hind margins bordered by two tine parallel lines, a little within which is a black stripe; primaries have a transverse yellow band beyond the disk, sometimes a little ochraceous, and often more or less encroached on by the brown gromel; on this are two ocelli, round, black, of vilriable size, and with or without central point, which is white with blue scales; behind cell a blackish indistinet sexual dash.

Secondaries have a small ocellus on second median interspace, in yellow ring (often wanting), and with or without white points; fringes concolored.

Under side yellow-brown; the band enlarged and of paler color; the ocelli repeated, enlarged; the marginal lines distinct; the brown area covered with abbreviated darker streakis, which over base and diskis form somewhat concentric broken rings, limited without by a common dark stripe; on primaries this stripe borders on the yellow band; on secondaries it is irregularly simmous from margin to margin, throwing out a rounded prominence against cell, followed by a rounded sinus on median interspace; across middle of cell and below it it dark stripe; the extra-discal area less streaked; the ocelli vary from nil to six, the full number being most often present, disposed in two groups of three, the middle one of each group largest; all black, rounded, in narrow yellow rings, and with white dots edgerl by blue scales. 


\section{SATYRUS II. III.}

Borly concolored; lecrs and palpi dark brown; antenne brown, finely ammlated with white; elub ferruginous. (II., Figs. 1, 2.)

Framde. - Expands 2.25 to 2.5 inches.

Upper side color of male; the band broader, clearer, and in most cases well definct on both erlges; sometimes, however, hazy on one or both; the ocelli large, variable in size, sometimes equal, sometimes the upper one larger, but most often the reverse; the white point surrounded by blue seales; the ocellus on secondaries sometimes large in yellow or ochraceous ring, with white dot, sometimes blind, and often wanting altogether; occasionally there are one or two additional black points, corresponding with the ocelli of lower side, though sometimes they are present when the ocelli are wanting.

Under side as in the male, yellow-brown, sometimes with a gray tint; usually the apex of primaries is grayish; the ocelli have clusters of blue scales; on secondaries they vary in number as in the male, from nil to six, but a larger per cent. than in the male have none. (II., Figs. 3, 4.)

Var. Texaya.

Of large size, the males expanding 2.25, the females nearly 3 inches; brown color, the band yellow to ochraceous; all exmples observed have a complete ocellus on upper side of secundaries. Under side more yellow than in the type, with a gray tint; six conspicuous ocelli, in yellow rings, the middle one of upper group almost always long oval. (Hig. 7.)

Var. Maritime.

Of small size, dark color, the banr reddish-yellow. Common on Martha's Vineyard and Nantucket. (Fig. 6.)

\section{Fors NEPIELL}

MALE. - Expands 1.75 to 2 inches.

Upper sile blackish-brown, the mirginal lines and stripe as in Alope, but often obsolete; primaries have two small black ocelli, placed as in Alope, without ring, but in some examples a faint yellowish shade represents the ring; sometimes a white dot in each ocellus, but usually the lower one is blind; secondaries either with or without ocellus, but if present, it is blind and without ring.

Under side dark yellow-brown, finely streaked, as in Alope, but with less distinctness, and in many examples the discal stripe is nearly or quite obsolete, especially on secondaries; the ocelli of primaries enlargerl, the rings distinct but. not clear yellow, being dusky, or more or less obseured; secondaries have small ocelli in fine russet rings, with central white dot and a few bluish seales; the 


\section{SATYLL' II. III}

number varies from nil to six, but much the larger proportion of examples have six, and very few have under three. (111., Figs. 1, 20.)

FEMALE. - Expands from 2 to 2.5 inches.

Upper side lighter, more brown than the male, and the area which in flope is oecupied by the band, is of a slightly paler sharle than the rest of the wing; the ocelli large, with white centres and blue scales, and either without rings or imperfectly ringed with dusky yellow, the hind wing either with or without an ocellus. Inder side paler, the area of the band a little lighter than elsewhere; the rings sometimes quite bright, but oftener dull or obseure yellow; the ocelli of secondaries rarely six in number, most often under three, and many examples have none at all. (III, Fig.s.3.4.)

VAT. Ohymét

In size expuls the typical form. 'The males are almost black; the ocelli very small and without rings, but in some eximples there is a faint russet or yellowish tint about them, and perhaps on the space between. (On the moler side the rings are russet or ochlaceous on both wings. 'This form inhalyits Indiana and westward to the locky Momtains. (IiI., Figs. 5, 6.)

Eorr. - Comoidal, roumderl at bise and somewhat flattened, truncater, the sides slightly convex; marked hy about eighteen prominent vertical ridges which spring from the lowel part of sirle; the spaces between crosied by numerous fine low ridges; summit rounderl, and covered with shallow cells, in three to four rows, not concentric, but iregularly spiral aromen a central star made up of six rhomboids; color lemon-yellow. (Figs. $a, a^{2}$.) Duration of this stage fourteen to twenty-eight days, accorling to the temperature.

Youxg Lurv1.- - Iength 1 inch; the anteriol segments thickest; the posterior extremity nearly square or sub-areuate, with a projecting point at either side; on each side of the body are three rows of long white bristles, one subdorsal, one on middle, and one over the feet, besides a demi-row on '2, 32, and 4, between the two upper lows; these spring from prominent papilla, and the effect is to make the borly seem many-siled; the dorsal rows have one bristle on each of segments 2, 3 , and $t$, and these are bent forward, but two on each of the others, all bent back; the demi-row and the side row have one to each sergment, all bent forward the lower row has two to each, and all are turned back; color earnation, with a medio-dorsal crimson line, and three similar lines on each side; legs and pro-legi pinkish; head large, one half broader than "2, hroarler than high, sub-globose, nurrowing upwards, the top a little depressert; color light 
yellow-brown, specked with brown, and sparsely pilose; in some examples there are cloudy brown patches over upper part of face; of the five ocelli in arc, the middle one is large, emerald-green, in a black ring, the next one above is brown, the upper one and the sixth, back of the arc, are black, and the other two are yellow-brown. (Figs. $b, b^{2}, c, c^{2}$.)

The larva become lethargic very soon after leaving the egg, and so hibernate. As soon as they feed in the spring, the color begins to change from pink to pale green, the crimson lines to red; in a few days the green becomes deep colored, or perhaps blue-green, and the stripes a darker green. (Figrs. $d, d^{2}$.)

After first moult: length .16 inch; cylindrical, the anterior segments thickest, the back arched and sloping from 6 or 7 to 13 ; ending in two conical tails, each much tuberculated, with stiff bristles, and one long bristle at the apex; each segment several times creased, and on the ridges thus caused are white tubercular points, each giving a short, blunt, or clubbed and curved white hair; color pale green, with seven longitudinal dark green stripes, one medio-dorsal, and three on each side; of these three, two are close together in middle, the other is just over the basal ridge, which is pale yellow; tails reddish; legs and prolegs pale green; head nearly as before, light green, with white conical tubereles in vertical rows, each tuberele with short white hair. (Fig.e.) To next moult fourteen to twenty-three days.

After second moult: length .32 inch; shape as before; whole upper surface one shade of yellow-green, except a dark medio-florsal stripe; the basal ridge yellow; in some examples there is seen an indistinct green line on middle of side; head as before. (Fig. f.) 'lo next moult fourteen to twenty-four days.

After third moult: length .44 to .54 inch; color yellow-green; body much covered with white hails, which are depressed, making quite a downy coat (individuals differed much in this respect, as the hairs were longer or shorter, some being almost shaggy); the lateral line more distinct, green; head somewhat higher and narrower than before; color pale yellow-green. (Fig. g.) As this stage progressed, some of the larve underwent a change in color; the green side line became faint yellow, and the medio-rlorsal band was on either erlge pale yellow, while the whole dlorsal area was of a decided yellow tint as compared with the side; but most retained the green line, and both side and dorsum were one shade of color: 'Io next moult fourteen to eighteen days.

After fourth moult: length $8.7,8.9$ inch. This stage continued from twenty. four to twenty-eight days to chrysalis.

Muture Larva. - Length \& 1.25 inch, greatest breadth .16 ; $\$ 1.6$ inch, breatth .2; cylindrical, obese, thickest in middle segments, the dorsum arehed and 
sloping towarks either extremity; ending in two sharp, conical, divergent tails; each segment creased five or six times, the intervening ridges covered with fine white papilla, each of which sends forth a white hair, longer or shorter, if long, appressed to the surface; color yellow-green, but there wis much variation, some examples being uniform on back and sides, in others the dorsum was more yellow; so the yellow-green was either light or dull; on middle of dorsum a dark green stripe, obsolescent in the middle segments; along basal ridge a yellow stripe; on the side in some examples, a faint yellow line, in others there was no line, but a mere discoloration; under side, legs aud pro-legs deep green; spiracles oral. color red-buft; head sub-globose, narrowing upwards, a little higher than broat, the top slightly depressed; covered with conical white papilla in vertical row's, each with a white hair; color vivid-green; the third ocellus much the largest, emerald-green, the others reddish. (Fig. $h, h^{2}$.) The larva suspends to a button of white silk, and the dorsum is then convex, the anterior segments being turned at a right angle, bentings at 5. (Fig. i.)

Cimpsidis. - Length, \& .56 to 6 inch, brealth .2 to .22 inch; 9 length .8, breadth .2.2 to .2t inch; cylinrtrical, the abdomen conical; the wing cases slightly raised at the margins; hearl case short, romdly excavated at the sides, the top narrow, sometimes nearly square or a little arched, sometimes depressed; mesonotum slightly prominent, roundly carinated, the sides nearly flat, or a little convex; whole surface of the male one shade, either of yellow-rreen or deep green, covered with smooth specks and patches of a lighter color, but which sarcely affect the general green hue; along the imner margins of wing cases a crean-colored line; another on keel of mesonotum, and one across top of head case. (Fig.j.) In the female there are three longitudinal yellowish cloudy bands, one on midlle of abdomen to mesonotum, the other's sub-dorsal, extending from end to end; the wing cases clouded with darker green in long rays. (Figs. $k, k^{2}$.) Duration of this stage about fourteen days.

The larve of OLYMPUs, in their later stages, were distinguishable from those of Alope or typical Nephele. Thus,

After third moult: there was present a distinct yellow side stripe, narrower than the basal, but as deep colored as that; also, the medio-dorsal green stripe had a narrow edge on either side of yellow.

Mature Larva. - Length, of 1.36 inch; greatest breadth, 14 inch; slender, yellow-green, the dorsum brighter' thin the sides; the upper' stripe either deep yellow or pale yellow, distinct always; the dorwal band edged with deep or pale yellow. (III., Fig. a.)

Chrysalis. - Color bluish-green, finely mottled, streaked and specked with whitish; the lines along the wing cases, mesonotum, and head white. (III., Fig. $b, \delta$. 
Alope flies from North Carolini to New York, and under the form Texana, in parts of 'T'exas, possibly elsewhere in the southwest; Nephele, throughont Cinada, and slightly modified (Olympus) from Indiana to the Rocky Mountains, and again modified (Boöpis) to the Pacific. In New York and New England, both Alope and Nephele fly, together with all manner of intergrades. Sonth of New York, Nephele dloes not appear to have been taken, unless occasionally in the adjacent parts of New Jersey or Pennsylvania ; certainly, in Virginia it is utterly unknown. In Camada, Nephele appears to be the sole form, except that intergrates are sometimes found along the sonthern borter. Mr. Caulfield, of Montreal, writes: "I have never taken a specimen of Nephele showing any tendeney towarl Alope, nor have I seen any Canadian examples showing it." In northeast Ohio, Alope is rare, but Nephele is abundant at some sensons. At Tolerlo, northwest Ohio, Alope is reported unknown, but Nephele is present, though it is rare. In the middle and southwest parts of the same State, both forms are either unknown or are very rarely met with. In Michigan, I cannot learn that Alope flies, but $N_{e}$ phele is common, and apparent intergrades are sometimes seen.

Alope was described by Fabricius as fuscous, with a yellow (flava) band, with two ocelli on fore wing; on hind wing, one ocellus above, six beneath. 'The band is broad in the female, usually narrower in the male, pale yellow in both sexes. 'The ocelli on fore wings are round, or sometimes oval, are either large or small, often equal, but sometimes the upper one is larger, at other times the lower one. Now and then a third pupilled ocellus appears (II., Fig. 5), and individuals have been taken with but one ocellus, and this is always the upper one. Some examples have a black point in the band, which may be considered as a rudimentary ocellus. (III., Figs. 10, 11.) On the upper side of hind wing is often at complete ocellus, but in many cases there is a black point only, or even this is wanting. Sometimes there are from one to three black points (II., Figs. 1, 2), and very rarely, a second complete ocellus (Fig. 5). The males most often have six suall ocelli on under sille of hind wings, disposed in two groups of three, the middle one of each group the largest; the females vary more in the number of these ocelli, and most often have a smaller number than six. Of 248 examined, 62 per cent. have 6,75 per cent. have over 3,8 per cent. have 0 . Of $25 \%$, ts per cent. have 6,52 per cent. have over 3,16 per cent. have 0 .

'To the northward, Alope is blackish-brown, but at the extreme south or southwest, brown prevails, and the under side has a tint of yellow more or less deciderl nver whole under surface, often mixed with gray. The baur is yellow, sometimes slightly ochraceous. 'I'his differs so much from the northern type that I have called it var. Texanu. (II., Fig. T.) All examples of both sexes which I have seen have a complete ocellus on hind wing, and six ocelli beneath, of latge size and in distinct ochrey rings. 
At Martha's Vineyard, distant about seven miles from the main-land, and on Nantucket. which is some fifteen miles further at sea, a small form is found which I have called var. Mroritime. (II., Fig. 6.) It is very black, and has a rerdish-yellow band, not a yellow one, ats in Alope. Whether it is restricted to the islands, or appears on the adjacent coast, I have not been able to ascertain.

Nephele was described by Kirby as follows: "Wings brown; prinaries, both above and below, with a paler sub-matrginal broad band, including two eyelets, the upper ones surromded by a paler atmosphere, with a black iris and white pupil; on the under side the atmosphere is most distinct and forms a kind of glory romel the crelets," etc. Apparently this is a description of a female. The wings of the male are blackish-brown, the ocelli are small, usually without rings, and often without pupils. (III., Figs. 1, 2 8, 3, 49, Cimadian examples).

There is a certain belt of latitude which includes most of the State of New Fork and sonthern Now England, in which both Alope and Nephele are found, tomether with every posible intergrade. 'Towards the sonthern border of this belt, or in the Iowlands, as along the valley of the Hudson River, Alope pure trpe prevails; in the Catskill IIomtains, and to the northem borter, pure Nephete is found, but with Nephele, in all its localities within the belt, are intergrades. In the Catskills, I have taken Alope as conspicuously banded as any in Virginial, but such examples are rare, forming. perhaps, two or three per cent. of the flight. These intergrades are distinguishable by the atmosphere about the ocelli. That Kirby calls the "pale" atmosphere appears in the males also, and in both sexes gradually widens and becomes less ohseure till it culninates in a clear yellow band, that is, in Alope. (111., Figs. 7-13.)

Of $7 \&$ Nephele pure type, from Canarla, all have 6 ocelli beneath hind wing; of $10 \&, 20$ per cent. have 6,60 per cent. have over 3,10 per cent. have 0 ; so that there is an excess of ocelli in both sexes, but especially in the male, as compared with Alope.

The form which abounds in Illinois, Wisconsin. Nehraska, and west to the

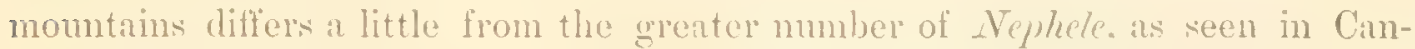
ada, though individuals are found there which are not distinguishable from it. But a series of examples from Canada and one from Illinois will show a perceptible difference. 'The males of this western form are almost black, the ocelli are very small and without rings; but in some cases there is a faint russet or yellow glow about the ocelli, and perhaps this will suffuse the space between them. On the under side the rings are russet or ochraceous on hoth wings. The females are nearly always dark, without the "paler atmosphere" mentioned by Kirby. This is what I have called var. Olympues. (III., Figs. 5, 6.) But occasionally an example appears with a pale yellow atmosphere about the ocelli, as in some in- 
tergrades of New Tork. Of 168 examined, 14 have 6 ocelli, 1 has 5, 1 has 2. Of 19 \&. 10 per cent. have 6,50 per cent. have over 3 ; the males agreeing with $N$ eplecle of Camada.

Boöpis was described as distirguished from Nephele by the absence of ocelli on under side of hind wings. The male is dark brown, and the ocelli on under fore wings have nearly always yellowish rings, often faint. In the female, the rings are enlarged, and sometimes the field is yellow-tinted, and occasionally this is nearly clear yellow, making a broad, but clouded, band. 'This again resembles some of the intergrades before spoken of. Of 58,4 have 2 obsolescent ocelli beneath hind wings, 1 has 1 . Of 78,1 has 5,5 have 2,1 has 1 ; so that there is manifestly a decrease in the number of ocelli, as was pointed out by Dr. Behr. Fig. 6, Plate 1II., is a good representation of Boöpis ?.

Some Nephele females are undistinguishable from females of Booppis, but the difference between the males is more marked, the former showing a full complement of small ocelli in most cases, and but three or less very rarely, the other never exceeding three, so far as I have observed. Boöpis flies from Arizona to British Columbia.

These Satyrids live in grassy fields, or in open woods in which much grass grows. The eggrs are laid on grass and the caterpillars make that their food. In many sections of the country, the butterties swarm in their season, and were it not for the fact that grass is usually cut for hay at the time the caterpillars are maturing, whereby countless numbers must be destroyed, they would swarm everywhere in their localities. 'There is but one annual brood. In the Catskills, the butterflies begin to appear about middle of July, and in certain places hundreds may be taken during a summer's day. On the flower's of the hardhack, Spirea tomentosa, which blooms in old fields in July, multitudes gather. So on buckwheat when in blossom. The flight is low, with tremulous wing, and for but a short distance. About the end of July, the females are ready to deposit their eggs, which hatch during middle and last half of August. The caterpillars go into lethargy at once, descending to the base of the plant, and must revive the next spring, as soon as the frosts are over, and warm rains make the fields green.

Mr. Sendder, in his "Butterflies," speaks of the multitudes of Alope (Mari(ima) to be seen at times on Nantucket, "a contimuous stream." I spent some time on Martha's Vineyard, at Oak Bluffs, in July, 1877, and on the grassy plains back of the town I searched daily for butterflies. 'The first Alope-_Laritima seen were two males fresh from chrysilis, 230 July. On 26th, the first female appeared, and I took that day 12 \&, 1 \&. I left the Vineyard, and Mr. 'T. L. Mead, who had come there just at that time, undertook to get cygs for me. On 10th August, or fifteen days after the first female had been seen, he began to 


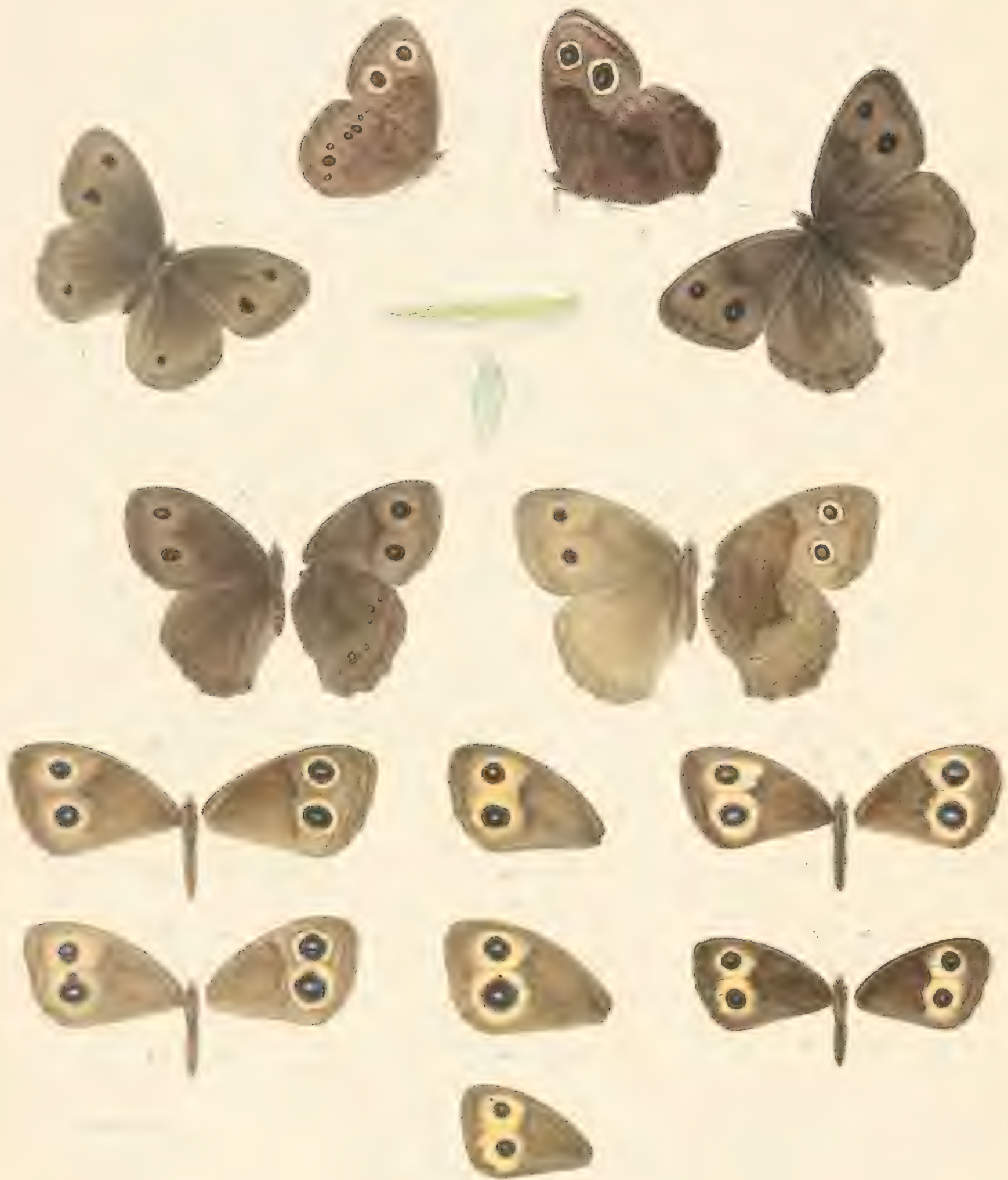
inclose females in bags orer grass, and hefore 18 th, had got 125 erges, which were sent me. I mention this, because it fixes the time at which the females laly their egrs after they have left their chrysalids, as it has been stated that ovipovition does not take place till five or six weeks after that event, which is erroneols.

On the prairies of Illinois and Wisconsin, and doubtless farther west to its limit, Vephele-Olympus abounds. Dr. J. P. Hoy, of Racine, Wisconsin, writes: "Nephele is the most abundant butterfy on the prairies four miles west of Racine, the most common species in midsummer:"

Nothing, howerer, was known till recently of the preparatory stages of Alope or Sephele, except what was stater in Harris, 3il ed., 186.2, where we read of Alope: "The caterpillar is pale green with dark green stripe; the head is romol and the tail ends in a short fork. The chrywalis is elongated, roundish at the sides, with the hearl notcherl." In 1877 , in the Canalian Entomologrist, vol. ix., p. 14l, I gave the full history of Nephele, having bred one butterfly from a lot of about filty erge laid hy a female taken in the Catskills the previous year. The caterpillats from the Marthat's Vincyarl egres of $187 t$ all died during the winter, from my not having leaned how to take care of them. But in 1878, I determined to try agnin. and applierl to several correspontents for egrgs of Alope, Nephele, and the Hllinois type, and streceerled in getting many. At this time Alope and Nephele were regarderl hy on most experienced lepidopterists as two distinct species, and it was thonght that the intergrades did not bridges over the chasm which separated them. I was anxious to determine the position of these intergrades, and had hegrm to suspeet. from what I har seen at Martha's Vineyard, where Vephele seemed to run into Alope, that we had here another case of dimorphisun.

Professor Lintner and Dr. James A. Bailey sent exress of Alope from Albany, New York; Rev. Georere D. Ilulst sent eggen of Alope from females canght, at IOboken, New Jersey; egres of Trphele were obtained from the Catskills, and Mr. Charles E. Worthington sent many of Nephele-Olympus from Chicago. Besides these, I was able to secure Alope egrgs myself at Coulburgh, West Virginia. In every case the egge were laid by typieal females, not intergrades, confined over growing grass, and the females were sent me, that I might note the type. These five localities are separated by considerable distances: ILobolien is one hundred and fifty miles sonth of Albany; the Catskills, at the point from which ergess weresent, are thirty-five miles sonthwest of Albany, but have two thousand feet greater elevition; Conlburgh is eight humdred miles nonthwest of Albany ; and Chicago is one thousand niles west of Albany and eight hundred northwest of Coalburgh. 


\section{SATYRUS II., III.}

These lots of egrgs were kept apart, and as the caterpillars hatched they were placed on grass in separate pots, and left in a cool room for the winter. Some of the Illinois eggr, however, were sent to Mr. C. P. Whitney, of Milford, New Hampshire, to be placed on ice. Apparently they hatched in transit, and in February, I received the caterpillars in good condition after their five months' sleep. Since that time, I have subjected several species of caterpillars to prolonged cold when in their first stage, and the result has constantly been that they were more healthy for this treatment, and there has been very little loss by disease or from want of vitality at moulting time in the subsequent stages.

On $23 d$ February, one of the Catskill Nephele passed its first moult, and before 4th March, several of that lot had passed that moult. One Coalburgh Alope and one Hoboken Alope passed first moult 7 th March. Two from Illinois passed same moult Sth March. 'I'o the end some of the Catskill larve were in advance of all, and some of the Illinois lingrered behind all. The stagres of one Coalburgh Alope and one Nephete-Olympus were as follows:-

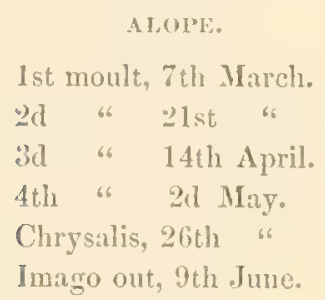

OLYMPUS.

$$
\begin{aligned}
& \text { 1st moult, 8th March. } \\
& 21 \text { " } 21 \text { st "6 } \\
& \text { in a nh Ipril. } \\
& \text { 4th " } 26 \text { th } 6 \\
& \text { Chrysulis, 17th May. } \\
& \text { Imaggo out, 30th May. }
\end{aligned}
$$

Here Olymme, though later than Alope at first moult by one day, passed its stages more rapidly and reached imago ten days sooner, and probably this was one of the caterpillars which wintered on ice. I had not separated these at the time from the rest of the brood, but subsequent experiments have iuvariably shown that the effect of cold applied to the caterpillar is to hasten all the stages.

'The caterpillars of these several broods could not be distinguished from each other up to the third moult. After that, they were in general alike, but the Illinois examples showed a distinct yellow stripe on the upper part of the side, and on either edge of the green medio-dowal stripe was a yellow line. The Catskill Nephele showed faint traces of the yellow stripe, but the Alope, at this stage, none at all.

After fourth moult, the same peculiarities appeared, there being a distinct yellow stripe on the Nephele-Olympus. As the stage progressed, some of the Alope, as well as some Catskill Nephele, developed an indistinct stripe, other's not. From third moult to maturity, the Alope from all localities, and the Catskill Nephele, 


\section{SATYRUS II., III.}

varied somewhat in the shade of green, being more or less yellow, in some, yellow prevailing on dorsum, green on the sides. 'They varied also in the clothing of the surfice, some being covered with short down, others with rather long and appressed hairs. 'There was no constant character by which Nephele could be distinguished from Alope, but the Nephele-Olympus differed perceptibly from the others. 'They were long and slender, and deep yellow-rgreen with distinct side stripe.

The chrysalids of Alope and Catskill Nephele were alike in color, yellow-green. The female chrysalids were clouded with datker green, and the edges of head and wing cascs were cream color. The Olympus chrysalids were blue-green, lighter or darker, and the edgings were white. 'They also could be readily distinguished.

One chrysalis of Albany Alope gave a male butterfly without band, but with a narrow yellow nimbus about the ocelli, - an intergrade. One chrysalis of Catskill Nephele gave a typical female Alope, with broad yellow band, but the wings were darker than in southern examples. This is figured in Plate II., 3, 4. The Coalburgh chrysalids producer typical Alope butterlies, all of them. Two Otympus gave males of their own type. In 187T, a female butterfly which emerged from the Catskill chrysalis before spoken of, was an intergrade.

'Therefore, sonth of the belt of dimorphism, Alope produced Alope, but inside the belt, Alope produced intergrade, and Vephele produced Alope and also an intergrade. And Nephele-Olympus, again, outside the belt, produced its kind. That Nephele, north of the belt, breeds true is certain, because the intergrades and Alope are not found there.

I believe Alope to have originated in the southern form Pegala Fab., which is characterized by its large size, its broad rufous band, and single ocellus on fore wing, and by six ocelli in both sexes on under hind wing; and I regret that I am not able to properly figure this form in connection with Alope. I canuot do so, because I know nothing of the preparatory stages, though by the kindness of the late Dr. O. C. Sparrow and of Mr. W. H. Ashmead, of Jackionville, Florida, repeated attempts to obtain the eggs have been made, but all without success. So far the females have refused to lay when confined with grass. Perhaps before this Volume closes I may yet succeed. Pegala is restricted to the vicinity of the Gulf of Mexico and a strip along the Atlantic coast, at least as far to the north as Charleston, South Carolina; but does not appear at Indian River, Florida, nor, as far as observed by Mr. Mead and others, in the interior of that State. It seems to be mainly a coast species. I cammot learn that Pegalcb and Alope fly in the same localities or even in the same districts. 'There appears to be a belt in the cotton States, or from Georgia to Mississippi at least, in which Alope is 
unknown, and below the northern border of which it loes not pass. Ant Pegale is confined to the district south of this belt, though probably it may enter it here and there. The time may have been when the belt was occupied by both these forms and intergrades, just as now Alope and Nephele occupy the northerm belt. If Alope flourished in its larval state on meadow grasses, which are not found in the Cotton States, rather than coarse saw grass or seaside grass, then its tendency would be toward the country which produced the former, and there would be a movement toward the north and northwest. At the same time there would be a withdrawing of the parent form from the border's of the original territory, because there the food plant was not in perfection, and so a belt would come to intervene between the parent and the variety. The intergrades which had arisen would follow one form or the other, and tend to revert to the parent or to become nerged in the variety. Favorable conditions might rencler one or more of them permanent, as with Alope-Texrma, which now seems to possess a territory of its own to the southwest. Certainly the parent form would be more or less modifierl by the absorption of the intergrades, if not permanently. yet so that now and then sports would be thrown out in the direction of Alope. Hence the occasional examples of two-eyed Pegala. 'That, on the other hand, the intergrades nearest the strong variety would tend to merge in it also, when cross-breeding had ceased by the disappearance of the parent form, we may infer from the fact that when Alope is suppressed the tendency of the species is to the pure type Nephele, the intergrades at last totally disappearing.

Alope enters its dimorphic belt from the south and emerges Nephele on the northem side, while within are all mamer of intergrades. If in this belt the conditions were to become unsuited to the support of any Satyrus, and the forms which now occupy it were to become extinct, either suddenly or gradually, we should have to the south Alope and to the north Nephele, two good species, with nothing, in the absence of intergrades, to show how one of these forms could have been related to the other. The conditions would be similar to those between Pegala and Alope now.

Pegala possesses in perfection many points which are found in one or other of all the members of the sub-group. It is considerably the largest, though occasiomally an Alope-Texanc fully equals it. Its peculiar brown color on upper side and gray-brown on lower side passes, into Alope, which gradually changes into the darker shate of Nephele. The rufous becomes yellow in Alope, but breaks out in that species in certain localities, as seen in var. Muritima. After the band has become suppressed in Nephele, every now and then it reappears in greater or less degree, even in Olympus and Boöpis. A single ocellus is now a prominent 


\section{SATYRUS II., III.}

characteristic of Pergala, but there has come to be a certain modification, so that in some cases, in the female, there are two complete ocelli, but in many more of both sexes there are dots and small spots in place of a second ocellus. In Alope and the rest there are two ocelli, not always complete or equal, and occasionally one is suppressed. When this happens it is always the lower one, which is winting in Pergale. There is a tendency to variation in the number of these ocelli, a second one sometimes appearing in Peyala, but a thirl one sometimes in Alope, and in the last named species and the rest of its sub-group, there are not unfrequently one or two small spots on the fore wings, as of incipient ocelli. The single ocellus invariably seen at anal angle in Pegala is often wanting or incomplete in the other forms; and the six ocelli of under hind wing, almost invariably present (but sometimes six on one wing, five on the other - never less, so far as observed), vary from six to nil in all the others.

It is to be noticed that the belt within which these Satyrids are dimorphic is nearly coterminous on the north and south with the dimorphic belt of Limenitis Arthemis and its co-form Proserpina. Arthemis alone occupies the northern part of the continent, but in a section of territory extending from Naine to Wisconsin, and which covers much of New York and New England, it is dimorphic with Proserpina, as shown in this Volume. Proserpince aloue emereses from this belt on the south, and grades imperceptibly into Ursula. And the dimorphism of Papilio Tumes originates in this same belt. So far as known, however, there is no western limit to the dimorphism in these species, and therein they differ from Alope. It is difficult to conjecture what influence could have brought about the suppression of Alope in the whole west, and have reproduced the Canada form, and allowed it to flourish so luxuriantly. One cammot conceive what there is of climate or else in common between Canada and the prairies to effect this result.

After the first of my papers on these Satyrids appeared in the Canadian Entomologist, I received several letter's calling my attention to published lists of butterflies of different western States, in which Alope is set down as present, and usually both Alope and Nephele. I wrote to the authors of these lists, and in many cases examples of the butterflies called Alope were sent me. In every instance, what had passed by that name was either what I should call Nephele, or what would be an intergrade if taken in Now York. In the west these are not intergrades, because there is no Alope in that region, and so no commingling of the two forms. I limit the name Alope to the typical form. These apparent intergrades are never found where Alope flies alone, before it approaches the dimorphic belt, but they appear occasionally to the westward throughout the Nephele territory, and should be regarded as examples of reversion. 


\title{
CHIONOBASI.
}

\author{
CHIONOBAS IDUNA, 1-4.
}

NFIV SPECIES.

Princartes in male much produced, costal margin nearly straight; hind margin of primaries in both sexes slightly rounded, of secondaries deeply sinuate; the exterior outline of discal band on under side of secondaries not scolloped, irregular.

MALE. - Expands 2.5 inches.

Upper side brown-orange, bright on primaries, less intense on secondaries; hind margins edged by a narrow fuscous border, of nearly uniform width on secondaries, but narrow on primaries at inner angle, and much expanded at apex, the inner side entire; costal border of primaries dark brown; upon the disk, from the lower outer angle of cell to sub-median nervure, and encroaching somewhat on the cell next above median, an oblique, dark brown band, the exterior side convex, the interior somewhat undefined, nearly lost in the brown shade that covers the basal half of cell ; on the upper discoidal interspace a large, oval, black ocellus, without iris, with small white pupil; sometimes in the next interspace above is a minute, round, black ocellus, either with or without white pupil, and a similar one, but blind, in the second median interspace; this last ocellus however, may be large and pupillated, and accompanied by a small blind ocellus in the first median interspace; the number of ocelli therefore varies from one to four, and when four are present, two are large and pupillated; and whatever the number, they are so placed that a straight line would pass through the centre of each one; secondaries have the costal margin slightly flecked with brown; at outer angle sometimes a small, brown, sub-triangular spot, but often wanting; on the second median interspace a small ocellus, either with or without white pupil; often this ocellus is wanting; fringes of primaries fuscous cut with sordid white at middle of each interspace; of secondaries fuscous, largely pure white in the interspaces.

Under side of primaries paler; a dusky shade over cell corresponding to the oblique band; costal edge gray-brown, irrorated with blackish-brown next base, with white beyond; at apex gray and white equally mingled; the hind margin 


\section{CHIONOBAS I.}

pale gray-brown; cell slightly flecked with brown next sub-costal nervure; the discoidal ocellus repeated, and also that on second median interspace when present abore.

Secondaries white on costal margin, the remainder of wing dead-leaf brown upon a white ground, the sub-color appearing most distinctly next beyond cell, along median nervules and over abdominal margin; the whole surface covered by fine, abbreviated, brown streaks, least densely on costal margin, most next base and over sub-median interspace, and for a broad space along hind margin; a white point next the margin on the middle of each interspace; the ocellus, when present above, repeated; and in a line with this, a series of white points, one on each interepace across the wing to costa - representing, perhaps, obsolete ocelli, which might sometimes be found more or less complete; the disk crossed from margin to margin by a broad, irregular band, narrowly edged on either side by a blackish-brown border; the space within the band not differing in shades of color from that beyond; the exterior border commences on costa just above outer angle in a wedge-shaped spot which reaches the second discoidal nervule, then continues by a single curve, convex outwardly, to upper branch of median, at which point it curves ontward again to the middle of the adjoining interspace, and continues in a line nearly straight almost to lower branch of median, then obliquely forward till it strikes this branch, from which it proceeds in a straight line to margin; this outline may be briefly described as composed of a straight line, a single curve, a square offset, and a straight line to margin, and is quite unlike the scolloped outline of the similar band in the nearest allied species, Gigas; the outline of the basal side is that of a double curve, at first convex towards base of wing, and most advanced on sub-costal nervure, then returning, the extreme concavity being on median, opposite the beginning of the line on costa.

Body blackish-brown above, black beneath, the abdomen gray-brown; legs black, the tibia gray-brown; palpi black with gray hairs interspersed; antenna brown, beneath gray; club dull ferruginous, gray beneath.

Fesale. - Expands 2.6 inches.

Upper side paler than in the male, fading beyond the disk into buff; the oblique band wanting; base of cell on primaries, and that portion of cell next. sub-costal nervure brown; primaries have two large ocelli, the upper one pupillated, the lower one sometimes blind, and one or both accompanied by a small blind ocellus on the interspaces next preceding; secondaries marked as in the male. Under side of both wings paler than in the male; the outlines of the band sinilar.

The individuals represented on the Plate were sent me by Mr. James Behrens, 

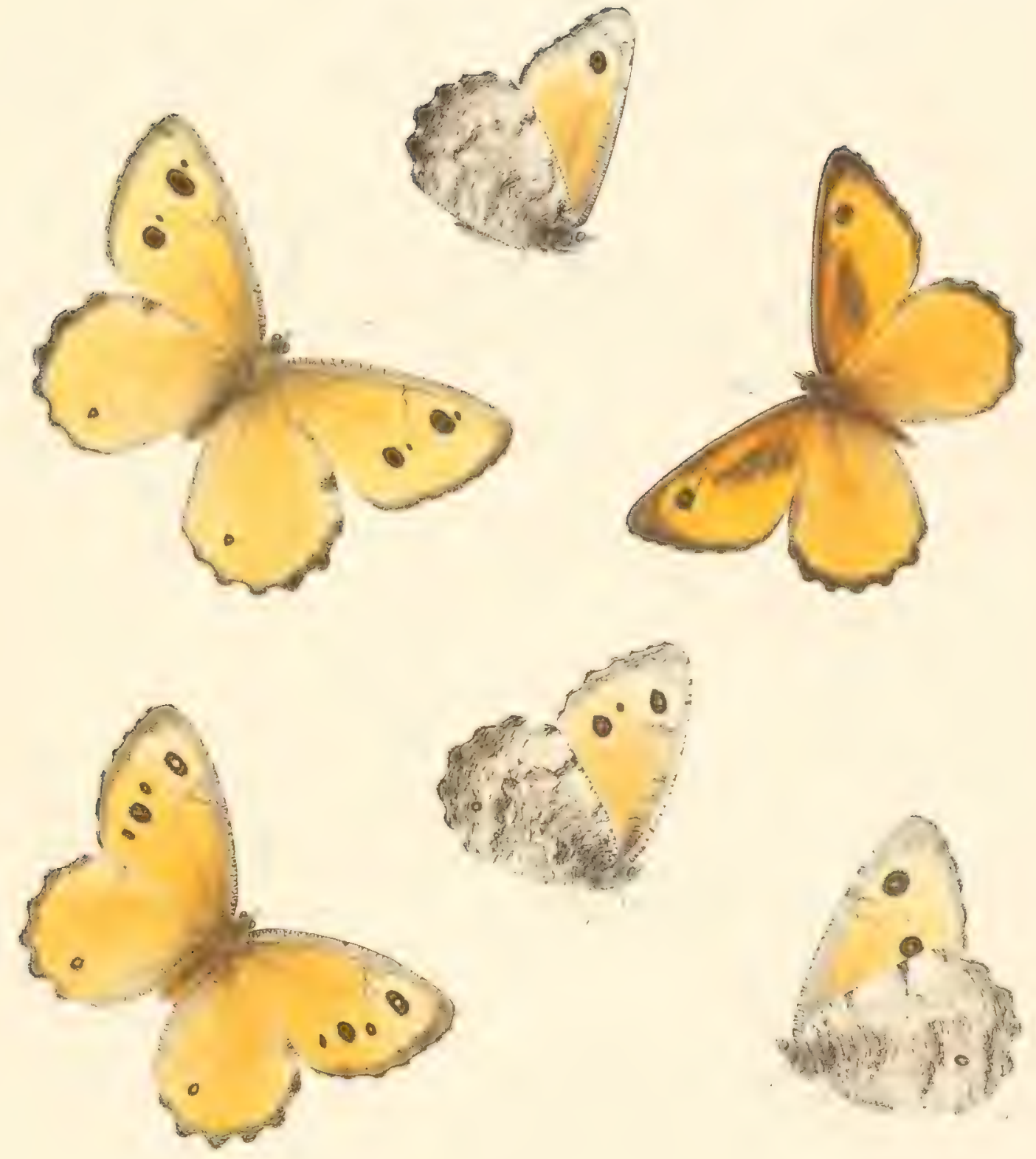


\section{CHIONOBAS 1.}

to whose zeal and skill lepidopterists owe the discovery of several new species of Californian butterties, and a better acquantance with many rare ones. Mr. Behrens wrote, 26th June, 1873: "I caught seven of the large Chionobas in Mendocino County. It seems to be a very local species, and confined to high ridges in the depth of the red-wood forest. 'They would alight on a hot, sandy spot, or on a fallen tree, or on the fresh leaves of young oak trees, always in the heat of the sum. Fallen trees and dense thicket make the chase for them difficult. 'Whey are very vigilant and shy, but will return to a spot they have once visited, though for a short hour of the day only, either earlier or later, according to the state of the atmosphere and wind, and when tired from their usual high, rapid flight. Water and moisture do not seem to attract them. They should be looked for in the month of May, as soon after they become shattered. It is almost impossible to obtain a perfect specimen later."

Iduna is one of the largest known species of Chionobas, rather surpassing even Gigas, Butler. These two form a sub-group, separated by no wide interval from Nevalensis, Felder, and Califomiea, Boistuval. 'The several species of this genus are mostly alpine or boreal, Lduna and (rigas apparently being the exceptions, the former living upon ridges of moderate elevation, and Gigas being taken at quite low levels. 'I'hree other species, Chryxus, Uhleri, and Semidea, inhabit the mountains of Colorado, and of these Chryxus is taken in California and at Hudson's Bay (Calcis, Scudder, proving to be the feruale of this species), and Semidea abundantly on the summits of the White Mountains, New IIampshire. Over the most northern portions of the Continent still other species of Chionobas are found, and of these all seem to inhabit corresponding parts of Europe and Asia.

Idena may readily be distinguished from Gigas. It has less curvature of costal margin of primaries, and much less rounded hind maryin; the same wing is also more produced, or pointed apically; the ocelli are diflerently arranged, those of Idna being set in a straight line, of Gigas irregularly, the small ocellus of first median interspace lying outside a straight line connecting the larger. 'This peculiarity is observable in the two females in my own collection, and also in the mique male in British Museum collection, as mentioned by Mr. Butler, who first directed my attention to this peculiarity of the species. On the under side, the outer edge of the discal band in Gigas is scolloped from margin to margin; in Iduna it is not scolloped, but irregular. 'These differences may be seen by reference to the Plate, and they are constant in all the individuals of either species at present known in collections. 



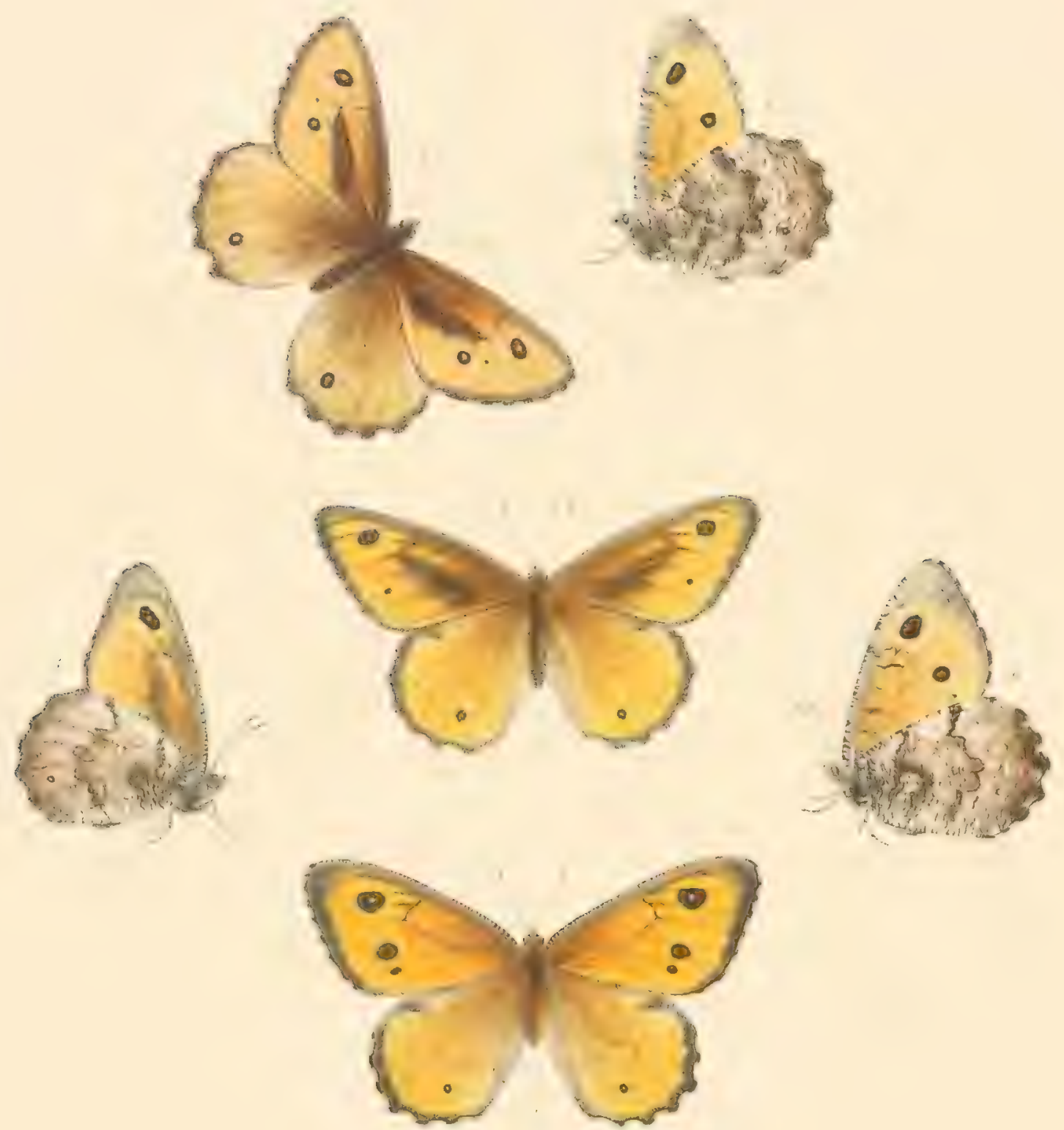


\title{
CHIONOBAS II.
}

\author{
CIIIONOBAS GIGAS, \& I. 2; \& PI. I. 5, 6. \\ Chionolas Gigas, Butler, Cat. of Satyrida in Brit. Mus., p. 161, pl. 2, 1868.
}

Primanies in male much produced, costal margin in both sexes moderately arched; hind margins of primaries in both sexes much rounded; the exterior outline of discal band of under side of secondaries regularly scolloped.

MLLE. - Expands 2.4 inches.

Upper side fulvous-ochraceous; hind margins edged by narrow fuscous borders which are of uniform wilth throughout and quite to apex; dostal border of primaries dark brown, as is also the base and that part of cell next sub-costal nervure; the oblique discal band blackish-brown, well defined; on upper discoidal interspace a small oval black ocellus, and another on second median interspace, each with white pupil; on upper median interspace, outside a line connecting the centres of the two ocelli, a black point. Secondaries have the costal margin flecked with brown, and a small patch of brown at outer angle; on second median interspace an ocellus; fringes of both wings alternately fuscous and white quite to apex of primaries. Under side of primaries somewhat orangetinted, the costal margin and apical area whitish crossed by fine dark brown streaks; hind margins pale fuscous; base and upper half of cell streaked with fuscous; the ocelli repeated. Secondaries pretty uniformly covered with fine, abbreviated, brown streaks on a white ground; the base and hind margin washed with brown; the discal band narrow, of a deeper shade of brown, the edges distinct, the exterior irregularly scolloped, the basal a double curve; the ocellus repeated. Body dark brown above, black-brown beneath; legs light; palpi blackish; antemma dull ferruginous.

Female. - Same size.

Upper side lighter than in the male, faling somewhat beyond the disks; the oblique band wanting; primaries have either three or four ocelli; when three are present the two largest are placed as in the male, the third on upper median interspace, corresponding to the point seen in the male; when four are present, the fourth is small, on the sub-median interspace, in line with the two large ones; 


\section{CHIONOBAS II.}

the marginal border broader than in male; under side of primaries pale fulvous on disk, the hind margin fuscous, the apex and costal margin white, and both margins streaked and specked with brown; the two principal ocelli repeated, the others often wanting; secondaries densely streaked from base to margin, the white ground appearing but slightly on the disk and somewhat more at outer angle; the discal band as in male, scolloped very regularly on its outer edge, the inner sometimes lost in the dense markings of base.

From Vancouver's Island.

The figures of the male on the Plate are copied from drawings made from the unique example in the British Museum Collection, by the kindness of Mr. Butler, who certifies to their accuracy. The figures of the female on Plate I., represent one of three females taken on Vancouver's Island, 15th July, 1873, by the late Mr. G. R. Crotch, who wrote that "they were all found on a potato patch, at the extreme end of Tannich Inlet, about fifteen miles from Victoria, flying in company with Parnassins Clodius and Argynnis Bremnerii. No males were taken." 


\title{
CHIO NOBAS II.
}

\author{
CHIONOBAS CALIFORNICA, 3-6. \\ Chionotas Californica, Boisduval, Ann. de la Soc. Ent. de Belgique, Vol. XII., p. 62, 1868. \\ Ibid. Lep. de la Calif. p. 62, 1869.
}

Primaries in male much produced, costal margin nearly straight; hind margins of primaries in both sexes nearly straight; the exterior outline of the discal band on under side of secondaries irregularly scalloped.

M.ıLE. - Expands 2.4 inches.

Upper side brown-orange, nearly as in primaries of Tduna, but uniform on both wings; hind margins edged by narrow fuscous borders of nearly equal width throughout and extending quite to the apex of primaries; costal border of primaries dark brown, as is also the base and all of the cell except a stripe at outer angle, where the ground color is exposed ; the oblique discal band scarcely distinguishable in color from the darker portion of cell; primaries have an oval black ocellus on upper discoidal interspace, and a small blind one on second median interspace. Secondaries have the costal margin flecked with brown, and a small patch of brown scales at outer angle; on second median interspace a small pupillated ocellus - (probably in a series of specimens the ocelli will be found to vary as in Iduna); fringes of both wings alternately fuscous and yellow in equal degree.

Under side of primaries paler; costal edge gray, specked and streaked transversely with dark brown, next before apex white; apex gray-brown, shading into brown on hind margin; the cell next sub-costal nervure slightly specked with brown. Secondaries whitish, washed with pale brown from base to hind margin, but slightly along costal and inner margins, where the white shade predominates; the basal area streaked transversely and densely with brown; the inner margin and costal edge slightly streaked; the hind margin edged by a narrow brown border; remainder of wing nearly free from streaks and of a pretty uniform shade of color; the disk crossed by a broad band the exterior outline of which is irregularly scolloped; the interior outline sinuous, at first convex toward base of wing, and most advanced on sub-costal nervure, then 


\section{CHIONOBAS II.}

returning, presenting a deep square sinus on median nervure, after which its course is wavy to the sub-median nervure, where it terminates; the ocellus repented.

Body blackish-brown above, black beneath, the abdomen brown; legs and palpi black; antennæ brown, gray beneath; club dull ferruginous, gray beneath.

Female. Expands 2.5 inches.

Upper side of a deeper color than the male, alike on both wings, with broader and blacker marginal borders; costa of primaries brown, gray next apex; the oblique discal band wanting; the two principal ocelli larger and pupillated, and in addition to these, a third, blind, on sub-median interspace; the ocellus on secondaries as in male. Under side more distinctly marked than in male; apex of primaries ashy-white, the marginal border gray-brown; the large ocelli repeated, the pupils conspicuous; the third ocellus represented by a point. Secondaries whitish over larger part of disk, washed with brown beyond the band, the color deepening toward hind margin; the whole wing streaked and specked with brown; the outlines of the discal band distinct; the ocellus obsolete, except the white pupil.

From California, and described by Dr. Boisduval as found, according to Lorquin, from whom the four examples in his collection were received, "on high mountains, next the snow line;" lout on what mountains or in what section of the State is not mentioned. Dr. Boisduval presented Mr. Scudder with one of the males and myself with the corresponding female, and from these the drawings on the Plate have been made. Mr. Scudder informs me that the four were inspected by himself in Paris, and that they were alike in color and unarkings. The species differs noticeably from Idune and Gigas in color, being darker, and of uniform shade on both wings, and nearly so in both sexes. In shape of the wings, it most resembles Gigas. On the under side the male is nearly destitute of markings; the female is distinctly marked, and shows much more white and less density of brown streaking than Gigas, in this respect approaching Iduna. The exterior outline of the discal band is scalloped, but not so regularly as in Gigas. In that species the general course of the outline is parallel to the hind margin; in Califomica the parallelism is broken by the prominent dentations on the two upper median interspaces. The course of the interior outline of the band differs from that of Idema, which presents a double curve, in that it is in the form of a single prominent curve, followed by a deep sinus and a wavy line beyond to inner margin. From the interior outline of the band on Gigas it differs in nearly the same degree. Nevadensis, Felder, is only known to me fiom the description in the "Voyage of the Novara," and the accompanying figures of upper and under side of the male. The shade is 


\section{CHIONOBAS II.}

shown to be a uniform tan color; the primaries are broader than in Californica, and less produced apically, the fuscous marginal border is scalloped on its immer edge across the entire wing; the deep brown shade of the oblique bar on disk passes quite around the cell, and joins the equally deep color of costal margin; on secondaries there is a long fiscous stripe from outer angle to middle of wing. The under side agrees with Californica in being nearly deprived of markings, but the discal band of secondaries is quite different; it is narrower by one half at its origin on costal margin, and is more regularly scalloped on its exterior side. It is also scalloped in same way on the basal side, and in this respect it resembles no one of the allied species. The description expressly states that both the basal and exterior outlines of the band are "crenated."

As the four species of this group differ so decidedly in respect to this discal band, I have thought it well to indicate more particularly the peculiarities of each, by the following cuts.
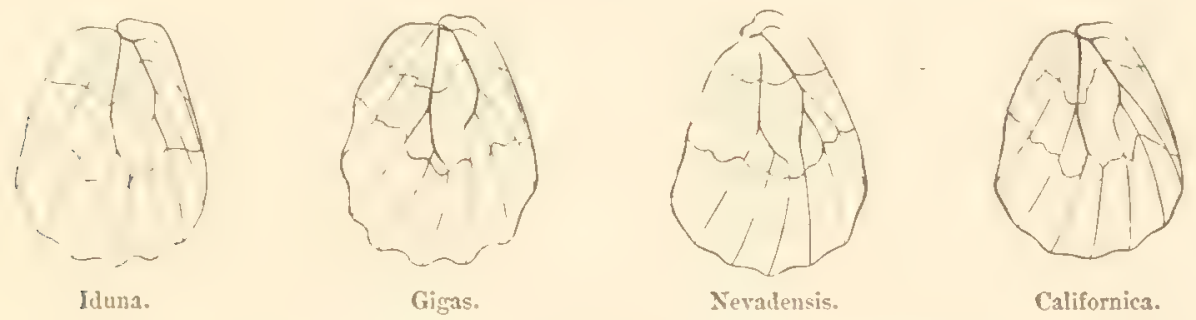

I have retained the generic name Chionobas, Boisduval, for the species herein figured, in preference to that of (Eneis, Huibner, which of late has been forced into prominence, for three reasons: first, that Boisduval is the earliest author who defined and limited the genus; second, that in my opinion Eneis, as applied to the genus so defined and limited, has no authority whatever, it having been not only a mere catalogue name, but a name given to an assemblage or batch of butterflies, embracing some that belong to Chionobas and some that belong to Satyrus; and thirdly, whether it has authority or not, it certainly cannot be made to embrace one of these species. I regard the so called Hibnerian genera of butterflies as mostly worthless, and would reject nearly every one which has not been introduced by a subsequent author in a proper way, that is, under definition and limitation, and then, though the mere name be Huibner's, the authorship of the genus should be attributed to the systematist who so properly uses it; of course to the wholesale overthrow of Hiibner's priority in the matter of genera. Dr. A. Speyer, in a late issue of the Ent. Zeit., Stett. 1875, v. 36, p. 98, in his paper on "Europäisch-Amerikanische Verwandtschaften," uses these words in reference to this very question of Chionobas versus Eneis: "The limit of the permissible has been overstepped many 


\section{CHIONOBAS II.}

times, as, for instance, in the introduction of IIubner's name CEneis for the genus Chionobas, Bois. Huibner divides the species in this genus into two separate groups, Eumenis and Eneis, and in both mixes them up with species of the genus Satyrus. Under Eumenis he places Autonöe, Aello, Semele, and T'arpeja. Under Eneis, Norna, Bore, Celano, Jutta, and Arethusa. The generic character's which he gives for Eumenis are: "the upper side of the wings banded with ochre-yellow, under side of the hind wings white fringed and delicately marbled;' for (Eneis, 'both wings on upper side spotty rust-yellow, below marbled gray banded.' 'Thus Hübner has not even recognized the very natural genus Chionobas as such, let alone characterizing it sufficiently." And as Mr. A. R Wallace states, Ammiv. Address, 1872, p. 18, while discussing the subject of the Hiibnerian genern, "Such a mode of defining genera (by facies) is undoubtedly superficial, and it can only be by the purest accident that a group so characterized can correspond in extent to any real genus." It needs nothing farther than the definitions of these groups as given to prove that neither of them embrace Idune and its allies. 


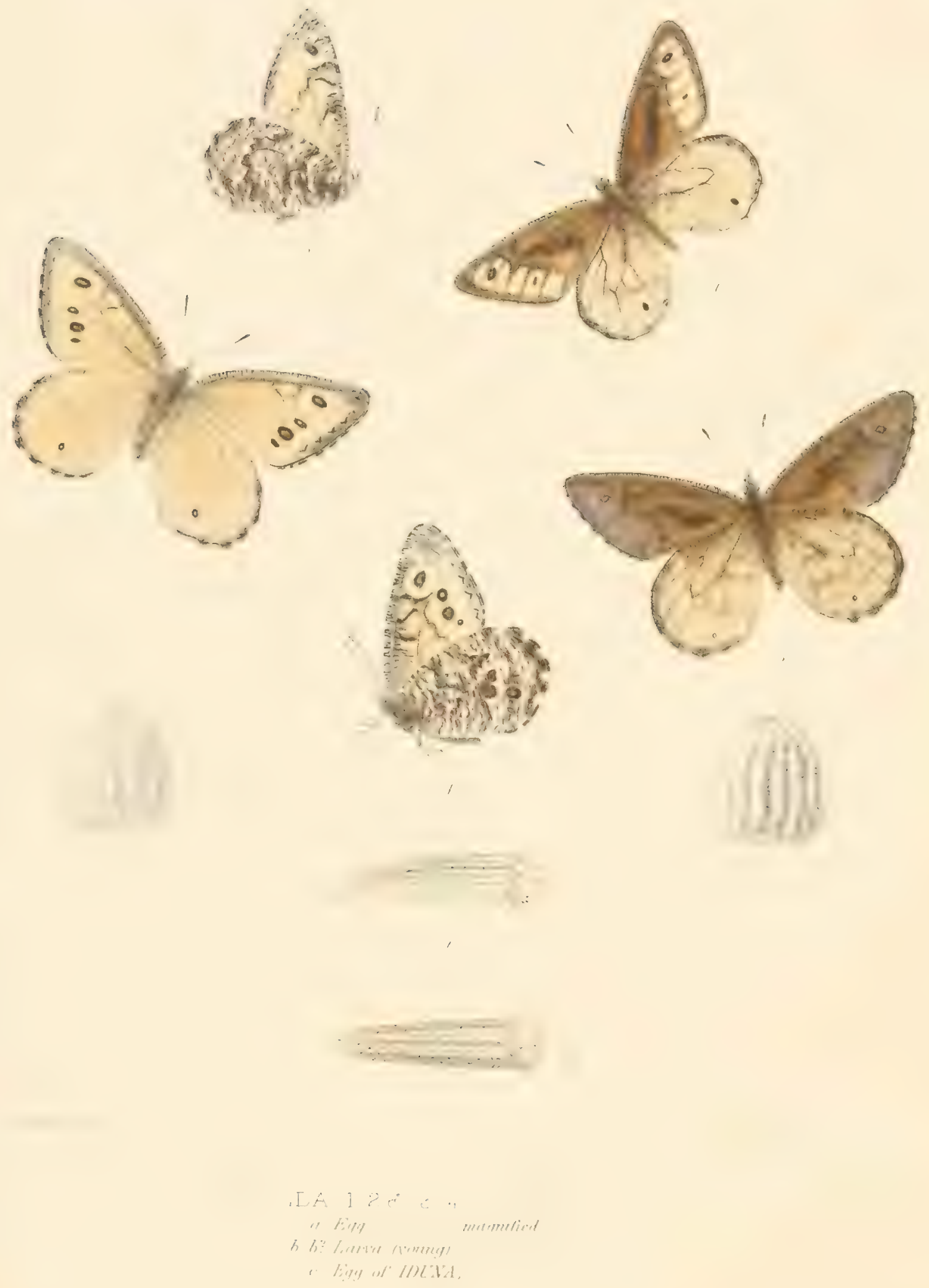


\title{
CHIONOBAS III.
}

\author{
CHIONOBAS IVALLDA, $1-5$. \\ Chionobas Ivallda, Mead, Can. Ent., X., p. 196, 1878.
}

MALE. - Expands from 1.8 to 2.3 inches.

Upper side of primaries blackish-brown, varying in individuals from dark to pale; the costal margins finely and transversely streaked gray and brown; the hind margins narowly edged with brown; on the lower side of cell and partly within it a black sexual band, sometimes obsolescent; between the nervules a series of elongated gray-ochraceous spots, nearly or quite filling the interspaces, usually six in number; but sometimes the uppermost one is wanting; in one example examined there is no trace of these spots (Fig. 5); on the second spot from costa is a black ocellus, always small, sometimes minute, with white pupil; and in about one fourth the examples there is a mimute spot on the lower median interspace, rarely large enough to admit a pupil.

Secondaries gray-ochraceous, edged with brown; in submedian interspace is usually a small pupilled ocellus; fringes brown at the ends of the nervules, white in the interspaces.

Under side of primaries gray-ochraceous, the costa black and white; the upper part of cell streaked transversely with brown, - sometimes the entire cell; about three fifths the distance from base to arc some of these streaks become confluent and form a sinuous bar; the disk is crossed by a brown stripe, which projects a long tooth upon upper branch of median; below this the stripe is twice roundly incised, and sometimes projects a spur along the sub-median interspace nearly or quite to the hind margin; the apical area finely streaked with brown on white ground; the ocelli repeated.

Under side of secondaries whitish, with an ochraceous tint over the disk and marginal area; much covered with dark brown abbreviated streaks, which at base and on middle of disk are largely confluent; the wing crossed by a broad mesial band, the edges of which are dark, the outer irregularly crenated or 


\section{CHIONOBAS III.}

serrated, with a spur along the upper side of lower branch of sub-costal; the imner edge angular from costa to median, with a deep angular sinus at median; the ocellus repeated.

Body above, dark brown; beneath, the thorax blackish, abdomen yellow-brown; legs yellowish, the long hairs of the fenora black; palpi black, in front brown; antemie amulated brown and gray, on under side gray; club ferruginous above, gray below, the tip black.

Fenale. - Expands fiom 2.1 to 2.4 inches.

Upper side more yellow; the costal and hind margins as in the male; the ocelli vary from two to four, - there being in the latter case one in each median interspace; and usually all, or at least the three upuermost, are pupilled; secondaries and the under side of both wings as in male; sometimes there is a small ocellus on either side of the large one on secondaries.

EGG. - Sub-conic, broadest at base, nearly as broad as high; rounded at top; ormamented by about eighteen vertical ridges, the sides of which are irregularly excavated; part of these terminate at about three quarters the distance from base to summit, and the remainder gradually sink to the surface; the spaces between, over the top, irregularly and shallowly pitted (Fig. a).

Youvg Larva. - Length .11 inch; body stont anteriorly, tapering from fourth segment to last, which ends in two blunt conical tails, each of which sends out a short teminal white bristle; color at first soiled white, soon after"greenish-white, striped with dull red, or rect-brown; a broad stripe on iniddle of dorsum; on the upper part of the side another, rumning to the end of tail; a thirl, sul)stigmatal, somewhat macular; between the dorsal and lateral band a brown line, and a second just below the lateral; on each segment from three to twelve on either site are three rows of clubbed hairs, each of which springs from a tubercle; head large, rounded, narrowing towards top, the surfice thickly covered with shallow punctures; color dull yellow; across the upper front face is a curved row of four rounded brown tubereles, and a second row of six across middle; and from each springs a dark clubbed hair; the ocelli black (Fig. b).

This larva was sent by Mr. Mead from Virginia City, Nev., and was but just out of the egg when received. It har energed on the upper part of one side, and was clasped about the shell when I opened the box. 'This was August 18, 1877. It lived till September 21, and when very near the first moult was aceidentally killed. It fed rearlily on grass, and in behavior was not unlike other Satyricls at sime stage. It is eviclent that this species does not hybernate immediately from the egge, but the length of the first stage was such that I apprehend hybernation would naturally occur when the larva was about half grown. As the body enlarged the anterior sergments equaled the head in diameter, the last segment becane red-brown, and a collar of same color appeared upon the 


\section{CIIONOBAS IIT.}

second. This stage of Teallda closely resembled the comesponting one of $C$. Aello, as figured by Mr. Scudter; hut the egge diflers in shape materially; that of sello being marked by straight beaded ridges, and heing narrower at base than towards the summit. So little is known of the preparatory stages of species of Chionobas, that even the meager contribution I am thus able to make will he an addition of some importance.

N1. Mearl found Feellde on Freel's Peak and on Tallac Mountain, near Lake Tahoe, during the litter part of July and early in August, at an elevation of nine to ten thousand feet above the sea. On the grassy northern slopes of Tallac Mountain it was pretty abundant. He regards it as local and extremely rare in most parts of its habitat, funding no examples in a very thorough explorition of the mountain crests about Summit, which is also near Lake Tahoe, and but few on Freel's Peak. Mr. Morrison, the same season, took a few examples about Summit, and Mr. Henry Edwards had occasionally taken one or more there in previous vears. 'l'he melanized male figured on the plate (Fig. 5), was taken by Mlr. Morrison. 'The egg obtained hy Mr. Mead was laid hy a female confined in a small portable cage, contrived by him, and dercribed in Psyche, vol. 2. 1). 1 s. I copy his description, that his mode of obtaining egres may be more extensively known to Lepidopterists. "I have found a little device, rery convenient. on excursions where only a limited amomnt of baggange can be carried, for inducing butterflies to lay egres. I hat a number of wire frames made, each consisting of two rings about five inches in diameter, connected by wire uprights, about seven inches high, the joints being all soldered. 'These frames will fit in, side by side, so as to require only a moderate amount of room. I had a similar number of round tin box covers made, differing in size sufficiently to nest together. A few cylindrical flat-bottomed bags of gauze, of suitable size to fit over the lings, completed the apparatus. If the food-plant is not too large it may he transplanted to one of the tin covers (in which the gauze-covered frame is set); otherwise a branch may be placed in a bottle of water within the cage and the female introduced. In this simple way the eggs of more than a score of buttertlies were obtained during the summer."

Ivallde is closely allied to C. Chryxus Doubl., the differences being mainly in color. Mr. Mead notices that Iuallda is almost exactly like Hipparchia Ridingsii Edw., "which," he adds, "has not only the appearance but the habits of a Chionobas."

On the Plate is also given the ecgrg of C. Iduna, received from Mr. O. T. Baron. It is subconic, broadest at base, nearly as broad as high, the top a little depressed, the sides ormamented by about eighteen vertical ridges, which are somewhat sinnous, elevated, and sharp, their sides irregularly excavated. The larger part of these extend from base to summit, about which they form a beaded rim (Fig. c). 



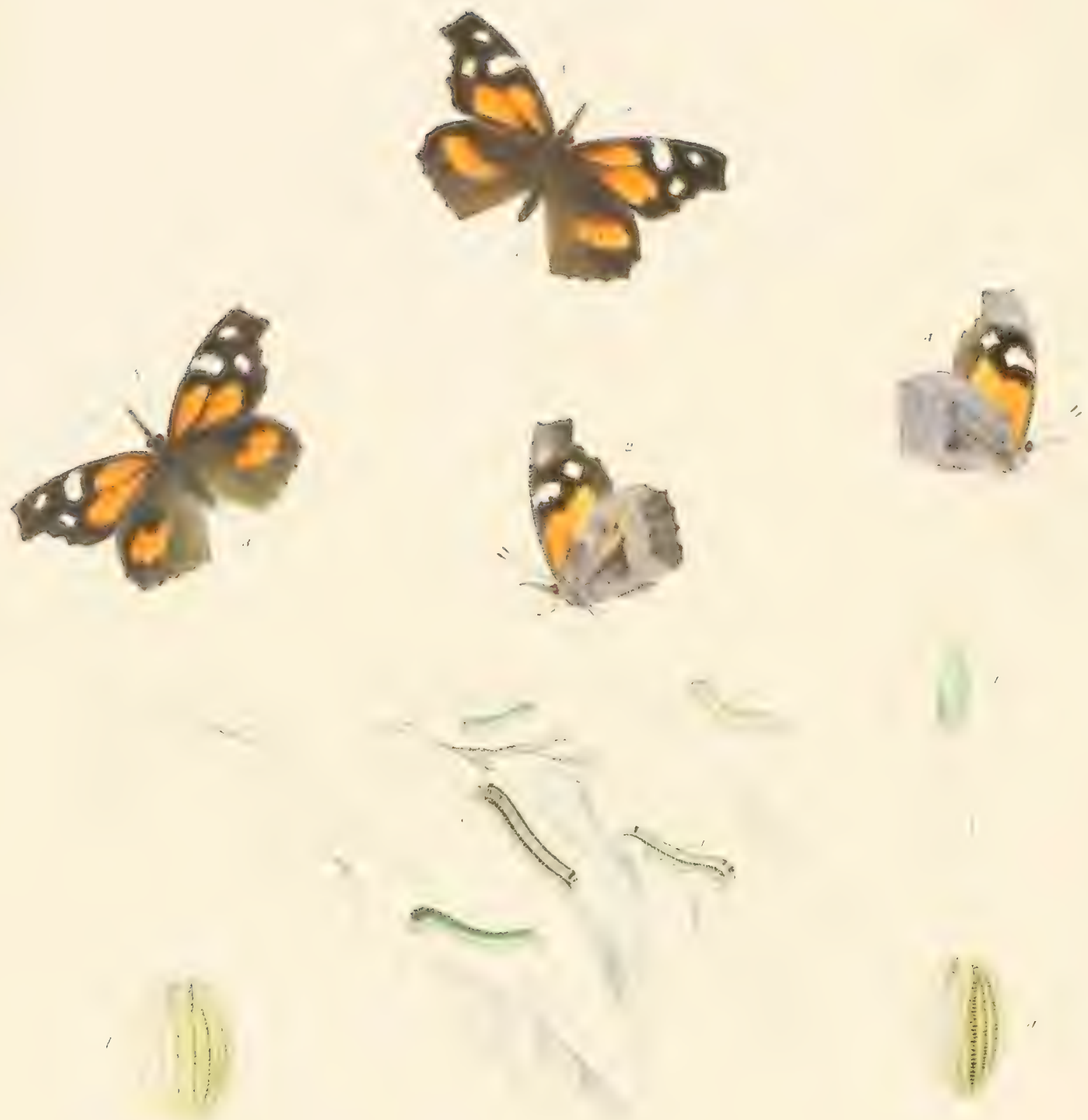

1. Huwer coll thela

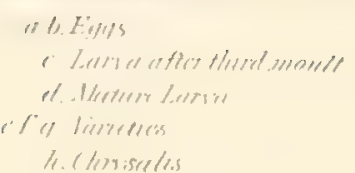




\title{
L I B Y T H E A.
}

\author{
$+\cdots$ \\ LIBYTHEA BACHMANI, 1-A.
}

Lithylect bachmani, Firtand, Silliman's Joumal, vol. xiii. 1852, fir. Saunders, Canalian Entomologist, vol. i 186, fin.

MuLe. - Expands 1.8 inch.

Upper side of primaries brownish-black, of secondaries brown clouted with black near base; primaries have a yellow-fulvous patch oceupring neals half the cell next median nervure, and a large sub-rhomboirlal patch of same color below cell, not extending beyond sul)-median; on the costal margin, a long, marrow, white spot beyond cell, sometimes divided unequally into two, the smaller being on costa; a small sul)-marginal, white spot, sometimes quadrangular, sometimes irregularly rounded, on the upper median interwace, and a sub-apical white spot about half the size of the last; these spots are usually pure in color, but sometimes are partially tinted with fulvous, and fulvous seales form to them a narow edging. Secondiries have a broad, extra-discal, tramsverse, fulvous band, extending from sub-eostal nervure to lower branch of median, rather indistinct as it approaches this last nervure; fringes luteous, fuscous at ends of nervules.

Under side brown, sometimes olivaceous, clouded with cretaceous, occasionally lilac-tinted, or vinous, at apex and somewhat along hind margin of primaries, and over whole of recondinies; on these last these shades form a large triangle, one broad side of which crosses the disk, one lies along the abdominal margin, and the third a little within the costal edge, to which it sends a curved branch; within this triangle is a small brown space, usually sub-triangular, but sometimes a narrow stripe only, confined nearly to the median nervure, with a narrow patch across the origin of the median nervules; primaries yellow-fulvous from base over two-thirds the cell, and helow cell almost to hind margin; the two extra-discal white spots repeated, but the sub-apical sometimes lost in the eretaceous patch. Body and palpi dark brown above, gray-brown beneath; legs griy-brown, eyes crimson; antenna and club dark brown.

Female. - Expands '2 inches.

Similar to male except that the under side of seconduries has often no appearance of clouded surfice, and is then of an uniform vinous-brown, or in an oblique light, lilaceous. 


\section{I.IFYTHE.}

EGG.-Color pale green; in shape an oblate spheroid, somewhat pointer at base and a little truncated and depressed at summit; maked by many horizontal corrugations, and longitudinally by eighteen to twenty narrow, prominent ribs which proceed from base and terminate, some of them irregularly, at about fourfifths the distance to summit, while eight, increasing gradually in prominence, terminate abruptly at the rim of the summit, which is flattened as in Grapta; these long ribs cut on either side, as in Grapta, by grooves perpendicular to the surface of the egrg; they are also frequently deflected somewhat from a direct line. (Fig. a.)

Another egg. within one day of the appearance of the larva, differed from the above; the length being sensibly increased by the flattening of the corrugations, and, at the same time, the transverse diameter enlarged from the unfolding of the ribs, which had become scarcely more than lines upon the surface. (Fig. b.)

'The Larva emerge from the egg in four days; in length 06 inch; greenishbrown, translucent, covered with fine hairs. (f) the first moult I am unable to speak, but after passing the second, in four to five days from the erg, they are .25 inch in length, slender, cylindrical, entirely one shade of dull green, somewhat pilose, each segment transversely creased; two days later the third moult takes place; length 6 inch; head pale green; body velvety-green, with a pale dorsal line and a faint, whitish, lateral stripe from second to last segment; each segment creased and marked by rows of whitish, tuberculated points; under side and legs pale green.

The Mature Larva is one inch long; head bi-lobed, pale green; body dark velvety-green; the dorsal line distinct, yellow; the lateral stripe yellow, as are also the tuberculated points; on the side of third segment is a black point; under side and legs pale green.

Another larva, after third moult, was marked as follows: the dorsum dark green, edged on either side by a gray line, and successively by a band of yellow, another gray line, and a black band to the legs'; the third segment wholly black, and fifth partially; the entive upper surface finely tuberculated with yellow; pro-legs black; legs pale green. 'The markings were similar after fourth moult.

Two other larve were green, with a lateral black band above the feet, and a few black patches on third and eleventh segments.

Chrysalis. - Length .5 inch; sub-triangular, compressed laterally; head case square; mesonotal process rounded, prominent; color blue-green ; a fuint yellow dorsal line passes from last segment to middle of boay, where it forks, sending a branch along each wing cover to the top of head case and meeting; there is also a lateral yellow line from end of last segment to edge of wing cover; the abdominal segments marked by many whitish tubercles. Time from laying of egy to appearance of the imago sixteen to seventeen days. 


\section{I,IBYTHEA.}

Bachmani appears to be the sole representative of its genus east of the Mississippi, mless possibly L. 'Terend, Codart (L. MLotya of Hubner, and Bois. and Lec.), a West Indian species, should be foumd in the extreme South. The grenus itself is very restricted, there being, according to Kirby (Cat. Di. Lep.), but eight known species: three belonging to this Continent, one to Europe and Western Asia, one to Afriea, one to Mauritius, one to India and Java, and one to the Eastern Archipelago, - a remarkable distribution. Of the third American species, L. Carinenta, found in South Ameriea and Mexico, a few specimens have been brought from Arizona and New Mexico by the naturalists of the United States Govermment Lxpeditions. 'T'he genus is peculiar in many respects, but in none more than in the development of the palpi, which are parallel to the axis of the body, instead of nearly at right angles to it, and present the appearance of an immense rostrum projecting from the front of the liead, - as may be seen by reference to the Plate. The uses of the palpi of Lepidoptera are not understood, except so far as they serve for a protection to the spiral tongue, and the cause of their extraordinary prominence in Libythea rather than in other genera is not apparent. If they were not pacific little creatures, these butterflies might seem to be furnished with an "engine," as Spenser ealls it, to inspire with caution evil-minderl foes, such as wasps, dragon-flies, and that "wicked wight," "foe of laire things," the "greisly tyrant spider."

$$
\begin{aligned}
& \text { "Like as a warlike brigandine applyte } \\
& \text { To fight, layes forth her threatfull pilies afore } \\
& \text { The engines, which in them sal deatl doo hyde; } \\
& \text { so did this lilio outstreteh his fearefull hornes." }
\end{aligned}
$$

And surely the fiercest enemy might hesitate before that portentous beak and those red eyes blazing like carbuncles. Nevertheless, I am sorry to have to say that wasps and spiders mintain the mastery, and cause havoc, not only among these, but all butterflies. And dragon-flies (Libellule pounce upon them as do hawks on small birds, bearing away their prey to be devoured at leisure. Even the heavy-bodied, great-winged Papilios camnot escipe these pirates of the air.

Libythea differs also from most gencra of butterflies in that the males are tetrapod and the females hexapod, agreeing in this respect with the Erycinide only. In the Papilionide and IIesperide, all species and both sexes are hexapod. In the Nymphalida, which embraces Argynnis, Vanessa, Satyrus, etc., all the species are tetrapod, also in both sexes. Nevertheless these last are furnished with two pseudo-legs, not adapted to locomotion, and which appear as flat, furry lappets folded down upon the front of the thorax.

Although Bachmani is widely distributed, it is nowhere recognized as a com- 


\section{I.IBY'THE.1.}

mon species. And yet the late Mr. D. B. Walsh, in a letter to me dated April, 1S63, says, that in the month of June preceding, he had found this species "in swarms," near Jonesborough, in Southern Illinois, "along the travelled road." Mr. Sculder gives Dr. Harris as authority for its having been found in Massachusetts, and informs me that it has also been found so far north as the neighborhood of the White Mountains, in New Hampshire. Mr. Saunder's mentions its occurrence in Ontario, Canada. In West Virginia I have seen a few individuals every season, but have regarded the species as one of the rarest. On 1st August, 1872, I noticed a female fluttering about a small tree of Celtis occidentalis, in my garden, at Coalburgh, alighting frequently on the ends of the branches, and evidently ovo-positing. She made, perhaps, a dozen descents for this purpose before she flew away. 'The eggs were laid singly on the immature leaves at extreme ends of the branches, and 1 found, on examination, that nearly every branch had its egrg. On the 5th, several of these eggs had hatched in the glass to which I hat transferred them. But the larva were exceedingly delicate, and one after another dropped of the leaves till all were dead. I have since experienced the same difficulty in starting these larve in confinement, though those of most other butterflies can be reared from the egg with great certainty. But I was able to replenish the stock from the tree when the larva had become a few days old, and thenceforward had no difficulty whatever. It was easy to discover the feeding place of one of them from their habit of stripping the sides of the leaf at its extremity, leaving the midrib untonched. There is something in their attitude when at rest that distinguishes them from other butterfly larva. For hours they remain with the head and upper segments thrown back and arched, atter the manner of the typical Sphingide. Or the anterior segments are raised from the leaf and eurver forward, the second, third, and posterior segments being swollen, and the middle ones flattened dorsally, an odd habit I have not observed in any other species. In 1873, I again found eggs and larva upon the same young tree, but earlier in the season, making it certain that there were two or more broods of the imago. 'The first noticed were on 28th June, and fresh eggs were found at intervals up to 1st September.

When about half grown, the larva in confinement might be seen slowly making their way up the side of the glass, by means of a rigzag ladder which they spun as they went, and the glass became well coated with this kind of web. After the fourth-moult, they began to fasten the leaves loosely together, and stretched several threads across the top of the glass. 'These threads were quite strong enough singly to bear the weight of a caterpillar, and I have seen one cross the dianeter of the glass in this way, walking feet upward; in this case the traveller proceeded cautiously, stopping several times and throwing at thread 


\section{LIBYTHEA.}

to the right or left by a corresponding movement of its head, whereby to attach its unsteady bridge to a neighboring line or leaf.

When ready to transform, they spin buttons of red silk upon the side of a leaf, suspend themselves as do the Dymphatide, and in about eight hours become chrysalids. 'The chrysalis is a beatiful object, of a delicate green, ormamented with yellow lines, and helmet-shaped.

1 have noticed another remarkable peculiarity in these larve. On 30 th August, I returned home after an absence of but three days, and found the leaves that I had placed in the glass with four larva, which had just passed their third moult at my departure, dried up and all the larve changed to chrysalids, thus crowding into less than three days changes which naturally require six. The chrysalids were not more than half the usual size, and the butterflies that came from them were small and pale colored. 'Twice also I inclosed linve just after their third moult, in a tin box with fresh leaves, and forwarded by mail to Miss Peart, who was then near Philadelphia, expressly to secure a drawing at that stage, and before fourth moult, which should not occur till the fourth or fifth day after the third moult. But though the distance was only two days, in one case the larva on its arrival had fixed for chrysalis, and in the other had actually changed. Miss L'ent wrote, on 1st August, that the larva mailed 29th July had arrived 31st, but was in chrysalis, and from no want of food, as the leaves were fresh. I should apprehend, therefore, that in these cases the larve had not passed the fourth moult, but had proceeded to chrysalis directly from the third. Apart from the difference in size, there is no mistaking the third moult for the fourth, from the peculiar markings assumed at this last.

All the caterpillars of Bachmani observed in 1872 were green, and I should not then have credited a statement of rariation in color. But of those fed in 1873 , several were marked more or less with black, in spots or bands.

I am not aware of any other food-plant for this species than Celtis occidentalis. This tree is a favorite with many other larva, especially of the Apaturas, Celtis, and Clyton, and Grapta interrogationis. G. comma will feed on the leaves in confinement, but unwillingly. 




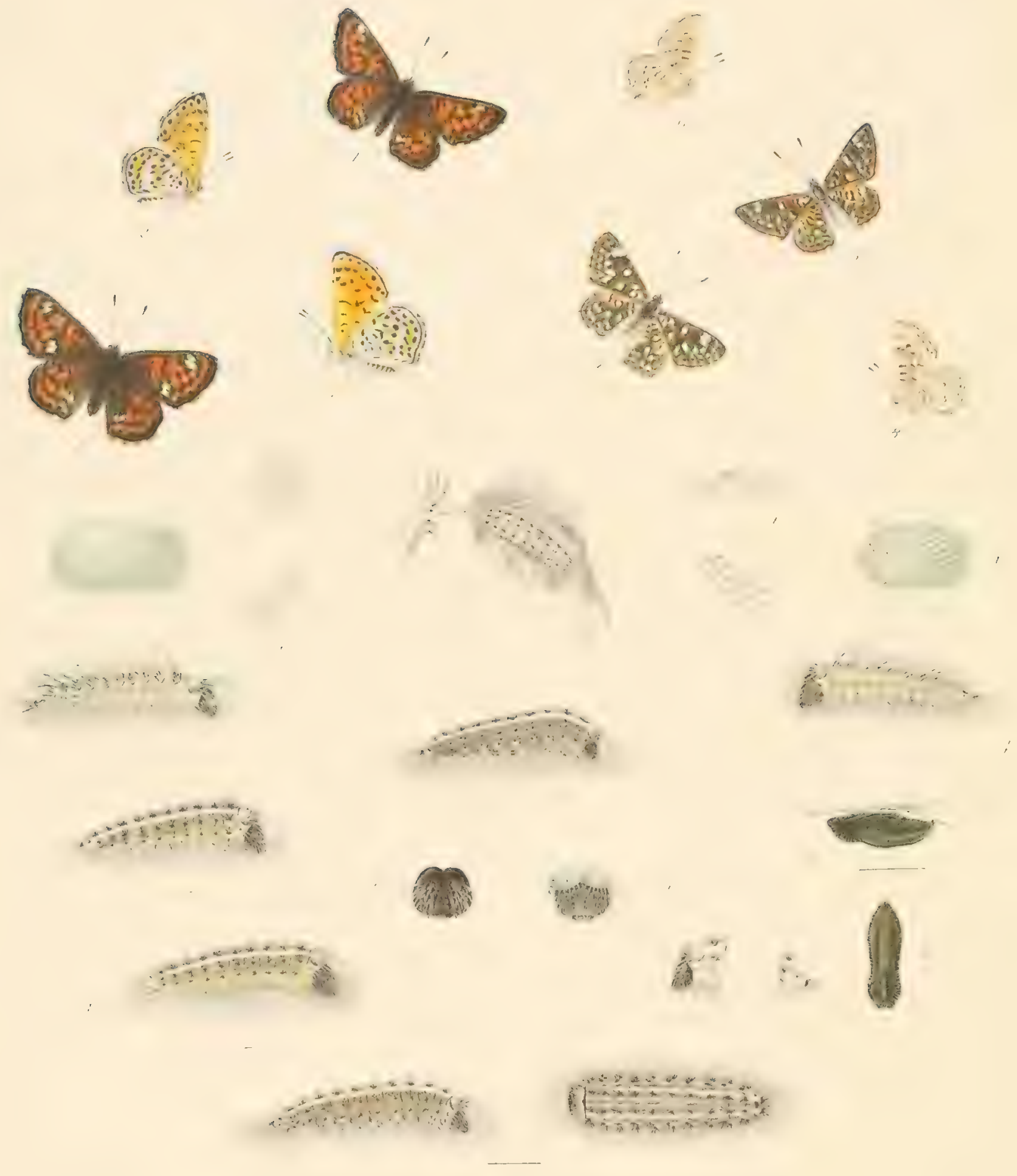




\title{
LEMONIAS I.
}

\author{
LEMONIAS NAIS. 1-4.
}

Lemonias Nais, Edw. (Chrysophanus Nais), Trans. Amer. Ent. Soc., V., 291, 1876.

MALE. - Expands 1.5 inch.

Upper side fulvous and dark brown, spotted with black, the disks being fulvous, the bases and margins brown; a fulvous dash on costal margin of primaries at base; hind margins edged by a black line; the narrow brown border is followed by a series of rounded black spots, completely crossing both wings; in some examples the submarginal fulvous area is broad, in others it is reduced to a series of fulvous crenations on the anterior side of the rounded spots; next preceding is a common black band made up of narrow confluent spots; a similar band crosses the disks, with a sharp bend round the end of cell of primaries; at the extremity of each cell a black transverse bar, and three others within, near the midlle; also below are three in line with the others; primaries have a small white submarginal spot, and an indistinct whitish or yellowish spot near inner angle; fringes alternately, but irregularly, brown and white.

Under sicle of primaries orange, except for a little spot of white or buff quite at the margin in each interspace, and a dash of same color in subcostal interspace; hind margin edged by a black line; the whole wing spotted black, representing in small the marks of upper side. Secondaries yellow-white or buff, with black marginal line, the spots repeated as on primaries; between the two outer rows an orange belt, and orange over outer part of cell and in the interspaces below cell.

Body above, dark brown, below, either white or buff; the abdominal segments at their edges, on sides, fulvous; legrs, pale orange, the femora white, and the first pair (which are aborted in this sex) white; palpi white; antennæ annulated black and white; club black, reddish at tip. (Figs. 1, 2.)

Fesale. - Expands from 1.3 to 1.4 inches.

Marked like the male, but the colors are lighter, and in many examples the fulvous area is more extended. (Figs. 3, 4.) 


\section{LEMIONIAS I.}

EGG. - Button-shaped, the top depressed; covered with a white, vitreous coating, or net-work, in six-sided meshes, each angle sending out a short tapering filamentous spine (Fig. $a^{3}$.); these spines are wanting in the concentric rows about the micropyle (Fig. $a^{2}$.), and the meshes there are five-sided, and in the central rosette rhomboidal; the egg under this net-work is sage-green, and through it, whitish-green (Fig. a.). Duration of this stage about twelve days.

Young LiRva. - Length, .0t inch; cylindrical, thickest at third segment, tapering posteriorly, the dorsum a little arched, each segment rounded; color greenish-yellow, a pale crimson stripe along middle of side; from 3 to 12 , two dorsal rows of broad, oval, flattened, tuberculated processes, from each of which comes a pencil of five long, recurved black hairs, one being shorter than the rest; along lower part of side, from 2 to 13 , are three long, depressed white hairs to each segment, and under these some fine and shorter ones; on 2 is a dark dorsal oval process, considerably elevated, the top rounded, and on its anterior part are six long hairs on each side the medio-dorsal line, all turned forward; in front of these is a fringe of long white hairs which falls over the head; 13 is brown at extremity, and the hairs extend back almost horizontally, a little depressed; feet and pro-legs yellow-green; head a little broader than 2 , obovoid, bilobed, slightly pubescent; color dark brown; the head is not retractile, but is partly covered by 2 (Fig. b.). Duration of this stage about fifteen days.

After first moult: length about two days after the moult, .11 inch; somewhat flattened, broader than high, the dorsum highest at 3, a little arched, and, as well as the sides, tapering to 13 ; the head bent down and under, and partly concealed by 2 ; color at first pale green dorsally, later, dull white with a faint green tint; a brown stripe along upper part of side, the lower part of side and of the body pale yellow-green; on dorsum two rows of brown, conical, low, blunt-tipped tubercles, from 3 to 12 ; on the side, in line with the stripe, a row of similar, but smaller, tubercles, from 3 to 13 ; and lower down, another row, still smaller, from 3 to 12 ; from the dorsal tubercles rise pencils of short, straight, divergent hairs, about twenty-four in number, black; from the upper lateral row similar pencils, shorter and fewer, black; from the lower row a few short, divergent black hairs, and under them several long white hairs, depressed; on 2 is a yellowish, vitreous, low, rounded protuberance, divided into two at the medio-dorsal line, the back part and middle of each half beset with short, straight black hairs, but from the front proceed long white hairs, which come down over the face; on the side of 2 are two small pencils of hairs in vertical row, the upper one lying between the two lateral rows of other segments, a few white hairs from each; at the extremity of 13 a black tuberculation, with short black and long white hairs projecting 


\section{LEIIONIAS I.}

horizontally; the white hairs from the different segments form a complete fringe around the body, including both extremities; head broader than high, obovoid, the sides rounded, the top depressed, the vertices rounded; color black, covered with a yellow down on lower two-thirds, and with many long, depressed, white hairs (Fig. c.). 'T'o next moult nimeteen days.

After second moult: length three hours after the moult, .19 inch; same shape and appearance as at next previous stage; the dorsum dull white, with a brown line down the middle; the brown stripe as before, the rest of side reddish-yellow; the dorsal white area is elerated above the segments at either ent, that is, above 2 and 13, and ends abruptly, and 13 dorsally is of same hue as the sides; head as before (Fig. d.). 'To next moult fifteen days.

After third moult: length one day after the moult, .26 inch, grreatest breadth, .05 inch; shipe and appearance as before; the dorsum dull white, the medio-dorsal stripe pink-gray, the sides pink-hrown mottled with white; head as before (Figs. $e, e^{2}$.). To next moult eleven days.

Aiter fourth moult: length eighteen hours after the moult, .46 inch; greatest breadth, .15 ; height, .16 inch.

Mature Larra. - Length, .7 inch; the head bent under, and, scen from above, both ends are rounderl; the general shape long oval, the last segments narrowest; viewed sidewise, 3 and 4 are highest and the slope is gradual to 13 , rapid to head; the dorsum elevated, forming a flat ridge from 3 to 12 , with rather abrupt ends and sides; color of dorsum dull pinkish-ferruginous, with decided white along the edge of the elevaterl part; a dark medio-dorsal line or stripe; the sides of body wine-red, finely mottled with whitish on the upper part; on the lower, green and reddish are blended, and beneath green prevails; the two lower rows of tubercles yellow; in all there are six rows of tubercles, - one sub-dorsal and two lateral on either side; the upper and lower extend from 3 to 12, the other from 3 to 13 ; those of the dorsal rows are short, conical, blunt, and each sends out a pencil of many very short, straight, divergent black hairs; those of second row are small, with similar pencils of hairs, but fewer in number; those of lorrer row are still smaller, with a pencil of half a dozen black hairs like the rest from the upper part, but undel them, long, depressed white hairs falling to feet; on 2 are two large rounded processes, white, vitreous, with several short, black hairs, but from the fronts come long white hairs which bend down, screening the face; on the side of 2 are two small pencils of hairs in vertical line, the upper lying between the lateral rows of the other segments, the hairs black, the other a little below the line of lower row, and griving both black and white hairs; over the feet also on 3 and 4 each is a slight tubercle with two or three white hairs; 13 is dark colored dorsally, with a tuft of black hairs on 


\section{LEMONIAS I.}

side in line with upper lateral row, and both black and white hairs at the end, the latter long, horizontal (Fig. $/$ ) ; the white hairs from the several segments form a fringe completely around the larva; head obovoid, the sides well rounded, the top depressed, the rertices rounded and covered by the protuberances of second segments (Figs. $f^{3}, f^{4}, f^{5}$.) ; color black, or black-brown; the lower twothirds thickly covered by a yellow down, with a few long, depressed white hairs. There was no variation perceptible in the shape of the head from second moult to maturity (Figs. $f, f^{2}$.). From fourth moult to pupation, sixteen days. (The whole body, in the last two larval stages, was covered with minute hairs, which camnot be represented on the Plate, and at the base of each hair was a white point, griving a mottled appearance under the glass.)

Cimis ALIs. - Length, .45 inch; greatest breadth across abdomen, .15, across mesonotum, .14 inch; cylindrical, the abdomen long, ovoid, pointed at the extremity, not turned under, next thorax compressed; head-case square at top, sloping flatly at the sides; the mesonotum rounded, very little elevated; whole surface, except the wing-cases, thickly and equally beset with short whitish hairs; color of anterior parts and wing-cases gray-brown; the general color of abdomen greenish, rather dark; a dorsal line and two sub-torsal bands gray-brown, and one line of same color on side; the erescent over eye orange. 'The chrysalis is held by a girdle about the middle. (Figs. $h, l^{2}{ }^{2}$.)

Nais is found in Arizona, New Mexico, and hits been taken at least as far to the north in Colorado as Denver and Boulder. Mr. B. Neumoegen observed it in South Colorado in 1SSO, especially at Oak Creek Canon, where it was common. He wrote that it first appeared there about the middle of July, but was most abundant toward the end of the month and beginning of August, but had entirely disappeared by the middle of August. It was always found on open clearings, flying from 10 A. M. to 2 P.M., and invariably settled near moist places. Its flight wis of a rapid, zigzag character, much resembling Melited.

Mr. II. K. Morrison found the species abundant in Graham Mountains, Arizona, in 1882, and says: "I found Nais at an elevation of from 8,000 to 10,000 feet, on the flowers of 'White Sagre, Eurotia lanata. It usually holds its wings flat while at rest, but moves them more than does L. Palmerii."

On July 20, 18\$1, I received from Mr. Doll, the acrent employed by Mr. Neumoegen in making collections of Lepidoptera in Arizona, several egrgs of Nais. One was still perfect; the rest had each a hole in the top, exactly at the micropyle, from which the larva liad escaped. In the cotton which accompanied the eggrs, were four young larva, less than one day old. The egress had been laid on twigs and leaves of. Mesquit, Prosopis juliflora, by females confined in big. I gathered various sorts of leaf to tempt the little creatures to eat, anong them 


\section{LEMONIAS I.}

peach and wild cherry. On 22d, it was evident that the cherry had been nibbled at, but only one caterpillar was living, and that died two days later.

On 26th July, came another lot of eggss and larve fiom Mr. Doll. They had been twelve days on the road, in the mail, in tin box, with Mesquit leaves. There were half a dozen eggs unlatched, several caterpillars but lately out, and some were in the act of emerging from round holes at the middle of the depressed tops. I put these caterpillars in a glass with wild cherry leaves only, as the former ones seemed to have eaten cherry a little, but in course of the next three or four days one after another died, not liking the food. When but two were left, I tried wild plum, giving the tenderest terminal leaves, and at last har hit upon the right plant. One leaf had been dropped upside down into the glass, and next day its edges were stitched to a leaf it had fallen upon, and they were somewhat chawn together. Twenty-four hours later the upper leaf was quite closed up, so that I had to slit one side of it to get a view of the tenant, which was resting on the midrib, and had made for itself a thick bed of silk. It had not eaten the leaf which concenled it, but another at a little distance, so that it must have come completely forth to feed. 'I'wo days later, on again slitting the leaf, I could see-that the neck of the caterpillar was swollen, - sure sign of an ap. proaching moult. 'I'he moult was discovered to have taken place after anothet interval of two days, and the caterpillar ws moving about. For the present it rested on the midrib of a fresh leaf in full view, but on the third day it stitched the edges together slightly, and retired. Just then I was compelled to leave home, returning on $23 \mathrm{~d}$, and left my subject in charge of a member of my family. It was reported healthy, and the day I returned closed up the hitherto open end of its leaf, and was seen no more, and evidently did not come out to feed till after the 27th, on which day it passed the second moult. On 5th September, it had covered itself within a leaf, both edges of which rested on the side of the glass, and had fastened them to the glass, so that from the outside I harl a good view. On 9th, I saw it at a distance from its nest, and same day caught it retreating into it. On 11th, it passed the third monlt. Soon after, I sent this caterpillar to Mrs. Peart, in Philadelphia, by express, in its glass jar, for a portrait. 'The distance is about six hundred miles, and the package was three days in reaching its destination. On 21st, I received the caterpillar again, quite uninjured by the jomrney, and by six days of close confinement. It was concealed when it reached me, and two days later it passed the fourth and last moult. Three days later, it again went to Philadelphia, for another portrait, and there remainer till pupation. This occurred 9th October, and the imago cane from chrysalis 11th November, a female, rather smaller than the average of the free females, but fully as large as any male. So that it had not been much aflected by change of climate and food, confinement and travel. 


\section{LEMONIAS I.}

This caterpillar was slow in all its movements, rested for hours in one spot, did not care for much concealment immediately after a moult and in the middle of the stage, but when another moult approached, shut itself up closely, and was only to be seen one or two days after the moult had passed. It did not eat of the leaf which enclosed it, as so many caterpillars which conceal themselves in leaves do, but went to an outside leaf to feed. And it eat very little as compared with species of Lycana or of Thecla, which I have had. As so little is known of the early stages of any of the Lemoniine, these particulars are somewhat important. The eggs of $N$ ais are in shape very like those of Lycma Pseudargiolus, and similarly, are covered with a reticulated coating. But the meshes of this are five-sided, whereas in the Lycrena they are four-sided, and rhomboidal. In Thecla Henrici the ineshes are three-sided. Each angle of the netting, in Nais, sends up a filamentous spine, but in L. Palmerii these are replaced by rounded knobs, and this is more in the style of both the Lycrena and Thecla mentioned. The caterpillars have heads partly covered by the second segment, but neither head nor feet are retractile, as in the Lycanida. The tubercles and their appendages in the several rows are alike in shape and number from 3 to 12 , and in this respect $N$ ais differs from all spined butterfly larva known to me. The fringes of long hairs around the entire base of the body, and falling over the head, are also peculiar. The chrysalis is girt with a belt, as in the Lycanidw, but it is more in the middle; and the abdomen is remarkably elongated, is not turned under at the extremity, and is thickly clothed with bristling hairs. 


\title{
LEMONLAS I.
}

\author{
LEMONIAS PALMERII. 5-8.
}

Lemonias Palmerii, Elwards, Trans. Aner. Eint. Soc., III., 189, 1870.

MALE. - Expands about one inch.

Upper side sepia-brown, with patches of fulvous near base of primaries, and along both hind margins; the basal half of costal margin and the whole of cell of secondaries also fulvous; spotted with black and white; a common sub-marginal row of minute white spots, each with a small rounded black spot in its posterion side; an extra-discal row on primaries, and a discal on secondaries, the former zigzag, the latter irregular, a black spot on the basal sicle of each; at the end of each cell a white bar between two black, a similar set of spots near base, and others below the cells; fringes white, cut with pale brown at the tips of the nervules except at the apices.

Under side ochraceous, deep colored on dikk of primaries; the white spots repeated, enlarged, and the discal row on secondaries confluent, forming a conspicuous band; the black sub-marginal points repeated, but mere dots; the other black marks represented by ferruginous.

Body above same color as wings, benenth white, the sides of abdomen yellowish ; legs and palpi white; antenna annulated white and black, club black tipped with orange.

Fesrale. - Expands 1.2 inch.

Upper side a shade paler, the fulvous marginal patches more conspicuous, the white spots larger. Under side of both wings whitish to the discal bands, beyond to base ochraceous.

EGG. - Button-shaped, higher than Nais, the top elevated to the edge of a pan-shaped depression which has sloping sides and flat bottom (Fig. $i^{22}$.); surface covered by a white vitreous net-work, the meshes larger in proportion than those of Nais, and with a rounded knob at each angle (Fig. $i^{3}$.); color whitish-green (Fig. i.). Duration of this stage about twelve days. 


\section{LEIIONIAS I.}

TOUNG LARTA. - Length, 04 inch; cylindrical, thickest at 3, tapering posteriorly, the dorsum a little arched, each segment rounded; color yellow-green; from 3 to 12, two dorsal rows of broad, oval, flattened brown processes, from each of which comes a pencil of five long, recurved, black hairs, one being shorter than the rest; along lower part of side, from 2 to 13, are three long and depressed white hairs to each segment, and under them some fine and shorter ones; on 2, is a dark brown, oval, tumid process, and on the anterior half are six long black hairs on either side the medio-dorsal line, all turned forward; in front of these is a fringe of long white hairs which fall over the head; 13 is brown at extremity, and the hairs extend back horizontally, or a little depressed; feet and pro-legs yellow-green; head a little broader than 2, obovoid, bilobed, slightly pubescent; color dark brown. (Fig. $k$.) The head is not retractile but is partly covered by 2.

The young larva is almost precisely like Nais at same stage, but is more green, and the red stripe on side is wanting.

Palmerii is common in New Mexico and Arizona, and probably in Southern Utal.. It was described in 1870 , from a single male brought from Utah by $\mathrm{Dr}$. Palmer, and for a long time this remained unique in collections. But Messrs. Neumoegen, Doll, and Morrison have brought in large numbers.

Mr. Morrison writes: "I found L. Palmerii at Fort Thomas, Arizona, in May; elevation 1,800 feet. It was flying only on Mesquit, both on the leaves and flowers, more often on the latter. It flies very quickly, and when at rest generally holds its wings perfectly flat, and sometimes will flutter them rapidly, but it never holls them back to back, like 'Thecla. I found Palmerii also at Grant, Ariza., in June, - elevation 1,500 feet, - always on Mesquit, and with the same habits."

I received from Mr. Doll, at Tucson, 26th May, 1881, a box containing about fifty egrs of Palmerii, with twigs and leaves of Mesquit, on which they had been laid. A few of the eggs had hatcher, but the larvæ had apparently escaped. On 27th, I saw one come from its egg, from the depressed top, a round hole being eaten out, just large enough to permit egress. None of the shell was consumed. I did not at the time know the plant, but supposed it to be a species of Cassia, and therefore provided leaves of Cassia marilandica. But the larva, some half dozen in number, all died, and I was able to learn nothing of the subsequent stages. After this the larva of $\mathrm{L}$. Nais were found to like leaves of wild plum, and probably Palmerii would have eaten the same.

Lemonias is one of the genera in the family Erycinida, of which Mr. H. IV. Bates says, in the Linnæan Society Journal, vol. ix., 1863: "The Erycinida are well distinguished from all other butterllies, with the exception of the genus 


\section{LEMIONIAS I.}

Libythea, forming a separate group allied to the Erycinida, ${ }^{1}$ by the anterior pair of legs in the males being aborted, without tarsal joints or trace of claws and spines, the same legrs in the females being of normal structure." Also: "The metamorphoses are variable, some genera resembling the Nymphalida, in the chrysalis being suspended by the tail, and others the Lycanida, in being recumbent and girt with silken threads. 'Too little is known of the caterpillars to enable us to say whether they offer any peculiarity." Nearly all the species are found in America. Again quoting $\mathrm{Mr}$. Bates: "The family appears to be most numerous and flourishing in the equatorial zone, diminishing in the number of its representatives as one approaches either tropic, and with very few exceptions the species are confined to the shates of the great forest which covers the lower levels of nearly the whole of this vast region. I collected myself 370 species on the banks of the Amazon." "A large number of genera have the habit of settling on the under side of leares near the ground, extending their wings flat on the leaf. In many genera, on the contrary, the position of the wings in repose is vertical, and a few species settle on the upper surface of leaves with the wings half elevated." "Very few species frequent Howers."

In my Catalogue, $187 \overline{7}$, nre enumerated eight species of Erycinidæ, to which Nuis should have been added. And recently two other species, Ares Edw. and Cleis Edw. have been described as of our fauna from the Morrison collections of 1852 .

${ }^{1}$ By some authors, Libythea is regarded as an aberrant group of the Nymphalida. 

. 

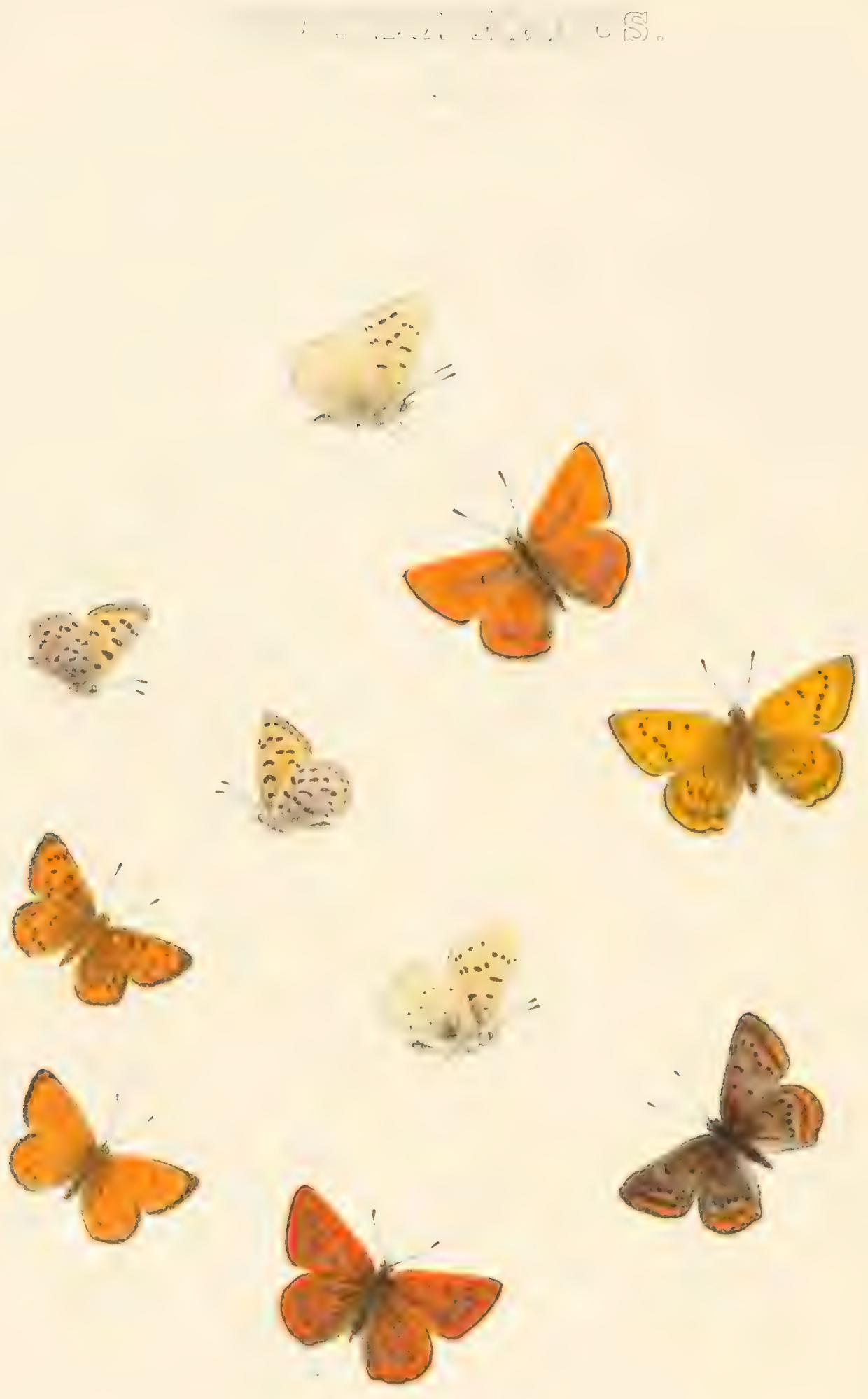


\section{CHRYSOPHA N US I.}

\section{CHRYSOLHANUS RUBIDUS, 1-3.}

Chrysophanus rubidus, liche, l'mec. Ent. Soe. I'hil. 1866, p. 208.

Mate. - Expands 1.35 inch.

Upper side bright copper-led, secondaries only having a narrow marginal borter of paler color; on are of primaries a fuscous bar and in cell a spot; on are of secondaries a streak; otherwine immaculate except as the spots of under side are faintly seen through the delicate wings; hind margins edged by a black line ; fringes gray-white.

Under sile buff; primaries have a sub-marginal row of brown spots, wanting apically; a simuous row of six rounded black spots across disk, the sixth duplex; a bax on are, two spots in cell and one below cell; secondaries immaculate.

Body fuscous, bencath buff; legs and palpi buff; antenna amulated with black and white; club fuscous, tip fulvous.

Female. - Same size.

Upper side yellow-fulrous; secondaries much obscured by fuscous, especially next base and just anterior to the red marginal border; primaries have a sunilar border preceded by a fuscous band; the extra-discal row of spots distinct; a large spot on are and one in cell ; secondaries have a discal streak and four spots beyond, part of an incomplete transverse row; under side as in the male.

This species was originally taken in Oregon by Professor Gabb, while engaged in a geological survey, but from. what locality is not known. It is also among the buttertlies collected in Montana, by Dr. Hayden's expedition of 1870 . 


\section{CHRYSOPHA NUS 1 .}

\section{CHRTSOPHANUS CUPREUS, 4-7.}

Chrysophanus cupreus, Edwards, Trans. Am. Ent. Soc. 1870, p. 20.

Male. - Expands 1.1 inch.

Upper side bright copper-red, color of Rubidus; hind margins narrowly bordered by fuscous; both wings crossed by a tortuous, extra-discal row of fuscous spots and points; a large fuscous spot on are of primaries and a point on that of secondaries.

Under side of primaries red-ochraceous; spots as above, but enlarged, and in addition, two in cell, all edged with buff; the marginal border as above, grayish, having on its imner edge a row of small brown spots; secondaries paler, much irrorated with black at base; upon hind margin a royv of separated orange lumules, against which, next marginal edge, are traces of brown spots; the extradiscal spots as on upper side, but in addition, there are eight others, three on costal margin, two in cell, two ou arc, and one on abdominal margin.

Body fuscous, below pale buff; legs and palpi buff; antennæ annulated black and white; club fuscous, tip fulvous.

Female. - Expands 1.2 inch.

Color pale red, marked on both sides as in the male; the spots much enlarged and conspicuous.

This species is also found in Oregon, but I am unable to give its exact locality. It is as yet exceedingly rare in collections. 


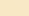




\title{
('IIRISA PII I N US I.
}

\author{
CHIYSOPHANUS SIRIUS, S-10.
}

Clurvophanus Siritu, Edwards, Trans. Am. Ent. Soc. 1871, p. 2\%0.

MALE. - Expands 1.:3 inch.

Upper side brilliant copper-red, deepest on costal margin of primaries and on both hind margins and all the nervures, the interpaces having a brown shade when viewed directly, but fiery-red otherwise; on the hind margin of recondaries the deep red border is broken into spots towards anal angle, these spots inclowing black lumules that are produced by the expansion of the black line that edges both margins; discal spot of primaries a straight fuscous bar; a fuscous point in cell; discal mark of secondiries a streak, and three or four points beyond cell; fringes gray-white.

Under side of primaries buff with a red tint, of secondaries buff; primaries have a sub-marginal row of romolerl fuscous spots, obsolete apically; a bent row across the disk, rounded, nearly equal; a bar on are, a spot and point in cell and a spot below cell on sulp-mediam intersace; secondaries hate a tortuous row of points or minute spots, and three points nearer base forming a line across the wing.

Body alove fuscous, beneath pale huff; legs buff; palpi same; antemne annulated black and white; club fuscous, tip ferruginous.

Fenclie. - Same size.

Upper side fuscous, the disk of primaries pale fulvous, more or less obscured hy fuscous, of secondaries still darker; all the spots of under sinte are discovered through the wing, those of secondaries much enlarged; within the fuscous marginal borter of primaries a deep fulvous stripe which curves around inner angle; secondaries have a marginal band of fulvous serrations, within each of which is a fuscous spot.

The female of this species bears a striking resemblance to the female of Lycrum Heteronea, as may be seen by referring to our Plate of the latter.

The genus Chrysophanus (Polyommatus of Boisduval) embraces many beautiful 
I.

species, and is well represented in North America, especially in the Rocky Mountains and on the Pacific slope. These little butterflies frequent the open country rather than woods and forests, and such as are found in the Eastern and Middle States are very common in old fields and pastures. The eggs of most butterflies are beautiful objects when seen under the microscope, differing infinitely in form and ormamentation, and I know of none that surpass in beauty those of our two Atlantic species of Chrysophanus, Hyllus and Phleas, var. Americana. These eggs are round and flattened, and in case of Hyllus covered with a delicate frosting; in Phleas the whole surface is occupied by hexagonal depressions, that give the appearance of a bit of honeycomb. The caterpillars of this genus are oval, onisciform, with small retractile heads and retractile feet. So far as is known, the American species feed on the leaves and flowers of Dock (Rumex), Sorrel (R. acetosella), and Golden-Rod (Solidago). The European species feed also on Polygonum. The chrysalis is supported by a girdle, after the manner of the Papilionidie. 


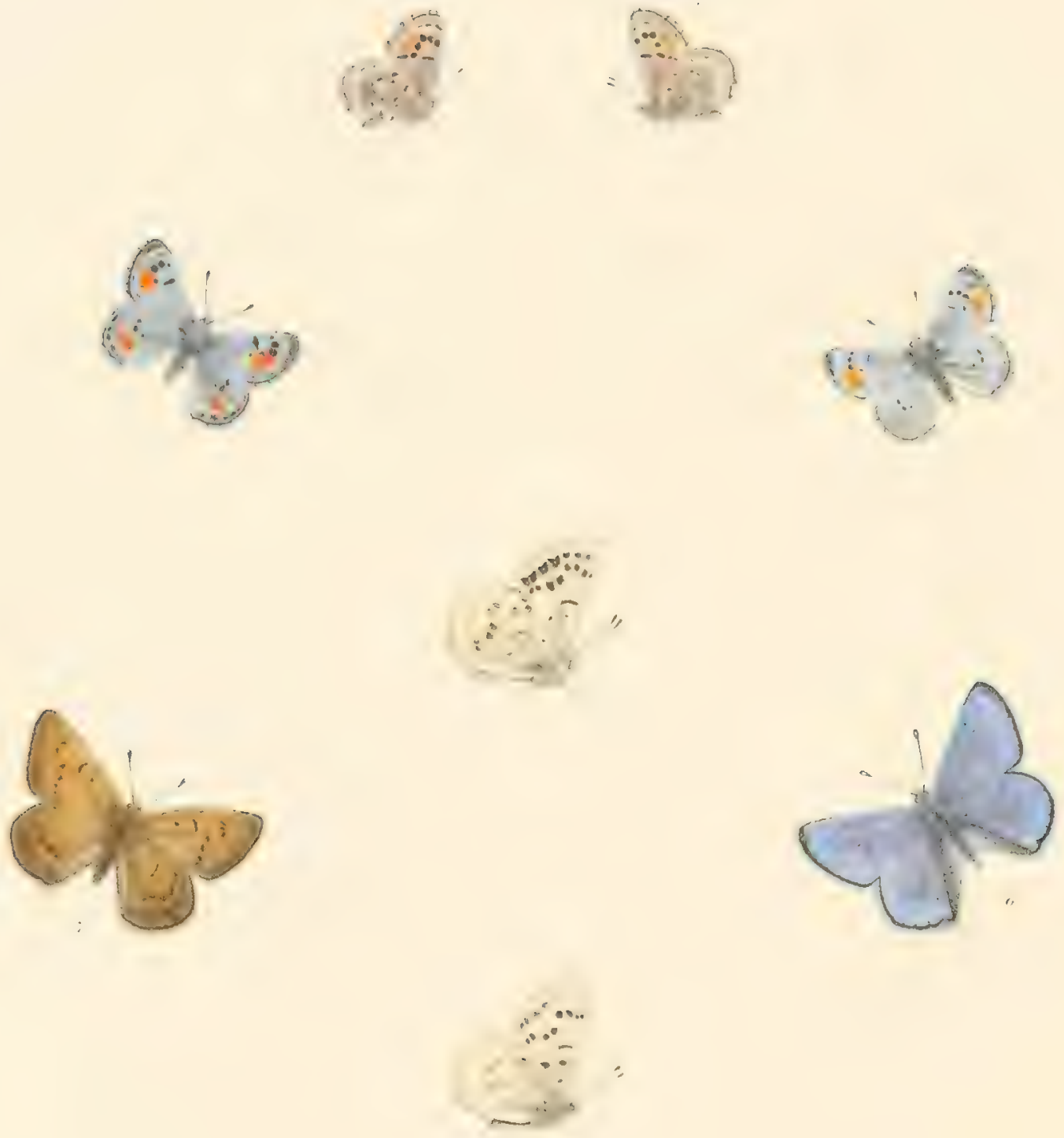


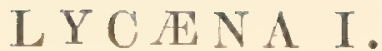

\section{LYCENA REGIA, $1-1$.}

\author{
Lyecena Regia, Boisduval, Ann. Soc. Ent. de Belg. XII., p. $46,1868$. \\ Ibid. Lep. de la Car. p. 46, 1869.
}

MATE. - Expands 1.1 inch.

Upper side brilliant silvery blue; the hind margins edged by a black line; primaries have a narrow black marginal border, rather broad at apex, macular in the discoidal and two upper median interspaces; an extra discal row of either four or five rounded black spots, three being in a bent transverse line half-way between the end of the cell and the hind margin, the others forming an oblique line with the lowest of the three, and placed upon the median interspaces; at the end of the cell a thansverse black streak; near the margin, a little above imner angle, two small patches of orange, varying in size and distinctness in individuals. Secondaries have two small black spots at the end of the cell, and sometimes there are faint traces of a macular mitrinal band; fringes long, alternately and equally white and fuscous on primaries, and on secondaries white, with a few fuscous hairs at the tip of each nervule.

Under side of primaries brownish-gray, towards apex gray-white; of secondaries gray, either brown or white over the basal area, brown on the disk and gray nest hind margin; the spots of upper side of primaries repeated, and, with the addition of a sixth spot on the sub-merlian interspices, they form a row quite across the wing; a black streak at the end and a small spot in the middle of the cell; near the hind margin a transverse black line interrupted by the two orange spots, which re-appear and are somewhat enlarged and are confluent. Secondaries have an irregular series of eight black spots across the disk, the two on the discoidal interspaces being at some distance back of the line; at the end of the cell a streak and three spots near base.

Body above blue, beneath brownish-gray; legs whitish; palpi white with black hairs at tip; antenne amnulated with white and fuscous; club black, tipped with white.

Feylle. - Same size.

Upper side rather less silvery than in the male; primaries have a broad and 


\section{LYCENA, I.}

continuous black border, preceding which is an indistinct black line, interrupted by the orange spots; these are much larger than in the male and are confluent; the extra-discal spots enlarged and the three upper ones confluent. Secondaries have a large orange spot near anal angle (which does not re-appear on the under side), a marginal row of rounded black spots and an indistinct sub-marginal line; also two spots on the discoidal interspaces, and in some examples, two or three black points on the disk. Under side much darker than in the male, especially over the basal area of each wing, and the spots less conspicuous, often partly obsolete.

This lovely species inhabits the coast region of Southern California, and is not uncommon at San Diego, according to Mr. Henry Edwards, flying over the swampy land elose to the shores of the harbor. Mr. Behrens found it at Gilroy, Santa Clara County, which is its most northern limit, as known at present. 


\section{Y C ENA I.}

LTCENA HETERONEA, 5-8.

Lycana Heteronca, Boisduval, Ann. Soc. Ent. de France, 18.52, p. 298.

MALE. - Expands 1.4 inch.

Upper side violet blue, with a strong pink reflection, silvery blue at the extreme edge of each wing; immaculate; the hind margins narrowly bordered with black; fringes white.

Under side grayish-white; primaries have a sub-marginal row of brown spots, those next apex often obsolete, and a tortuous row across the disk; a bar at the extremity of the cell, two spots within the cell and one below, on sub-median interspace. Secondaries sometimes immaculate, but most often with an obsolescent sub-marginal row of spots, and another row across the disk; a streak at the end of the cell and three points near base.

Body above blue, beneath gray-white; legs white; palpi white with fuscous hairs at tip ; antenna fuscous ammulated with white above, whitish beneath; club fuscous.

Fenita. - Same size.

Upper side yellow-brown, with pale lumules along the hind margin of secondaries, which are however sometimes obsolete; the spots of the discal row on under side of each wing, and also the basal spots, re-appear on the upper side, and are distinct even when faint or obsolescent beneath.

This insect marks the passage of Lycana into Chrysophanus (Polyommatus) as stated by Dr. Boisduval, the female bearing a close resemblance to the female of C. Sirins.

Iteteronea is found in Colorado and California, and probably in the intervening States.

Mr. II. Edwards says: "It is certainly not exclusively a mountain species, and its range extends from close to the sea-shore near San Francisco to the high peaks of the Sierra Nevada. I have found it most commonly in open places or meadows in the midlle of the pine forests of the mountains, and particularly about Lake Tahoe. I also met with it in the Yosemite Valley. It is never, however, found in large numbers, and may be called one of our rare species." 


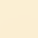




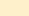




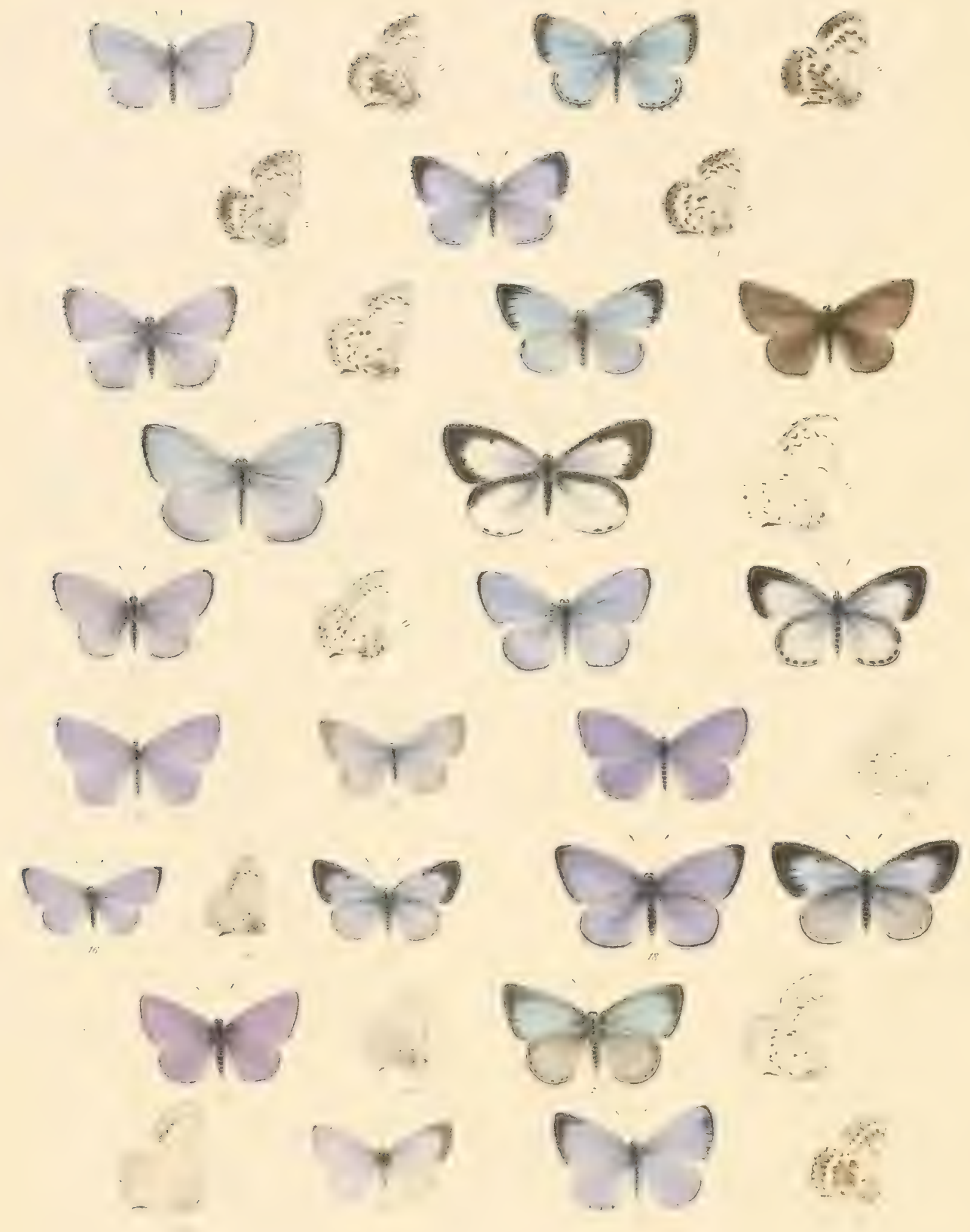




\title{
LYC ENA II., III.
}

\author{
LYCANA PSEUDARGIOLUS, 1-27.
}

Lyccena Pseutargivius, Boisduval and Leconte.

Winter form, 1. Lucr, Kirby, Finn. Bor.-Amer., IV., p. 299, pl. 3, 1837.

" "2. Margivata, Elw., Papilio, III., p. \$6, 1883.

"6 3. Vlolacea, Edw., Proc. Ent. Soc. I'liil., YI., p. 201, 1S66; id., But. N. A., I., p. 149, pl. 19.

Nigra, dimorphic of (not o), l. c., plo 49.

Var. Ciskned, Edw., l’apilio, III., I. $8,1883$.

Spring form. Pstudargiolus, Bois, and Lec, Lep. des Amer. (text, not plate), p. 11s, 1S33; Edr., But. N. A., I., p. 153, 11.50.

Argrolus, Abbot and suith, Ins. Ga., pl. 15, 1797.

Summer form. NrefectA, Edw., I'roc. Acad. Nat. Sci., Phil., p. 56, 1862; il., But. N. A., I., p. 155, pl. 50; Bois. and Lec., 1. c., plate, figs. 1, 3.

Pacific form, winter and spring :-

Prasus, Bois., Ann. Soc. Ent. de Fr. $2^{\text {mo }}$ ser., X., p. 299, 1852.

Var. Ecur, Edw., Proc. Ent. Soc. P'hil., II., p. 506, $186 t$.

EGG. - Diameter, 02 inch; round, flat at base, the top flattened and depressed; the surface covered with a white lace-work, the meshes of which are mostly lozenge-shaped, with a short rounded process at each angle; color of the shell under this covering delicate green. (Figs. a $a^{1}$.) Duration of this stage, in A pril, 6 to 8 days; in May, June, and September, 4 to 5 days.

Youvg Larva. - Length .04 inch; the under side flat, legs retractile, upper side round, the dorsum highest at 4 , and both dorsum and sides slope gratdually to 13; surface pubescent; on either side of the medio-dorsal line a row of white clubbed hairs, one at the posterior end of each segment; similar hairs about the base, and in front of 2 , making a complete fringe around the body; color either greenish-white or brownish-yellow; hend minute, obovoid, black, retractile. (Fig. b.) Duration of this stage 4 to 5 days in spring, 3 in summer.

After first moult: length .07 and .0S inch; nearly same shape as before, with pubescent surface and dorsal and basal hairs; color in spring and fall brownish-yellow; in summer the same, as well as greenish-white, and occasionally reddish. (Fig. e.) Duration of this stage from 3 to 5 days. 
After second moult: length .12 to .16 inch; general shape as before, but the dorsum is now covered from 3 to 10 by a low, broad, continuous, tubereulous ridge, cleft to the borly at the junctions of the segments, the anterior edge on cach segment depressed, the sides incurved; 2 is more flattened than before, and the outer border is thickened into a rounded rim, leaving within the curve a flat, depressed space; surface pubescent; about the base a fringe, as before, and a few short hairs on summit of dorsum; color in spring, pale green, the dorsum tvhitish, usually with a median reddish line or stripe from 3 to 10, often macular; in summer, variable, buff or pale green, without spots, the second segment brown; in some examples the dorsum and sides are mottled with dark green and brown; occnsionally one is wine-red throughout, or rerl with a white basal stripe, and white along the edges of the dorsal tuberculations; in fall, dull green, more or less marked brown. (Fig. (l) Duration of this stage 3 to 4 days.

After third moult: length .18 to .2 inch; in slape nearly as before, the dorsum higher, segment 2 more produced and flattened; the long hairs on dorsum lost, but the basal fringe as before; color variable, as in previous stage. (Figs.e to $e^{4}$.) Duration of this stage 3 to 4 days.

After fourth moult: length .25 to .3 inch; maturity is renched in 3 to 4 days.

Mature Larta. - Length in spring and fall, .4 inch, in summer, .5 to .55 inch; shape long oval, the base flat, dorsum high and sloping both ways from about the middle, the last segments flattened; the second segment is bent forward to the plane of base, produced, flittened, and wholly conceals the head when the larva is at rest; viewed from above the sides are nearly parallel, the two ends (scgments 2 and 13) are about equally romder ; from 3 to 10 inclusive is a dorsal ridge made of tuberculous processes closely joined at the junctions of the segments, the front edge of each depressed, the posterior edge raised and rounded, so that ench process seems to fit into the next preceding; 2) is depressed in middle, and the whole outer edge is thickened and rounder; color variable, in spring, usually as follows: the ridge whitish, often stained red, or it is brown, light or dark; the upper part of side olive-green, with a darker green, or sometimes a dull red, patch along the posterior erlge of each segment; below this area pale green, and along base more or less brown; 11 to 13 are mottled in slades of green, often with brown, and 2 is either sreen or brown; if the latter, then with a brown patch in the depression; under side pale blue-green; color in summer, sometimes yellow-white or all delicate green, 2 being brown; or the ridge is light green and the sides dark, often with brown patches over all; or light green, with a inediororsal macular deep green band, and a similar one along base; or the whole surface may be wine-red, or even chocolate-brown; color in fall, green, with more or 
less brown in irregular patches (Figs. $f$ to $f^{6}$ ); hearl small, obovoid, dark brown, glossy, placed on the end of a long, conical neck, which can be thrust out to al length equal at least to the brearth of two of the borly segments (Figs. $i^{1}-i^{3}$ ), and when withdrawn is, together with the head, completely within segment 2 ; color of neck blue-green. (Figs. $i, i^{\sharp}$.) 'The surface of the body is velvety, and this appearance is owing to minute stellate glassy processes, scarcely raised above the surface, and only visible under a powerful magnifier, mostly six-rayerl, and each sending up from the centre a filament which is a little longer than one of the rays; these stars are arranged in pretty reegular rows, and are light except when on brown ground, in that case brown; but in the fall lanve the stars on brown gromel are observed to be sometimes pink. (Fig.n.) On 11 near the posterior edge, on middle of dorsum, is a transverse wary slit, in an ovil rased rim, out of which, at the will of the larva, is protpuded slightly an ovoid green membrame (Fig. h); and on 12, back of and ontside the stigmata, is a mark like a stigma on either side, but a little larger; from this, also at will, may proceed a membranous cylinder, the top rounded, truncated, and turnet in, but which, when fully expanted, displays a crown of tentacles. (Figs. $m-m^{2}$.)

Before pupation, the larva sometimes changes color to pink, and from pink to brown, or becomes brown without the pink stage; others retain their natural hues, but these fade. From fourth moult to pupation, 5 or 6 diys.

Cinirsulis. - 5 from egges of Violaceu: average leneth, .263 inch; breadth acloss mesonotum, .0916 inch; acrosis ablomen, .123 inch.

27 from ergss of Psencturyiolus: average length, 318 inch; breadth across mesonotum, .119 inch; across ablomen, .159 inch.

25 from egres of Neglecte of July: averige length, .29S inch ; breadth across mesonotum, .1 inch; across aljolomen, .14 inch.

3 from eggs of Neglecta of September: average length, .293 inch; brealth across mesonotum, .I inch; across abdomen, .136 inch.

The ventral side straight, the dorsal rounded, and evenly, except for a slight depression below mesonotum, the abdomen broad and high; head case narrow, rouncled at top; mesonotum somewhat prominent, romded; color dirk brown or yellow-brown, varying; the wing cases dark, and sometimes green-tinted; on abdomen two sub-clorsal rows of blackish dots, and sometimes a medio-dorsal dark line from end to end (Figs. g, Pseudargiolus, h, Fiolacea, nat. size); surface covered with short fine hairs. (Fig. $g^{1}$.) Duration of this stage, in the brood from Violnced, in the only instance in which a butterfly lins emerged, 21 clays, most of the chrysalids hibermating; in the brood from Neglecta of July, 10 and 11 days, with irregular disclosure for some weeks after, most chrysalids hibernating. 
Since the publication of Tol. I., in which Psendargiolus, Neglecta, and Violacen were griven as three distinct species, their history has come to be thoroughly known, and it is found that they, together with Lucia and other forms, constitute one polymorphic species, which has possession of the broad continent, from the borenl regions to Mexico. The history is so peculiar that I have concluded to devote two Plates to the phases of the butterfly and its biology. It was not possible, while Vol. I. was in hand, and before the preparatory stagres of any of these forms had been discovered, to know that they comprised but a single species, and till such time they were rightly regarded as distinct. On the first Plate are represented typical examples of each of the principal forms of the butterfly, with such striking varieties as I have been able to obtain; and these figures, in connection with the two Plates in Volume I., illustrate the species fully.

The general history is as follows:-

1. In the high boreal regions, the species is one-brooded, and at the same time dimorphic, the two forms under which it manifests itself being Lucia and Violacea. Lucic (Figs. 1, 2) has been received from Yoncon River, from Lake Winnipeg, and Anticosti. Kirby's type specimen was taken in lat. 54, though the exact locality is not given. Violccea (Figs. 5, 6) flies at St. Michael's, Alaska, and on Anticosti.

2. At about lat. $45^{\circ}$, the more moderate climate allows a second generation to mature during the same season, and this is made up of the form Neglecta. (Figs. 10 to 12.) The first, or winter, generation now becomes tri-morphic, by the development of a form intermediate between Lucia and Fiolacea, viz., Marginate (Figs. 3, 4), and these three, together with Neglecta, inhabit the country at least as far south as Long Island.

3. At about lat. $39^{\circ}$, on the Atlantic, two of the forms of the first generation are found to have been suppressed, viz., Lucia and MLarginata, and the third alone, Violacea, remains to represent that generation. But it is somewhat altered, the blue color having become darker, and the under surface purer white; and it has developed an entirely new form of its own, restricted to one sex, viz., the black male. (Fig. 7.) This was figured in Vol. I. as female. On its discovery, in 1867, I took it to be female without question, as melanism in butterflies, when confined to one sex, is almost invariably found in the female. Especially is this the case in Lycrena, and I am informed by Mr. A. G. Butler that there is no other species of Lycana known in which the melanic dimorphic form is male. In 1878, I was led to make an examination of the genital organs of one of these black examples, and found it to be male. Since then I have made very many examinations, in successive years, and have not seen a melanic female.

4. But in lat. $40^{\circ}$, at the west, in Colorado, the original forms Lucia and 
Violuced are found, and notwithstanding the ligh elevation the latter discover's the melanic male; and the second generation is Veglecta. (Figs. 13, 14.)

j. In Arizona, at or about lat. $33^{\circ}$, Tioluece alone appears, but in a modified form, Cincrea (Firs. 16, 17), no black male and no Lucia so far having been taken; and the second generation apparently is Pseudergiolus. (Figs. 18, 19.)

6. In the Atlantic district, from lat. $40^{3}$ or $39^{2}$ southwart, the summer generation is Neglecta, but there is an intermediate or interpolated generation, flying in May, viz., Pseudaryiolus. (Figs. 8,9.)

7. In Cilifornia and Arizona, the species is represented in part by what is very near to Neglectu, or else a small Pseudargiolus, viz., Echo (Fig. 21\&), but maimly by a morlified form, Piasus, which has two generations not differing from each other. (Figs. 20\%, 26\%, 27\%.)

'The three forms of the winter generation are found in Ontario, Quebec, New England, and New York; to the west, at least as far south as Racine, Wis. In their teruitory, they appen at the same time, neither preceding another, as is shown by observations of Rev. Geo. D. Inlst, at Brooklyn, N. Y.; Dr. E. C. Howe, at Yonkers, N. Y.; and Rev. Thos. W. Fyles, at Cowansville, P. Q. (In Papilio, Vol. III., 1SS3, is a full statement by myself of the facts on this point, as also on others concerning the present species, which I can but briefly allude to in this paper.) Violaced, Harginata, and Neglectu have been taken on Pike's Peak, Colorato. Fiolaced-nigma is not known to have been taken to the north of Conlburgh, W. Ta., nor in Ohio or Inlinois, so far as I can learn; but it flies in Tennessee, N. Carolinal, and Georeria, and, as before said, in southern Colorado. Occasional examples of Pseudurgiolus have been taken near Pittsburgh, Pa., and at Racine, Wis, but to the north of middle West Virginia the form seems to be exceptional.

I shall grive the history of the species as it has been worked ont at Coalburgh. The first butterlies of early spring are Tiolaced, and they are generally abundint when the peach and wild plum trees are in blossom, or from about 10 th of March to the middle or end of April, according as the season is early or late. 'This form is vastly more mumerous in imfividuals than any of the later ones, and sometimes they may be seen by thousands in a molning's walk. A few warm days in February bring out many examples, but these are sure to be cut off by frosts and snow a little later. The earliest appearance recorded in twenty years is 17 th February, and the latest date of first appearance is Tth April. The Dogwood, Cormus (Figr. 1, Lyc. III.), on the flowers of which the female deposits her egg's, does not usually mature its flower buds till about the middle of April, sometimes late in the month, and the earliest egrgs have been found on 13 th April. This food plant of the caterpillar of the winter form was unknown 
till $18 \%$, when many eggs were obtained by confining a female butterfly over a branch in flower. After that, there was no difficulty in finding both eggs and caterpillars. The former are laid singly, low down on the side of a floweret, and usually well within the flower head. As soon as hatched, the young larva cuts a minute hole, the diameter of its head, into the lower part of the unopened bud, just above the calyx, and feeds upon the filaments of the stamens. After its first moult, it bores into the side of the calyx to get at the ovules; but as the flowers mature and the ovary hardens, the boring is from the top, inside the tube of the calyx, and follows the stalk of the pistil to the ovule. Finally, belated larve are compelled to gnaw the seed vessel after it has become woody, and in several instances have been found eating the stem below the flower. It is not unusual for the larva in confinement to eat of the white involucre of the flower, but I hitve never observed them to eat of the leaves, even when no other food has been given them. As the egrgs laid when the flowers of Cornus are in bud procluce larve which mature at about the time the flowers fall, it follows that many belated lauvie must starve.

I do not know of any other food plant for the winter brood than Comus, though in confinement the larve have eaten the flowers of Begonia, Nasturtium, and Asclepias; also Clover blossoms, but not readily, and females confined over Clover have refused to lay eggs on it. The larve on Cornus, in their later stages, viry greatly in color and markings, having more or less green, either light or dull, with white, brown, and crimson. But in the younger stages they are much the color of the flowers they feed on, and are thus in some degree protected from their numerons enemies, spiders, hemiptern, etc. In confinement, when food is scanty, they will prey on each other, burrowing into the body in the same way they do into a flower.

Following Violacea, and flying at the same time with the latter half of that generation, comes Pseudurgiolus, the lirgest form of the series, and differing considerably from Yiolacea in general appearance.

In 1877, I observed a female of this form lovering about a staik of Rattleweed, Cimicifuga racemosa, which was in bud, and this suggested the confining one of them in a bag over the plant. The immediate result was that many eggs were laid, and thenceforth, in successive years, ecgrs and larve have been found in abundance. The Rattle-weed (Fig. 2, Lyc. III.) sends up a stalk to the height of five or six feet, branching more or less, and each branch terminates in a spike from eight to twelve inches long, bearing round, greenish-white buds, arranged in rows. The lower buds mature first, and the flowering proceeds slowly from base to top, the whole period lasting at least six weeks. 'The eggs are usually laid on the buds, and the young larva bores into the side, and gradually eats the contents, till a mere shell is left; then moves to a fresh bud, and so on. 
If there happen to be three or four larre on one stalk, by the time they are mature the buds are nearly all drillert. 'The small larval head is set on the end of a long, extensile neck. (Fig. $i^{3}$.) The hole eaten is just linge enough to admit the head, and as the larva feeds the second segment is pressed hard agrainst the bud, so as to permit the ntmost elongattion of the neck. By this means the interior of the bud is wholly excavated. The second larval segment has its top elevated, compressed, and bent forward, and at all stages, when the larva is at rest, the head is withdram into this segment and quite concealed. (Figs. $i, i^{ \pm}$.)

Immediately following Pseudargiolus comes Nerfecta, flying in June, from about the first of the month, and is on the wing four or five weeks. 'This form is smaller than Pseudargiolus, but in general appearance is not escentially different from it, and is therefore unlike riolacea. But though so similar, these two forms are distinct in origin, Neglecta certainly in some degree, and probably altogether, being in direct descent from Violacea of $\Lambda$ pril. Both these forms are represented by a comparatively small number of individuals.

After these June Negleck have passed away, at intervals through the summer and fall to October, a few individuals which might be either Pseudargiolus or Neglectu, for nught that appears, differing in size, though none are so large as the average Pseudargiolus of May, here and there are seen. But there is no general brood. These late butterflies lay erg's on Actinomeris squarosa (Fig. 3, Lyc. III.), and probably somewhat on $\mathbf{A}$. helianthoides, one or the other of which is in flower for many weeks. I lave also found a mature caterpillar on the imported shrub Dimorphantus Mantchuricus, eating the flower buds.

'The first clew to the history of any of these forms was through the fall butterflies, Mr. T. L. Mead, here at Coalburgh, in 1873, having noticed a female Neglecta ovipositing on $\Lambda$. scquarrosa. On being shut in a bagg over the plant it laid many eggs. But the chrysalids proceeding from these eggs died during the winter. From others, obtained from larve from same plant the next year, there emerged three Violacea in February, 1875. Again, in March, 18S2, two Tiolacea came from similar chrysalids.

On all the plants, when the larve are rearly to pupnte, they fall to the ground, and doubtless conceal thenselves under sticks and stones. The mature larva will drop at the slightest jur, though when younger they cling firmly.

Such, then, are the generations of this species at Coalburgh. In other localities not much has been observed, or at lenst made known. In June, 1S78, Prof. J. H. Comstock, at Ithaca, N. Y., sent me several larvo on flowers of Viburnum acerifolium, which probably came from eggs of Neglecte. At London, Ontario, Mr. Wm. Saunders found larve on Dogwood, 12th July, and five of them gave Neglecla butterflies. Mr. Saunders relates that, on food failing, he gave the 
larve willow leaves, which they ate. At Yonkers, N. Y., Dr. Howe saw females of Lucia ovipositing on Dogrrood in April and May, 1878. So far as I am aware, this comprises all that has been published respecting the preparatory stages of any of these forms outside of my own observations.

The inter-relationship of the forms is complicated, but will be found nearly as follows:-

1. The chrysalids from the late larva, which feed on Actinomeris, hiberuate and produce Violacea in spring.

2. The chrysalids from Violacea, in spring, in part disclose Neglecta, in June following, and are the parents of that brood, but most of them hibernate, and produce Violacea the next year. So fir, I have not succeeded in carrying Violacea chrysalids through the winter. They have died late in the fall or early in the winter, either from being kept too dry in the house, or from mould when I have endeavored to keep them damp. But two which were found dead 27 th November, on having the wing cases removed, showed the full colors of Neglecta, 18 19. I have at the date of this writing, 14th January, 1884, one chrysalis of last spring which is alive. These facts show sufficiently the tendency of part of the chrysalids to hibernate. In no other way than by hibermation can the multitudes of the butterflies of this form in spring be accounted for, as the fer larva and fewer chrysalids of the fall can produce but the merest fraction of that flight.

3. The chrysalids from the May greneration, or Pseudargiolus, probably produce butterflies in small numbers in July and later, after the June Neglecta have passed away, but most of them hibernate, and give Pseudargiolus the following May, or earlier. I do not know that I have had a butterfly emerge the same season from a chrysalis of this form, as I found in 1883 that previous observations were imperfect, because till this year I had confounded the larva of Neglecta feeding on Cimicifuga with those of Pserdargiolus on same plant; that is, the late larra with the carly ones. But on 27th November, 1883, out of twenty-seven chrysalids of Pseudargiolus, which formed between 20 th Jume and Sth July, six were dead, and the wings of 182 ? showed full color of Neglectu; two were partially colored, one not at all. Five then died when about to issue from chrysalis, and this is proof that part of the chrysalids of this form give butterflies the same season. The remaining twenty are alive on 14 th January, $18 S 4$.

Out of twenty-five chrysalids from Neglecta, formed between 1st and 22d July, 1833, five gave buttertlies (Neglecta) on 14th, 15th, 16th July, at ten and eleven days' pupation. On 27 th November, four were dead, but showed full color, 18 39. The remaining sixteen are alive 14 th January, 1SS4. In former years, chrysalids from Cimicifuga have given butterflies on 13th, 15th, 17th July; the 

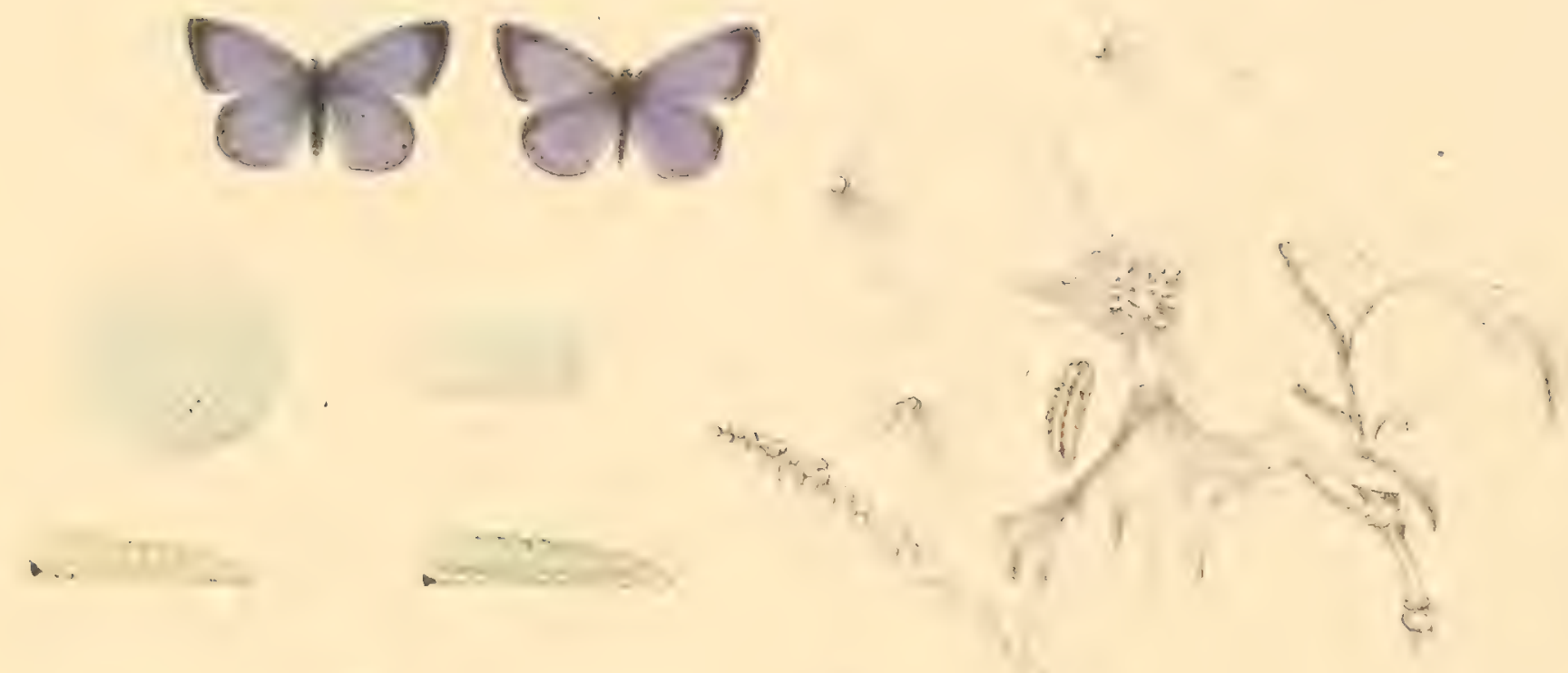

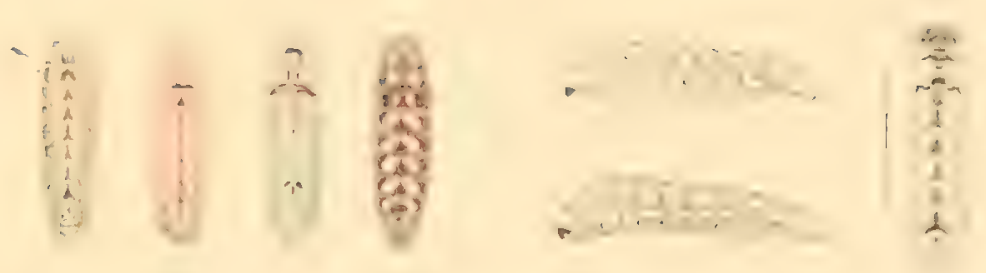
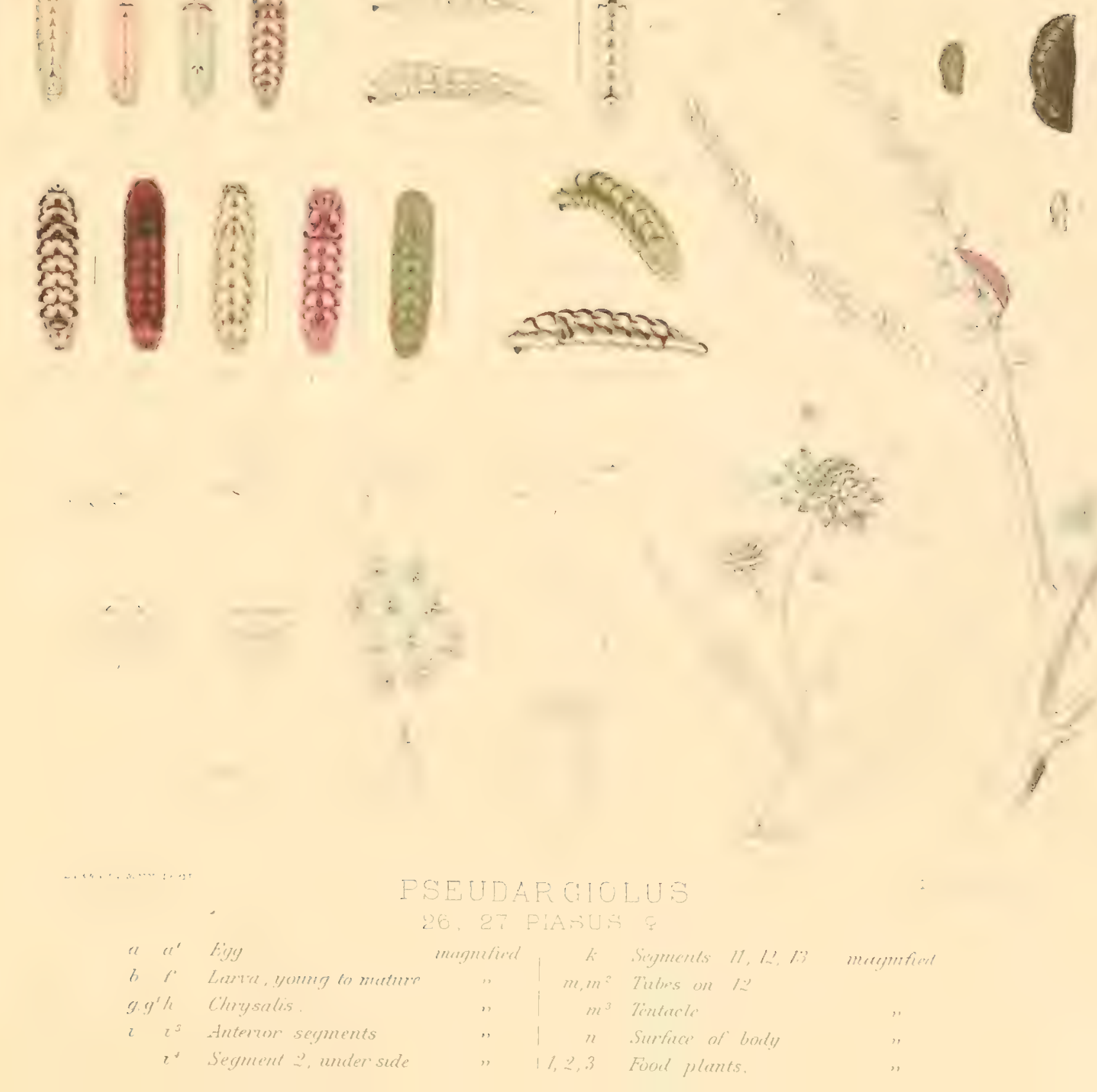

4th, 10th, 10th August; 1st and 14th September. These mily have been all from Neglecta, but there is nothing to show that some might not have been from Psendargiolus.

In the spring, there certainly is no comection between Violucen and Psendargiolus. Every year, when the first egriss of Fioluced are being lairl, some butterflies of the other form are on the wing, and before the larve of Fiolucea are mature the bulk of the I'seudurgiolus greneration has appeared. About 1st June, this form is pasuing nway, and is often entirely gone; and just then come the fresh examples of Negleck, which are in direct deseent from Violueen. The period from laying of the erger to divelosure of butterfly from Fiolacen, in the only instance in which a butterfly has come from egre of that form the same yenr, was fifty-three days, on Gth June. And many years' observations show that Neglecta begins to appear in the early days of Jume, becoming abundant about the midrlle of that month. It is only by a connection between Psendargiolus and the other forms in the fall that any inter-relationship can be found ; that is, some chrysalits of Pseudurgiolus give butterlies which mite with butterflies from chrysalids of the June Neglecta to produce the fall larve, from which come Vinlueer in Ajril. Otherwise Pseutargiolus would be set in the middle of the series, with no link in either direction. The true second generation of the year, in Virminis, is $\Lambda_{\text {Tey- }}$ lecta, appearing in June. Pseulargiolus is an interpolated spring generation, the first in the year of its series. Its second comprises a part of the fer butterflies which fly between July and Octoher. If these late butterlies were suppressed, Psendurgioles would stand ats a distinct species, with no trace of its relation to the other forms. So if anywhere to the northward the winter form was suppressed, Neglecta alone would represent the species, and Mr. Sinunders is confident that about London, Ont, this is the condition. Prof. Lintuer describes Neglecte as appearing in swarms at Centre, N. Y., - as Tiolaced sometimes does in Virginia, but Neglecta never, - "the air has seemed blue from the myriads," and as flying there, and also in the vicinity of Albany, from middle of Maly to middle of Jume; while the winter forms have been wholly unknown to collectors till recently, a single example having been taken here and there. These myriats of course are from hibernating chrysalids. Nay at Albany is early spring, and Veglecer comes with the first blossoms, just as Violacer in Virginia comes in April, with the blossoms. Neglecta at Albany is the winter form. But two derrees farther south, or about New York city, the three primary winter forms abound in early spring.

On the Pacific coast, the species is represented in part by indivicluals not distinguishable from Neglecta, viz., Echo (Fig. 21), but more by Pirsus, of which Echo is a variety. In southern California there are two grenerations of the butterly; the first appearing in February and early March, the second last of April 
and early May. Mr. W. G. Wright carefully watehed the appearance of these broods, the past rear, and sent me scores of examples of each. Fig. 26 represents 9 Piusus of the early brood, 27 of the later. I give the females, because in this sex the differences between the forms is most decided. I do not discover any tangible difference between these two broods in either sex, except that some few of each are var. Echo, which, as I liave said, is close to Neylecte. The usual Piasus $?$, as is seen by these Figures 26,27 , most resembles Tiolacea, having the black borders as in that form. Picsus of (Fig. 20) is of a deep violet-blue; and the uncler side of all examples of both sexes is like Neglecta. I look upon this western form as an off characters of the primary form of the species having been in some degree recovered, especially in the females.

Violacen-cinerea appears to be the Arizona winter form, the under side ashgray, all the markings obscure. (Figs. 16, 17.) Mr. Morrison brought many examples in 1882 from Mt. Graham at considerable elevation. With them were others, nearly full-sized Pseudargiolus (Figs. 18, 19), but of a deeper blue than is usual at the east; the under side not pure white, but slightly gray.

On Plate II. are given some curious aberrations, as Fig. 23, a bi-formed Neglecta, taken at Coalburgh; Fig. 21, a female sent me by MIr. IIulst; a suffused Lucia, Fig. 25, also from Mr. Hulst. Fig. 22 represents a 9 from ecrgy laid by Pseudargiolus, the chrysalis having been laid on ice for seven days, the butterfly emerging in thinty-one days after removal. In the pattern of under side it approaches Marginatu.

In 1877, I noticed that the spikes of Rattle-weed were much frequented by ants, and presently that where the ants were lapre were sure to be found also. There soon appeared indications that the ants were attracted by the larre; they caressed them with their antenne, ruming up and down their backs, and the larva in no way resented this familiarity, not even withdrawing their heads from the buds they were excavating. Especially did the ants seem to linger about the last segments, and the eleventh particularly, and it occurred to me that there might be some exulation from the surface of 11 , or elsewhere, or from the stellate processes, as I saw no special organs for excreting any fluid. Not having a suitable glass at hand, I sent some of the larve to Prof. Lintner, at Albany, and by return of mail heard that he had observed two processes on 12 , cylindrical, with barbed hairs. Nothing more was discovered that summer, as the season for these larve was over when the observations were made. But in October, the same year, I chanced to find some of the larva of the fall brood, and sent them to Dr. Hagen for examination, in due time receiving this reply: "Dr. Mack found directly three secretory organs." The next day, farther: "I have exam- 
ined carefully your larro, and some in alcohol of Lycana Argus and Corydon. All have the organs alike. On the penultimate segment you find outside and behind the stigmata two large white spots, each one of which craginates a white membranous tube, just like the finger of a glove, the top of which is not entirely dram out. I have seen the tube frequently, and if I blow a little the tube is inraginated instantly. On the antepenultimate serment is a larger and tranversal opening behind and between the stigmata near the apical border. It looks like a closed month with its lips, but I have not seen anything protruding from it. But in an alcoholic larva of Argus I saw an ovcid cragination." Dr. I Iagen also referred me to a paper hy II. Guenée, Ann. Soc. Ent. de Erance, ser. 4, Vol. VII., 1S67, p1).696-7, and Plate 13, in which are described and figured similar organs in Lycena Betice. 'This author relates that while observing the litrva of Beetice he noticed two openings altogether like those of the stimmata, and as he turned the caterpillar about it suddenly made spring out of these holes a peculiar body, which he cannot compare to anything better than to the tentacles which certain polypi put forth at will. Ancl clescribing these, he groes on to say: "At the summit of the 10th segment" (the 11th, counting the head as one), "is fomnd another opening placed transversely and sumomeded by a raised pad. From the mildle of this opening comes forth, at the will of the caterpillar, a sort of transparent, hemispherical vesicle, which gives escape to a fluid sufficiently abumdant to form a good-sized drop, which reprodnces itself when it is absorloed. The caterpillar only secretes this fluid when it is disturber. . . . As to the end which nature proposes by this exceptional structure, it is not easy to divine it."

In 1878 , I was able to make more satisfactory olsservations, begimning with the larva of Pseudurjiolus, on liattle-reed, and experimented in various ways on both larve and ants. In each subsequent year I have continued the observations, and in 1883 especially I lost no opportunity. The ants, when discovered on a stem, are almost invariably on or near the larva. 'They rum orer the body, caressing incessantly with the antenna, and undoubtedly with the object of persuading the larva to emit the fluid from 11. Much of the caressing is done about the anterior segments, and while the ants are so employed, or rather while they are alsent from the last segments, the tubes of 12 are almost constantly exposed to full extent, and so remain, without retracting, until the ants come tumbling along in great excitement, and put either foot or antenua directly upon or close by the tubes, when these are instantly withdrawn. The ants pay no heer to the tubes, so far as touching them with intention, but at once turn to 11 , caress the back of that segment, put their mouths to the orifice there, and show every sign of eager expectancy. By holding a hand-rglass on 11, a movement will speedily be apparent, and there will protrude a dark green mammilloid membrane, from the top 
of which exudes a tiny drop of clear green fluid. This the ants drink greedily, tro or three of them perhaps standing over it. The demonstrations of the ants are of the most gentle nature, caressing, entreating, and as the little creatures drink in the fluid, lifting their heads as if to prolong the swallowing, there is a manifest satisfaction and delectation that is amusing to see. They lick away the last trace, and stroke the back of the segment, and wait to see if their conxing avils anything. If not, they run about, some seeking other larro on same stem, some with no apparent object, but presently all return, and the caressings go on as before. The intervals between the appearance of the globule vary with the condition of the larva. If exhanster by yielding to the frequent solicitations, some minutes may elapse, and the tubes menwhile will remain concealed; but a fresh larva requires little urging, and the mere intimation of the presence of an ant in the vicinity is enough to cause the tubes to play rapilly, and one grlobule to follow another, sometimes without a retracting of the membrane and before the near approach of the ants. I have counted six emissions in serenty-five seconds. The tubes are usually expanded when the ants are awr from the last segments, and are retracted when they come near. I counted the length of these periods of complete and quiet expansion, ten, twenty, fifty, and to eighty-two scconds, the period always ending with the approach of the ants. I experimented largely, introducing ants to larve in glass tubes, and placing larve from my tubes upon stems of the growing plant where the ants had access to them. When a fresh larva was brought to the stem, as soon as the ants discovered it, there was an immense excitement and a rush for the last larral segments. The larva forthwith relieved itself by the excretion of the fluid, and the tubes stood out with tops expanded between the periods. If I placed a fresh larva on a stem on which were no ants, there was no excitement in the larva, no appearance of the tubes, and no movement on 11 . If ants were now transferred to this stem at once the larva changed its beharior.

The tubes in the present species are white, cylindrical, of nearly eren size, rounded at the top, and sturited there with minute processes from which come the tentacles. (Fig. $\mathrm{m}^{2}$.) These are long, slender, tapering, armed with fine filamentous spurs disposed in whorls, and they stand out straight, making a white hemispherical dome over the cylinder, and none of them dip below the plane of the base of the dome. When the tube comes up, the rays are seen to rise in a close pencil, and as the dome expands they take position. On the contrary, when the tube is withdram, the top of the dome sinks first, and the rays come together. (Fig. $m^{1}$.)

The position of these organs is apparent in the younger larval stages, but till after the second moult I believe the larva has no power to project the tubes, and 
not till the latter part of the same stage to emit the secretion. The ants, when confined with larva in the first stage, treat them with indifference. I introduced ants to larve in separate glass tubes, some larve being at the middle and some near the end of the sccond stage; that is, before the second moult. One of the larva was caresserl several times, but no tube appeared. One larva objected to the ant, thrashed its anterior sergments about, and the ant left it. Introduced ant at one day after third moult; ant, greatly excited at finding itself imprisoned, ran about the tube, often coming close to the larva, even tonching it, and then ran across it, apparently taking no heed of it. But after the ant lakd quieted, it came to larva, soliciting as usual. 'Then the tubes were seen, and a drop of fluid came from 11, which the ant drank cagerly. It retumed to 11 several times, but obtained no more. On same day, introduced an ant to two larva in last part of third stage; that is, just before the third moult. There was a slight movement of the tubes in one larra, a mere point protruding, but no more, and no fluid. The other larva clid not lespond at all, and the ant left both.

But on another day, experimenting with a larva also in third starge, the tubes were seen to play actively. I could not make ont a drop on 11, but the ant held its mouth at the orifice for some seconds. It is after the fourth moult, in the last larval stage, that the fluid flows freely at the solicitations of the ants. This occurs, however, only with the summer lanve, on Rattle-weed, the flower of which is of exceeding sreetnes: I do not remember to have seen an ant on a Dorrrood flower but in a single instance, and when ants are placed with Dogrood larve they soon become imlifferent to them. Just so, in the fall, when the larve are feeding on Actinomeris, which has a dry flower, bitter to the laste. I have seen an ant approach a mature larva on this plant, and after a moment's investigation turn away. My olservations in ISiS led me to think that the tubes served as sigmals to the ants to appronch segment 11, and sul)sequent observations afford no better explanation. I have observed in larva of last stage, where no ants were present, that the tubes were occasionally but irregularly protruded, one appearing without the other, or both at same time, a very little or almost fully out, but without the tentacles spreading; and at such times I never could see any movement at 11 . The presence of the ants scems necessary to that; that is, the larva emitted the fluid when aware that its friend was near. Any teasing on my part failed to provoke a discovery of the tubes, as seems matural, for they certainly are not for defense. At least four species of ants accompany these larvœ, the smallest of which is scarcely one eighth inch long. The gentle demonstrations of these little creatures were most interesting, as if asking favors but claiming no right, and grateful for what they got.

In 1879, Dr. J. Gibbons Hunt kindly made observations on these larval organs, 
with dissections. I had asked Dr. Hunt whether there were special glands beneatl the membrane of 11 , and an opening at the top of the vesicle. Neither gland nor orifice was discovered. The fluid appeared to exude through minute pores all over the membrane. Nor was there any comnection between the tubes of 12 and this organ of 11 .*

Dr. Aug. Weismamn wrote: "You should try and observe what enemies the larva have. It is conceivable that there are such enemies as are afraid of ants." I have found three species of parasites about these larva. One is dipterous, a Tnchina fly. This deposits eggs on the skin of the larva in second larval stage, and on the second or third segment. As the grubs hatch, they eat their way through the skin, and emerge when full grown in the last larval stage, and make for themselves a hard pupa case, out of which in a few days comes a fly. 'Two other's are hymenopterous and minute. One is identified by Prof. Riley as Apanteles congregatus Say. The eggs of these species are deposited singly within the very young larva, and the grub eats its way out when the larva is but half grown, and proceeds to spin for itself a cylindrical cocoon of yellow silk, from which in a few days the perfect insect will break forth. 'The fourth parasite is also hymenopterous, an Ichneumon fly, a species of Anomalon, as $\mathrm{Mr}_{\mathrm{r}}$. E. 'T. Cresson tells me. 'This appears to sting the larva only in the last or perhaps the last two stages. 'The destruction of larve by these and other parasites is immense. If any of them attack the mature larva, as the Anomalon does, the grub will pass into the chrysalis and destroy that, and multitudes of chrysalids of different species of butterfly do so perish. But our Lycena appears to be singularly free from parasites in the pupa stage, and indeed I have never lost one from such cause. Why it is so favored will perhaps appear from the incident I relate. On 20th June, 1878 , in the woods, I saw a mature larva on Rattle-weed, and on its.back, facing to the tail, stood a large ant. At less than two inches behind, on the stem, was one of these Anomalon flies, watching its chance to thrust its ovipositor into the larva. I bent the stem and held it horizontally before me without alarming: either of the parties. The fly crawled a little nearer. and rested, and again nearer, the ant standing motionless, but plainly alert and knowing of the dan-

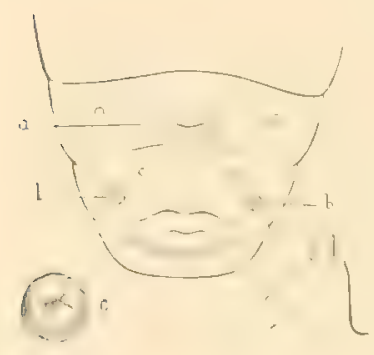
ger. After several advances, the fly turned its abdomen under and forward, thrust out the ovipositor, and strained

* The figure $k$ on Plate is too small to slow distinctly the position of the organs on 11 and 12, and Mrs. Peart has therefore made a greatly enlarged figure of the last segments of Psculargiolus larva to accompany this note: $a$ indicates the opening on 11 with its raised lips; $b$, the position of the tubes on 12 , wholly withdrawn; $c$, the top of the tube as it appears when slightly protrulerl; $l$, still farther projected, the tentacles in pencil. 'Tlue little rings, without letter, indicate the spiracles, or breatling looles. 
itcelf to the utmost to reach its prey. The sting was just about to strike the extreme end of the larva, when the ant made a dash at the fly, which flew away, and so long as I stood there, at least five minntes, did not return. 'The lurva had been quiet all this time, its head buried in a flower bud, but the moment the ant rushed and the fly fled it seemed to become aware of the danger, and thrashed about the end of its borly in great alarm. 'The ant saved the larva, and it is certain that Ichneumons wonld in no case get an opportunity to sting so long as such a vigilant gurd was about. It seems to me that the advantage is mutual between the larve and ants, and that the former know their protectors, and take satisfaction in rewarding them. This was the only occasion which has fallen under my observation in which the actual attempt to sting was defeated; but on 16th June, 1881, I saw several larva and several ants on a stem of Rattle-weed, aloont which one of these flies was hovering. It came very near to one larva, but an ant, not standing upon the latter, ran at the fly, which then departed. On 20th June, 1879, I saw another fly creeping along a sten on which was a half-grown larva, but no ant. The fly moved up, put one leg on the larva, rested an instant, turned round, and whien I thought it was about to give the fatal thrust it hesitated, and after standing quiet more than two minutes flew away. I concluded that either the larva was too young for the purpose of the fly, or that the latter discovered that it hat alreaty been parasitized. I have introduced house flies to larra in tubes, and there was no alam, nor was any notice taken, thongh the flies buzzed about and even stood on the larve.

Whether all other species of Lycana are supplied with the special organs above described I cannot say. Very little observation seems to have been made on this point. 'line books have rarely spoken of cither the organs, or of ants attending the larve, and in most cases the observations seen to have been isolated, and the object for which the ants attended the larve undiscovered; or if the organs were observer, the connection with the ants was not. In Newman's British Butterflies, Lond. 1871, p. 125, I find this sentence quoted from Prof. Zellel": "I could not perceive that these caterpillars ( $\mathrm{I}_{\text {. }}$. Tectom) hart a cone capable of being protruded, like that which we find in L. Corydon, and which the ants are so fond of licking." Guenée, as has been seen, discovered the tubes and the organ on 11, and saw the fluid exude therefrom, but could not conjecture its object.

Dr. Hargen caller my attention to the following mention in Stett. Ent. Zeit., XXVI. p. 115, 18t5: "Mr. C. Plotz says that he found caterpillars of L. Argus on Calluna vulgaris. Was puzzled at seeing that every caterpillar had an ant standing on its back, and saw about forty larva near ant hills, the ants always on the larva, standing or walking, and apparently the caterpillars were in no way 
molested by them; indeed, the ants seemed to try and defend the larva from him. Of all these larva none were infested by Ichneumons, and all produced butterflies." 'This list observation is very interesting.

Rev. I. C. McCook informed me that in the spring of 1877 he saw a small green larva on Cimicifuga racemosa, and "a black ant attending it, stroking the tail incessantly, moving away, and returning to go through the same process. He watched this for two hours, and saw that the purpose of the ant was at least friendly, but was at a loss to explain these strange manipulations." Mr. Saunrers (Can. Ent. x. 14) relates that he hat observed ants rmung over larve of L. Scudderii, and that the discovery of the larva was made casy by the presence of the ants.

I have observerl similar organs in larva of L. Comyntas and L. Melissa, both of which species I have bred from the egg. The organs of Comyntas are of same shape as in Pseudroryiolus, both the cone and the tube and its tentacles; and on introducing ants, the behavior of the larva was as in the other species. As to Metissa, I am not able to say whether the tentacles precisely agreed in shape with those figured on our Plate, but they stood erect upon the rome in same manner, and the fluid appeared on 11. Guenée figures the tentacles of Bretica as spindle-shaped, and instead of standing erect they droop about the dome and are quite feathery.

In the allied sub-families, Thecla and Chrysophanus, no such organs have been discovered, and I apprehend a sufficient generic distinction, if one were needed between two groups whose preparatory stages are so different, will here be found, especially between Lycana and Chrysophanus, which some collectors still persist in uniting in one genus. 


\section{LTCENA III.}

\section{EXPLANATION OF THE PLA'TE.}

$a-a^{2}$. EGG; magnifed.

b. Iouxa Larva; magnifiel.

c. Larva after first moult ; magnified.

d. Larva after second monlt ; magnified.

e. Larva after thind moult; magnified.

$e^{1}$ - $c^{4}$. Larva after third moult; magnified, slowing various coloring.

f. MITtRE LARVA of Trotacea; natural size.

$f^{1}, f^{1}$. Mature Larva of P'seudargulus; mannified.

$f^{\circ}$. Mature Larva of fall brood; magnified.

$f^{2}-f^{6}$. Mature Larwe of all broods ; magnified, slowing various coloring.

g. Cinrysals from egro of P'seudargolus; natural size.

7). The same; magnified.

h. Clnysalis from exer of VIOtaces ; natural size.

i. Anterior segments mature Larva ; showing position of head, at rest.

$i^{4}$. Under sile of semment 2 ; slowing same.

$i^{1}-i^{3}$. Head and neck.

h. Last serments ; slowing the orifice on 11 , and the position of the organs on 12.

m. Orean of 12 partly expraded.

$m^{1}$. T'lue tentacles in pencil.

$m^{2}$. The tentacles fully expranded.

$m^{3}$. Tentacle.

2. Section of dorsum; largely magnified, showing the stellate processes.

1. Dogrvoor (Cornus) in blossom; the spring food-plant.

2. Rattle-sveel (Cimicifuga); the summer food-plant.

3. Actinomeris squarrosa; the fall food-plant. 



\title{
LIST OF SPECIES
}

OF THE

\section{DIURNAL LEPIDOPTERA OF AIERICA}

\author{
NORTH OF MEXICO
}

BY

\section{WILLIAM H. EDWARDS}

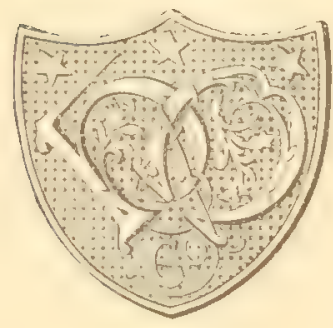

BOSTON

HOUGHTON, MIFFLIN AND COMPANY

New York: 11 East Seventeenth Street

The Biversioe 12 ress, Camorioge

1884 



\section{ADVERTISEMENT.}

TrE Synopsis of North American Butterflies which accompanied Volume I. was issued in 1872, and for various reasons, anong them the imperfect knowledge of many of the species described and of their distribution, which I shared with the other lepidopterists of the comtry, it was much at fault. In 1856, I published in the Transactions of the American Entomological Society a Catalogue of the Diurnal Lepidoptera of America, north of Mexico, which was unquestionably an advance upon the Synopsis. In the intervening years many supposed species had been found to be synonymous, and many others to have been erroneously credited to our fauna. Corrections were made accordingly. The generic names were somewhat changed, and most of those in the Hesperida dropped. A revised edition of the Catalogue has recently been printed in Volume XI. of the 'Transactions spoken of, 1884, with extended references, and in all respects as complete as $I$ am able to make it. The present List follows the revised Catalogue, and the numbers of the species in the two correspond. The List gives no synonyms, but simply the names of species and varieties. For information beyond that I refer to the Catalogue, which may be had separately on application to Mr. E. T. Cressov, Post-office Box 1577, Philadelphia, Pa.

WM. H. EDWARDS.

Coalburgit, W. VA., November 1, 1884. 



\section{LIST OF SPECIES}

OF THE

\section{DIURNAL LEPIDOPTERA OF AMERICA NORTH OF MIEXICO.}

PAPILIONID 仺。

\section{PAPILIONINE.}

Papilio, Linn.

1. Ajax, Lim.

1. (1.) Winter form Walshii, Edw.

Var. Abbotii, Edw.

(2.) Winter form Telamonides, Felk.

2. Summer form, Mareellus, Bd.

2. Philinor, Lim.

3. Machaon, var. Aliaska, Sc.

4. Oregonia, Edw.

5. Zolicaon, Bd.

6. Americus, Koll.

7. Nitra, Edw.

8. Indra, Reak.

9. Pergamus, H. Edw.

10. Brevicauda, Saund.

11. Bairdii, Edw.

12. Asterias, Fab.

Var. Asteroides, Reak.

13. Troilus, Linn.

14. Palamedes, Dru.
15. Turnus, Linn.

Dim. form \& Glaucus, Linn.

16. Eurymedon, Bd.

17. Rutulus, Bd.

Var. Arizonensis, Edw.

18. Daunus, Bd.

19. Pilumnus, Bd.

20. Cresphontes, Cram.

21. Thoas, Limn.

22. Polydamas, Limn.

Pannassius, Latr.

23. Clodius, Mén.

Var. Ménétriésii, H. Edw.

24. Smintheus, Doubl.-Hew.

Var. Behrii, Edw.

Var. Hermodur, H. Edw.

25. Nomion, Fiscli.

26. Eversmanni, Mén.

q Wosnesenski, Mén.

Var. \& Thor, H. Edw.

PIERIN无.

Neopiasta, Behr.

27. Menapia, Feld.

Var. Suffusa, Stretch. 
PIERIS, Schr.

28. Amaryllis, Fab.

29. Ilaire, Grodt.

31. Monuste, Linn.

:i1. Beckerii, Edw.

:, S. Sisymbri, Bd.

:3. Nelsonii, Edw。

3. Occidentalis, Reak.

Winter form Calyce, Edw.

35. Protodice, Bd.-Lec.

Winter form Vernalis, Edw.

36. Napi, Esp.

Aretic form Bryoniæ, Ochs.

Var. Hulda, Edw.

1. Winter form Venosa, Sc.

2. Winter form Oleracea-hiemalis, Harr.

Var. Borealis, Gro.

Var. Frigida, Sc.

Aberr. Virginiensis, Edw.

3. (1.) Summer form Acadica, Edw.

(2.) Sunmer form, a. Pallida, Sc.

b. Castoria, Reak.

(3.) Summer form Oleraceaxstiva, Harr.

37. Virginiensis, Edw.

38. Rape, Linn.

Var. Marginalis, Sc.

Var. Yreka, Reak.

Var. Mannii, Mayer.

Var. Nov-Augliæ, Sc.

Nathalis, Bd.

39. Iole, Bd.

Var. Irene, Fitch.
Anthocharis, Bd.

40. Lanceolata, Bd.

41. Creusa, Doubl.-Hew.

4.2. Hyantis, Edw.

13. Olympia, Edw.

14. Rosa, Edw.

4.5. Ausonides, $\mathrm{Bd}$.

Var. Coloradensis, H. Edw.

46. Cethura, Feld.

47. Morrisoni, Edw.

48. Thoosa, Sc.

40. Sara, Bd.

5). Reakirtii, Edw.

51. Stella, Edw.

5.. Julia, Edw.

5:). Genutia, Fab.

\section{Callidryas, Bd.}

7. Eubule, Linn.

5.). Sennæ, Linn.

56. Philea, Linn.

5. Agarithe, Bd.

Kricogonia, Reak.

58. Lyside, Godt.

Summer form Terissa, Luc.

59. Fantasia, Butl.

60. Lanice, Lintn.

Colias, Fab.

(11. Eurydice, Bd.

Dimorphic form Amorphæ, $\mathrm{H}$. Edw.

62. Cæsonia, Stoll.

63. Meadii, Edw. 


\section{LIST OF SPECIES.}

64. Hecla, Isef.

Var. Glacialis, McLach.

NYMPHALID五。

Var. Hela, Str.

65. Boothii, Curt.

Var. Chione, Curt.

66. Eurytheme, Bd.

1. Winter form Ariadne, Elw.

2. Winter form Keewaydin, Edw.

3. Summer form Eurytheme, Bd.

6. Hagenii, Edw.

6s. Philodice, Godt.

Var. Anthyale, Hüb.

6?. Eriphyle, Edw.

7). Harfordii, H. Edw.

71. Occidentalis, Sc.

7.. Christina, Edw.

Southern form Astriea, Edw.

HELICONINA.

IIELICONIA, Latr.

93. Charitonia, Linn.

DANAINE.

DiN.us, Latr.

94. Archippus, Fab.

95. Berenice, Cram.

96. Strigosa, Bates.

Dircenna, Doubl.

97. Klugii, Fab.

NYMPHALIN E.

Colexis, Doubl.

7:). Alexandra, Edw.

74. Edwardsii, Behr.

7.). Emilin, Edw.

Ti. Interior, Sc.

Fab.

7T. Scudderii, Edw.

7s. Pelidne, Bd.

7?. Palæno, Linn.

81. Chippewa, Edw.

i1. Nastes, Bd.

¿.. Noina, Str.

เ3. Behrii, Edw.

\section{Terias, Swain.}

4. Gundlachia, Poey.

i.). Proterpia, Fab.

si. Nicippe, Cram.

¿i. Mexicana, Bd.

¿. Damaris, Feld.

83. Westwoodii, Bd.

90. Lisa, Bd.-Lec.

91. Delia, Cram.

3). Jucunda, Bd.-Lec.

99. Delila, Fab.

Agraulis, Bd.-Lec.

100. Vanilla, Linn.

Arginnis, Fab.

101. Idalia, Dru.

102. Diana, Cram.

103. Nokomis, Edw.

104. Nitocris, Edw.

105. Leto, Bchr.

106. Carpenterii, Edw.

107. Cybele, Fab.

108. Aphrodite, Fab.

109. Alcestis, Edw.

110. Nausicaa, Edw.

111. Lais, Edw.

112. Atlantis, Edw. 
113. Electa, Edr.

114. Columbia, H. Edw.

115. Hesperis, Edw.

116. Hippolyta, Edw.

117. Bremnerii, Edw.

11S. Zerene, Bd.

119. Monticola, Behr.

Var. Purpurascens, H. Edw.

120. Rhodope, Edw.

121. Behrensii, Edw.

122. Halcyone, Edw.

123. Chitone, Edw.

124. Coronis, Behr.

125. Callippe, Bd.

126. Neradensis, Edw.

127. Edwardsii, Reak.

128. Liliann, H. Edw.

129. Rupestris, Behr. Var. Irene, Bd.

130. Laura, Edw.

131. Macaria, Edw。

132. Inornata, Edw.

133. Adiante, Bd.

13̂t. Artonis, Edw.

13อ. Clio, Edw.

136. Opis, Edw.

137. Bischoffii, Edw.

13S. Eurynome, Erlw.

139. Nontivaga, Belur.

Var. Erimna, Edw.

140. Egleis, Bd.

111. Myrina, Cram.

1.2. Triclaris, Hiib.

143. Helena, Edw.

144. Nontinus, Sc.

145. Chariclea, Schneid.

Var. Obscurata, McLach.

146. Butlerii, Edw.

1t7. Boisduvallii, Somm.
148. Freya, Thunb.

Var. Tarquinius, Curt.

149. Polaris, Bd.

150. Frigga, Thumb.

151. Improba, Butl.

152. Bellona, Fab.

153. Epithore, Bd.

Var. Kreimhild, Str.

Euptoieta, Doubl.

154. Claudia, Cram.

155. Hegesia, Cram.

$$
\text { Melites, Fab. }
$$

156. Phacton, Drury.

157. Cooperi, Behr.

15S. Chalcedon, Doubl.-Hew.

Var. Dwinellei, H. Edw.

159. Colon, Edw.

160. Anicia, Doubl.-Hew.

161. Nubigena, Behr.

162. Quino, Behr.

163. Baroni, H. Edw.

164. Rubicunda, H. Edw.

165. Editha, Bd.

166. Helvia, Sc.

167. Sterope, Edw.

168. Acastus, Edw.

169. Palla, Bd.

170. Whitneyii, Behr.

171. Hoffmamni, Behr.

172. Gabbii, Behr.

173ิ. Harrisii, Sc.

174. Ulrica, Edw.

175. Dymas, Edw.

176. Perse, Edw.

177. Chara, Edw.

17S. Leanira, Bd.

Var. Obsoleta, H. Edw. 


\section{LIST OF SPECIES.}

179. Alma, Str.

180. Hulvia, Edw.

1S1. Thekla, Edw.

182. Bollii, Edw.

183. Minuta, Edw.

184. Aricline, Edw.

185. Nymplı, Edw.

\section{Phyciodes, Doubl.}

1S6. Nycteis, Doubl.-Hew.

$$
\text { Var. Drusius, Edw. }
$$

187. Carlota, Reak.

188. Vestil, Ëlw.

189. Phaon, Edw.

1!11). Tharos, Dru.

1!1. Batesii, Reak.

192. Pratensis, Behr.

193. Orseis, Edw.

194. Camillus, Edw.

Winter form Emissa, Edw.

Var. Pallida, Edw.

Var. Mata, Reak.

195. Mylitta, Edw.

196. Montana, Behr.

197. Picta, Edw.

\section{Eriesia, Doubl.}

198. Frisia, Poey.

1:19. T'exana, Edw.

200. Punctata, Edw.

\section{Srichloe, Bois.}

201. Janais, Dru.

202. Mediatrix, Feld

203. Adjutrix, Sc.

204. Erodyle, Bates.

205. Crocale, Edw.
Crstineura, Doubl.

206. Amymone, Mén.

$$
\text { Grapra, Kirby. }
$$

207. Interrogationis, Fab.

1. Dim. form Fabricii, Edw.

2. Dim. form Umbrosa, Lintn.

20). Comma, Harr.

1. Winter form Harrisii, Edw.

2. Summer form Dryas, Edw.

21)!. Satyrus, Edw.

1. Dim. form Satyrus, Edw.

2. Dim. form Marsyas, Edw.

-11. IIylas, Edw.

-11. Rusticus, Edw.

212. Filunus, Edw.

21:. Silvius, Edw.

¿11. Zephyrus, Edw.

ב1.). Gracilis, Gr.-Rob.

¿li. Silenus, Edw.

1. Dim. form Silenus, Edw.

2. Dim. form Oreas, Edw.

117. Progne, Cran.

־1s. J. Album, Bd.-Lec.

$$
\text { VANessa, Fab. }
$$

-1!. Antiopa, Linm.

․) (). Californica, Bd.

2.21. Milbertii, Godt.

$$
\text { Prrameis, Doubl. }
$$

2.20. Atalanta, Linn.

2.2:). Huntera, Fab.

-2. Cardui, Limm.

2.2. Carye, Huib.

$$
\text { Juxoxis, Doubl. }
$$

2.21. Coenia, Hüb.

․․․ Genoveva, Cram. 


\section{LIST OF SPECIES.}

Axartia, Doubl.

2.2. Jatropha, Linn.

Eurema, Bois.

…! Lethe, Fab.

Eunica, Felder.

:?) Monima, Cram.

Timetes, Bois.

2::1. Coresia, Godt.

2:j2. Petreus, Cram.

233. Elencha, Doubl.-Hew.

2:). Chiron, Fab.

Diadema, Bois.

2:35. Misippus, Linn.

Lisiexitis, Fab.

2:31i. Ursula, Fab.

Var. Arizonensis. Edw.

2:7. Arthemis, Dru.

1. Dim. form Lamina, Fab.

2. Dim. form Proserpina, Edw.

2:35. Weidemeyerii, Edw.

239. Disippus, Grodt.

Var. Floridensis, Str.

2-11). Eros, Edw.

Var. Obsoleta, Edw.

211. Hulstii, Edw.

242. Lorquini, Bd.

HeterociroA, Bois.

243. Californica, Butl.

\section{Apatura, Fab.}

214. Celtis, Bd.-Iec.

245. Antonia, Edw.

Var. Montis, Edw.
246. Leilia, Edw.

247. Alicia, Edw.

248. Clyton, Bd.-Lec.

1. Dim. form Proserpina, Sc.

2. Dim. form Ocellata, Edw.

24?. Flora, Edw.

:.)0. Cocles, Lintn., Mss.

Papina, Westwood.

2.)1. Troglodyta, Fab.

252. Morrisonii, Edw.

\section{SATYRINE.}

Debis, West.

253. Portlandia, Fab.

Neonyapua, West.

254. Canthus, Bd.-Lec.

25\%. Gemma, Huib.

250. Henshawi, Edw.

257. Areolatus, Sm.-Abb.

25:. Eurytris, Fab.

259. Sosybius, Fab.

260. Rubricata, Edw.

Cexompupha, West.

261. Californica, Doubl.-Hew.

Var. Ceres, Butl.

Var. Galactinus, Bd.

Var. Eryngii, H. Edw.

Var. Palla, H. Edw.

262. Elko, Edw.

263. Inornata, Edw.

264. Ochracea, Edw.

265. Ampelos, Edw.

366. Kodiak, Edw. 


\section{LIST OF SPECIES.}

267. Brenda, Edw.

265. Pamphiloides, Reak.

Ereibia, Dalm.

26?. Fasciata, Butl.

271). Discoidalis, Kirby.

271. Vesigus, Doubl.-Hew.

27:2. Rossii, Curt.

2-:;. Disa, var. Mancinus, Doubl.-Hew.

27. Inadenii, Ediw.

27.). 'Tyndarus, var. Callias, Edw.

27i. Epipsoden, Butl.

27. Sofia, Str.

27. Magdalena, Str.

Geirocieilus, Butl.

27?. 'Tritonia, Edw.

Hipparcima, Fab.

2sil. Ridingsii, Edw.

$2 \mathrm{il}$. Dionysius, Sc.

$$
\text { SAtrrus, West. }
$$

282. Pegala, Fab.

283. Alope, Fab.

1. Dim. form Alope, Fab.

Var. Iexana, Edw.

Var. Maritima, Edw.

2. Dim. form Nephele, Kirby.

Var. Olympus, Edw.

Var. Boopis, Behr.

Sub-var. Incana, Edw.

284. Ariane, Bd.

285. Baroni, Edw.

286. Paulus, Edw.

287. Gabbii, Edw.

2S8. Wheelerii, Edw.

289. Meadii, Edw.

290. Silvestris, Edw.
291. Oetus, Bd.

292. Charon, Edw.

293. Sthencle, Bd.

Chionobas, Bois.

294. Gigas, Butl.

295. Iduma, Edw.

296. Californica, Bd.

297. Nevadensis, Feld.

298. Chryxus, Doubl.-Hew.

29!. Calais, Sc.

300. Ivallda, Mead.

: 11 . Varuna, Edw.

:30.2. Uhleri, Reak.

30:\%. 'Tarpein, Esp.

:31. 'l'aygete, Iüub.

:11.). Jutta, Hiib.

:ili. Semidea, Say.

:07. Crambis, Frey.

:30. Subhyalina, Curt.

\section{LIBFTIEIN ג一.}

309. Bachmani, Kirtl.

310. Carinenta, Cram.

ERYCINID王.

ERYCININA.

Lemonias, West.

:11. Mormo, Feld.

312. Duryi, Edw.

313. Cythera, Edw.

314. Virgulti, Behr.

315. Nais, Edw.

316. Palmerii, Edw.

317. Ares, Edw.

Dim. form Cleis, Edw. 
Eurtgora, Bois.

in. Abreas, Edw.

$$
\text { Chlephelis, Gr.-Rob. }
$$

:319. Crenius, Linn.

:'-11. Borealis, Gr.-Rob.

:-1. Australis, Edw.

:-2.). Nemesis, Edw.

Eunexia, Latr.

:3::1. Atala, Poey.

\section{LYCAENID Æ.}

\section{LYCANIN E.}

\section{Thecla, Fabr.}

:)- Gerunus. Br.

325. Crysalus, Edw.

:321. Halesus, Cram.

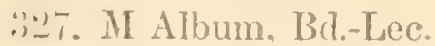

:2- Favomius, Sin.-Abb.

32!?. Autolycus, Edw.

:3). Alcestis, Edw.

:3: 1. Humuli, Harr.

:.:.). Melinus, Huib.

:3:3. Acadica, Edw.

334. Californica, Edw.

Var. Cygnus, Edw.

335. Itys, Edw.

336. Auretorum, Bd.

337. Dryope, Edw.

338. Sylvinus, Bd.

33!! Edwardsii, Saund.

311. Wittfeldii, Edw.

341. Calanus, Iriib. Var. Lorata, Gr.-Rob.

342. Ontario, Edw.
:3.:. Strigasa, Harr.

344. Putnami, H. Edw.

345. Spadix, H. Edw.

346. Tetra, Behr.

347. Chalcis, Behr.

348. Srepium, Bd.

Var. Fulvescens, H. Edw.

349. Nelsoni, Bd.

Var. Exoleti, H. Edw.

Var. Muirii, H. Edw.

3). Adenostomatis, H. Edw.

3.). T. 'Tacita, H. Edw.

3.). Spinetorum, Bd.

:3). Siva, Edw.

:i.). Castalis, Edw.

:.5.5. Smilacis, Bd.-Lec.

:3.ti. Acis, Dru.

$3 \%$. Poeas, Hüb.

:3... Columellit, Fab.

:3.5. Clytie, Edw.

still. Leda, Edw.

3it. Ines, Edw.

31i2. Behrii, Edw.

316. Augustus, Kirby.

:ii1. Iroides, Bd.

3i5. Fotis, Str.

:iib. Irus, Godt.

Var. Arsace, Bd.-Lec.

Var. Mossii, H. Edw.

36-. Henrici, Gr.-Rob.

36. Er. Eryphon, Bd.

3199. Niphon, Hüb.

370. Affinis, Edw.

:31. Dumetorum, $\mathrm{Bd}$.

?:-0. Apama, Edw.

:3i:.) Sheridanii, Edw.

37 . Lita, Edw.

375. Fuliginosa, Edw.

:76. Titus, Fab. 


\section{LIST OF SPECIES.}

Feniseca, Grote.

37\%. Tarquinius, Fab.

$$
\text { Chrysophanus, Doubl. }
$$

378. Arota, Bd.

379. Virginiensis, Edw.

350. Hermes, Edw.

351. Xanthoides, Bd.

3S2. Dione, Sc.

383. Editha, Mead.

3S4. Gorgon, Bd.

3.-5. 'Thoe. Bd.-Lec.

3า6. Mariposa, Reak.

3`7. Zeroe, Bd.

3is. Helloides, Bd.

3ง9. Florus, Elw.

3!!0. Dorcas, Kirby.

3!1. Epiximthe, Bd.-Lec.

:312. Hypophleas, Bd.

Var. Feildenii, McLach.

:3:?. Cupreus, Edw.

:3! t. Snowi, Edw.

:195. Rubiclus, Behr.

3:110. Sirius, Edw.

\section{Lycexa, Fab.}

:3! T. Heteronea, Bd.

:3!n. Clara, H. Eilw.

:39. Lycea, Edw.

f10. Fulla, Edw.

411. Dredalus, Behr.

411.2. Srepiolus, Bd.

f11:;. Icaroides, Bd.

Var. Maricopa, Reak.

411. Amica, Edw.

4115. Pembina, Edw.

4lui. Pheres, Bd.

417. Phileros, Bd.

405. Ardea, Edw.
409. Kodiak, Edw.

410. Xerres, Bd.

411. Antiacis, Bd.

Var. Behrii, Edw.

Var. Mertila, Edw.

Aberr. Oreus, Edw.

412. Couperii, Gro.

413. Afra, Edw.

414. Lyggdamas, Doubl.

Western form Oro, Sc.

415. Sagrittigera, Feld.

416. Speciosa, H. Edw.

417. Sonorensis, Feld.

418. Podarce, Feld.

419. Aquilo, Bd.

420. Rustica, Edw. .

421. Enoptes, Bd.

422. Glaucon, Edw.

423. Battoides, Behr.

424. Shasta, Edw.

425. Melissa, Edw.

426. Scudderii, Edw.

427. Lotis, Lintn.

428. Acmon, Doubl.-Hew.

429. Aster, Edw.

430. Ammetta, Mead.

431. Amma, Edw.

432. Pseudargiolus, Bd.-Lec.

1. Winter form Lucia, Kirby.

2. Winter form Marginata, Edw.

3. Winter form Violacea, Edw.

Var. o Nigra, Edw.

Var. Cinerea, Edw.

Spring form Pseudargiolus, Bd.Lec.

Var. Arizonensis, Edw.

Summer form Neglecta, Edw.

Pacific form Piasus, Bd.

Var. Echo, Edw. 
433. Amyntula, Bd.

434. Comyntas, Godt.

435. Honica, Reak.

436. Alce, Edw.

437. Gyas, Edw.

438. Cyna, Edw.

439. Filenus, Poey.

440. Isophthalma, Herr.-Schaeff.

441. Fxilis, Bd.

442. Ammon, Luc.

443. Marina, Reak.

444. 'Theonus, Luc.

445. Striata, Edw.

\section{HESPERID E.}

Carterocephalus, Led.

446. Mandan, Edw.

447. Omaha, Edw.

\section{Ancyloxipha, Feld.}

448. Numitor, Fab.

Copzodes, Speyer.

449. Procris, Edw.

450. Arene, Edw.

451. Wrightii, Edw.

452. Myrtis, Edw.

453. Eunus, Edw.

Thruelicus, Speyer.

454. Garita, Reak.

455. Powescheik, Park.

$$
\text { Pamphila, Fab. }
$$

456. Massassoit, Sc.

457. Zabulon, Bd.-Lec.

Var. Hobomok, Harr.
Dim. 9 Pocahontas, Sc.

Var. \& Quadraquina, Sc.

458. Taxiles, Edw.

459. Ruricola, Bd.

460. Oregonia, Edw.

461. Columbia, Sc.

462. Colorado, Sc.

Var. Idaho, Edw.

463. Nevada, Sc.

464. Manitoba, Sc.

465. Juba, Sc.

Var. Viridis, Edw.

466. Sassacus, Harr.

467. Harpalus, Edw.

468. Pawnee, Dodge.

469. Ottoe, Edw.

470. Lasus, Edw.

471. Cabelus, Edw.

472. Napa, Edw.

473. Netea, Sc.

474. Rhesus, Edw.

475. Carus, Edw.

476. Uncas, Edw.

477. Licinus, Edw.

478. Seminole, Sc.

479. Attalus, Edw.

480. Yuma, Edw.

481. Snowi, Edw.

482. Leonardus, Harr.

483. Meskei, Edw.

484. Nemorum, Bd.

485. Sylvanoides, Bd.

486. Agricola, Bd.

487. Milo, Edw.

488. Pratincola, Bd.

489. Verus, Edw.

490. Campestris, Bd.

491. Huron, Edw.

492. Morrissonii, Edw. 
4!!:?. Phyleus, Dru.

t!! B. Brettoides, Edw.

4:15. Brettus, Bd.-Lec.

4!1\%. Chusen. Edw.

4!:- Draco, Edw.

t!r. Sabuleti, Bd.

499. Otho, Sm.-Abb.

Var. Egreremet, Sc.

ju(1. Peckius, Kirloy.

511. Mystic, Sc.

.112. Siris, Edw.

.713. Mirdon, Edw.

ill. Cernes, Bd.-Lec.

.05. MImataaqua, Sc.

506. Verna, Edw.

ini. Vestris, Bd.

万IS. Metacomet, Harr.

5)!?. Bellus, Edw.

511. Accius, Sm-Abb.

511. Loammi, Whit.

\$12. Horus, Edw.

i13. Deva, Edw.

il1. Lunus, Edw.

515. Maculata, Edw.

511. Panoquin, Se.

517. Ocola, Edw.

万人. Ethlius, Cram.

719. Pittacus, Edw.

iz⿲丿丨日 Python, Edw。

521. Cestus, Edw.

522. Rhena, Edw.

.23. Bimacula, Gr.-Rob.

.) t. Pontiac, Edw.

525. Dion, Edw.

ji. Arpa, Bd.-Lec.

万-T. Palatka, Edw.

is. Melane, Edw.

5.?. Vitellius, Sm.-Abb.

530. Delaware, Edw.
531. Lagus, Edw.

532. Byssus, Edw.

533. Phylace, Edw.

534. Osyka, Edw.

535. Comus, Edw.

536. Eufala, Edw.

537. Arabus, Edw.

538. Fusca, Gr.-Rob.

539. Nereus, Edw.

540. Hiamma, Sc.

541. Viator, Edw.

Amblyscirtes, Speyer.

542. Vialis, Edw.

543. Nysa, Edw.

544. Eos, Edw.

545. Samoset, Sc.

546. Enus, Edw.

517. Simius, Edw.

548. Cassus, Edw.

549. Nanno, Edw.

550. 'I'extor, Hüb.

Prrgus, West.

551. Ericetorum, Bd.

5อ๊2. Oceanus, Edw.

553. Domicella, Erichs.

Var. Nearchus, Edw.

50̃t. Tessellata, Sc.

Var. Montivagus, Reak.

555. Centaureæ, Ramb.

556. Philetas, Edw.

557. Caspitalis, Bd.

558. Xanthus, Edw.

559. Scriptura, Bd.

560. Nessus, Edw.

Nisoniades, Speyer.

561. Brizo, Bd.-Lec. 
562. Icelus, Lintn.

563. Somnus, Lintn.

561. Lucilius, Lintn.

565. Persius, Sc.

566. Alpheus, Edw.

567. Ausonius, Lintn.

568. Afranius, Lintn.

569. Martialis, Sc.

570. Juvenalis, Fab.

571. Petronius, Lintn.

572. Propertius, Lintn.

573. Nævius, Lintn.

574. Pacuvius, Lintn.

575. Tatius, Edw.

576. Clitus, Edw.

577. Funeralis, Lintn.

578. 'Tristis, Bd.

Systasea, Butler.

579. Zampa, Edw.

Pifolisora, Speyer.

580. Catullus, Fab.

581. Pirus, Edw.

582. Ceos, Edw.

583. Hayhurstii, Edw.

584. Libya, Sc.

585. Lena, Edw.

Achlyodes, IVest.

586. Thraso, Hüb.
Eudnuus, Swains.

587. Electra, Lintn.

588. Pylades, Sc.

589. Nevada, Sc.

590. Bathyllus, Sm.-Abb.

591. Moschus, Edw.

592. Hippalus, Edw.

593. Drusius, Edw.

594. Epiginn, Butl.

595. Lycidas, Sm.-Abb.

596. Cellus, Bd.-Lec.

597. Hesus, West.-Hew.

598. Zestos, IIüb.

599. 'Tityrus, Fab.

600. Proteus, Linn.

601. Simplicius, Stoll.

602. Albo-fasciatus, Hew.

603. Dorus, Edw.

Errcides, West.

604. Urania, West.-Hew.

605. Texana, Sc.

606. Sanguinea, Sc.

607. Batabano, Lef.

608. Amyntas, Fab.

Pyrrhol'yga, West.

609. Araxes, Hew.

Megathrurus, Riley.

610. Yuccx, Bd.-Lec.

Var. Coloradensis, Riley.

611. Cofaqui, Str.

612. Neumoegenii, Edw. 



\section{SYNOPSIS}

$(15$

\section{NORTH AMERICAN BU'TTERFLIES.}

REVISED AND BROUGH'T' DOIVN 'IO 1882.

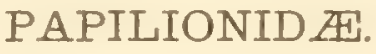 \\ PAPILIONINA. \\ PAPILIO, Linnæus.}

1. Ajax, Linn.

1. 1. winter form WaLsiri, Eur.

var. Aвbotit, Elw.

2. winter form 'Teisuronides, Feld.

2. summer form Marcellus, Bd.

2. Philenor, Linn.

3. Machaon, var. Alisski, Scud.

4. Oregonia, Edw., Tr. A. E. Soc., 5, 208, 1876 ; id., But. N. A., v. 2, pl. 7, Pap ${ }^{\circ}$ Oregon; Washingtou 'T'er.

5. Zolicaon, Bd.; Edw., 1. c., v. 2, pl. 6, Pap.

6. Indra, Reak.; Edw., 1. c., v. 2, pl. 9, Pap ${ }^{\circ}$.

7. Pergamus, H. Edw., Pr. Cal. Acad. N. Sei., 5, 423, 1874. Sonthern California.

8. Brevicauda, Saund.; Edw., 1. c., v. 2, pl. 8, 8 B., Pap ${ }^{\circ}$. Newfoundland; Anticosti; Labrador.

Anticostiensis, Str., Lep., pl. 2, 1873.

9. Bairdii, Edw., 1. c., v. 2, pl. 10, Papº.

10. Asterias, Fab.

bi-form., Edw., l. c., v. 2, pl. 11, Papo.

var. Asteroides, Reak.

aberr. Calverleyil, Grote; Edw., l. c., v. 2, pl. 11, Papo. 
11. Americus, Koll, Denkschr. Akad. Wiss. Wien, Math. Nat. Cl., 1, 354, 1850. Sadalus, Lutcas, Rev. Zoöl., 1852, 133, pl. 10. Arizona.

12. Troilus, Linn.

13. Eurymedon, Bd.; Edw., l. c., v. 2, pl. 1, Pap var. Albanus, Feld.

11. Rutulus, Bd.

15. Turnus, Limn. ; Edw., 1. c., v. 2, pl. 3, 4, 5, Pap. dim. form, \&, Glaucus, Linn.; Edw., l. c., v. 2, pl. 3, 4, cit. bi-form, Edw., l. c., pl. 5, cit. interm. form, id., pl. 5, cit.

16. Daunus, Bd.; Edw., 1. c., v. 2, pl. 2, Papº.

17. Pilumnus, Bd.

18. Palamedes, Drury.

19. Cresphontes, Cram.

PARNASSIUS, Latreille.

20. Clodius, Mén.

21. Baldur, Edw., Cat. Lep., 12, 1877. Clarine, Bd.; Edw., But. N. A., v. 1, 17, pl. 4.

22. Thor, H. Edw., Papilio, 1, 4, 1881. Yucon River, Alaska.

2:?. Smintheus, Doubl. var. BeIrII, Edw.

var. Herisodur, H. Edw., Papilio, 1, 4, 1881. Colorado.

24. Nomion, Fisch., Ent. Russ., 2, 242, pl. 6, 1823 ; Bd. Sp. Gen., 1, 397, pl. 2. Alaskat.

25. Eversmanni, Mén.

PIERINAE.

PIERIS, Schrank.

26. Amaryllis, Fab., Ent. Syst., III., 1, 189, 1797. Southern Texas.

27 . Ilaire, Godt.

28. Menapia, Feld.

29. Beckerii, Edw.; Edw., ơ, But. N. A., v. 1, pl. 8; \&, v. 2, pl. 1, Pieris.

:31. Sisymbri, Bd.; Edw., I. c., v. 2, pl. 1, cit.

30 a. Callidice, Esper, Schmett, I., 2, pl 115, 1800 ; Bd. Sp. Gen., I., p. 542 , 1836. St. Michael's, Alaska. 


\section{NORTH AMERICAN BUT'TERELIES.}

31. Occidentalis, Reak.

winter form CALYCE, Edw.

summer form Occidentalis, Reak.

32. Protodice, Bd.

winter form Vervalis, Edw.

summer form Protodice, Bd.

33. Napi, Esper.

arctic form Bryoniz, Ochs.; Edw., Papilio, 1, 86, pl. 2, f. 4, 1881.

Alaska.

var. HuldA, Edw., 1. c., pl. 2, f. 5.

1. winter form Vexosa, Scud.; Edw., l. c., pl. 2, f. 6.

aberr. Fluva, Edw., 1. c., 98. California.

2. winter form Oleracea-Hiemalis, Harr.; Edw., l. c., pl. 2, f. S.

var. Bonestis, Grote; Edw., 1. c., pl. 2, f. 9.

var. Frigida, Scud.

aberx. Virglatexsis, Edw. Northern.

3. 1. summer form AcADic1, Edw., 1. c., 87, pl. 3, f. 10, 11 . Newfoundland.

2. summer form, a. Paldida, Scud.; Edw., 1. c., pl. 3, f. 12, 13.

b. C.storis, Reak. o; Edw., I. c., pl. 3, f. 14.

aberr. Flata, Edw., l. c. 94. Califomia.

3. summer form Oleracea-estiva, Harr.; Edw., l. c., pl. 3, f. 15, 16.

34. Virginiensis, Edw., But. N. A., v. 1, 34, pl. 9 ; id., Papilio, 1, 95, pl. 3, f.

17, 18. West Virginia.

3.. Rapæ, Limn.

var. Manni, Mayer; Stet. Ent. Zeit., 1851, p. 151. West Virginia; Georgia.

var. Nov.-Axgliz, Scud.

NATHALIS, Boisduval.

36. Iole, Bd.

var. IRENe, Fitch.

ANTHOCHARIS, Boisduval.

Group I.

37. Lanceolata, Bd.

Group II.

35. Creusa, Doubl. 
39. Hyantis, Edw., Tr. A. E. Soc., 3, 205, 1871. Colorado to California.

40. Olympia, Edw., 1. c., 3, 266, 1871; id., But. N. A., v. 2, pl. 1, Anth. West Virginia; Indiana; Nebraska.

40 a. Rosa, Edw., Papilio, 2, 45, 1882. West Texas.

41. Ausonides, Bd.; Edw., But. N. A., v. 2, pl. 1, Anth. var. Coloradensis, H. Edw., Papilio, 1, 50, 1881. Colorado.

\section{Group III.}

42. Cethura, Feld.

Cooperi, Behr.; Edw., But. N. A., v. 1, 38, pl. 10.

43. Morrisoni, Edw., Papilio, 1, 50, 1881. Southern California.

44. Thoosa, Seud., Hayden Bull., 4, 257, 1878. Utah.

45. Sara, Bd.

46. Reakirtii, Edw.

47. Stella, Edw., Can. Ent., 11, 87, 1879. Nevada; California.

48. Julia, Edw., Tr. A. E. Soc., 4, 61 ; id., But. N. A., pl. 2, Anth., Colorado; New Mexico; Arizona.

49. Genutia, Fab.; Edw., 1. c., pl. 2, cit.

50. Eubule, Linn.

CALLIDRYAS, Boisduval.

51. Sennæ, Limn., Syst. Nat., 2, 764, 1766; Butler, Lep. Exot., 59, pl. 23. Florida.

52. Agarithe, Bd., Sp. Gen., 1, 623, 1836; Butler, l. c., 121, pl. 45. Florida. 53. Philea, Linn.

GONEPTERYX, Leach.

54. Lyside, Godt.

1. winter form LYSIDE, Godt.

2. summer form Terissa, Lucas, Rev. Zoöl., 1852, p. 429. Texas.

55. Fantasia, Butler, Tr. Ent. Soc., 1871, p. 170, pl. 7, f. 6. Texas.

56. Lanice, Lintn. MSS. Rio Grande, Texas.

COLIAS, Fabricius.

Group I.

57. Eurydice, Bd.

58. Cæsonia, Stoll. 


\section{NORTH AMERICAN BUTTERFLIES.}

\section{Group II.}

59. Meadii, Edw.

\section{Group III.}

60. Hecla, Lef.

var. Glachalis, Mctachl., I. Soc. Jl., 14, 108, 1878. Grimnell Land.

var. IELA, Str., Br. Bull., 3, 33, 1850. Hudson's Bay; Kotzebue Sound, Alaska.

(i1. Boothii, Curtis.

var. ChIONe, Ross.

6.2. Eurytheme, Bd.

1. 1. winter form Ariadve, Edw., But. N. A., v. 2, pl. 4, Colias.

2. winter form KEEWAYDN, Edw., 1. c., v. 2, pl. cit.

2. summer form Eurrtheme, Bd.; Edw., l. c., v. 2, pl. cit.

63. Christina, Edw.

\section{Grodp IV.}

64. Eriphyle, Edw., 'Tr. A. E. Soc., 5. 202, 1876. British Columbia.

65. Philodice, Godt.; Edw., But. N. A., v. 2, pl. 2, 3, Colias.

var. Anthyale, Hüib.; Edw., l. c., v. 2, pl. 2, cit.

var. Albixtc, Edw., 1. c., v. 2, pl. 2, cit.

var. Melanic, id., pl. 3, cit.

61\%. Harfordii, H. Edw., Pr. Cal. Acad. N. Sci., v. 6, 1877. California.

Barbara, H. Edw., 1. c., v. 6, 1877.

67. Chrysomelas, H. Edw., 1. c., v. 6, 1877. California; Utah.

68. Occidentalis, Scud.

69. Interior, Scud.

Philodice, var. Lanrentina, Scud., Pr. Bost. Soc. N. H., 18, 4, 1876.

Cape Breton Island; Quebec; Maine.

70. Emilia, Edw.

71. Edwardsii, Behr.

72. Astræa, Edw., Tr. A. E. Soc., 4, 61, 1872. Montana.

73. Alexandra, Edw.

74. Scudderii, Reak.

75. Pelidne, Bd.; Edw., But. N. A., v. 2, pl. 1, Colias.

76. Nastes, Bd.; Edw., I. c., v. 2, pl. I., cit.

var. Morva, Str., Br. Bull., 3, 34, 1880. Hudson's Bay.

77. Chippewa, Edw. 


\section{SYNOPSIS OF}

7S. Palæno, Limn.

var. WerdaNd, Herr.-Schäff., Schmett. Eur. 1, f. 41, 42, 1843; f. 403, 404, 1848. Kotzebue Sound.

$$
\text { Group V. }
$$

79. Behrii, Edw.

TERIAS, Swainson.

Group I.

S). Nicippe, Cram.

81. Proterpia, Fab.

82. Gundlachia, Poey, Hist. Nat. de Cuba, 1, 246, pl. 24, 1851. Texas; Arizona.

83. Westwoodi, Bd.

84. Mexicana, Bd.

85. Damaris, Feld., Reise Novara, p. 198, 1865; Edw., Papilio, 2, 20, 1882. Arizona.

86. Lisa, Bd.

Group II.

87. Delia, Cram.

88. Jucunda, Bd.

\section{NYMPHALID画.}

NYMPHALINA.

HELICONIA, Latreille.

89. Charitonia, Linn.; Edw., But. N. A., v. 2, pl. 1, Char.

DANAINA:

DANAIS, Latreille.

90. Archippus, Fab.

91. Berenice, Cram.

92. Strigosa, Bates.

DIRCENNA, Doubleday.

93. Klugii, Hüb., Zutr. Ex. Schmett., f. 801, 802, 1837. Rio Grande, Texas. (Auct. Lintner.) 


\section{NORTII AMERICAN BUTTERELILS.}

\section{NYMPHALINE.}

COLAENIS, Doubleday.

94. Julia, Fab.

95. Delila, Fiab.

AGRAULIS, Blanchard.

96. Vanillæ, Linn.

ARGYNNIS, Fabricius.

Group I.

97. Idalia, Drury.

aberr. Asmitaroth, Fisher.

98. Diana, Cram.; Edw., But. N. A., v. 2, pl. 7, Argyn. (prepar. stages).

99. Nokomis, Edw.; Mead, Wheeler Rept., 5, 751, pl. 35, 1875.

100. Nitocris, Edw., Tr. A. E. Soc., 5, 15, 1874. Arizona; Nevada.

\& aberr. Nokomis, Str., Ruff. Rept., pl. 1, f. 3, 4, 1878.

101. Leto, Behr.

102. Carpenterii, Edw., 1. c., 5, 204, 1876. Arizona.

103. Cybele, Fab.

104. Aphrodite, Fab.

105. Alcestis, Edw., 1. c., 5, 289, 1876. Illinois; Iowa; Colorado.

106. Nausicaä, Edw., 1. c., 5, 104, 1874. Arizona.

107. Atlantis, Edw.

108. Electa, Edw., Field and Forest, 3, 143, 1S78. Colorado.

109. Columbia, H. Edw., Pr. Cal. Acad. N. S., v. 6, 1877. British Columbia.

110. Bremnerii, Edw. Tr. A. E. Soc., 4, 63, 1872 ; But. N. A., v. 2, pl. 4, Argyn. British Columbia; Washington 'Terr.

111. Hippolyta, Edw., Can. Ent., 11, 82, 1879. Oregon.

112. Behrensii, Edw.

113. Rhodope, Edw., Tr. A. E. Soc., 5, 13, 1874; But. N. A., v. 2, pl. 6, Argyn. British Columbia.

114. Hesperis, Edw.

115. Zerene, Bd.

form Hrdaspe, Bd.

Zerene, Behr.

var., Edw., But. N. A., v. 1, pl. 32.

var. Purpurascexs, II. Edw., Pr. Cal. Acad. N. Sci., v. 6, 1877.

form Moxticola, Behr. 
116. Nevadensis, Edw., 8 (not \$), But. N. A., vol. 1, pl. 33.

var. Meadi, Edw., Tr. A. E. Soc., 5, 1872 ; But. N. A., v. 2, pl. 2 , Argyn.

11.. Edwardsii, Reak.

11: Halcyone, Edw.

11!. Coronis, Behr.

Nevadensis \&, Edw., But. N. A., v. 1, pl. 33.

120. Callippe, Bd.

1.1. Liliana, H. Edw., Pr. Cal. Acad. N. Sci., v. 6, 1877. California; Utah. aberr. Bıroni, Edw., Tr. A. E. Soc., 9, 3, 1881.

122. Laura, Edw., Can. Ent., 11, 49, 1879. Nevada; California.

123. Chitone, Edw., 1. c., 11, 82, 1879. Utah; Arizona.

124. Irene, $\mathbf{B d}$.

125. Macaria, Edw., Field and Forest, 3, 86, 1877. California.

126. Rupestris, Behr.; Edw., But. N. A., v. 2, pl. 7, Argyn.

127. Inornata, Edw., Tr. A. E. Soc., 4, 64, 1872 ; But. N. A., v. 2, pl. 5, Argyn. 12s. Adiante, Bd.

129. Opis, Edw., Tr. A. E. Soc., 5, 105, 1S74; But. N. A., v. 2, pl. 3, Argyn. British Columbia.

130. Bischoffi, Edw., Tr. A. E. Soc., 3, 189, 1870; But. N. A., v. 2, pl. 3, Argyn. Sitka, Alaska.

1:3. Clio, Edw., Tr. A. E. Soc., 5, 106, 1874. Colorado; Montana.

132. Eurynome, Edw., But. N. A., v. 2, pl. 1, Argyn. 1872. Colorado.

1:).: Artonis, Edw., Tr. A. E. Soc., 9, 2, 1881. Colorado; Nevada.

I:)4. Montivaga, Behr.

Arge, Str., Catl., p. 114, 1878.

135. Egleis, Bd.

\& Mormonia, Bd., Lep. de la Cal., p. 58.

Group II.

136. Myrina, Cram.

1:3. Triclaris, Huib.

1:3. Helena, Edw.

139. Chariclea, Schneid.

var. Obscurata, McLach., L. Soc. Jl., 14, 110, 1878. Grinnell Land.

140. Boisduvalii, Somm.

141. Freya, Thunb.

142. Montinus, Scud.

143. Polaris, Bd. 
THE

\section{BUTTERFLIES}

OF

North America

WITH

COLORED DRAWINGS AND DESCRIPTIONS

$\mathrm{BY}$

W. H. EDWARDS

SECOND SERIES.-PART I.

NEW YÓRK

PUBLISHED BY HURD AND HOUGHTON

Cambrioge: The kibersioe presg

MAY, 1874 

THE

\section{BUTTERTILIES}

$\mathrm{OF}$

North AmERICA

WIT!

COLORED DRAWINGS AND DESCRIPTIONS

BY

W. H. EDWARDS

SECOND SERIES.-PART II.

1840

NEW YORK

PUBLISHED BY HURD AND HOUGHTON

Cambridge: The lhibcrside Hercsg

LONDON: TRÜBNER \& CO.

1874 

THE

\section{BUTTERTIIES}

oF

North AmERICA

VITH

COLORED DRAWINGS AND DESCRIPTIONS

BY

W. H. EDWARDS

SECOND SERIES.-PART III.

NEW YORK

PUBLISHED BY HURD AND HOUGHTON

Cambrioge: The laiberside fleresg

LONDON: TRÜBNER \& CO.

I 875 

THE

\section{BUTTERFLIES}

OF

North America

WITH

COLORED DRAWINGS AND DESCRIPTIONS

/ BY

W. H. EDWARDS

SECOND SERIES.-PART IV.

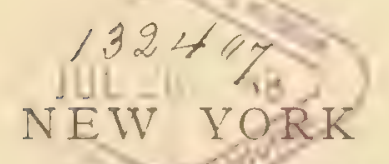

PUBLISHED BY HERD AND HOUGHTON

Cambrioge: The khíbergíde pregs

LONDON: TRÜBNER \& CO.

November, 1875 

THE

BUTTERFLIES

of

North AMERICA

WITH

COLORED DRAWINGS AND DESCRIPTIONS

BY

W. H. EDWARDS

SECOND SERIES.-PART V.

NEW YORK

PUBLISHED BY HURD AND HOUGHTON

Cantbrioge: Tlye kíberside foregs

LONDON: TRÜBNER \& CO.

JULY, I 876 

THE

\section{BUTTERFLIES}

OF

North AMERICA IVITH

COLORED DRAWINGS AND DESCRIITIONS

PY

W. H. EDWARDS

SECOND SERIES.-PART VI

NEW YORK

PUBLISHED BY HURD AND HOUGHTON

Cambrioge: The kituersioe Fregs

LONDON: TRÜBNER \& CO. 

THE

\section{BUTTERFLIES}

oF

North AMERICA IVITH

COLORED DRAWINGS AND DESCRIPTIONS

BY

W. H. EDWARDS

SECOND SERIES.-PART VII.

124769

BOSTON

HOUGHTON, OSGOOD AND COMPANY

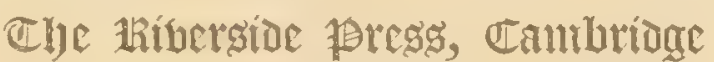

LONDON: TRÜBNER \& CO.

I 878

(y 

THE

\section{BUTTERFLIES}

OF

North AMERICA $\because$ ITH

COLORED DRAWINGS AND DESCRIPTIONS

BY

W. H. EDWARDS

SECOND SERIES.-PART VIII.

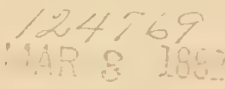

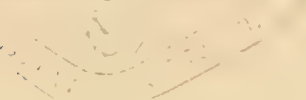

BOSTON

HOUGHTON, OSGOOD AND COMPANY

ene taibcrsioc 扫regs, Cambrioge

LONDON: TRÜBNER \& CO.

I 879 

THE

\section{BUTTERFLIES}

OF

North America

|VITH

COLORED DRAWINGS AND DESCRIPTIONS

BY

W. H. EDWWARDS

SECOND SERIES.-PART IX.

BOSTON

HOUGHTON, MIFFLIN AND COMPANY

Clye Katoerside foresg, Cambrioge

LONDON: TRÜBNER \& CO.

I 880 

THE

\section{BITTERTLIES}

OF

North AMERICA

พıтн

COLORED DRAWINGS AND IDESCRIPTIONS

BY

W. H. EDWARDS

SECOND SERIES - PART $X$

125297

BOSTON

HOUGHTON, MIFFLIN AND COMPANY

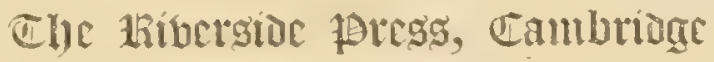

LONDON: TRÜBNER \& CO.

I882 

THE

\section{BITTERPLIES}

OF

Norti AMERICA

IVITH

COLORED URAWINGS AND DESCRIITIONS

BY

W. H. EDWARDS

SECOND SERIES.-PART XI.

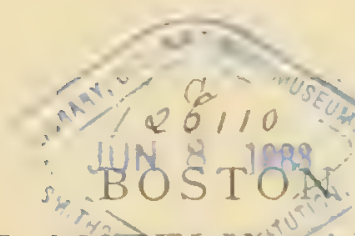

HOUGHTON, MAEEE AND COMPANY

Che kibcrgito presg, Cambriogr

LONDON: TRÜBNER \& CO.

1883 

THE

\section{BUTTERFLIES}

or

NORTH AMERICA

IVITH

COLORED DRAWINGS AND DESCRIPTIONS

BY

W. H. EDWARDS

SECOND SERIES.-PART XII.

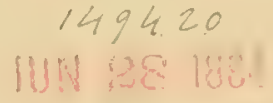

BOSTON

HOUGHTON, MIFFLIN AND COMPANY

Che kibersior foress, cambutoge

LONDON: TRÜBNER \& CO.

$188_{4}$ 

$\Gamma \mathrm{HE}$

\section{BUTTERILLIES}

or

Norti AMERICA

WITH

COLORED DRAIINGS AND DESCRIPTIONS

BY

W. H. EDWWARDS

SECOND SERIES.-PART XIII.

BOSTON

HOUGHTON. MIFELIX AND COMPANY

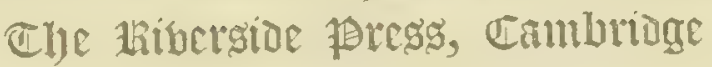

LONDON: TRÜBNER \& CO.

I 885 




\section{A.TVERTISEMENT.}

Tru Second Volume of the "Butterflies of North America" will not be strictly confined to the descriptions and delinentions of new species. In the Advertisement to the First, I mentioned the fict that the preparatory stages of even our old and common species of buttertlies were scarcely better known than in the days of Abbot, well nigh a century ago. But within the past four or five years a great advance has been made in this respect, and what was true in 1868 is no longer so. 'Through the labors of a few zealous naturalists, it is now possible to trace from the egg, through successive larval phases to the chrysalis and butterfly, a large number of North Anerican species about which little or nothing was then known. 'To illustrate some of these changes will, I hope, render this volume both interesting and valuable.

I am pleased to be able to say that I have the coöperation of Miss Peart and Mrs. Bowen, which is an assurance that the execution of the Plates shall equal in fidelity and finish those before published. The Plates belonging to each Genus will not always be issued in sequence, as is observable in Part I., but when the close of the Volume is reached, all will be found in proper order.

With the last Part, a revised Synopsis of Species will be given.

Coalbergin, IV. VA., April 1, 1874.

IV. II. EDIVARDS. 


$\begin{array}{llll}3 & 9088 & 00724 & 8842\end{array}$

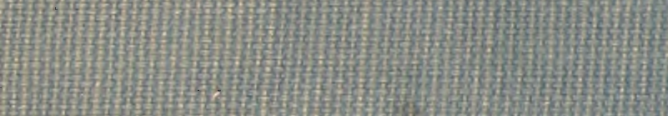

3.

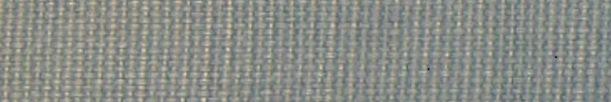

